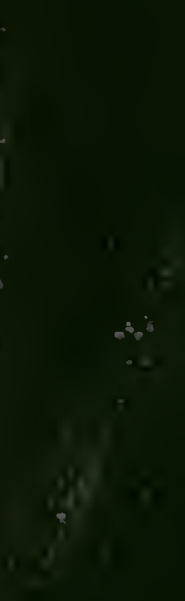






$$
\text { . }
$$





\section{MEDUSAE OF THE WORLD \\ VOLUME I}

\section{THE HYDROMEDUSAE}

BY

\section{ALFRED GOLDSBOROUGH MAYER}

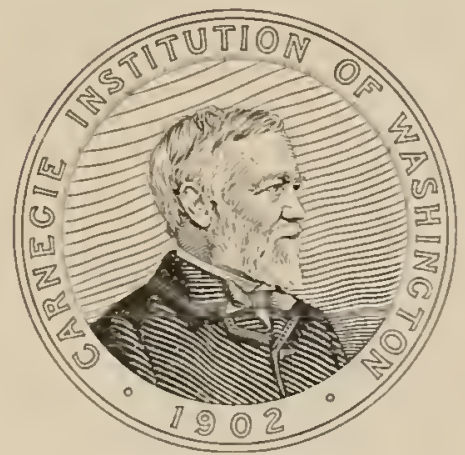

WASHINGTON, D. C.

Published by the Caknegie Institution of Washington 
CARNEGIE INSTITUTION OF WASHINGTON

Publication No. iog, Vol. I

Copies of this Book

were first issued

AUG 91910 


\section{CONTENTS.}

\section{VOLUME I.}

Introduction . ................................................

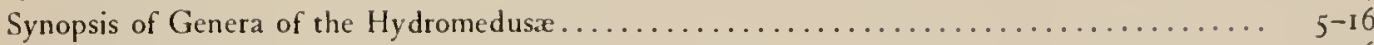

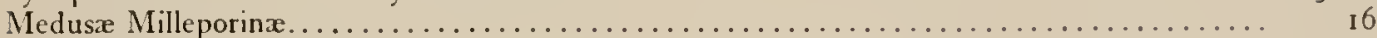

Anthomedusx........................................ 196

Genera of the Anthomedusx:

Pachycordyle....... 2 I

Amalthea......... 22

Pennaria..........23

Trichorhiza........ 28

Steenstrupia........ 29

Iybocodon......... 37

Microcampana...... 44

Dicodonium........ 44

Sarsia........... 47

Stauridiosarsia.......64

1 Iydrichthys........66 66

Eucodonium.......6.68

Ectopleura........6.68

Corynitis.........7 7

Slabberia......... 73

Margelopsis......... So

Zanclea........... 85

Leptomedusxe............

Genera of the Leptomedusa:

Thaumantias......... 108 .

I,aodicea..........20 I

Melicertum ........207

Melicertissa. . . . . . . 209

Orchistoma ........2II

Timoides........2I 2
Zancleopsis............ gr

Pteronema........... 92

Eleutheria........... 93

Minestra............. 96

Ctenaria............. 98

Cladonema............. 98

Dendronema............ I02

P'rotiara............... 105

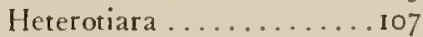

Stomotoca............. 108

Dissonema............ II5

Pandea. ............ I I6

Turris............... 120

Conis............... $3^{0}$

Calycopsis 130 , vol. $2 \ldots+49$ I

Cytxis ............, $13^{2}$
P'odocoryne............ I35

Turritopsis............ 443

Oceania............. 46

Stylactis............. 49

Thamnostylus.......... I5I

Thamnitis........... 152

Lymmorea............ I53

Bougainvillia.......... 555

Nemopsis..........172

Rathkea............ I75

Chiarella...........182

Bythotiara............ 85

Sibogita I86, vol. 2.....49 I

Niobia.............. I 87

Proboscidactyla......... I 88

IVillsia.............. 93

$196-230$

Staurodiscus.........2I3

Dichotomia..........223

Dipleurosoma.........22t

Toxorchis............228

Netocertoides..........220

MIonobrachium........230 



\title{
MEDUSAE OF THE WORLD.
}

\author{
THE HYDROMEDUSAE.
}

\section{INTRODUCTION}

This work was commenced in 1892 at the suggestion of Dr. Alexander Agassiz while I was a student in his marine laboratory at Newport. Dr. Agassiz's plan was that we produce conjointly a work upon the Medusx, Siphonophora, and Ctenophorx of the Atlantic coast of North America. In pursuance of this plan, Dr. Agassiz sent me upon expeditions to Halifax, Nova Scotia; Eastport, Maine; Charleston, South Carolina; and Tortugas, Florida. It was also my privilege to accompany him as his assistant upon his expeditions to the Bahamas, and to the coral regions of the tropical Pacific. During these years the majority of our American species were captured and drawings of them made from life.

The description of all of the then known American Atlantic forms was completed by me in I9oo, but unfortunately the pressure of other and more important work prevented the revision of the manuscript by Dr. Agassiz, and thus it remained in the Museum of Comparative Zoology at Harvard University until r 904 , when Dr. Agassiz generously returned it to me with permission to publish it in any manner whatsoever. Thus the original plan was reluctantly abandoned.

During the four years that elapsed while the manuscript lay unstudied at Harvard, new forms had been discovered along our coast; and Nutting and Hargitt had published their papers upon the hydroids and medusx of the Woods Hole region.

It was necessary to thoroughly revise the manuscript, and in order to render it of greater service, I have attempted to extend the original work to include descriptions of all known forms of medusx from all parts of the world. This extension was made possible through the generous establishment by the Carnegie Institution of Washington of a Marine Research Laboratory at Tortugas, Florida. Many forms were collected upon a cruise of the Carnegie Institution yacht Physalia from Boothbay Harbor, Maine, to Tortugas, Florida; and new or interesting medusa have been obtained each season upon excursions over the tropical Gulf Stream, and among the Bahamas. My official position in connection with the laboratory has afforded me every possible facility in time and opportunity for the prosecution of these studies, and I can not too kindly express my sense of gratitude to the executive officers of the Carnegie Institution for their generous support.

To Geheimrath Prof. Dr. Anton Dohrn, and to his able corps of associates at the Stazione Zoologica, 1 am indebted for numerous kindnesses shown to me during my visit to the laboratory at Naples from November to February, 1907 and 1908.

I have also enjoyed full privileges of study in the libraries of the Museum of Comparative Zoology at Harvard University; in the Boston Society of Natural 
History; the American Museum of Natural History; Columbia University, the National Museum at Washington, and the Museum of the Brooklyn Institute of Arts and Sciences. Through these facilities I have been enabled to review nearly all of the published works upon medusx, but the review of literature can not pretend to completeness for I907 and I908, although all papers of those years which the author could discover are recorded.

Moreover, Profs. William K. Brooks and Louis Murbach have been so kind as to lend some of their original drawings, which are reproduced in this work, and the following gentlemen have generously granted permission for the reproduction of figures from their published works, thus enabling us to present text-figures of many forms which would otherwise have been represented merely by descriptions: Dr. Alexander Agassiz, Director of the Museun of Comparative Zoology at Harvard University; Dr. Henry B. Bigelow, of Harvard; Dr. R. P. Bigelow, of the Massachusetts Institute of Technology; Prof. Edward T. Browne, of the University of London; Prof. Dr. Carl Chun, of Leipzig; Prof. Dr. S. Goto of Tokyo; Geheimrath Prof. Dr. Ernst Haeckel, of Jena; Prof. C. W. Hargitt, of Syracuse University; Prof. Dr. Cl. Hartlaub, of Helgoland; Prof. W. C. M'Intosh, of Aberdeen University; Prof. Dr. Otto Maas, of München; Prof. C. C. Nutting, of Iowa; Prof. Henry F. Perkins, of Vermont; and Prof. Dr. Ernst Vanhöffen, of Kiel.

I have always felt that each working naturalist owes it as a duty to science to produce some general systematic work, and this has been an actuating motive in the production of this book. But chiefly have I been moved to the task through respect for the wishes of $m y$ generous friend and master in science, Alexander Agassiz. Nor can one remain insensible to the rare grace of form and delicate beauty of color of these creatures of the sea, associated as their study is with memorials of the labors of a host of distinguished naturalists. Dry though these pages must be to the reader, to the writer they are replete with memories of the ocean in many moods, of the palm-edged lagoons of coral islands sparkling in the tropic sun, of the cold, gray waters of the northern sea bestrewn with floating ice, of days of withering calm in the heat of the torrid zone, and of adventure in the hurricane; all centering around the absorbing study of the meduse. Love, not logic, impels the naturalist to his work.

This book attempts to present a new classification of the meduse. With every respect for Haeckel's great work, it has appeared to me that its subdivisions are of ten too precise to be convenient, and too artificial to accord with nature. Moreover, many of Haeckel's genera are founded upon intergrading characters, and are thus imperfectly separated. The young of many meduse appear in one genus, and the adults in another. The aim of Haeckel's system is to emphasize distinctions, whereas my aim is to indicate relationships. I therefore attempt to separate genera upon positive, not upon relative, distinctions. For example, if we define one genus as having a narrow manubrium (Margelis), and another as having a wide manubrium (Bougainvillia), we must either institute a third genus for newly-discovered medusæ with manubria of moderate width or place them doubtfully in one or the other of the genera of the extreme members of the series.

On the other hand, if we define one genus as having eight tentacles, and another as having nine or more tentacles, there can be no confusion between them, for the difference, although slight, is positive and numerical, not qualitative and intergrading.

I have not described hydroids which do not produce free-swimming medusx, although I grant it is wholly illogical to admit Podocoryne into a system which excludes Hydractinia, or to include only those species of Stylactis which produce 
medusæ and to exclude those which produce sessile gonophores. Nevertheless this should be clearly understood and must be accepted as an artificial limitation of the work.

I have thus attempted to describe only such hydroids as are known to produce medusx, and have endeavored to bring the systematic arrangement of the medus:c more nearly into accord with that of the hydroids. A strictly natural system including both hydroids and medusx can not be constructed, for many of the hydroids remain undetermined. Moreover, dissimilar hydroids (Syncorync, Stanridium) may give rise to similar medusx (Sarsia); or the reverse may be the case, as in the meduse of Bougainvillia and Nemopsis, or that of the two sorts of medusa (Sarsia and Cladonema) which may arise from hydroids of Stauridia.

These and many other cases of a similar nature interpose a barrier to our attempts to invent a natural system which includes all hydroids and medusxe within its embrace. At present, I believe, we must content ourselves with a compromise between a natural and an artificial arrangement, confiding in the belief that as more and more of the hydroids are discovered it will become correspondingly more possible to arrange the medusx in a natural system. After consultation with Prof. C. C. Nutting we have mutually decided that the promulgation of such a system is at present inadvisable. Such a system has, indeed, been proposed by von Lendenfeld, I $88_{+}$(Zool. Anzeiger, Bd. 7), but has gained no acceptance.

Much confusion has been introduced through the habit, in vogue among marine expeditions, of sending all of the medusx to one specialist and the hydroids to another. Thus the sessile and the reproductive stages of the same animals are worked upon independently from different view-points by different men.

I am inclined to regard the Trachymedusa and Narcomedusx as being transformed actinulæ, for they commonly develop through an actinula larva in which the bell grows out as a collar-like, or intertentacular lappeted expansion from the sides of the body after the tentacles have appeared, and the tentacles of the actinula become those of the medusa. The medusa of the Anthomeduse and Leptomedusx is formed upon a different plan, for the tentacles grow outward from the bell-margin after the bell has developed. I believe, therefore, that the bell of the Trachymedusx and Narcomedusx is not homologous with that of the Anthomedusx and Leptomedusx. It is evident that the entodermal otoliths of the Trachymedusx and Narcomedusx are not homologous with the ectodermal otoliths of Leptomedusx. Budding and alternation of generations occur in both classes of veiled medusx.

I believe that the medusa-shape has been acquired independently in the Trachylina and Leptolina forms of veiled medusa.

The colored plates contained in this volume consist of drawings, from life, of medusa of the Atlantic coast of the United States. The text-figures, on the other hand, are chiefly outline tracings from the illustrations of many authors; and are presented in order to spare the reader the trouble of consulting numerous scattered works of reference. 'These outline copies of previously-published drawings of medusa were carefully traced from the originals by Mr. Carl Kellner, artist of the Tortugas Marine Laboratory of the Carnegie Institution.

Other outline figures are from life, and the majority of these were drawn by the author while studying at Mousehole, Cornwall, England, and at the Naples Zoological Station during the autumn and winter of 1907 and 1908.

This book aims to be something more than an old-fashioned systenatic treatise, for it attempts to record, if not to review, all works upon the embryology, cytology, œecology, physiology, etc., of all forms coming within the scope of the text. 
Many of the medusa are modified more or less profoundly by environmental conditions, and this gives rise to numerous local races, the determination of the relationships between which is all but impossible in the present state of our knowledge. Experimental work in this field is in its infancy, yet the few observations of Hallez on Bougainvillia and of Browne in his experiments in maintaining various hydroids under different conditions in aquaria suggest that the results of more extended studies will be of great benefit to the systematist in determining the natural limitations of species. A striking example of the profound effect of environmental changes is seen in the experiments of Goldfarb, I906, upon Eudendrium, wherein he showed that after the regenerative process had entirely ceased in the dark, it could be recalled into activity by an exposure of only five seconds to the daylight.

At present the natural classification of the species of such genera as Obelia, Phialidium, Eutima, Bougainvillia, etc., is impossible, and the Linnean system is inadequate to the task of expressing their actual relationships. Indeed, with the exception of the sponges and corals, there is no phylum of the animal kingdom more difficult to classify than the medusa.

In a work of this magnitude there must needs be both errors and omissions, and for these I can but present my apologies in advance of their discovery, trusting that all such will soon be discovered and announced, and that science may be more advanced than hindered through the publication of this book. I trust that none of my esteemed contemporaries will feel aggrieved at such criticisms of their labors as may appear in the following pages, for should anyone find cause for such offense, he may console himself in the fact that I am obliged to confess to having found more to criticize and amend in my own previously-published papers than in those of any other living naturalist. 


\section{HYDROMEDUSÆ OR VEILED MEDUSÆ.}

Medusa with a velum, or diaphragm, which partially closes the marginal opening of the bell. When ripe the sexual products are found in the ectoderm.

With a double marginal nerve-ring, one above and one below the velum.

Without gastric filaments. Development either direct from actinula larva or through alternation of generations from hydroids.

\section{Order 1. ANTHOMEDUSÆ Haeckel, 1879.}

Hydromedusa with gonads in the ectoderm of the manubrium. Without otocysts. The hydroids are of the Tubularian order.

Family No. I, CODONIDE.

Anthomedusæ with ring-like gonad encircling the manubrium. Four to six simple, unbranched radial-canals. Simple, umbranched tentacles.

\section{Subfamily No. I, SARSIANÆ.}

Some or all of the tentacles arise singly, not in clusters, from bell-margin.

PAchycordyle, Weismann, $1883=$ Parvanemus (?), Mayer, 1904 .

Degemerate meduse without tentacles, radial or circular canals. Hydroid: Pachycordyle Weismann.

Aмalthæa, Schmidt, 1854 .

Four rudimentary tentacles, four radial-canals, and a ring-canal. Hydroid: Corymorpha.

Pennaria, Oken, I815; Goldfuss, I820=Globiceps, Haeckel, I879.

Similar to Amalthaa, but the hydroid is Pennaria.

Trichorhiza, Russell, igo6.

Medusa resembles Pennaria, but the hydroid is Trichorhiza.

Steenstrupia, Forbes, I $846=$ Euphysa, Forbes, I $8+8=$ Euphysora, Maas, 1905 .

Four radially situated tentacles, one of which is long, the other three short. Bell radially symmetrical. Hydroid: Corymorpha.

Hyвocodon, L. Agassiz, $1862=$ Hybocodon + Amphicodon, Haeckel, 1879 .

One or more well-developed tentacles arise from base of one of the four radial-canals. With rudimentary tentacles at the bases of the three orher radial-canals. Bell asymmetrical. Hydroid: Hybocodon Agassiz.

Microcampana, Fewkes, 1889.

With one long and five short tentacles, arising at ends of six radial-canals.

Dicodonium $=$ Dicodonium + Dincma, Haeckel, 1879 .

Two well-developed and two rudimentary tentacles. No meridional lines of nettle-cells over exumbrella.

Sarsia, Lesson, $1843=$ Codonium + Sarsia + Syndictyon, Haeckel, 1879 .

Four equally developed tentacles with abaxial, ectodermal ocelli. No meridional lines of netrle-cells over the exumbrella. Hydroid: Syncoryne.

Stauridiosarsia new subgenus. Medusa similar to Sarsia, but the hydroid is Stauridia.

Hydrichthys, Fewkes, 1888.

Medusa resembles Sarsia, but there are no ectodermal ocelli upon the tentacle-bulbs. Hydroid: IIydrichthys, Fewkes; commensal or parasitic upon fish.

Eucononium, Hartlaub, i 907 .

Medusa resembles Sarsia, but stomach is mounted upon a gelatinous peduncle. The four tentacles terminate each in a knob-shaped extremity.

Ectopleura, L. Agassiz, i 862 (sens. ampl.).

With two or four tentacles. Eight meridional lines of nettle-cells over the exumbrella. Hydroid: Ectopleura. 
Corynitis, McCrady, I857.

Four knobbed tentacles. Manubrium cruciform in cross-section. Ocelli upon tentaclebulbs. Hydroid: Syncoryne (Hargitt).

Slabberia, Forbes, I846=Slabberia +Dipurena + Bathycodon, Haeckel, i879.

Four knobbed tentacles. Manubrium tubular and encircled by two or more ring-like gonads. Hydroid: Syncoryne.

\section{Subfamily No. 2, MARGELOPSINÆ.}

Four radially placed clusters of marginal tentacles. No oral tentacles. A ring-like gonad encircles the stomach. Four simple, unbranched radial-canals. Hydroids a re pelagic Tubularians, and the medusa arise by budding from their sides.

Margelopsis, Hartlaub, i 897 .

Characters of the medusa are those of the subfamily. Hydroid: Margelopsis, in which the tentacles are disposed in definite circlets.

Pelagohydra, Dendy, igo3.

Medusa similar to Margelopsis. Hydroid: Pelagohydra. Its tentacles arise irregularly from sides of the hydranth, and are not disposed in definite circlets.

\section{Family No. 2, CLADONEMIDÆ.}

Tentacles branch dichotomously or complexly, or give rise to a linear series of nematocystbearing filaments along their abaxial sides. Gonads ring-like, or segregated upon the interradial and adradial sides of the manubrium.

\section{Subfamily No. I, PTERONEMINÆ.}

Manubrium without oral tentacles.

Zanclea, Gegenbaur, $1856=$ Zanclea + Gemmaria, Haeckel, 1879 .

With two or four tentacles, each of which gives rise to an abaxial row of nematocystbearing branches. With meridional rows of nettle-cells upon the exumbrella. No ocelli upon the tentacle-bulbs. No brood-pouch above the stomach. Hydroid: Gemmaria McCrady; Allman.

Zancleopsis, Hartlaub, I907.

Similar to Zanclea, but without meridional lines of nettle-cells over the exumbrella. With ectodermal ocelli upon the outer sides of the tentacle-bulbs.

Pteronema, Haeckel, i 879.

Similar to Zanclea, but with a brood-sac above the stomach. Four tentacles.

Eleutheria, Quatrefages, 1842.

Four to six bifurcated tentacles, and an equal number of simple unbranched radialcanals. There is an ectodermal brood-sac above, but not connected with the stomach. The medusa is hermaphroditic and the germ-cells develop in the brood-sac. Hydroid: Clavatella Hincks.

Mnestra, Krohn, 1853; Günther, I903.

Degenerate medusa parasitic upon Phyllirrhö̈. Four to no tentacles, each with an abaxial line of nettle-warts. Four perradial meridional lines of nettle-cells over the exumbrella. Four radial-canals. Throat is blocked by a cavernated mass of entoderm.

\section{Subfamily No. 2, DENDRONEMINE.}

Manubrium with oral tentacles.

Ctenaria, Haeckel, 1879.

Two marginal tentacles with abaxial filaments. Four bifurcated radial-canals. Simple oral tentacles. Brood-sac above the stomach. 
Cladonema, Dujardin, i 843 .

Four or five hifurcated or eight to ten simple radial-canals. Branched marginal tentacles. Simple oral tentacles. No brood-sac above the stomach. Hydroid: Stauridia Dujardin.

Dendronema, Haeckel, i 879.

Similar to Cladonema, but with branched oral tentacles and with brood-sac above stomach.

Family No. 3, OCEANID E, sensu Vanhöffen.

Anthomedusx in which the gonads are segregated and developed upon the interradial or adradial sides of the manubrium. With unbranched marginal tentacles. Mouth with four lips.

Subfamily No. I, TIARIN E.

Unbranched radial-canals. Marginal tentacles separate; not grouped into clusters. No oral tentacles. Tentacles hollow. When present the ectodermal ocelli are upon the abaxial sides of the tentacle-bulbs. With the exception of Calycopsis all of the genera have four radial-canals.

Protiara, Haeckel, i $879=$ Halitiara, Fewkes, 1882.

Four radially placed, well-developed tentacles. Four interradial gonads with smooth outer surfaces. With or without marginal cirri. External surfaces of gonads smooth. Four cruciform, simple lips. No ocelli on the velar sides of the tentacles.

Heterotiara, Maas, igo5.

Eight or more tentacles. The ring-canal gives rise to blindly-ending centripetal vessels. Sтомотоса, L. Agassiz, I862 = Amphinema + Stomotoca + Codonorchis, Haeckel, 1879 .

Two well-developed and many rudimentary tentacles. External surfaces of the adradial gonads are thrown into transverse folds. Hydroid: Perigonimus.

Dissonema, Haeckel, i 879 .

Similar to Stomotoca, but the gonads finally migrate outward along the four radial-canals.

Pandea, Lesson, i 843 .

Four or more tentacles. Gonads four interradial, folded ridges on the sides of the stomach but these gonads are not completely separated in the four principal radii. Hydroid: Dendroclava (? ?).

Turris, Lesson, $18+3=$ Tiara + Turris + Catablema, Haeckel, 1879 .

Four or more tentacles. Four interradial horseshoe-shaped gonads on the stomach wall. These are composed of more or less fused ridges or network-like swellings. They are completely separated in the four principal radii. Hydroid: Clavula Wright.

Conis, Brandt, i834; Haeckel, i 879.

Similar to Pandea, but the tentacle-bulbs give rise to abaxially-placed clubs which bear ocelli.

Calycopsis, Fewkes, I 882.

Sixteen simple, separate radial-canals. Eight transversely folded, adradial gonads. Ring-canal simple.

\section{Subfamily No. 2, MARGELIN $A$.}

With four unbranched radial-canals. With oral tentacles, or nematocyst-knobs, upon the lips. Tentacles solid. When present the ectodermal ocelli are upon the inner (velar) sides of the tentacles.

CүтæIs, Eschscholtz, I829=Cytccis + Cubogastcr. Haeckel, I 879 .

Four simple marginal tentacles. With simple, unbranched, oral tentacles.

Podocoryne, Sars, $1846=$ Dysmorphosa + Cytcandra, Haeckel, 1879 .

Eight or more simple marginal tentacles. With simple, unbranched, oral tentacles. Hydroid: Podocoryne. When present the peduncle above the stomach is solid and gelatinous. 
Turritopsis, McCrady, i 856.

Eight or more simple marginal tentacles. The entodermal walls of the radial-canals above the stomach are composed of vacuolated cells forming a peduncle-like base for the stomach. The mouth is studded with a row of nematocyst-bearing knobs. With ectodermal ocelli on the relar sides of the tentacles near their bases. Hydroid: Dendroclava (Brooks).

Oceania sensu Kölliker, I853; Gegenbaur (in part) 1856.

Medusa similar to Turritopsis, but with solid gelatinous, non-vacuolated peduncle above the stomach. Hydroid: Clava-like.

Stylactis, Allman, i 864 .

Degenerate medusæ, with four to eight rudimentary marginal tentacles and no oral tentacles. Hydroid: Stylactis.

Thamnostylus, Haeckel, 1879 .

With two simple, marginal tentacles, and with branched oral tentacles.

Thamitis, Haeckel, i 879 .

Four radially placed, simple, marginal tentacles, and branched oral tentacles.

Lymnorea, Péron and Lesueur, I $809=$ Limnorea + Thamnostoma, Haeckel, I 879.

Eight or more simple, marginal tentacles. Branched oral tentacles.

Bougainvillia, Lesson, $1843=$ Margelis + Lizusa + Hippocrene, Haeckel, 1879 .

With branched oral tentacles. The marginal tentacles are grouped in four radial clusters. All of the tentacles are filiform. Hydroid: Bougainvillia.

Nemopsis, L. Agassiz, i 849 .

Similar to Bougainvillia, but each cluster of marginal tentacles consists of a median pair of clavate tentacles flanked by filiform tentacles. Hydroid: Bougainvillia.

RATHKEA, Brandt, I $837=$ Lizzia + Lizella + Ratlikea + Margellium, Haeckel, 1879 .

With eight clusters of marginal tentacles. Simple or branched oral tentacles. Ringcanal simple.

Chiarella, Maas, i 897 .

Sixteen (eight double) clusters of marginal tentacles. The ring-canal gives rise to centripetal vessels. Branched oral tentacles.

Subfamily No. 3, DENDROSTAURIN E.

With branched radial-canals. No oral tentacles. Marginal tentacles arise singly, and are not grouped into clusters. Tentacles hollow. No cirri or marginal clubs.

Bythotiara, Günther, igoz.

Four bifurcated radial-canals and a ring-canal. Four interradial gonads.

Sibogita, Maas, igo4.

Four principal radial-canals, which branch complexly. Four interradial gonads. Ringcanal present.

Niobia, Mayer, igoo.

Four principal radial-canals, two of which bifurcate so that six canals reach the circular vessel. Four interradial gonads. The marginal tentacles develop into medusæ, and are cast off.

Proboscidactyla, Brandt, i $838=$ Dyscannota + Dicranocanna + Willeta +Proboscidactyla, Haeckel, 1879 .

The four primary radial-canals give rise to simple or branched side branches. No ringcanal. With intertentacular lines of nematocysts upon the exumbrella above the bell-margin. Gonads on the adradial sides of the stomach extending outward along the sides of the four main radial-canals. 
Willsia, Forbes, 1846 .

Similar to Proboscidactyla, but with six or more primary radial-canals. The hydroid belongs to the genus Lar Gosse.

Order 2. LEPTOMEDUS $Æ$ Haeckel, 1886.

Hydromedusæ with gonads upon the radial-canals. When present the otoliths are of ectodermal origin. The medus $x$ arise through alternation of generations from Campanularian hydroids.

Family No. I, THAUMANTIADÆ.

Leptomedusæ without lithocysts.

Subfamily No. I, MELICERTINÆ.

With simple, unbranched radial-canals and an equal number of lips, without oral tentacles. Cirri or marginal clubs may or may not be present.

Thaumantias, Eschscholtz, $1829=$ Tetrancma + Thaumantias, Haeckel, 1879 .

Four or more tentacles. Four radial-canals. No marginal clubs or cirri. Hydroid: Thaumantias.

LAODicea, Lesson, $18+3=$ Octonema + Loodice, Haeckel, i 879 .

Four or more tentacles. Four radial-canals, with marginal clubs or cirri. Hydroid: Cuspidella.

Melicertum, Oken, I815; sensu L. Agassiz, I862=Melicertella +Melicertum, Haeckel, i 879 .

With eight or more tentacles. Eight radial-canals. No marginal clubs or cirri. Hydroid: Melicertum Agassiz.

Melicertissa $=$ Melicertissa + Melicertidium, Haeckel, 1879 .

Similar to Melicertum, but with marginal clubs or cirri between the tentacles.

Orchistoma, Haeckel, i 879.

More than eight radial-canals. With or without marginal clubs or cirri.

Timoides, H. B. Bigelow, igo4.

Four radial-canals. The ring-canal gives rise to blindly-ending centripetal diverticula. Numerous tentacles and cirri. Four gonads on the four radial-canals. Stomach mounted upon a peduncle.

Subfamily No. 2, POLYORCHINÆ.

The radial-canals give rise to branches which end blindly and do not connect with the marginal ring-canal.

STAurodiscus, Haeckel, i 879 .

With four radial-canals, each of which gives rise to two side branches, which end blindly.

Ptychogena, A. Agassiz, i862, i865.

With four radial-canals which give rise to numerous blindly-ending side branches. Gonads leaf-shaped and developed upon the side branches of the radial-canals.

Polyorchis, A. Agassiz, i 862 to i 865.

With four radial-canals which give rise to numerous blindly-ending side branches. Numerous sac-like, sausage-shaped gonads attached to the radial-canals and to their side branches. Ring-canal simple. Bell-margin not cleft into lappets.

SpIRocodon, Haeckel, i $879=$ Goniomeandrus, Kirkpatrick, I903.

Similar to Polyorchis, but the ring-canal gives rise to blindly-ending, centripetal branches, and bell-margin is cleft into lappets. 
The radial-canals give rise to branches which connect with the ring-canal.

Cannota, Haeckel, i 879 .

With four radial-canals, each of which gives rise to two side branches which join the ring-canal.

Cuvieria, Péron, i $807=$ Berenice, Haeckel, i 879 .

With four main radial-canals which give rise to numerous non-dichotomous side branches. Gonads on the terminal ramuli of the canals.

Dichотомia, Brooks, igoz.

With four main radial-canals which divide dichotomously two or more times. The gonads extend outward from the stomach over the canals.

Dipleurosoma, Axel Boeck, I866= Tetracannota, Mayer, I 900 .

With three or more main radial-canals which give rise to non-dichotomous side branches. Gonads on the canals adjacent to the stomach. Hydroid: Cuspidella (?).

Toxorchis $=$ Toxorchis + Cladocanna, Haeckel, I 879 .

Four or more main radial-canals which branch dichotomously one or more times. Gonads on the outer branches of the canals near the ring-canal.

Netocertoides, Mayer, I900.

Eight main radial-canals which branch dichotomously. Gonads extend outward from the sides of the stomach along the radial-canals.

Family No. 2, EUCOPID E.

Leptomedusæwith lithocysts, and with less than eight radial-canals upon which the gonads are developed.

Subfamily No. I, OBELINE.

With eight adradial lithocysts. Four radial-canals. Stomach without a peduncle.

Eucopella, von Lendenfeld, i 883 .

Degenerate medusæ. No tentacles. No manubrium. Branched radial-canals. Hydroid: Eucopelln.

Agastra, Hartlaub, i 897 .

Degenerate medusæ. No manubrium. Simple, unbranched radial-canals. Hydroid: Campanularia (?).

Eucope, Gegenbaur, i 856.

Basal bulbs of the tentacles are simple and hollow, and do not project inward into the gelatinous substance of bell. Lithocysts on bell-margin. Hydroid: Campanularia.

Obelia, Péron and Lesueur, 1809.

Entodermal cores of tentacles project inward into the gelatinous substance of the bell. Otocysts on bases of tentacles. Hydroid: Obelia.

Tiaropsis, L. Agassiz, i 849 .

An ocellus with entodermal pigment above each lithocyst. Tentacle-bulbs simple and hollow.

Subfamily No. 2, PHIALINE.

With more or less than eight lithocysts. Four to five radial-canals. Stomach without a peduncle.

Clytia, Lamouroux, I8 $12=$ Epenthesis, McCrady, I857.

Sixteen tentacles alternating with sixteen lithocysts. Four radial-canals. No cirri. Hydroid: Clytia. 
Phialidium, Leuckart, $1856=$ Oceania, Agassiz, i862, 1865 .

Sixteen or more tentacles. More than sixteen lithocysts. Four radial-canals. No rudimentary tentacles. No cirri. Hydroid: Campanulina.

Phialucium, Maas, 1905.

Similar to Phialidium, but with permanently rudimentary tentacle-bulbs. Hydroid unknown.

Bl.ACKFordia, Mayer.

Numerous tentacles and lithocysts. Entodermal cores of some or all of the tentacles project inward into the gelatinous substance. Four radial-canals. No cirri. No permanently rudimentary tentacles.

Pseudoclytia, Mayer, igoo.

Five radial-canals, five lips, five gonads. Numerous tentacles and lithocysts. No cirri.

Gastroblasta, Keller, i $883=$ Multioralis, Mayer, 1900 .

Two or more manubria. No cirri. The medusa propagates by fission.

Eucheilota, McCrady, i 857 .

Four or more closed vesicular lithocysts. Four radial-canals. Marginal or lateral cirri. Hydroid: Campanulina (?).

Mrtrocoma $=$ Phialis + Mitrocoma + Mitrocomium + Mitrocomella, Haeckel, 1879.

Similar to Eucheilota, but the lithocysts are contained in open folds of the velum. No entodermal ocelli such as are found in Tiaropsis.

Staurophora, Brandt, $1834=$ Staurostoma + Staurophora, Haeckel, i 879 .

Mouth an open, cruciform, gutter-like slit extending down the four radial-canals.

Subfamily No. 3, EUTIMIN Æ.

With eight adradial lithocysts. Stomach mounted upon a gelatinous peduncle. Four radial-canals.

SAPHENia, Eschscholtz, i 829.

Two tentacles. Numerous cirri.

Eutıma, McCrady, I $857=$ Eutima + Eutimeta + Octorchis + Octorchandra

+ Eutimalphes, Haeckel, 1879 .

Four or more tentacles. Numerous cirri or marginal warts. Four or eight gonads upon the four radial-canals. Hydroid: Campanopsis (Claus, Brooks).

Eutımum $=$ Eutimium + Octorchidium, Haeckel, $\mathrm{I} 879$.

Similar to Eutima, but without cirri. Hydroid: Campanulina(?)

Subfamily No. 4, EIRENIN E.

With more than eight lithocysts. Stomach mounted upon a gelatinous peduncle. Four or six radial-canals.

Phortis, McCrady, I 857 .

Four or more tentacles. No cirri. Four radial-canals. Hydroid: Phortis Brooks.

Irenopsis, Goette, 1886, non Ireniopsis, Mayer, i 894.

Six or more tentacles. Six radial-canals. Six lips. Six gonads.

Eirene, Eschscholtz, $1829=$ Irene + Irenium, Haeckel, i 879 .

Four or more tentacles. Numerous marginal warts or cirri. Four or eight gonads developed upon limited parts only of the four radial-canals. Hydroid: Campanulina (?)

Tima, Eschscholtz, 1829 .

Similar to Eirene, but with gonads upon the entire lengths of the four radial-canals. Hydroid: Campanulina (?) 
Leptomedusæ with otocysts, and with eight or more radial-canals.

Octocanna, Haeckel, i 879 .

Eight radial-canals, $45^{\circ}$ apart. Eight lips. No ocelli. (Is this a young Equorea?)

Octogonade, Zoja, i 896 .

Similar to Octocanna, but the marginal sense-organs have ocelli as well as lithocysts.

Stomoвrachium, Brandt, 1835 = Stomobrachium + Staurobrachium, Haeckel, 1879 .

Eight or more simple, unbranched radial-canals, which arise at equal intervals from the margin of the stomach. Four lips.

Halopsis, A. Agassiz, I863, i 865.

Radial-canals arise in four groups from the four perradial corners of stomach. Four lips.

ÆQuOREA, Péron and Lesueur, $1809=$ Equorea + Rhegmatodes + Mesonema

+Polycanna, Haeckel, 1879 .

More than eight simple, unbranched radial-canals which arise separately from the margin of the stomach. More than four lips. Subumbrella smooth, without gelatinous papilla-like protuberances. Hydroid: Campanulina.

Zygodactyla, Brandt, I 835 ; sensu Agassiz, i862.

Similar to Equorea, but with interradial rows of papilla-like, gelatinous protuberances upon the subumbrella.

ZYGocanNA $=Z$ ygocanna + Zygocannota, Haeckel, 1879.

With bifurcated or branched radial-canals which arise at equal intervals from the margin of the stomach. More than four lips. No peduncle.

Zygocannula, Haeckel, i 879 .

Similar to Zygocanna, but the stomach is mounted upon a gelatinous peduncle.

\section{Order No. 3. TRACHYMEDUSF Haeckel, 1866.}

Medusæ with a marginal velum, and with lithocyst concretions of entodermal origin. With simple uncleft bell-margin.

Family No, I, OLINDIADE.

Some or all of the tentacles project from the sides of the bell, above the margin, and have adhesive disks. Gonads linear, sac-like, or folded, and developed upon the four or six radialcanals. The tentacles arise separately and are not grouped in clusters.

Gonionemus, A. Agassiz, 1862,1865 .

All of the tentacles project from sides of bell in a zone slightly above bell-margin. All have adhesive disks. Four radial-canals. Lithocysts external, on bell-margin. No centripetal canals. Development through an attached hydra stage. (Perkins.)

Cubaia, Mayer, i 894 .

Similar to Gonionemus, but with two sets of tentacles, one arising from the bell-margin and the other set projecting from the sides of the bell, as in Gonionemus.

Vallentinia, Browne, igo2.

Similar to Cubaia, but with lithocysts inclosed within the gelatinous substance of the bell, adjacent to the ring-canal, and on the inner side above the velum. (Is this a young Olindias? )

Olindias, F. Müller, i861.

Similar to Vallentinia, but with blindly-ending, centripetal diverticula from the ring-canal. 
Olindioides, Goto, 1903.

Similar to Olindias, but with six radial-canals (two bifurcated and two simple). Six gonads. Four lips. The exumbrella tentacles project at various levels from the sides of the bell.

Family No. 2, PETASIDÆ Haeckel, 1879.

Trachymedusa with four radial-canals upon which the linear or sac-like gonads are developed. Tentacles without adhesive disks. Four lips.

Petasus $=$ Petasus + Dipetasus + Petasuta + Petachnum, Haeckel, i879.

Tentacles arise at equal intervals, not grouped into clusters. No centripetal canals. Free marginal lithocyst-clubs.

Aglauropsis, F. Müller, i 865.

Similar to Petasus, but the lithocysts are vesicular, and project from the bell-margin between the tentacles.

Craspedacusta, Lankester, $1880=$ Limnocodium, Allman, 1880 .

Tentacles arise singly as in Pctasus and $A$ glauropsis, but the lithocyst concretions are each inclosed in a cavity within the gelatinous substance of the velum on the imner (centripetal) side of the ring-canal. (The medusa lives in fresh water among waterlilies.) The hydroid is devoid of tentacles.

Microhydra, Potts, i 885.

Is possibly identical with Limnocodium, but the mature medusa is unknown. The young medusa has no lithocysts, and it arises by budding from a minute hydroid which has no tentacles.

Meotias, Ostroumoff, i 896.

Tentacles arise at equal intervals, not in clusters. Numerous centripetal, blindly-ending canals arise from the ring-canal.

Gossea, L. Agassiz, 1862.

Tentacles grouped into clusters. No centripetal canals. Lithocyst concretions free or inclosed.

Family No. 3, LIMNOCNIDID Æ.

Numerous hollow tentacles which project singly, not in clusters, from the sides of the bell in a zone slightly above the margin. Tentacles without adhesive disks. Numerous inclosed lithocysts on the exumbrella side of the velum. Mouth a round opening. Gonads developed diffusely in the ectoderm of the stomach-wall. Four (occasionally five or six) radialcanals. Medusa-buds arise from the sides of the stomach, and are set free.

Limnocnida, Günther, i 893 .

Generic characters are those of the family. The only known species is L. tanganjica from the fresh-water lakes of Central Africa, and the Niger liver.

Family No. 4, PTYCHOGASTRID E.

Numerous more or less isolated clusters of tentacles, some of which bear adhesive disks. Numerous free lithocyst-clubs. Eight radial-canals. Four lips. Stomach eight-lobed. These stomacl-lobes are in the radii of the radial-canals, and are bound to the subumbrella hy means of eight mesenterial partitions. The gonads are upon the eight stomach-lobes, and each is more or less divided by the mesentery so there may be eight double (sixteen) gonads.

Ptychogastria, Allman, $1878=$ Pectyllis + Pectis + Pectanthis, Haeckel, 1879 .

The generic characters are those of the family.

Family No. 5, TRACHYNEMIDE.

Trachymedusx with eight simple radial-canals upon which the gonads are developed. No mesenterial partitions in the subumbrella. Tentacles without adhesive disks. Ringcanal simple without centripetal branches. 


\section{Subfamily No. 1, RHOPALONEMIN Æ.}

Trachynemidæ in which the stomach lacks a peduncle.

Rhopalonema, Gegenbaur, i $856=$ Trachynema (young medusa), Gegenbaur, i 854

= Trachynema + Rhopalonema + Marmanema, Haeckel, 1879 .

With eight well-developed radial tentacles, and eight or more small cirrus-like or clubshaped interradial tentacles. All tentacles arise in a single row. Eight gonads localized on the eight radial-canals. Four lips.

Sminthea, Gegenbaur, i 856.

Similar to Rhopalonema, but with only eight tentacles, one at the foot of each of the eight radial-canals.

Homoennema, Maas, i $893=$ Colobonema, Vanhöffen, igo2=Isonema (in part), Maas, 1906.

Similar to Rhopalonema, but the tentacles are all of one sort. No sinall club-shaped or cirrus-like tentacles. Four lips.

Pantachogon, Maas, 1893 (sens. ampl.).

Gonads not localized as in IIomconema and Rhopalonema, but developed diffusely over the radial-canals. Four lips.

Halicreas, Fewkes, I882=Halicreas + Haliscera, Vanhöffen, 1902

$$
\text { =Isonema (in part), Maas, Igo6. }
$$

The mouth is a simple round opening, without four lips. (In all known species the radial-canals and ring-canals are very broad and flat.) Wart-like protuberances may be present upon the sides of the exumbrella. Radial tentacles large, interradial, small. Tentacles arise in a single row.

Botrynema, Browne, igo8.

Similar to Halicreas, but the tentacles are grouped in linear clusters in a single row around the bell-margin.

Crossota, Vanhöffen, igoz.

The tentacles arise in several rows from the bell-margin. Mouth with four lips.

\section{Subfamily No. 2, AGLAURIN $Æ$.}

Stomach mounted upon a peduncle.

Aglaura, Péron and Lesueur, i 809 .

Eight gonads upon the peduncle above the stomach. Sexes separate. Development direct.

Aglantha $=$ Aglantha + Agliscra, Haeckel, 1879 .

Eight gonads upon the subumbrella, or at the turning points of the eight radial-canals between the peduncle and the subumbrella. Sexes separate.

Amphogona, Browne, igo4.

Similar to Aglantha, but medusa is bisexual, four of gonads being male, and four female.

Stauraglaura, Haeckel, i 879.

Four gonads, one upon each alternate radial-canal.

Persa, McCrady, i 857 .

Two gonads on two of the radial-canals, $180^{\circ}$ apart. The six other radial-canals are sterile.

Family No. 6, GERYONID尼.

Trachymedusæ with four or six radial-canals upon which the flat, expanded, leaf-like gonads are developed. Stomach mounted upon a gelatinous peduncle. The ring-canal gives rise to blindly-ending centripetal canals.

LiRıope, Lesson, I843= Liriantha + Liriope +Glossocodon +Glossoconus, Haeckel, i 879 .

Four radial-canals. Four gonads. Four lips. With four primitive, solid, radial, and four solid interradial, and four hollow, flexible, radially-placed tentacles; all twelve of which may be found upon the medusa at one and the same time. Development direct through a free-floating, actinula-like larva.

Geryonia, Péron and Lesueur, $1809=$ Geryones + Geryonia + Carmaris

+Carmarina, Haeckel, 1879 .

Similar to Liriope, but with six radial-canals, six gonads, six lips, etc.; instead of four. 
Order No. 4. NARCOMEDUSE Haeckel, 1879.

Veiled medusæ with bell-margin cleft into intertentacular lappets. With free lithocystclubs, containing concretions of entodermal origin. These medusæe develop from actinula larva either directly or by budding. The bell grows outward from the sides of the body of the actinula, or the medusa-bud, leaving the tentacles stranded in the partially closed-over clefts between the lappets of the bell. The Narcomedusxe are thus medusiform, actinula-like animals, the bell of which is not homologous with that of the Anthomedus $x$ or Leptomedusx.

Family No. I, SOLMARIDA.

Narcomedus $x$ in which the outer margin of the stomach is plain, entire, and without peripheral stomach-pouches. Saccules may, however, arise from the sulumbrella floor of the stomach.

Solmaris $=$ Polycolpa (young) + Solmaris, Haeckel, 1879 .

Without subumbrella saccules. Gonad is a simple annulus in ectoderm of subumbrella floor of stomach.

Pegantha = Pegasia + Polyxenia + Pegantha + Solmoneta (in part), Haeckel, 1879.

With out-pocketings on the subumbrella floor of the stomach. The gonads are developed in these subumbrella saccules.

Family No. 2, ÆGINID E, sens. ampl.

Narcomedusæ in which the central stomach gives rise to simple or cleft marginal outpocketings in the radii of the tentacles.

Cunantha, Haeckel, i8 89 .

Four tentacles. Four peronial strands in the tentacular radii. Four simple, uncleft, peripheral stomach-pouches in the radii of the tentacles. This "genus" is probably only a young stage of Ægina.

\#gINA, Eschscholtz, 1829=Cunarcha + Egina + Solmundus, Haeckel, 1879 .

Four tentacles. Four peronial strands. Four cleft (= eight peripheral) stomach-pouches, outer margins of which may be still further divided.

Solmundella $=$ Eginell $a+$ Solmundella, Haeckel, 1879.

Two tentacles. Four peronial strands. Four cleft (= eight peripheral) stomach-pouches. An apical (exumbrella) sense-organ is present in larva, but does not persist in adult. Derived from Egina by the disappearance of half of its tentacles.

Hydroctena, Dawydoff, 1903.

Two tentacles. No peronial strands. Two simple, uncleft stomach-pouches in the tentacular radii. There is an apical (exumbrella) sense-organ consisting in a ciliated pit containing two lithocyst-clubs. A median axial canal extends upward from the stomach to the bottom of the sensory pit.

Cunoctantha, Haeckel, i8 89.

Eight tentacles. Eight peronial strands. Eight simple, uncleft stomach-pouches in the tentacular radii.

EgINura = Cunoctona + Eginura, Haeckel, 1879 .

Eight tentacles. Eight peronial strands. Eight cleft (=sixteen peripheral) stomachpouches. The outer margins of these pouches may be still further divided so as to give thirty-two marginal pouches.

Æginopsis, Brandt, 1835 .

Four tentacles. Eight peronial strands. Eight cleft (=sixteen peripheral) stomachpouches. Derived from Eginura by the disappearance of half of its tentacles.

Cunina, Eschscholtz, 1829.

Nine or more tentacles, and an equal number of peronial strands. Peripheral stomachpouches simple, uncleft and equal in number to the tentacles, in the radii of which they are developed. With otoporpæa above the sense-clubs. 
Solmissus, Haeckel, i879.

Similar to Cunina, but without otoporpæ.

Cunissa $=$ Cunissa $+\not$ Eginodorus, Haeckel, 1879 .

Nine or more tentacles, and the same number of peronial strands. Peripheral stomachlobes twice as numerous as the tentacles, being cleft in the tentacular radii.

Æginodiscus, Haeckel, i 879.

Eight tentacles, sixteen peronial strands. Sixteen cleft (=thirty-two peripheral) stomachpouches.

\section{MEDUSÆ MILLEPORINÆ.}

Under this heading we may place the degenerate, free-swimming medusa of Millepora. They have no velum and are thus separated from the veiled medusx or Craspedota. Not only is the velum absent, but the medusa is also devoid of a peripheral canal system and of marginal tentacles.

The medusa Milleporine and Craspedota are doubtless derived from a common ancestral phylum, but have departed widely, one from the other, so that the Craspedota are constantly characterized by a diaphragm-like membrane, or velum, which partially closes the opening of the bell-cavity at the tentacular margin; whereas this structure is absent in the Milleporina.

The only known forms of Medusæ Milleporina are those of Millepora.

\section{Millepora alcicornis (Medusa).}

Millepora (medusx), Hickson, 1900, Proc. Roy. Soc. London, vol. 66, p. 3, figs. I-I0.-Duerden, 1899, Journal of the Institute of Jamaica, March, 1899.-Hickson, 1906, Cambridge Natural History, vol. I, Colenterata, P. 259, fig. 129.

Each medusa lies in an ampulla, or cavity, of the corallum, and is attached by a narrow stalk to the innermost part of the wall of the cavity. The bell is 0.4 to $0.6 \mathrm{~mm}$. in diameter and is devoid of radial or circular canals or velum. It consists of a median lamella of entoderm covered on the exumbrella and subumbrella sides by an ectodermal epithelium. There are no tentacles, but instead there are 4 or 5 swollen masses of nematocysts $90^{\circ}$ or $72^{\circ}$ apart, near the bell-margin, but projecting from the sides of the exumbrella. The manubrium is greatly swollen, and fills the greater part of the bell-cavity. A mouth may (or may not?) be present. There are 1 to 5 , usually 3 or 4 , large ova in the ectoderm (?) of the manubrium. The central entodermal cavity of the manubrium consists of an axial chamber which of ten gives rise to 4 perradial pouches which project into the entoderm of the manubrium, and end blindly. In some medusæ these pouches do not exist, in other specimens there are but 2 or 3 , but probably the most common condition is that of 4 pouches $90^{\circ}$ apart. The fully-developed ova occupy positions alternating with the pouches. Dr. Duerden observed that these medusæ are set free and swim slowly about with infrequent feeble pulsations. Soon after liberation the ova begin to be discharged into the water and the medusa dies after 5 or 6 hours of life, having discharged all of its eggs.

The Pacific millepores also produce medusx (see Hickson, S. J., 1891, Quart. Journ. Micros. Sci., 1898; Proc. Zool. Soc. London; and Philosoph. Trans. Roy. Soc. London, B, vol. I79). 


\section{VEILED MEDUS/E.}

\section{MEDUSE CRASPEDOT E Gegenbaur, 1856.}

Ciryplocarpe, Escнscholtz, 1829 , Syst. der Acaleplix.

Gymnophalma, Forвzs, 1848 , British Naked-eyed Medusa.

Craspedota, Gegen Bau R, 1856 , Zeit. für wissen. Zool., Bd. 8, 1?. 217.

Craspedot 2 , Ha eckit, 1879 , Syst. der Medusen.-MAAs, 1893 , Ergeb. der I'lankton-Expredition, Bd. 2, K. C.

\section{CHARACTERS OF THE VEILED MEDUSA.}

Medusa with a velum or diaphragn which partially closes the marginal opening of the hell-cavity; with ectodermal gonads (i. e., the sexual products when ripe are commonly found in the ectoderm). Without gastric filaments. With a double marginal nerve-ring, one above and one below the velum. Development either direct or through alternation of generations from hydroids.

\section{Order ANTHOMEDUSE Haeckel, 1879.}

Oceanide (in part), Gegenbaur, 1856 , Zeit. für wissen. Zool., Bd. 8, PP. $218,219$.

Tubularia (in part), Agassiz, L., 1862, Cont. Nat. Hist. U. S., vol. 4, p. 337.

Anthomedusa, Haecker., 1879 , Svstem der Medusen, p. 3.-Vaviörfen, 1891 , Zoologischer Anzeiger, Bd. 14 , Pp. 439, 442.Mass, 1905, Craspedoten Medusen der Siboga Expedition, p.5; 1897, Mem. M. C.Z. at Harvard Coll., vol. 23, p.9.Hartlaub, 1892, Nachrichten kgl. Gesell. Wissenschaften Göttingen, p. 17; 1897, Nordisches Plankton, Nr. 12, P. 4.Hargitt, 1905, Bull. U. S. Bureau of Fisheries, vol. 24, p. 29.

\section{CHARACTERS OF THE ANTHOMEDUSA.}

Hydromedusa in which the gonads are contained within the ectoderm of the manubrium. There are no marginal otocysts or sensory clubs. The hydroids are of the Tubularian order. We may distinguish three families:

(I) Codonida with simple tentacles, and with the gonad in the form of one or more rings encircling the manubrium. No oral tentacles.

(2) Cladonemid $a$ with feathered or branched marginal tentacles. Gonads ring-like, or more or less separated. With or without oral tentacles.

(3) Oceanida with gonads confined to the interradial or adradial sides of the manubrium and separated one from another in the meridians of the principal radii. With or without oral tentacles. With unbranched marginal tentacles.

The bell in the Anthomedusæ is without marginal lappets, and usually dome-shaped. The tentacles arise from the bell-margin, not from the sides of the bell. The velum is simple and annular, and is provided with circular muscles serving to produce the periodic contractions of the bell. The bell-margin is simple and entire, and there are no otocysts, otolithclubs, or club-shaped sense-organs. Marginal cirri rarely present. In the young medusa the exumbrella is more or less besprinkled with nematocysts, but these usually disappear or become less conspicuous in the adult; although definite nematocyst tracts of ten persist over the exumbrella, this being far more commonly seen in Anthomedusie than in other orders of Hydromedusx.

The tentacles usually arise singly from the bell-margin, and are usually simple and unbranched. Ectodermal ocelli are often found upon the tentacle-bulbs, and Romanes showed that in Sarsia these subserved a visual function, and that the medusa was strongly attracted by rays between the red and violet. The main shafts of the tentacles are thickly covered with nematocysts, which may be mounted upon filaments or converted into adhesive organs, as in the Cladonemidx. The tentacle-bulbs are hollow, and connected with the gastrovascular system of the medusa.

The radial-canals are usually simple, but in the Tiarine they often give rise to short, blindly-ending diverticula, which may be glandular in function. Glandular swellings are found in the walls of the radial-canals of Lymorea alexandri, and probably in those of Dysmorphosa dubia and Slabberia halterata. A ring-canal is present in all genera excepting 
Pachycordyle and the Williadi, where it has become filled with a more or less solid core of entoderm cells. The ring-canal is usually simple, and rarely gives rise to blindly-ending diverticula.

The proboscis, or manubrium, is usually flask-shaped, and the mouth in most of the Codonidx is a simple round, or cruciform, opening, but in the Oceanid $x$ it is surrounded by lips which are more or less folded or crenated. Oral tentacles are found in the Margelinx, and in some Cladonemidx. The stomach is often mounted upon a solid, conical peduncle,

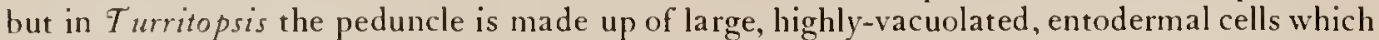
constitute the walls of the proximal parts of the 4 radial-canals. The medus $æ$ are carnivorous, feeding upon crustacea, fishes, and other medusæ or Siphonophoræ.

In the Codonidæ the gonad encircles the manubrium in a ring-like manner, the mature genital products being found in the ectoderm on the sides of the stomach. In the genus Slabberia there are 2 or more of these genital rings. In the Oceanidx, however, the gonads are restricted to the interradial, or adradial, sides of the stomach. Haeckel, 1879 , believed that they were radial in position, corresponding with the radial-canals, but Vanhöffen, 1891 , showed that this was an error, for they are commonly interradial, or on both sides of each radial line. In Eleutheria, according to Hartlaub, and possibly in other Cladonemidx, the genital products are developed in the ectoderm of a peculiar brood-pouch, which is not connected with the stomach, but is invaginated from the general ectodermal wall of the subumbrella. In the Williadi and in Nemopsis the radial corners of the stomach extend outward along the radial-canals, and the gonads develop upon the sides of these pouches. Eleutheria is successively hermaphroditic, either sex preceding, but in all other Anthomedusæ the sexes are separate. The mature genital products are usually found in the ectoderm, although they often originate in the entoderm. The eggs are cast out into the water by the breaking down of the ectodermal walls of the manubrium, but in some species of Bougainvillia, or in Margelopsis, or Hybocodon, the larva may be retained until they have passed into the planula or even into the actinula stage. None of the Anthomedusæ are known to develop directly from the egg into medusæ, hut the hydroid stages of many genera remain unknown. Wherever the sexual development is known it is through hydroids of the Tubularian order, in which the medusx bud out separately and are not protected in special capsules or sporangia.

Asexual development of medus $x$ is found in Codonidx, in medus $x$ of the genera $H y b o-$ codon, Slabberia, and Sarsia, and in the Oceanida in the genera Cytais, Dysmorphosa, Bongainvillia, Rathkea, and in the Williadi. In some of the Williadi the medusa-buds are borne upon stolons which arise either from the radial corners of the stomach, or from the forks of the radial-canals. In the case of Sarsia and Hybocodon the budding medusæ develop as in hydroids, the entoderm of the parent medusa forming the entoderm of the budded medusa, and the ectoderm of the bud being formed from the ectoderm of the parent. In Rathkea, Chun, 1895 , discovered that the budding medusa is formed out of the ectoderm of the parent, although a connection is finally established between the entoderm of the bud and that of the parent a short time before the hud is set free. In Bougainvillia niobe, on the other hand, I find that the budding medusa is formed entirely from the ectoderm of the parent, no connection being established between the entoderm of the hud and that of the parent. In the genus $N$ iobia the tentacle-bulbs develop into medusæ and are set free.

The majority of the Anthomedusx undergo a considerable development while swimming freely in the water. In some cases, however, the medusa may, at times, become mature and even discharge their genital products while still attached to the hydroid. This is seen in Pennaria, Podocoryne, Sarsia, and Stylactis. Among the most short-lived medusæ are those of Pachycordyle, which have neither tentacles, marginal sense-organs, nor radial nor circular canals.

All of the Anthomedusæ are inhabitants of salt water. They are rare in the open ocean far from land, but are abundant along coasts, especially along continental shores, and many of them thrive in harbors where the water may be more or less brackish. They appear to be the simplest, and phylogenetically the oldest, of the Hydromedusa. 
Family CODONIDE Haeckel, 1879 , sens. amend.

Sarsiade (in part), Forbes, $18{ }_{4} 8$, British Nakej-eyed Medusa, p. 55.

Sarsiada + Tubularida, McCRadv, $185 i$, Gymn. Charleston Harbor, p. 21.

Sarsiade (in part) + Tubularidz+ Pennaride (in part), A Gassız, L., 1862, Cont. Nat. Hist. U. S., vol. 4, Pp. $3.39,342$.

Sarsiada + Orthocorynida + Tubularide + Pennarida, Agassiz, A., 1865, North Amer. Acalephx, pp. 175. 183, 186, 189.

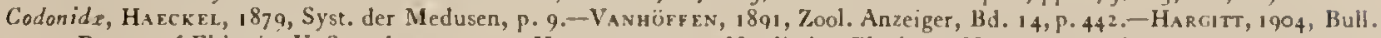

Bureau of Fisheries U.S., vol. 24, p. 29,-HartlacB, 1907 , Nordisches Plankton, Nr. 12, pp.5, 6.

Codoninat Corynida+Tubularida, von LendenfeLD, 1884, Zool. Anzeiger, Bd. 7, PP. 446, 447 .

\section{FAMILY CHARACTERS.}

Anthomedusx in which the gonad is ring-like and encircles the manubrium. Mouth without oral tentacles or prominent lips. The 4 to 6 radial-canals are simple and unbranched. When ocelli are present they are found upon the outer sides of the tentacle bulbs. There are no marginal otocysts. The tentacles are neither branched nor feathered.

Medusa of the genera Sarsia, Steenstrupia, Ectopleura, Pennaria, Amalthara, Trichorhiza, Hybocodon, Hydrichthys, Corynitis, and Margelopsis are known to develop asexually through alternation of generations from Tubularian hydroids. Direct development of medusæ from the egg is unknown in this family, although medusæ are budded asexually from the manubrium of some species of Sarsia, from the basal bulbs of the tentacles of $H$ ybocodon, and from those of Sarsia. Actinula larvæ are set free from the manubrium of Margelopsis and Hybocodon.

Haeckel, 1879 , considered the presence or absence of an apical projection upon the bell, and the presence or absence of an axial canal extending upward from the stomach into this apex, to be a criterion for the separation of genera. It should be borne in mind, however, as was pointed out by Vanhöffen, 1891 (Zool. Anzeiger, pp. 439-446), that the young medusa often lack an apical projection and axial canal, whereas the mature individuals possess these characters. They are also highly variable in development. We have therefore considered these characters to be of specific but not generic value.

A natural classification of the Codonidx can not be based upon the characters of the medusæ alone, for the medusæ of Pennaria and Amaltha are similar, while their hydroids are distinct, the former being Pennaria and the latter Corymorpha, and an equally remarkable condition is presented by hydroids belonging to the two genera Syncoryne and Stauridia, both of which give rise to medusx belonging to the genus Sarsia. This peculiar case is still further complicated by the fact that at least one species of Stauridia hydroid gives rise to a Cladonema medusa.

In $H y d r i c h t h y s$ we meet with an extraordinary case of parasitism or commensalism of the hydroid, and in Margelopsis we find a free-floating hydranth, recalling the hypothetical ancestral form of the Siphonophoræ. Margelopsis is also interesting in that its medusæe form, apparently, a connecting link between the Codonidx and the Bougainvillex, although they are more closely related to the Codonida than to the last-named family. Indeed their resemblances to the Bougainvillex are probably due to mere parallelism and not to bloodrelationship.

The Codonida may conveniently be divided into two subfamilies, as follows:

(1) Sarsiana, with simple, unbranched, marginal tentacles, which arise singly from the bell-margin. One or all of the tentacles may be degenerate or absent.

(2) Margclopsine, with marginal tentacles grouped into clusters. 
The following table defines the characters of the genera of Codonidx.

\section{Subfamlit No. 1. Sarsianze.}

With simple marginal tentacles which arise singly from bell-margin. One or all of the tentacles may be rudimentary or absent.

Tribe I. ANEMIDI.

Without tentacles or chymiferous canals.

l'achycordyle, Weismane, 188 3 ; Hargitt, 1904=Parzanenul (?) Marer, 1904.

Medusa without tentacles, marginal sense-organs, radial-canals or circular canal. Hydroid: Pachycordyle, Wessmann.

Tribe II. Amalthiadi.

The hydroid is Corymorpha. Meclus $x$ have 4 radially placed, rudimentary tentacles and 4 radial-canals.

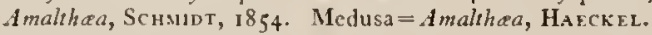

With 4 rudimentary tentacles, 4 radial-canals, and ring-canal. Genital products on manubrium. Hydroid: Corymorpha.

Tribe III. Pennaridi.

Medusæ similar to those of Tribe II, but hydroid is Pennaria.

Pennaria, Oken, 1815; Goldfuss, 1820 .

With 4 rudimentary tentacles, 4 radial-canals, and ring-canal. Genital products within manubrium. Hydroid: Pennaria.

Tribe IV. PSEudorennarid 1.

Medusa similar to those of Tribes II and III, but hydroid is Trichorhiza.

Trichorhiza, Russelz, 1906.

Medusa similar to Pennaria, but hydroid is Trichorhiza.

Tribe V. EupHysids.

With small or rudimentary tentacles situated at bases of all but one radial-canal, and with one or more well-developed tentacles situated at base of remaining radial-canal. Bell may or may not possess an apical projection, or an axial canal extending into it from stomach-cavity.

Steenstrupia, Forbes, $1846=$ Euphysa, Forbes, 1848 ; Euphysora, MaAs, 1905 .

The bell is radially symmetrical and the 4 radial-canals are all of equal length. I long and 3 short tentacles. Hydroid: Corymorpha.

Hybocodon, L. AGASS1z, $1862=$ Amphicodon, HAECKEL, I 879 .

The bell is asymmetrical. One of the 4 radial-canals is long, the one opposed to it short, and the two other canals of intermediate length. One long tentacle arises from the base of the long radial-canal, while the other 3 tentacles are short In old medusæ of Hybocodon one is apt to find 2 or more tentacles at the base of the long radial-canal, and the medusa. is in the Amphicodon stage. Hydroid: Hybocodon.

Microcampana, Frwhes, 1889 .

With 6 radial-canals and 6 tentacles, one of which is well-developed and 5 are rudimentary. Hydroid unknown.

Tribe VI. Dicononidi.

With 2 well-developed, diametrically opposite tentacles, and 2 rudimentary tentacles. With or without an apical projection and with or without axial canal extending upward from the stomach into apex of bell.

Dicodonium, HaEckel, 1879 .

With 4 simple radial-canals and 4 radially placed tentacles; 2 of the tentacles are long, and 2 short. Gonad is ring like and surrounds stomach. No lines of nettling cells over exumbrella.

Tribe VII. Sarsiadi.

Bell radially symmetrical. With 4 equally-developed, unbranched, marginal tentacles. With or without an apical projection, and with or without an axial canal extending upward from stomach into apes of bell. (1) The manubrium is encircled by a single ring-like gonad. (2) With 2 or more ring-like gonads upon the manubrium.

Sarsia, Lesson, $1843=$ Syndictyon, A. Agassiz, 1862; Codonium, Hatckel, 1879.

Manubrium slender and tubular. Each tentacle-bulb bears an abaxial, ectodermal ocellus. Hydroid: Syneoryne. Also Stauridia.

Hydrichthys, Fewkes, 1888.

Medusa similar to Sarsia, but without ocelli upon the tentacle-bulbs. Hydroid: Hydrichthys.

Encodonium, Hartlaub, 1907.

Medusa similar to Sarsia, but stomach is mounted upon a gelatinous peduncle, and tentacles end each in a knob.

Ectopleura, L. Agassiz, 1862.

8 longitudinal lines of nematocysts extend from bases of tentacles to apex of bell. Hydroid: Fctopleura.

Corynitis, MCC RADY, 1857 .

$M$ anubrium cruciform in cross-section, and bound to the 4 radial-canals by hollow mesenteries. 4 radially placed marginal tentacles which are covered with wart-like clusters of nematocysts. Their basal bulbs bear ocelli. Hydroid: Syncoryne.

Slabberia, Forres, $1846=$ Dipurena, MCCRADY, 1857. Dipurena + Bathycodon, HaECkEl.

Similar to Sarsia, but with two or more ring-like gonads upon the manubrium. Hydroid: Syncoryne.

\section{Subamily No. 2. Margelopsine.}

With 4 radially-placed clusters of marginal tentacles. No oral tentacles. Gonads ring-like, and encircling the manubrium. Margelopsis, Hartlaub, 1897 .

Marginal tentacles are grouped in 4 radially-situated clusters. Gonad ring-like, and surrounds manubrium. No oral tentacles, mouth is a simple round opening. Medusæ develop by budding from a free-floating hydranth, Margelopsis. This interesting genus recalls the Bougainvillidi in its radially situated clusters of marginal tentacles. It resembles the Codonide in its ring-like gonad, and in the absence of prominent lips and oral tentacles.

Pelagohydra, Dendy, ig03.

Medusa similar to Margelopsis but hydroid is Pelagohydra, and differs from hydroid of Margelopsis in that tentacles arise at irregular intervals from the sides of the hydranth and are not arranged in definite verticils as in Margelopsis. $\mathrm{H} y$ droid is pelagic. 


$$
\text { - }
$$


Plate 1.

Fig. I. Pachycordyle degeneratus, male. Nassau Harbor, Bahama Islands, July 19, 1903.

Fig. 2. Budding hydranth of Pennaria tiarella with female medusa-bud still attached. Agassiz Laboratory, Newport, Rhode Island, July 5, 1895. Found attached to eel grass in shallow water.

Fig. 3. A recently liberated male medusa of Pennaria tiarella. Agassiz Laboratory, Newport, Rhode Island, July, 1895.

Fig. 4. Hydroid stock of Pennaria tiarella, natural size. Agassiz Laboratory, Newport, Rhode Island, July, I 895.

Fig. 5. Pennaria tiarella. From the coral reef at Tortugas, Florida, May 7 , I905.

Fig. 6. Stcenstrupia virgulata. From a drawing made from life by Dr. Alexander Agassiz at Nahant, Massachusetts, August 21, 1862.

Fig. 7. Steenstrupia rubra, male. Oregon Inlet, Pamlico Sound, North Carolina, November 12, 1904.

Fig. 8. Hybocodon forbesii. Tortugas, Florida, May 25, 1905.

Fig. 6, from a drawing by Dr. Alexander Agassiz.

Figs. I to $5,7,8$, from life, by the author. 


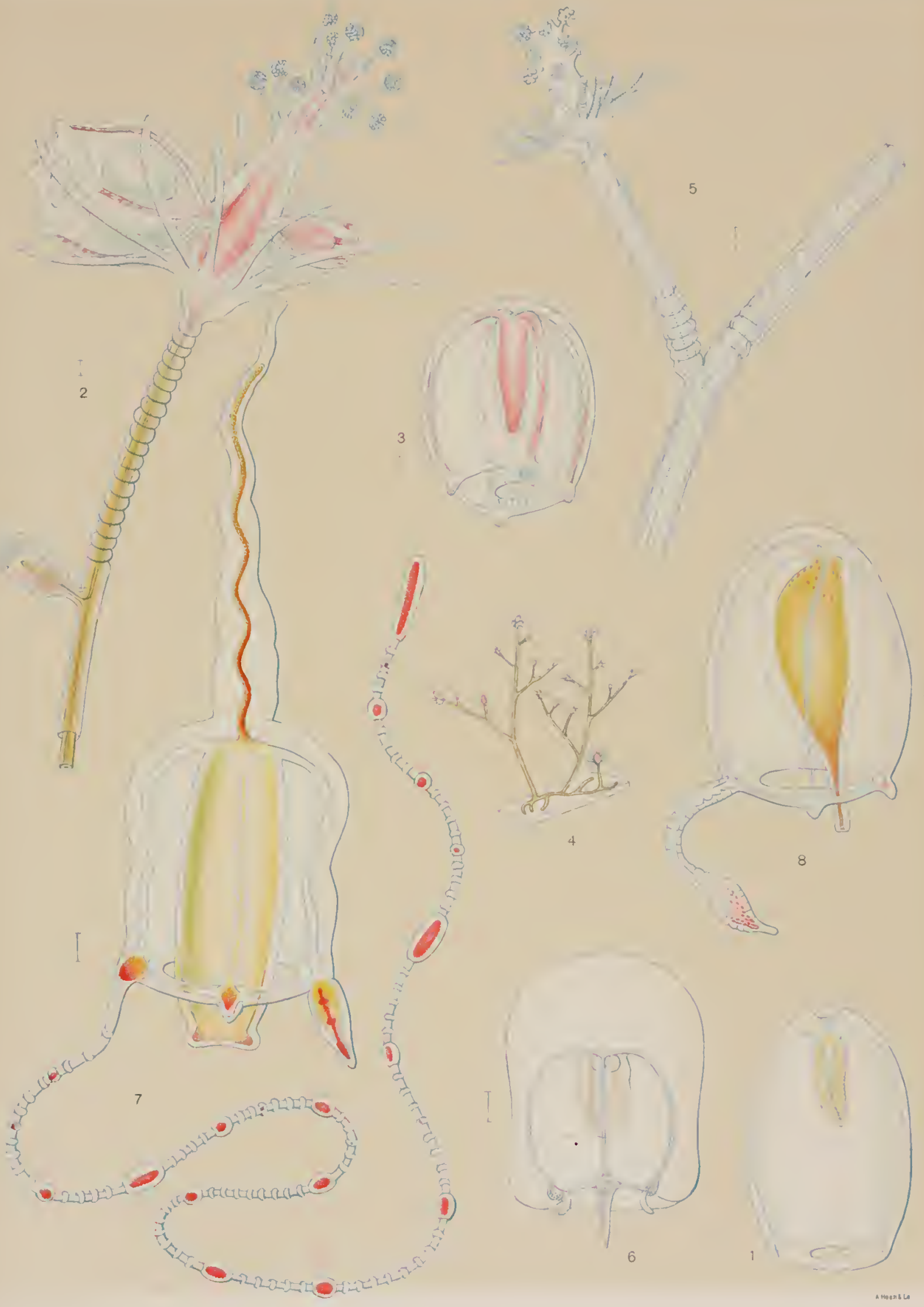





\section{DESCRIPTION OF GENERA AND SPECIES OF ANTHOMEDUSÆ.}

Genus PACHYCORDYLE Weismann, I883.

Pachvordyle, Wismanx, 1883, Entstehung Sexualzellen Hydromedusen, Pp. 87, 217. -11arcitr, 1904, Mitih. 7.ool. Siation Neapel, Bd. 16, p. 553

Parzanemus, Mayer, 1904, Mem. Nat. Sci. Museum BrookIyn Institute Arts and Sci., vol. 1, No. 1, p.6.

GENERIC CHARACTERS.

Codonida without tentacles, radial-canals, or circular vessel. Manuhrium surrounded by a ring-like gonad. The hydroid-stock is Pachycordyle.

Except the medusx of Millepora, these are the most degenerate and short-lived of the free-swimming Hydromedusx. They are even more degenerate than are the medusx of Corymorpha and Pennaria, and may be compared with Eucopella (R. von Lendenfeld, $188_{3}$.

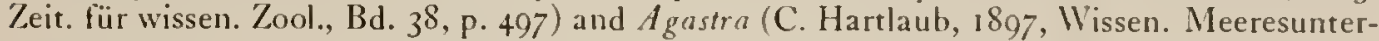
such. Biologisch. Anstalt auf Helgoland, Neue Folge, Bd. 2, Heft 1, Abt. 2, p. 504, taf. 22. figs. 5, 8-10). In these last-named medusx we find neither manubrium nor marginal tentacles, but there are 8 otocysts and a velum, and the radial and circular vessels are well developed.

\section{Pachycordyle weismanni Hargitt.}

Pachycordyle aveismanni, Hargitт, 1904, Mitth. Zool. Station Neapel, Bd. 16, Heft 4, p. 553, plate 21, figs. 1-8.

(?) Pachycordyle napolizana, Wrisinann, 1883 , Die Entstehung der Sexualzellen bei den Hydromedusen, Jena, pp. $87,217$.

Medusa pyriform, $2 \mathrm{~mm}$. high, $1.3 \mathrm{~mm}$. wide. Tentacles and marginal sense-organs lacking. No radial-canals. Ring-canal a mere fissure with vestiges of an entodemal lining near the margin. Velum narrow, with a small opening. Manubrium large, conical, and without a peduncle. Ripe ova are in the entoderm, and are discharged very soon after medusa is liberated. Mouth lacking. Manubrium orange or dark-brown, other parts colorless. The medusa swims with a short, jerky motion, but lives only one or two hours.

The hydroid is found in the Bay of Naples growing upon the shell of Fusus rostratus. The colony arises from a delicate, reticulated hydrorhiza. Hydrocaulus sparingly branched, 3 to $8 \mathrm{~mm}$. high. Perisare dull yellowish-brown, not extending beyond base of the hydranth. Hydranths club-shaped, with subconical hypostome. 8 to 16 irregularly arranged filiform tentacles, delicate and thread-like when expanded. Body of hydranth orange or reddish, hypostome whitish. Not more than 2 or 3 medusa-buds are borne on the side of the stem of each budding polyp. Occasionally the medusa-buds develop on the side branches, more commonly on the main stems. The ova originate in the entoderm where they remain until discharged into the water from the manubrium of the medusa. This species may possibly be the female form of Weismann's Pachycordyle napolitana. On Weismann's lydroid, however, there were no free medusx, only sessile gonophores. All of Weismann's specimens were males, while Hargitt's were females, and it is possible, as Hargitt states, that the females only give rise to frec-swimming medusx.

\section{Pachycordyle degeneratus.}

Plate I, fig. I.

Parranemus degeneratus, Mayre, 1904, Memoirs Nat. Sci. Muurum Brooklyn Institute of drts and Sci., vol. 1, No. I, P. 6, plati 3 , fig. 22 .

Bell thin-walled, about $0.75 \mathrm{~mm}$. high and $0.3 \mathrm{~mm}$. in diameter. Bell-walls quite rigid. velum powerful and well developed. There are neither tentacles, radial-canals, circular vessel, nor marginal sense-organs. Manubrium spindle-shaped, and about a third as long as height of bell. Fluids within the stomach-cavity are maintanied in rapid motion, apparently through the action of cilia. Near aboral end of bell is a deep conical cicatrice which apparently marks the place of last connection between the medusa and its hydroid stock. Bell is translucent and milky in color, while manubrium is cream-colored. Only 5 specimens, all males, were found in Nassau Harhor, Bahamas, on the nights of July is and 19, 1903. 
They swam actively in arcs of circles, but all died early in the morning although maintained in large glass dishes filled with pure sea-water. They appeared to be mature, for sperm was discharged constantly from the sides of the manubrium.

The hydroid is unknown, and possibly the medusa may not belong to the genus Pachycordyle, though in the medusa stage it conforms with the generic character of the medusx which are set free from Pachycordyle weismanni of Naples.

\section{Genus AMALTHEA Schmidt, 1854.}

Corymorpha (hydroid), Sars, M., 1835 , Beskriv og Jagttagelser, p. 7 .

Corymorpha (medusa and hydroid), Srennstrup, i8 54 , Vidensk. Meddel. Nat. For. Kjöbenhavn, p. 46.

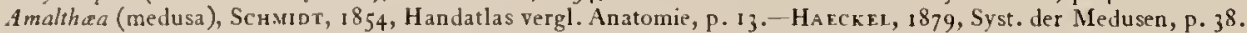

Amalthoa, Allman, 1872 , Monog. Tubularian Hydroids, p. 393.-Loman, 1889, Tijdschrift, Nederland. Dierk. Vereen, Ser. 2, Deel. 2, p. 270.

Corymorpha, Hartlaub, 1905, Zoolog. Jahrb., Abth. Syst., Suppl. 6, p. 543; 1907, Nordisches Plankton, Nr. 12, p.75.

\section{GENERIC CHARACTERS OF THE FREE MEDUSA.}

Codonidæ with 4 rudimentary tentacle-bulbs, 4 radial-canals, and a ring-canal. Hydroid is Corymorpha, but distinguished by the character of its medusæ. The majority of species of Corymorpha hydroids do not give rise to free-swimming medusx. Hydroid of Amalthea might therefore be called Amalthaa. The medusx of Amaltha a resemhle those of Pennaria, but the manubrium is usually longer, and extends beyond the velar opening.

Hartlaub, 1907, includes the medusæ of Steenstrupia, Euphysa, and Amalthaa in the genus Corymorpha, for they all arise from identical hydroids; while the medusæ differ as follows: Steenstrupia, 3 short, and I long tentacle, and with an apical projection and axial canal above the stomach. Euphysa, similar to Steenstrupia, but without an apical projection or axial canal. Amalthera with 4 rudimentary tentacles.

\section{Amalthæa sarsii Allman (Medusa only).}

Corymor pha sarsii, Ste enstrup, I854, Vidensk. Meddel. Naturhist. For. Kjöbenhavn, p. $4^{8}$.-Bonnevif, i 898 , Zeit. für wissen.

Zool., Bd. 43, p. 476.-Hartlavr, 1907, Nordisches Plankion, Nr. I2, p. 86, fig. 82.

Amalthea sarsii, Aleman, i 87 I, Monog. Tubularian Hydroids, p. 393.-Haecket, 1879, Syst. der Medusen, p. 38.

(?) Amalthio amebigera, Ha fckre, Ibid., p. 38, taf. I, figs. 10, it.

It is not certain that this hydroid gives rise to free-swimming medusæ, though when artificially set free the medusæ swim about actively.

The bell of the attached medusa-bud is elongate with a subconical basal apex and with fairly thick bell-walls. It is $4 \mathrm{~mm}$. high. There are usually 4 equally developed rudimentary tentacles, but occasionally one of the tentacles is longer than the others. Velum well developed. 4 straight, slender radial-canals. Manubrium spindle-shaped. Mouth a round opening studded with nematocysts. In the male the manubrium projects one-third its length beyond velar opening, but in the female it is shorter and the mouth is at the level of velar opening. Ova are few in number. When immature they are amoboid, but when older they become spherical and project over the surface of the gonad, attached by short pedicels. The gonad encircles the entire manubrium. Manubrium straw-yellow, tentacle-bulbs light-red. Found off coast of Norway. Hydroid: Corymorpha sarsii.

\section{Amalthæa uvifera Schmidt.}

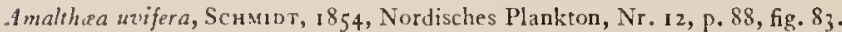

Corymor pha uvifera, Hartlaub, 1907, Handatlas der vergleich. Anatomie, p. 13, taf. 9, fig. 2.

This medusiform gonophore is not known to be set free. It is borne upon branched stolons which arise from the sides of the polypite above the basal circlet of long tentacles. Each stolon is tree-like and gives rise to $3^{\circ}$ to 40 grape-like medusa-buds, so that each hydroid gives rise to more than 100 buds in various stages of development.

In the medusa-bud (when about to be set free ?) there are 4 large globular, rudimentary tentacle-hulbs. The bell is higher than a hemisphere, with walls thin at apex. Manubrium 
spindle-shaped, as long as the depth of the bell-cavity. The hydroid is Corymorpha wifera, found at Loppen Island, about ro miles from Hammerfest, at a depth of about I fathom.

\section{Amalthæa vardöensis Loman.}

Amalhera vardöensis, Loman, 1889, Tijdschr., Nederland. Dierk. Ver., Ser. 2, Deel. 2, p. 271, text-fig. 5, taf. 13, figs. 1-9, 15 .

Hydroid about $50 \mathrm{~mm}$. high. The thin, transparent perisarc extends only over lower half of stem. The terminal polypite is sharply set off from the stem by a constriction at its base. Nearly 50 large rentacles in basal circlet at wide base of polypite. Over 100 very short tapering oral tentacles in 7 to 9 circlets. I 6 to 20 peduncles arise in a circlet from the sides of the polypite between the basal and oral tentacles. Each peduncle bears a number of medusabuds, which have 4 radial-canals and 4 equally developed, very short tentacle-bulbs. The hydroid is translucent rose-colored. Found in Busse Sound at Vardö, $71^{\circ}$ N. lat., Norway. For details of histology, see Loman.

\section{Amalthæa (?) Hybocodon (?) januarii Steenstrup.}

Corymorpha jonuarii, Steenstrup, 1854 , Vidensk. Meddel. Nat. For. Kjöbenhavn, p. 46.-SArs, 1861 , Annals and Mag. Nat. Hist., vol. 8 , p. 356 .

Amalthea januarii, Altman, 1871, Monog. Tubularian Hydroids, p. 394.-Haecket, 1879, Syst. der Medusen, p. 39.

Described by Steenstrup from a single imperfect hydroid found in the harbor of Rio Janeiro, Brazil. The hydrocaulus is about $150 \mathrm{~mm}$. long and $8 \mathrm{~mm}$. wide. About 80 tentacles in the proximal circlet, and these a re about $50 \mathrm{~mm}$. long. The oral circlet was imperfect and can not be described. There were about 40 branched peduncles above the basal circlet of tentacles. These bear numerous medusa-buds having 4 equal tentacle-bulbs, but oblique margins. The free medusæ are unknown.

\section{Genus PENNARIA Oken, I8I5.}

Pennaria (in part), OKen, 1815, Lehrbuch der Naturgesch., Bd. 1, p. 94.

Pennaria (hydroid), Goldruss, 1820 , Handbuch der Zoologie, p. 89.

Pennaria (medusa), MCCRady, 1857 , Gymn. Cliarleston Harbor, p. 50.

Pennarjat Halocordyle, Allman, 1871 , Monog. Tubul. Hydr., pp. 363,368 .

Pennaria, Agassiz, L., 1862, Cont. Nat. Hist. U.S., vol. 4, p. 278.-Acassiz, A., 1865, North Amer. Acal., p. 187.-Hartlalla, 1907, Nordisches Plankton, Nr. 12, P. 72. Prescles, 1903, Archiv. Entwick.-mech., Bıl. 14, p. 55 (regeneration).

Pennaria, Agassiz and Mayer, 1899, Bull. Mus. Coinp. Zool. at Harvard Collo, vol. 32, p. 161.-Clarkr, 1907, Mem. Museum Comp. Zool. Harvard Coll., vol. 35, p. 6.

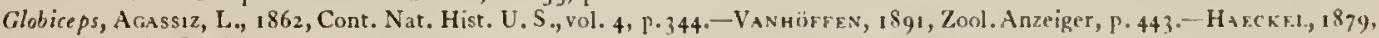
Syst. der Medusen, p. 39.

Globiceps (hydroid), Ayers, 1852 , Proc. Boston Soc. Nat. Hist., vol. 4, p. 193.

Fucoryne (liydroid), L.f.idy, 1855, Journ. Acall. Nat. Sci. Phila., ser. 2, vol. 3, part. 2, p. 139, plate 10, figs. 1-5.

The rype-species of this genus is Pennaria disticha of Goldfuss, 1820 , from the Mediterranean. Oken's "Penmaria" is wholly indefinite, including as it does Phumularia, Aglaophenin, etc.

\section{GENERIC CHARACTFRS.}

Codonida with 4 permanenty rudimentary tentacles, which are reduced to mere hasal bulls. The hydroid stock is a Pennaria.

Medusa of the genus Pemsarin may become mature, and discharge their genital products while still attached to the hydroid, and at the same time other individual medusa from the same stock may be set free in an immature state. Generally, however, the genital products are discharged a few hours after the medusx are set free into the water.

There is no generic difference berween the medusa of Pennaria and medusa belonging to the genus Amalthara, but their hydroids are different. The hydroid stock of Amalthara is Corymorphn, and is closely related to the hydroids of the medusa genera $\mathrm{Hybocodon}$, Stcen. strupia, and Ectopleura. The hydroid of the medusa genus Pemmoria McCrady is Pemaria Goldfuss (Globiceps Ayers). On account of this decided difference in their hydroids we have separated Pennaria from Amahhos $=($ Corymorpha), for their apparent similarity is only a case of parallelism. 


\section{Pennaria disticha Goldfuss (European).}

(?) Pennaria marina, Imperato, 1599, Dell' historia naturale libri ventoto, Napoli, P. 747.

Pennaria cavolini, Schneidir, I 892, Jena. Zeitsch. Naturw., Bd. 20, P. 435, taf. 14 , figs. 49-54 (histology).-Du Plessis, I881, Mittheil. Zool. Sta. Neapel, B.l. 2, p. 147.-Picter, 1893, Revue Suisse Zool., tome 1, p. 12, plate I, figs. 7-9.-WeisMann, 1883, Entstehung Sexualzellen bei Hydromedusen, Jena, pp. 121, 218, taf. 17, figs. 1-5.-Allman, 1872, Monog. Tubularian Hydroids, pp. $3^{64}, 367$, fig. 80.-Kölnikre, 18 47 , Neue Denkschr. Schweiz. Ges. Naturw., B3. 8, p. 49, plate 2, fig. 24.-Ehrenerro, 1834 , Abhandl. d. k. Akad. d. Wissens., Berlin (1832) Teil 1, p. 297.-Gast and Godrwski, 1903, Archiv. für Entwickelungs-mech., Bd. 16, p. 76, 22 figs., taf. 2, 3; 26 figs. (regulation and restitution in injured colonies).

Pennaria disticha, Bedot, 1901, Revue Suisse Zool., tome 9, P. 459; tome 13, 1905, p. 96 (citation of papers to 1850). GoldFuss, I 820 , Handbuch der Zool., p. 89.

Pennaria symmetrica, Clarke, I 879, Bull. Mus. Comp. Zool. at Harvard College, vol. 5, p. 240, plate t, figs. 2, 3.

Penmaria - P PEgles, 1903, Archiv. Entwickelungs-mech., Bd. I4, p. 55, fig. (regeneration).

Sertularia pennaria, Delle, ChiajE, I $841-44$, Animali senza vertebre del Regno di Napoli, vol. 5, pp. 5, 17, plate 157, figs. 3 , 14,$15 ;$ Ibid., 1822 , tav. 43 .

(?) Sertularia pennaria, Linnwus, 1758 , Systema Naturæ, edit. 10, p. 813 .

Sertolara pennaria, Cavolın, 1785, Mem. Polipi marini, Napoli, p. 134 , plate 5 .

Globiceps globator, HakCkeL, 1879 , Syst. der Medusen, p. 40.

(?) Medusa, Euphysa globator, LeuckakT, $185^{6}$, Archiv. für Naturgesch., Bd. 22, p. 28, taf. 2, fig. 4 .

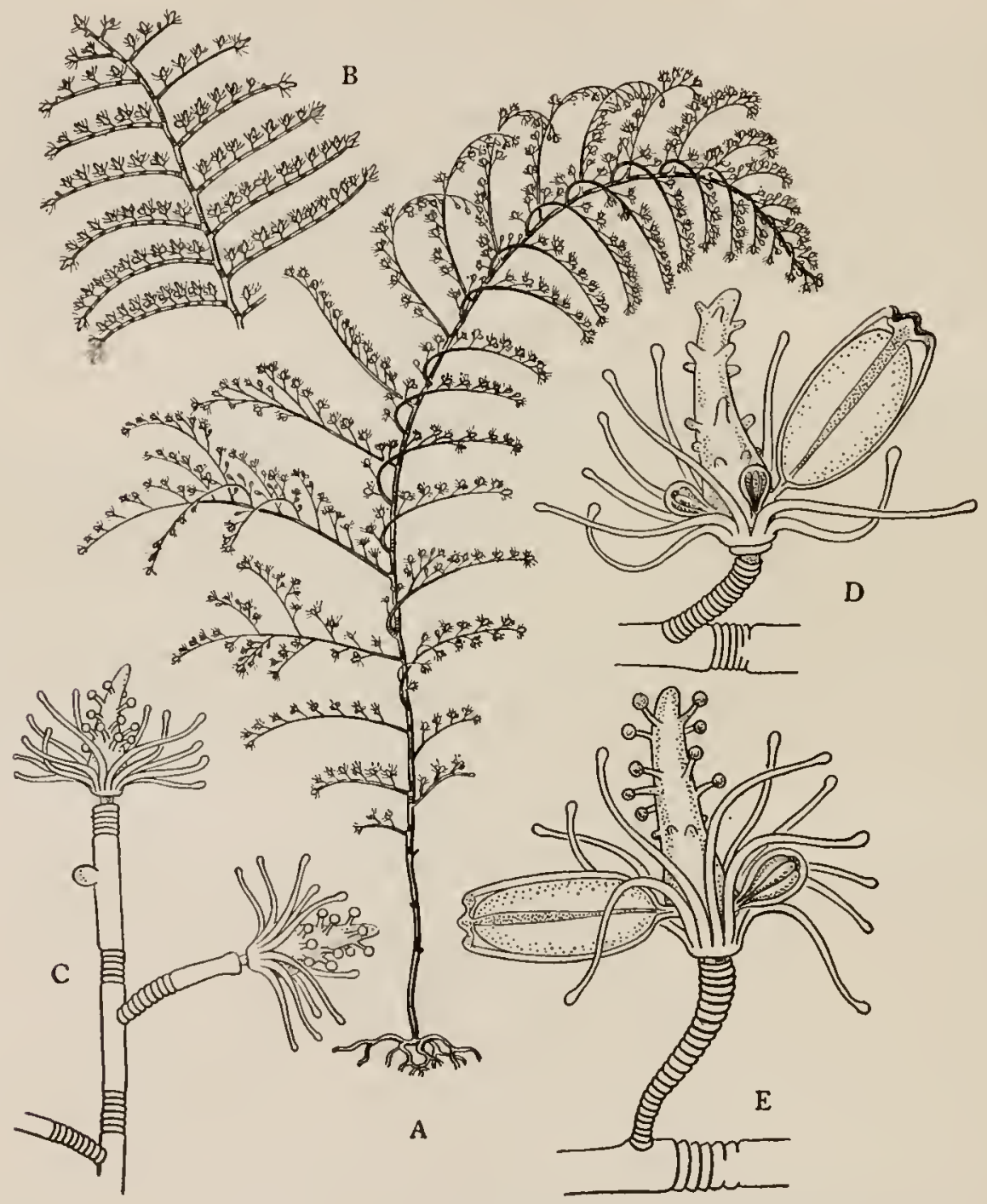

Fic. 1.-Pennaria distichn, from nature, by the author, from specimens collected by Dr. Lobianco in the Bay of Naples.

$A$, liydrocaulus, natural size. $B$, terminal branches showing law of growth. $C$, terminal polypite. $D$ and $E$, hydranths showing completely-annulated pedicels. 
This hydroid is one of the earliest forms known, yet reliable information from the systematic standpoint is still incomplete. One of the best modern descriptions is that of Allman, 1872. I believe the American "Pennarin tiarclla" to he closely related to P'. distichn. The only difference appears to be that the terminal ramuli in $P$. disticha are ringed throughout, whereas in $P$. tiarella they are usually ringed only at base and summit, although I have seen an occasional one ringed throughout in the American hydroid. (See W. S. Wallace, I 908 , Year Book of the Carnegie Institution.)

In the European hydroid, $P$. disticha, the stems become about 150 to $175 \mathrm{~mm}$. high. The main stem is slightly zigzag and with a uniform growth-curve from base to summit. There are about forty side branches, regularly alternate. Perisarc annulated at the origins of the hranches and on the ultimate hydranth-bearing ramuli. Hydranths flask-shaped, with a single verticil of about 10 to 13 basal filiform tentacles each about I to 2 times as long as the body of the hydranth, and each ending in a blunt, slightly swollen tip. About 20 short, stiff, knobbed tentacles, irregularly arranged in 3 verticils, arise from the sides of the hydranth above the hasal verticil of tentacles. The medusa-buds are similar to those of Pennaria tiarella and are without ectodermal ocelli upon their tentacle-bulbs. The medus $x$ usually wither upon the hydroid without being set free, but this often occurs also in $P$. tiarella, especially in the warm water of Florida.

Weismann, 1883 , found that the germ-cells originate in the ectoderm of the inner layer of the bell-nucleus and do not wander from their place of origin, becoming mature in the free medusa, or when the medusa-bud is ripe.

Very elaborate studies upon regeneration, regulation, and restitution in injured colonies were carried out by Gast and Godewski, 1903.

This hydroid is found in the Mediterranean. Pictet, 1893 , found it at Amboina, Malay Archipelago. It occurs at Naples, Italy, from May to November.

\section{Pennaria tiarella McCrady (American). \\ Plate 1, figs. 2-5. \\ RFFERENCES To the AMERICAN Hydrotd.}

Globiceps tiarella, Agassiz, L., 1862, Cont. Nat. Hist. U. S., vol. 4, P. 344.-Arer, 1852, Proc. Boston Soc. Nat. Hist., vol. 4.

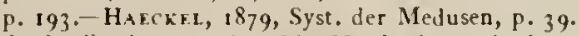

Pennaria tiarella, Agasstz, A., I865, North. Amer. Acal.,p. 187, figs. 311-315.-Nutring, 1901, Bull. U. S. Fish Commission for 1899, vol. 19, pp. 337, 374, figs. 14, 83.-HARGrT, 1900, Amer. Naturalist, vol. 34, p. $3^{87}$, plates $1-4$, 36 figs.; Bull. of the Bureau of Fisheries U. S., for 1904 , vol. 24, p. 32, plate 3; 1904, Archiv. für entwickelungs-mech. organism, Bd. 18, p. 453, taf. 24-28; 1902, Amer. Naturalist, vol. 35, p. 3ir, figs. 8, 9; p. 597, fig. 36; I899, Biol. Bulletin Woods Hole, vol. I, p. 35-40, 6 figs. (grafting experiments); 1900, Science, New series, vol. 12, p. 340; and 1901, Biol. Bulletin Woods Hole, vol.2, p. 223 (variations of hydroids and medusa.)-MCCradr, 1857, Gymn. Charleston Harbor, p. 51,-Svallwood, 1899, American Naturalist, vol, 33, p. 86I, 7 figs. (histology).-Hartlack, 1907, Nordisches Plankton, Nr. 12, p. 72, figs. 68-70.-Golpfarb, 19o6, Journ. Experimental Zool., vol. 3, p. ${ }_{4} 8$ (regeneration). Pennaria tiarella $=(P$. symmetrica, Clakke $)$, Congdon, 1907, Proc. American Acad. Arts and Sci., vol. $42, p \cdot 4^{6} 4$. Pennaria, sp., 'Тнаснек, 1903. Biol. Bulletin, vol. 4 , P. 96.

Pennaria gibbosa, Agassiz, L., 1862, Cont. Nat. Hist. U. S., vol. 4, pp. 278, 344; vol. 3, plate 15, figs. I, 2.

Halcordyle tiarella, Al.Lsan, 1871 , Monog. Tubul. Hydroids, p. 369 .

Fucaryne elegans, LeIDy, 1855, Marine Invert. N. J. and R. I., P. 4, plate 10, figs. 1-5.

THE AMERICAN PENNARIA.

Medusa.-The bell is about $2 \mathrm{~mm}$. in height, and is ellipsoidal, heing higher than it is hroad. Bell-walls very thin, flexille, and much distorted by the renarkably large ova, which are situated within the ectoderm of the manubrium and often fill the entire cavity of the bell. There are 4 small, rudimentary tentacle-hulbs, without ocelli, I at the base of each radialcanal. Radial-canals straight and quite broad. Velum wide and powerful. Manubrium of male more slender than that of female, the latter being usually greatly distended with $f$ or 5 large ova. Several ova are often set free into the water before the medusa is liberated from the hydroid stock. The medusa is commonly mature at the time of its liberation, and it is probable that it does not usually survive for more than a few hours, though Dr. A. Agassiz has maintained them alive for several weeks. The entoderm of the manuhrium is rose-pink, and there are a number of deep-pink blotches in the entoderm of each radial-canal. The entoderm of the tentacle-bulbs is pearly-white, as are also the eggrs within the manulorium. These colors vary considerably in hue and may be almost white. 
Hydroid.-The hydroid is very abundant upon eel-grass, seaweeds, stones, or wharves, below low tide. The stems arise from a ramifying stolon. They attain a height of $\mathrm{I} 00 \mathrm{to}$ I 25 $\mathrm{mm}$. The main stems branch alternately, the longest and oldest side branches being found nearest the base of the stock. The side branches give rise to simple or slightly branched

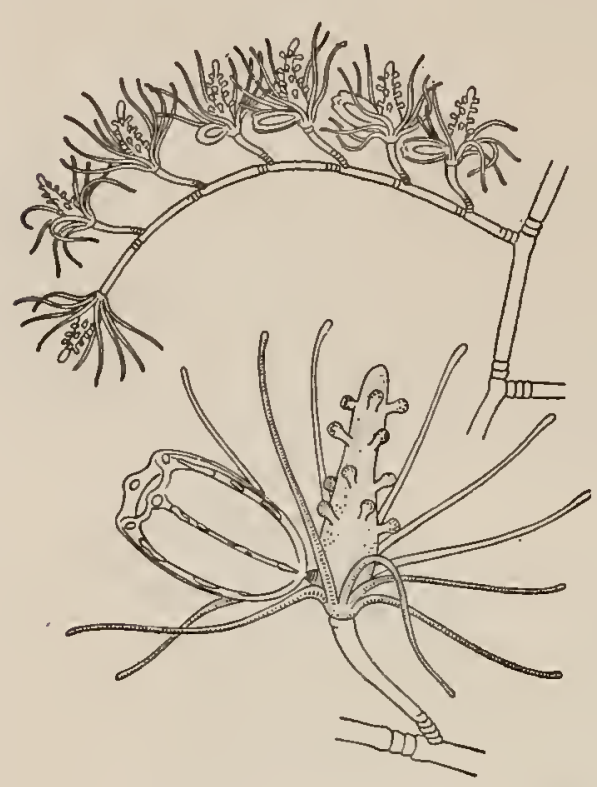

FiG. 2.- Southern variety of Pennaria tiarella. From life, by the author, Tortugas, Florida, May 27,1908 .

Branch of hydroid and enlarged view of a polypite showing pedicels ringed only at their bases. ramuli from their upper sides. These ultimate ramuli are annulated at base with 5 to 6 rings, and the main stem and primary branches are annulated beyond each branch. The stems are covered with a chitinous, horny perisarc. The polyp-heads are flask-shaped, and the mouth is situated at the extremity of a long, slender, conical throat-tube. There are 2 or 3 verticils of oral tentacles, each row being composed of 5 to 7 short, stiff tentacles, each terninating in a knob-shaped cluster of nematocysts. Besides these there is a single circlet of I 2 to 6 long, flexible tentacles near the proximal base of the polypite. The medusa-buds develop upon the sides of the polypites between the oral and basal rows of tentacles. There are usually not more than 2 or 3 buds upon each polypite at the same time. The entoderm of this hydroid is white to rose-colored, the ectoderm silvery and translucent, and the perisarc horny-yellow to black.

This hydroid ranges from the West Indies and Bermudas to the coast of Maine. Pennariagibbosa L. Agassiz, of the Florida coast and West Indies, is probably identical with $P$. tiarella, hut the medusæ of the southern form wither on the stem as do those of $P$. disticha. Indeed Agassiz's figure in 1862 , shows the ultimate pedicels of his $P$. gibbosa, from Key West, Florida, ringed throughout as in the Mediterranean Pennaria disticha.

Hargitt, I9oo, has made a study of the life-history and development of $P$. tiarella. Early in the summer the hydroids are found growing on rock-weed, piles of docks, etc.; while late in the summer they take to eel-grass. The early summer brood is not so bright in color, and the medusæ mature more slowly than in.the late brood. The individual hydranths of the late brood are, however, smaller than those of the early summer brood. The medusæ discharge their ova soon after liberation, and then die rapidly. The ova are 0.4 to $0.5 \mathrm{~mm}$. in diameter and are heavily laden with yolk. They are creamy-white to orange in color. The cleavage is found by Hargitt to be subject to much individual variability, so that an extraordinarily irregular, loosely connected mass of cells is formed, resembling the condition described hy Rittenhouse, I907, in Turritopsis nutricula. No matter how irregularly shaped the embryo may be, it results finally in the formation of a spherical solid morula, and this soon changes into a pear-shaped, ciliated, planula larva. In 5 to 7 days after the beginning of development, the larva setrle down and then develop into small monogastric hydroids covered with ringed perisarc, and provided with whorls of tentacles as in the adult. Hargitt finds that the removal of small parts of the segmenting eggs does not alter the future history of development. The eggs may also be divided at the first or second cleavage and will still develop into normal larva. Moreover, Hargitt finds that single eggs sometimes separate normally into two masses, each of which gives rise to a normal embryo. The irregularities in cleavage observed by Hargitt have been seen also by Miss Cora J. Beckwitl. She finds that the segmentation is mytotic, not amitotic; the nuclear division constantly outnumbering the cytoplasmic so that a syncytium is formed.

Hargitt, I90I, states that hydroid stocks of Pennaria which grow upon eel-grass in shallow water are more pinnatified in their branching, and more highly colored than are those which grow upon stones, etc., in deep water. He also finds that the medusa of the deep-water hydroids are less active than are those developed upon the hydroids which grow in shallow 
water, and are often retained until they wither upon the stems after having cast out their genital products.

I have found only the pale form of Pennaria on the Florida Reefs, and its medus $x$ appear to cast out their genital products before being set free, as is described by Hargitt for the deepwater forms of Woods Hole, Massachusetts. In Florida, Pennaria grows in tuft-like clusters upon gorgonians. This tropical form is called Pennaria gibbosa by L. Agassiz, but those seen by me can not be separated from the Pennaria of the coast of New England.

Hargitt, I 899, carried out a series of grafting experiments upon Pemmaria and other hydroids. He finds that pieces of hydroids of the same species may readily be grafted one upon the other, both in oral or aboral relations, there being little or no evidence of polarity in the regenerative process. Pieces of opposite sex but of the same species will readily unite in any manner, but pieces belonging to hydroids of different genera would not unite. Elaborate studies of this character were also carried out hy Gast and Godewski, 1903, on $P$. disticha.

In 1900 and I901, Hargitt studied the variations of the medusa and hydroids of $P_{e n-}$ naria. The medusa sometimes displays ectodermal blister-like protrusions on its exumbrella, and is variable in other respects.

According to H. Müller, I907 (Zeit. für wissen. Zool., Bd. 89), the eggs of Pennaria develop at the expense of the weaker egg-cells of the ovary, which they engulf as food to form the yolk-granules.

Thacher, 1903, shows that in Pennaria, Campanularia, and Eudendrium, the hydranths, when they degenerate, are absorhed not by liquefaction of their protoplasm, or by the withdrawal of the polyps as a whole; but absorption takes place hy the degenerating cells of both ectoderm and entoderm being turned into the digestive tract of the hydroid.

Goldfarb, I go6, finds that light is absolutely essential for the normal growth, development, and regeneration of Penmaria. He finds, however, that this is true in a sense also for Eudendrium, but not to the same degree, for Eudendrium ramosum colonies, kept in the dark until all the influence of their previous illumination has been lost, will not then regenerate new hydranths unless they be again exposed to light; but the surprisingly short exposure to light of only 5 seconds will suffice to restart the regenerative process.

\section{Pennaria rosea von Lendenfeld.}

Pennaria rosea, von Lendenfeld, 1884, Proc. Linnean Soc. New South Wales, ser. 1, vol. 9, p. 594, plate 24, figs. 40, 42.-Bale, 1888, Ibid., ser. 2, vol. 3, p. $747=$ P. australis, Bate, $188_{4}$, in Cat. Australian Hydroid Zoophytes, $\Gamma \cdot 45$.

Main axial stems $80 \mathrm{~mm}$. long, with about 20 alternately arranged, pinnate side branches. 4 to 6 hydranths on each branch. Hydrorhiza and main stems intensely hlack and opaque: outer half of each stem light-yellow, proximal half intense black. Hydranths rose-colored. with 9 to 14 oral, and 7 to 12 filiform, basal tentacles. Medusx are produced on the proximal hydranths. The medusa bell is slender, oval, $2 \mathrm{~mm}$. high, $1 \mathrm{~mm}$. wide. 4 large rudimentary tentacle-bulbs with a minute external ocellus upon each. Manuhrium with sperm or ova fils the entire cavity of subumbrella. Ova discharged after medusa is set free. Color, intense rose.

Coast of New South Wales, Australia. Mature in May.

This species is distinguished from the European and American Pennaria hy its tentacular ocelli.

\section{Pennaria adamsia von Lendenfeld.}

Pennaria adamsia, von Lendenffid, 1884 . Proc. Linnean Soc. New South Wales, vol.9, 13. 595, plate 25, figs.45-48; plate 26, fig. 49 .

Medusa.-The male meduse are $1.5 \mathrm{~mm}$. Iong and only $0.7 \mathrm{~mm}$. wide; while the female medusx are $1.5 \mathrm{~mm}$. long and as broad as they are high. The male medusa have 4 radially situated marginal tentacles, about as long as the width of the hell. These tentacles have well-developed hasal bulhs with minute ocelli, and the tentacles move alout freely. The spermatozoa fill the space between the manubrium and the sides of the subumbrella, and are discharged within an hour after the medusa has heen set free. The female medusæ are broad, and the tentacles are mere rudiments without ocelli. The bell-cavity is filled with ova, which are soon discharged. 
Hydroid.--The stems are 60 to $80 \mathrm{~mm}$. long, zigzag, and with 15 to 20 alternate branches. The longest branches are nearest the base and are about $12 \mathrm{~mm}$. long. There are about 8 hydranths, I.7 mm. long, on each branch. These hydranths are slender, the proximal ones only about half as large as the distal primary one on each branch. There are 2 verticils of oral tentacles, each with 4 tentacles alternating in position with those of the other row. These oral tentacles are short and each ends in a nematocyst-knob. The uppermost row of 4 oral tentacles is in the 4 perradii, and the lower row in the 4 interradii. There are 24 long filiform tentacles in a single row at the broad base of the polypite. These are about as long as the polypite itself. The perisarc of the hydrorhiza and main stems is opaque and black, and the side branches are yellow. The hydranths are white.

Coast of New South Wales, Australia. Medusæ are produced in March.

This species is distinguished by the minute ectodermal ocelli upon the tentacle-bulbs of the male medusa, and by the length of its tentacles. There are also but 2 verticils of oral tentacles.

\section{Pennaria pacifica Clarke.}

Pennaria pacifica, Clarke, 1907, Mem. Museum Comp. Zool. Harvard Coll., vol. 35, No. I, p. 6, plate I, figs. I-6.

Hydrocaulus 20 to $35 \mathrm{~mm}$. high. Internodes of the main stem without annulations at their distal ends, and with only 1 or 2 rings at their proximal ends. Branches alternate. Peduncles taper slightly to the base where there are 2 or 3 annulations. Hydranths with I 2 to 14 filiments, and about 16 capitate tentacles somewhat irregularly arranged.

Pinco Island, Gulf of Panama, tropical Pacific.

Distinguished only by its few annulations at the internodes of the main stem. It is probably only a local variety of $P$. tiarella.

\section{Pennaria? vitrea Agassiz \& Mayer.}

Pennaria vilrea, Agassiz and Mayer, Bull. Mus. Comp. Zool. at Harvard Coll., vol. 32, p. 161, plate I, figs. I, 2.

Bell is $3 \mathrm{~mm}$. in height; walls thick and rigid. There are 4 rudimentary tentacle-bulbs. Velum not prominent. The 4 radial-canals are straight and narrow. The manubrium in the female specimen was retracted within the cavity of the bell, but it was flask-shaped in the male and projected for a short distance beyond the velar opening. These conditions, however, may be merely different states of contraction and not constant differences; but as we observed only two individuals, one a male and the other a female, we can not be certain upon this point. The ova are large and pyriform, and are grouped in 4 interradially arranged clusters within the manubrium. The mourh-opening is simple, and there are no fimbriations or appendages.

Prominent circular muscles were olserved in the ectoderm of the cavity of the bell in the female, but these were not seen in the case of the male. It is possible, however, that they become apparent only during certain states of contraction. In the female the ova and tentacular bulbs were flesh-colored, and the entoderm of the mouth was green. In the male the tentacular bulbs were green, the entoderm of the manubrium pink, and the lips green.

Found among the Fiji Islands, off Kimbombo Island, November 25, and off Mbatiki Island, December 5, I 897 .

Not having seen the hydroid I am very doubtful concerning the generic identity of this medusa with Pennaria.

Genus TRICHORHIZA Russell, 1906.

Trichorhiza, Russell, 1906, Proc. Zool. Soc. London, p. 99, plate 5.

\section{GENERIC CHARACTERS.}

The medusa is similar to that of Pennaria, but with one tentacle-bull somewhat better developed than the 3 others. The hydranth is solitary, with a branched, filiform hydrorhiza. The perisarc forms a cup into the cavity of which the hydranth may be partially retracted. There are 2 verticils of tentacles, an oral and a basal: and the medusa-huds arise from the sides of the hydranth between these 2 verticils. The type-species is Trichorhiza brumnca Russell, from the Firth of Clyde, Scothand. 
Trichorhiza brunnea Russell.

Trichorhiza brunnea, Russk..., 1906, Proc. Zool. Soc. London, p. 99, plate 5, figs. 1-2; Abstract, Proc. Zool. Soc. London, No. 26, p. 6, Feb. 13, 1906 .

Mature medusa unknown. When newly set free from the hydroid the medusa is pyriform, with a thin-walled bell, well-developed velum, and 4 rudimentary tentacle-bulbs, one of which is larger than the others. The manubrium when extended is as long as the depth of the bell-cavity, and it is cylindrical, narrow, and provided with a simple, circular mouthopening which is surrounded by nematocysts. There are 4 simple, straight radial-canals. but no gonads. The manubrium and tentacle-bulbs are yellow, the former being faint and the latter golden in color.

This medusa is liberated by a solitary hydroid which was found on June 29, 1905, at a depth of 17 fathoms in Ethick Bay, Bute, Firtl of Clyde, Scotland. The hydrorhiza of the

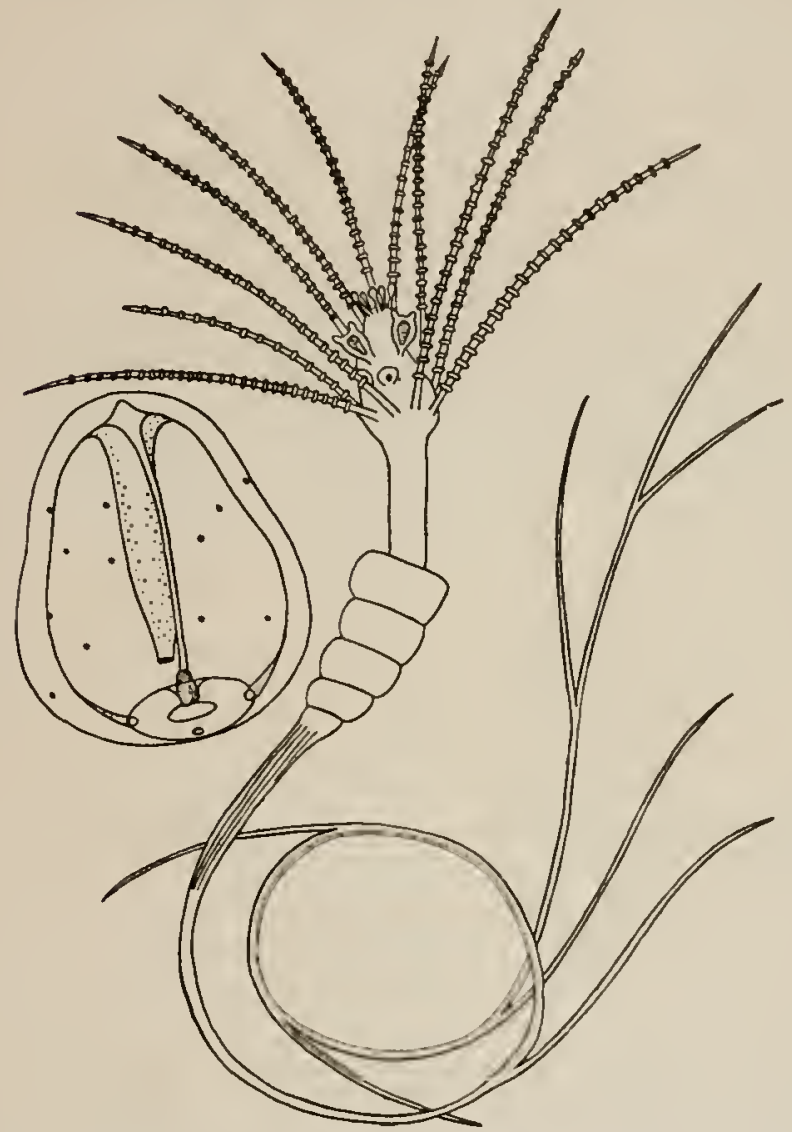

Iin. 3.-Trichorhizabrunnea, after Russell, Proc. Zool. Soc., London, 1 gor. Hydroid, and enlarged view of recently liberated nedusa.
Trichorhiza was entwined among and around the tentacles of Corymorpha nutans. The hydroid is $11 \mathrm{~mm}$. in total length, the hydranth itself being only $1.5 \mathrm{~mm}$. long. The hydrorhiza is long, filiform, and sparingly branched, with about 6 simple branches which arise from its lower (aboral) half. The cœnosarc does not appear to extend over this branched lower half of the hydrorhiza. Above the upper end of the hydrorhiza the perisarc extends to form a cup-like hydrotheca, which bears + transverse grooves. Immediately below this hydrotheca the perisarc displays several longitudinal lines. Hydranth conical, $1.5 \mathrm{~mm}$. long and $0.8 \mathrm{~mm}$. wide, with an oral circlet of 7 very short tentacles having knobshaped ends. There is also a basal circlet of 12 filiform tentacles, which are ringed with nematocysts and are tapering, and fully as long as the hydranth itself. 8 or 10 medusa-buds arise at various levels from the sides of the polypite between the basal and oral circlets of tentacles.

The perisarc of the hydrorhiza is straw-colored, and that of the hidrotheca chocolate-colored. Body of hydranth pale reddish-brown, tentacles translucent white.

This hydroid bears some resemblance to Blastothcla of Verrill. I878. Amer. Jour. Sci., ser. 3, vol. 16, p. 374 .

Genus STEENSTRUPIA Forbes, 1846.

Steenstrupia, Forars, 1846, Annals and Mag. Nat. Hıst., vol. 18, P. 287.-I_veckart, 1856, Archiv. für Naturgesch., Bd.22, P.29. Stcenstrupia + Euphysa, Hafcker., 1879, Syst. der Mcdusen, pr. 29, 31.-13rown., 1895, Trans. Liverpool Biol. Association, vol. 9, rp. $247,24^{8}$.

Euphysa + Steenstrupia, Ariassiz, I., 1862, Cont. Nat. Host. U.S., vol. 4, pP. 342,343.-HAkekk.1, 1864 , Jena. Zejtsch. für

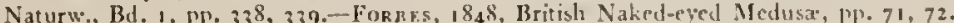

Euphysa, Agassiz, A., i865, North Amer. Acal., p. 189.-Bigriow, 1904, Bull. Mlus. Comp. Zool. at Harvard Coll., vol. 39. p. 251.-Vanhïmpren, 1891 , \%ool. Anzciger, Bel. 14, P. 443.

Fuphysora, MaAs, 1905 , Hydromedusen der Siboga Expedition, 5.6 .

Ileterosiephanus + Steenstrupiat Euphysa, HARtLaub, 1go7, Nordisches Plankton, Nr. 12, 1'1. 74, 76, So. 
The type-species of this genus is Steenstrupia rubra Forbes, I846, from the Atlantic coasts of Europe.

GENERIC CHARACTERS.

Codonidx with radially symmetrical bell, and with 4 radially situated tentacles, I of which is well developed while the 3 others are short or rudimentary.

This genus is separated from $H y$ bocodon by its radially symmetrical bell. In $H$ ybocodon I radial-canal is long, I short, and 2 of medium length; but in Stecnstrupia the 4 radial-canals are all of the same length.

Synopsis of the Characters of Medusa of the Genus Steenstrupia.

\begin{tabular}{|c|c|c|c|c|c|}
\hline & $\begin{array}{l}\text { S. rubra Forbes = } \\
\text { S. flaveola Forbes } \\
=\text { S. galanthus } \\
\text { Haeckel = (?) E. } \\
\text { gracilis Brooks = } \\
\text { (?) S. cranoides } \\
\text { Haeckel=S. lin- } \\
\text { eata Leuckart. }\end{array}$ & $\begin{array}{l}\text { S. aurata = Euphy- } \\
\text { sa aurata Forbes, } \\
=\text { E. a arata }+ \text { E. } \\
\text { mediterranea } \\
\text { Haeckel =(?) E. } \\
\text { virgulata A. } \\
\text { Agassiz. }\end{array}$ & $\begin{array}{l}\text { S. tetrabrachia }=\text { E. } \\
\text { tetrabrachia H. B. } \\
\text { Bigelow. }\end{array}$ & S. bigelowi Maas. & $\begin{array}{l}\text { S. australis von } \\
\text { Lendenfeld. }\end{array}$ \\
\hline $\begin{array}{l}\text { Shape and size } \\
\text { of bell in } \mathrm{mm} \text {. }\end{array}$ & $\begin{array}{l}\text { Bell has well-devel- } \\
\text { oped apical pro- } \\
\text { jection. } 5 \text { high, } \\
3 \text { wide. }\end{array}$ & $\begin{array}{l}\text { Dome-like apex. } \\
\text { Cylindrical sides. } \\
6 \text { high, } 4.5 \text { wide. } \\
\text { Bell-walls and } \\
\text { apex thick. }\end{array}$ & $\begin{array}{l}\text { Pyriform. } 4 \text { high, } \\
2.5 \text { wide. }\end{array}$ & $\begin{array}{l}\text { Pyriform. 10 high, } \\
5 \text { wide. }\end{array}$ & $\begin{array}{l}\text { Half-egg-shaped. } \\
2.5 \text { high, } 1.7 \\
\text { wide. }\end{array}$ \\
\hline $\begin{array}{l}\text { Condition of ten- } \\
\text { tacles. Lengtb } \\
\text { in terms of bell- } \\
\text { radius }(r) \text {. }\end{array}$ & $\begin{array}{l}3 \text { long, narrow ten- } \\
\text { tacle-bulbs with- } \\
\text { out tentacles, all } \\
\text { similar. I long } \\
\text { tentacle ringed } \\
\text { with nematocysts. } \\
\text { Length }=7 \mathrm{r} \text {. }\end{array}$ & $\begin{array}{l}3 \text { small, similar, } \\
\text { rudimentary ten- } \\
\text { tacle-bulbs. I } \\
\text { long tentacle. } \\
\text { Length }=2 \text { r+. } \\
\text { No ocelli. No } \\
\text { definite rings of } \\
\text { nematocysts on } \\
\text { tentacles. }\end{array}$ & $\begin{array}{l}3 \text { short tentacles, } \\
\text { each }=r \text { long. I } \\
\text { large tentacle } \\
\text { about } 7 r \text { long. } \\
\text { All tentacles } \\
\text { sparsely ringed. }\end{array}$ & $\begin{array}{l}3 \text { short tentacles } \\
\text { about } 2 r \text { long } \\
\text { and not ringed. } \\
\text { One longtentacle } \\
4 r \text { long, with } \\
\text { many prominent } \\
\text { partial rings of } \\
\text { nematocysts. }\end{array}$ & $\begin{array}{l}3 \text { tentacle-bulbs, } \\
\text { and i long tenta- } \\
\text { cle, ringed with } \\
\text { nematocysts. } \\
\text { Long tentacle } \\
\text { about } 8 \text { r long. }\end{array}$ \\
\hline $\begin{array}{l}\text { Axial-canal above } \\
\text { stomach. }\end{array}$ & $\begin{array}{l}\text { Arial canal always } \\
\text { present. }\end{array}$ & No axial-canal. & No axial-canal. & $\begin{array}{l}\text { Present. Small, } \\
\text { slender. }\end{array}$ & No axial-canal. \\
\hline $\begin{array}{l}\text { Length of manu- } \\
\text { brium in terms } \\
\text { of bell-radius } \\
(r) \text {. }\end{array}$ & $\begin{array}{l}\text { I. } 5 r \text {. Stomach } \\
\text { mounted on sbort } \\
\text { peduncle. }\end{array}$ & $\begin{array}{l}1.25 \text { r. No ped- } \\
\text { uncle. }\end{array}$ & $\begin{array}{l}2.5 r \text { long. Mounted } \\
\text { on very short ped- } \\
\text { uncle? Mouth } \\
\text { extends slightly } \\
\text { beyond velar } \\
\text { opening. }\end{array}$ & $\begin{array}{l}\text { 1.5 r long. Mouth } \\
\text { not quite reacb- } \\
\text { ing level of velar } \\
\text { opening. }\end{array}$ & $\begin{array}{l}\text { I.5 r long. Cylin- } \\
\text { drical. }\end{array}$ \\
\hline Gonads. & $\begin{array}{l}\text { Single gonad en- } \\
\text { circles stomach, } \\
\text { leaving mouth and } \\
\text { peduncle free. }\end{array}$ & $\begin{array}{l}\text { Single gonad en- } \\
\text { circles stomach. }\end{array}$ & $\begin{array}{l}\text { Eggs developed in } \\
8 \text { adradial, longi- } \\
\text { tudinal rows, in } \\
\text { ectodermon sides } \\
\text { of stomach. }\end{array}$ & $\begin{array}{l}4 \text { wide interradial, } \\
\text { ectodermal swell- } \\
\text { ings on sides of } \\
\text { mid-region of man- } \\
\text { ubrium. Separated } \\
\text { by } 4 \text { narrow, per- } \\
\text { radial spaces. }\end{array}$ & $\begin{array}{c}\text { Gonad encircles } \\
\text { manubrium. }\end{array}$ \\
\hline Color. & $\begin{array}{l}\text { Tentacle-bulbs and } \\
\text { stomach light- } \\
\text { pink to reddish- } \\
\text { brown. Bell apex } \\
\text { sometimes faint } \\
\text { pink. }\end{array}$ & $\begin{array}{l}\text { Variable. Tenta- } \\
\text { cle-bulbs may be } \\
\text { yellow, orange, } \\
\text { red, or colorless. } \\
\text { Manubrium red- } \\
\text { dish to yellow or } \\
\text { faint purple. }\end{array}$ & $\begin{array}{l}\text { Gonads brownish- } \\
\text { yellow. Mouth } \\
\text { pink. Tentacle- } \\
\text { bulbs and rings } \\
\text { pink. }\end{array}$ & $\begin{array}{l}\text { Entoderm of man- } \\
\text { ubrium, canals, } \\
\text { and tentacles dull } \\
\text { yellow. }\end{array}$ & $\begin{array}{l}\text { Mouth deep violet. } \\
4 \text { brown patches } \\
\text { on gonad. Tenta- } \\
\text { cle-bulbs and long } \\
\text { tentacle brown } \\
\text { with violet spots. }\end{array}$ \\
\hline Where found. & $\begin{array}{l}\text { Atlantic coasts of } \\
\text { Norway, Ger- } \\
\text { many, England, } \\
\text { Scotland, and Ire- } \\
\text { land. (Mediter- } \\
\text { ranean?) (South- } \\
\text { ern United States, } \\
\text { Atlantic coast?) }\end{array}$ & $\begin{array}{l}\text { Mediterranean and } \\
\text { Atlantic coasts of } \\
\text { Europe. }\end{array}$ & $\begin{array}{l}\text { Suvadiva Atoll, } \\
\text { Maldive Islands, } \\
\text { Indian Ocean in } \\
\text { January. }\end{array}$ & Malay Archipelago. & $\begin{array}{l}\text { Harbor of Sydney, } \\
\text { New South } \\
\text { Wales, Australia. }\end{array}$ \\
\hline Hydroid. & $\begin{array}{l}\text { Corymorpha nu- } \\
\text { tans, Sars, 1835; } \\
\text { Hincks, } 1868 \\
\text { Allman, } 1871\end{array}$ & $\begin{array}{l}\text { Corymorpha nana, } \\
\text { Alder, } 1857 \text {. }\end{array}$ & Unknown. & $\begin{array}{l}\text { This medusa is pro- } \\
\text { bably identical } \\
\text { with S. tetrabra- } \\
\text { chia. Hydroid } \\
\text { unknown. }\end{array}$ & Unknown. \\
\hline
\end{tabular}


The hydroid generation is Corymorpha Sars, $1835=$ Halatractus of Allman, $187 \mathrm{I}$.

Haeckel, I 879 , restricts Steenstrupia to describe medusx having characters as above, but with an apical projection upon the bell, and with an axial canal extending upward into this projection from the stomach. Euphysa he would restrict to include forms which lack an apical projection and an axial canal. As Vanhöffen, I $89 \mathrm{I}$, rightly states, an apical projection is always lacking in young medusa and is highly variable in its development even in mature individuals of the same species. The same is true of an axial canal. Moreover, among species discovered since Haeckel wrote his "System der Medusen," Euphysa tetrabrachia, Bigelow, I 904 (Bull. Mus. Comp. Zool. at Harvard Coll., vol. 39, p. 251, plate I, fig. I), has a well-developed apical projection, and no axial canal, and would therefore have no place in Haeckel's system.

Maas, 1905, would institute a genus Euphysora to describe Codonidæ having I large, and 3 well-developed but still considerably smaller tentacles. Here again, however, we meet with a condition of degree only. When, for example, are the 3 small tentacles large enough to be Euphysora or small enough to be Steenstrupia? In order to avoid confusion, it appears best to combine all of these forms under one generic name. Vanhöffen, 189I, suggests Euphy'sa as the proper generic name to include all of these forms, but Steenstrupia takes precedence over Euphysa, for it was used by Forbes in 1846 , while Euphysa was first used by him in 1848 .

Bigelow finds that the eggs of $S$. tetrabrachia are arranged in $\$$ adradial longitudinal lines in the ectoderm of the stomach, and Maas states that in $S$. bigelowi the gonads are interradial and separated by very narrow linear interspaces in the 4 principal radii. These conditions are interesting, for they foreshadow those characteristic of the Oceanida where the gonads are interradial or adradial, and are often quite wilely separated in the principal radii.

Hartlaub, I907, defines /eterostephanus (Allman, I871) as a Steenstrupia-like medusa-bud, not known to be set free from its Corymorpha-like hydroid. Medusa with a single tentacle, ringed at its base, and terminating distally in a knob. The only known species is $H$. annulicornis, Allman, I $87 \mathrm{I}=1 /$ ybocodon annulicornis Haeckel. This was first described by M. Sars, 1859 , as Corymorpha? annulicornis.

\section{Steenstrupia rubra Forbes.}

Plate 1, fig. 7.

Corymor pha nutans (hydroid), SARS, M., $1 \$ 35$, Beskriv. og Jagtt., p. 6, plate 1, fig. 3; SARS, O., 1877, Fauna Littor. Norveg., tome 3, p. 2, taf. 2 , figs. $25-28$.

Corymor pha nutans (hvdroid), BrDot, 1905, Revue Suisse de Zool., tome 13, p. 63 (literature to 1850 ).

Corymor pha nutans (hydroid and medusa), Hartlaub, 1907, Nordisches Plankton, Nr. 12, p. 76, figs. $72-75$ (complete list of authors, localities, and best modern description of hydroid and medusa).

Corymorpha nutans, Hincks, 1868, Hist. British Hydroid Zooplytes, p. 127, plate 22.-Al.r.ax, 1871, Monog. Tubularian Hydroids, p. 388 , plate 19 .

Corymorpha nutans $=S$, galanthus (Haeckel.) $=S$. faveola, Forbes $=S$. rubra, Forbes, Browne, 1896, Proc. Zool. Soc. London, pp. 463,464 , plate 16 , fig. 1 (review of literature).

Steenstrupia galanthus, Bedot, 1905 , Revue Suisse de Zool., tome 13, P. 148 (literature to 1850 ).-HAEckeL, 1879 , Syst. der Medusen, p. 31. Hybocodon nutans, Ibid., p. 34.-Mül.LF, 1908, Zeit. für wissen. Zool., Bd. 89, p. 52, taf. 5, figs. 20-24 (origin and structure of the eggs).

Steenstrupia rubra, Hartlava, igo4, Wissen. Meeresuntersuch. Kommiss. Meere Kiel, Abth. Helgoland, Neue Folge, Bd. 5, p. 105 , fig. 3.

Steenstrupia rubra (Forbes), Brawne, 1895, Trans. Liverpool Biol. Soc., vol. 9, p. 247.

Steenstrupia rubra (medusa) + S. faveola, Forвеs, 1848, British Naked-eyed Medusx, pp. 73 , 74, plate 13, figs. 1, 2.

Seenstrupia cranoides, HaEcker, 1879, Syst. der Medusen, p. 30, taf. 2, figs. 10-14.

Steenstrupia gracilis, Brooks, 1882 , Studies Johns Hopkins Univ. Biol. Laboratory, vol. 2, p. 144.-MArer, 1900 , Bull. Mus. Comp. Zool. at Harvard Coll., vol. 37, p. 29, plate 16, figs. $36,37$.

Stecnstru pia lineata, Levckart, 1856, Archiv. für Naturgesch., Bd. 22, P. 29, taf. 2, fig. 6.-Spagsor.ixi, 1876, Catalogo Acalefi Mediterraneo, p. 17, taf. 1, figs. 1-4.-H.teckel, i879, Syst. der Medusen, p. 30.-DU Pless1s, 1888, Recueil Zool. Suisse, tome 4, p. 543 .

This medusa is found on the coasts of Europe from Norway southward to the Mediterranean. $S$. cranoides Haeckel $=S$. lineata Leuckart, from the Mediterranean, appears to be identical with $S$. rubra. S. gracilis Brooks, of the Atlantic coast of the United States south of Virginia, is probally identical with $S$. rubra of Furope, but the hydroid of the American form remains unknown. I believe that $S$. lineata, $S$.cranoides, and $S$. gracilis are identical, and that they are probably identical with $S$. rubra liorbes.

For description of S. rubra of Europe, see synoptic table of species of Stecnstrupia. 
In the American form the development of nematocyst-rings upon the long tentacle is subject to great variability. The Mediterranean $S$. cranoides Haeckel lacks such rings, whereas they appear to be better developed in northern Atlantic specimens from the coasts of Europe. The same difference appears to be exhibited by our American specimens, those from Tortugas, Florida, being unringed or only slightly ringed, while those from North Carolina are often profusely ringed. The apex of the bell often bristles with nematocysts, but in some inedusa it may be smooth.

Browne, I 896 (pl. I6, fig. I), gives a figure of $S$. rubra derived from specimens found by him at Valencia Island, off the Irish coast. He shows a narrow conical peduncle above the stomach, the peduncle being about one-fifth as long as the gastric portion of the manubrium. No such peduncle has been observed in the American $S$. "gracilis," when the bell is expanded, although when it is somewhat contracted the appearance of a well-developed peduncle is often produced. On the other hand, when the stomach is widely distended with food and the bell expanded no peduncle may be seen. Haeckel's series of figures (taf. 2, figs. IO-I2) will

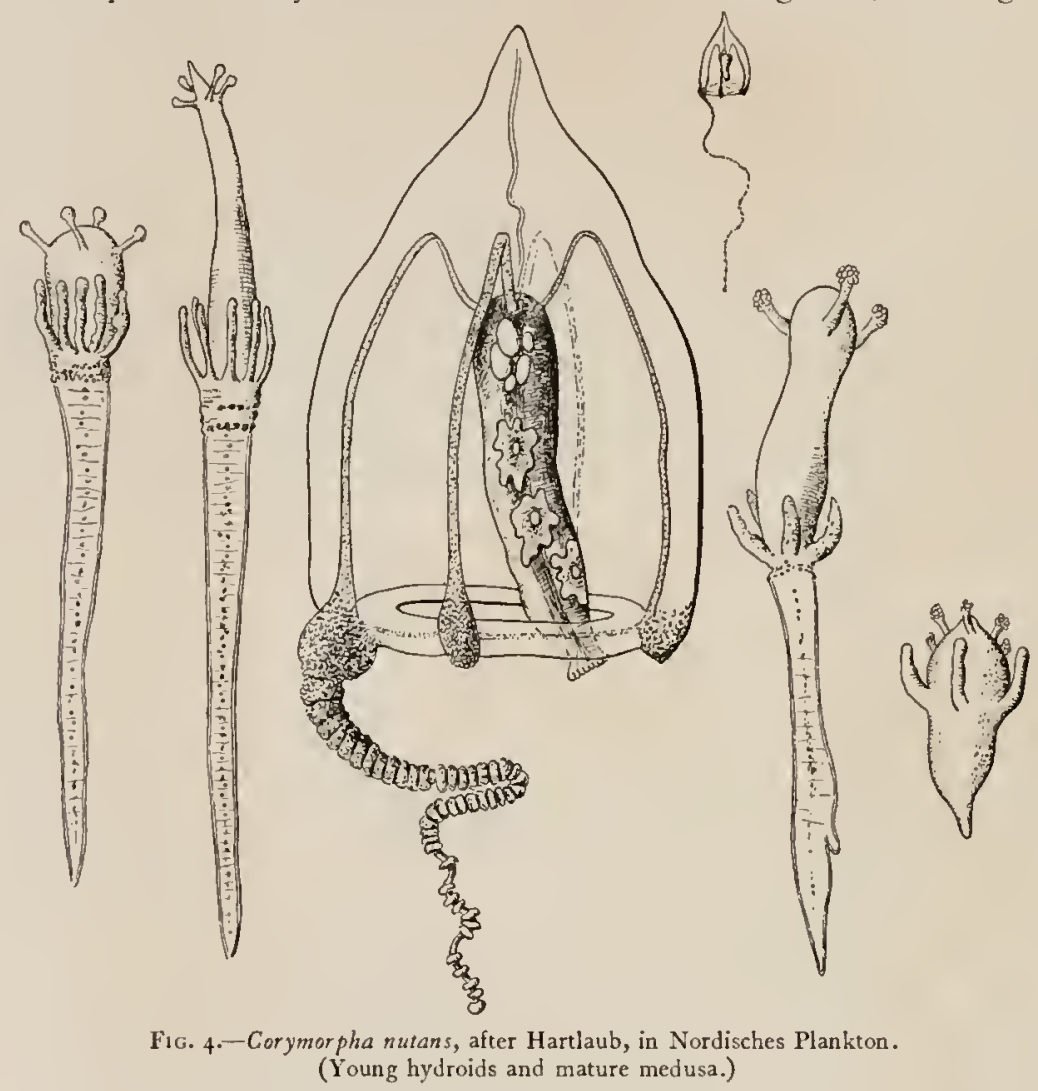

serve to illustrate the formation of a peduncle-like body of gelatinous substance above the stomach through contraction of the bell. I have frequently seen the same phenomenon in our American $S$. "gracilis" $=S$. cranoides Haeckel. I have also observed this peduncle in living medusæ of $S$. rubra taken off the coast of Cornwall, England.

Hartlaub, 1907, gives a list of the bibliography and of localities for this species, and his description of the medusa and the young hydroid are the best yet produced (see fig. 4).

The egg is amoboid as in Amalthar. The young hydroid has a single circlet of 4 short, knobbed, oral tentacles, and another circlet of 5 to 8 simple, flexible, filiform basal tentacles. H. Müller, I 908 , finds that the full-grown eggs are very few in number, having developed at the expense of other weaker egg-cells in the ovary, which they devour. The exoplasma is quite wide and is separated from the germinal vesicle. The ooplasma is a network of delicate fibers of wide mesh, and the exoplasma and endoplasma are distinct, one from another. The egg contains numerous pseudo-cells in advanced stages of degeneration and also yolk-granules. 
The following description of the medusa is derived from a study of specimens found by the author off the coast of the United States:

The bell is $5 \mathrm{~mm}$. high and surmounted by a slender conical projection about $2 \mathrm{~mm}$. long. There are 4 tentacles. One of these is about $10 \mathrm{~mm}$. long, and is ringed at irregular intervals by prominent swellings, between which there are small rings at fairly regular inter-

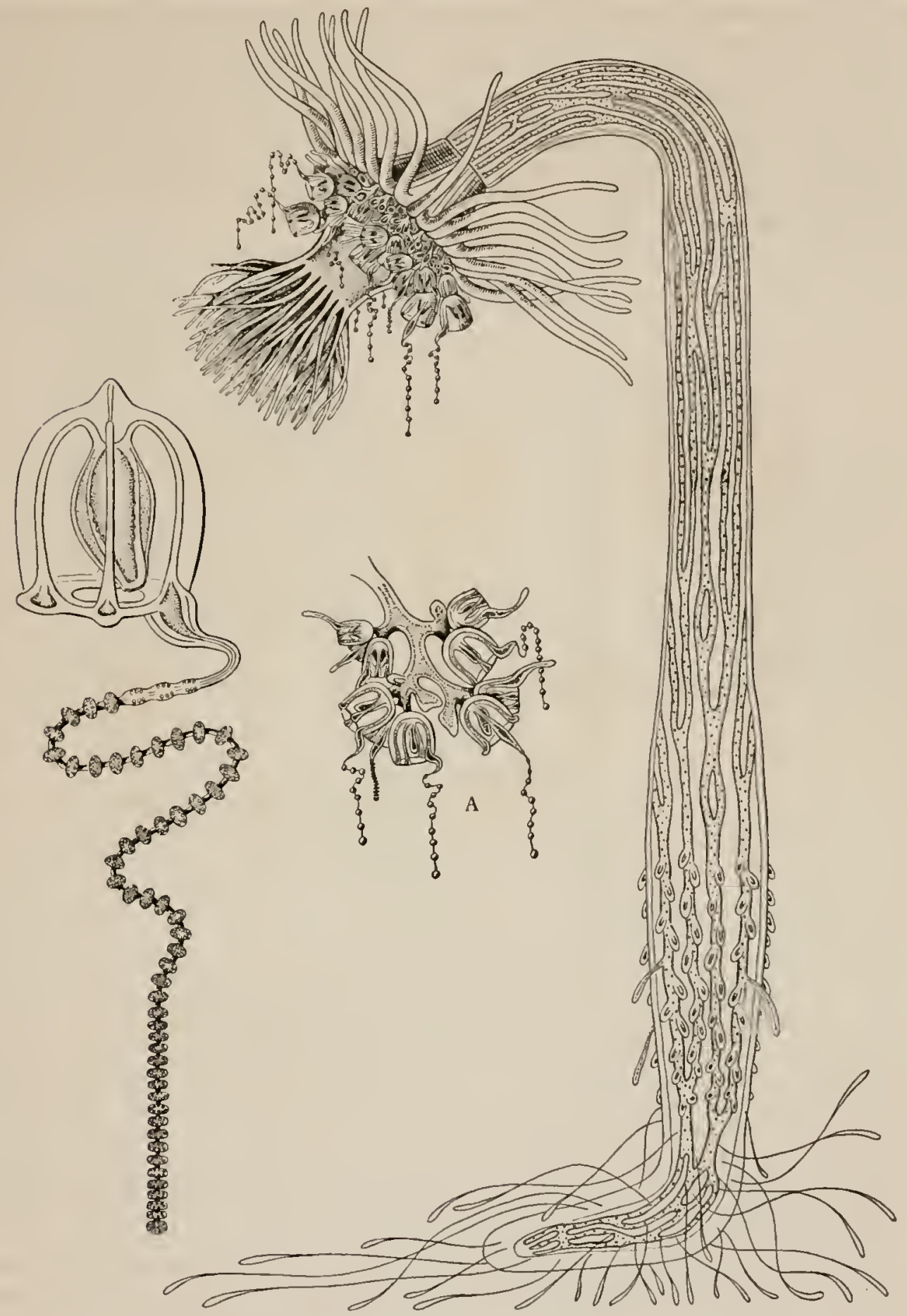

Fig. 5.-Corymorpha nutans, hydroid and medusa, after Allman, in Ray Society, $1871-72$.

A. Detail showing manner in which medusa bud of from hydranth. 
vals. The tentacle which is diametrically opposite to the long tentacle is tapering, and about $0.25 \mathrm{~mm}$. long; while the 2 other tentacles are mere bulbs. The velum is well developed. There are 4 narrow radial-canals, and a slender ring-canal. A long, slender, sinuous canal extends from the aboral apex of the stomach upward into the apical projection of the bell. In mature medusa the manubrium extends a short distance beyond the velar opening. Ordinarily the mouth is a simple, round opening at the tapering extremity of the manubrium, but when widely open, as in our figure, it shows 4 thick but not prominent lips. The genital products are found in the manubrium, and in the female the eggs project from the surface of the ectoderm. Entoderm of manubrium intense yellow-green and rose-color. Apical canal intense yellow, often flecked with rose-color. The entoderm of the tentacle-bases is rosecolor and yellow, while the entoderm of the large annular swellings is rose-color. When young the apical projection is not very high, the tentacles short, and without nematocystrings, and the manubrium short and tapering; not extending beyond the velar opening as in the mature medusa.
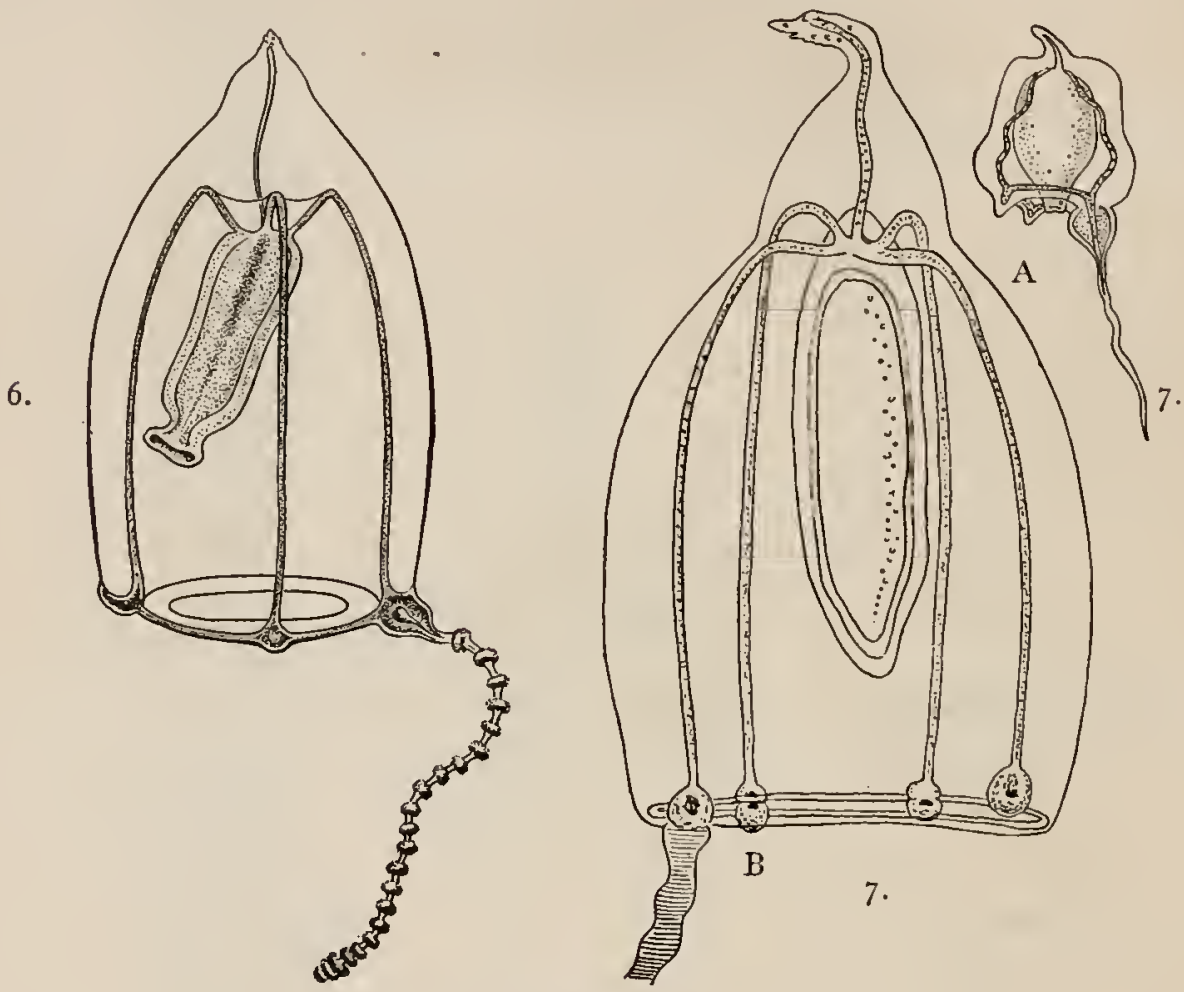

Figs. 6 and $7 .-$ Steenstrupia rubra.

6.-From life, by the author. Off Mousehole, Cornwall, England, October 23, 1907.

7. $-A$. After Leuckart ("S. lineata"), 1856, Archiv. fur Naturgesch., Bd. 22.

$B$. After Spagnolini ("S. lineata"), 1876, Catalogo Acalefi Mediterraneo.

Found at Oregon Inlet, Pamlico Sound, North Carolina, in November, and at Beaufort, North Carolina, and Tortugas, Florida, in summer. It is apparently identical with $S$. cranoides and $S$. lineata of the Mediterranean.

Definite rings of nematocysts are not found upon the tentacles of the young medusa, and are very variable in their development in mature specimens, some being profusely ringed and some entirely unringed. Haeckel describes only unringed individuals from the Mediterranean, his specimens being similar to those found by me at Tortugas, Florida.

I am inclined to believe that this Mediterranean and tropical American medusa will prove to be identical with, or only a variety of, S. rubra of the Atlantic coasts of western Europe. Certainly no differences, other than those well within the limits of common variability, can be detected between the medusx of $S$. rubra and $S$. lineata $=S$. cranoides; but a 
careful comparative study of the hydroids of these forms must be made before we may safely assert either that they are identical or separate species.

The hydroid of S. rubra is Corymorpha nutans of Sars, and is common on sandy bottoms, off the northern coasts of Europe, at moderate depths. The stems of the hydroid are solitary, and are about 50 to $75 \mathrm{~mm}$. high, and about $4 \mathrm{~mm}$. wide at the widest part. The whole stem is corrugated by numerous narrow longitudinal bands. The widest part of the stem is usually at a short distance above the lower end. This lower end is bent sharply at right angles to the main part of the stem and bears long, hair-like filaments which serve to anchor the hydroid. There are also blunt, papilla-like processes which arise from the sides of the stem above the bent portion. The polypite is large and flask-shaped, and has a basal zone of 30 or more long, tapering tentacles, about as long as the polypite itself. In addition to these tentacles there are 6 to 7 closely crowded verticils of oral tentacles, which are much shorter and thinner than the proximal. 15 to 20 branched peduncles arise from the sides of the polypite close to the bases of the proximal circlet of tentacles, and bear the medusa-buds. The hydranth is light-red, the stem being paler than the polypite. On the English coast the medusa-buds are set free during the summer.

Allman gives a good description of the hydroid.

\section{Steenstrupia aurata.}

Euphysa aurata, (medusa) Forbes, 1848 , British Naked-eyed Medusa, p. 7 I, plate I3, fig. 3 .

Euphysa aurata (medusa) + E. mediterranea, Ha cскв.1., i 879 , Syst. der Medusen, p. 32, taf. 2, figs. 8, 9.

Euphysa mediterranea, DU PLEssis, 1888, Recueil Zool. Suisse, tome 4, P. 543.

Euphysa aurata (Forbes), Browne, 1895, Trans. Liverpool Biol. Soc., vol. 9, p. 248; 1896, Proc. Zool. Soc. London, p. 474

Euphysa aurata, Browne, 1905, Proc. Roy. Soc. Edinburgh, vol. 25, P. 749.-Bedot, 1905, Revue Suisse de Zool., tome I3, p. 134 .

Corymor pha nana, (hydroid) Alder, I 857 , Cat. Zooph. Northumberland and Durham, p. II I, plate 7, figs. 7, 8.-HiNcks, I 868, Hist. British Hydroid Zooph., p. 130, plate 22, fig. 3.

Corymorpha nana, Hartlaub, 1907, Nordisches Plankton, Nr. 12, p. 81, figs. 76-78 (list of authors and localities).

(?) Euphysa virgulata, Acassiz, A., I865, North Amer. Acal., p. 189, figs. 316-319.

This medusa is found off the Atlantic coasts of western Europe and in the Mediterranean. Steenstrupia virgulata of Massachusetts Bay is probably identical with $S$. aurata. For description of the European form, see synoptic table of characters of the species of Steenstrupia. The European $S$. aurata appears to be smaller than the American S. virgulata.

\section{Steenstrupia virgulata $=(?)$ S. aurata Forbes. \\ Plate 1 , fig. 6.}

(?) Steenstrupia aurata, Forbes, 1848, British Naked-eyed Medusæ, p. 7 I, plate 13, fig. 3.

Eu physa virgulata, Agassiz, A., I865, North Amer. Acal., p. I89, figs. 316-319.-HaEcxer, 1879, Syst. der Medusen, p. 33.Nuttinc, I9oi, Bull. U.S. Fish Comm., vol. 19, p. 370.--Hargitr, 1904, Bull. U. S. Bureau of Fisheries, vol. 24, p. 33. Corymor pha virgulata, Hartlaub, 1907 , Nordisches Plankton, Nr. 12, p. 84 , fig. 79 .

Adult medusa.-The bell is pyriform, with a broad, dome-shaped apex. It is 5 to $12 \mathrm{~mm}$. in height, and 4.5 to $9 \mathrm{~mm}$. in diameter. Surface of exumbrella smooth and without rows of nematocysts. There are 4 tentacles, one at the base of each radial-canal; 3 of these are mere rudimentary bulbs, but the fourth is large and conical. Its surface is thickly covered with nematocyst-cells of large size. There are 4 simple, straight radial-canals, and a slender, circular vessel. The velum is wide, with an indented, free edge. The manubrium is cylindrical without a peduncle, and extends about half the distance from the inner apex of the bell-cavity to the level of the velar opening. No apical, axial canal. The mouth is a simple, round opening without prominent lips. The genital products are contained within the ectoderm of the manubrium. Manubrium light-yellow. The entoderm of the radialcanals near the bases of the tentacles is intense pink, and the ectoderm of the tentacles is milky-white. This species was found by Dr. Alexander Agassiz, in Massachusetts Bay, at Nahant, and is recorded from Woods Hole, Massachusetts, by Nutting and Hargitt.

The figure here shown is reproduced by his kind permission from Dr. Alexander Agassiz's drawing of the medusa. There is no difference between this medusa and $S$. antrata of Europe except that the American form appears to be larger; but the hydroid of the American medusa is unknown, and until this is discovered it will be impossible to determine the identity of the Anerican form. 


\section{Steenstrupia tetrabrachia.}

Euphysa tetrabrachia, Bigelow, H. B., 1904, Bull. Mus. Comp. Zool. at Harvard College, vol. 39, p. 251, plate I, fig. I. (?) Euphysora bigelowi, MaAs, 1905, Craspedoten Medusen der Siboga Expedition, Monog. 10, P. 7, taf. 1, figs. 1-3.

Bell $4 \mathrm{~mm}$. high, $2.5 \mathrm{~mm}$. wide. Pyriform, with solid apical projection. One long sparselyringed tentacle about 4 times as long as the bell is high. 3 other, smaller tentacles, each about one-third as long as the bell-height. These bear each about 3 rings of nematocysts, while the long tentacle bears about 6 such rings. Velum well developed. Manubrium large, spindleshaped, with mouth projecting beyond the velar opening. Gonads on sides of stomach. Eggs arranged in 8 fairly distinct rows. Bell colorless. Gonads brownish-yellow. Manubrium pinkish. Tentacle-bulbs and rings on tentacles rose-pink. Suvadiva Atoll, Maldive Islands, Indian Ocean; in January.

This medusa is probably redescribed by Mas as E. bigelowi.

\section{Steenstrupia bigelowi.}

Euphysora bigelowi, MaAs, I905, Craspedoten Medusen der Siboga Erpedition, Monog. 10, p. 7, taf. I, figs. 1-3; 1906, Revue Suisse de Zool., tome 14, p. 84, pl. 2, figs. I, 2.-Müller, 1908, Zeit. für wissen. Zool., Bd. 89, p. 59.

(?) Euphysora tetrabrachia, Bigelow, 1904, Bull. Mus. Comp. Zool. at Harvard College, vol. 39, p. 25 I, plate I, fig. 1.

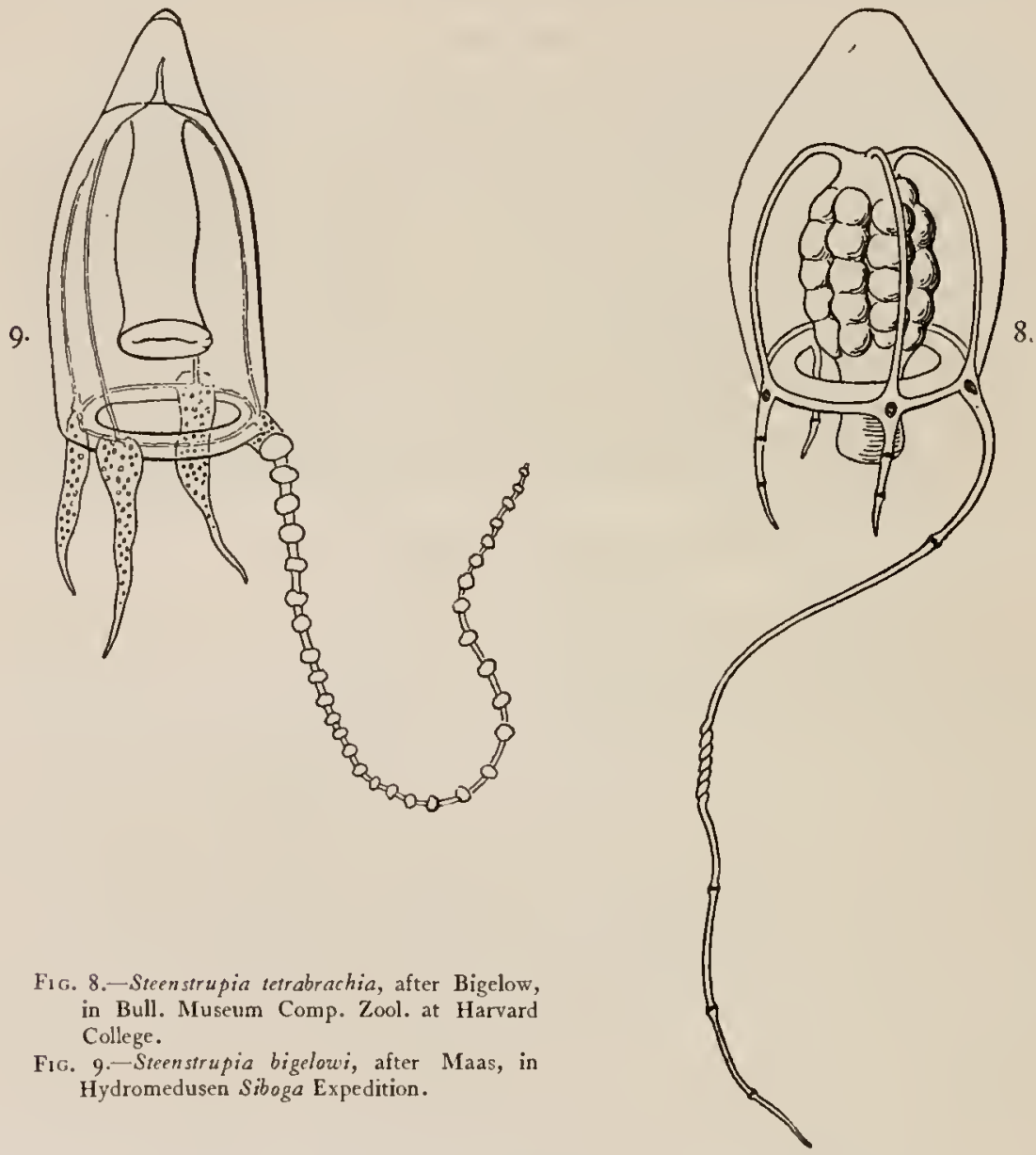

Bell $13 \mathrm{~mm}$. high; more than twice as high as it is wide, and with a well-developed a pical projection. Bell-cavity $10 \mathrm{~mm}$. deep. Apical projection $3 \mathrm{~mm}$. high. Side walls thin. 4 tentacles at the bases of the 4 radial-canals. One of these tentacles is longer than the bellheight and bears about 30 swollen nematocyst-warts. The 3 other tentacles are each onethird to half as high as the bell and are tapering, without nematocyst-warts, but covered with diffuse nettling cells. Manubrium spindle-shaped, not extending beyond the velar opening. 
In most specimens there is a blindly-ending axial canal extending into the gelatinous substance of the apical projection, but this is not constantly present. The gonads are developed upon the sides of the stomach, leaving only the basal and mouth ends of the manubrium free. A cross-section shows that they are separated by 4 minute, perradial, longitudinal lines. There are therefore 4 interradial gonads. There are no medusa-buds produced by the medusa.

The entoderm of the manubrium, radial-canals, and tentacle-bulbs is filled with yellow pigment granules. The nematocyst clusters on all 4 tentacles are red.

Found quite commonly in the Malay Archipelago, at Sulu, Ternate, Damar, Manifa, Saleyer, and Amboina.

This form differs from the closely allied S. tetrabrachia Bigelow, from the Maldive Islands, in that in the Maldive species there are a few rings of nematocysts upon the tentacles, whereas in $S$. bigelowi there are only warts, not inclosed rings. Also there appears to be no axial canal in $S$. tetrabrachia, whereas this is usually seen in $S$. bigelowi. The size constitutes a disparity in the two medusæ $4 \mathrm{~mm}$. high in S. tetrabrachia and about $13 \mathrm{~mm}$. in $S$. bigelowi. Future studies will probably show that these distinctions are not of specific value, but merely changes due to growth and variation, and that the two medusa are identical and should be called S.tetrabrachia. "Euphysa" tentaculata, Linko, 1905 (Zool. Anzeiger, Bd. 28, p. 214), from Barents Sea has also 3 well-developed tentacles, and is $5 \mathrm{~mm}$. high, with orange-colored manubrium and oval bell. It may be Hybocodon pendula.

\section{Steenstrupia australis.}

Euphysa australis, von Lendenfeld, $188_{4}$, Proc. Linnean Soc. New South Wales, vol. 9, p. 586, plate 21, fig. 33.

Bell is $2.5 \mathrm{~mm}$. high, $1.7 \mathrm{~mm}$. wide. Half-egg-shaped and symmetrical. No lines of nematocysts over the exumbrella. One very long retractile tentacle, 2 to 3 times as long as the bell-height. This tentacle has a large basal bulb, and is covered with rings of nematocysts. The other 3 tentacles are mere basal bulbs terminating in a knob-shaped cluster of nematocysts. Velum well developed. 4 straight radial-canals. Manubrium arises from the center of the umbrella cavity, and is cylindrical and about half as long as the bell-height. The gonad encircles the manubrium. Mouth deep violet. 4 brown patches upon the gonad, and a few brown spots on manubrium near its base. Tentacle-bulbs and the large tentacle brown with violet spots. Port Jackson, New South Wales, in May and June. Rare. Hydroid unknown.

\section{Genus HYBOCODON L. Agassiz, 1862.}

Hybocodon, Agassiz, L., I 862, Cont. Nat.Hist. U.S., vol. 4, p. 243.-Agassiz, A., 1865, North Amer. Acal., p. I93.-VANü̈f zx, 1891 , Zool. Anzeiger, Bd. 14, p. 443.-Brown E, 1896, Proc. Zool. Soc. London, p. 466.-HartLAc B, 1905, Zoolog. Jahrbuichern, Suppl. 6, p. 544; 1907, Nordisches Plankton, Nr. 12, p. 96.

Hybocodont Amphicodon, HaEckel, 1879, Syst. der Medusen, pp. 33, 35.

Amphicodon, Browne, 19oz, Annals and Mag. Nat. Hist., ser.7, vol.9, p. 275.

Diplura, Allman, 187i, Monog. Tubularian Hydroids, p. 326.

Corymorpha, Agassiz, A., 1865, Ibid., p. 192.

This genus was established in 1862 by L. Agassiz for Hybocodon prolifer, a medusa which arises by budding from a Corymorpha-like hydroid on the New England coast. According to Browne, 1896 , this medusa is also found off the northern coast of Europe. It is probable that the same medusa was described by Steenstrup, 1842 , from Iceland, as Corymorpha fritillaria, but the hydroid from which Steenstrup supposed this medusa to be derived is certainly not Hybocodon, but may be an Amalthea or Diplura. Steenstrup does not figure a basal circlet of tentacles upon the polypites, which have only an oral circlet, and below this a circlet of medusiform gonophores, each with a 4 -sided bell, and 4 equally developed rudimentary tentacles. It is probable that the hydroids of $H_{y}$ bocodon differ more among themselves than do the medusx, and no final classification of the medusx can be attempted until all of the hydroids have been discovered.

\section{GENERIC CHARACTERS.}

Codonidx with asymmetrical bell. One of the 4 radial-canals is long, I short, and 2 of medium length. There are $\mathrm{I}$ or more long tentacles at the foot of the long radial-canal; and 3 small or rudimentary tentacles, I at the foot of each of the 3 other radial-canals. The hydroid is Hybocodon. 
Haeckel, I 874 , instituted the genus $A$ mphicodon to include medusa with 3 rudimentary tentacles, and a cluster of 2 or more long tentacles at the foot of the longest radial-canal. Vanhöffen, I891, Browne, I896, and Hargitt, I90I, have pointed out, however, that the young medusæ commonly have but I long tentacle, and that others appear, and develop from the side of the basal bulbs of this original tentacle; thus the genus "Amphicodon" is only a mature $H$ ybocodon. These secondary tentacles may appear before or after the medusabuds begin to develop upon the tentacle-bulbs. According to Hargitt, I902, I904, Perkins, I904, and Linko, 1905, the sexual products of the manubrium become mature while medusa-buds are still being produced upon the tentacle-bulbs.

\section{Synopsis of the Species of Hybocodon.*}

\begin{tabular}{|c|c|c|c|c|}
\hline . & H. prolifer L. Agassiz. & $\begin{array}{l}\text { H. pendula Haeckel= } \\
\text { Corymorpha pendula } \\
\text { L. Agassiz. }\end{array}$ & H. forbesii Mayer. & H. unicus Browne. \\
\hline $\begin{array}{l}\text { Shape and size of bell } \\
\text { in } \mathrm{mn} \text {. }\end{array}$ & $\begin{array}{l}\text { Dome-shaped. } 2.5 \text { high, } \\
2.2 \text { wide. I radial- } \\
\text { canal long, } 2 \text { inter- } \\
\text { mediate length, and I } \\
\text { short. Long and short } \\
\text { are } 180^{\circ} \text { apart. }\end{array}$ & $\begin{array}{l}\text { Quite similar to H. pro- } \\
\text { lifer. } 5 \text { high, } 3.5 \\
\text { wide. }\end{array}$ & $\begin{array}{l}\text { Ellipsoidal, asymmetri- } \\
\text { cal. } 2.5 \text { high, } 2.1 \\
\text { wide. }\end{array}$ & $\begin{array}{l}\text { Bell-shaped. } 3 \text { high, } \\
2 \text { wide. }\end{array}$ \\
\hline $\begin{array}{l}\text { Number of longitudi- } \\
\mathrm{nal} \text { lines of nemato- } \\
\text { cysts on exumbrella. }\end{array}$ & $\begin{array}{l}2 \text { extend upward from } \\
\text { base of well-developed } \\
\text { tentacle, and } 1 \text { from } \\
\text { base of each of } 3 \text { rudi- } \\
\text { mentary tentacle-bulbs. }\end{array}$ & As in H. prolifer. & None. & $?$ \\
\hline $\begin{array}{l}\text { Condition of well-de- } \\
\text { veloped tentacle, or } \\
\text { cluster of tentacles, } \\
\text { at base of longest } \\
\text { radial-canal. }\end{array}$ & $\begin{array}{l}1 \text { to } 3 \text { well-developed ten- } \\
\text { tacles at base of longest } \\
\text { radial-canal. Medusa- } \\
\text { buds are produced at } \\
\text { bases of these tentacles. } \\
\text { Often only I well- } \\
\text { developed tentacle pro- } \\
\text { duced. }\end{array}$ & $\begin{array}{l}\text { Only I well-developed } \\
\text { tentacle. No medusa- } \\
\text { buds. }\end{array}$ & $\begin{array}{l}\text { Only I well-developed } \\
\text { tentacle. No medusa- } \\
\text { buds. }\end{array}$ & $\begin{array}{l}\text { Only I well-developed } \\
\text { tentacle "between } 2 \\
\text { rudimentary basal } \\
\text { bulbs." No medusa- } \\
\text { buds. }\end{array}$ \\
\hline $\begin{array}{l}\text { Condition of } 3 \text { rudi- } \\
\text { mentary tentacles. }\end{array}$ & Mere basal bulbs. & $\begin{array}{l}1 \text { mere basal bulb. } 2 \\
\text { small tentacles. Small } \\
\text { tentacles } 90^{\circ} \text { and } \\
\text { basal bulb } 180^{\circ} \text { from } \\
\text { large tentacle. }\end{array}$ & $\begin{array}{l}1 \text { short conical tentacle. } \\
2 \text { mere basal bulbs. } \\
\text { Short conical tentacle } \\
180^{\circ} \text { and basal bulbs } \\
90^{\circ} \text { from long tentacle. }\end{array}$ & 3 mere basal bulbs. \\
\hline Gonads. & $\begin{array}{l}\text { Developed over ectoderm } \\
\text { of manubrium. Actinula } \\
\text { larva develop upon sur- } \\
\text { face of gonad in ecto- } \\
\text { derm of manubrium. }\end{array}$ & $\begin{array}{l}\text { On ectodermal sides of } \\
\text { manubrium. No ac- } \\
\text { tinulx seen attached } \\
\text { to gonad. }\end{array}$ & $\begin{array}{l}\text { On manubrium. No } \\
\text { actinule attached to } \\
\text { gonad. }\end{array}$ & $?$ \\
\hline Color. & $\begin{array}{l}\text { Entoderm of tentacle- } \\
\text { bulbs, radial-canals, } \\
\text { and stomach orange to } \\
\text { deep blood-red. }\end{array}$ & $\begin{array}{l}\text { Pink granules in tenta- } \\
\text { cle-bulbs. Entoderm } \\
\text { of manubrium pink } \\
\text { and lilac. }\end{array}$ & $\begin{array}{l}\text { Entoderm of tentacles } \\
\text { and manubrium yel- } \\
\text { low, flecked with red. }\end{array}$ & $?$ \\
\hline Where found. & $\begin{array}{l}\text { North Atlantic coasts of } \\
\text { Europe, Iceland, and } \\
\text { America. }\end{array}$ & $\begin{array}{l}\text { Coast of New England, } \\
\text { United States. }\end{array}$ & $\begin{array}{l}\text { Bahama Islands, and } \\
\text { Florida coast. Com- } \\
\text { mon in spring months, } \\
\text { at surface. }\end{array}$ & $\begin{array}{l}\text { Stanley Harbor, Falk- } \\
\text { land Islands. }\end{array}$ \\
\hline Hydroid. & $\begin{array}{l}\text { Hydroid described by L. } \\
\text { Agassiz, } 1862 \text {, as } \mathrm{H} \text {. } \\
\text { prolifer. }\end{array}$ & $\begin{array}{l}\text { Hydroid is Hybocodon } \\
\text { pendula = Corymorpha } \\
\text { pendula L. Agassiz. }\end{array}$ & Unknown. & $\begin{array}{l}\text { Hydroid may be } H \text {. } \\
\text { chilensis Hartlaub, } \\
\text { 1905. }\end{array}$ \\
\hline
\end{tabular}

*For description of $H$. chilensis Hartlaub, $H$. christina Hartlaub, $H$. pulcher Hartlaub, and $H$. (?) jonuarii, see text.

\section{Hybocodon prolifer L. Agassiz.}

Plate 2, fig. 1; plate 3, fig. 3 .

(?) Corymorpho fritillaria, STEenstrup, 1842, Generations-wecksel., p. 20, taf. 1, figs. $41-46$ (the medusa only nuay be identical with 11 . prolifer; the hydroid appears to be an Amalthea or Diplura).

(?) Steenstrupia plobosa, Sars, 1859 , Christiania Vidensk. Selsk. Forhandl., p. IOI.-Koren and Danielssen, i 877 , in Sars's Fauna I ittoralis Novegix, tome 3, p. 20, taf. 1, figs. $1-6$.

(?) Corymorpho annulicornis (young medusa), KoREN and Danielssen, 1877, Ibid., p. 8, taf. I, figs. 7-13. 


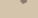

,

$$
\text { . }
$$




\section{Plate 2.}

Fig. I. Hybocodon prolifer. Woods Hole, Massachusetts, March 4, I907. This drawing shows one of the normal aspects of the medusa, with the bell somewhat contracted. When the bell is extended the mouth comes to the level of the velar opening.

Fig. 2. Hybocodon pendula. Newport, Rhode Island, April 23, I897.

Fig. 3. Hybocodon forbesii. Tortugas, Florida, June 26, I906.

Fig. 4. Dicodonium jeffersoni. Tortugas, Florida.

Fig. 5. Dicodonium floridana. Tortugas, Florida, June 17, 1897.

Drawn from life, by the author. 


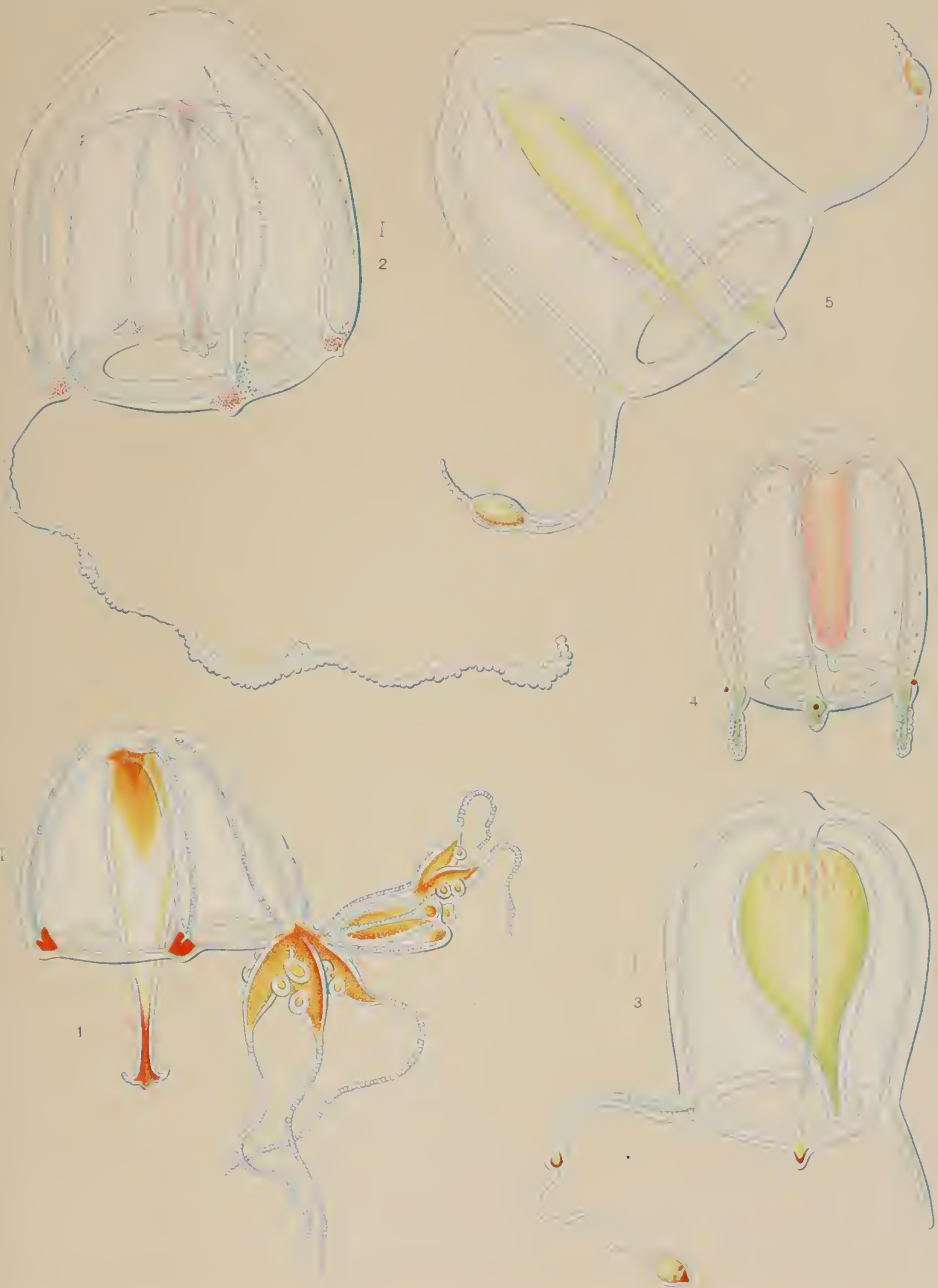



Hybocodon prolifer (hydroid and medusa), AGassiz, L., 1862, Cont. Nat. Hist. U. S., vol. 4, pp. $24 \hat{j}, 343$, plate 23a, figs. 10, 11; plate 25, 19 figs.

Hybocodon prolifer, Agassiz, A., 1865, North Amer. Acal., p. 193, figs. 325-328.-AlLvas, 1871, Monog. Tubul. Hydroids, p. 422.-VERRILl, I873, Invert. Animals, Vineyard Sound, p. 736, plate 38, fig. 282.-Bo14, 1878, Jena. Zeitschr. für Naturw., Bd. 12, p. 195, taf. 7, figs. 7-9.-Nutring, 1901, Bull. U.S. Fish Commission, vol. 19. p. 341, fig. 76. - H.akgitT, 1904, Bulletin Bureau of Fisheries U. S., vol. 24, 8. 33, plate 2, fig. 2; 1901, American Naturalist, vol. 35, p. 580 , fig. 39; Ibid., 1902, vol. 36, p. 552; 1901, Biol. Bulletin Wuods Hole, vol. 2, p. 222.-Prerkiss, 1904, American Naturalist 38 , p. 516 (simultancous sexual and asexual reproduction).

(?) $H$ ybocodon prolifer, Browne, 1896, Proc. Zool. Soc. London, p. 466.

Hybocodon prolifer $+H$. annulicornist? Amphicodon fribillariat? A. globosus + A. amphipleurus, HaEck EL, 1879, Syost. der Medusen, pp. $33,35,36,37$, taf. I, figs. 7-9.

(?) Amphicodon fritillaria, Browne, 1895 , Trans. Liverpool Biol. Soc., vol. 9

(?) Amphicodon gravidum, Linko, 1905, Zool. Anzeiger, BU. 28, p. 215 (simultaneous sexual and asexual reproduction).

(?) $H$ ybocodon prolifer, Browne, 1905 , Proc. Roy. Soc. Edinburgh, vol. 25, p. 752.

Non Hybocodon prolifer, Bonnev1E, 1899, The Norwegian North Atlantic Expedition, 1876-1878, vol. 26, Hydroida, p. 28, plate I, fig. 6.

Hybocodon prolifer, Hartlauk, 1907, Nordisches Plankton, Nr. 12, p. 98, figs. 94-97.-MÜller, H., 1908, Zeit. für wissen. Zool., Bd. 89, pp. 62, 73 (origin and structure of the eggs).

(?) Iybocodon gravidum $+H$. islandicus $+H$. amphipleurus, Hartlave, 1907, Nordisches Plankton, Nir. 12, pp. 104, 106, figs. 99, 100.

The following description is derived from studies made of medusx from the southern coast of New England, United States:

Adult medusa.-Bell about $2.5 \mathrm{~mm}$. high and $2.2 \mathrm{~mm}$. wide. It is asymmetrical, the side bearing long tentacles being longer than the other sides; or as Browne aptly describes it, the margin is not at right angles to the longitudinal axis of the bell, but slopes toward the side bearing the cluster of long tentacles. The 4 radial-canals are of lengths corresponding to the sides of the bell. The canal leading to the cluster of long tentacles is the longest; while the canal diametrically opposite to this is the shortest, the 2 other canals being of intermediate length. There are 3 small, rudimentary tentacle-bulbs, 1 at the foot of the shortest canal, and $I$ at the foot of each of the intermediate canals. The cluster of tentacles at the foot of the long radial-canal has wide, hollow, tapering basal bulbs. The main shaft of each tentache is, however, slender, cylindrical, and contractile, and is annulated at regular intervals by well-developed clusters of nematocysts. Young medusa commonly have but a single long tentacle, but as growth proceeds they sometimes develop another and finally a third; and all 3 grow to be of equal length, and form a conspicuous cluster. A number of medusa-buds in various stages of development arise from the sides of the hollow base of the one or more long tentacles, near the bell-margin. These medusa-buds thenselves develop a single long asymmetrical tentacle even before the bud is mature. When ready to be set free they resemble the parent medusa in that they are sometimes observed to be developing a third generation of medusa upon their tentacle-bulbs. 5 longitudinal lines of nematocyst-cells extend from the bases of the tentacles to near the apex of the bell. 3 of these rows arise from the hases of the 3 rudimentary tentacles, and extend up over the surface of the exumbrella immediately over the radial-canals. In addition to these there are 2 rows which start from the base of the well-developed tentacles, and extend upward over the exumbrella surface on both sides of the long radial-canal. The velum is well developed. The radial-canals are narrow and straight. The manubrium is a simple tube, which usually extends about two-thirds the distance from the inner apex of the bell-cavity to the velar opening. The mouth has 4 short lips with their edges surrounded by nematocysts. The mature eggs are found in the ectoderm of the stomach, and there they develop into actinula larva before being set free. The entoderm of the tentacle-bulbs is intense orange. The rows of nematocysts upon the exumbrella often display an orange tinge, as does also the entoderm of the stomach.

Hydroid. - The hydroid was found in Massachusetts Bay, growing in tide-pools where the water was very pure. Stems about $50 \mathrm{~mm}$. in height. They grow singly, or in small clusters, and do not branch. Each stem terminates distally in a single large polypite. The stems are not more than $\mathbf{I} \mathrm{mm}$. in diameter at the base, gradually enlarging toward upper end, and are about $3 \mathrm{~mm}$. in diameter at base of polypite. They are covered with a delicate sheath of chitinous perisarc, which widens and displays several well-developed annulations near the base of the polypite. The polypite is flask-shaped with a very broad base; the mouth is situated at the extremity of a narrow cylindrical neck, which is capable of much distension. There are 2 oral verticils, each composed of about 16 tentacles. The tentacles of the row 
near the mouth are only about half as long as those of the lower circlet. In addition to these there are about 25 long, tapering, hollow tentacles in a zone surrounding the base of the polypite. During the breeding season, which occurs from January until May, great numbers of medusæ are developed upon the sides of the polypite immediately above the circlet of basal tentacles. The budding medusa arise singly from the sides of the polypite and are not produced in clusters upon peduncles as in $H$ ybocodon christina, $H$. chilensis, and $H$. pulcher. Longitudinal bands of orange pigment extend up the stem of the hydroid. The entoderm

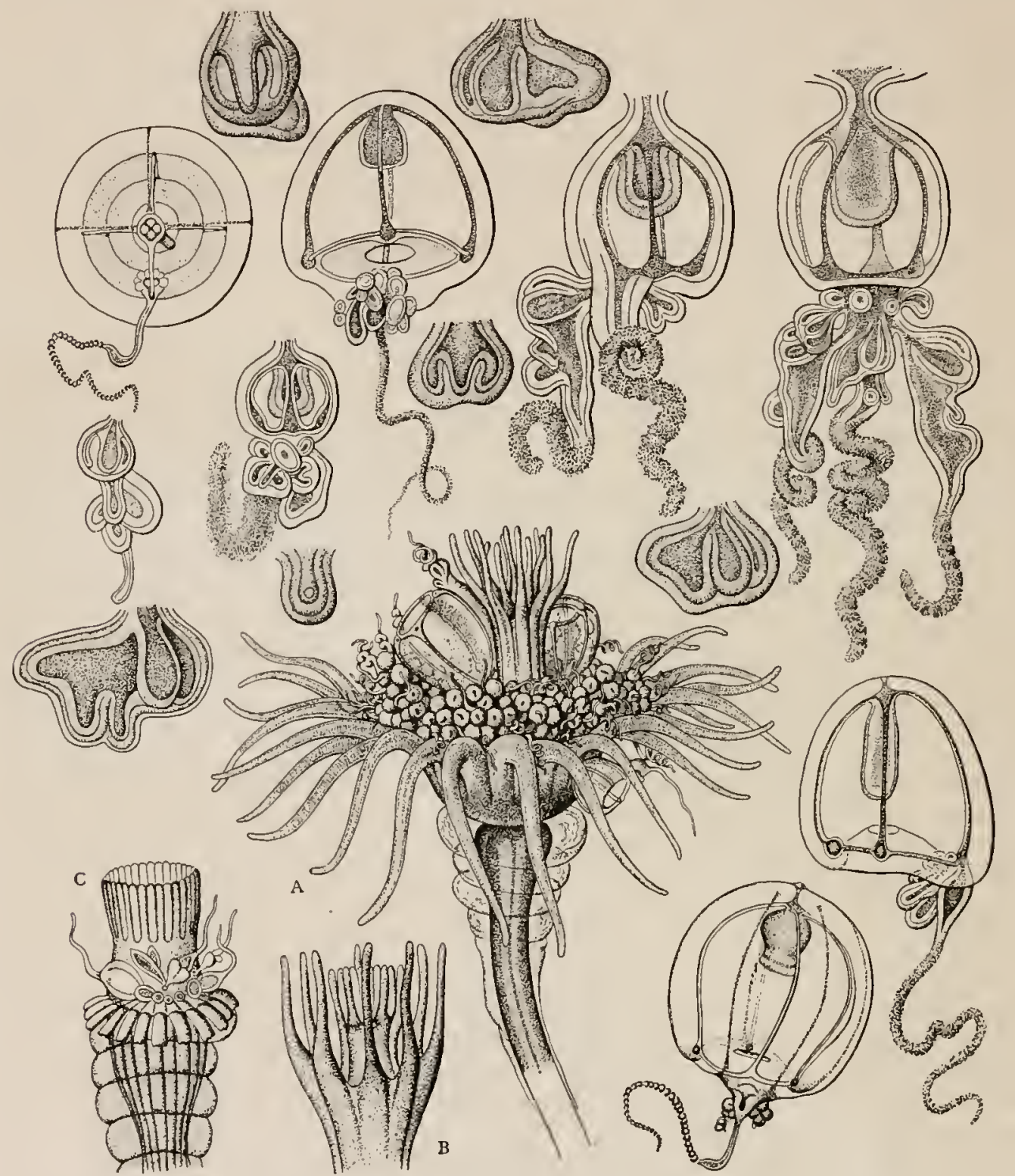

Fig. 10.-Hydroid, young, and budding medusx of $H$ ybacodon prolifer, after L. Agassiz, in Con. Nat. Hist. U. S., vol. 4.

(A.) Mature hydranth. (B.) Oral extremity of hydranth. (C.) Dissection sbowing intertentacular zone of medusa-buds.

Remaining figures are of medusa-buds and young medusx.

of the polypite is orange. L. Agassiz has shown that the entoderm of the stem is thrown into longitudinal ridges which form partial septa projecting into the cavity of the stem. The cavity, however, is continuous, and the septa do not fuse as in some other Hyboconidx.

This species is found upon the New England coast. According to Browne, I 896 , it is found upon the British, and also on the Irish coast, at Valencia, and off Iceland (Steen- 
strup) and Norway (Sars). It is apparently widely distributed over the North Atlantic, along the shores of continents and islands. It is rarely taken far from some coast. We can not be certain that the American and European forms are identical until the hydroids of both are discovered.

Hargitt, I904, states that the egg-cleavage is closely similar to that of Pennaria. Also Browne, 1895, and Hargitt, 1902, 1904, find that the ova begin their development within the walls of the manubrium of the medusa and are set free as actinula. Müller, 1908, and Hargitt, 1904, find that the developing embryos within the walls of the manubrium absorb their fellow ova, as has been observed by Doflein in $\mathcal{T}$ ubularia mesembryanthemum, and by Allen in $\tau$. crocea. Developing actinulx and budding medusæ are abundant at Woods Hole, Massachusetts, during the spring months.

Hargitt, I902, and Perkins, I904, find that actinula larvæ develop upon the manubrium at the same time that medusa-buds are being set free from the tentacle-bulbs. When set free the actinula have ro tentacles. The mouth and oral zone of tentacles develop only after the actinula is set free; and appear at the pole which was adjacent to the parent medusa during the attached period. Linko, I905, also observed this sinultaneous process of development of medusa-buds and of actinula larva in his "Amphicodon gravidum," which develops actinulæ with I I tentacles. It is probably identical with $H$. prolifer. A single specimen was found in Barents Sea, north Russia.

H. Müller, I 908, finds that the ova a re large and amcboid. Only about 2 eggs survive to maturity in the ovary; the others having been devoured by the successful eggs. The ooplasma is a network, the exoplasma being narrow-meshed and the endoplasma wider. There are numerous pseudo-cells in degenerate stages, sometimes dividing amitotically.

Hybocodon pendula Haeckel.

$$
\text { Plate 2, fig. } 2 .
$$

Corymorpha nutans (hydroid), Strmpsos, 1853 , Marine Invert. Grand Manan, p. 9.

Corymorpha pendula (hydroid), AgAssiz, L., 1862, Cont. Nat. Hist. U. S., vol.4, Pp. 276, 343, plate 26, figs. 7-17. -VERRILL, 1873 , Invert. Anim., Vineyard Sound, pp. 510,736 , plate 36 , fig. 273.

Corymor pha pendula, Hartlau B, 1907, Nordisches Plankton, Nr. 12, p. 85, fig.81 .-Nutring, 1901, Bull. U.S. Fish Commission, vol. 19, Pp. 337, 370, fig. 15.-MAr, 1903, American Naturalist, vol. 37, p. 579, 12 figs. (histology and embryology).

Corymorpha pendula (medusa), Agassiz, A., 1865 , North Amer. Acal., p. 192, fig. 324.

Hybocodon pendula, HarGitT, 1904, Bulletin Bureau of Fisheries U. S., vol. 24, P. 34, plate 2, fig. 3.

Hybocodon pendulus (medusa), HaEckel, 1879, Syst. der Medusen, p. 34 .

Monocaulus pendulus, Alzivan, i 871 , Monograph Tubularian Hydroids, p. 397.

Adult medusa.-Bell pyriform and about $5 \mathrm{~mm}$. in height. It is relatively higher than the bell of $H$. prolifer, and the gelatinous substance at the apex is much thicker. There are 5 rows of nematocysts upon the exumbrella, as in $H$. prolifer. The basal bulb of the well-developed tentacle is much smaller than in $I I$. prolifer, and no medusa-buds have been observed to arise from it. The well-developed tentacle is 2 to 3 times the length of the bell-height. Its surface is studded with large, swollen rings of nematocysts, which give it a heavy appearance. The tentacles at the bases of the 2 intermediate radial-canals are quite well developed, and this is not the case in $H$. prolifer. The velum is wide and thin. The radial-canals are narrow and straight. The manubrium is longer than in $H$. prolifer, and extends a short distance beyond the velar opening. There is a small peduncle. The lips are thickly covered with nematocysts. Pink pigment-granules are found in the entoderm of the tentacle-bulbs. The entoderm of the manubrium is pink and lilac, and contains also some pink pigment-granules.

II ydroid.-The hydroid (Corymorpha[Hybocodon] pendula) is found in depths of 10 to 100 fathoms off the New England coast, with its base buried in the sand. It is 80 to $125 \mathrm{~mm}$. in height, and $6 \mathrm{~mm}$. in diameter at the widest part. It always grows singly and is never branched. The mid-region of the stem is very thick and is covered with a canaliculated conosarc, but the basal end narrows considerably, as does also the region near the free upper extremity, which is long, slender, and pendulous. The stem is anchored by a number of root-like, tubular, fleshy processes. The perisarc exists only as a thin delicate film. The head of the polypite is large and highly contractile. There is a single verticil of long, hollow tentacles at base of polypite. The mouth is situated at the extremity of a large flask-shaped proboscis, 
and is surrounded by a couple of rows of numerous irregularly arranged tentacles. These oral tentacles are highly contractile, and are much smaller than those at the lower base of the polypite. The medusæ are borne upon branched stolon-like diverticula of the side walls of the polypite, immediately above the zone of basal tentacles. Fully-developed medus $x$ have not been seen to be set free from the hydroid, but the similarity of the most advanced medusabuds observed to the free medusa found in the ocean leaves but little doubt concerning this point. May, 1903, has studied the histology and embryology, and concludes that the medusabuds may at times become free, but usually mature while still attached to the hydranth. This species has been found from Vineyard Sound to the mouth of the St. Lawrence River. The medusa appears upon the southern New England coast in April and May, but is not seen during the summer months, although the hydroid is abundant at this time.

It is possible that Euphysa tentaculata Linko, 1905, is identical with $H$. pendula (see Zool. Anzeiger, Bd. 28, p. 214). Linko's medusa is from Barents Sea, north of Russia. I have referred to this medusa in the description of Steenstrupia bigelowi.

\section{Hybocodon forbesii Mayer.}

Plate 1, fig. 8; plate 2, fig. 3 .

Hybocodon forbesit, MaYre, 1894, Bull. Mus. Comp. Zool. at Harvard College, vol. 25, No. 11, p. 236, plate I, fig. 1; 1904, Memoirs Nat. Sci. Museum Brooklyn Institute, vol. 1, No. I, p. 8, plate 2, fig. 13 .

Medusa.-Bell asymmetrical, about $2.5 \mathrm{~mm}$. in height and ellipsoidal in shape, being slightly higher than broad. The gelatinous substance is of uniform thinness. There is a single well-developed tentacle situated at the base of the longest radial-canal. A short, conical tentacle is found at the base of the shortest radial-canal, and two smaller tentacle-bulbs are situated one at the base of each of the intermediate canals. The well-developed tentacle is about as long as the bell-diameter. Its base is small, and hardly greater in diameter than the shaft of the tentacle. Its free extremity is fusiform, and covered with prominent nematocyst-cells. No medusa-buds have ever been observed. The velum is narrow. The 4 radialcanals are straight and slender and the circular canal is narrow. There are no rows or clusters of nematocysts upon the exumbrella. Manubrium is spindle-shaped and swollen, and the mouth is a simple, round opening situated at the extremity of a narrow tubular neck, which extends beyond the velar opening. The entoderm of the terminal swelling of the large tentacle is yellow streaked with red. Entoderm of manubrium yellow with red flecks.

This species is found in Nassau Harbor, New Providence Island, Bahamas, and at Tortugas, Florida, in March to May. It is an abundant surface form. I have captured many hundreds of specimens, but have never found them producing either medusa-buds or actinula larvæ. It is distinguished by its decided yellow and orange color, and the absence of meridional lines of nettle-cells over the exumbrella.

\section{"Hybocodon unicus."}

Amphicodon unicus, Browne, I902, Annals and Mag. Nat. Hist., ser. 7, vol. 9, p. 276.

(?) Hybocodon chilensis (hydroid), Hartlaub, I905, Zoolog. Jahrbüchern, Suppl. 6, p. 545, fig. W.

Bell $3 \mathrm{~mm}$. high, $2 \mathrm{~mm}$. wide, bell-shaped. I solitary tentacle between 2 rudimentary basal bulbs; 3 perradially situated bulbs without tentacles. Medusa-buds (?) Manubrium cylindrical, nearly as long as the umbrella cavity. Color (?) Asymmetry of bell (?) One specimen was found by Vallentin, and briefly mentioned without figures by Browne, from Stanley Harbor, Falkland Islands. Hybocodon chilensis Hartlaub, from the coast of Chile, may prove to be the hydroid of this medusa (?) It will be impossible to identify the medusa from the brief mention of it given by Browne, unless, indeed, it be rediscovered in Stanley Harbor.

\section{Hybocodon chilensis Hartlaub.}

Mybocodon chilensis, Hartzaur, 1905, Zoolog. Jahrhüchern, Suppl. 6, p. 545, fig. W.

(?) Amphicodon unicus (medusa), Browne, 1902, Annals and Mag. Nat. Hist., ser. 7, vol. 9, p. 276.

(?) Steenstrupia occidentalis (medusa), Fewkes, 1889, Bulletin Essex Institute, Salem, vol. 21, No. 7, p. 107, plate 3, fig. 1. Hybocodon occidentalis, HarteavB, 1905, Zoolog. Jahrbüchern, Suppl. 6, p. 545 .

As Hartlaub states, this hydroid may be the stock of Amphicodon (Hybocodon) unicus Browne, from the Falkland Islands. 
The hydrocaulus is very thick and massive, about $50 \mathrm{~mm}$. long and unbranched save for the presence of its roots and stolons. It is covered with a stiff layer of chitin, which is not expanded at the base of the polypite. Polypite large, with 17 to 20 proximal tentacles, each about $6 \mathrm{~mm}$. long. There are also about 27 oral tentacles arranged in several rows. Above the bases of the proximal tentacles there are 8 long, thick, medusa-bearing stolons, which are thickly covered with numerous clusters of medusa-buds. Each medusa-bud has a single very large tentacle. The stem of the hydroid is rusty yellow and the polypite light rose-color. Found at Calbuco, Chile, South America.

This $H y$ bocodon is closely related to, or possibly identical with, the form from Nonvay described by Bonnevie under the name $H$ ybocodon prolifer, but it differs from $H$. prolifer Agassiz in having large, specialized, medusa-bearing stolons. Hartlaub proposes to call this Norwegian hydroid Hybocodon christince.

Fewkes, 1889 (Bull. Essex Inst., and also Amer. Naturalist, vol. 32, p. 597), gives a brief description of a medusa from the coast of California which he calls by two names, Steenstrupia occidentalis and S. californica; and which may be derived from $H y$ bocodon chilensis. This medusa is described as follows: Size (?) Bell ovoid without an apical prominence. 4 (?) 5 (?) rows of meridional lasso-cells extend upward from the 4 tentacle-bulbs, over the exumbrella toward the bell-apex. I long tentacle and 3 rudimentary tentacle-bulbs at the bases of the 4 radial-canals. The long tentacle is ringed at regular intervals and has a large pigmented basal bulb from which there arise numerous medusa-buds. Color (?) Velum well developed. 4 straight, narrow radial-canals. Manubrium shorter than the depth of the bell-cavity. No axial canal. Coast of California, United States.

Hartlaub proposes to call this medusa Hybocodon occidentalis. I find nothing in Fewkes's description to distinguish it from $H$. prolifer L. Agassiz, but apparently there is less difference between the medusa of the various forms of $H y$ bocodon than between their hydroids.

Hybocodon christinæ Hartlaub.

Tubularia prolifer $=$ Hybocodon prolifer, Bonnevie, 1899, The Norwegian North Atlantic Expedition, 1876-79, vol. 26, Hydroida, p. 28 , plate 1, fig. 6 .

Hybocodon christinc, HARtLAUB, 1905, Zoolog. Jahrbüchern, Suppl. 6, p. 546; 1907, Nordisches Plankton, Nr. 12, p. 102, fig.98.

The medusa attributed by Bonnevie to this hydroid has a single well-developed tentacle with a basal cluster of large medusa-buds, each bud bearing a single tentacle. The medusabuds resemble $H$. prolifer, but the hydroid is distinguished by bearing its medusx upon 8 branched peduncles.

Hydrocaulus unramified, tubular, springing from a ramified hydrorhiza; occurrence solitary; longitudinal striping, no collar; height about $50 \mathrm{~mm}$. The hydranth has $\mathrm{I} 4$ proximal tentacles and 2 distinct circles of (oral) distal tentacles. The oral tentacles are shorter and more numerous than the proximal. There are 8 blastostyles in a circle about midway between the oral and basal tentacles, and these bear numerous medusæ upon short pedicels. The medusa-buds have 4 very wide radial-canals, and I highly developed tentacle which exhibits at its swollen base the bud-rudiments of 4 new medusæ even before the first has become detached. This species is distinguished by its well-developed, branched, medusabearing stolons. Found off Bodö, Norway. It is closely related to $H$. chilensis Hartlaub, of the northern coast of Chile.

The medusa-buds in $H$. christina appear to be confined to the under side and the sides of the base of the well-developed tentacle.

Hartlaub, 1907 , finds that the medusa becomes $4 \mathrm{~mm}$. high and $3 \mathrm{~mm}$. wide, with thin bell-walls and an evenly rounded apex. The 4 radial-canals and ring-canal are band-like, and wider than in other species of Hybocodon.

Hybocodon pulcher Hartlaub.

Auliscus pulcher, SAyundsson, 1899 , Vid. Meddel. Nat. For. Kjöbenhavn, Ser. 6, Aarg. 1, P. 425, taf. 4, 7 figs.

Hybocodon pulcher, Hartlaub, 1905, Zool. Jahrbüchern, Suppl. 6, p. 545; 1907, Nordisches Plankton, Nr. 12, p. 96, figs. $92,93$.

Hydroid 40 to $50 \mathrm{~mm}$. high with an oral circlet of 30 short tentacles, and another circlet of 24 to 30 long tentacles around widest part of body of the hydranth. The only distinctive characters of this species are the well-developed medusa-bearing stolons, the symmetrical 
bell, and 2 large principal tentacles of the budding medusa. In $H$. prolifer, on the other hand, the medusæe are usually set free with but one well-developed tentacle. The bell of $H$. pulcher may become asymmetrical in later life (?) The hydrorhiza is thin and branching. There is a flexible collar-like perisarc at the base of the hydranth. Medusæ are developed upon stolons from the hydranth above the circlet of long tentacles. When set free the medusa is 1.5 to $2 \mathrm{~mm}$. high, of symmetrical form. 5 longitudinal lines of nematocysts extend up the sides of the bell to the apex. 3 small tentacle-bulbs. 2 equally well-developed tentacles arise side by side, from the base of one of the radial-canals. Entoderm of manubrium and tentacles red. Found off Iceland. I believe this form is probably identical with $H$. prolifer.

Genus MICROCAMPANA Fewkes, 1889.

Microcampana, FEwxes, 1889, Amer. Naturalist, vol. 32, p. 595; Bull. Esser Inst., Salem, vol. 21, No. 7, p. I11.

The type-species is Microcampana conica Fewkes, from Santa Cruz Island, off the coast of California.

\section{GENERIC CHARACTERS.}

Anthomedusæ with 6 radial-canals, and 6 radially placed marginal tentacles. One of these tentacles is well developed, and the other 5 are rudimentary.

It is possible that the vaguely described Rhabdoon singulare, of Keferstein und Ehlers, (186r, Zoolog. Beiträge, p. 86, taf. I3, figs. 6, 7), from Messina, Mediterranean, is a form of Microcampana, but there are apparently 12 longitudinal lines of nettling cells over the exumbrella, and it is uncertain whether there are 4 or 6 radial-canals. The bell is $1.5 \mathrm{~mm}$. high and oval with uniformly thin walls. It is possibly an abnormal medusa of Velella.

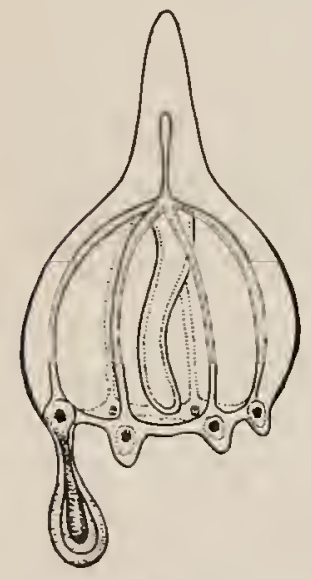

Fig. 11.- Microcampana after Fewkes in American Naturalist.

\section{Microcampana conica Fewkes.}

Microcampana conica, Frwkes, 1889, Bull. Essex Inst., Salem, vol. 21, No. 7, p. 111, plate 4, fig. 8; American Naturalist, vol. 32, p. 595, fig.

Size (?) Bell conical with a well-developed, elongate, conical apex; slightly asymmetrical. Exumbrella smooth, without meridional rows of nematocysts. 6 marginal tentacles, $60^{\circ}$ apart. 5 of these are rudimentary, but the sixth is club-shaped, and about half as long as the bell-height. 6 straight, narrow radial-canals and a ring-canal. Manubrium conical to spindle-shaped, about as long as the depth of the bell-cavity. There is a long, slender, straight, axial canal above the stomach. Bell pink, tentacle-bulbs bright-red, manubrium yellow. Found off Santa Cruz Island, California; under the cliffs of Punta Diablo.

Genus DICODONIUM Haeckel, 1879, sens. ampl.

Dicodonium + Dinema, HaEckel, 1879 , Syst, der Medusen, pp. 27, 28.

Non Dinema, Van Beneden, 1867 , Mém. Acad. Roy.des Sci. Belgique, tom.36, art.2, pp. $127,130$. Dicodonium, Vanhöffen, 1891, Zool. Anzeiger, Bd. 14, P. 443.

Sarsiella, Hartlaub, I907, Nordisches Plankton, Nr. I 2, p. 66.

The type-species of this genus is Dicodonium cornutum Haeckel, I879, of the Red Sea. Dinema Van Beneden is a medusa which arises by budding from a Perigonimus-like hydroid and therefore belongs to the Tiarinæ. We use the term Dicodonium in the sense proposed by Vanhöffen, I89I.

\section{GENERIC CHARACTERS.}

Codonid $x$ with 2 well-developed and 2 rudimentary tentacles. No meridional lines of nettle-cells upon the exumbrella. An apical projection to the bell and an axial canal projecting upward from the stomach, may or may not be present.

Some of the so-called "species" of Dicodonium are probably only abnormal specimens of Sarsia with 2 tentacles instead of the normal 4. 


\section{Plate 3.}

Fig. I. Dicodonium jeffersoni. Tortugas, Florida, June 15, 1897.

Fig. 2. Sarsia mirabilis, young medusa. Nahant, Massachusetts, March 26, $1 \$ 97$.

Fig. 3. Hybocodon prolifer. $t^{\prime}$, primary; $t^{\prime \prime}$, secondary tentacle beginning to develop; $m$, young medusa-buds. Agassiz Laboratory, Newport, Rhode Island, September I7, 1895 .

Fig. 4. Sarsia mirabilis, mature male. Nahant, Massachusetts, May 7 , 1897.

Fig. 5. Hydroid of Sarsia mirabilis with ripe male medusa-bud attached to the hydranth. Swallows Cave, Nahant, Massachusetts, May 8 , I 897 .

Drawn from life, by the author. 

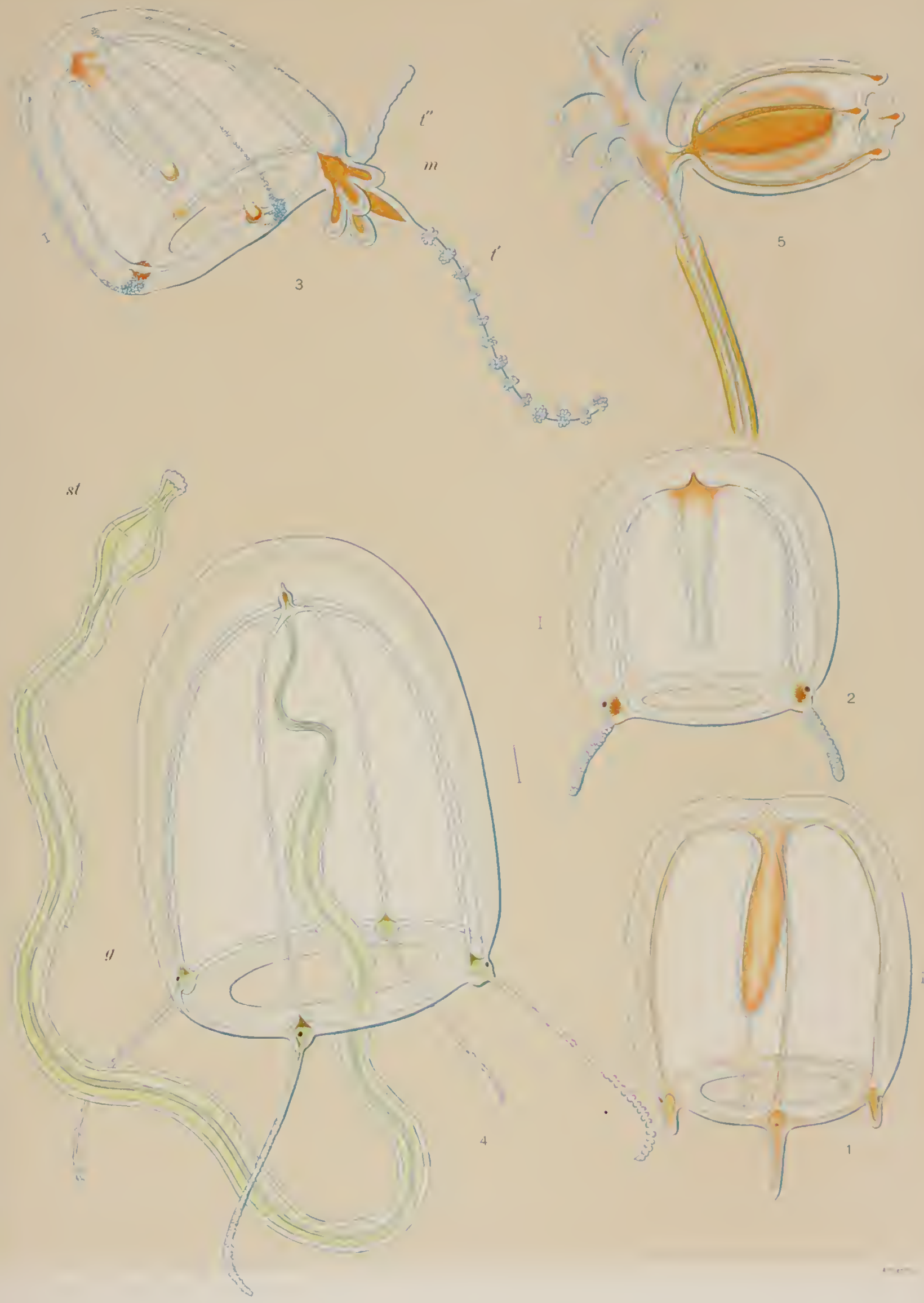

Tabular Description of the Medusa of Dicodonium.

\begin{tabular}{|c|c|c|c|c|c|c|c|}
\hline & $\begin{array}{l}\text { D. cornutum } \\
\text { Hacekel. }\end{array}$ & $\begin{array}{l}\text { D. dissonema } \\
\text { Haeckel. }\end{array}$ & $\begin{array}{l}\text { D. ocellatum } \\
\text { = Dinema } \\
\text { ocellatum } \\
\text { Haeckel. }\end{array}$ & $\begin{array}{l}\text { D. floridana } \\
\text { Mayer. }\end{array}$ & $\begin{array}{l}\text { D. jeffersoni } \\
\text { Mayer. }\end{array}$ & $\begin{array}{c}\text { D. adriaticum } \\
\text { Graeffe. }\end{array}$ & $\begin{array}{l}\text { D. dinema }= \\
\text { Sarsiella } \\
\text { dinema } \\
\text { Hartlaub. }\end{array}$ \\
\hline $\begin{array}{l}\text { Shape and size } \\
\text { of bell in } \\
\mathrm{mm} \text {. }\end{array}$ & $\begin{array}{l}\text { With bulging } \\
\text { sides, and } \\
\text { pointed } \\
\text { apex. } 4 \\
\text { high, } 4 \text { wide. }\end{array}$ & $\begin{array}{l}\text { Bell-shaped to } \\
\text { egg-shaped } \\
\text { with blunt } \\
\text { conical } \\
\text { apex. }\end{array}$ & $\begin{array}{l}\text { Bell-shaped } \\
\text { to hemi- } \\
\text { spherical. } 5 \\
\text { high, } 4 \text { to } 5 \\
\text { wide. Ex- } \\
\text { umbrella } \\
\text { besprinkled } \\
\text { with tufts of } \\
\text { nettle-cells. }\end{array}$ & $\begin{array}{l}\text { Cylindrical with } \\
\text { dome-like } \\
\text { apex. } 4 \\
\text { high, } 3 \text { wide. }\end{array}$ & $\begin{array}{l}\text { Dome-like } \\
0.75 \text { high, } \\
0.5 \text { wide. }\end{array}$ & $\begin{array}{l}\text { Bell-shaped } \\
\text { wuth a small, } \\
\text { conical, api- } \\
\text { cal projec- } \\
\text { tson. } 4 \text { high, } \\
3.5 \text { wide. }\end{array}$ & $\begin{array}{l}\text { Half-egg- } \\
\text { sliaped. } 3 \\
\text { high, z wide. }\end{array}$ \\
\hline $\begin{array}{l}\text { Lengtl of } 2 \\
\text { long tenta- } \\
\text { eles in } \\
\text { terms of } \\
\text { bell-radius } \\
(r) \text {. }\end{array}$ & $\begin{array}{l}\text { Curled uj- } \\
\text { ward. } ; r \\
\text { long. A } \\
\text { row of bris- } \\
\text { tlıngclusters } \\
\text { of nettle- } \\
\text { cells on their } \\
\text { abasial } \\
\text { sides. Tips } \\
\text { club-shaped. } \\
\text { Basal bulbs } \\
\text { small. }\end{array}$ & $\begin{array}{l}6 r \pm \text { long. } \\
\text { Very large } \\
\text { basal bulbs } \\
\text { and with an } \\
\text { abaxial ocel- } \\
\text { lus. }\end{array}$ & $\begin{array}{l}2 \text { long, with } \\
\text { fairly large } \\
\text { tentacle- } \\
\text { bulbs, each } \\
\text { with an ab- } \\
\text { axial ocellus. }\end{array}$ & $\begin{array}{l}2 \text { long with a } \\
\text { knob-like } \\
\text { swelling near } \\
\text { tip. Extreme } \\
\text { tip ends in } \\
\text { thin lash. No } \\
\text { ocelli. }\end{array}$ & $\begin{array}{l}\text { long. Basal } \\
\text { bulbs bear } \\
\text { ocelli. }\end{array}$ & $\begin{array}{l}8 \text {, long. A } \\
\text { large car- } \\
\text { mine ocellus } \\
\text { on each ten- } \\
\text { tacle-bulb. }\end{array}$ & $\begin{array}{l}2 r+\text { loug. } \\
\text { Basal bulbs } \\
\text { small; with } \\
\text { ocelli. }\end{array}$ \\
\hline $\begin{array}{l}\text { Condition of } \\
2 \text { rudimen- } \\
\text { tary tenta- } \\
\text { cle-bulbs. }\end{array}$ & Not present. & ? & Mere bulbs. & $\begin{array}{l}\text { Small, taper- } \\
\text { ing, rudimen- } \\
\text { tary. }\end{array}$ & $\begin{array}{l}\text { Mere basal } \\
\text { bulbs with } \\
\text { abarial } \\
\text { ocelli. }\end{array}$ & $\begin{array}{l}\text { Mere basal } \\
\text { bulbs with } \\
\text { sinall car- } \\
\text { mine ocelli. }\end{array}$ & Absent. \\
\hline $\begin{array}{l}\text { Arial canal } \\
\text { above stom- } \\
\text { ach. }\end{array}$ & $\begin{array}{l}\text { Well devel- } \\
\text { oped. }\end{array}$ & Present. & Not present. & Not present. & $\begin{array}{l}\text { A small axial } \\
\text { canal is } \\
\text { present. }\end{array}$ & Not present. & - \\
\hline $\begin{array}{l}\text { Shape of man- } \\
\text { ubrium, } \\
\text { and length } \\
\text { in terms of } \\
\text { bell-radius } \\
(r) \text {. }\end{array}$ & $\begin{array}{l}\text { Spindle-shap- } \\
\text { ed. i.5 r } \\
\text { long. Mouth } \\
\text { a simple } \\
\text { round open- } \\
\text { ing sur- } \\
\text { rounded by } \\
\text { nettle-cells. }\end{array}$ & $\begin{array}{l}\text { Spindle-shap- } \\
\text { ed. } 2 \text { to } 3 \\
\text { times as } \\
\text { wide in mid- } \\
\text { dle as at } \\
\text { either end. }\end{array}$ & $\begin{array}{l}\text { Club-shaped. } \\
5 \text { to } 7 r \\
\text { long. }\end{array}$ & $\begin{array}{l}\text { Flask-shaped, } \\
\text { widest above, } \\
\text { but near mid- } \\
\text { dle. }\end{array}$ & $\begin{array}{l}\text { Cylindrical, } \\
\text { with a nar- } \\
\text { row tubular } \\
\text { mouth-end. }\end{array}$ & $\begin{array}{l}\text { Short, tbick, } \\
\text { and four- } \\
\text { sided. }\end{array}$ & $\begin{array}{l}\text { Spindle- } \\
\text { shaped, } \\
6 r \text { long. }\end{array}$ \\
\hline Gonad. & $\begin{array}{l}\text { Ring-like, swol- } \\
\text { len, encir- } \\
\text { cling middle } \\
\text { third of } \\
\text { manubrium. }\end{array}$ & $\begin{array}{l}\text { Large swollen } \\
\text { gonad en- } \\
\text { circles stom- } \\
\text { ach. }\end{array}$ & $\begin{array}{l}\text { Gonad en- } \\
\text { circles stom- } \\
\text { ach, thickest } \\
\text { near mouth. }\end{array}$ & $\begin{array}{l}\text { Encircling } \\
\text { stomach. }\end{array}$ & $\begin{array}{l}\text { Large gonad } \\
\text { encircles } \\
\text { stomach } \\
\text { from base to } \\
\text { near mouth. }\end{array}$ & $\begin{array}{c}\text { In stomach } \\
\text { wall. }\end{array}$ & $\begin{array}{l}\text { Encircles en- } \\
\text { tire stom- } \\
\text { ach. }\end{array}$ \\
\hline Color. & $\begin{array}{l}\text { Stomach, ten- } \\
\text { tacles, and } \\
\text { nettle-ring } \\
\text { of margin } \\
\text { dark purple- } \\
\text { red. }\end{array}$ & ? & $\begin{array}{l}\text { Bell-margin } \\
\text { rose-red. } \\
\text { Nematocyst } \\
\text { clusters of } \\
\text { exumbrella } \\
\text { black. } \\
\text { Ocelliof ten- } \\
\text { tacle-bulbs } \\
\text { black. }\end{array}$ & $\begin{array}{l}\text { Entoderm of } \\
\text { stomach and } \\
\text { tentacles yel- } \\
\text { low. Knob- } \\
\text { like ends of } \\
\text { tentacles } \\
\text { flecked with } \\
\text { red to orange. }\end{array}$ & $\begin{array}{l}\text { Entoderm of } \\
\text { stomach } \\
\text { creamy } \\
\text { pink; of } \\
\text { tentacle- } \\
\text { bulbs deli- } \\
\text { cate green } \\
\text { or pink. } \\
\text { Ocelli red. }\end{array}$ & $?$ & $\begin{array}{l}\text { Entoderm } \\
\text { brownish- } \\
\text { yellow. }\end{array}$ \\
\hline Where found. & $\begin{array}{l}\text { Red Sea, Gulf } \\
\text { of Suez. }\end{array}$ & $\begin{array}{l}\text { Coast of Aus- } \\
\text { tralia. }\end{array}$ & $\begin{array}{l}\text { Trieste, Adria- } \\
\text { tic Sea. }\end{array}$ & $\begin{array}{c}\text { Tortugas, Flor- } \\
\text { ida. On sur- } \\
\text { face in June } \\
\text { to July, rare. }\end{array}$ & $\begin{array}{l}\text { Tortugas, Fla. } \\
\text { May to } \\
\text { Junc, com- } \\
\text { mon. }\end{array}$ & $\begin{array}{l}\text { Trieste, Adria- } \\
\text { tic Sea. }\end{array}$ & $\begin{array}{l}\text { Normandy, } \\
\text { coast of } \\
\text { France. } \\
\text { Mediterran- } \\
\text { ean? }\end{array}$ \\
\hline Remarks. & $\begin{array}{l}\text { Development } \\
\text { unknown. }\end{array}$ & $\begin{array}{l}\text { Development } \\
\text { unknown. }\end{array}$ & $\begin{array}{l}\text { Development } \\
\text { unknown. } \\
\text { 1s this an } \\
\text { abnormal } \\
\text { Sarsia with } \\
\text { only } 2 \text { ten- } \\
\text { tacles? }\end{array}$ & $\begin{array}{l}\text { Development } \\
\text { unknown. } \\
\text { Occasionally } \\
\text { rudinentary } \\
\text { tentacles de- } \\
\text { relop so as to } \\
\text { be almost as } \\
\text { long as the } \\
\text { larger pair. }\end{array}$ & $\begin{array}{l}\text { Development } \\
\text { unknown. }\end{array}$ & $\begin{array}{l}\text { Development } \\
\text { unknown. } \\
\text { This specics } \\
\text { is distin- } \\
\text { guished by } \\
\text { stiff sensory } \\
\text { haurs which } \\
\text { border ocelli. }\end{array}$ & \\
\hline
\end{tabular}


Dicodonium cornutum Haeckel.

Dicodonium cornutum, HakckeL, 1879, Syst. der Medusen, p. 27, taf. I, fig. 6.

Haeckel found this species at Tur, near Sinai, in the Red Sea. See tabular description of medusæ of Dicodonium. It has no ectodermal ocelli upon the bulbs of the 2 large tentacles.

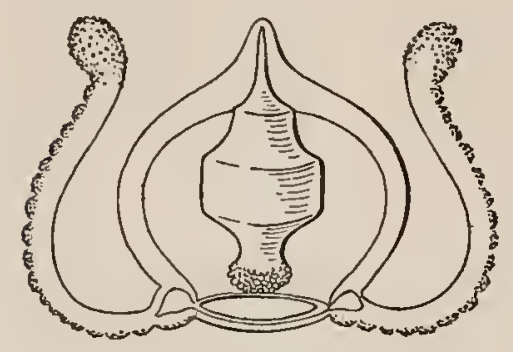

Fig. 12.-Dicodonium cornutum, after Haeckel, 1879 .

Haeckel presents a beautiful figure of the medusa, drawn from life.

Dicodonium dissonema Haeckel.

Dicodonium dissonema, HazckeI, 1879 , Syst. der Medusen, p. 27.

Haeckel describes this from a preserved specimen from the coast of Australia. See tabular description of the medusæ of Dicodonium.

"Dicodonium ocellatum."

This medusa is described by Busch from Trieste, Adriatic, and it is probably an abnormal Sarsia with only 2 of its 4 marginal tentacles developed. See tabular description of the medusæ of Dicodonium.

\section{Dicodonium floridana Mayer.}

$$
\text { Plate 2, fig. } 5 \text {. }
$$

Bell about $4 \mathrm{~mm}$. high and $3 \mathrm{~mm}$. wide, with thin, uniform, vertical walls and a slight apical projection. There are 2 equally-developed, diametrically opposed tentacles, each about three-fourths as long as the bell-height. Near the outer end of each of these tentacles there is a large, knob-like, swollen region, which terminates in a thin, tapering, nematocystbearing lash. The knob-shaped swelling is hollow and its cavity is connected with the general gastrovascular system of the medusa by means of a slender tube which extends through the entodermal core of the tentacle. The basal bulbs of the tentacles are not large, and there are no ocelli.

In addition to the 2 long tentacles, there are 2 small, tapering, rudimentary tentaclebulbs $90^{\circ}$ from the large tentacles. The velum is well developed. There are 4 straight, narrow radial-canals and a simple, narrow circular canal. The manubrium is flask-shaped, being narrower at its base than at its middle point. The mouth projects slightly beyond the velar opening, and is a simple, round opening at the extremity of a long, tapering neck. The gonads are within the wall of the manubrium. The entoderm of the stomach is yellow, and that of the distal bulbs of the tentacles yellow flecked with orange. The entoderm of the basal bulbs of the tentacles is also tinged with yellow.

This medusa is occasionally found at Tortugas, Florida, in June. Occasionally a specimen is taken in which the normally rudimentary tentacles have developed so as to be nearly as long as the pair of large tentacles, thus illustrating the imperfect line of separation between Dicodonium and Sarsia.

\section{Dicodonium jeffersoni Mayer.}

$$
\text { Plate 2, fig. } 4 \text {; plate } 3 \text {, fig. I. }
$$

Dinema jeffersoni, MAY̌r, 1900, Bull. Mus. Comp. Zool. at Harvard College, vol. 37, p. 30 , plate 37 , fig. 126.

The bell is dome-shaped, higher than a hemisphere, and about $0.75 \mathrm{~mm}$. high. The exumbrella surface is sparsely sprinkled with nematocysts. There are 2 short marginal tentacles, and 2 rudimentary tentacle-bulbs. The tentacles are radially situated, and are covered with numerous small wart-like clusters of nematocysts. There are 4 ectodermal ocelli, I upon the outer side of each of the 4 tentacle-bulbs. The velum is well developed. There are 4 straight, narrow radial-canals and a narrow circular vessel. The manubrium is about as long as the depth of the bell-cavity. It is simple, cylindrical, and tube-like, and the mouth is a round opening at the extremity of a short, cylindrical neck. A simple canal 
projects upward from the stomach into the gelatinous substance of the apex of the bell. This is probably only the remnant of the connection between the medusa and its hydroid stock. The gonad is ring-like, and encircles the stomach, leaving the short proboscis free.

The entoderm of the tentacles and tentacle-bulbs is of a delicate green or pink. The entoderm of the stomach is creamy pink. The ocelli are bright-red, and all other parts are colorless.

This medusa is quite common at the Tortugas, Florida, in May and early June. Although small, it appears to be mature, for sperm is often given off from the gonad of the males.

\section{Dicodonium adriaticum Graeffe.}

Dicodonium adriaticum, GraEFFE, 1884, Arbeit. Zool. Inst. Wien, Bd. 5, p. 351.

Bell $4 \mathrm{~mm}$. high, $3.5 \mathrm{~mm}$. wide, bell-shaped, with a small, conical, apical projection. 2 long, radially placed tentacles, more than $12 \mathrm{~mm}$. long, with large, thick, basal bulbs, each with a large carmine ocellus upon the abaxial side of the bulb. 2 tentacle-bulbs at the bases of the 2 radial-canals $90^{\circ}$ away from the large tentacles. These basal bulbs have small red ocelli. Each of these 4 ocelli are bordered by a ring of stiff sensory hairs. There are 4 small, interradial tentacle-bulbs without ocelli. Thus there are 2 long tentacles, and 6 rudimentary tentacle-bulbs. 4 radial-canals. Stomach short, thick, and 4 -sided, with the gonads in the stomach-wall. Mouth simple, with 4 lips. Found at Trieste, Adriatic Sea, in October.

\section{Dicodonium dinema.}

Sarsiella dinema, Hartlaub, 1907, Nordisches Plankton, Nr. 12, p. 67, fig. 63 .

Bell oval, half-egg-shaped, $3 \mathrm{~mm}$. high, $2 \mathrm{~mm}$. wide. Exumbrella thickly besprinkled with nematocysts. Only 2 tentacles, $180^{\circ}$ apart. These are longer than the bell-diameter. They have small basal bulbs, each with a reddish-brown ocellus. No trace of tentacle-bulb or tentacles $90^{\circ}$ apart from the well-developed tentacles. Manubrium about 2 times as long as the bell-height. Spindle-shaped and encircled throughout by the gonad. Manubrium, tentacles, and 4 radial-canals brownish-yellow. Found off the coast of Norway and in the Mediterranean (?) Is this an abnormal young Sarsia with only 2 tentacles? Hydroid unknown. Medusa rare.

\section{Genus SARSIA Lesson, 1843.}

Sarsia, Lesson, 1843, Hist. Zooph. Acal., p. 333.-A gassiz, L., 1849, Mem. Amer. Acad., New Series, vol. 4, p. 224; 1862, Cont. Nat. Hist. U.S., vol. 4, p. 211.-WAGNer, 1885, Wirbellosen des Weissen Meeres, p. 76.-VANHöfFen, 1891, Zool. Anzeiger, Bd. 14, p. 442.- Hartlaub, 1897, Hydromedusen Helgolands, p. 454; 1907, Nordisches Plankton, Nír. 12, p. 7.- ion Lendenfeld, $188_{4}$, Proc. Linnean Soc. New South Wales, vol.9, p. 582.-Chun, 1895 , Bibliotheca Zoologica, Bd. 1, Heft. 19, p. 4.-Goetre, 1904, Zool. Anzeiger, Jahrg. 27, p. 473 .

Coryne + Syndictyon, Agassiz, A., 1865 , North Amer. Acal., p. 175.

Coryne (hydroid), Calkins, 1899, Proc. Boston Soc. Nat. Hist., vol. 28, p. 336.

Codonium + Sarsia + Syndictyon, Ha eckel, 1879 , Syst. der Medusen, pp. 13, 16, 20.

Syncoryne, Weismann, 1883 , Entsteb. Sexualzellen Hydromedusen, Pp. 56, 216.

Syncoryne (hydroid), Hartiaub, 1905, Zool. Jahrbüchern, Suppl. 6, p. 524.-Nutting, 19o1, Proc. Washington Acad. Sci., vol. 3 , p. 165 .

Syncoryne (medusa), Hargitt, 1904, Bull. U. S. Bureau of Fisheries, vol. 24, pp. 29, 30.

Syncoryne, BEDOT, Igo5, Revue Suisse de Zool., tome 13, p. 119 (citation of all references to 1850 ).

Syndicion, A Gassiz, A., 1862, in L. Agassiz's Cont. Nat. Hist. U.S., vol.4, p. 340.-MAYE.r, 1904, Mem. Nat. Sci. Museum Brooklyn Institute, vol. 1, P. 7 .

Sienyo, Dujardin, $18_{45}$, Annales Sci. Nat., ser. 3, tome 4, p. 257

The type-species of this genus is Sarsia tubulosa of the northern coasts of Europe. This medusa was first described by Lesson, I 843 . The hydroid form was first described by Gärtner, I774, in Pallas's Eleunch. Zooph., under the name of Coryne. Ehrenberg, Sars, and Allman introduced the name Syncoryne. Stauridia producta also gives rise to a medusa which can not be distinguished from Sarsia.

\section{GENERIC CHIARACTERS.}

Codonidæ with 4 long, simple, equally developed tentacles, 1 at the foot of each radialcanal. The manubrium is tubular and surrounded by a ring-like gonad. There is an ectodermal ocellus upon the outer side of each tentacle-bulb. There are no meridional nematocyst-tracts upon the exumbrella. 
An apical projection of the bell may or may not be present; and there may or may not be an axial canal extending upward from the stomach into this projection. The hydroid is Syncoryne or Stauridia.

We use the name Sarsia in the sense defined by Vanhöffen, 189I (Zool. Anzeiger, p. 442).

In I 862, I865, A. Agassiz described, under the generic name Syndictyon, a Sarsia having reticulate nematocyst-cells upon its exumbrella, and clusters of such cells upon its tentacles. These are, however, only characters of immaturity and largely disappear in the full-grown medusa, which is a true Sarsia in all respects. In 1879 , Haeckel formed the genus Codonium to include medusx resembling Sarsia but distinguished by the possession of an apex upon the bell into which a blindly-ending axial canal extends from the stomach. A bell-apex and axial canal are characters which are acquired during growth in varying degrees by almost all species of Sarsia, and are therefore not of generic value.

Two European and one American species of Sarsia produce medusæ by asexual budding from the tentacle-bulbs or from the walls of the manubrium. Chun, I 895 (Bibliotheca Zoologica, Heft 19, fig. 2), showed that both ectoderm and entoderm of the manubrium take part in the formation of these proliferating medusæ; the entoderm of the manubrium forming the entoderm of the daughter medusa, and the same being true of the ectoderm. Sarsia prolifera Forbes, described and beautifully figured by Haeckel, i 879 , under the name Codonium codonophorum, produces medusa-buds upon its tentacle-bulbs.

The majority of Sarsia medusæ are probably produced asexually by hydroids of the genus Syncoryne, but at least one medusa identical with Sarsia is derived from the hydroid called Stauridia Dujardin, 1843 . Such medusæ may conveniently be placed in a subgenus Stauridiasarsia. A medusa which appears to be closely related to Sarsia is produced by the remarkable parasitic hydroid $H$ ydrichthys.

The generic name Syncoryne was restricted by Allman, $1871-1872$, to designate the hydroid which produces the medusa Sarsia. The name $S$ yncoryna was first proposed by Ehrenberg, who applied it to hydroids now known as Clava, Coryne, etc., and in this old sense it does not apply exclusively to the hydroid of Sarsia. By general consent, Allman's name has been accepted in this restricted sense, Calkins, I 899 , being almost alone in maintaining that the generic name of the hydroid should be Coryne.

The commonly accepted arrangement is to retain the old name Coryne to include hydroids in which the reproductive elements are produced in fixed sporosacs growing upon the hydranth, while Syncoryne applies to like hydroids which, however, produce free medusx.

Weismann, $188_{3}$, found that the germ-cells of both sexes of $S$ yncoryne sarsii originate in the ectoderm of the budding medusa, and do not wander from their place of origin, but become mature in the free medusa. Goette, I904, finds, however, that in Sarsia the sperm originates and remains in the peripheral ectoderm of the manubrium of the medusa, but the egg-cells, contrary to Weismann's contention, originate in the entoderm of the medusa-bud while it is still attached to the hydroid, but afterwards they migrate into the ectoderm of the manubrium, where they mature.

Many of the species of Sarsia display considerable individual variability, the colors of the manubrium and tentacle-hulbs ranging from green or yellow to red. An apical projection and an axial vessel above the stomach may or may not be developed, and the length of the manubrium at maturity is subject to much variability. Moreover, the hydroids may form densely or sparingly branched colonies in accordance with environmental conditions, and as is well known in $S$. mirabilis, free medusx are produced in early spring, whereas late in the season the medusæ mature while still attached to the hydroids. Much confusion has been introduced into the synonymy of the genus, and different stages of the same medusa have occasionally received different specific names.

Sarsia "nodosa" Busch, I851, appears to be the young of some European Sarsia. The exumbrella of very young medusa of Sarsia are usually besprinkled with nettling cells and their tentacles bear prominent nematocysts, and Busch's medusa displays both of these characters. (See Hartlaub, Ig07, Nordisches Plankton, Nr. 12, p. 68, fig. 64.) 
Tabular Description of the Medusce of Sarsia.

\begin{tabular}{|c|c|c|c|c|c|}
\hline & $\begin{array}{l}\text { S. tubulosa Lesson, } \\
18_{43} *\end{array}$ & $\begin{array}{l}\text { S. mirabilis L. Agassiz, } \\
{ }_{1} 8_{49} \dagger\end{array}$ & $\begin{array}{l}\text { S. eximia }=\text { Syncor- } \\
\text { yne eximia } \\
\text { Hincks, } 1868 \text {. }\end{array}$ & $\begin{array}{l}\text { S. radiata von } \\
\text { Lendenfeld. }\end{array}$ & $\begin{array}{l}\text { S. conica = Codon- } \\
\text { ium conicum } \\
\text { Hackel. }\end{array}$ \\
\hline $\begin{array}{l}\text { Shape and size of } \\
\text { bell in mm. }\end{array}$ & $\begin{array}{l}\text { Egg-shaped. Half- } \\
\text { ellipsoidal. toto } \\
12 \text { high, } 6 \text { to } 8 \\
\text { wide. With or } \\
\text { without apical } \\
\text { projection. }\end{array}$ & $\begin{array}{l}\text { As in S. tubulosa, } 7 \text { to } \\
10 \mathrm{high}, 4 \text { to } 8 \text { wide. }\end{array}$ & $\begin{array}{l}\text { Oval with quite } \\
\text { thick walls, } 3 \\
\text { high. } 2 \text { wide. }\end{array}$ & $\begin{array}{l}\text { Semi-ovate. } 3 \\
\text { high, } 2.5 \text { wide. }\end{array}$ & $\begin{array}{l}\text { Barrel-shaped witl } \\
\text { long pointed } \\
\text { apex. } 12 \text { high, } 4 \\
\text { wide. }\end{array}$ \\
\hline $\begin{array}{l}\text { Character of } 4 \text { ten- } \\
\text { tacles. Length } \\
\text { in terms of bell- } \\
\text { radius }(r) \text {. }\end{array}$ & $\begin{array}{c}\text { Basal bulbs small; } \\
\text { each wth abaxial } \\
\text { ocellus. Tentacles } \\
\text { about } 4 \text { to } 6 \\
\text { long, and without } \\
\text { prominent clusters } \\
\text { of nettle-cells. }\end{array}$ & As in S. tubulosa. & $\begin{array}{l}\text { Basal bulbs Jarge, } \\
\text { with abaxial ocel- } \\
\text { lus on cach. Ten- } \\
\text { tacles about } 4^{r} \\
\text { long. }\end{array}$ & As in S. eximia. & $\begin{array}{l}7 \text { long, with small } \\
\text { basal bulbs. }\end{array}$ \\
\hline $\begin{array}{l}\text { Shape and length } \\
\text { of manubrium } \\
\text { in terms of bell- } \\
\text { radius }(r) \text {. }\end{array}$ & $\begin{array}{l}\text { Narrow, cylindrical } \\
\text { at its base. Mid- } \\
\text { dle part cylindri- } \\
\text { cal, swollen by } \\
\text { gonad. Stomach } \\
\text { small, spindle- } \\
\text { sbaped. Mouth at } \\
\text { end of short coni- } \\
\text { cal neck, as in } \\
\text { S. mirabilis. } \\
\text { Length } 4 r \text {. }\end{array}$ & $\begin{array}{l}\text { Narrow tubular base. } \\
\text { Mlid-region swollen and } \\
\text { cylindrical. Line of } \\
\text { demarcation between } \\
\text { narrow, cylindrical, } \\
\text { basal, and wide middle } \\
\text { part very sharp. } \\
\text { Stomach swollen and } \\
\text { spindle-shaped and } \\
\text { near outer end of the } \\
\text { manubrium. Beyond } \\
\text { stomach there is a } \\
\text { short, tapering, narrow } \\
\text { neck. Mouth is a } \\
\text { round opening. Total } \\
\text { length } 3 \text { to } 6 \text {. Average } \\
4 r \text {. }\end{array}$ & $\begin{array}{l}\text { Cylindrical; wide } \\
\text { above, with nar- } \\
\text { row, short, tubular } \\
\text { neck above mouth. } \\
\text { Length about } 2 r \\
\text { or less. }\end{array}$ & $\begin{array}{l}\text { As in S.eximia, } \\
1.5 r \text { long or } \\
\text { less. }\end{array}$ & $\begin{array}{l}\text { Spindle-shaped, } \\
\text { only } 1.5 \text { to } 2 \text {, } \\
\text { long. }\end{array}$ \\
\hline Gonads. & $\begin{array}{l}\text { Ring-like and de- } \\
\text { veloped over } \\
\text { nearly the whole } \\
\text { length of the } \\
\text { manubrium, leav- } \\
\text { ing a short dis- } \\
\text { tance at both ends } \\
\text { free. No medusa- } \\
\text { buds. }\end{array}$ & $\begin{array}{l}\text { Thick ring encircling } \\
\text { manubrium. Begin- } \\
\text { ning abruptly at a short } \\
\text { distance from base, } \\
\text { and extending to upper } \\
\text { part of stomach, leav- } \\
\text { ing both ends of nuan- } \\
\text { ubrium free. }\end{array}$ & $\begin{array}{l}\text { Encircles manu- } \\
\text { briun from base } \\
\text { to mouth end, } \\
\text { leaving only short } \\
\text { neck above the } \\
\text { mouth free. No } \\
\text { medusa-buds. }\end{array}$ & As in S. eximia. & $\begin{array}{l}\text { Encircles stomacl, } \\
\text { leaving both ends } \\
\text { free. }\end{array}$ \\
\hline Color. & $\begin{array}{l}\text { Èntodern of stom- } \\
\text { ach green, bluish } \\
\text { lilac, or red. } \\
\text { Tentacle-bulbs } \\
\text { green, blue, or red. } \\
\text { Ocell, black. }\end{array}$ & $\begin{array}{l}\text { Entoderm of stomach } \\
\text { usually green, sorne- } \\
\text { tines green and red, } \\
\text { or red. Tentacle-bulbs } \\
\text { green or red. Ocelli } \\
\text { black. }\end{array}$ & $\begin{array}{l}\text { Entoderm of s:om- } \\
\text { ach yellowish- } \\
\text { red to reddlish- } \\
\text { brown or green. } \\
\text { Ocelli black in } \\
\text { young and red in } \\
\text { mature nedusa. } \\
\text { Tentacle-bulbs } \\
\text { red, or brownish- } \\
\text { red. }\end{array}$ & $\begin{array}{l}\text { Entoderm of } \\
\text { manubrium } \\
\text { and tentacle- } \\
\text { bulbs deep } \\
\text { brown. }\end{array}$ & : \\
\hline Where found. & $\begin{array}{l}\text { North Atlantic } \\
\text { coasts of Europe } \\
\text { to Arctic Ocean. }\end{array}$ & $\begin{array}{l}\text { From coast of New Jer- } \\
\text { sey northward to Arctic } \\
\text { Ocean. Coasts of Nor- } \\
\text { way, northern Russia, } \\
\text { Greenland, Alaska to } \\
\text { northern Chile along } \\
\text { Pacific coast to South } \\
\text { America. }\end{array}$ & $\begin{array}{l}\text { Coast of England, } \\
\text { Scotland, Helgo- } \\
\text { land, Norway, } \\
\text { Juneau, Alaska, } \\
\text { North Pacific } \\
\text { (Nutting). }\end{array}$ & $\begin{array}{l}\text { New South } \\
\text { Wales, Aus- } \\
\text { tralia. }\end{array}$ & Indian Ocean. \\
\hline Hydroid. & $\begin{array}{l}\text { Syncoryne sarsia } \\
\text { Loven. Hartlaub, } \\
\text { 1905, describes } \\
\text { (this hydroid?) } \\
\text { from Terra del } \\
\text { Fuego, Antarctic. }\end{array}$ & $\begin{array}{l}\text { Syncoryne "mirabilis" } \\
\text { L. Agassiz. S. reticu- } \\
\text { lata is a closely related } \\
\text { variety (sec text). }\end{array}$ & $\begin{array}{l}\text { Svncoryne eximia, } \\
\text { Allman. }\end{array}$ & $\begin{array}{l}\text { Syncoryne radi- } \\
\text { ahi. }\end{array}$ & Unknown. \\
\hline
\end{tabular}

*Description based on accounts by European writers.

†Description based on original observations of medusie found off southern coast of New England, L'nited States. 
A number of Syncoryne hydroids have been described which probably produce Sarsia medusæ, but are not known so to do. Among these may be mentioned Syncoryne crassa Picter, 1893 (Revue Suisse Zool., tome I, p. 8), a small hydroid only $2 \mathrm{~mm}$. high and relatively thicker and shorter than $S$. pulchella of Allman, 1871 (Monog. Tubularian Hydroids, p. 279, plate 6, fig. 3). Pictet's hydroid comes from Amboina, Malay Archipelago. It has 30 to 40 short, knobbed tentacles, and the medusa-buds arise singly between the tentacles. The hydrorhiza is net-like, and the hydroid is pale orange in color.

Hartlaub, 1907, has made a masterly study of the genus Sarsia, and shows that the species fall conveniently into two groups: the Eximia group, with short manubrium occupied entirely by the gonad, which extends from its base to near the mouth, and the $\mathcal{T}$ ubulosa group,

Tabular Description of the Meduse of Sarsia.-Continued.

\begin{tabular}{|c|c|c|c|c|c|}
\hline & $\begin{array}{l}\text { S. prolifera Forbes } \\
=\text { S. codono- } \\
\text { phora Haeckel. } \\
\text { (See text.) }\end{array}$ & $\begin{array}{l}\text { S. gemmifera Forb. } \\
=\text { S. siphono- } \\
\text { phora Haeckel. }\end{array}$ & $\begin{array}{l}\text { S. hargitti }=\text { S. pro- } \\
\text { ducta Hargitt. }\end{array}$ & $\begin{array}{l}\text { S. flammea Hart- } \\
\text { laub, } 1907 .\end{array}$ & $\begin{array}{c}\text { Sarsia (Stauridio- } \\
\text { sarsia)producta= } \\
\text { Stauridia producta } \\
\text { Wright, Hartlaub. }\end{array}$ \\
\hline $\begin{array}{l}\text { Shape and size of } \\
\text { bell in } \mathrm{mm} \text {. }\end{array}$ & $\begin{array}{l}\text { Bell-sbaped, with } \\
\text { or witbout apical } \\
\text { projection. } 2.5 \\
\text { to } 8 \text { high, } 3 \text { to } 8 \\
\text { wide. }\end{array}$ & $\begin{array}{l}\text { Bell ellipsoidal. } \\
8 \text { high, } 6 \text { wide. }\end{array}$ & $\begin{array}{l}\text { Pyriform. } 1.5 \text { high, } \\
1 \text { wide. }\end{array}$ & $\begin{array}{l}\text { Oval. } 12 \text { high, } 7 \\
\text { wide. }\end{array}$ & $\begin{array}{l}\text { Three-fourths-egg- } \\
\text { shaped. } 10 \text { high, } \\
7 \text { wide. }\end{array}$ \\
\hline $\begin{array}{l}\text { Character of } 4 \text { ten- } \\
\text { tacles. Length } \\
\text { in terms of bell- } \\
\text { radius }(r) \text {. }\end{array}$ & $\begin{array}{l}\text { Basal bulbs very } \\
\text { large and wide, } \\
\text { witb black or red } \\
\text { ocelli. Tentacles } \\
\text { hollow, tapering. } \\
2 \text { to } 6 \text { r long; } \\
\text { with clusters of } \\
\text { medusa-buds } \\
\text { upon their bases. }\end{array}$ & $\begin{array}{l}\text { Well-developed } \\
\text { basal bulbs with } \\
\text { abasial ocelli. } \\
\text { Tentacles } 4 r \text { long. }\end{array}$ & $\begin{array}{l}\text { Well-developed } \\
\text { hasal hulbs with } \\
\text { abaxial ocelli. } \\
\text { Tentacles } 2 r \text { long. }\end{array}$ & $\begin{array}{l}\text { Tentacle tips knob- } \\
\text { like. Shafts cover- } \\
\text { ed with broken } \\
\text { (partial) rings. } \\
\text { No ocelli. }\end{array}$ & $\begin{array}{l}\text { Large basal bulbs } \\
\text { witb abasial ocelli. } \\
\text { Tentacles about } 3 \\
\text { to } 4 \text { rlong. }\end{array}$ \\
\hline $\begin{array}{l}\text { Shape and length } \\
\text { of manubrium } \\
\text { in terms of bell- } \\
\text { radius ( } r) \text {. }\end{array}$ & $\begin{array}{l}\text { Spindle-shaped with } \\
\text { narrow neck and } \\
\text { simple, round } \\
\text { mouth-opening. } \\
\text { About } 1.5 r \text { long. }\end{array}$ & $\begin{array}{l}\text { Very long, tubular, } \\
\text { with spindle- } \\
\text { shaped stomach } \\
\text { near outer end. } \\
\text { Mouth at extrem- } \\
\text { ity of narrow } \\
\text { neck. Manubrium } \\
8 \mathrm{r} \text { long. }\end{array}$ & $\begin{array}{l}\text { Spindle-shaped at } \\
\text { bothends, narrow- } \\
\text { er and tubular in } \\
\text { middle. } 2 \text { to } 3 r \\
\text { long. A circlet of } \\
\text { medusiform } \\
\text { gonads(=medusa- } \\
\text { buds?) near prox- } \\
\text { imal end of man- } \\
\text { ubrium. }\end{array}$ & $\begin{array}{l}\text { Conical-spindle- } \\
\text { shaped, only two- } \\
\text { thirds as long as } \\
\text { the depth of the } \\
\text { bell-cavity. }\end{array}$ & $\begin{array}{l}\text { Cylindrical, about } \\
3 r \text { long. }\end{array}$ \\
\hline Gonads. & $\begin{array}{l}\text { Encircling stomach. } \\
\text { Medusæ pro- } \\
\text { duced asexually } \\
\text { upon the tentacle- } \\
\text { bulbs. }\end{array}$ & $\begin{array}{l}\text { Gonad (?) } \\
\text { Medusa produc- } \\
\text { ed asexually by } \\
\text { budding from } \\
\text { sides of manu- } \\
\text { brium. There may } \\
\text { be } 10 \text { to } 22 \text { or } \\
\text { more of these } \\
\text { budding medusa } \\
\text { upon manubrium } \\
\text { at one and same } \\
\text { time. Law of bud- } \\
\text { ding discussed in } \\
\text { text. }\end{array}$ & $\begin{array}{l}\text { Gonad (?) } \\
\text { Medusiforen buds } \\
\text { on stomach in cir- } \\
\text { clet near base. }\end{array}$ & $\begin{array}{l}\text { Ring-like, encirc- } \\
\text { ling the manu- } \\
\text { brium from its } \\
\text { base to near } \\
\text { mouth. }\end{array}$ & $\begin{array}{l}\text { Gonad at hase of } \\
\text { stomach. No me- } \\
\text { dusa-buds. }\end{array}$ \\
\hline Color. & $\begin{array}{l}\text { Entoderm of tenta- } \\
\text { cles and stomach } \\
\text { yellow to sage- } \\
\text { green. Mouth or- } \\
\text { ange. Ocelli } \\
\text { brown. Tentacle- } \\
\text { bulbs contain red } \\
\text { entodermal pig- } \\
\text { ment. }\end{array}$ & $\begin{array}{l}\text { Entoderm of stom- } \\
\text { ach, tentacles, and } \\
\text { radial-canals or- } \\
\text { ange-yellow to or- } \\
\text { ange-red. Ocelli } \\
\text { black. }\end{array}$ & $\begin{array}{l}\text { Basal part of manu- } \\
\text { brium orange. } \\
\text { Distal end hlue- } \\
\text { green. Tentacle- } \\
\text { bulbs orange, } \\
\text { edged with green. } \\
\text { Ocelli black. }\end{array}$ & $\begin{array}{l}\text { Entoderm fiery red } \\
\text { or orange. }\end{array}$ & $\begin{array}{l}\text { Stomach brownish, } \\
\text { gonads yellowish- } \\
\text { wbite, tentacle- } \\
\text { bulbs red. Ocelli } \\
\text { black. }\end{array}$ \\
\hline Where found. & $\begin{array}{l}\text { English Channel to } \\
\text { Mediterranean. }\end{array}$ & $\begin{array}{l}\text { Atlantic coasts of } \\
\text { Europe, from } \\
\text { Norway south- } \\
\text { ward to Canary } \\
\text { Islands. }\end{array}$ & $\begin{array}{l}\text { No Man's Land, } \\
\text { near Woods Hole, } \\
\text { Massachusetts, } \\
\text { United States. A } \\
\text { single specimen } \\
\text { was found. }\end{array}$ & Arctic Ocean. & $\begin{array}{l}\text { Coast of Great } \\
\text { Britain to Helgo- } \\
\text { land. }\end{array}$ \\
\hline Hydroid. & Unknown. & Unknown. & Unknown. & & Stauridia producta. \\
\hline
\end{tabular}


with long, tubular manubrium with the gonad confined to a short length near its free outer end. He states that the Eximia group are represented by such forms as Sarsia eximia, brachygaster, flammea, barentsi, prolifera, angulata, and apiculata. The Tubulosa group are represented by $S$. tubulosa, densa, decipiens, litorea, pulchella, frutescens, mirabilis, reticulata, princeps, rosaria, etc.

The genus Plotocnide Wagner, 1885, is defined by Hartlaub, 1907, as a Sarsia-like medusa with nettle-cells upon the exumbrella. The gonad surrounds the manubrium from the base downward. No ocelli. Hydroid unknown. It appears to me that unless it be proven that the hydroid is different from Syncoryne, this genus should be merged with Sarsia.

Weismann, I88I (Zool. Anzeiger, Bd. 4, p. 6I), shows that the circulation of fluids within the gastrovascular cavity of Coryne pusilla is aided by the rhythmical contraction of the walls of the gonophore. The systole and diastole are not always of equal duration, but each ranges from 60 to 75 seconds. Thus the circulation in certain hydroids may be aided by periodic peristaltic contractions as well as by the movement of cilia.

Annandale, 1907, Journal and Proc. Asiatic Society of Bengal, vol. 3, finds Syncoryne flamentata, sp. nov., developing free medusx and growing in brackish pools of one-third the salinity of sea water at Port Canning, Lower Bengal. The mature medusa is unknown.

Tabular Description of the Medusce of Sarsia.-Continued.

\begin{tabular}{|c|c|c|c|c|c|c|}
\hline & $\begin{array}{l}\text { S. rosaria = Coryne } \\
\text { rosaria A. Agassiz, } \\
\text { I } 865 .\end{array}$ & $\begin{array}{l}\text { S. minima von } \\
\text { Lendenfeld. }\end{array}$ & $\begin{array}{l}\text { S. brachygaster } \\
\text { Grönberg, } \\
1898 .\end{array}$ & $\begin{array}{l}\text { S. angulata } \\
\text { Mayer. }\end{array}$ & $\begin{array}{l}\text { S. gracilis } \\
\text { Browne, } 1902 .\end{array}$ & $\begin{array}{l}\text { S. princeps } \\
\text { Haeckel, } 1879 .\end{array}$ \\
\hline $\begin{array}{l}\text { Shape and } \\
\text { size of bell } \\
\text { in } \mathrm{mm} \text {. }\end{array}$ & $\begin{array}{l}\text { Oval, with small } \\
\text { apical projection. } \\
15 \text { to } 30 \text { high, 10 } \\
\text { to } 15 \text { wide. }\end{array}$ & $\begin{array}{l}\text { Ovate. } 3 \text { high, } \\
2.5 \text { wide. }\end{array}$ & $\begin{array}{l}\text { Three-fourths- } \\
\text { egg-shaped, } \\
\text { widest above } \\
\text { the middle. Is } \\
\text { to i } 8 \text { high, } 8 \\
\text { to } 10 \text { wide. }\end{array}$ & $\begin{array}{l}\text { Half-egg-shap- } \\
\text { ed. } 3 \text { high, } \\
2.8 \text { wide. } 4- \\
\text { sided in con- } \\
\text { traction. }\end{array}$ & $\begin{array}{l}\text { Cylindrical, } \\
\text { thick-walled. } \\
5 \text { high, } 3 \text { wide. }\end{array}$ & $\begin{array}{l}\text { Conical with thin } \\
\text { walls. } 28 \text { to } 40 \\
\text { high, } 15 \text { to } 3^{\circ} \\
\text { wide. }\end{array}$ \\
\hline $\begin{array}{l}\text { Character of } \\
4 \text { tentacles. } \\
\text { Length in } \\
\text { terms of } \\
\text { bell-radius } \\
(r) .\end{array}$ & $\begin{array}{l}\text { Basal bulbs large: } \\
\text { each with abaxial } \\
\text { ocellus. Tentacles } \\
3 \text { to } 4 \text { rlong. } \\
\text { Basal bulbs } \\
\text { flanked by pads } \\
\text { of nettle-cells. }\end{array}$ & $\begin{array}{l}\text { Tentacles about } \\
2.5 r \text { long. }\end{array}$ & $\begin{array}{l}\text { Basal bulbs } \\
\text { large with a } \\
\text { small abaxial } \\
\text { ocellus. Ten- } \\
\text { tacles } 3 \text { to } 4 \\
\text { rlong. }\end{array}$ & $\begin{array}{l}\text { Basal bulbs } \\
\text { large, with well- } \\
\text { developed ab- } \\
\text { axial ocellus. } \\
\text { Tentacles } 2 r \\
\text { long. }\end{array}$ & $\begin{array}{l}\text { Ocelli on basal } \\
\text { bulbs. Each } \\
\text { tentacle } 3 r \\
\text { long, termina- } \\
\text { ting in a nema- } \\
\text { tocyst-knob. }\end{array}$ & $\begin{array}{l}\text { Basal bulbs } \\
\text { elongate, con- } \\
\text { ical, and fianked } \\
\text { by pad-like clus- } \\
\text { ters of nemato- } \\
\text { cysts. Each bulb } \\
\text { bears small ab- } \\
\text { axial ocellus. } \\
\text { Tentacles } 8 \text { r } \\
\text { long. }\end{array}$ \\
\hline $\begin{array}{l}\text { Shape and } \\
\text { length of } \\
\text { manubrium } \\
\text { in terms of } \\
\text { bell-radius } \\
(r) \text {. }\end{array}$ & $\begin{array}{l}\text { Spindle-shaped, } \\
\text { only } 1.5 \text { to } 2 \mathrm{rlong} \text {. }\end{array}$ & As in S.rosaria. & As in S. eximia. & $\begin{array}{l}\text { Shaped as in } \mathrm{S} \text {. } \\
\text { rosaria. } r \text { to } \\
\text { one-twelfth } r \\
\text { long. }\end{array}$ & $\begin{array}{l}\text { Two-thirds as } \\
\text { long as the } \\
\text { depth of the } \\
\text { bell-cavity. }\end{array}$ & $\begin{array}{l}\text { Tubular, cylin- } \\
\text { drical, with a } \\
\text { round mouth- } \\
\text { opening } 4 r \\
\text { long. }\end{array}$ \\
\hline Gonads. & $\begin{array}{l}\text { Encircles stomach, } \\
\text { leaving both ends } \\
\text { free. No medusa- } \\
\text { buds. }\end{array}$ & As in S. rosaria. & As in S. eximia. & As in S. rosaria. & (?) & As in S. rosaria. \\
\hline Color. & $\begin{array}{l}\text { Entoderm of stom- } \\
\text { ach ranges from } \\
\text { yellow to pink or } \\
\text { reddish-brown to } \\
\text { purple. Tentacle- } \\
\text { bulbs yellowish- } \\
\text { brown to red. }\end{array}$ & $\begin{array}{c}\text { Entoderm } \\
\text { brown. }\end{array}$ & $\begin{array}{l}\text { Entoderm of } \\
\text { stomach and } \\
\text { tentacle-bulbs } \\
\text { orange-red. } \\
\text { Ocelli black. }\end{array}$ & $\begin{array}{l}\text { Entoderm of } \\
\text { stomach and } \\
\text { tentacle-bulbs } \\
\text { robin-egg } \\
\text { blue; never } \\
\text { red. Ocelli } \\
\text { deep-brown. }\end{array}$ & (?) & $\begin{array}{l}\text { F.ntoderm of ten- } \\
\text { tacle-bulbs and } \\
\text { manubrium pur- } \\
\text { ple. Ocelli } \\
\text { black. }\end{array}$ \\
\hline Where found. & $\begin{array}{l}\text { Pacific coast of } \\
\text { North America, } \\
\text { southern Califor- } \\
\text { nia to Puget } \\
\text { Sound. }\end{array}$ & $\begin{array}{l}\text { Port Jackson, } \\
\text { New South } \\
\text { Wales, Aus- } \\
\text { tralia. }\end{array}$ & $\begin{array}{l}\text { Spitzbergen and } \\
\text { Greenland, in } \\
\text { summer. }\end{array}$ & $\begin{array}{l}\text { Bahamas } \\
\text { Tortugas, } \\
\text { Florida. Win- } \\
\text { ter to mid- } \\
\text { summer. }\end{array}$ & $\begin{array}{l}\text { Stanley Harbor, } \\
\text { Falkland Is- } \\
\text { lands. }\end{array}$ & $\begin{array}{l}\text { Greenland and } \\
\text { Spitzbergen, in } \\
\text { summer. }\end{array}$ \\
\hline Hydroid. & $\begin{array}{l}\text { Syncoryne rosaria } \\
\text { A. Agassiz and } \\
\text { Fewkes. }\end{array}$ & $\begin{array}{l}\text { Syncoryne min- } \\
\text { ima. }\end{array}$ & Unknown. & Unknown. & $\begin{array}{l}\text { (? ?) } \\
\text { Syncoryne sar- } \\
\text { sii Hartlaub, } \\
1905 \text { (?) Is } \\
\text { this medusa a } \\
\text { young Slab- } \\
\text { beria? }\end{array}$ & Unknown. \\
\hline
\end{tabular}




\section{Sarsia tubulosa Lesson.}

Syncoryna sarsï (hydroid), LoveN, 1835, K. Vet. Acad. Handl. för Ar., p. 275, plate 8, figs. 7-10.

Oceania subulosa (medusa), SARs, M., 1835, Beskriv og Jagtt., p. 25, plate 5, fig. II. Also: Syncorine sarsii, 1846, Fauna littor. Noveg., part. 2, p. 2, tab. 1, figs. 1-6.

Syncoryne sarsii, Loven, 1837, Archiv. für Naturgesch., Jahrg. 3, p. 321, taf. 6, fig. 25.-Weismann, i 883, Entsteh. Sexualzellen bei Hydromedusen, Jena, pp. 56, 216.-Garstang, 1894, Journal Oxford Club, vol. 2, No. 30, p. 7.-Citron, 1902, Archiv. Naturges., Jahrg. 68, pp. I, 26, taf. I, 2 (sensory cells of tentacles).-Hincks, I868, British Hydroid Zoophytes, p. 52, plate 7, fig. 3.-Allman, 1872, Monog. Tubularian Hydroids, p. 275.

Syncoryne sarsi and Sarsia iubulosa, BEDOT, 1905, Revue Suisse de Zool., tome 13, pp. 120, 147 (all literature 1835-1850). Sarsia tubulosa, Lesson, 1843, Hist. Zooph. Acalëphes, p. 333. - Schulze, 1973, Ueber den Bau von Syncoryne Sarsii, p. 14, taf. 3.-Romanes, 1885, Jellyfish, Star-hish, and Sea Urchins, etc., International Scientific Series, vol. 49 (reactions to stimuli).-Linko, 1905 , Zool. Anzeiger, Bd. 28, p. 212 .- Hartlsu B, 1907, Nordisches Plankton, Nr. 12, p. I 9, figs. 10-16.-

Browne, 1903, Bergens Museums Aarbog, No. 4, p. 9; 1895, Proc. and Trans. Liverpool Biol. Soc., vol. 9, p. 246. Sarsia tubulosa, SARs, $1835=$ Sarsia macrorhyncha, Busch, I851; Browne, E. T., 1905, Proc. Royal Soc. Edinburgh, vol. 25, p. 758 .

Syncoryne gravata, Hiscks, 1868 , Hist. British Hydroid Zooph., p. 53.

Sarsia tubulosat S. macrorhyncha, Hafckel, 1879, Syst. der Medusen, pp. 16, 19.

Sarsia tubulosat S. pulchella, Forres, 1848 , British Naked-eyed Medusa, pp. 55, 57, plate 6, figs. 2, 3 .

Coryne pusilla, Agassiz, L., 1862, Cont. Nat. Hist. U. S., vol. 4, p. 340.

(?) Syncoryne Sarsii, HartLAU B, 1905, Zoolog. Jahrbuichern, Suppl. 6, p. 525, fig. F (hydroid from Terra del Fuego).

Sarsia macrorhyncha, Busch, 1851 , Beobach. wirbell. Seeth., p. 10, taf. 3, figs. 7-10; taf. 4, figs. I, 2 .

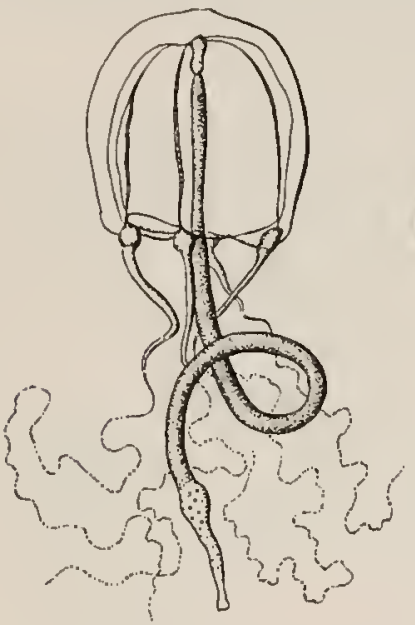

I3.

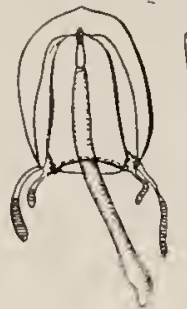

14.

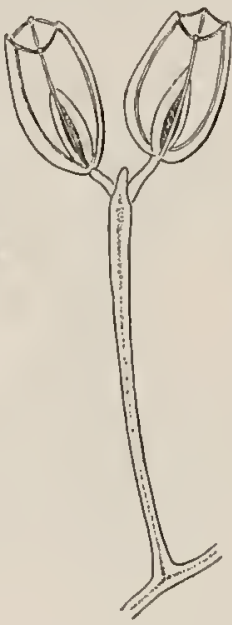

14.

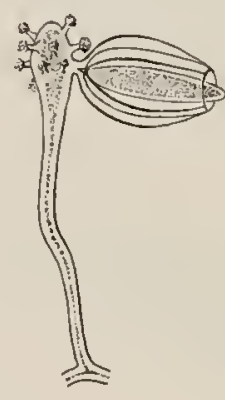

I5.

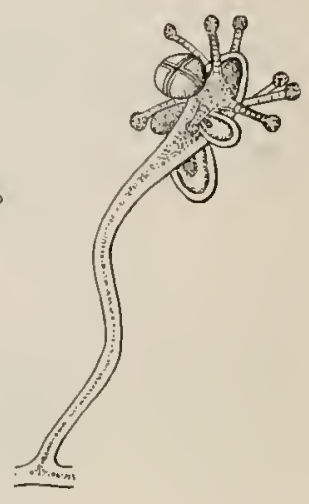

I 5 .

FrG. 13.- "Sarsia litorea," after Hartlaub, in Nordisches Plankton.

Fig. 14. "Sarsia decipiens," after Hartlaub, in Nordisches Plankton.

Fig. I 5.- "Syncoryne gravata," after Hincks, in British Hydroid Zoophytes-probably hydroid of Sarsia mirabilis.

This medusa is found off the English coast early in the spring, but it disappears before August. It is evidently an Arctic species, is abundant off the northern coasts of Europe, and is found off Iceland. It is very closely related to, if not identical with, the American S. mirabilis, but may possibly be distinguished by its more slender and higher bell, its very long manubrium, and its somewhat shorter tentacles. All of these characters are, however, very variable in Sarsia mirabilis, and I have become convinced that the American and European forms are at most only varieties, one of the other. For details see the tabular description of medusæ of Sarsia.

Romanes, 1885 , carried out many interesting physiological experiments upon this species, and showed that its ocelli are organs for the perception of light. The medusa is sensitive only to rays between the red and violet, and is strongly attracted by the light. The smallest part of the bell-margin is capable of initiating and maintaining the rhythm of the bell, but if the margin be entirely removed all pulsations of the bell instantly cease, while the cut-off margin continues to pulsate. Stimulation of the subumbrella of the bell causes contraction of the manubrium (proboscis), and indeed the bell, when deprived of its margin, still responds by contractions to all sorts of stimuli, chemical, thermal, electrical, or mechanical, although sustained rhythmical pulsation is never resumed.

The hydroid is $S y n c o r y n e$ sarsii, which is common in shallow water along the coasts from England to Norway. The polypites are spindle-shaped and elongate and have about I 2 to 


\section{Plate 4 .}

Fig. I. Sarsia mirabilis. Abnormal medusa with a tentacle arising from the side of the manubrium. Nahant, Massachusetts, May 8, I897. Metschnikoff, I870, observed a similar abnormality in Slabberia catenata.

Fig. 2. Median section of a young medusa of Sarsia mirabilis. The ocellus on the right-hand tentacle is shown as if depigmented in order to illustrate its structure. The eye on the left-hand tentacle-bulb is shown normally pigmented.

Figs. 3 and 4. Sarsia mirabilis var. reticulata, young medusa. Figure 4, one of the nematocyst-cells from the tentacles of figure 3. Agassiz Laboratory, Newport, Rhode Island, June I3, I 895 .

Drawn from nature, by the author. 

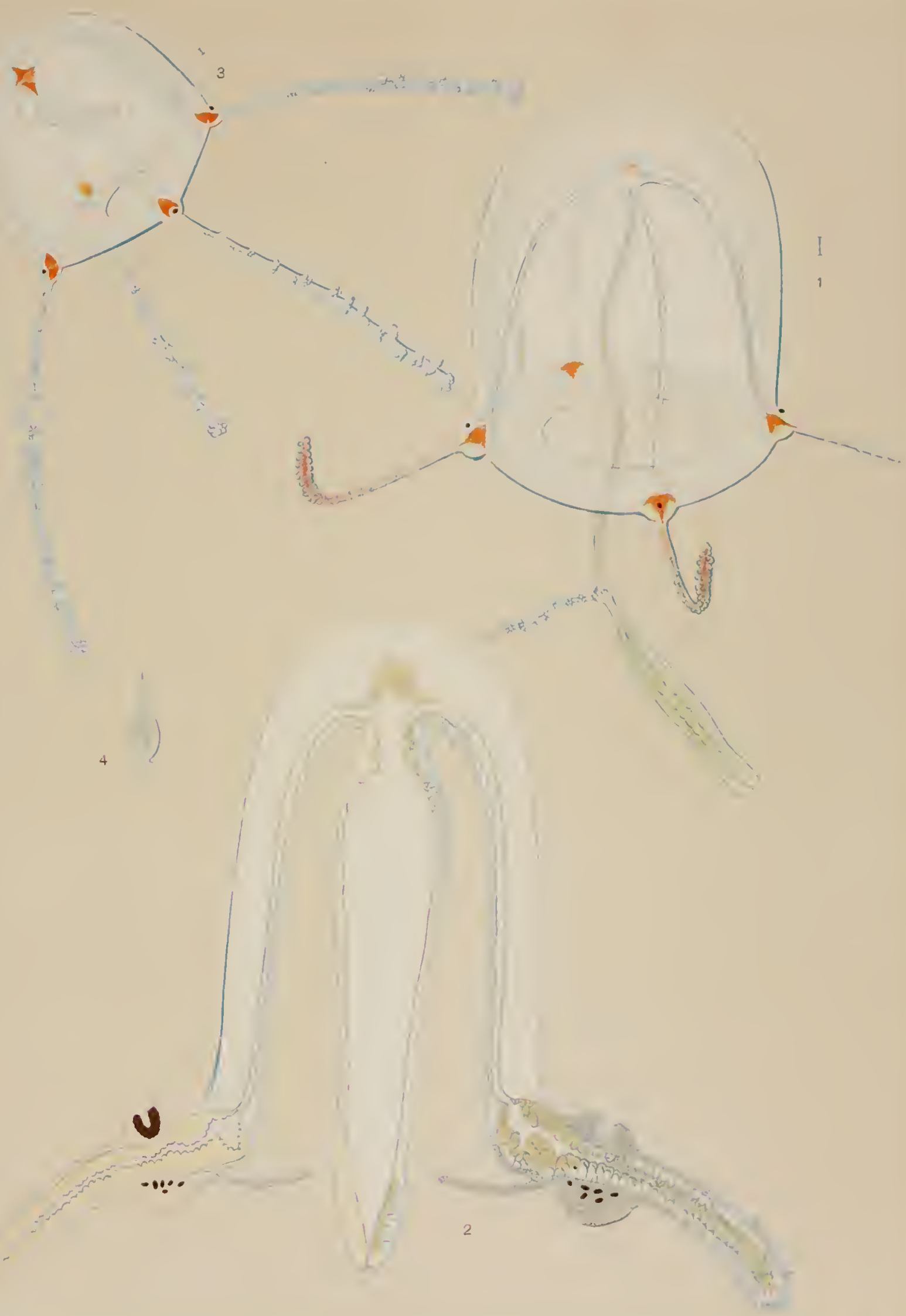

I6 short tentacles which arise at irregular intervals from their sides. Each of these tentacles ends in a knob-like cluster of nematocysts. The 2 or 3 medusa-buds arise from the sides of the polypite between the tentacles. The stems of the hydroid are quite smooth, sparingly branched, and about 12 to $15 \mathrm{~mm}$. high. The stems are translucent, slightly horny in color, and the polypites are light-red.

I can not determine any well-defined distinctions between $S$. sarsii and $S$. mirabilis, excepting that in $S$. sarsii the medusa-buds appear always to arise from near the middle of the sides of the polypite between the tentacles, whereas in $S$. mirabilis the medusa-buds arise from near the base of the polypite at or below the level of the lowest zone of tentacles.

Hartlaub has given excellent figures and descriptions of a number of medusx which are closely related to Sarsin tubulosa, if not mere varieties of the latter. These are $S$. pattersoni Haddon, S. frutescens Allman, S. decipiens Hartlaub, S. litorea Hartlaub, and S. pulchella Forbes. (See Hartlaub, I907, Nordisches Plankton, Nr. I2, pp. 29, 30, 32, 36; figs. 20-22b, $23,24,28,29$.) I hesitate to quote these as distinct species, for I have observed the same or nearly the same variations among individuals in swarms of $S$. mirabilis at Nahant, Woods Hole, and Newport on our coast. A statistical study, or better still, a study of the respective hydroids, is required before we can hope to determine these so-called "species" with certainty.

Garstang, I 894 , observes that the hydroid of $S$. tubulosa gives rise to dimorphic medusx, as does $S$. mirabilis on the coast of New England, where early in the spring the medusx are set free, whereas in May they mature while still attached to the hydroid.

Sarsia tubulosa Lesson, variety Sarsia mirabilis L. Agassiz.

Plate 3 , figs. 2, 4, and 5; plate 4 , figs. 1 and 2.

Literature relating to the AMerican variety of Sarsia tubulosa.

Sarsia mirabilis, Agassız, L., I849, Mem. Amer. Acad., New Ser., vol. 4, p. 224, plates 4, 5.-STimpson, 1853 , Marine Invert. Grand Manan, p. 11.-Haeckel, 1879, Syst. der Medusen, p. 17.-Fewkes, 1881, Bull. Mus. Comp. Zool. at Harvard Coll., vol.8, p. 141 , plate 3, figs. 11, 12.-Levissen, 1893, Vid. Meddel. Nat. For. K jöbenhavn (5), Bd. 4, p. 143.-Bırula, 1896 , Annuaire Musée Zool. Imp. Sci. St. Pẻtersbourg, tome 1, p. 332.-Hartlaug, I9o7, Nordisches Plankton, Nr. 12, p. 37, figs. 30-40.-Linko, 1900, Mém. Acad. Sci. St. Pẻtersbourg, sẻr. 8, vol. 10, No. 4, p. I1, taf. 1, figs. 1-12 (structure of ocelli); 1905 , Zool. Anzeiger, Bd. 28, p. 212; 1900, Traveaux Soc. Impériale des Nat. St. Pẻtersbourg, tom. 29, p. 151 .

Sarsia mirabilis (medusa), Agassiz, L., 1862, Cont. Nat. Hist. U. S., vol. 4, pp. 211-217; vol. 3, Ibid., plate 18, figs. 15-25a.

Sarsia glacialis, Mörch, 1857 , Beskriv af Grönland, p. 95.

Coryne mirabilis (hydroid), AGassiz, L., I862, Cont. Nat. Hist. U. S., vol. 4, Pp.185-211, plates 17-19; vol. 3, 1bid., figs. I-16, plate 17; figs. I-14, plate 18; figs. $1-27$, plate 19.

Coryne mirabilis, Agassiz, A., 1865, North Amer. Acal., p. 175, figs. 282-285.-Catkins, I899, Proc. Boston Soc. Nat. Hist., vol. $28, \mathrm{p} .336$.

Oceania iubulosa, Gould, 184 , Invert. of Mass., p. 348

Syncoryne mirabilis, Altmav, I871, Monog. Tubul. Hydroids, p. 278.-Hargit, 1904, Bulletin Bureau of Fisheries U. S., rol. 24, p. 30, plate v, fig. 1; 1901, Amer. Naturalist, vol. 35, p. 578, fig. 33; 1903, Scicnce, vol. 16, p. 344 (variations). Hartlaur, 1905, Zool. Jahrbüchern, p. 526; Zool. Jahrb., Syst. Abth., 1901, Bd. 14, p. 356.-Torrer, 1902, Univ. California Publications, vol. 1, p. 31.-Nurrixg, Igol, Bull. U. S. Fish Commission, vol. 19, pp. 328, 372, figs. 3, 81.

(?) Syndiciyon angulatum (young medusa), MUrbach and Shearer, 1903, Proc. Zool. Soc. London, vol. 2, p. I68.

(?) Sarsi barentsii (young red-colored medusa), Liwko, 1905, Zool. Anzeiger, Bd. 28, p. 214 (north of Russia).

(?) Euphysa ientaculata (abnormal medusa with only 3 well-developed tentacles), Lixko, 1905, Zool. Anzeiger, Bd. 28, p. 214 (Barents Sea, North Russia).

Syncoryne densa, Hartuab, 1897, Wissen. Meeresuntersuch. Komm. Meere. Kiel, Helgoland, Neue Folge, Bd. 2, p. 452 , taf. I 6b, figs. 4, 11; taf. I6c, figs. 7, 8 (hydroid forms dense tufts). Also: Sarsia sp., Hartlat'B, 1896, Verhandl. Deutsch. Zool. Gesell., Leipzig, Bd.6, Vers., p. 182 (medusx with branched manubria); 1907, Nordisches Plankton, Nr. 12, p. 26, figs. 17-19, $22 a$ (hydroid and medusa).

The following description is derived from a study of medusæ and hydroids obtained off the southern coast of New England, United States.

Adult medusa.-Bell is half-egg-shaped, about $7 \mathrm{~mm}$. in height and $4 \mathrm{~mm}$. in diameter. There is no apical projection, and the gelatinous substance is not very thick at the aboral pole and becomes successively thinner near the margin. There are $\neq$ long, highly contractile tentacles, one at the base of each radial-canal. The surface of each tentacle is covered with prominent nematocyst-cells, which are clustered especially at the outer end of the tentacle. Each tentacle arises from a well-developed basal bulb which contains a single ectodermal ocellus upon the outer nerve-ring on the abaxial side of the tentacle-bulb. According to Linko, I 900 , the ocellus is composed of a cup-shaped invagination of densely pigmented ectodermal cells between which there are spindle-shaped bipolar nerve-cells. The ento- 
dermal core of the tentacle is hollow, and its lumen is continuous with the gastrovascular system of the medusa. The ectodermal cells of the tentacle-bulb are very thick and are probably nervous in function. The velum is well developed, being wide and thin. There are 4 straight, slender radial-canals, and a simple, narrow, circular tube. A short, blindlyending tube extends upward from the base of the stomach into the gelatinous substance of the bell. The entodermal cells of this small projection are several layers thick. The manubrium is long and extends far beyond the velar opening. Its proximal part is slender and tubular, but in its outer parts it is much distended by the genital products and consists of a long, wide, cylindrical tube. The line of demarcation between the narrow and the wide part of the manubrium is very sharp. The mouth is a simple opening at the extremity of a short flask-shaped proboscis, and the lips are studded with nematocysts. The mature genital products are found in the ectoderm of the distal part of the manubrium. The entoderm of the manubrium is usually green, but occasionally it is red. The entoderm of the tentaclebulbs is either red or green, and in some individuals the entoderm of the bulb is red while the ectoderm is green.

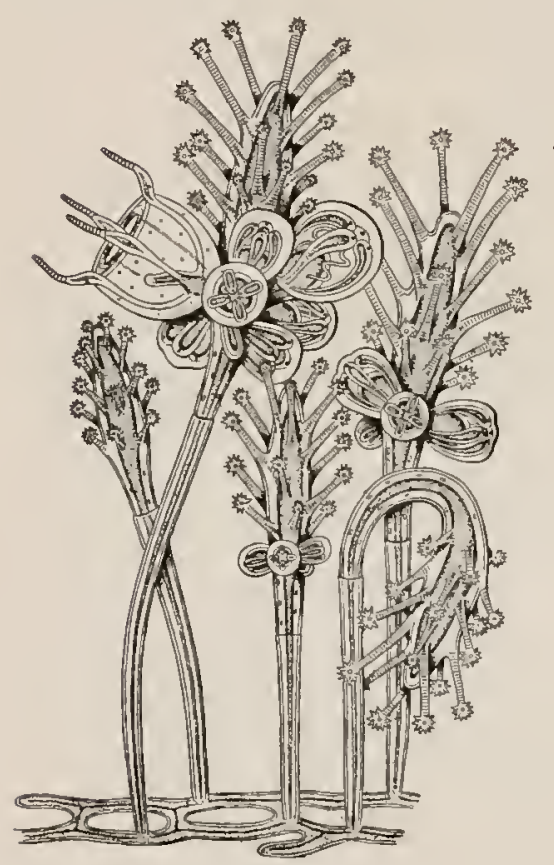

FIG. 16.- "Syncoryne pulchella."

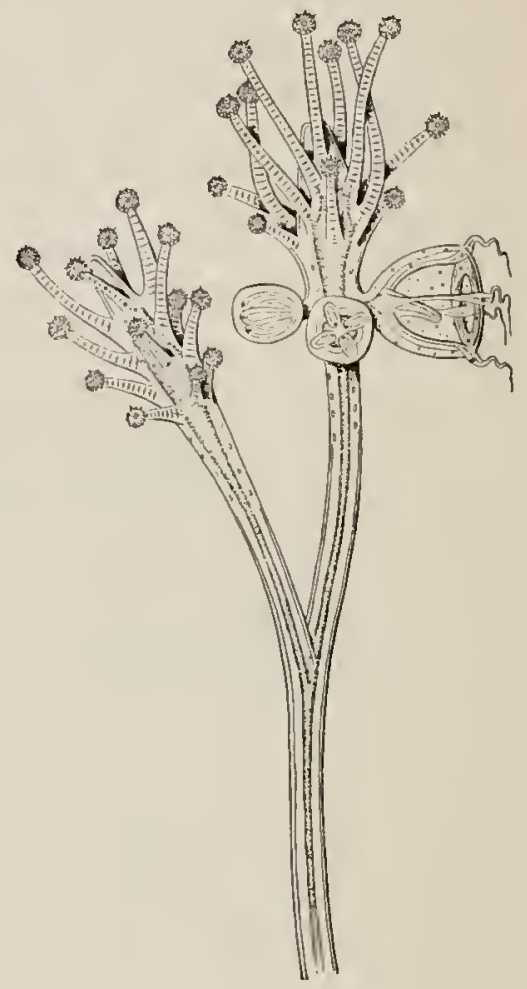

FIG. 17.-"Syncoryne frutescens."

The above figures are after Allman, in Ray Society, $1871-72$.

Hydroid and young medusa.-The hydroid stock is Syncoryne mirabilis. The stems are attached by a creeping stolon. They are about 15 millimeters in height and branch profusely. The main stems and also the side branches terminate each in a single polypite. The stems are incased in an unannulated chitinous perisarc, which terminates sharply at the bases of the polypites. Each polypite is fusiform and has about 12 to 18 tentacles which arise in 3 or more indefinite whorls from the sides of the polypite. These tentacles are not long, but are quite contractile. Each terminates in a knob-shaped cluster of nematocystcells. The mouth of the polypite is a simple round opening situated at the extremity of a conical proboscis. Medusa-buds are developed upon the sides of the polypites immediately below the tentacles, near the lower base of the polypite. Each polypite bears I to 4 medusa-buds in various stages of development. In Massachusetts Bay the breeding season begins early in March and lasts until the end of May. During March the medusa-buds 
develop 4 long tentacles, and are set free in an immature state, but during the last half of the breeding season they fail to develop tentacles or give rise to mere short lashes upon their basal bulbs; and they become sexually mature while attached to the hydroid, the manubrium of each bud being greatly distended with the genital products. This observation was first made by L. Agassiz, I 862 (pp. I 89,203 ), and has been confirmed by us in hydroid stocks obtained in Swallow's Cave, Nahant, Massachusetts. Plate 3, fig. 5, is derived from one of these sexually mature medusa-buds found upon a hydroid on May 8, i 897 . It will be observed that the manubrium of the bud is distended with sperm, while the tentacles are not developed. In this connection it is interesting to observe that Pcnnaria and Podocoryne carnea sometimes give rise to medusæ which are sexually mature at their time of liberation, while in other stocks of the same species the medusæ are set free in an immature condition. Garstang, I 894 , observes the same phenomenon in the European $S$. sarsii.

This hydroid of our Sarsia is very abundant, from March until May, in Massachusetts Bay, where it appears to grow equally well both in pure sea-water and in the brackish mouths of rivers. The medusx appear in great numbers on the southern coast of New England
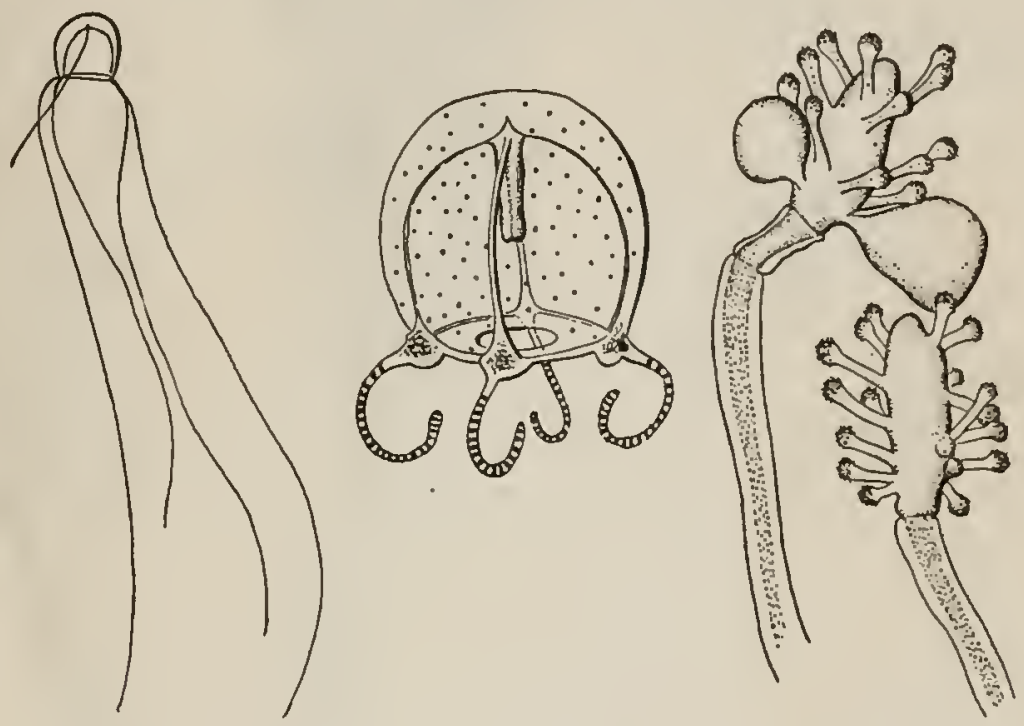

Fig. 18.-Hydroid and medusa of "Sarsia densa," after Hartlaub, in Nordisches Plankton.

between February and April. They become rare during May, and are not seen during the summer months. The hydroid extends northward to the Greenland coast, but has not been recorded from Beaufort, North Carolina, or farther south. Linko and Birula, i 896 , found it in the White Sea, and Linko, I905, records it from the eastern parts of Barents Sea between Kanin and Kolgujew Islands. Calkins, Torrey, and Hartlaub have found this medusa along the Pacific coast of America as far south as Chile. I believe $S$ yncoryne densa Hartlaub from Helgoland to be an environmental form of $S$ mirabilis.

We have observed an abnormal medusa of Sarsia mirabilis in which a single welldeveloped tentacle arose from the side of the manubrium at the point of juncture of the long tubular basal region and the gemmiferous part of the manubrium. (See plate 4, fig. I). This abnormal tentacle was studded with clusters of nematocyst-cells. It lacked a basal bulb and had no ocellus. Asexual budding of medusa from the walls of the manubrium is not known in Sarsia mirabilis. Medusæe of Sarsia with branched manubria are described by Hartlauh, i 896 , I907.

Professor Hartlaub finds that in Sarsia mirabilis the stomach is confined to the distal end of the manubrium and the gonad is confined to the mid-region of the manubrium ahove the stomach. Both the proximal and distal ends of the manubrium lack the gonad. On the other hand, in $S$. braclyygaster and $S$. cximia there is no differentiated stomach-region, and the gonad may extend over the whole, or nearly the whole, length of the manubrium. 
The chief and possibly only well-marked point of difference between the forms S. mirabilis and $S$. tubulosa is that in the hydroid of $S$. mirabilis the medusa-buds arise from near the base of the polypite, whereas in the hydroid of $S$. tubulosa they arise from points higher up on the sides of the polypite, between the tentacles.

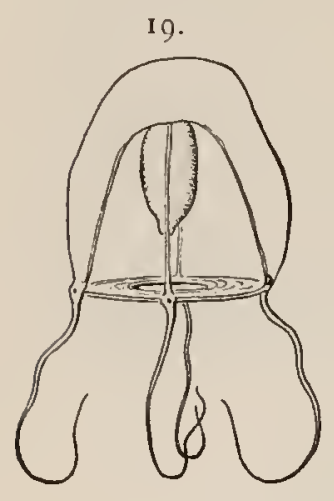

19.
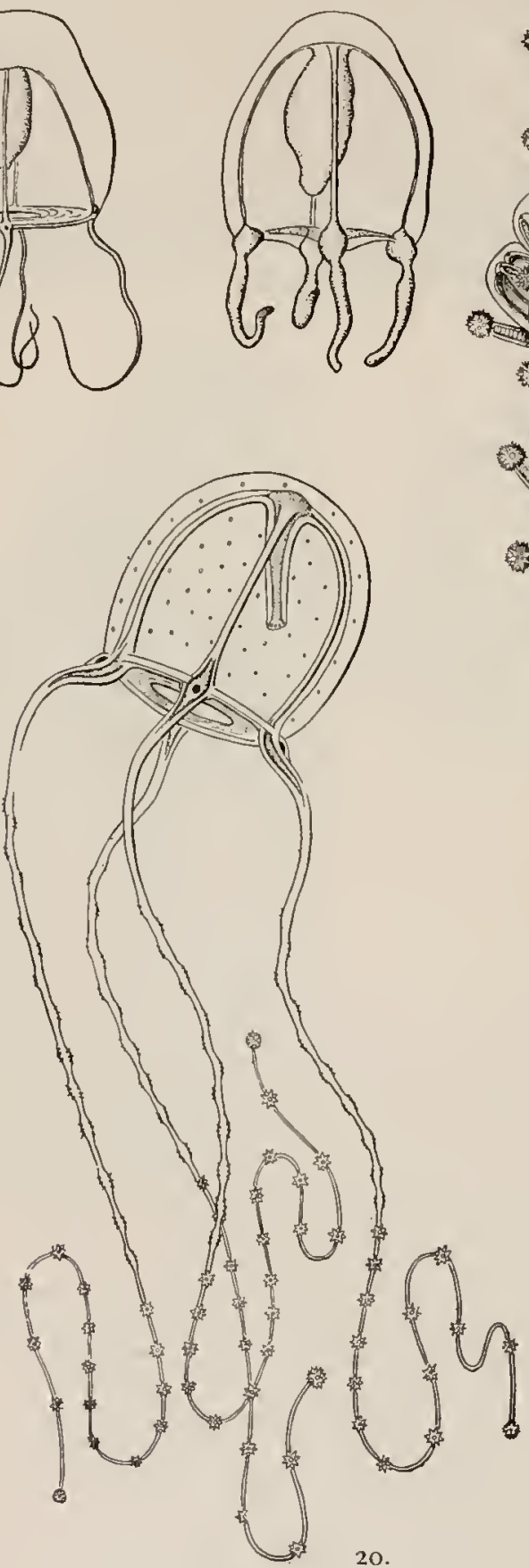

20.

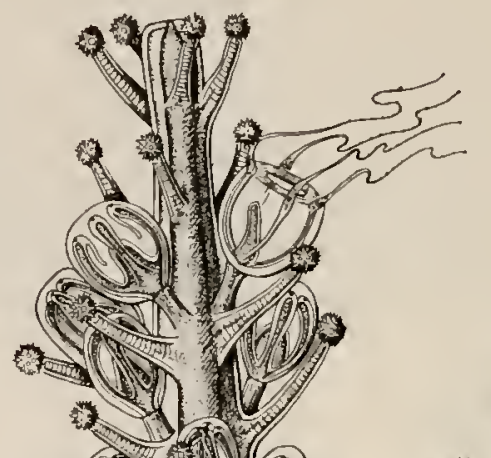

.
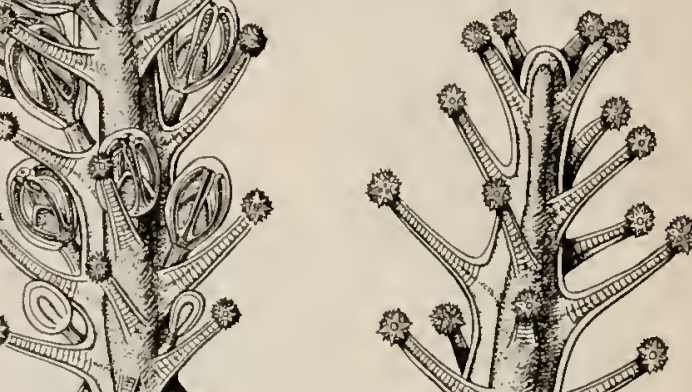

)

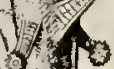

(4)

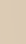




\section{Plate 5 .}

Fig. I. Sarsia angulata. Nassau Harbor, New Providence Island, Bahamas, July, 1903.

Fig. 2. Corynitis agassizii. Charleston Harbor, South Carolina, September, 1897.

Fig. 3. Ectopleura minerva. Tortugas, Florida.

Fig. 4. Ectopleura dumortieri, young medusa. Agassiz Laboratory, Newport, Rhode Island, June, 1893 .

Fig. 5. Ectopleura dumortieri, mature male. Agassiz Laboratory, Rhode Island, July, 1896 .

Fig. 6. Sarsia mirabilis var. reticulata. Nahant, Massachusetts, March 25, 1897 .

Drawn from life, by the author. 


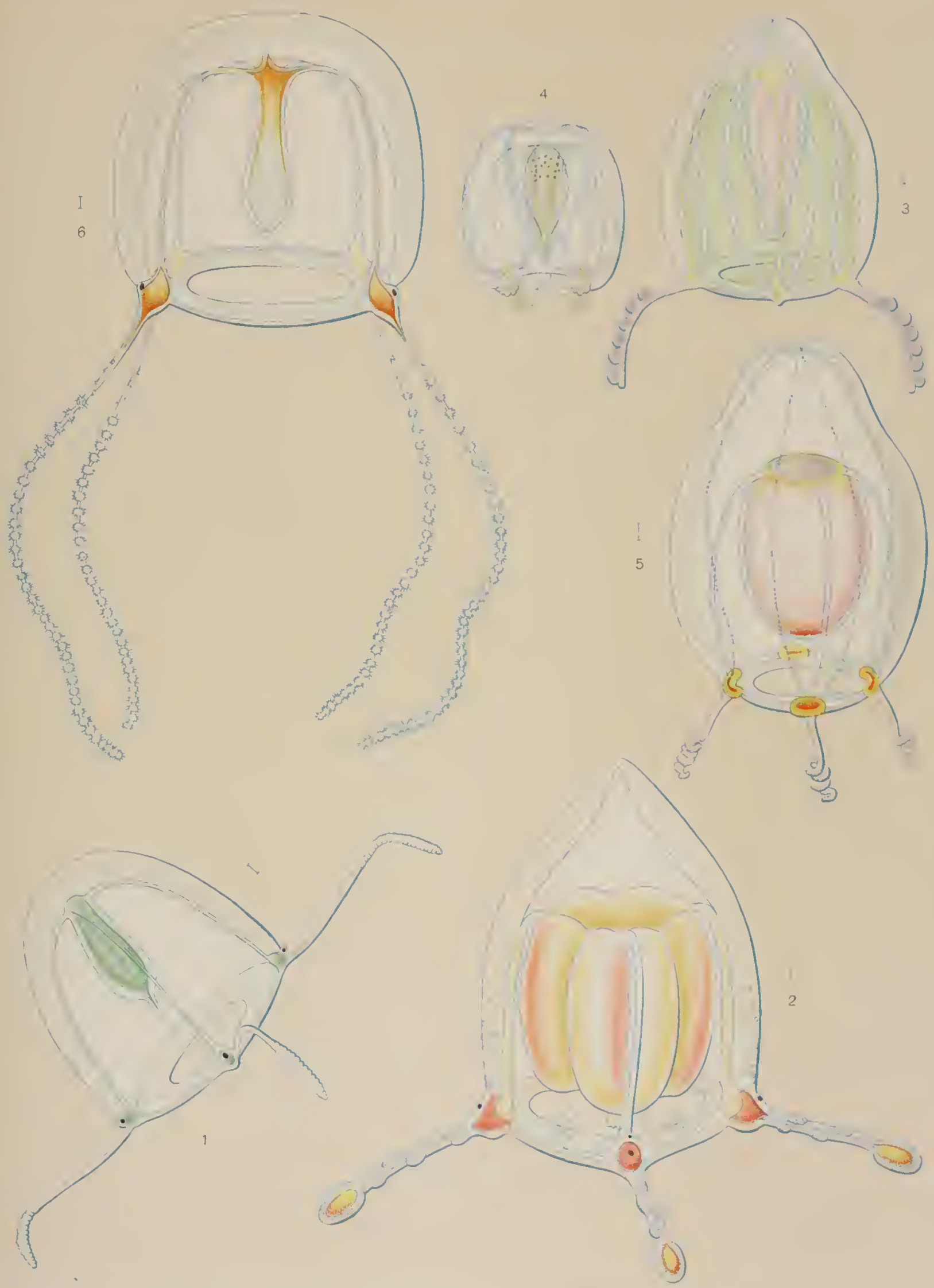



Sarsia mirabilis var. reticulata.

Plate 4 , figs. 3 and 4 ; plate 5, fg. 6.

Syndictyon reticulatum, A. Agassiz in L. Agassiz's, 1862, Cont. Nat. Hist. U.S., vol. 4, p. 340.-Agassiz, A., 1865 , North Amer. Acal., p. 177, figs. $290-300$.

Syncoryne reticulata, Allkas, 1871 , Monog. Tubul. Hydroids, p. 283.

Syndictyon reticulatum, Hakckr., 1879, Syst. der Medusen, p. 21 .

(?) Syndictyon reticulatum, MAAs, 1893 , Ergeb. der Plankton-Expedition, I3d. 2, K. c., P. 67.

(?) Sarsia turricula, McCRADY, 1857, Gymn. Charleston Harbor, p. 36, plate 8, figs. 6-8.

Syncoryne reticulata, HargrT, 1904, Bulletin Bureau of Fisheries IT. S., vol. 24 . P. 30.

Sarsia reticulata, Hartlaub, 1907 , Nordisches Plankton, N'r. 12, p. 45 , figs. $41^{-4} 43$.

(?) Sarsia pulchella, AlLman, 1871, see Hartlaub, 1907, Nordisches Plankton, Nir. 12, p. 34, fig. 27 (abnormal twin medusa,

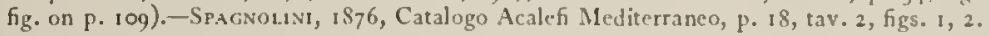

Adult medusa.-Bell ellipsoidal in shape, being about $+\mathrm{mm}$. in height and $3.5 \mathrm{~mm}$. in diameter. No apical projection. Gelatinous substance quite thick at the aboral pole, but thin at the bell-margin. There are 4 long, highly contractile tentacles, I at the hase of each radiat-canal. Surfaces of these tentacles covered with prominent nematocyst capsules. Basal bulbs of tentacles well developed and each one contains an ectodermal ocellus upon its outer side. Velum wide and thin. There are 4 straight, narrow radial-canals, and a slender circular vessel. Manubrium short and club-shaped, and does not extend far beyond the velar opening. Mouth a simple, round opening. Genital products developed along the greater part of the length of the manubrium. The entoderm of the mamubrium and tentacle-hulbs is lorick-red. Hydroid and young medusa.-Smaller than Coryne mirabilis, being not more than $3 \mathrm{~mm}$. in height. Stems slender and hardly ever branch, excepting in old specimens, which sometimes give rise to a singte branch near the base of the stem. Polypites large and club-shaped, and having several whorls composed of 8 to ro short tentacles. The medusa develop among the tentacles near the proximal base of the polypite. When set free the young medusa is remarkably large, being about $1.5 \mathrm{~mm}$. in diameter. The bell is covered with reticulated clusters of nematocyst-cells (plate + , figs. 3,4 ) which are especially numerous near the bellmargin above the circular canal. Some of these nematocyst-cells are large and round, while others are narrow and long. The tentacles are thickly covered with helically arranged clusters of nematocyst-cells. These cells (plate $4, f i g .+$ ) are ellipsoidal in shape and are mounted upon a short hasal pedicel. Each cell gives rise to a long, sharp-pointed, sensitive hair. The nematocyst thread lies coiled in a helix within the cavity of the cell. As the medusa becomes mature the reticulated nematocysts disappear from the surface of the exumbrella and the nematocysts upon the tentacles become less prominent. This medusa is found upon the New England coast from April until June. It is distinguished from Sarsia mirabilis only by its nematocyst-covered tentacles and exumbrella and its small hydroid. It appears also to be constantly brick-red, while $S$. mirabilis is highly variable in color. It is often impossible to distinguish mature medusx of $S$. reticulatn from those of $S$. mirabilis. It is possible that the $S$. pulchella of Spagnolini, 1876 , from Naples, Italy; is identical with $S$. reticulata.

\section{Sarsia eximia Boehm.}

Coryne eximia, Allman, 1859. Annals and Mag. Nat. Hist., ser. 3, vol. 4, p. 141; 1864, Ibid., vol. 13, P. 357.

Syncoryise eximia, Hincrs, 1868 , Hist. British Hydroid Zooph., p. 50, plate 9, fig. 2.-Allman, 1871 , Monog. Tubul. Hydroids, p. 282 , plate 5 .

Sarsia eximsa, Bofir , 878 , Jena. Zeitschrift für Naturw., Bd. 12, p. 191, taf.6, figs. 7-26; taf. 7, figs. I-6.一(In part), HarcKEL, 1879 , Syst. der Medusen, p. 17. - Hartlau B, i 894 , Wissen. Mecresuntersuch. Kommis. Meere. Kiel, Helgoland, Ser. 2, Bd. I, p. I 87 .

Syncoryne eximia (hydroid), Nutring, 1901, Proc. Washington Acas. Sci., vol. 3, p. 166, plate 14, figs. 3, 4.

Sarsia eximia, Browse, ino5, Proc. Roy. Soc. Edinburgh, vol. 25, p. 756 (hydroid and medusa).-Broch, 19o5, Bergens Museums Aarbog, No. 11, p. 4 .

Sarsia eximia $=$ S. breionica, Hartlaub, 1907, Nordisches Plankton, Nr. 12, p. 8, figs. 1, 2a, $2 b$ (full list of recent literature). Syucoryne eximia, Browse, 1907, Journal Marine Biol. Association, vol. 8, p. 37 (growth of the hydroid).

This form is found off the coasts of Great Britain, Helgoland, Shetland Islands, Nomway, and Juneau, Alaska (Nutting). For details of the medusa, see tabular description of the medusx of Sarsin.

The hydroid is about $30 \mathrm{~mm}$. high, forming a bush-like cluster of profusely branched stems; the branches are short and simple and arise very irregularly from the main stens, and are usually faintly ringed at their points of origin. The main stem is usually unringed. 
except at its base, and is quite smooth. The polypites are very elongate, spindle-shaped, and have about 16 to 24 short, knobbed tentacles arranged in 4 to 6 somewhat irregular verticils. The medusa-buds arise singly upon short peduncles near the bases of the tentacles of the lower verticils. The entoderm is red to reddish-lyrown and the stems are yellow.

Browne found that confinement in an aquarium under somewhat unnatural conditions caused the hydroid to grow rapidly and to form stolons, these being developed from branches

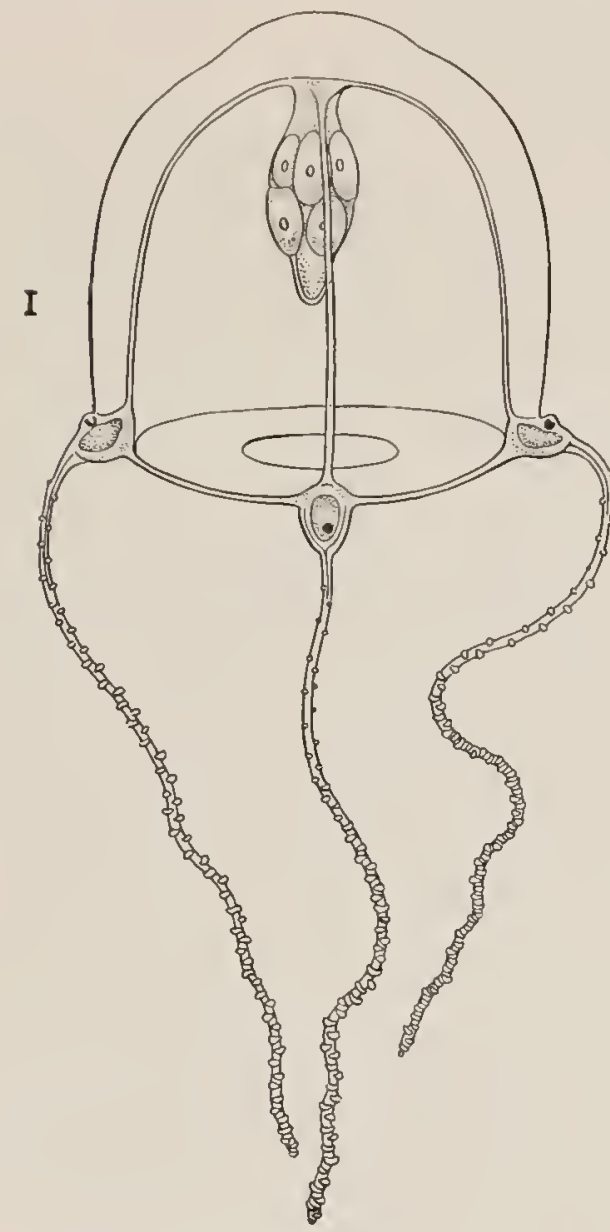

Fig. 21. - Sarsia eximia, from life, by the author. Mousehole, Cornwall, England, Nov. 14, 1907. which touched the glass sides of the aquarium. He also discovered that the medusa becomes mature in from 7 to 10 days after being set free from the hydroid. Later, in I907, Browne found that one of these hydroids placed in a glass tube with a constant current of water passing through it grew in length from 14 to $77 \mathrm{~mm}$. in the course of 9 days, and developed branches having a total length of $500 \mathrm{~mm}$. The hydroid was fed upon copepods.

Sarsia radiata von Lendenfeld.

Sarsia radiata, von Lendenfeld, 1884 , Zool. Anzeiger, Jahrg. 7 p. $584 ; 188_{4}$, Proc. Linnean Soc. New South Wales, vol. 9, Pp. $58_{3}, 635$; plate 20, figs. 3 I, 32 ; plate $3 \circ$, figs. I-4.

Medusa.-Bell semiovate, slightly higher than broad, $3 \mathrm{~mm}$. high, $2.5 \mathrm{~mm}$. wide. 4 tentacles, each about 1.5 times as long as bell-height, and with large bulbs about half as wide as the manubrium. Ocelli (?) Velum wide. 4 straight radial-canals. Manubrium cylindrical, half as long as the bell-height. The gonad incases the sides of the manubrium from the inner apex of the bell-cavity to near the mouth. No medusabuds. Entoderm of manubrium and tentaclebulbs deep brown. Other parts colorless.

Iydroid. - The hydrocauli arise from a creeping hydrorhiza which anastomoses in a very open network. The perisarc terminates with an oblique elliptical margin at the hase of each hydranth, and the hydranth is provided with a muscle at this point which enables it to bend downward and "shut up" as if it were the blade of a penknife. The hydranths are spindleshaped, narrow, and elongate; and are, including their hydrocauli, 3 to $5 \mathrm{~mm}$. high. They have 6 to 8 verticils, each of 4 tentacles, situated in 4 meridional lines, $90^{\circ}$ apart. These tentacles are all knobbed at their ends. The hydranths which produce medusie are shorter than the sterile polypites. The medusx bud out from the lower half of the polypite between the tentacles. The entoderm is intensely brown in color, and the perisarc is bright brownish-yellow. Other parts colorless. Found on the coast of New South Wales, Australia. The medusæ are produced in April and May.

Sarsia conica.

Codonium conicum, Hafcker, 1880 , Syst. der Medusen, p. 634 .

Bell barrel-shaped with conical apex one-third as long as the sides of bell. $12 \mathrm{~mm}$. high, 4 mm. wide. 4 tentacles longer than bell-height, and with small oval basal bulbs. The manubrium is half as long as the depth of the hell-cavity. The stomach is subspherical and swollen by the encircling gonad. The mouth is at the end of a short, cylindrical throat-tube which is free of gonads. Color (?) There is a long axial canal above the stomach. Indian Ocean. Briefly described, without figures, by Haeckel. 
Sarsia rosaria Haeckel.

Coryne rosaria, Agassiz, L., i862, Cont. Nat. Hist. U.S., vol. 4, P. 340.-AGassiz, A., 1865, North Amer. Acal., p. 176, fig 289. Sarsia rosaria, Hakcket, 1879 , Syst. der Medusen, p. I 8.

Sarsia rosarja $=$ Syncoryme rosaria, Fewkes, 1889 , Amer. Naturalıst, vol. 23, p. 597, plate 25, fig. 7; text-figs. 8, 9 (hyitroid?). Syncoryne occidentalis, FewKEs, I8S9, Bull. Ėsses Inst., Salem, vol. 21, No.7, p. 99, plate 3, figs. 2, 3.

(?) Syndictyon angulatum, MUra.ch and Shearer, 1903, Proc. Zool. Soc. London, vol. 2, p. 168.

Codonium apiculum, MUrвach and Stzerkzk, 1903, ['roc. Zool. Soc. London, vol. 2, p. 165, plate 17, fig. I; plate 22, figs. 4, 5; 1902, Annals and Mag. Nat. Hist., ser. 7, vol. 9, p. 72.

Sarsia apiculat $S$. rosaria, Harthaub, 1907, Nordisclies Plankton, Nr. 12, pp. 17, 50, figs. 9, 45.

Bell 15 to $30 \mathrm{~mm}$. high, 10 to $15 \mathrm{~mm}$. wide, with fairly thick walls and small apical projecrion. + equally developed, radially placed tentacles 1.5 to 2 times as long as hell-height. The basal bulbs of these tentacles are large and are flanked on either side by a large nematocyst-pad. Each tentacle-bulb bears an ahaxial ocellus. There are 4 slender, straight-edged radial-canals and a narrow ring-canal. The velum is well developed. Manubrium short and spindle-shaped, and mouth about at the level of the velar opening. There is a short axial canal above the stomach. The gonad encircles the stomach, leaving both ends free. No medusa-buds. The colors are quite variable as in other species of Sarsia. The tentaclebulbs range from yellow through red to brownish-red, and the stomach is yellow, pink, or reddish-violet to purple.

This is the most abundant Sarsia along the Pacific coast of the United States. It occurs in great swarms in San Francisco Harbor in spring; and in Victoria Harbor, Puget Sound, in July.

The hydroid is Syncoryne rosaria found by A. Agassiz and Fewkes in shallow water attached to piles of wharves. Each tentacle terminates in a knob, and the hydroid is a true Syncoryne.

\section{Sarsia minima von Lendenfeld.}

Sarsia minima, von Lfndenfeld, 1884, Proc. Linnean Soc. New South Wales, vol. 9, pp. 584, 915, plate 21, figs. 34, 35.

Bell of medusa $3 \mathrm{~mm}$. high and $2.5 \mathrm{~mm}$. wide with "a long manubrium like the northern Sarsix." It is therefore readily distinguished from Sarsia radiata, which has a short manubrium. S. minima has a spindle-shaped, nearly cylindrical manubrium which extends for about half its length beyond the velar opening. The + marginal tentacles are somewhat longer than the bell-height and are covered with rings of nematocysts. The entoderm of the stomach is pale brown, other parts colorless.

Hydroid.-The stems are 2 to $3 \mathrm{~mm}$. high and arise from a creeping, slightly branched, non-anastomosing hydrorhiza. The perisarc which invests the hydrorhiza and hydrocauli is irregularly annulated or wavy throughout, and terminates at the bases of the hydranths in a transverse margin. The hydranths are slender, spindle-shaped, 0.6 to $0.8 \mathrm{~mm}$. long, and with 8 to 12 irregularly scattered tentacles, all of which are knobbed at their ends. When they produce buds they become stouter, and are so thickly covered by the budding medusie "that nothing of their bodies remains visible." The perisarc is reddish-brown.

This hydroid is found at Port Jackson, New South Wales. Australia, overgrowing Obclia geniculata, on buoys and submerged ropes. The medusæ are produced in April and May. Von Lendenfeld did not obtain any mature medusx.

\section{Sarsia brachygaster Grönberg.}

Sarsia brachygaster, Grönberg, 1898, Zoolog. Jahrb., Abth. Syst., Bd. 11, p. 459, taf. 27, figs. 3, 4.-HarTlavB, 1907, Nordisches Plankton, Nr. 12, p. 11, fig. 3 .

Bell 15 to $18 \mathrm{~mm}$. high and 8 to $10 \mathrm{~mm}$. wide and three-fourths-egg-shaped, the greatest breadth being above the middle. + radially situated tentacles, each being about twice as long as the bell-height. Basal bulbs of these tentacles well developed, and a single very small ocellus upon the outer side of each bull,. Manubrium cylindrical, and two-thirds as long as height of bell-cavity. Mouth situated at extremity of a short cylindrical neck. The gonad is tubular and surrounds the stomach. No medusa-buds. The manubrium, gonads, tentacle-bulbs, and tentacles are orange-red. The ocelli are black. 
Grönberg found this species at Spitzbergen in summer, and he also identified it among a collection of medusæ from Jakobshavn, Greenland, where it appears to be rarer than at Spitzbergen.

\author{
Sarsia angulata Hartlaub.
}

Plate 5, fig. I; plate 6, fig. 3 .

Syndictyon angulaium, Mayer, 1900, Bull. Mus. Comp. Zool. at Harvard College., vol. 37, p. 5, figs. 6-S, plate 3; 1904, Memoirs Nat. Sci. Brooklyn Institute Museum, vol. 1, No. 1, p. 7, plate 1, fig. 6.

Non Syndictyon angulatum, Murbach and Shearer, 1903, Proc. Zool. Soc. London, vol. 2, p. 168.

Sarsia angulata, Hartlaub, 1907, Nordisches Plankton, Nr. 12, p. 16.

Bell $3 \mathrm{~mm}$. high; half-egg-shaped, with moderately thick walls. Becomes almost square in cross-section when contracted. There are 4 slender tentacles with fairly thick spindleshaped ends. These tentacles are each about as long as bell-height and their distal halves are tapering and are armed with nematocysts. The basal bulbs of the tentacles are not very large, and each one bears an ocellus formed by a cup-like invayination of ectodermal cells. The velum is large, and the radial-canals and circular vessel are of fine caliber. The manubrium is spindle-shaped with a narrow tubular cesophagus and without an aboral projection. It is about two-thirds as long as the height of the bell-cavity. The gonad encircles it, extending from the base to near the mouth, leaving the throat-tube free. The entoderm of the tentaclebullss and manubrium is robin-egg blue, while the ocelli are deep-brown, almost black. All

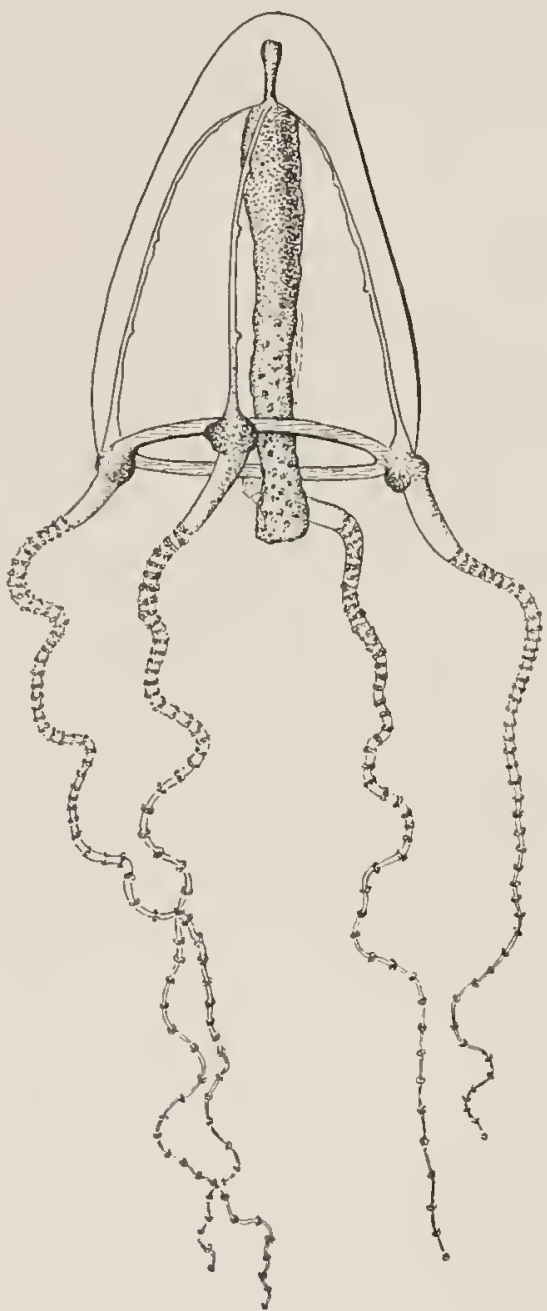

Fig. 22.- Sarsia princeps, after Hartlaub, in Nordisches Plankton. other parts are hyaline. This medusa is abundant in the Tongue of the Ocean, Bahama Islands, in June and July, and was found at Turks Island in January. It is rare at Tortugas, Florida.

\title{
Sarsia gracilis Browne.
}

Sarsia gracilis, Browne, r 902, Annals Mag. Nat. Hist., ser. 7, vol.9, p. 275. (? ?) Syncoryne sarsii (hydroid), HartLaub, 1905, Zoolog. Jahrbüchern, Suppl. 6, p. 525, fig. F.

Bell $5 \mathrm{~mm}$. high, $3 \mathrm{~mm}$. wide; cylindrical, with moderately thick walls and quadrangular margin. 4 tentacles, about as long as the bell-height, and ending each in a large knob containing nematocysts. An ocellus on the basal bulb of each tentacle. Manubrium about two-thirds as long as the depth of the umbrella cavity. Color (?) Gonads (?) Found at Stanley Harbor, Falkland Islands, by Vallentin, and hriefly described without figures by Browne. The hydroid, Syncorync sarsii, described by Hartlaub from southern Terra del Fuego, may be the stock of this medusa.

The medusa may be a young Slabberia (?)

\section{Sarsia princeps Haeckel.}

Codonium princeps, HAECKEI, 1879 . Syst. der Medusen, p. 13 , taf.1, figs. 1, 2 . Sarsia princeps, HAECKEL, 1879, Ibid., p. 655.-Linko, 1905, Zool. Anzeiger, BJ. 28, p. 2r 2.-Browne, 1903, Bergens Museums Aarbog, No. 4 , p. 8, plate 1, fig. 1; plate 3 , fig. 4.-HartLaub, 1907, Nordisches Plankton, Nr. 12, p. 47, fig. 44.

Codonjum princeps, LeVinsen, i $\$ 93$, Vid. Meddel. Nat. For. Kjöbenhavn

(5), Bd. 4, P. I 43.-GrönkerG, 1898 , Zoolog. Jahrb., Abth. Syst., Bd. 11, p. $45^{8}$, taf. 27 , figs. I, 2 .

Bell thin-walled and conical, about 25 to $40 \mathrm{~mm}$. high, and $15 \mathrm{~mm}$. wide. There is a short, conical, apical projection. There are 4 tentacles with long conical basal bulbs. The shafts of these tentacles are very contractile, three or four times as long as 


\section{Plate 6.}

Figs. I and 1'. Hydroid of Ectopleura dumortieri. Dredged from a depth of 5 fathoms in Newport Harbor, Rhode Island, August, 1896. Figure I, enlarged view; figure I', natural size.

Fig. 2. Medusa of Ectopleura dumortieri. Agassiz Laboratory, Newport, Rhode Island, July, 1892.

Fig. 3. Sarsia angulata. Turks Islands, Bahamas, January 20, 1893. Fig. 4. Protiara formosa, male. Nassau Harbor, Bahamas, June, 1903. Fig. 5. Protiara formosa, female. Tortugas, Florida, June 10, 1897.

Fig. 6. Protiara formosa, young medusa. Turks Islands, Bahamas, January 20, 1893 .

Fig. 7. Zanclea gemmosa. Manubrium of the medusa shown in figure 5 , plate 7 .

Drawn from life, by the author. 


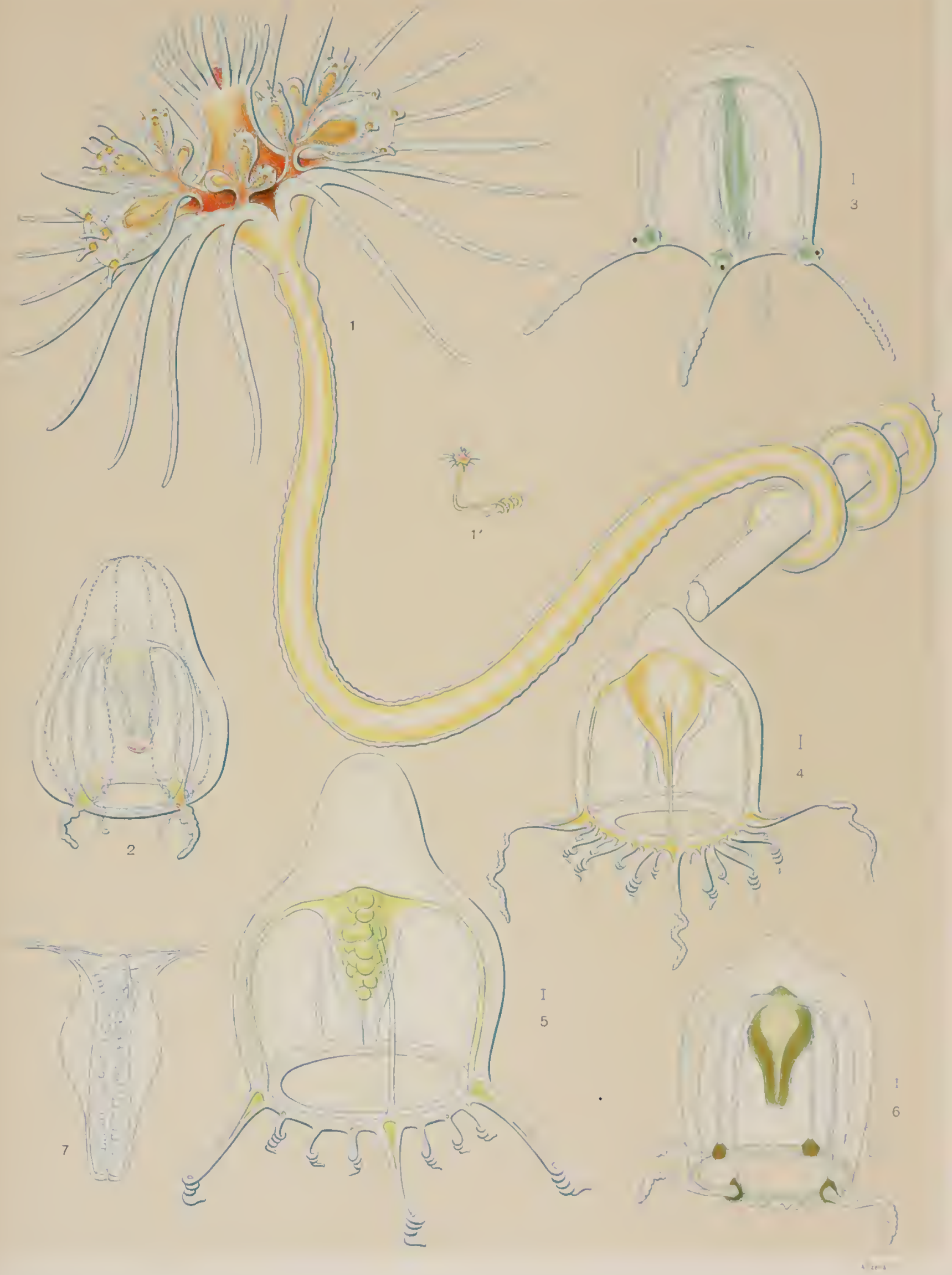



the bell-height, and covered with alternately arranged, wart-like clusters of nematocysts. A small ocellus is situated on the outer surface of each tentacle-bulb near the bell-margin. There are also 2 globular swellings, one on either side of each tentacle-bulb adjacent to bell-margin. The velum is narrow. There are 4 narrow, ragged-edged radial-canals and a slender circular canal. A short axial canal extends upward from the stomach-cavity into the gelatinous substance of the apical projection of the bell. The manubrium is long and cylindrical, and extends for about one-third of its length beyond the velar opening. The mouth is a simple opening without prominent lips. A single, short, rubular gonad is developed upon the sides of the manubrium. The manubrium, gonads, and tentacle-bulbs are purple. The ocelli are black.

This species is found off the coasts of Greenland and Spitzlergen, where it appears to be common. Grönberg, 1898 , found it to be abundant at Spitzbergen, and Linko, 1905, found it to be common in Barents Sea, north of Lapland, Russia. It is the largest known Sarsia. Grönberg's description is based upon the study of living medusx. Hartlaub also gives an excellent figure of the medusa, which we reproduce.
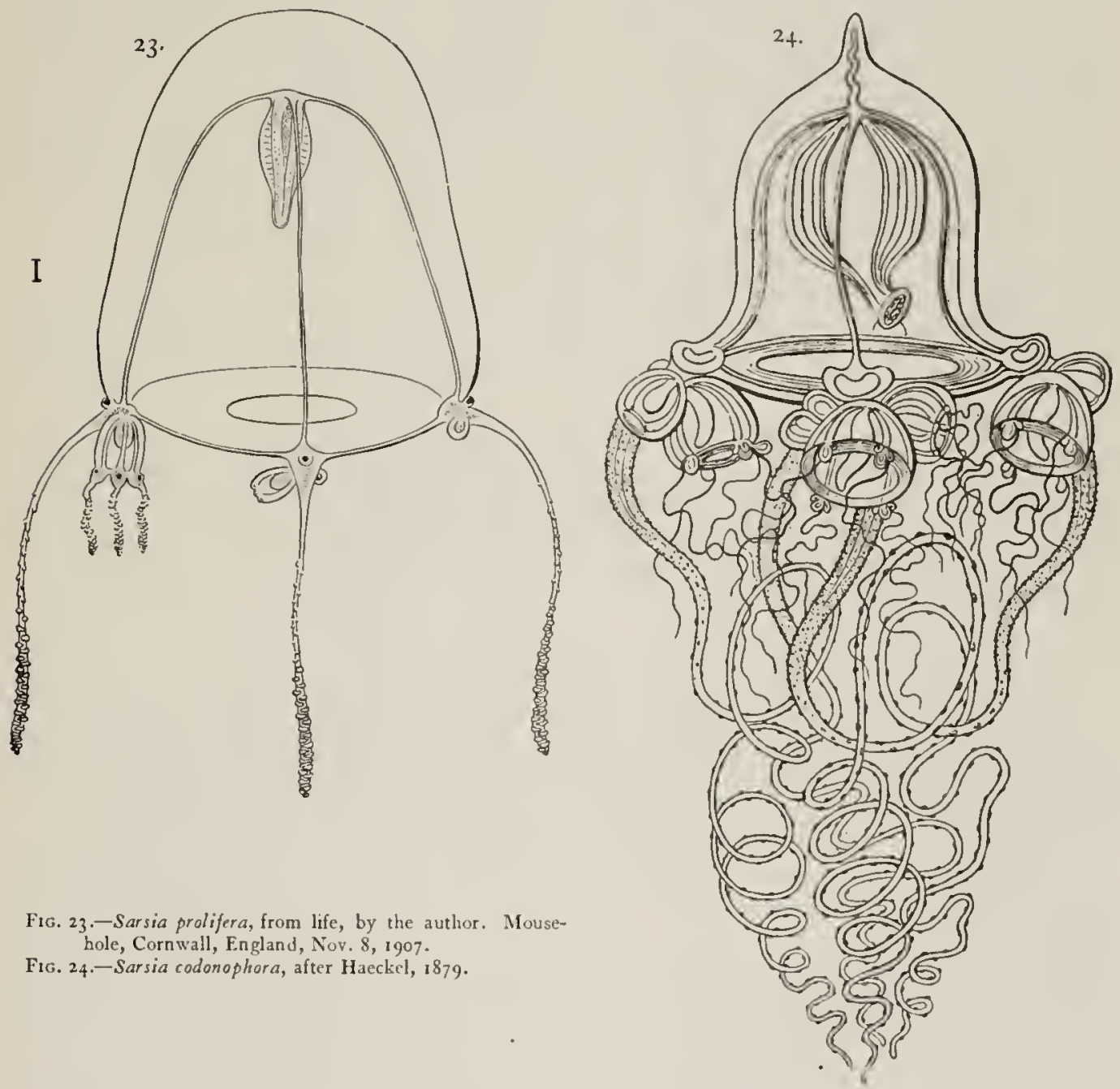

Sarsia prolifera Forbes.

Sarsia prolifera, Foress, 1848, British Naked-eyed Medusx, p. 59, plate 7, fig. 3.-Buscu, 1851, Beobacht. wirbellos. Seetl., p. I, taf. I, figs. 1 -6.-BEDot, 1905, Revue Suisse de Zool., tome 13, p. 147 (all literature to 1850).-HartlauB, 1907, Nordisches Plankton, Nr. 12, p. 15, figs. 7, 8 .

Syncor yne prolifera, Allman, 1871 , Mronog. Tubularian Hydroids, p. $8_{3}$, fig. $3^{8}$.

Codonium codonophorum $+S$ arsia prolifer, HAECK zL, 1879 , Syst. der Melusen, pp. 14, 18, taf. 1, fig. 3 .

Sarsia codonophora, HAECKEL, 1880, Ibid., p. 655. 
In 1848 Forbes described this medusa from Penzance Bay, southern England, where it was abundant in August, 1846 , and in 1879 , and where I found it in November, 1907. Haeckel describes that which may prove to be the same species from the Mediterranean. The points of difference between the two medusæ will be brought out in the following description.

The bell is bell-shaped; in Forbes's medusa (fig. 23) $3 \mathrm{~mm}$. wide and + high; in Haeckel's, (fig. 24), $8 \mathrm{~mm}$. wide and $8 \mathrm{~mm}$. high. Forbes's medusa lacks an apical projection, while Haeckel's has a short, conical, pointed apex. Also, in Forbes's medusa there was no axial canal above the stomach while in Haeckel's there was a narrow, axial vessel. Moreover, in Haeckel's medusa the margin of the bell flares outward, while in Forbes's specimen this is not the case.

It is well known to students of the Anthomedusæ that apical projections and axial canals are exceedingly variable, and may be absent or present in individuals of the same species. The outward flaring of the bell may be brought about through contraction. Haeckel's medusa appears to be merely a large, highly-colored specimen of $S$. prolifera Forbes.

The 4 marginal tentacles are I to 3 times as long as the bell-height. Their basal bulbs are large and tapering and about as wide as they are long. The tentacles taper gradually from base to shaft and are hollow. Clusters of i to 3 medusa-buds at a time are developed upon the tentacle-bulbs immediately below the bell-margin. When set free these medusx are already producing another asexual generation of medusæ upon their tentacle-bulbs. The 4 radial-canals and ring-canal are straight and very narrow. The manubrium is spindleshaped and nearly as long as the hell-heiglit in Haeckel's, but not half so long in Forbes's medusa. The mouth is at the end of a narrow neck and is a simple, round opening. The stomach is encircled by the gonad, leaving the base and the throat-tube free.

Entoderm of tentacles and manubrium yellow to orange or sage-green. Each tentaclebulb bears a prominent ectodermal brown-colored ocellus.

If it be true that Forbes's and Haeckel's forms are identical the medusa must range from southern England to the Mediterranean. It appears to be rare and its hydroid is unknown.

Allman, 187 I (p. 83, fig. $3^{8}$ ): gives a figure of a medusa which closely resembles Forbes's Sarsia prolifera.

I found numerous specimens of this medusa off Mousehole, Mounts Bay, Cornwall, England, early in November, Igo7. They accord well with the descriptions of Forbes and of Busch. The entoderm of the manubrium and tentacle-bulbs was sage-green; the tips of the tentacles light reddish-brown, and occasionally there was some reddish-brown pigment in the central entoderm of the stomach. The gonad encircled the stomach, leaving both ends of the manubrium free.

\section{Sarsia gemmifera Forbes.}

Sarsia gemmifera, Forbes, $1 \$ 48$, British Naked-eyed Medusa, p. 57, plate 7, fig. 2.- Chun, 1895 , Bibliotheca Zoologica, Heft 19, Pp. 4, 7, taf. 1, figs. 5, 6 (law of development of medusa-buds).-Browne, 1905, Proc. Roy. Soc. Edinburgh, vol. 25, p. 757.-Broch, I 905, Bergens Museums Aarbog, No. 11, p. 4.

Codonium gemmiferum + Sarsia siphonophora, HA Eckel, I879, Syst. der Medusen, pp, 15, 20, taf. 1, fig. 4 .

Codonium gemmiferum, B к. ot, 1905, Revue Suisse de Zool., tome 13, p. 132 (citation of literature to 1850 ).

Purena gemmifera, Hartlaub, 1907, Nordisches Plankton, Nr. 12, p. 58, figs. $54-58$.

This medusa is found off the Atlantic coasts of Europe from Norway southward. Haeckel's Sarsia "siphonophora" from the Canary Islands is probably another name for the same species.

When young the medusa produces medusa-buds upon its manubrium. These arise in a spiral line, one following the other, down the sides of the manubrium. The oldest of the primary medusa-buds is nearest the base (uppermost) and the youngest nearest the mouth of the manubrium.

These primary medusa-buds are attached to the sides of the manubrium by short pedicels, and secondary and tertiary medusa-buds arise from the sides of these pedicels. Thus when the oldest (uppermost) original medusa-bud is set free, the secondary bud upon its pedicel remains attached to the manubrium and continues to develop, and when it in turn is set free the tertiary bud completes its development; this process takes place with each and every one of the series of buds. 
This successive freeing of the three series of buds produces various appearances at different periods of time, and in this manner we may explain the condition observed by Haeckel, 1879, in Sarsia "siphonophora," where the buds appeared in two series, the oldest and largest of the upper series being at about the middle of the manubrium, while the oldest of the lower series was near the base of the stomach. Forbes, 1848 (plate 7 , fig. $2 e$ ), shows an intermediate stage in the budding process, and an early stage is shown by Chun, 1895 (fig. $25 \mathrm{~A}$ ). The law of succession in development of the medusa-buds is clearly demonstrated by Chun.

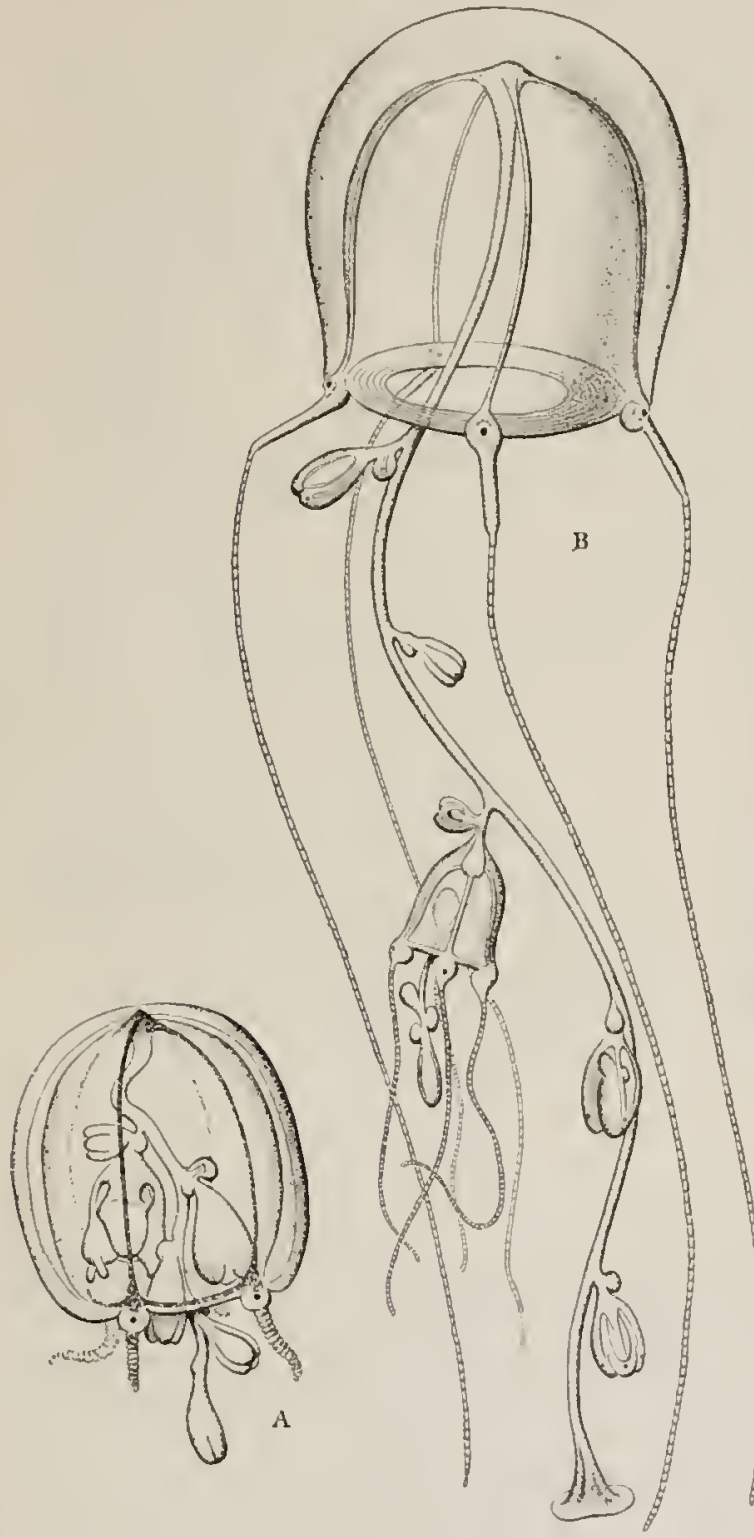

Fic. 25.-Sarsia gemmifera, showing law of bulding. After Chun, in Bibliotheca Zoologica, Heft 19, taf. 1, 1895. $A$, early; $B$, later stages of the process of budding. Both ectoderm and entoderm of the manubrium take an equal share in the formation of the budding medusa.

For details of the character of the medusa, see tabular description of the medusa of Sarsia.

Haeckel failed to observe the secondary and tertiary medusa-buds upon the pedicels of the budding medusa in his Sarsia siphonophora, but this is probably due to an oversight, for in all other respects his medusa appears to be identical with $S$. gemmifera Forbes.

The gonad develops at the distal end of the manubrium after the budding process has ceased. Possibly there may be 2 or more ring-like gonads? (See Hartlaub, 1907.) If this be the case the medusa may be identical with Dipurena fertilis Metschnikoff, 1871 .

\section{Sarsia hargitti.}

Goryne producta, Hargitr, 1902, American Naturalist, vol. 36, p. 550 , fig. 3 .

Syneoryne producta, HaRGIT, 1904, Bulletin Bureau of Fisheries U.S., vol. 24, P. $3^{\circ}$, plate 1, fig. 1 .

A medusa called Sarsia producta is produced by budding from the hydroid of Stauridia producta Wright; and as this name takes precedence over that of Hargitt's medusa, it is necessary to rename the American species.

Bell $1.5 \mathrm{~mm}$. high, and $1 \mathrm{~mm}$. wide. Apex dome-like and rounded, and sides slightly compressed. Bell-cavity only about half as deep as the height of the bell. There are 4 long, equally developed tentacles with large basal bulbs, each with a large, ectodermal ocellus. Velum well developed. The 4 radialcanals are narrow, straight, and smoothedged. The manubrium projects far beyond the velar opening, but is capable of great contraction. Its terminal part is bulb-like, while the basal portion is spindle-shaped and bears a whorl of medusiform gonads. The stomach gives rise to a blunt, dome-shaped aboral projection. The mouth is a simple, round opening. The hasal part of the manubrium is orange, and its free end blue-green. The tentacle-bulbs are orange, edged with delicate green. The ocelli are black. A single specimen was found by Hargitt at Woods Hole, Massachusetts, on August 
I0, IgOI. It is distinguished from all other American species of Sarsia by its medusiform gonads borne upon the manubrium (text-fig. 26). It is not known whether medusæ are set free from the manubrium of the parent medusa.

\section{Sarsia flammea Hartlaub.}

Sarsia eximia (in part), HAcckel, I879, Syst. der Medusen, P. I7.

Sarsia fammea, Linko, 1905, Zool. Anzeiger, Bd. 28, p. 212.-Hartlaur, 1907, Nordisches Plankton, Nr. 12, p. I2, figs. 4-6. (literature); 1903, Zool. Centralblatt, p. 22.

Bell high oval, I $2 \mathrm{~mm}$. high, $7 \mathrm{~mm}$. wide, walls quite uniform and of moderate thickness. 4 tentacles, with well-developed, simple basal bulbs without ocelli. Tentacle tips slightly enlarged, club-like. Nematocysts over distal halves of tentacles arranged in prominent, broken rings. 4 slender, straight radial-canals. Manubrium thick, conical, spindle-shaped; only two-thirds as long as the depth of the bell-cavity. No axial-canal above the stomach. Gonad ring-like, encircling the manubrium from base to near the mouth. Stomach and tentaclebulbs light fiery-red or orange.

From the Arctic Ocean.
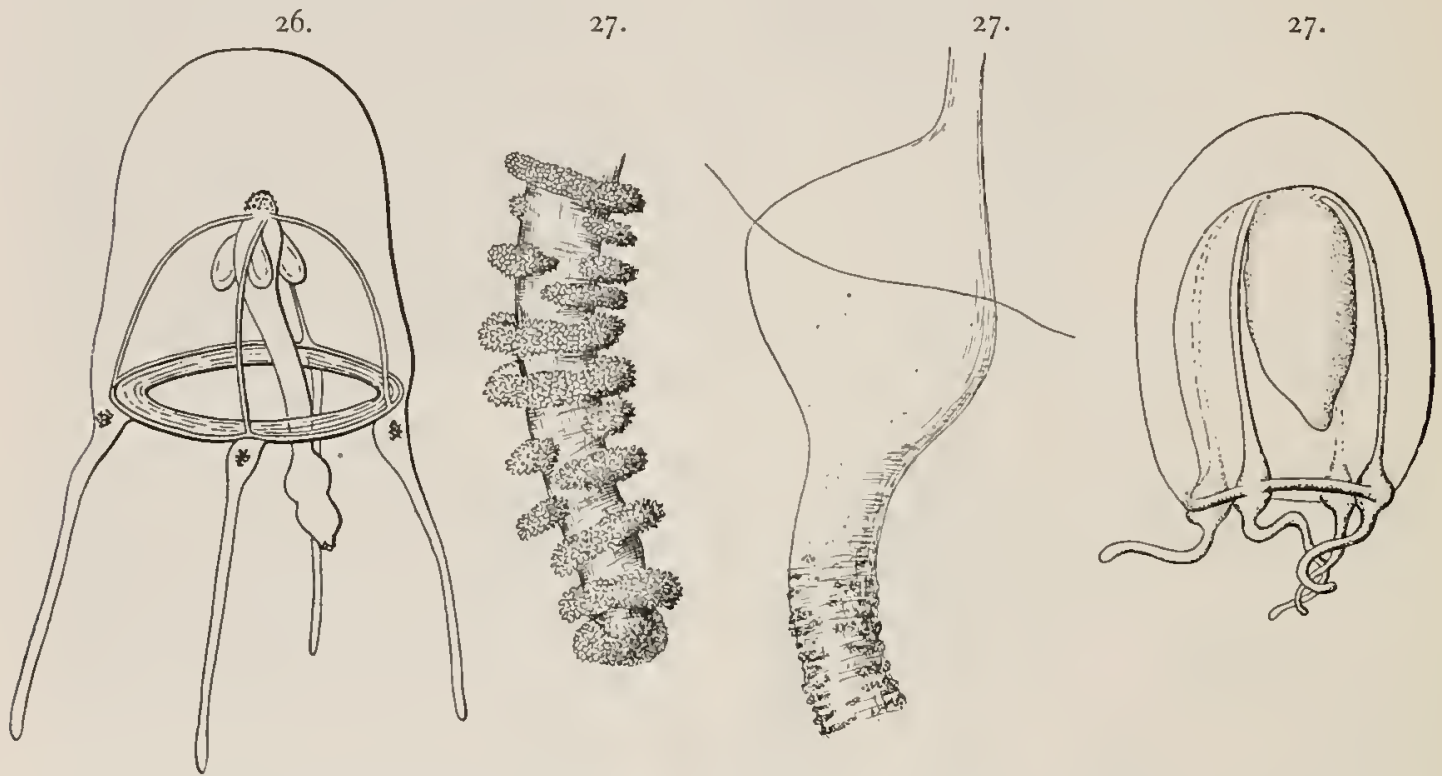

Fic. 26.--Sarsia hargiti, after Hargitt, in Bull. U. S. Bureau of Fisheries.

Fic. 27.- Sarsia flammea, after Hartlaub, in Nordisches Plankton. Showing arrangement of nematocyst clusters on tentacles.

Separated from Sarsia eximia and S.brachygaster by its lack of ocelli, and from $S$. brachygaster also by its smaller size. The best description is that of Hartlaub, I907. Hydroid unknown. It is possible that this may be the medusa of the parasitic hydroid called Hydrichthys mirus Fewkes.

Genus SARSIA, Subgenus STAURIDIOSARSIA nov. subgen.

Stauridium, Hartlaub, 1895, Zeit. für wissen. Zool., Bd.61, p. 142; 1907, Nordisches Plankton, Nr. 12, p. 52.

\section{CHARACTERS OF THE SUBGENUS.}

Medusa similar to Sarsia, but the hydroid is Stauridia, not Syncoryne.

The name Stauridia should not be applied to these medusæ, for it was first used by Dujardin, I 843 , to describe a hydroid which gives rise to a Cladonema medusa. It may be well to apply the new generic name Stauridiosarsia to hydroids which resemble Stauridia, but produce Sarsia-like medusæ. 
Sarsia (Stauridiosarsia) producta.

Non Stauridie, Dujardis, 1843 , Ann. Sci. Naturelles, sér. 2, tom. 20, p. 370.

Stauridia producta, WRiGhT, 1858, Edinburgh New Philos. Journ., sér. 2, p. 283 , plate 7, figs. 6-8.

Stauridium productum, Hisexs, 1868, British Hydroid Zoophytes, p. 68, plate 12, figs. I, i a.-Hartlaub, 1895, Zeit. für wissen. Zool., Bd. 6r, p. 142, taf.7, figs. 1-19; taf. 8, figs. 1-4; taf. 9, figs. 1, 2, 6; 1907, Nordisches Plankton, Nr. 12, p. 53, figs. 47-50.

The medusa is a Sarsia, but the hydroid is similar to Stauridia, and differs from Syncoryne, the hydroid of Sarsia, in that there is a basal circlet of simple, knobless tentacles; whereas all of the tentacles of Syncoryne terminate in knobs. The tentacles of Stauridia
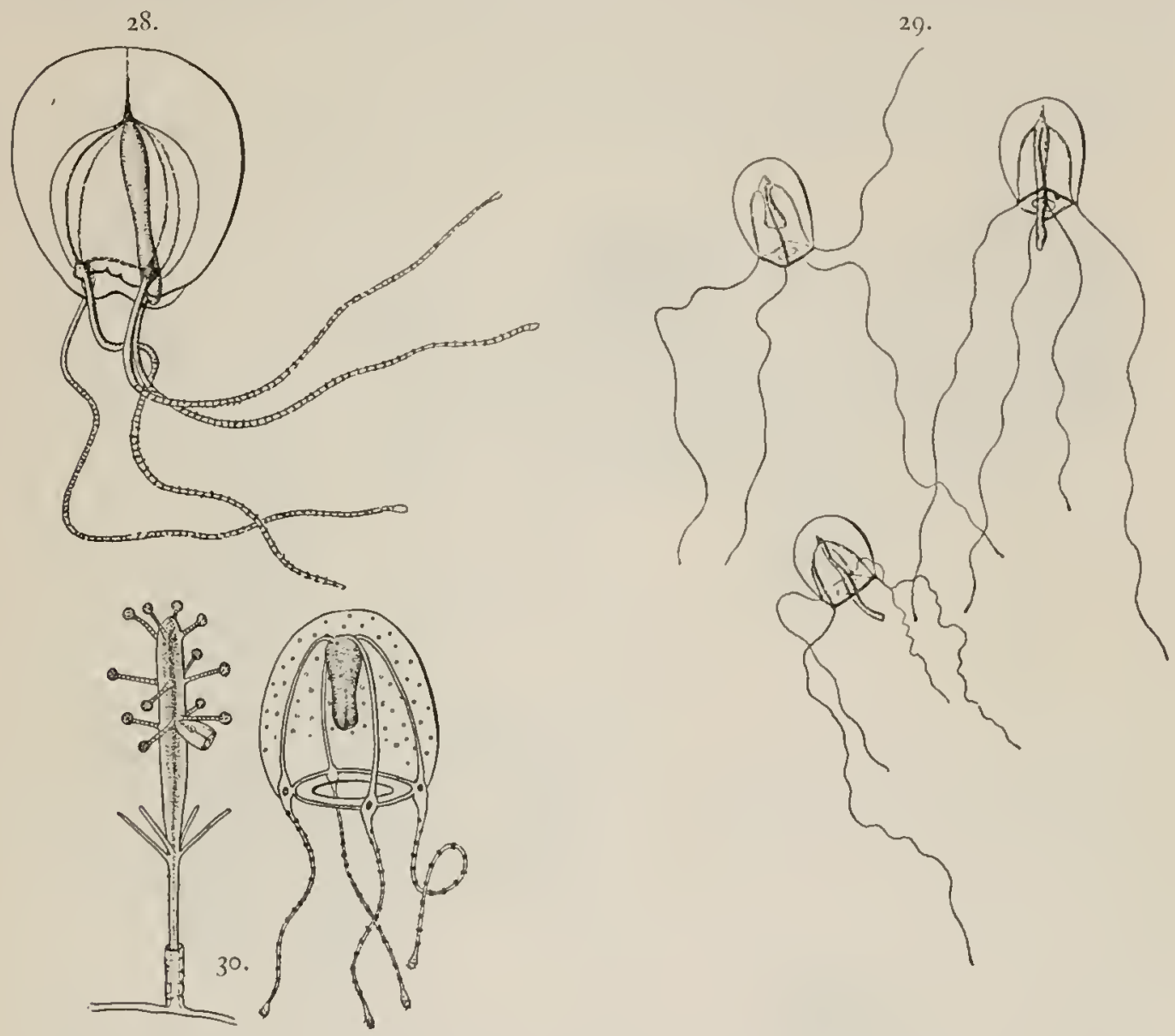

Fug. 28.-Sarsia produrta, after Hartlaub, in Nordisches Plankton.

Fig. 29.-Medusac of "Sarsin producta," natural size; after Hartlaub, in Nordisches Plankton.

FiG. 30.- "Stauridium produchum," after Hincks, in British Hydroid Zoophytes. Hydroid and young medusa.

are of two sorts-the simple, short, stiff, tapering, knobless basal circlet, and above them several circlets of knobbed tentacles which arise from the sides of the hydranth. In Syncoryne, on the other hand, we find only knobbed tentacles. Thus two distinct genera of hydroids produce one and the same genus of medusa. Moreover, Dujardin, 1843 , discovered that the hydroid which he called "Stauridie" produces the medusa Cladonema radiatum.

As the name Stauridia is preoccupred by Dujardin to designate the hydroid of Cladonema it can not be applied to the medusa of Stauridia producta. I therefore call the medusa of Stauridia producto by the name Sarsia producta, thus indicating its relationships when in the reproductive stage.

The medusa Sarsia producta, which is produced by the hydroid Stauridia producta, may be described as follows:

Bell $10 \mathrm{~mm}$. high, $7 \mathrm{~mm}$. wide, three-fourths-egg-shaped, with thick, gelatinous walls. 4 equally developed, radially placed tentacles; 1.5 times as long as the bell-height. Tentacle- 
bulbs large, each with an abaxial, ectodermal ocellus. Manubrium cylindrical, with about one-third of its length extending beyond the velar opening. A short, conical axial canal above the stomach. Gonad extends from the base to the distal end of the manubrium. No medusabuds. Stomach brownish, gonads yellowish-white, tentacle-bulbs and axial canal red.

Helgoland and British coasts.

The hydroid has a thin-branching hydrorhiza, from which a number of club-shaped hydranths arise singly. These hydranths are each about $2 \mathrm{~mm}$. long, with a proximal circlet of 4 to 6 short knobless tentacles, and above 2 or 3 more or less irregular circlets of large knobbed tentacles, usually with 4 tentacles in each circlet. The medusa-buds are produced from the sides of the hydranth above the basal circlet of tentacles. The hydranths are red. The hydroid and medusa are described in detail by Hartlauh, 1895 .

The English and Helgoland forms differ considerably and they may be regarded as varieties one of the other (see Hartlaub, 1895, p. 157). The hydrorhiza of the English form anastomoses, while that of the Helgoland hydroid branches sparingly and does not anasto-

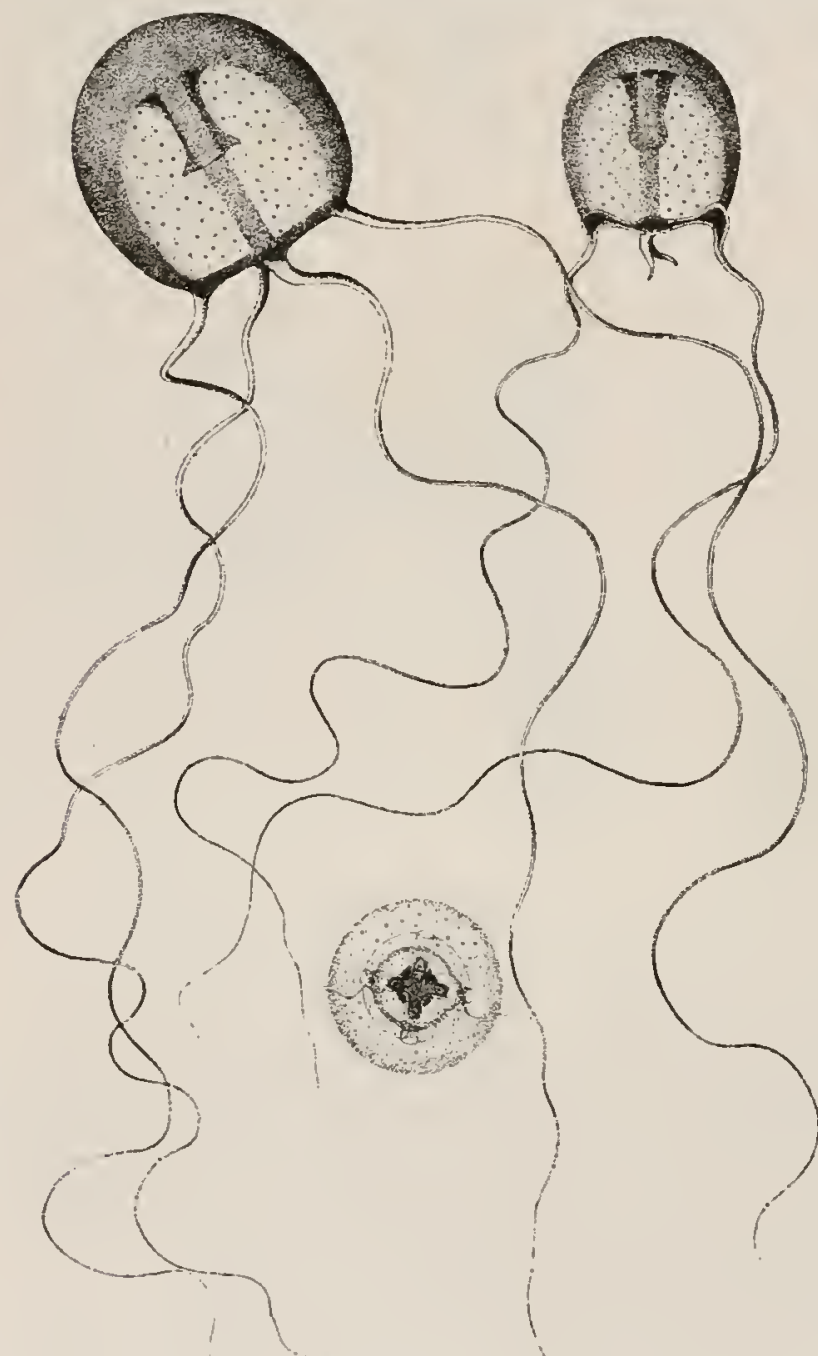

Fig. 31.-Young medusa of Hydrichthys mirus, from Fewkes, in Bull. Museum Comp. Zool. at Harvard College. mose. In the English form the knobbed tentacles are in whorls of 4 each, whereas in the Helgoland hydroid there are of ten 5 , occasionally 6 , tentacles in each whorl. In the English form the medusa are said to arise from the bases of the tentacles, while in the Helgoland form they arise from the sides of the polypite between the knobless basal circlet and the lowest circlet of knobbed tentacles. Finally the Helgoland medusa has a largeaxial canal above the stomach, and this appears to be absent in the English medusa.

Genus HYDRICHTHYS Fewkes, 1888.

Hydrichthys, Fewnes, i 888 , Bull. Mus. Comp̣. Zool. at Harvard Coll., vol. 13, p. 224; 1888, Annals and Mag. Nat. Hist., ser. 6 , vol. I, p. $364 .-$ Hargitr, I 904, Bull. U. S. Bureau of Fisheries, vol. 24, p. 32 .

(?) Plotocnide, Hartlaub, 1907, Nordisches Plankton, Nr. I2, p. 68 .

\section{GENERIC CHARACTERS.}

The medusa resembles Sarsia, but is without ocelli upon the tentacle-bulbs. The mature medusa has not been determined. The hydroid is firmly attached to the side of a fish (Seriole zonata), and is probably parasitic, and degenerate in many respects. All of our knowledge of this remarkable form is derived from Fewkes, 1888. It differs widely from all other known forms of Tubularian hydroids.

In default of knowledge of the mature medusa we must remain in doubt concerning its true place in our classification. It is possible that Sarsia flammea Hartlaub may be the mature stage of this medusa. 


\section{Hydrichthys mirus Fewkes.}

Hydrichthys mirus, Fewkes, 1888, Bull. Mus. Comp. Zool. at Harvard Coll., vol. 13, No. 7, pp. 224-232, plates 4, 5, 7 figs.; 1888, Ann. and Mag. Nat. Hist., ser. 6, vol. I, p. 364; 1888, l'roc. Boston Soc. Nat. Hist., vol. 23, p. 391.-Hargitr, 1904 , Bulletin Bureau of Fisheries U. S., vol. 24, p. 32.

Mcdusa.--The adult medusa is undetermined, hut may possibly be Sarsia flammea. The most advanced medusx reared by Fewkes had the following characters: Bell rounded, without apical projection. and in form somewhat fuller than a hemisphere. Size (?) Outer surface of bell besprinkled with nematocysts. Bell-walls of moderate thickness, becoming thinner near the margin. There are + long, equally developed, radially situated tentacles, with long, tapering basal bullss which lack ocelli. The 4 radial-canals are hroad and straight and there is a simple, narrow, circular vessel. Manubrium cylindrical and about half as long as the depth of the bell-cavity. Mouth surrounded by + simple lips (?). The entoderm of the manubrium is yellow and orange, while that of the tentacle-bulbs is orange. Other parts of the medusa are colorless.

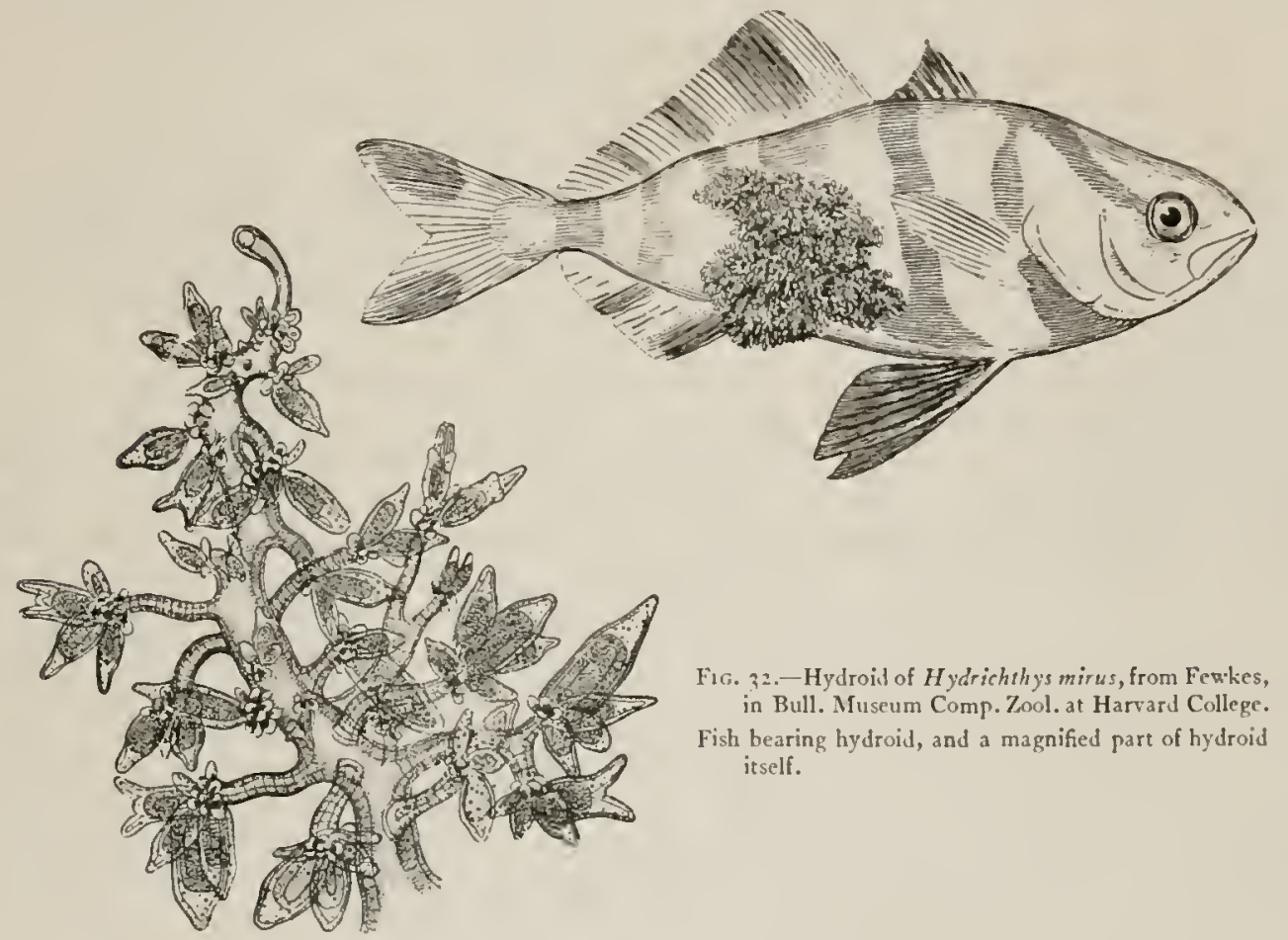

Young medusa.- When first detached from the hydroid the medusa has but two diametrically opposite tentacles, and is more active in its movements than it is when it acquires four tentacles. This may, however, have been due to the injurious effects of confinement.

IIydroid.- The hydroid was found by Fewkes firmly attached to the side of a small fish, Seriola zonata. The hydroid colony arises from a basal network of tules which forms a plate-like hydrorhiza enbedded under the scales of the side of the fish, upon which it is probahly a parasite. This basal network gives rise to tubular gonosomes and also to filiform, flaskshaped bodies, which recall the spiral zooids of Hydractinia, excepting that they appear to have a terminal mouth-opening.

The medusa-bearing gonosomes are conical and gradually taper from base to summit, where there may be a terminal opening. Irregularly distributed side branches arise from the main axis of the gonosome, and most of these give rise to medusa-buds. These side branches are usually simple, although occasionally they branch. They are hollow and in communication with the entodermal cavity of the main stem.

Clusters of medusa-buds in various stages of development arise from the ends of the branches. When set free these medusx have but 2 tentacles, but later 2 more tentacles develop. 
All parts of the hydroid stock are highly contractile and the gonosomes and zooids are without chitinous sheaths.

The hydroid is colorless, but the medusa-buds are reddish and orange in color. The terminal parts of the flask-shaped zooids are also pigmented with reddish-orange.

A single stock of this hydroid was found by Fewkes in Narragansett Bay, Rhode Island, attached to a fish, Seriola zonata, in August, 1887. The fish was swimming near the surface and was apparently but little injured by the presence of the parasite.

It is interesting to observe that Alcock, 1892 (Annals and Mag. Nat. Hist., ser. 6, vol. 10, p. 207, I fig.), has discovered a hydroid of the genus Stylactis which is commensal upon a fish, Minous inermis. This hydroid, however, produces no medusæ.

Genus EUCODONIUM Hartlaub.

Eucodonium, Hartlaub, 1907, Nordisches Plankton, Nr. 12, p. 71.

The type species is Eucodonium brownei Hartlaub=Dipurena sp. Browne, from the British Coast.

\section{GENERIC CHARACTERS.}

Codonidx with 4 equally developed, radially placed tentacles, each of which terminates in a distal knob. Stomach mounted upon a gelatinous peduncle. Hydroid unknown.

This genus is distinguished from Sarsia and Slabberia by the gelatinous peduncle upon

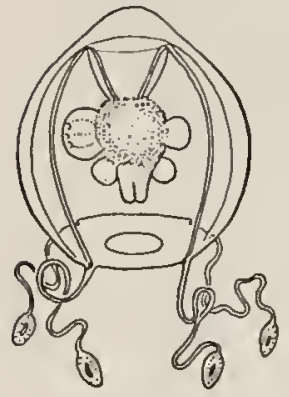

33.

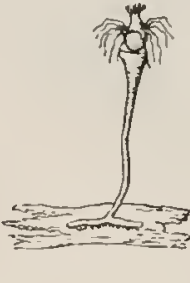

34 .

Fig. 33.-Eucodonium brownei, after Browne, in Proc. Zool. Soc. London.

FIG. 34.-Hydroid of Ectopleura dumonierii, from Europe, after Hincks in British hydroid Zoophytes. which the stomach is placed. It is distinguished from Dysmorphosa by the terminal knobs of its tentacles and by its ring-like gonad.

\section{Eucodonium brownei Hartlaub.}

Dipurena sp., Browne, 1896 , Proc. Zool. Soc. London, p. 473, plate 16, fig. 2. Eucodonium brownei, Hartlaub, 1907 , Nordisches Plankton, Nr. 12, P. 71 , fig.67.

Bell pyriform, thin-walled, I $\mathrm{mm}$. wide. 4 radially placed, slender tentacles with small basal bulbs. Tentacles twice as long as the bell-height and with scattered nematocysts along their lengths, and each with a large, swollen, nematocyst-bearing knob at outer end of tentacle. No ocelli. Velum wide. 4 straight, narrow radial-canals.

Stomach short, mounted upon a conical, gelatinous peduncle. Mouth a simple, round opening at about the level of the velum. Medusa-buds arise from the sides of the stomach. The tentacle-bulbs are blackish, stomach and terminal knobs of the tentacles, dull dark-brown. Found at Plymouth, England, in September. Gonads(?) This is a young medusa, but we can not refer it to any known mature form.

Genus ECTOPLEURA L. Agassiz, 1862 (sens. amend.).

Tubularia dumorieri, VAN BENEDEN, I 844, Mém. Acad. Belgique, tome 17, p. 50, plate 2.

Ectopleura, Agassiz, L., 1862, Cont. Nat. Hist. U.S., vol.4, p.343.-Agassiz, A., 1865, North Amer.Acal., p.191.-Hanckel, 1879, Syst. der Medusen, p.21.-Frwkes, 1882, Bull. Mus. Comp. Zool. at Harvard Coll., vol. 9, p. 295 ; I883, Bull. Mus. Comp. Zool. at Harvard Coll., vol. I1, p. 85, plate 1, fig. 11.-Allman, 1871, Monog. Tubul. Hydroids, p. 423.Hinck5, 1868, British Hydroid Zooph., vol. I, p. 123.-Vanhörfen, 1891, Zool. Anzeiger, p. 443.-Hartlaub, i894, Wissen. Meeresuntersuch. Komm. Deutsch. Meere Kiel, Abth. Helgoland (I), Bd. I, P. I88; 1907, Nordisches Plankton, Nr. 12, p. 93.--Browne, 1905 , Proc. Roy. Soc. Edinburgh, vol. 25, p. $74^{8}$.

This genus was founded by L. Agassiz, 1862, the type species being E. dumortieri which was first described by Van Beneden, I844, from the coast of Belgium under the name $\mathcal{T} u b u$ laria dumortieri.

\section{GENERIC CHARACTERS.}

Codonidx with 2 or 4 simple, unbranched tentacles situated at the bases of 2 , or of all, of the 4 radial-canals. 8 longitudinal rows of nematocysts extend from the 4 tentacle-bulbs over the surface of the exumbrella to the apex of the bell. The manubrium is short and blunt, and the mouth is a simple, round opening. The hydroid is Ectopleura, and is closely related to Tubularia. 
The discovery of Ectopleura pacifica and E. minerva makes it necessary to amend the generic definition to include medusæ with 2 as well as with 4 tentacles.

Ectopleura is distinguished from Zanclea by its unbranched tentacles.

\author{
Ectopleura dumortieri L. Agassiz. \\ Plate 5, figs. 4, 5; plate 6, figs. 1, 1', 2. \\ Literature Relating to the European Mrdusa.
}

Tubularia dumortieri, VAN Benedn, 1844, Mém. Acad. Belgique, tome 17, p. 50, plate 2.-Johnston, 1847, Hist. British Zoophytes, p. 50, plate 7, figs. I, 2 .

Ectopleura dumortieri, AGassız, L. 1862 , Cont. Nat. Hist. U. S., vol. 4, p. 342

Eciopleura dumortieri, Hincks, 1868, Hist. British Hydroid Zoophytes, p. 124.

Ectopleura dumorticri, AlLaAn, 1871-72, Monog. Tubularian Hydroids, p. 424.-Böhs, 1879, Jena. Zeitschrift für Naturw. Bd. 12, p. 198, taf. 7, figs. 10-13.-HaEckel, 1879, Syst. der Medusen, p. 22.

Non Ectopleura dumortieri, Grazrfe, 1884 , Arbeit. Zool. Inst. Wien, Bd. 5, p. 354 .

Ectopleura dumortjeri, Hartlaub, 1894, Wissen. Meeresuntersuch. Komm. Meere Kiel, Helgoland (1), Bd. 1, p. 188. -BrowNF, 1905, Proc. Roy. Soc. Edinburgh, vol. 25, P. 748.

Ectopleura dumortieri, HartLaUb, 1907, Nordisches Plankton, Nr. 12, p. 94, figs. 90, 91.

Tubularia dumortieri, B ЕDот, 1905, Revue Suisse de Zool., tome 13, P. 126 (citation of literature, 1844-48).

Literature Relating to the American Medusa.

Ectopleura ochracea, A. Agassiz, in L. Agassiz's 1862, Cont. Nat. Hist. U. S., vol. 4, p. 343.-AGassız, A., 1865, North Amer. Acal., p. 191, figs. 320-323.- Ha eckel, 1879, Syst. der Medusen, p. 22.-Fewkes, 1882, Bull. Mus. Comp. Zool. at Harvard College., vol. 9, p. 295, plate 1, figs. 15, 16, 35, 36.-Nutring, 19oi, Bull. U. S. Fish Commission, vol. 19, p. 373, fig. 82.--Hargitt, J 904, Bullet in Bureau of Fisheries U.S., vol. 24, P. 32, plate 2, fig.1.-AGassiz, A., and WoodWOrth, 1896 Bull. Museum Comp. Zool. at Harvard College., vol. 30, p. 149, plate 6, fig. 6 (photograph of the medusa).

Ectopleura, sp., H.4яGitT, 1908, Biol. Bulletin, vol. 14, p. 106, figs. 8-11.

The finding of the hydroid of our American Ectopleura "ochracea" leads me to believe that there are no specific differences between the European and American forms, and that both should be called Ectopleura dumortieri, this being the older name. Hartlaub, 1907, however, believes that $E$. dumortieri is smaller and has somewhat thicker bell-walls than $E$. ochracea, but our American medusa varies considerably in these respects, as do also specimens which I captured in the English channel in 1907.

The following description is based upon a study of large numbers of specimens obtained at Newport, Rhode Island, United States.

Adult medusa.-The bell is pyriform and is about $3 \mathrm{~mm}$. high and $2.5 \mathrm{~mm}$. wide. The gelatinous substance is very thick and is especially so at the aboral pole. 8 longirudinal lines of nematocyst-cells extend over the surface of the exumbrella from the basal bulbs of the 4 tentacles to the bell-apex, where they meet in a point. There are 4 equally developed, short tentacles with large basal bulbs. The outer surface of these tentacles is thickly covered with nematocyst-cells, and their distal ends are coiled in a close helix. Velum narrow. There are 4 narrow, straight radial-canals and a simple, narrow, circular tube. The manubrium is fusiform and extends not more than two-thirds the distance from the inner apex of the bell-cavity to the level of the velar opening. There is no peduncle, and the mouth is a simple round opening, the edge of which is armed with clusters of nematocysts. A short, blunt, axial canal is often seen projecting upward from the stomach into the gelatinous substance of the apex of the bell. The gonads are developed in the ectoderm encircling the stomach. In hrilliant specimens the tentacle-bulbs are yeliow with a red core.

The middle region of the entoderm of the manubrium is lilac-colored, the upper part delicate yellow, and the lower end red or pink, hut very often the medusa is dull purple or dull brownish-purple.

Hydroid.-The hydroid shown in plate 6, figs. I, I' was found in August, in Newport Harbor, Rhode Island, at a depth of about 10 fathoms. It is a Tubularian belonging to the family Hyboconidæ Allman, and is apparently identical with 'Tubularia (Ectopleura) dumortieri of Van Beneden, $18+4$.

The hydroid is about $25 \mathrm{~mm}$. in length, and was found clinging to the stems of Obelia. The stems of the Extopleura are isolated. Most of them are simple and unbranched, but occasionally they give rise each to a single side branch near the lower end. The lower end of the Ectopleura is coiled around the stem of the Obelia in a close helix. The stem of the Ectopleura 
is covered by a delicate investment of perisarc which displays a number of small annulations near the upper end. The stem terminates in a single, large polypite, which is broad and flask-shaped. The mouth is situated at the extremity of a tubular proboscis, and is surrounded by a single verticil of about 16 short, flexible tentacles. In addition to these there is another verticil of about 24 long, fleshy tentacles at the wide base of the polypite. These long tentacles are not very contractile. They taper gradually from base to end. The tentacles at the base of the polypite are about three times as long as are those surrounding the mouth. The medusa-buds are borne in numbers on short, branching peduncles which arise from the sides of the polypite in a zone immediately above the basal tentacles. When set free each medusa has 4 short tentacles, and the 8 longitudinal rows of nematocysts upon the exumbrella are well developed. The ectoderm of the stem of the hydroid is a delicate, fleshy-yellow and the entodermal core is flesh-colored pink. The entoderm of the polypite is fleshy-pink and yellow.

This medusa is very common throughout the summer in Narragansett and Buzzard's Bays, and on the southern coast of New England east of New Haven, Connecticut. It has not been taken north of Cape Cod. It has been recorded from Beaufort, North Carolina, and I found it in Winyah Bay, South Carolina, but it has not been taken either at Charleston, South Carolina, or at the Tortugas, Florida. It is found in the English Channel and off the North Sea coasts of England, Scotland, Holland, and Germany. As in America, it appears to be abundant only in a few localities. I found several specimens of this medusa in the English Channel in October, I907, and they appear to be identical in all respects with medusæ from the southern coast of New England, in America. Hargitt has recently discovered the hydroid at Woods Hole, Massachusetts.

\section{Ectopleura minerva Mayer.}

Plate 5, fig. 3 .

Ecropleura, sp., Fewkes, I883, Bull. Mus. Comp. Zool. at Harvard College, vol. II, p. 85 , plate I, fig. II.

Ectopleura minerva, Mayer, I 900 , Bull. Mus. Comp. Zool. at Harvard College, vol. $3^{8}$, p. 31 , plate 16, fig. $3^{8}$; plate 37 , fig. I25. (?) Eciopleura dumorieri, Graefre, I894, Arbeit. Zisol. Inst. Wien, Bd. 5, P. 354.

This medusa has 2 well-developed and 2 rudimentary tentacles, instead of 4 equally developed tentacles as in the northern species of Ectopleura.

Bell $2.5 \mathrm{~mm}$. high and pear-shaped, with a well-developed apical projection. Bell-walls of moderate thickness. 8 rows of nematocyst-cells extend from the 4 tentacle-bulbs to the apex of the bell. There are 2 well-developed tentacles and 2 small tentacle-bulbs. There are 6 to 9 separate wart-like swellings upon the outer side of each of the 2 large tentacles. These swellings are crowded with nematocysts. Basal bulbs of tentacles small and without ocelli. There are 4 straight, narrow radial-canals and a slender, circular vessel. The velum is well-developed. Manubrium pear-shaped and about two-thirds as long as the depth of the bell-cavity. It is wider near the middle than at either end. The mouth is a simple, round opening. A simple, short, conical style-canal extends upward into the apical projection of the bell.

The entoderm of the manubrium and tentacles is a delicate purple, while the supporting lamella of the bell is of a decided green. There are a large number of brilliant yellow spots in the entoderm of the radial-canals and tentacle-bulbs.

This form is rare at Tortugas, Florida. It was found by Fewkes at the Bermudas. A similar medusa was described by Graeffe, 1884 , from Trieste, Mediterranean, under the name Ectopleura dumortieri. Pacific.

Ectopleura minerva may prove to be identical with $E$. pacifica Thornely, from the tropical

\section{Ectopleura pacifica Thornely.}

Ectopleura pacifica, Thовnely, rgoo, Zool. Results, A. Willey, Part 4, p. 452, plate 44, figs. I, i a, Cambridge, England.

Hydroid.-Stems simple, unringed, diminishing in width toward the base, and $20 \mathrm{~mm}$. high, rising from a creeping stolon which connects the colony. Some of the stems give rise to stolons near their bases. The polypite is abruptly marked off from the supporting stalk. 
There are two verticils of tentacles of i 8 to 20 each. The basal tentacles are very long, and the oral ones are short, and with knob-shaped (?) ends. The medusa-buds are borne in clusters of from 7 to 9 on branched peduncles, which arise from the body of the polypite between the two verticils of tentacles. When about to be set free each medusa-bud has 2 well-developed tentacles, thus resembling $E$. minerva of Tortugas, Florida. E. pacifica is common in Blanche Bay, New Brirain, South Pacific. It is attached to floats, fish-baskets, etc. Color (?) This hydroid may be identical with E. minerva of the tropical Atlantic coast of North America.

\section{Genus CORYNITIS McCrady, I857.}

Corynitis, McCrady, 1\$57, Gymn. Charleston Harbor, Proc. Elliott Soc. Charleston, p. 29.-AGassiz, L., 1862, Cont. Nat. Hist. U. S., vol. 4, p. 340.-AGassiz, A., 1865, North Amer. Acal., p. 183.-Alz.vax, 1871, Monog. Tubularian Hydroids, p. 286.

Coryneles, Hazcker, 1879 , Syst. der Medusen, p. $4^{8}$.

Plotocnide, Wagser, 1885 , W'irbellosen Weissen Meeres, p. 74.

Corynetes, VanhöFrEn, 1891, Zool. Anzeiger, Bd. 14, p. 442.

Non Corynitis, Murbach, 1899 , Quart. Journ. Mic. Sci., New Series, vol. 42, p. 354 (this is Zanclea).

(?) Modeeria, Protiara (young medusa), Ha eckel, 1879 , Syst. der Medusen, p. 47.

(?) Tiaricodon, Browne, 1902, Annals and Mag. Nat. Hist., ser. 7, vol. 9, p. 276.

Non Corynitis, Nutting, 1901, Bull. U. S. Fish Commission for 1899 , p. 372 (this is Zanclea).

Non Corynitis, Hargıtr, 1904, Bull. U. S. Bureau of Fisheries, vol. 24, P. 42 (this is Zanclea).

Syncoryne linvillei (hydroid), Hargitr, 1904, Biological Bulletin, Woods Hole, vol. 7, p. 251, I fig.; Ibid., 1908, vol. 14, p. 101, fig. I.

The type species of this genus is Corynitis agassizii described by McCrady from Charleston Harbor, South Carolina.

\section{GENERIC CHARACTERS.}

Codonidx in which the manubrium is cruciform in cross-section. The 4 tentacle-bullss have large, abaxial, ectodermal ocelli. The tentacles are unbranched and terminate each in a knob-like cluster of nematocysts, and the shaft of each tentacle is besprinkled with wartlike clusters of nematocysts. There are 8 irregular, longitudinal rows of nematocysts upon the exumbrella, + of these being radial and 4 interradial in position. The hydroid is Syncorync.

McCrady, I857, and L. Agassiz, I862, described a hydroid which they ascribed to Corynitis agassizit, but which is certainly very close to, if not identical with, the hydroid generation of Zanclea. Hargitt, on the other hand, has discovered that Corynitis agassizii arises from a Syncoryne-like hydroid which he called $S$. linvillei.

In the medusx of Ectopleura, Zanclea, and Corynitis there are longitudinal patches of nematocysts upon the exumbrella. In Corynitis agassizii the tentacles terminate each in a knob-like club. In Zanclea dichotoma they terminate in a similar manner, but in addition they give rise to side branches all arising from the aboral side of the tentacles, and each terminating in a knoh-like cluster of nematocysts. In Corynitis, on the other hand, there are merely scattered wart-like clusters of nematocysts over the shaft of each tentacle. It is possible that Zanclea arose from some Corynitis-like medusa; certainly Zancleopsis dichotoma is intermediate in many characters between Corynitis agassizii and Zanclea gemmosa.

However doubtful the relationship may be between Corynitis and the Cladonemina, there can be no doubt of its close relationship to Slabberia and Sarsia. The young medusa of Corynitis can not be distinguished from the young of Slabberia.

Murbach and Nutting are mistaken in their Corynitis medusa, which is clearly Gemmaria (Zanclea). The medusa of Corynitis is so clearly described and figured by McCrady as to be unmistakable. I have frequently taken it in Charleston Harbor, South Carolina, where McCrady discovered it, and his figure and description enable one instantly to recognize it. It lacks the feathered tentacles of Gemmaria (Zanclea).

Hargitt, 1904, at first followed Murbach in this erroneous identification of Corynitis, but his final discovery of the Syncoryne-like hydroid of Corynitis enabled him not only to correct the mistake, but to establish the close relationship between Corynitis and other Sarsialike medusæ. 
Corynitis agassizii McCrady.

Plate 5, fig. 2 .

Corynitis agassizii, McCrady, 1857, Gymn. Charleston Harbor, p. 30, plate 9, figs. 3-8.-AGassiz, L., 1862, Cont. Nat. Hist .

U. S., vol. 4, p. 340.-Agassiz, A., 1865, North Amer. Acal., P. 183.-Allman, 1871, Monog. Tubul. Hydroids, p. 287. Corynetes agassizii, HaEckex, 1879, Syst. der Medusen, p. 49.

(?) Corynetes agassizii, Maas, 1893 , Ergeb. der Plankton Exped., Bd. 2, K. c., p. 67 .

Non Halochar is spiralis (hydroid), AGassiz, L., 1862, Cont. Nat. Hist. U. S., vol. 4, p. 239, plate 20, figs. 10-10 C.

Coryne agassizii (hydroid), MCCrady, I857, Gymn. Charleston Harbor, pp. 29, $3^{2}$.

Non Corynitis agassizii, HaRGitT, 1904, Bull. U. S. Bureau of Fisheries, vol. 24, p. $4^{2}$ (this is Gemmaria $=$ Zanclea).

Non Corynitis agassizii, NutTıng, 1901, Bull. IT. S. Fish Commission for 1899, vol. 19, p. 372, fig. 79 (this is Genmaria $=$ Zanclea).

Non Corynitis agassizii, Murbach, 1899, Quart. Journ. Microscop. Sci., New Ser., vol. 42, p.354 (this is Gemmaria=Zanclea). Syncoryne linvillei (hydroid), Hargitr, 1904, Biological Bulletin Woods Hole, vol. 7, p. 25I, I fig; I go8, Ibid., p. Ior, fig. I.

Adult medusa.-Bell miter-shaped and about $2.5 \mathrm{~mm}$. in height. 8 longitudinal rows of irregularly scattered nematocyst-cells are found upon the sides of the exumbrella immediately above the circular canal. 4 of these are situated above the tentacles and 4 are interradial in position. The radially situated rows of nematocysts are longer than the interradial. There are 4 straight, stiff tentacles, which are about three-quarters as long as the bell-diameter. Each tentacle terminates in a large, knob-shaped swelling, the outer surface of which is thickly covered with nematocysts. The entodermal core of this swelling is hollow and its lumen

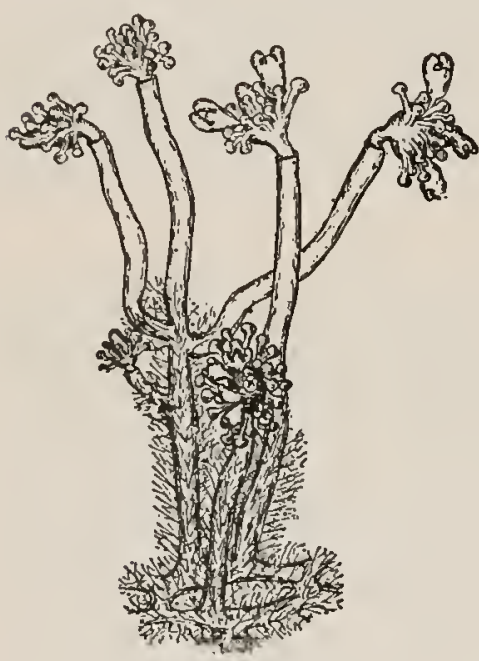

Fic. 35.-Hydroid of Corynitis, after Hargitt, 1908, Biological Bulletin. is placed in communication with the gastrovascular system of the medusa by means of a slender entodermal canal which extends through the entire length of the tentacle. Wart-like clusters of nematocysts are scattered over the shaft of each tentacle. The basal bulbs are large and hollow, and each one contains a single ectodermal ocellus upon the outer side. Velum well-developed. There are 4 straight radial-canals and a narrow circular tube. The large conical apex of the bell is hollow and in direct communication with the stomach of the medusa. The manubrium is very large and swollen and fills the greater part of the bell-cavity. It extends almost to the level of the velar opening. The mouth is situated at the extremity of a short aesophagus. It is without prominent lips. The gonads occupy the greatly swollen sides of the stomach, and their outer surfaces are smooth. 4 deep, interradial furrows extend down the sides of the stomach, so that the manubrium is cruciform in cross-section. The entoderm of the basal bulbs of the tentacles is strawberry-red and that of the terminal knobs of the tentacles is orange-yellow flecked with red-colored pigment-granules. The manubrium is dull yellow streaked with strawberry-red and the entoderm of the radial-canals is faint yellow. The ocelli are darkbrown or orange.

The hydroid is a Syncoryne, and is described by Hargitt. It grows in tufts which are sparingly branched and 15 to $30 \mathrm{~mm}$. high. The hydranths are vasiform with cone-shaped proboscis. There are 15 to 30 tentacles distributed over the proximal third of the body of the hydranth. These tentacles terminate each in a knob-like free end. The perisarc is plain or with only a slight annulation. The hydrorhiza is reticulated in a loose network. The medusa-buds are borne upon the body of the hydranth, usually in small clusters at the bases of the tentacles, each cluster supported upon a single peduncle, the terminal specimen always maturing first. The medusx, while still attached to the hydroid, have 2 well-developed, diametrically opposed, club-shaped tentacles and 2 small tentacle-buds. There are no ocelli. There are 4 radial-canals and the umbrella is bell-shaped. In formalin the hydroid is paleyellowish, hydranth somewhat brownish, and gonophores reddish-brown or pink. This hydroid was found by Dr. Henry R. Linville growing upon rocks and piles under "Milldam Bridge" west of Shelter Island, Long Island Sound, New York. It is described by Hargitt from preserved material under the name Syncoryne linvillei. When set free the medusx have only 2 tentacles and 2 small, basal bulbs. 
This medusa is very abundant in Charleston Harbor, South Carolina, during the summer and early autumn. It is also common in Great Peconic Bay, Long Island Sound, and at Woods Hole, in September. It has not been taken north of Cape Cod, Massachusetts, or at the Tortugas, Florida.

\section{Corynitis arcuata Haeckel.}

Corynetes arcuata, HAEcKEL, 1879 , Syst. der Medusen, P. 49.

This variety, or species, is distinguished from Corynitis agassizii by its long, narrow bell, about twice as high as it is broad, and by its long, thin tentacles. The nematocysts upon the tentacles are smaller and more numerous than they are upon the tentacles of $C$. agassizii. The stomach is small and bell-shaped, with a short oesophagus which does not extend beyond the velar opening. Haeckel gives the bell-height as 6 and the breadth $10 \mathrm{~mm}$; ; but judging from his description of the medusa these figures must be erroneously stated and should be reversed.

It is found off the coast of Brazil. Haeckel describes it from a single preserved specimen.

Corynitis (?) cœrulea.

Tiaricodon cœruleus, Browns, 1902, Annals Mag. Nat. Hist., ser. 7, vol. 9, p. 276.

This medusa is very briefly described by Browne, without figures. The gonads are not radially separated and there is nothing in Browne's description to indicate that the medusa belongs to the Tiarinæ. Its characters appear to be those of Corynitis.

Umbrella bell-shaped, $25 \mathrm{~mm}$. high, $24 \mathrm{~mm}$. wide, with a rounded sumnit. The exumbrella is smooth without nematocysts. 4 fairly stout, radially situated tentacles tapering to a point. Their basal bulbs are large and cylindrical, a little longer than broad, and with an ocellus. Velum narrow. The manubrium is placed upon a short, broad peduncle. It is quadrangular with 4 perradial folded lips about as wide as the stomach. The mouth extends nearly to the level of the velar opening. The gonads surround the stomach and extend outward over the peduncle as 4 perradial lobes. Found at Stanley Harbor, Falkland Islands. The young medusa resembles a Sarsia. The color is not stated by Browne.

Genus SLABBERIA Forbes, 1846.

Slabberia, Forbes, 1846 . Ann. and Mag. Nat. Hist., vol. 18, p. 286; 1848 , British Naked-eyed Medusa, p. 53.-Foraes and Goods1R, 1853, Tran. Roy. Soc. Edinburgh, vol. 20, p. 3 II.

Dipurena, MCCRadY, 1857, Proc. Elliott Society, Charleston, p.135.-AGass12, L., 1862, Cont. Nat. Hist. U. S., vol.4, p. 341.Agassiz, A., 1865, North Amer. Acal., p. 180.

Dipurenat Bathycodon, HaEckel, I879, Syst. der Medusen, pp. $23,26$.

Dipurena, Browne, I 898 , Proc. Zool. Soc. London for 1897, p. 816 .

Dipurena Dipurella, Hargitr, I904, Bulletin Bureau of Fisheries U.S., vol. 24, pp. 30, 31.

Dipurena, Vankörren, I89I, Zool. Anzeiger, Bd. I4, P. 442.-Brownf, 1905, Report on Pearl Oyster lisheries, Guif of Manaar, Supplementary Report 27, Roy. Soc. London, p. 133.

Slabberio (in part), Agassiz, L., I 862 , Cont. Nat. Hist. U. S., vol. 4, p. 341.

Slabberia (in part), Hacckel, 1879, Syst. der Medusen, p. 23.

Purenat Slabberia, Hartlaub, 1907, Nordisches Plankton, Nr. 12, pp. 55, 62.

In 1846 Forbes described a medusa under the name Slabbcria halierata. It had 4 radial-canals with a swollen region upon each canal. In other respects it resembled Sarsia, excepting that each of the 4 tentacles terminated in a knob-like extremity. Forbes believed the swelling on the radial-canals to be gonads and established the genus Slabberia with the following designation: "Umbrella campanulate; ovaries four, linear, in the course of the four simple, gastrovascular canals; peduncle proboscidiform, highly extensile, oral orifice circular; a marginal tentacle springing from an ocellated bull, and terminating in a colored globular body, placed opposite each of the gastrovascular canals."

Forbes laid especial stress upon the "gonads" upon the radial-canals, and he believed the manubrium to be simple and tubular, and failed to find collar-like swellings upon it. Haeckel, 1879 , p. 241 , and Browne, 1898 , p. 816 , find, however, that the gonads in Forbes's medusa are developed in separated ring-like annuli upon the manubrium and Browne, who sectioned the supposed "gonads," finds that they contain entodermal cells crowded with small nuclei, and they are doubtless mere glands similar to those seen upon the radial-canals of many Antho- 
Tabular Description of the Medusa of Slabberia.

\begin{tabular}{|c|c|c|c|c|c|c|}
\hline & $\begin{array}{l}\text { Slabberia bal- } \\
\text { terata Forbes, } \\
1846 .\end{array}$ & $\begin{array}{l}\text { S. strangulata }= \\
\text { Dipurena } \\
\text { strangulata } \\
\text { McCrady, } \\
1857 .^{2}\end{array}$ & $\begin{array}{l}\text { S. strangulata } \\
\text { var. fragilis } \\
\text { Mayer. }^{3}\end{array}$ & $\begin{array}{l}\text { S. catenata Forbes, } \\
\text { I } 853=\text { Dipurena } \\
\text { dolicbogasta } \\
\text { Haecliel, I } 879, \\
=\text { D. picta Mayer, } \\
\text { 1900=Sarsia } \\
\text { clavata Kefer- } \\
\text { stein, I } 862 .\end{array}$ & $\begin{array}{l}\text { S. opbiogaster = } \\
\text { Dipurena } \\
\text { ophiogaster } \\
\text { Haeckel, I } 879 . \\
\text { = Sarsia stran- } \\
\text { gulata Allman, } \\
\text { 1871.5 }\end{array}$ & $\begin{array}{r}\text { S. pyramis = Bathy- } \\
\text { codon pyramis } \\
\text { Haeckel, } 1879 .\end{array}$ \\
\hline $\begin{array}{l}\text { Shape and } \\
\text { size of bell } \\
\text { in } \mathrm{mm} \text {. }\end{array}$ & $\begin{array}{l}\text { Ellipsoidal. } \\
8 \text { high, } 6 \text { wide. }\end{array}$ & $\begin{array}{l}\text { Ellipsoidal to } \\
\text { hemispherical. } \\
2 \text { to } 4 \text { higb, } \\
4^{\text {to }} 3 \cdot 3 \text { wide. }\end{array}$ & $\begin{array}{l}\text { Ellipsoidal. } \\
4 \text { bigb, } 3 \cdot 5 \\
\text { wide. }\end{array}$ & $\begin{array}{l}\text { Ellipsoidal. } \\
2-4 \text { high, 1 } 6 \text { wide. }\end{array}$ & $\begin{array}{l}\text { Globular. } \\
5 \text { bigh, } 4 \text { wide. }\end{array}$ & $\begin{array}{l}\text { Рyramidal. } \\
\text { 4-sided. } 5 \text { high, } \\
5 \text { wide. } 4 \text { lines of } \\
\text { nettle-cells ex- } \\
\text { tended up ex- } \\
\text { umbrella in } 4 \\
\text { principal radii. }\end{array}$ \\
\hline $\begin{array}{l}\text { Cbaracter of } \\
\text { tbe } 4 \text { ten- } \\
\text { tacle-bulbs. }\end{array}$ & $\begin{array}{l}\text { Large with an } \\
\text { abaxial ocellus. }\end{array}$ & $\begin{array}{l}\text { As_in S. halter- } \\
\text { ata. }\end{array}$ & Very small. & As in S. balterata. & $\begin{array}{l}\text { Poorly developed, } \\
\text { with abasial } \\
\text { ocelli. }\end{array}$ & Ocelli? \\
\hline $\begin{array}{l}\text { Lengtb of } \\
\text { eacb ten- } \\
\text { tacle in } \\
\text { terms of } \\
\text { bell-ra- } \\
\text { dius }(r) \text {. }\end{array}$ & $2 r$ & $\begin{array}{l}\text { I. } 5 r \text {, quite } \\
\text { tbick. }\end{array}$ & $2 r$ very slender. & $2 r \pm$ & $2 r+$ & $4^{r+}$ \\
\hline $\begin{array}{l}\text { Number and } \\
\text { position of } \\
\text { nettle- } \\
\text { warts on } \\
\text { each ten- } \\
\text { tacle. }\end{array}$ & $\begin{array}{l}\text { large, terminal, } \\
\text { club-sbaped } \\
\text { knob. I to } 2 \\
\text { rings at base } \\
\text { of knob. }\end{array}$ & $\begin{array}{l}\text { Single knob-like } \\
\text { end and with } \\
\text { nettle-warts } \\
\text { on shaft of } \\
\text { eacb tent acle. }\end{array}$ & $\begin{array}{l}\text { As in S. strangu- } \\
\text { lata. }\end{array}$ & $\begin{array}{l}\text { Proximal halves of } \\
\text { tentacles smooth. } \\
\text { Outer halves } \\
\text { ringed with I } 5 \text { to } \\
3 \text { onematocyst } \\
\text { swellings. }\end{array}$ & $\begin{array}{l}\text { Tapering. Outer } \\
\text { parts thickly } \\
\text { covered with } \\
\text { prominent par- } \\
\text { tial rings and } \\
\text { spirals contain- } \\
\text { ing nettle-cells. }\end{array}$ & $\begin{array}{l}\text { Each tentacle ter- } \\
\text { minates in } \\
\text { "suctorial cup." }\end{array}$ \\
\hline $\begin{array}{l}\text { Character } \\
\text { of the } 4 \\
\text { radial- } \\
\text { canals. }\end{array}$ & $\begin{array}{l}\text { Narrow, straight, } \\
\text { each with swol- } \\
\text { len (glandular?) } \\
\text { enlargement at } \\
\text { two-tbirds } \\
\text { lengtb of canal } \\
\text { above margin. }\end{array}$ & $\begin{array}{l}\text { Narrow, straight, } \\
\text { witbout "glan- } \\
\text { dular" swell- } \\
\text { ings. }\end{array}$ & $\begin{array}{l}\text { As in S. strangu- } \\
\text { lata. }\end{array}$ & As in S. strangulata. & $\begin{array}{l}\text { As in } S . \text { strangu- } \\
\text { lata. }\end{array}$ & $\begin{array}{l}\text { Edges of radial- } \\
\text { canals lined } \\
\text { with gland-cells. }\end{array}$ \\
\hline $\begin{array}{l}\text { Length of } \\
\text { inanubrium } \\
\text { in terms of } \\
\text { bell-radius } \\
(r) \text {. }\end{array}$ & $4107 r$ & 4 to $7 \mathrm{r}$. & $2 r$ & 4 to $7 r$ & 8 to $12 r$. & $4^{r+}$ \\
\hline $\begin{array}{l}\text { Number of } \\
\text { ring-like } \\
\text { gonads } \\
\text { which en- } \\
\text { circle } \\
\text { manu- } \\
\text { brium. }\end{array}$ & $\begin{array}{l}2 \text { or } 3 . \text { J or } 2 \\
\text { small genital } \\
\text { rings below } \\
\text { middle, and a } \\
\text { longer one } \\
\text { near outer end } \\
\text { of manubrium. }\end{array}$ & $\begin{array}{l}\text { 2. Small ring } \\
\text { near middle, } \\
\text { and longer } \\
\text { outer ring. }\end{array}$ & $\begin{array}{l}\text { 2. As in } S \text {. } \\
\text { strangulata. }\end{array}$ & $\begin{array}{l}2 \text { or } 3 \text { as in S. bal- } \\
\text { terata. Preceding } \\
\text { development of } \\
\text { gonads medusa- } \\
\text { buds are borne on } \\
\text { manubrium (see } \\
\text { test). }\end{array}$ & $\begin{array}{l}4 \text { to } 6 \text { short, } \\
\text { swollen, sepa- } \\
\text { rated by short } \\
\text { intervals. }\end{array}$ & 8 separated rings. \\
\hline Color. & $\begin{array}{l}\text { Entoderm of ten- } \\
\text { tacle-bulbs } \\
\text { and tentacle- } \\
\text { knobs red- } \\
\text { dish-brown; } \\
\text { of manubrium } \\
\text { yellowisb- } \\
\text { brown. } \\
\text { Ocelli black. }\end{array}$ & $\begin{array}{l}\text { Variable shades } \\
\text { of yellow, red, } \\
\text { and green. } \\
\text { Ocelli black. }\end{array}$ & $\begin{array}{l}\text { Dull-yellow en- } \\
\text { toderm of } \\
\text { stomach and } \\
\text { tentacles. } \\
\text { Ocelli black. }\end{array}$ & $\begin{array}{l}\text { Stomacb yellow or } \\
\text { red. Gonads and } \\
\text { tentacles light-red. } \\
\text { Moutb, tentacle- } \\
\text { bulbs, and apex of } \\
\text { stomach brigbt- } \\
\text { yellow, red, and } \\
\text { purple. Ocelli } \\
\text { deep-purple brown. }\end{array}$ & $\begin{array}{l}\text { As in S. catenata. } \\
\text { Ocelli black. }\end{array}$ & $\begin{array}{l}\text { Stomach canals } \\
\text { and tentacles } \\
\text { light-green. } \\
\text { Mouth, tenta- } \\
\text { cle-bulbs and } \\
\text { terminal "an- } \\
\text { chors" darker } \\
\text { green. }\end{array}$ \\
\hline Where found. & $\begin{array}{l}\text { Soutbern coasts } \\
\text { of England } \\
\text { and Ireland. } \\
\text { Rare. }\end{array}$ & $\begin{array}{l}\text { Coast of United } \\
\text { States from } \\
\text { South Caro- } \\
\text { lina to Cape } \\
\text { Cod. }\end{array}$ & $\begin{array}{l}\text { Tortugas, } \\
\text { Maldive Is- } \\
\text { lands, In dian } \\
\text { Ocean, Bige- } \\
\text { low. }\end{array}$ & $\begin{array}{l}\text { West coast of Scot- } \\
\text { land to Mediter- } \\
\text { ranean. }\end{array}$ & $\begin{array}{l}\text { Southern coasts of } \\
\text { England and } \\
\text { Ireland to Med- } \\
\text { iterranean. (?) } \\
\text { Ceylon (Browne). }\end{array}$ & $\begin{array}{l}\text { Mediterranean, } \\
\text { Corfu; from } \\
\text { depth of } 20 \\
\text { fathoms, April, } \\
\text { I } \$ 77, \text { Hackel. }\end{array}$ \\
\hline
\end{tabular}

${ }^{1}$ Distinguished by 4 small, isolated (glandular ?) bodies upon its 4 radial-canals. Hartlaub, 1907 , believes tbese to be gonads which become mature only in old medusx.

2Distinguisbed by its quite thick tentacles, each ending in a single, knob-like cluster of nematocysts.

${ }^{3}$ Separated from $S$. strangulata only by its long, slender tentacles and uniform dull-yellow color.

${ }^{4}$ Hydroid a Syncoryne. Medusa distinguished by numerous total or partial rings of nettling cells which are developed over outer halves of tentacles. When young medusa-buds are borne on manubrium of free medusa.

${ }^{5}$ Is this a fully developed, mature condition of $S$. catenata (?).

"Distinguished by terminal "suctorial cups" on its tentacles and numerous glands (?) wbich line radial-canals. 
medusx. On the other hand, Browne found the gonads upon the manubrium, arranged in 2 or more isolated ring-like swellings. In 1853 Forbes and Goodsir describe another species of Slabberia, S. catenat $a$, which lacks glands upon its radial-canals, although Forbes states that they exist but are "scarcely to be traced."

In 1857 McCrady described a medusa under the name Dipurena strangulata, and in this the 4 radial-canals are simple, but the manubrium is tubular and encircled by 2 separated, ring-like gonads.

It is evident that Slabberia of Forbes is similar in all respects to Dipurena, excepting for the problematical swellings on the radial-canals. It seems best to drop Dipurena and retain the older name Slabberia. Swellings similar to those on the radial-canals of $S$. halterata are seen on the radial-canals of other Anthomedusx, such as Lymnorea alexandri and Dysmorphosa dubia. In $L$. alexandri the swellings are glandular and they are probably of similar function in the Slabberia of Forbes. Hartlaub (1907), however, st ates that these swellings are gonads which develop only in old medusa. He does not state, however, that he sectioned the medusa, and the matter appear's to me to be still in doubt.

\section{GENERIC CHARACTERS.}

Codonidx in which the manubrium is tubular and is encircled by two or more separated collar-like gonads. In other respects the medusa resembles $S$ arsia. The 4 radial-canals are simple and without gonads. The hydroid is Syncoryne.

In all known species of Slabberia each of the 4 tentacles terminates in one or more knoblike clusters of nematocysts.

Haeckel, 1879 , p. 26, instituted the genus Bathycodon for a medusa resembling Dipurena, but with short, blindly-ending diverticula upon its radial-canals. We define Slabberia as equivalent to Dipurena $+B$ athycodon as defined in Haeckel's System.

Haeckel suppresses the generic name Slabberia on the ground that it was incorrectly defined by Forbes, but if we are to retain only the correctly defined genera we must at once drop nearly all of those defined previous to 1850 , and even the majority of modern generic names must vanish! As knowledge increases it appears to me far less confusing to amend and retain old names rather than to drop them and substitute unfamiliar designations for familiar objects.

Hartlaub, i 907 , would distinguish Purena, with nettle-warts (not rings) upon the tentacles, whereas Slabberia he would confine to include medusæ having tentacles ringed with nematocysts. The distinction between broken rings ("warts") and complete rings appears to me to be too slight to be of generic value, but is an important specific distinction.

\section{Slabberia halterata Forbes.}

Slabberia halterata, Forbes, 1846 , Annals. and Mag. Nat. Hist., vol. 18, p. 286; 1848, British Naked-eyed Medus $x$, p. 53, plate 6, fig. 1.-AGassiz, L., 1862, Cont. Nat. Hist. U. S., vol. 4, p. 341 .

Dipurena halterata, HAғ.скEL, 1879 , Syst. der Medusen, p. 24.

Dipurena halherata, Browne, I 896 , Proc. Zool. Soc. London, p. 473; I897, Ibid., p. 816; I898, plate 49, figs. 2-2b.-Bkдо, 1905, Revue Suisse de Zool., tome 13, p. 133 (citation of literature 1846-49).

Slabberia halerala, Hartlac'B, 1907, Nordisches Plankton, Nr. 12, p. 64, figs. 61, 62.

Bell ellipsoidal, $8 \mathrm{~mm}$. high, $6 \mathrm{~mm}$. wide, with thick walls. Bell cavity about three-fourths as deep as the height of the bell. 4 slender tentacles with well-developed basal bulbs, each with an abaxial, ectodermal ocellus. Each tentacle terminates in a large, elongate, swollen tip with one or two complete rings of nematocysts above it. 4 radial-canals straight and narrow, and each exhibits I or 2 small (glandular?) swellings (gonads?) at about one-third the distance between the inner apex of the bell-cavity and the margin. Hartlaub, 1907, believes these swellings to be true gonads which become mature only in old medusæ.

The stomach-cavity extends upward a short distance above the base of the manubrium into the gelatinous substance of the apex of the bell.

The manubrium is + to 7 times as long as the radius of the bell. It is slender and tubular and there is a small, spindle-shaped stomach near its distal end. The mouth is at the end of a short, conical neck and is a simple, round opening. 
2 or 3 ring-like gonads girdle the manubrium. The two upper gonads are short, the uppermost one being near the middle of the manubrium, and the next lower separated from it by a short interval. The lowermost (distal) gonad is about twice as long as either of the others, and it is adjacent to and above the stomach.

The entoderm of the basal bulbs and terminal clubs of the tentacles is reddish-brown and of the manubrium yellowish-brown. The ocelli are black.

This medusa has been taken at infrequent intervals off the southern coasts of England and Ireland. The kest modern descriptions are given by Browne, 1898 , and by Hartaub, 1907 .

It is distinguished by the 4 small swellings on the 4 radial-canals. According to Browne these are probably glandular, but Hartlaub regards them as gonads which develop later than the gonads upon the manubrium. Hartlaub, apparently, has not sectioned the medusa, while Browne bases his conclusions upon a study of sections.

Slabberia strangulata Haeckel.

Plate 7 , figs. 1, 2, and 3 .

Dipureno strangulasa, McCrady, 1857, Gymn. Charleston Harbor, p. 33, plate 9, figs. 1, 2.

Dipurena cervicata, McCradv, 1857, Gymn. Charleston Harbor, p. 34 .

Dipurena conica, A. Agassiz in L. Agassiz's, 1862, Cont. Nat. Hist. U. S., vol. 4, p. 341 .

Dipurena cervicata, Agassiz, L., 1862, Cont. Nat. Hist. U.S., vol. 4, P. $34^{1}$.

Dipurena strangulata, AGassiz, L., 1862, Cont. Nat. Hist. U.S., vol. 4, P. 341 .

Dipurena conica, Agassiz, A., 1865, North Amer. Acal., p. 181, figs. $301,305$.

Dipurena strangulata $=$ Slabberia strangulata, HaEckeL, 1879, Syst. der Medusen, p. 23.

Dipurene conica, HAECKEL, 1879 , Syst. der Medusen, p. 24 .

Dipurena strangulata, Fewkes, i 881, Bull. Mus. Comp. Zool., vol. 8, p. 155, plate 4, fig. 5.-Brooks, 1882, Studies Johns Hopkins Univ. Biol. Lah., vol. 2, p. 136.

Dipurena conica, VERRILL, 1873 , Report Commiss. Fish and Fisheries for $1871-72$, p. 735 .

Dipurella clavato (immature), HargitT, 1904, Bulletin of the Bureau of Fisheries, vol. 24, p. 31, plate 1, fig. 3.

Dipurena conica, Nutring, 1901, Bull. U.S. Fish Commission for 1899, vol. 19, p. 373. - HargitT, 1901, American Naturalist, vol. 35, p. 578 , fig. 34 .

Purena strangulata, Harteavb, 1907, Nordisches Plankton, Nr. 12, P. 55, fign. 51-53.

In 1857 McCrady described those which he believed to be two distinct species of Dipurena, $D$. strangulata and D. cervicata, from Charleston Harbor, South Carolina. In I862-65, A. Agassiz described that which he believed to be another species, from Buzzards' Bay, under the name of D. conica. A careful study of Dipurena in Charleston Harbor, in September, 1897 , when the medusæ were exceedingly abundant, has convinced me that all of these forms are one and the same species. McCrady found only two individuals of D. strangulata and one of $D$. cervicata, and thus A. Agassiz was misled into the assumption that the northern form was a distinct species. The shape of the bell is, however, very inconstant, and the length of the manubrium in the Charleston medusæ is subject to a wide range of variability.

Adult medusa (plate 7 , fig. I).- The bell is quite variable in shape, for in some individuals it is hemispherical, while in others it is ellipsoidal and higher than a hemisphere. All gradations between these two extremes are observed. In a large individual in which the bell was hemispherical it was $4 \mathrm{~mm}$. in diameter; while another having an ellipsoidal bell was $4 \mathrm{~mm}$. in height and $3 \mathrm{~mm}$. in width. There are 4 stiff tentacles, one at the base of each radialcanal. Each tentacle terminates in a single, knob-like swelling which is covered with nematocysts. The entodermal core of this swelling is hollow, and its lumen is placed in communication with the general gastrovascular system of the medusa by means of a narrow thread-like canal which extends through the entire length of the tentacle. The basal bulb of each tentacle is large and there is a single, ectodermal ocellus mounted upon a short pedicel, upon the outer side of the bulb. The tentacles are all of equal length, and each one is about three-fourths as long as the bell-diameter. The velum is wide. There are 4 straight, simple radial-canals and a narrow, circular tube. The gastric cavity projects upward a short distance into the gelatinous substance of the bell at the point of intersection of the 4 radial-canals. The manubrium is always long and increases in length with advancing age. In mature medusæ it projects far beyond the velar opening and varies in length from 5 to $10 \mathrm{~mm}$. It is tubular and highly contractile, and the mouth is a simple, round opening. Four distinct regions may be distinguished upon the manubrium of the mature medusa. First, a long, narrow, tubular region, extending from the inner apex of the bell-cavity to about the level of the velar opening, then a short, fusiform, swollen region, then a short, narrow, tubular region similar in size to the 


\section{Plate 7.}

Fig. 1. Slabberia strangulata, mature male. Charleston Harbor, South Carolina, September 8, I897.

Fig. 2. Slabberia strangulata, half-grown medusa. Charleston Harbor, South Carolina, September II, I 897 .

Fig. 3. Slabberia strangulata, young medusa. Charleston Harbor, South Carolina, September 7, 1897 .

Fig. 4. Slabberia strangulata var. fragilis. Tortugas, Florida.

Fig. 5. Zanclea gemmosa, young medusa. Agassiz Laboratory, Newport, Rhode Island, September 17,1892 .

Drawn from life, by the author. 


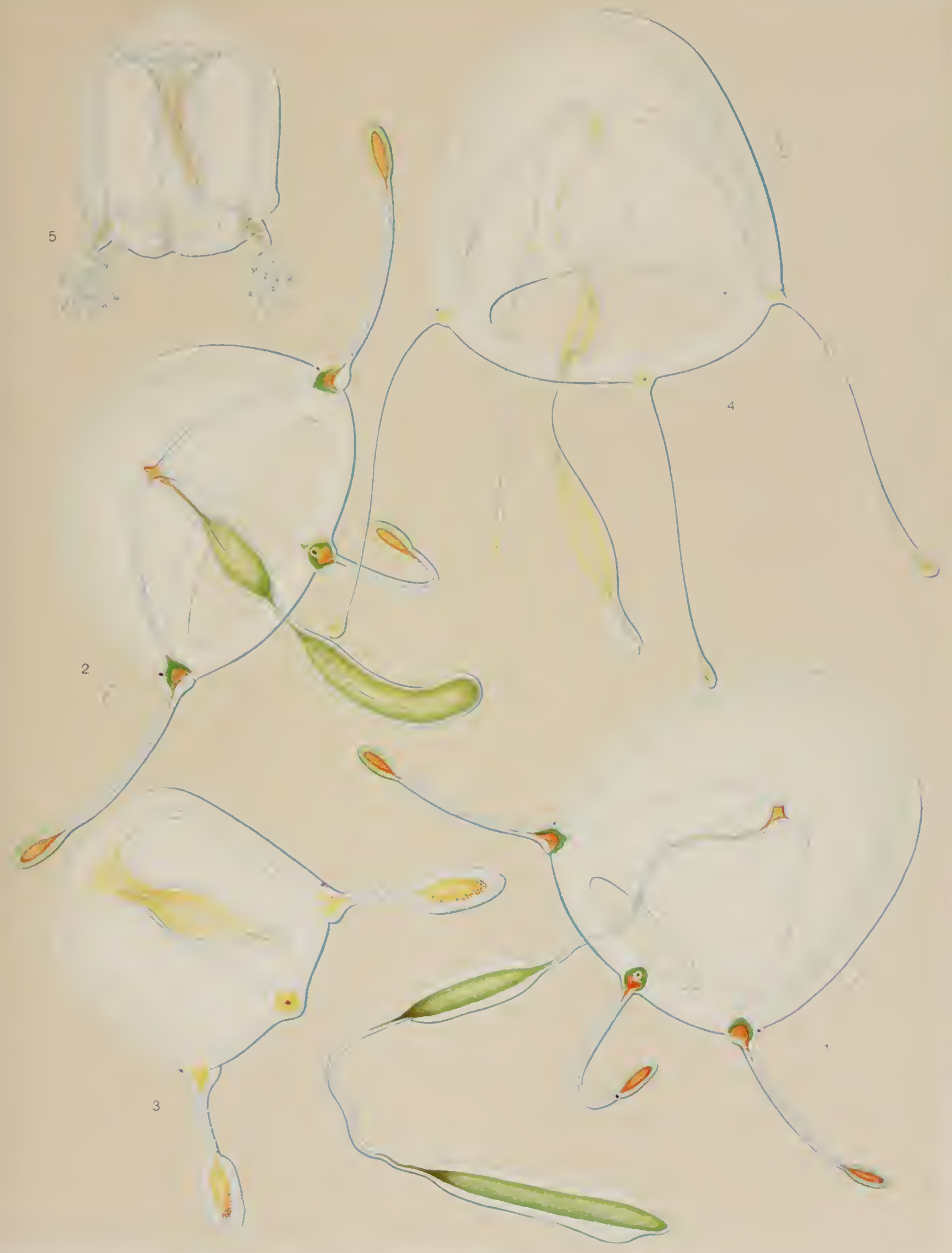



proximal part of the manubrium, and finally at the distal end a long, club-shaped, cylindrical region, at the extremity of which the mouth is situated. The 2 genital organs are found within the 2 swollen regions of the manubrium. The color of these medusa is quite variable, the entoderm of the manubrium and tentacles being either yellow, or yellow and red, or red, or green and red. In the young medusæ the entoderm of the manubrium is usually yellow, and of the tentacles yellow dotted with red granulations; while in the mature medusa the color of the entoderm is usually green or yellowish-green.

roung medusa (plate 7 , fig. 3 ).- - In the youngest medusa observed, the bell is cylindrical with vertical sides and a slight apical projection. The gelatinous substance is thin. There are 2 diametrically opposed tentacles each of which terminates in a single, large, nematocystcovered knob. The other 2 tentacles are as yet undeveloped and are represented by mere basal bulbs. There are 4 ocelli, one upon each basal bulb. The manubrium is a simple, short, conical tube and the mouth is a simple, round opening.

When the medusa is $\mathrm{I} \mathrm{mm}$. in height, a constriction appears near the proximal end of the manubrium, which thus becomes divided into an upper and lower swollen region. As development proceeds this constriction becomes more marked and finally the manubrium assumes the adult shape; the upper and lower swellings of the young proboscis corresponding to the two swollen regions of the manubrium of the adult medusa. Hargitt, 1904, describes the young medusa under the name of "Dipurella clavata."

This medusa is exceedingly abundant in August and September in Charleston Harbor, South Carolina. It has been found by Brooks at Beaufort, North Carolina; and by A. Agassiz and Verrill in Buzzards' Bay, Massachusetts. It has not been taken north of Cape Cod, Massachusetts, and has not been observed at the Tortugas, Florida.

Slabberia strangulata var. fragilis.

Plate 7, fig. 4 .

Dipurena fragilis, Mayer, 1900, Bull. Mus. Comp. Zool. at Harvard College, vol. 37, p. 29, plate 17, fig. 41. (?) Dipurena fragilis, Bıgelow, 1904, Bull. Mus. Comp. Zool. at Harvard College, vol. 39, p. 251.

Bell $4 \mathrm{~mm}$. high and half-egg-shaped, with moderately thick walls, becoming thinner near the margin. There are 4 long, slender tentacles, each about as long as the bell-height. These terminate each in a single knob armed with nematocysts. The tentacle-bulbs upon the bell-margin are not large, but each one bears a single, black ocellus in the ectoderm of its outer side. Velum wide. There are 4 straight, narrow radial-canals and a slender, circular vessel. Manubrium about twice as long as bell is high. It is slender and tubular, with two separate, swollen regions containing the gonads. The entoderm of the manubrium and of the basal bulbs of the tentacles is dull yellow, while the entoderm of the terminal knobs of the tentacle is a faint orange.

This variety is found at Tortugas, Florida, in June. Bigelow, I904, found a colorless Dipurena at Suvadiva Atoll, Maldive Islands, Indian Ocean, which he believes is probably identical with Dipurena fragilis.

$S$. fragilis may be distinguished from other American Dipurenx by its long, very slender tentacles, and the dull-yellow color of its entoderm.

Slabberia catenata Forbes and Goodsir.

Plate 8 , figs. 8 and 9.

Siabberia caterata, Forbes and Goodsir, 1853 , Trans. Roy. Soc. Edinburgh, vol. 20, p. 311 , plate 10, figs. $3 a-3 e$.

Dipurena dolichogaster, Haecker, 1864, Jena. Zeitschrift für Naturw., Bd.1, p. 337; 1879, Syst. der Medusen, p. 25, taf. 2, figs. $1-7$.

Dipurena catenata, НАЕскеL, 1890, Syst. der Medusen, p. 655.

Dipurena feriilis, Metschnixofr, E. and L., I 870 , VerhandI. Gesell. Freunde Nat. Moskau, tome 8, p. 343, taf. 3, figs. I-5. Sarsia dolichogaster, SPaGnolini, 1876, Catalogo Acalefi Mediterraneo, p. 18, tav. 2, fig. 3 (from Naples, Italy).

Dipurena dolichogaster, Chus, 1895 , Bibliotheca Zoologica, Heft 19, p. 6, taf. 1, figs. $1-4$.

Dipurena catenata, Monticell, 1897 , Atti Accad. Sci. Torino, vol. 32, p. 888, 1 fig. (abnormal specimen fron the Gulf of Cagliari, with a manubrium which gives off 2 side branches, eacl with mouth and gonad).

(?) Sarsia clavata, Keferstein, 1862, Zeitschrift für wissen. Zool., Bıl. 12, p. 27, taf. 2, figs. 1, 2.

(?) Sarsia, sp., Allmax, 1871 , Monog. Tubul. Hydroids, p. 8 , fig. 37.

(?) Sarsia clavata, Haeckel, 1879 , Syst. der Medusen, p. 19.

(?) Sarsia clavata (Syncoryne clavata), Graefre, 1884, Arbeit. Zool. Inst. Wien, Bd. 5, P. 351 (first description of the hydroid).

Dipurena piça, Mayer, 1900, Bull. Mus. Comp. Zool. at Harvard College, vol. 37, p. 29, plate 18, figs. 45, 46.

(? Sarsia clavala) + Slabberia casenata, Hartlaus, 1907, Nordisches Plankton, Ni. 12, pp. 51, 63, figs. 46, 59 . 


\section{DESCRIPTION OF AMERICAN SPECIMENS.}

Bell high with straight, vertical sides and flatly-rounded top, about $3 \mathrm{~mm}$. high and $\mathrm{I} .5$ $\mathrm{mm}$. wide. Bell-walls very thick and of a rigid, gelatinous consistency. Bell-cavity about two-thirds as deep as the total height of the bell itself. There are 4 radially situated, slender tentacles, all of the same length and not quite as long as the bell-height. Each of these tentacles terminates in 3 to 5 bulb-shaped, ring-like swellings containing nematocysts. The basal bulbs of the tentacles are large and swollen, and each of them bears a dark-purple, ectodermal ocellus upon its outer side. There are 4 straight, narrow radial-canals and a simple, slender, circular vessel. The velum is quite narrow. The manubrium is a slender tube about $5 \mathrm{~mm}$. long; and it exhibits two separate, annular, swollen regions marking the places where the gonads are situated. The mouth is a simple, round opening. The entoderm of the manubrium and of the tentacle-bulbs is of a beautiful custard-yellow, while the entoderm of the terminal series of knobs on the tentacles is of a rich port-wine color.

Several specimens were found in a surface-tow at Tortugas, Florida, early in August, 1898 , and in July, 1906 .

\section{DESCRIPTION OF EUROPEAN SPECIMENS.}

For details of the general characters of the European medusa, see tabular description of the medusæ of Slabberia.

Forbes and Goodsir, I853, describe this medusa from the western coast of Scotland, at Tobermory and Loch Laigh.

Keferstein, I862, and Allman, $1871-72$, describe that which I doubtfully believe to be this medusa from the coasts of France and England. It is the inmature condition before the appearance of gonads, while medusa-buds are still being produced upon its manubrium, and before the development of nettle-rings upon its tentacles. Chun, I895, has made a most careful study of this budding process in specimens from the Mediterranean.

Haeckel, 1879 , describes this medusa from the Mediterranean, but did not observe it in the stage wherein medusa-buds are being produced. An identical medusa is found at Tortugas, Florida.

Chun, 1895 , has made a careful study of the budding process. When the medusa is young the manubrium is slender and cylindrical and without gonads. Medusa-buds develop at this stage. These budding medusæ develop in a helical line at regular intervals down the sides of the manubrium. The oldest of the primary series of medusa-buds is nearest the base and the youngest nearest the mouth of the manubrium.

These primary medusa-buds are attached by narrow pedicels to the sides of the manubrium, and a second series of medusa-buds develop upon the sides of these pedicels, before the primary medusæ are set free. After the primary medusæ are set free the secondary medusabuds complete their development. Thus the manubrium may present various appearances; the oldest medusa-buds at any one time may be above, or below, or anywhere upon the manubrium. Before they are set free the budding medusæ begin to develop a secondary generation of medusa-buds upon their manubria.

The hydroid of this medusa is described by Graeffe from Trieste, Adriatic Sea. Graeffe succeeded in rearing the hydroid from the eggs of the medusa. It is a Syncoryne. The polypites are cup-shaped, only 2 to $3 \mathrm{~mm}$. long, and have 4 circlets of 4 tentacles each. The tentacles are short and stiff, and each one ends in a nematocyst-knob. The short stems of the hydroid are invested by an irregularly ringed perisarc. The hydrorhiza forms a mass of profusely branched anastomosing stolons. The medusa-buds arise from the sides of the polypites between the 2 lowest circlets of tentacles. When set free the medusa has a short manubrium and 4 tentacles. The tentacles have terminal nematocyst-knobs and a nettling ring.

The eggs are laid in May and June and the mature hydroid is found in October at Trieste.

Chun is of the opinion that Sarsia clavata is identical with "D. dolichogaster"; but Hartlaub regards $S$. clavata as being distinct and a true Sarsia. The absence of a series of rings upon the tentacles of $S$. clavata inclines me to agree with Hartlaub that it is a Sarsia and not to be confused with Slabberia catenata. Further studies appear to be required before any final opinion can be formed upon this case. 
Slabberia ophiogaster.

Sarsia strangulata, Alz.van, $1871-72$, Monograph Tubularian Hydroids, p. 46, fig. 17 .

Dipurena ophiogaster = Tetrapurena ophiogaster, Haxcxiz, 1879, Syst. der Medusen, p. 25.

Dipurena ophiogaster (?), Browne, 1905, Pearl Oyster Fisheries, Gulf of Manaar, Roy. Soc. London, Suppl. Report 27, p. 133, plate 2, figs. 1, 2 (from Galle Bay, Ceylon).

Purena strangulata, Hartlaub, 1907 , Nordisches Plankton, Nr. 12, p. 55, figs. $51-53$.

This medusa is found off the southern coasts of England and Ireland, and an apparently identical species is described by Browne from Ceylon. Dr. Lobianco kindly permitted me to study a specimen, which I consider to be of this medusa, from Naples, Italy.

For details, see tabular description of the medusa of Slabberia.
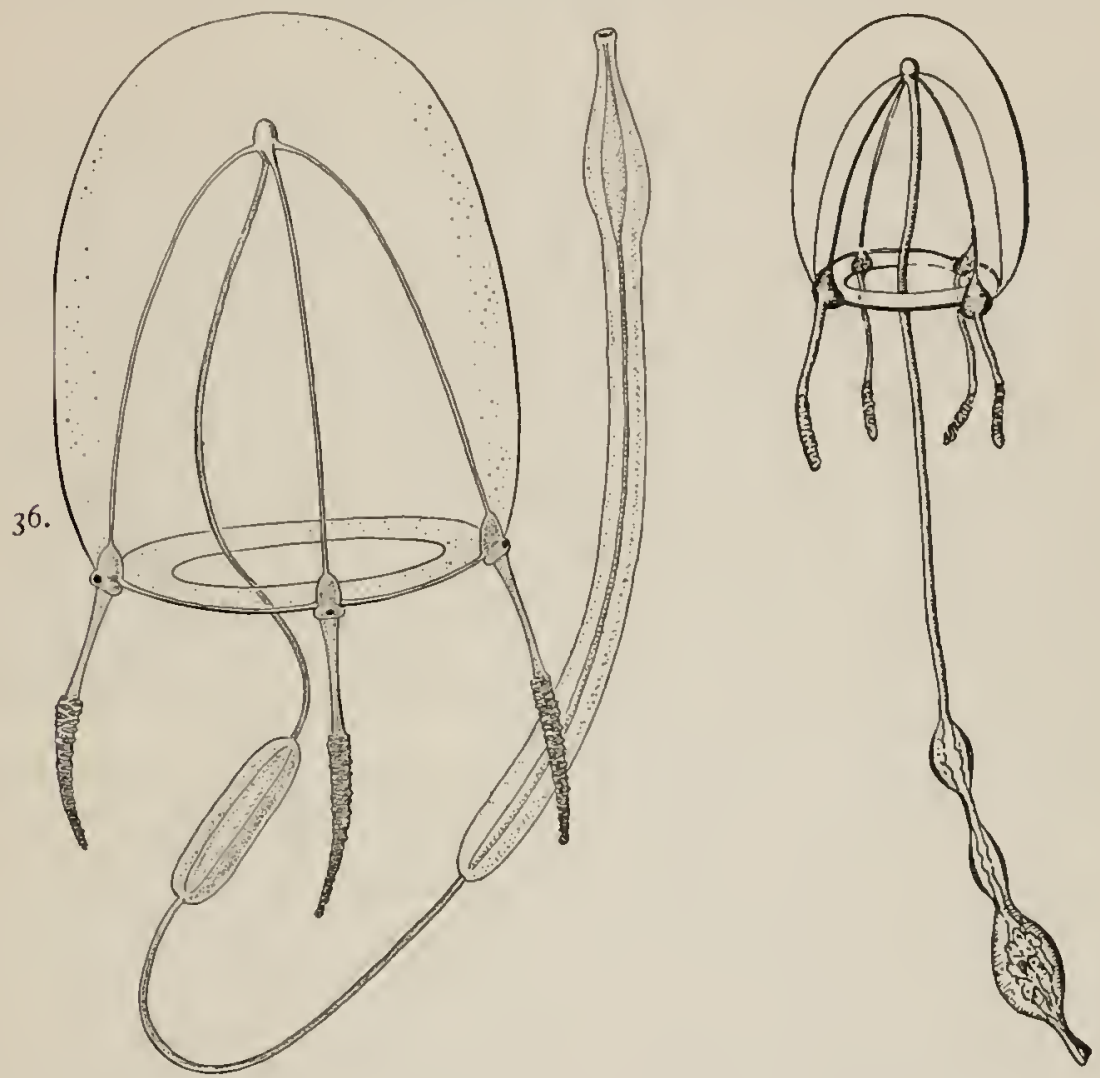

Fig. 36. Slabberia ophiogaster. Drawn by the author, from a specimen collected by Dr. Lobianco in the Bay of Naples. Fig. 37.- "Purena strangulata" (S. ophiogaster), after Hartlaub, in Nordisches Plankton.

In the specimen in Dr. Lobianco's collection from Naples, the bell is $5 \mathrm{~mm}$. high, $4 \mathrm{~mm}$. wide; oval, with thick walls. The manubrium is $13.5 \mathrm{~mm}$. long and has 2 gonads, one in the middle of its length and one adjacent to the stomach. The 4 tentacles are each $2.5 \mathrm{~mm}$. long, and their outer halves taper to a point and are covered with broken, partial rings of nettlecells. The proximal halves of the tentacles are smooth and cylindrical. The tentacle-bulbs are swollen below the bell-margin and have ocelli.

\section{Slabberia pyramis.}

Bathycodon pyramis, HaEckel, 1879, Syst. der Medusen, p. 26.

This Mediterranean medusa is distinguished from other species of Slabberin by the terminal "suction cups" upon its tentacles and by the numerous "glandular" organs which line the sides of the radial-canals. For details see the tabular description of medus $x$ of Slabberia. 
Nemopsis (hydroid only), McCrady, 1857, Gymn. Charleston Harhor, Proc. Elliott Society of Charleston, vol. 1, p. 163, plate 10, figs. $4^{-7}$

Margelopsis, Hartlaub, 1897, Hydromedusen Helgolands, Wissen. Meeresuntersuch., Biolog. Anstalt auf Helgoland, Neue Folge, Bd. 2, p. 482; Ibid., I904, Bd. 5, p. 99; 1899, Nachrich.k. Gesell. der Wissenschaften Göttingen, math.-phys. Klasse, p. 219; Zool. Centralbl., Bd. 10, p. 28; 1907, Nordisches Plankton, Nr. 12, p. 88.-Browne, 1903, Bergens Museums Aarbog, No. 4, p. 10.-MÍllter, 1908, Zeit. für wissen. Zool., Bd. 89, pp. 43, 73.

\section{GENERIC CHARACTERS.}

Anthomedusæ with simple, round mouth-opening without oral tentacles, or cruciform lips. With 4 radially placed clusters of marginal tentacles and 4 radial-canals. The ringlike gonad encircles the stomach. The hydroid is the pelagic Margelopsis.

The tentacles of the hydroid are confined to definite whorls. In 1857, McCrady described a free-floating hydroid from Charleston Harbor which has two whorls of tentacles, and between them a number of medusa-buds arise from the sides of the hydranth. When set free the medusæ bore some resemblance to $N$ emopsis, and McCrady believed them to be the young of Nemopsis gibbesii =Nemopsis bachei L. Agassiz. We now know this to have been a mistake, for Hartlaub, I899, discovered that actinula larva develop upon the sides of the manubrium in Margelopsis haeckelii. Then these actinula are set free with two whorls of tentacles, and medusa-buds develop from the sides of the hydranth between the whorls, and are set free, as in McCrady's hydroid, which is, indeed, a species of Margelopsis.

In 1904 Hartlaub found another free-floating hydranth (Margelopsis stylostoma) which is apparently detached from Tiarella singularis F. E. Schulze. It is apparent that the Siphonophoræ may have been derived from hydroid forms having a similar life-history.

The medusæ of this most interesting genus appear to form a connecting link between the Codonidæ and Margelidæ of Haeckel. They resemble the Codonidæ in their simple mouth-opening without oral tentacles or prominent lips, and in the single ring-like gonad surrounding the manubrium. On the other hand, they resemble the Margelidx in having the marginal tentacles grouped into 4 radially situated clusters. There are, however, no tentacular ocelli such as are seen in the Margelidx.

The Atlantic species are all very closely related and may prove to he but one. The chief distinctions are the number of tentacles upon each tentacle-bulb. For example: $M$. hartlaubii Browne has 2; M. haeckelii Hartlaub has 3 to $4 ; M$. gibbesi Hartlaub has 5 to 6.

The medusa of $M$. stylostoma, and the hydroid of $M$. hartlaubii are unknown, and it is possible that these two may be phases in the life-history of one and the same animal.

The so-called "Perigonimus sulphureus" Chun, i 889 (Sitzungsber. Akad. Wissen. Berlin, Jahrg. 1889, p. 524), and Steche, 1906 (Zool. Anzeiger, Bd. 31, p. 30, 2 figs.), is probably not a Perigonimus, but may give off pelagic hydranths. Chun found this hydroid growing upon a living shell of Hyalca in the Canary Islands. One portion of the net-like hydrorhiza gives rise to isolated polypites, and another portion to the medusa-buds. The hydranths arise directly from the hydrorhiza and are unbranched. They are barrel-shaped, large, and with an oral circlet of 6 to 9 short, blunt tentacles. One of the hydranths was sharply constricted by a ring-furrow in the middle of its length as if the oral end were ahout to be set free and to become pelagic (Steche). The medusa-buds also arise singly from the hydrorhiza, each of the medusa-buds being placed upon a short, unbranched peduncle. When set free the medusx have 4 short tentacles with swollen basal bulbs, and the manubrium does not project beyond the velar opening. The entoderm of the hydroid and medusa is sulphuryellow. The periderm of the hydroid is smooth and has none of the foreign bodies attached to it such as are seen in Perigonimus. According to Steche the colony feeds upon the eggs which are set free by the Hyalca on which it grows.

\section{Margelopsis haeckelii Hartlaub.}

Margelopsis hackelii, Hartlatb, 1897 , Wissen. Meeresuntersuch. Kommis., Meere Kiel, Helgoland, Neue Folge, Bd. 2, p. $4^{\$ 2}$, taf. I 6b, fign. 12-18; I 899, Nachricht. kgl. Gesell. Wissen. math.-phys. Klasse, Göttingen, Jahre I899, p. 219 , 3 fign.; 1907, Nordisches Plankton, Nr. 12, pp. 89, 91, fign. $84-86$ (best published description of hydroid and medusa).-Miulterer, 1908, Zeit. für wissen. Zool., Bd. 89 , pp. 43, 73, taf. 5, fign. 18, 19. 

Plate 8.

Fig. I. Zancleopsis dichotoma. Tortugas, Florida, May 28, I899. Figs. 2 and 3. Gemmaria costata (?), hydroid and medusa. Tortugas, Florida, June, I899. This is probably the hydroid of Zanclea costata.

Figs. 4 and 5. Zanclea gemmosa, young medusa. Figure 5 shows details of nematocyst-capsules of the tentacles. Agassiz Laboratory, Newport, Rhode Island, June 19, I893.

Fig. 6. Zanclea costata. Tortugas, Florida, May 15, Igo6.

Fig. 7. Zanclea costata. Details of nematocyst-knobs of tentacles.

Figs. 8 and 9. Slabberia catenata. Tortugas, Florida, August, I898. Figure 9 shows end of one of the tentacles of the medusa shown in figure 8 .

Drawn from life, by the author. 


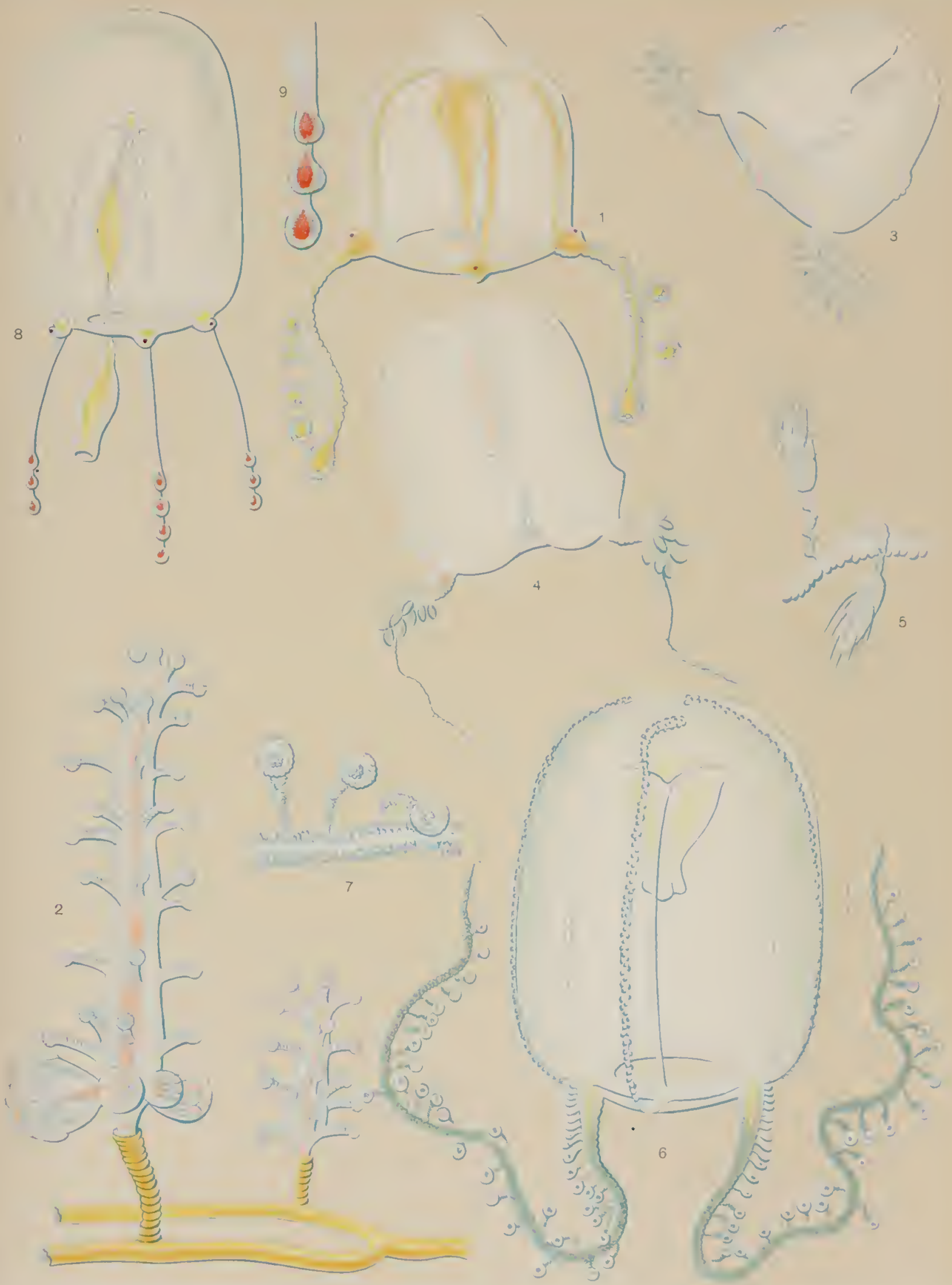



Medusa.-Bell pyriform with a flat apex 1.3 times as high as wide. $2 \mathrm{~mm}$. high. Gelatinous walls quite thick. 3 or 4 tentacles upon each of the + marginal tentacle-bulbs. These tentacles are ringed with nematocysts. No ocelli. + narrow, straight radial-canals and a wide axial-canal above the stomach. Manubrium wide, spindle-shaped, two-thirds as long as the depth of the bell-cavity. The upper third of the manubrium has no gonad, but the lower part is incased in a tubular genital organ which bears planulx. Tentacle-bulbs brown. Manubrium with dark-brown pigment granules. Found at Helgoland, German Ocean, in July and early in August.

Hydroid.- The planula which develop upon the manubrium of the medusa grow into actinula larvæ before being set free. The oral pole of the actinula is blunt and is adjacent to the wall of the stomach of the medusa, while the aboral pole projects outward from the stomach-wall into the bell-cavity. This aboral pole is conical and terminates in a suckershaped depression. There is a row of 5 to 7 short, somewhat club-shaped tentacles around the oral pole and two closely-set rows of alternately arranged tentacles near the aboral pole. Both aboral rows have together about 12 tentacles, and these are somewhat longer than the 5 or 7 oral tentacles. The middle part of the body of the actinula is devoid of tentacles.

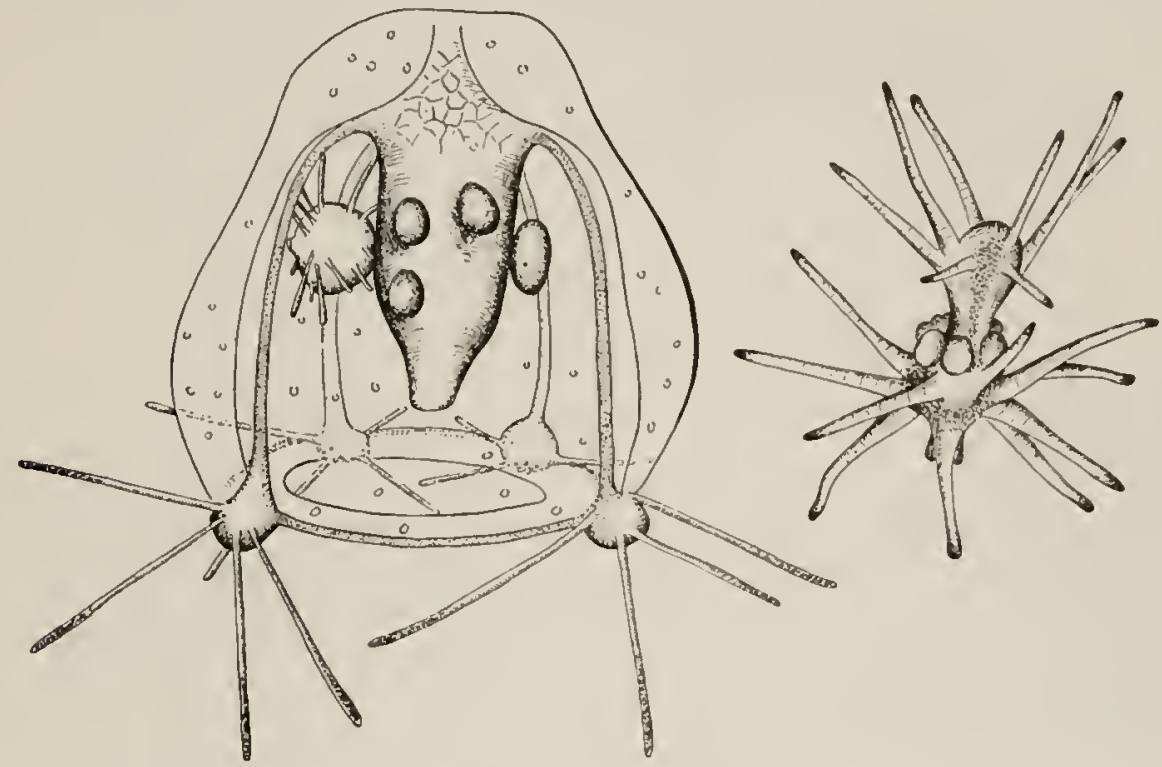

Fig. 38.-Hydroid and medusa of Margelopsis haeckelii, after Hartlaub, in Nordisches Plankton.

Medusa is about to set free an actinula larva.

Medusa-buds develop after the actinula has been set free and has become about $1 \mathrm{~mm}$. long. These medusa-buds develop in clusters from the sides of the body of the actinula close to the bases of the lower row of aboral tentacles with which they alternate in position. The medusa-buds develop 2 or 3 tentacles in each of their 4 marginal clusters while still attached to the actinula. Hartlaub found large numbers of these interesting hydroids floating in the water at Helgoland, late in August.

Müller, Igo8, has studied the origin and structure of the ova in the medusa. In common with $H y b o c o d o n$, the eggs are large, anceboid, and few in number when full grown, for the successful eggs devour the weaker ones in the ovary. 'The ooplasma is composed of wide irregular fibers, forming a somewhat narrow-meshed network. The exoplasma is distinct from the endoplasma and is wider in its meshes.

\section{Margelopsis stylostoma Hartlaub.}

Margelopsis stylostoma, Hartlate, 1903, Zoolog. Centralblatt, Bu. io, p. 28, fig. 2, fig. 4 (?); 1904, Wissen. Meeresuntersuch. Kommis. Deutsch. Meere, Abth. Helgoland, Neue Folge, BA. 5, P. 99, fig. 1, fig. 2 (?); 1907, Nordisches Plankion, Nr. 12, p. 91, fig. 87 ( 88 ?).

This is a small spindle-shaped, free-floating hydranth, with a sucker-like expansion at its aboral pole, and with three verticils of tentacles, i. e., 4 short-knobbed oral tentacles, a 
middle zone of about 10 to 12 long-knobbed tentacles, and a basal (aboral) zone of about io to 12 long-knobbed tentacles. Medusa-buds (?) This form closely resembles Tiarella singularis F. E. Schulze, 1876 , a small, isolated, attached hydroid found at Trieste. T'. singularis produces medusa at the base of the polypite below the third zone of tentacles.

Margelopsis stylostoma was found at Roscoff, northwest coast of France, in June.
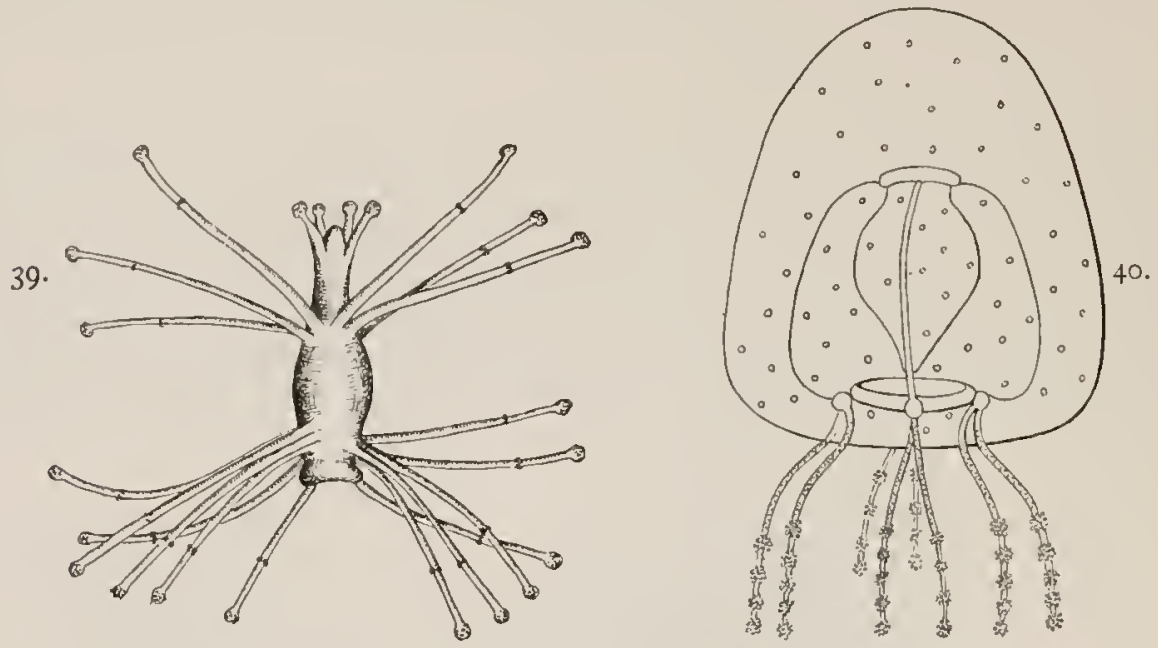

Fig. 39.- Hydroid of Margelopsis stylostoma, after Hartlaub, in Nordisches Plankton. Fig. 40.-Margelopsis harilaubii, after Browne, in Bergens Museums Aarbog, i 903.

\section{Margelopsis hartlaubii Browne.}

Margelopsis harllaubii, Browne, 1903, Bergens Museums Aarbog, No. 4, p. 10, plate 1, fig. 2, plate 3, fig. 3.-Hartlaub, 1907 , Nordisches Plankton, Nr. 12, p. 92, fig. 89 .

Bell $2 \mathrm{~mm}$. wide, $2 \mathrm{~mm}$. high. Egg-shaped, with thick walls. 8 marginal tentacles, 2 upon each radially placed marginal bulb. These tentacles are ringed with nematocysts, and are somewhat shorter than the bell-diameter. No ocelli. 4 narrow radial-canals. Stomach large, conical, with a broad, flat, quadrangular base, without an axial, apical canal. Mouth a simple, round opening. Gonad encircling the stomach. Color (in formalin): Gonads, stomach, and tentacle-bulbs yellowish-brown. Three specimens; coast of Norway, Osterfjord and Herlfjord, from depths of o to 200 fathoms.

\section{Margelopsis gibbesi Hartlaub.}

Plate 9, figs. 4-7.

Nemopsis gibbesii, MCCRAdy, 1857, Gymn. Charleston Harbor, p. 163, plate 10, figs. 4-7.-Frec11, 1898, Lethaca palcozoica,

Theil I, Bd. I, Lfg. 3, p. 565, Stuttgart (compared with the Graptolites as a floating Tubularian).

Margelopsis gibbesi, Hartlaub, 1903, Zoolog. Centralbl., Bd. 10, p. 28; 1899, Nachricbt. kgl. Gesell. Wissen. math.-phys.

Klasse, Göttingen, Jahre 1899, p. 223 , fig. 4 .

Bell somewhat higher than a hemisphere, $2.5 \mathrm{~mm}$. high, and walls quite thin and uniform. There are 4 radially situated clusters of marginal tentacles. Each cluster contains 5 or 6 tentacles which arise from a large common basal bulb. Tentacles taper regularly from base to tip, but the tip terminates in a knob of nematocysts. There are about i 5 rings of nematocysts upon the shaft of each tentacle and the entodermal axis of the tentacle is composed of chordate cells resembling those of Obelia. There are 4 straight, narrow radial-canals. Velum well developed. Manubrium wide and flask-shaped, and mouth a simple, round opening without prominent lips, and without oral tentacles. In the female the ova project prominently from the surface of the manubrium. The gonad surrounds the stomach on all sides. The bell of this medusa is highly contractile, often drawing together so as to cause the mouth to project beyond the velar opening. When the bell is relaxed, however, the manuhrium extends but little more than half-way from the inner apex of the bell-cavity to the velar opening. 


$$
\text { Plate 9. }
$$

Fig. I. Cladonema perkinsii. Nassau Harbor, Bahamas.

Fig. 2. Cladonema mayeri. Moat of Fort Jefferson, Tortugas, Florida, July, igo5.

Fig. 3. View looking down upon the aboral end of the stomach of Cladonema mayeri, showing the arrangement of the radial-canals.

Fig. 4. Margelopsis gibbesii, male. Beaufort, South Carolina, December 24. 1904.

Fig. 5. Margelopsis gibbesii, male. Oregon Inlet, Pamlico Sound, North Carolina, November I2, 1904.

Fig. 6. Margelopsis gibbesii, female. Cape Fear, North Carolina, December I, 1904.

Fig. 7. Tentacle of Margelopsis gibbesii.

Figs. 8 and 9. Stomotoca dinema, young females. Agassiz Laboratory, Newport, Rhode Island, July, I 892.

Fig. Io. Stomotoca dinema, young male. Agassiz Laboratory, Newport, Rhode Island, Septemper 15, 1896.

Fig. I, copied from a drawing by Prof. Henry F. Perkins.

Figs. 2 to Io, from life, by the author. 


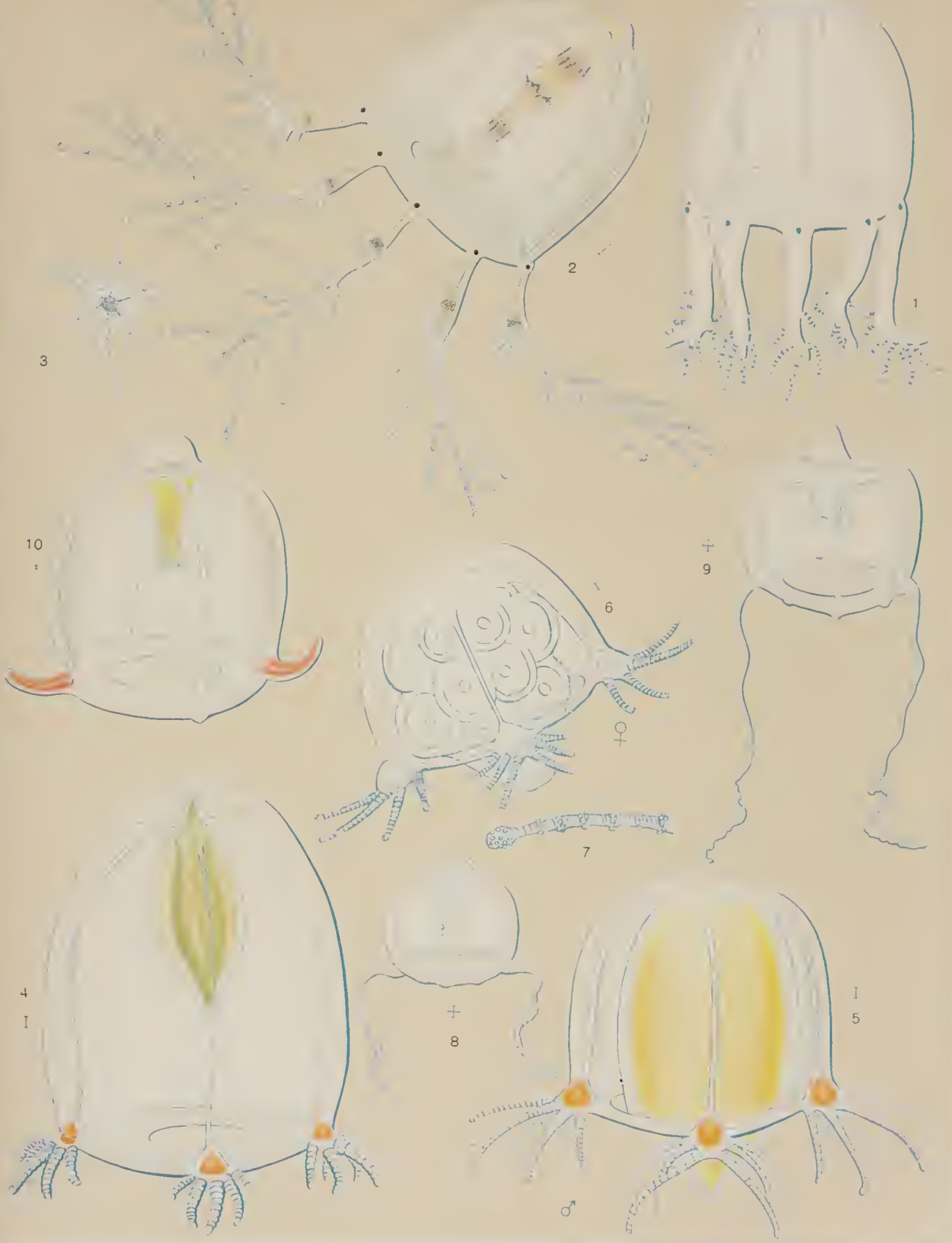



The entoderm of the four large tentacle-bulbs is dull-yellow. There are no ocelli. The entoderm of the manubrium was dull-yellow in two meduse, and dull-green in another. The difference is not a sexual one, however, for one of the males was yellow while the other was dull-green. The rwo yellow-colored medusa were found, one in Oregon Inler, Pamlico Sound, North Carolina; and the other at Southport, Cape Fear, North Carolina, in November. The green-colored male (plate 9, fig. 4) was found in Beaufort River, at Beaufort, South Carolina, on December 24, 1903 , 12 miles from the ocean, in brackish water.

McCrady, 1857 , presents a good figure of that which is probably the free-floating hydroid of this species. The hydroid is pear-shaped with a hollow cup-like projection from its broad aboral end. There are 2 whorls of tentacles, a circlet of about 8 tentacles around the broadest zone near the aboral end and a circlet of about 6 tentacles near the mouth. A number of medusa-buds develop from the sides of the hydranth in the middle region between the 2 circlets of tentacles. When set free the medusx have 4 short tentacles in each radial cluster. A single specimen was found by McCrady in Charleston Harbor. The cup-shaped projection from the aboral end of the hydranth is a feature which recalls the pneumatophore of the Siphonophoræ.

Genus PELAGOHYDRA Dendy.

Pelagahydra, DENDY, 1903, Quart. Journ. Microscop. Sci., vol.46, p. 1.-HartlaU B, 1903, Zool. Centralblatt, p. 27.

The type species is Pelagohydra mirabilis, Dendy, from New Zealand.

\section{GENERIC CHARACTERS.}

Medusa similar to Margelopsis. Hydroid pelagic and closely resembles that of Margelopsis, but tentacles arise irregularly from the sides of the hydranth, and are not arranged in definite circlets as in Margelopsis.

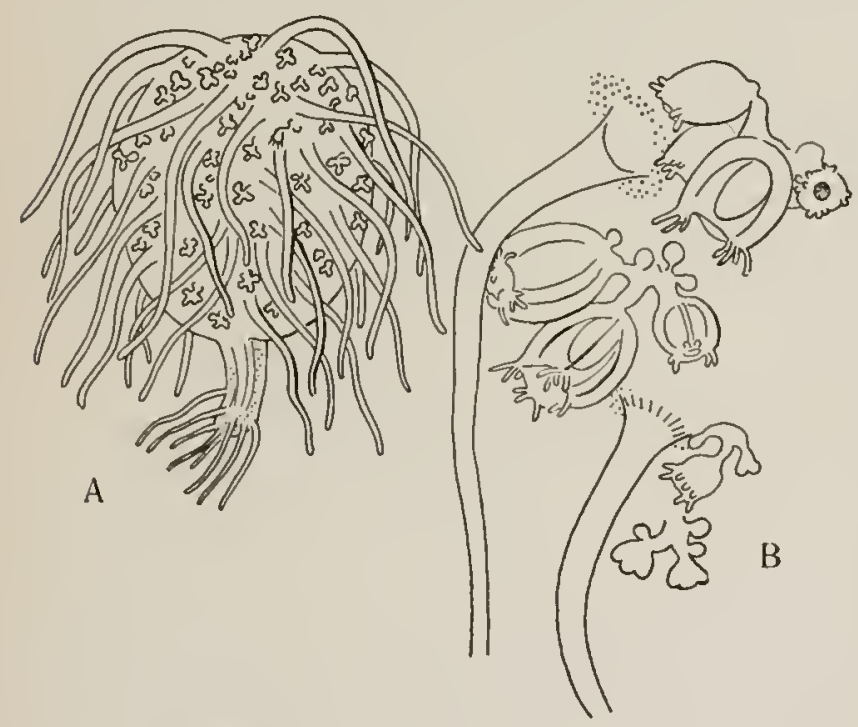

Fig. foa.-Pelagohydro mirabilis, after Denily, in Quarterly Journal Microscop. Science.

$a$, entire hydroid, twice natural size.

$b$, enlarged view, showing medusa-buds developing among tentacles.

Pelagohydra mirabilis Dendy.

Pelagohydra mirabilis, DEXDY, 1903, Quart. Journ. Microscop. Science, vol. 4 fi, p. 1, plate 12.-Hartlalib, 1903 , Zool. Centralbl., p. 27, fig. 3 .

Hydroid pelagic, with a translucent globular body $25 \mathrm{~mm}$. wide, constituring a float and a proboscis at the end of which the mouth is situated. The float bears many long, irregularly arranged tentacles. The proboscis is elongate, pink in color, and of the shape of a truncated cone. It has several irregular whorls of oral tentacles, the shortest being nearest the mouth. Medusx are borne upon branching stolons which arise from the sides of the float between the tentacles. When about to be set free the medusa is about $\mathrm{I} \mathrm{mm}$. wide, with + radial groups of marginal tentacles, each group arising

from a large, pink, basal bulb, and consisting of 5 tentacles, 2 large,.2 small, and I smallest median tentacle. + radial-canals. Manubrium pyriform and without oral tentacles. New Zealand.

\section{Family CLADONEMIDE.}

Cladonemide, Gegrngaur, 1856, Zeit. für wissen. Zool., Bd. 8, p. 220.-Haeckel. 1879, Syst. der Medusen, P. 98.-HartLuvb, 1887 , Zool. Anzeiger, Bd. 10, p. 651; 1907, Nordisches Plankton, Nr. 12, Pp.5, 110.-GixtwF, 1903, Mittheil Zool. Sta. Neapel, Bd. 16, pp. 56, 57 . 
This family is of such interest that we devote more than the usual space to its consideration. Haeckel, 1879 , classifies it as a family coordinate with the Codonidre, but Hartlaub, 1887 , showed that the genus Cladonema had an encircling gonad as in the Codonidx. The medusæ are, however, highly specialized, both in respect to their anatomy and their mode of life, and they are undoubtedly derived from some more simply-organized medusa among the Codonidx. The hydroid of Cladonema is a Stauridia, and is closely related to Syncoryne, the hydroid of Sarsia.

\section{CHARACTERS OF THE FAMILY CLADONEMIDA.}

Anthomedusa with feathered or branched marginal tentacles, and with four or more simple or branched radial-canals. The gonads may be ring-like and encircle the stomach, or they may be more or less separated so as to be interradial or adradial, or developed in a specialized brood-pouch above the stomach.

Hartlaub, 1887, and Perkins, 1902, show that in the genus Cladonema the genital products are developed over the entire gastric portion of the manubrium and the gonads are not confined to restricted meridians, as was believed to be the case by Haeckel. Hartlaub found that in Cladonema radiatum of the Mediterranean the genital products begin to develop in the entoderm. This species exhibits a successive hermaphroditism, although either sperm or ova may precede. Perkins, however, in his study of Cladonema perkinsii of the Bahamas, found that the genital products were developed in the ectoderm of the manubrium, and he failed to find sperm or ova in the entoderm.

In Eleutheria, Hartlaub, I886, I887 (Zool. Anzeiger), showed that the genital products are developed exclusively in the ectodermal lining of a peculiar brood-pouch above the stomach, and that the medusa is hermaphroditic. The brood-pouch is derived from the ectodermal layer of the bell-cavity and is not connected with the stomach of the medusa, but communicates with the bell-cavity by means of 6 interradial-canals.

Hartlaub, 1887 , divides the Cladonemidx into two groups, one with and the other without an apical brood-sac above the stomach. As this brood-sac is highly variable in its development, some specimens of Eleutheria apparently failing to develop it and, moreover, as it is a character which develops during the growth of the medusa and is not found in the young animal, it would seem that Haeckel's classification of the Cladonemidxe, based as it is upon the possession of constant characters, is to be preferred. Moreover, as has been shown by Günther, 1903, we can not yet state that the brood-pouch of other genera of Cladonemidxe is similar in structure to that of Eleutheria.

As is well known, Haeckel, I879 (Sitzungsber. Medicin. Naturwiss. Ges. Jena; see also Chun, 1880, Ctenophoren des Golfes von Neapel), drew an ingenious comparison between Ctenaria and the Ctenophoræ, and concluded that the Ctenophorx might have been derived from some form of Anthomedusa. Ctenaria appears to resemble the Ctenophoræ in its 2 feathered tentacles, 4 bifurcated radial-canals, and in a peculiar sheath at the base of each tentacle. However, Hartlaub's discovery that the brood-pouch in the closely-related Eleutheria is of ectodermal and not entodermal origin makes it appear that the resemblances between Ctenaria and the Ctenophoræ are of the nature of a mere parallelism and not indicative of a genetic relationship. Haeckel conpared the 8 adradial longitudinal lines of nematocysts upon the exumbrella of Ctenaria with the 8 rows of ciliated combs in the Ctenophoræ. An even more remarkable case of convergence is shown by Kofoid, I905 (Bull. Mus. Comp. Zool. at Harvard College, vol. 46, p. $16_{3}$, I plate), in the case of the Cystoflagellate, Craspedotella, which is bell-shaped and provided with a well-developed velum, the walls of which are contractile so that the mode of locomotion is similar to that of a medusa. There is thus an external similarity of form between this protozoan and a medusa offering an instance of convergence of a most striking character. Another remarkable instance of convergence is that of the pelagic holothurian Pelagothuria natatrix, which bears a close resemblance to a medusa (see Mem. Mus. Comp. Zool. at Harvard College, vol. 17, 1894). I believe also that the bell of the Narcomeduse is not homologous with that of the Anthomedusx and Leptomedusx, but is a mere outgrowth from the walls of the actinula larva. 
The Cladonemida are close relatives of the Codonida, this being illustrated most clearly by their hydroids, and they may properly be regarded as highly-specialized Codonida, as has been maintained by Hartlaub. For purposes of classification, however, I think it will be well to permit them to remain in a family of Anthomedusx coordinate with the Codonidx, for there is no single character which they have consistently in common with the Codonidx. For example, the gonad in Cladonema may be readily likened to that of the Codonidx, for it encircles the stomach on all sides, but in some species of Zanclea the gonads show a decided tendency to segregate interradially, and in Eleutheria they are developed in an ectodermal brood-sac which is not connected with the manubrium.

The most constant character of the Cladonemidx is their forked, or feathered, marginal tentacles.

The greatest difficulty in any attempt to classify the Cladonemidx among themselves arises from our lack of understanding of the nature of the brood-sac or apical cavity in the bell of the genera Pteronema, Ctenaria, and Dendronema; and no classification worthy of serious consideration can be effected until we know whether this sac is a mere extension of the stomach or an ectodemal reproductive cavity similar to that studied by Hartlaub in Elentheria.

Family: Cladonenide. Subfamily Pteronemina:

Manubrium without oral tentacles. With 4 to 8 simple radial-canals.

Zanclea Gegenisaur, 1856 . With 2 to 4 marginal tentacles at bases of 4 radial-canals. The tentacles give rise to an abaxial row of simple branches, each terminating in a cluster of nematocysts. With neridional rows of nematocysts upon the exumbrella. No ocelli. No brood-pouch above the stomach. 'The hydroid is Gemmaria McCrady, Allman.

Zancleopsis HartuatB, 1907. Similar to Zanclea, but with tentacular ocelli and without meridional row's of nematocysts.

Pteronema Ha ecket, 1879. With 4 well-developed tentacles similar in structure to those of Zanclea. With 4 simple radial-canals. With a brood-sac above the stomach. Hydroid unknown.

Eleutheria Quatrefages, 1842 . With 4 to 6 simple radial-canals, and an equal number of bifurcated tentacles. With a brood-pouch above the stomach. This brood-pouch is not connected with stomach-cavity, but communicates with bell-cavity by means of simple interradial pores. Genital products develop exclusively in brood-pouch. Medusa is hermaphroditic. Hydroid is Clavatella Hincks.

Mnestra Krons, 1853 (Archiv. für Naturges., Jahrg. 19, Bd. 1, p. 278). Medusa degenerate, sessile upon Phyllirlioë in the Mediterranean. With $\&$ to o small marginal tentacles having nettling capsules along their abarial sides. A ring of nematocysts extends around the bell-margin, and 4 linear tracts of nettle-cells extend upurard over the exumbrella, I from each tentacle-bulb. With 4 simple, unbranched radial-canals and ring-canal. No brood-pouch above stomach. Throat of medusa blocked by a spongy mass of entoderm. Medusa attaches itself by its mouth to throat of Phyllirhö, and the larva of the Mnestra probably develop within the gastric cavity of the Pliyllirhoz. It is elaborately described by Günther, 1903 (Mitt. Zool. Sta. Neapel, Bd 16, PP. 35-62, plates 2, 3).

Fanily: Cladonemide. Subfamily Dendronemina:

Ctenaria HAECKEL, 1879 . With 2 marginal tentacles, each of which gives rise to a row of nematocyst-bearing filaments. W'ith 4 bifurcated radial-canals. With simple, unbranched, oral tentacles. With an apical sac above the stomach. Hydroid unknown.

Cladonema Dujardis, 1843 . With 4 to 5 bifurcated radial-canals, or 8 to 10 simple radial-canals, or with both simple and bifurcated radial-canals. W'ith a tentacle at foot of each radial-canal. These tentacles branch dichotomously or complexly, and branches end in suckers or nematocyst-knobs. With simple, unbranched, oral tentacles. No brood-sac above stomach. Hydroid, Stauridia Dujardin.

Dendronema HAECKEL, $\$ \$ 79$. With bifurcated radial-canals, and dichotomously branched tentacles. Branches end in suckers, or in nematocyst-knobs. Mouth surrounded by + groups of dichotomously branched oral tentacles. 'l'here is an apical sac above the stomach.

\section{Genus ZANCLEA Gegenbaur, 1856 .}

Zanclea, Gegrnbatr, 1856, Zeit. für rissen. Zool., Bu. 8, p. 229.-Kryerstein und Ehlers, 1861, Zool. Beitr. in Neapel und Messina, p. 85.-Agassiz, L., I 862 , Cont. Nat. Hist. U. S., vol. 4, P. 344 .

7ancleat Gemmaria, Harcki.1., 1879 , Syst. der Medusen, pp. 102, 103.

Zanclea, Fewkrs, 1881, Bull. Mus. Comp. Zool., vol. 8, p. 150.-Haktlate, 1887, Zool. Anzciger, 13d. 10, p.654; 1907, Nordisches Plankton, Nr. 12, p. 112.-VANuörrks, 1891, Zool. Anzeiger, Jahrg. 14, p. 445.-Güxt1 Fr, 1903 , Mitt. Zool. Sta. Neapel, Bd. 16, p. 57 .

Gemmaria $=$ Zanclea, Brow:ve, 1905 , Proc. Roy. Soc. Edinburgh, vol. 25, p. 750.

Gemmaria, MCСrady, 1857, Gymn. Charleston Harbor, p.49.-AGassiz, A., 1865 , North Amer. Acal., p. $184 .-A l l a A, 1872$,

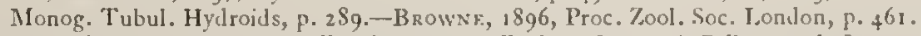

Non Gemmaria, Fetvers, 1881 , Bull. Mus. Comp. Zool. at Harvard College, vol. 8, p. 150. •

Gemmaria, Hartlatis, 1887 , Zool. Anzeiger, Bd.10, p. 654.-Ginther, 1903, Mitt. Zool. Sta. Neapel, Bd. 16, P. 57.

Gemmaria (hydroid), Hartlaen, 1905 , Zoologischen Jahrbüch., Supplement 6, p. 527.

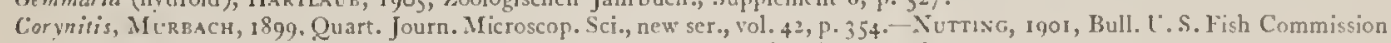

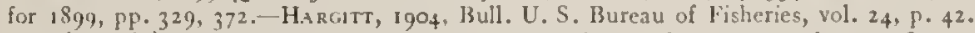

Halocharis (hydroid), Agassiz, L., 1862, Cont. Nat. Hist. U.S., vol. 4, [1.239, plate 20, figs. 10-10c.

Gemmariat Zandea, Hargit, 1908, Biol. Bulletin, vol. I4, P. 104 .

The type species of this genus is Zanclea costata Gegenbaur, I856, of the Mediterranean. 
Tabular Description of the Medusa of Zandea.

\begin{tabular}{|c|c|c|c|c|}
\hline & $\begin{array}{l}\text { Z. costata Gegenbaur, } \\
185^{6} \text {. }\end{array}$ & $\begin{array}{l}\text { Z. gemmosa McCrady, } \\
1857 \text {. }\end{array}$ & Z. implexa Allman, 1864. & $\begin{array}{l}\text { Z. cladophora = Gem- } \\
\text { maria cladophora A. } \\
\text { Agassi2, } 1865 \text {. }\end{array}$ \\
\hline $\begin{array}{l}\text { Shape and size of bell } \\
\text { in } \mathrm{mm} \text {. }\end{array}$ & $\begin{array}{l}\text { Ellipsoidal. } 4 \text { to } 5 \text { high, } \\
3 \text { to } 4 \text { wide. }\end{array}$ & $\begin{array}{l}\text { Pyriform. } 6 \text { high, } 4 \\
\text { wide. }\end{array}$ & $\begin{array}{l}\text { Dome-like to globular. } \\
1.5 \text { high, } 1.75 \text { wide. }\end{array}$ & Pyriform. Size (?) \\
\hline $\begin{array}{l}\text { Length of the }+ \text { merid- } \\
\text { jonal rows of nettle- } \\
\text { cells above tentacle- } \\
\text { bulbs, in terms of } \\
\text { bell-height. }\end{array}$ & $\begin{array}{l}\text { From tentacle-bulbs to } \\
\text { very near apex of bell. }\end{array}$ & $\begin{array}{l}\text { One-fourth to one-third } \\
\text { distance from margin } \\
\text { to apex. }\end{array}$ & 0.25 to 0.5 & 0.5 \\
\hline $\begin{array}{l}\text { Number and length of } \\
\text { tentacles in terms of } \\
\text { bell-radius }(r) \text {. }\end{array}$ & $\begin{array}{l}4 \text { tentacles, each } 3 \text { to } \& r \\
\text { long. }\end{array}$ & $\begin{array}{l}4 \text { tentacles, each } 3 \text { to } 4 r \\
\text { long. }\end{array}$ & $\begin{array}{l}2 \text { to } 4 \text { tentacles, each } \\
\text { about } 4 r \text { long. }\end{array}$ & $\begin{array}{l}2 \text { long and } 2 \text { short ten- } \\
\text { tacles; long tentacles } \\
4 r, \text { short over one-third } \\
r \text { long. }\end{array}$ \\
\hline $\begin{array}{l}\text { Character of abaxial } \\
\text { flaments upon ten- } \\
\text { tacles. }\end{array}$ & $\begin{array}{l}\text { Very numerous, slender, } \\
\text { and ending in a spheri- } \\
\text { cal capsule containing } \\
3 \text { to } 5 \text { nematocysts. }\end{array}$ & $\begin{array}{l}\text { Very numerous, slender, } \\
\text { and ending in a spheri- } \\
\text { cal capsule containing } \\
3 \text { to } 9 \text { nematocysts. }\end{array}$ & $\begin{array}{l}\text { Very numerous, slender } \\
\text { filaments, each ending } \\
\text { in an oval capsule } \\
\text { containing } 4 \text { to } 8 \\
\text { nematocysts. }\end{array}$ & $\begin{array}{l}\text { Very numerous, slender } \\
\text { filaments, ending in } \\
\text { knob-like clusters of } \\
\text { nematocysts. Num- } \\
\text { ber of nematocysts in } \\
\text { each knob? }\end{array}$ \\
\hline $\begin{array}{l}\text { Length and shape of } \\
\text { manubrium. }\end{array}$ & $\begin{array}{l}\text { Not quite half as long as } \\
\text { depth of bell-cavity. } \\
\text { Flask-shaped. }\end{array}$ & $\begin{array}{l}\text { Flask-shaped, } 4 \text {-sided. } \\
\text { As long as depth of } \\
\text { bell-cavity. Mouth } \\
\text { with } 4 \text { small lips. }\end{array}$ & $\begin{array}{l}\text { Urn-shaped. Only half } \\
\text { as long as depth of } \\
\text { bell-cavity. Mounted } \\
\text { upon short peduncle. } \\
\text { Mouth round opening. }\end{array}$ & $\begin{array}{l}\text { Conical. } 4 \text { prominent } \\
\text { lips. }\end{array}$ \\
\hline Gonads. & $\begin{array}{l}4 \text { interradial masses of } \\
\text { eggs on swollen sides of } \\
\text { stomach. }\end{array}$ & $\begin{array}{l}\text { On } 4 \text { interradial sides of } \\
\text { stomach. Much } \\
\text { swollen. }\end{array}$ & $\begin{array}{l}\text { On upper sides of } \\
\text { stomach, more or less } \\
\text { separated in } 4 \text { chief } \\
\text { radii. }\end{array}$ & $\begin{array}{l}\text { Gonad encircles stom- } \\
\text { ach. }\end{array}$ \\
\hline Color. & $\begin{array}{l}\text { Gonads red, tentacles } \\
\text { yellowish-brown. }\end{array}$ & $\begin{array}{l}\text { Entoderm of stomach } \\
\text { and tentacle-bulbs } \\
\text { creamy-pink. Ento- } \\
\text { derm of manubrium } \\
\text { delicate green. }\end{array}$ & $\begin{array}{l}\text { Stomach and tentacle- } \\
\text { bulbs brownish-red to } \\
\text { crimson. Entoderm } \\
\text { of tentacles orange. }\end{array}$ & $\begin{array}{l}\text { Tentacles light-brown. } \\
\text { Orange and yellow } \\
\text { spots in tentacle- } \\
\text { bulbs. Color of stom- } \\
\text { ach (?) }\end{array}$ \\
\hline Where found. & $\begin{array}{l}\text { Mediterranean. Common. } \\
\text { Medusa having only } 2 \\
\text { tentacles, but in other } \\
\text { respects similar to } Z \text {. } \\
\text { costata found at Tor- } \\
\text { tugas, Florida. }\end{array}$ & $\begin{array}{l}\text { West Indies northward } \\
\text { to Woods Hole. }\end{array}$ & $\begin{array}{l}\text { Atlantic coasts of west- } \\
\text { ern Europe to Medi- } \\
\text { terranean. }\end{array}$ & $\begin{array}{l}\text { Coast of Massachusetts, } \\
\text { Nahant, Woods Hole. }\end{array}$ \\
\hline Hydroid. & Hydroid (?) (see text). & $\begin{array}{l}\text { Hydroid: Gemmaria } \\
\text { gemmosa. }\end{array}$ & $\begin{array}{l}\text { Hydroid: Gemmaria } \\
\text { implexa. }\end{array}$ & Hydroid unknown. \\
\hline
\end{tabular}

GENERIC CHARACTERS.

Cladonemidx with 4 simple radial-canals, and 2 to 4 radially situated tentacles which give rise to filiform, knobhed, nematocyst-bearing side branches. The gonad is developed upon the sides of the stomach. There is no apical brood-pouch above the stomach. There are meridional lines of nettle-cells over the exumbrella. There are no tentacular ocelli. The hydroid is Gemmaria Allman, 1871 .

In 1857 , McCrady founded the genus Gemmaria for a Zanclea-like medusa with only 2 tentacles. Vanhöffen, I89I, and Browne, 1905, have observed that the 2-tentacled young of other species of these medusx often becomes 4-tent acled when adult, and according to Browne, 1905, "Gemmaria" implexa may become mature with 2 or with 4 tentacles. It is evident, therefore, that there are no definite generic distinctions between Zanclea and Gemmaria, the "Gemmaria" condition being only a developmental or retarded phase of Zanclea.

Murbach and Nutting have erroneously applied the name "Corynitis" to a 2-tentacled medusa of Zanclea. Apparently these authors had not seen the medusa of Corynitis, which is 
well figured by McCrady. I have frequently taken Corynitis in Charleston Harbor, South Carolina, where McCrady discovered it, and it is wholly different from any "Gemmaria" or Zanclea. (See also Hargitt, igo8.)

The common Zanclea of the southern coast of New England, in America, may become mature with only 2 tentacles, and with poorly developed lips. On the other hand, a very similar medusa is occasionally found in the same waters with + tentacles and with + welldeveloped lips. I am inclined to believe that these conditions represent developmental stages. or starved and well-fed states of one and the same medusa.

\section{Zanclea costata Gegenbaur.}

$$
\text { Plate } 8 \text {, figs. } 2,3,6 \text {, and } 7 \text {. }
$$

Zanclea costata, Gegenbaur, 1856, Zeit. für wissen. Zool., Bd. 8, p. 229, taf.8, figs. 4-7.-Harckel, 1879, Syst. der Medusen p. 103 .

Hydroid (?), Mayer, 1900, Bull. Mus. Comp. Zool. at Harvard College, vol. 37, p. 35, plate 41, figs. $137,{ }_{3} 8$.

Gegenbaur found many specimens of this medusa in the Mediterranean. His fully' developed medusx had 4 long, equally developed tentacles. For details see tabular description of the meduse of Zanclea.

I have found a medusa at Tortugas, Florida, which accords well with Zanclea costata, excepting that it has but 2 tentacles.

Medusa from Tortugas, Florida.-Bell $6 \mathrm{~mm}$. high and ellipsoidal, with bluntly-rounded apex. Without an apical projection. Bell-walls of uniform thickness everywhere. There are

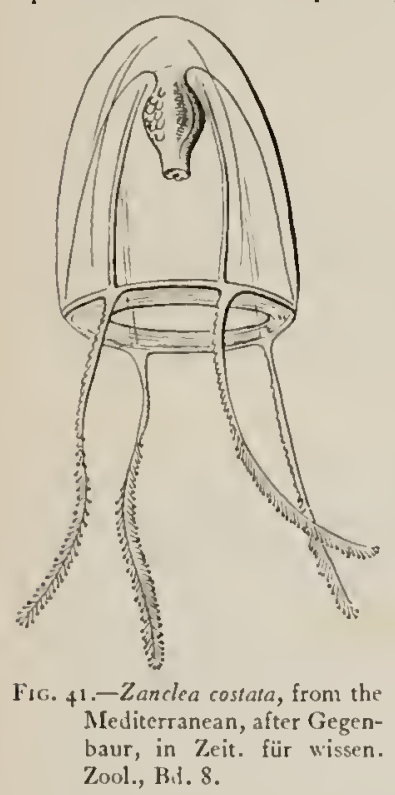
2 long, spindle-shaped, rough-looking tentacles somewhat longer than the bell-height. These are thickly covered with papilla and beset on their outer sides with a row of filaments, each of which ends in a spherical knob, the surface of which is covered with blunt papillæ. Each of these knobs contains a cluster of nematocysts (plate 8). Basal bulbs of tentacles are elongate, spindleshaped, and hollow. No traces of tentacle-bulbs $90^{\circ}$ away from the 2 long tentacles. 4 swollen lines of nematocysts extend upward over the exumbrella from the bases of the + radial-canals and nearly meet near the apex of the bell. Velum well developed. + radial-canals, and the circular vessel straight and narrow. Manubrium flask-shaped, with 4 simple lips. Entoderm of the manubrium and tentacles milky white, There were 4 interradial gonads. A single specimen was found in a surface-tow at Tortugas, Florida, on May 15, 1906.

This species is distinguished by its ellipsoidal, high, rounded bell, without a sharp-pointed apex, the 4 very long meridional lines of nematocysts over the exumbrella, and the spherical nematocystcapsules at the ends of the tentacular filaments.

The Tortugas medusa differs from Zanclea costata, as descrihed by Gegenbaur, in having but 2 tentacles. It is well known, however, that in Zanclea some individuals of the same species develop + while others become mature with but 2 tentacles.

Gegenbaur states that the female gonads are red (pink ?). In the Tortugas specimen the male gonads were milky-yellowish white.

Hydroid (plate 8, fig. 2). - That which is probably the hydroid stock of this species was found by Mayer, I9oo, at Tortugas, Florida, and erroneously ascribed to Zanclea gemmosa; but Murbach, 1899 (Quart. Journ. Micros. Sci., New Series, rol. 42, p. 354), describes and figures the hydroid of Zanclea gemmosa, and it is now evident that the form described by Mayer is specifically distinct from Z. gemmosa and is probably Zanclea costata, the medusa of which occurs at Tortugas.

Hydroid of Zanclea costata (?).- The hydrorhiza is creeping, tubular, and net-like, and gives rise at irregular intervals to short, more or less twisted lydrocauli. Borl the hydrorhiza and hydrocauli are covered with a horny, chitinous perisarc, which is annulated in the hydro- 
caulus. The hydrocaulus is corrugated and opaque in color throughout its length, and in this respect differs from the European $G$. implexa Allman, 187I. The fully developed hydranths are only $1.5 \mathrm{~mm}$. in height. They are elongate, spindle-shaped, and taper gradually from near the base to the summit, so that the diameter near the mouth is less than that near the base. The tentacles arise in 5 to 8 well-defined whorls from sides of hydranth, each whorl consisting of 4 to 6 tentacles. These tentacles are short and taper from base to end, terminating in a large knob containing nematocysts. The entodermal cores of the tentacles are composed of vacuolated cells. The tentacles are stiff and project rigidly outward from the sides of the hydranth. 4 to 8 medusa-buds in various stages of development arise from the sides of the hydranth near the base immediately below the lowest whorl of tentacles.

When set free the young medusa (plate 8, fig. 3 ) has 2 well-developed, radially situated, diametrically opposed tentacles, and 2 rudimentary tentacle-bulbs. There are 4 radially situated, nematocyst-bearing ridges upon the exumbreila, and these extend about half-way up the sides of the bell. The bell-walls are very thin and flexible. There are 4 straight, narrow radial-canals, and the manubrium is a short, simple tube with no trace of the gonad. The mouth is a simple, round opening. Before being set free the tentacles are coiled inward so as to lie within the bell-cavity. Soon after the medusa has become liberated, however, the tentacles uncoil and project outward. The deep-lying entoderm of the hydranths is a delicate creamy-pink, while the more superficial entoderm is translucent and milky in color. The cells of the superficial entoderm are large and vacuolated. The hydrorhiza and hydrocaulus is protected by a horny, yellow, amber-colored, chitinous sheath, but this does not extend over the hydranths. The hydroid was found at Tortugas, Florida, in June, i $\$ 99$, growing upon a piece of floating gulfweed (Sargassum).

\section{Zanclea gemmosa McCrady.}

Plate 6, fig. 7; plate 7, fig. 5; plate 8, figs. 4 and 5 .

Gemmaria gemmosa, MCCrady, i 857 , Gymn. Charleston Harbor, p. 49.

Zanclea gemmosa, MrCravy, 1857, Gymn. Charleston Harbor, p. 49, plate 8, figs. 4, 5.-Agassiz, L., 1862, Cont. Nat. Hist. U. S., vol. 4, P. 344.-Hartlaub, 1907, Nordisches Plankton, Nr. 12, P. 121, fign. 116 , I17.

Gemmaria gemmosa, Agassiz, A., i 865, North Amer. Acal., p. 184, fig. 306.- Haeckel, 1879, Syst. der Medusen, p. 104.Fewkes, i881, Bull. Mus. Comp. Zool. at Harvard College, vol. 8, No.8, p.150, plate 1, figs. 8-12.-Fewkes, 1884, American Naturalist, vol. I 8, p. 196, fig. 2.

Corynitis agassizii (hydroid), Murbach, 1899, Quart. Journ. Micr. Sci., vol. 42, p. 354, plate 34, fig. 12 (medusa, figs. II, $\mathrm{I}_{3}, \mathrm{1}_{4}$.)

Gemmarí sagittaria, HaEckel, 1879, Syst. der Medusen, p. 103, taf. 7 , figs. 3,4 (young medusa).

Zanclea gemmosa (hydroid), Wallace, I9o8, Carnegie Institution Year Book, No.7.

Adult medusa.-Bell $6 \mathrm{~mm}$. in height, and pyriform. There is a well-developed, solid, apical projection. Side walls quite thin. There are 4 long, radially situated tentacles with large, hollow basal bulbs, which lack ocelli. The shafts of the tentacles are crowded with large numbers of short filiform branches, which arise only from the dorsal (exumbrella) side of the tentacles, although the twisting of the tentacle may cause them to appear to arise from all sides. Each of these filiform branches terminates in a large spear-head-shaped body which bears a number of long, delicate, sharp-pointed bristles, and which contains 3 to 9 egg-shaped nematocyst-cells. A club-shaped swelling extends longitudinally from the base of each tentacle a short distance up the side of the exumbrella. These swellings are thickly covered with nematocysts. There are 4 straight, slender radial-canals, and a narrow circular vessel. The velum is wide and delicate. The manubrium is flask-shaped, and cruciform in cross-section and extends to the level of the velar-opening. The mouth is a simple, cruciform opening without prominent lips. The gonad is upon the sides of the stomach. These sides are greatly swollen and give to the manubrium its flask-shaped appearance. The entoderm of the manubrium and tentacles is of a delicate creamy-pink and the ectoderm of the manubrium is of a delicate shade of green.

Young medusa (plate 7, fig. 5; plate 8, figs. 4, 5).-In the medusa, I mm. in height, there are but 2 marginal tentacles. The bell-walls are very thin and the manubrium is a simple fusiform tube. There is no apical projection to the bell, and no trace of gonads upon the manubrium, and the mouth is a simple, round opening without cruciform lips.

This species extends from the West Indies to the southern coast of New England. It is quite common in Newport Harbor late in the summer. 
The hydroid stock has been described by Murbach under the name of "Corynitis agassizii," but is evidently a Gemmaria. The hydranths are $1.5 \mathrm{to} 2 \mathrm{~mm}$. in length and arise singly from a slender, threadlike, anastomosing hydrorhiza. The hydrorhiza is covered with a delicate perisarc, but this does not extend over any part of the hy. dranths. In this respect the species is very different from $Z$. costata. The hydranths are also more cylindrical and uniform in width throughout the polypite than in $Z$. costata. The tentacles are irregularly arranged and the medusa-luds are found not only near the base of the hydranth, but scattered along the sides. In Zanclea costata they are confined to a zone immediately under the lowest circlet of tentacles. The color of both forms is quite similar, excepting that the hydrorhiza is deep pink in the Z. gemmosa and rosinyellow in the Z. costata. W.S. Wallace found this hydroid growing upon floating Sargassum at Tortugas, Florida, in July, igos.

The young medusa here figured was obtained at Newport, Rhode Is- Fig. 2. $^{-}$Zanclea gemmosa, from Fewkes, in Bull. Mus., Comp. Zool. at Harvard College. land, and was identified by Dr. Alexander Agassiz as the young of Zanclea gemmosa.

Z. gemmosa readily devours the medusæ of Obelia.

\section{Zanclea implexa Allman.}

Coryne pelagica+Coryne implexa (hydroid and medusa), Alder, 1857, Catalogue Zoophytes Northumberland, Trans. Tyneside Nat. Firell Club, vol. 3 , pp. I 3 , is (of the "separate"), plate 7, figs. 1-6.

Zanclea implexa, Alzuan, 1864, Annals and Mag. Nat. Hist., vol. 13, p. 357.-Hiscks, 1868, Hist. British Hydroid Zoophytes, P. 59, plate 9, fig. 3.-Harteaub, 1907, Nordisches Plankton, Nr.12, p. 116, fign. 106-111 (list of localities, authors, and best description of the medusa).

Gemmaria implexa, Alevan, $1871-72$, Monog. Tubularian Hydroids, pp. 223, 290, plate 7, figso 1-10.-HafckrL, i S79. Syst. der Medusen, p. 105.-Jickelt, 1883, Morphol. Jahrbuch, Bd. S, p. 611, taf. 26 (histology).-Grakif , i884, Arbett Zool. Inst. Wien, B.1. 5, p. 353.-Brownr, 1896, Proc. Zool. Soc. London, 1. 461.- Harcitrt, 1904, Mith. Zool. Station Neapel, Bu. 16, p. 574, taf.22, figs. 27-29 (hydroid and medusa from the Bay of Naples).-Brow:r, 1905, Proc. Roy. Soc. Edinburgh, rol. 25, p. 750 .

This medusa is closely related to Zanclea gemmosa of the Atlantic coast of the United States, but it is much more swollen than the American form, and differs in other respects.

The bell is globular with fairly thin side walls and a thick, solid, dome-like apex. It is $1.5 \mathrm{~mm}$. high, $1.75 \mathrm{~mm}$. wide. There are 4 prominent nematocyst tracts extending onefourth to half the distance from the tentacle-bulbs up the sides of the bell, and the nettlecells in each tract are arranged in two rows.

There are usually 2 long tentacles $180^{\circ}$ apart alternating with 2 short tentacle-bullhs, but according to Browne, 1905 , the medusa may become mature wish 2 or with 4 long tentacles. The long tentacles are about twice as long as the bell-diameter and their upper, abaxial sides bear each a double row of numerous filaments, which terminate in oval capsules containing 4 to 8 nematocysts. The basal bulbs of the tentacles are globular, and lack ocelli.

There is a slight linear (glandular?) swelling occupying the midrlle third of each of the 4 radial-canals. The stomach is mounted upon a short peduncle and is urn-shaped, with a simple, round mouth-opening. The gonads surround the stomach and are more or less 
separated in the + principal radii. The basal bulbs of the tentacles and the stomach are brownish-red to bright crimson, and the entoderm of the tentacles is orange.

This medusa is found off the Atlantic coasts of Western Europe, and in the Mediterranean. Graeffe, i 884 , states that at Trieste, Adriatic Sea, the medusx bud forth from the hydroids in the spring, and a second brood appears to develop in summer.

The hydroid is Gemmaria implexa, well described and figured by Allman, 1871-72.

The stems of the hydroid are erect, 6 to $8 \mathrm{~mm}$. high, and arise at intervals from a creeping,

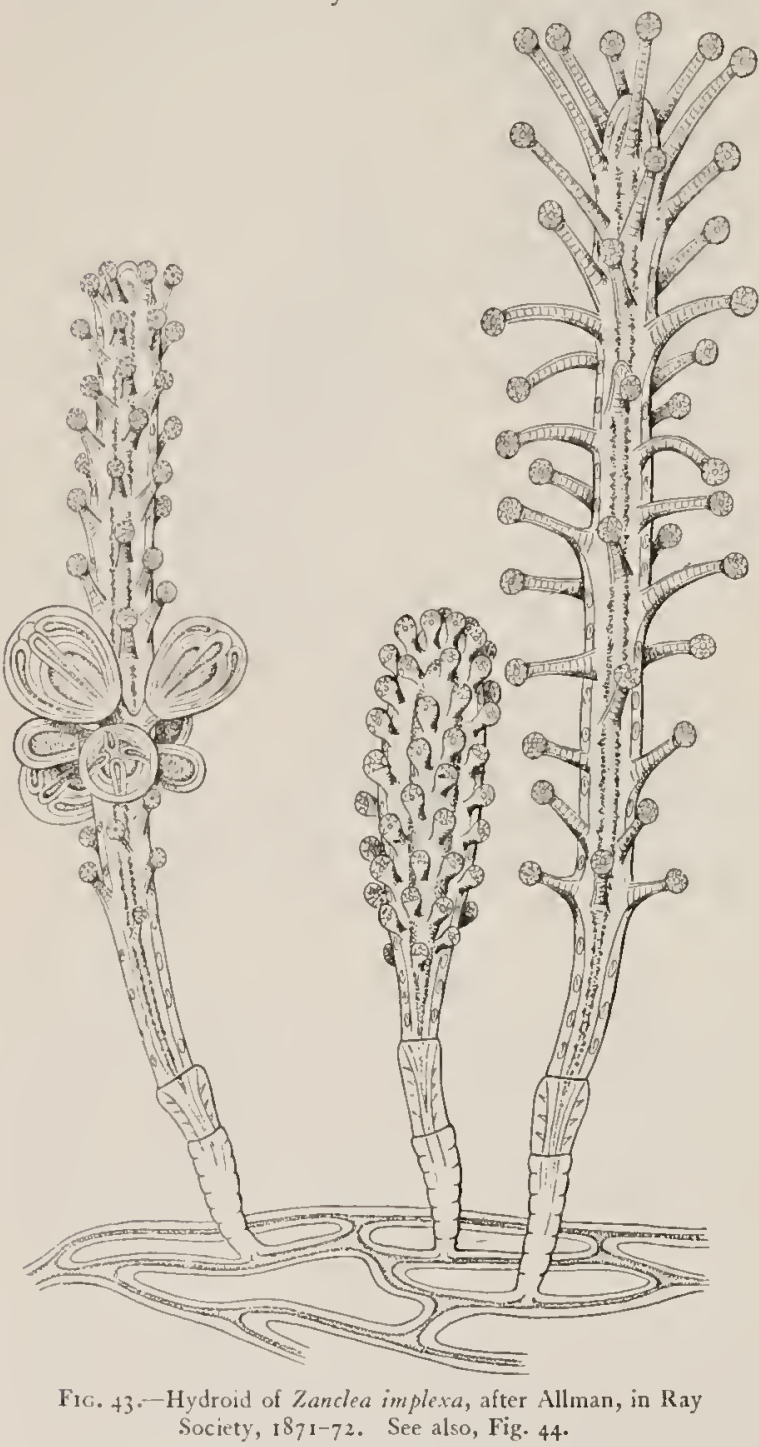
net-like hydrorhiza which is attached to shells, stones, etc., in shallow water. The stems are usually single, but occasionally they branch. The perisarc covers the hydrorhiza and extends as a transversely corrugated, opaque tuhe up the lower part of each hydranth. Below the zones of tentacles the perisarc becomes abruptly smooth, and ends in a slightly flaring cup. The hydranths are cylindrical to club-shaped, with dome-like peristome. There are 40 to 50 short tentacles, each ending in a knob of nematocysts. These tentacles are arranged in 10 to 13 irregular verticils of about 4 tentacles each, the tentacles being about $90^{\circ}$ apart. The medusabuds are borne upon peduncles which arise in clusters from the sides of the hydranth below the middle, but above the lowermost verticils of tentacles.

When set free the medusa has 2 well-developed tentacles which give rise to numerous filaments, each ending in a capsule bearing terminal bristles and containing several nematocysts. There are also 2 small tentacle-bulbs $90^{\circ}$ apart from the well-developed tentacles. The bell is oval and higher than a hemisphere and + lines of nenıatocysts extend up about one-fourth to one-third of the bell-height, one above each tentacle-bulb. The 4 radial-canals are straight and simple, and the manubrium is a simple tube with a round mouth-opening and straight cylindrical sides. It lacks a peduncle and is about half as long as depth of bell-cavity.

The hydranths are white with pale-pink entoderm. The perisarc on the proximal portion of the hydrocaulus is brown and on the distal portion, colorless. It is closely related to the hydroid of Zanclea gemmosa.

\section{Zanclea cladophora Hartlaub.}

Gemmaria cladophora, Acassiz, A., 1865, North Amer. Acal., p. 184, figs. 307-310.-Hakck L, 1879, Syst. der Medusen, p. 104.Nutring, 1901, Bull. U.S. Fish Commission for 1899, vol. 19, p. 371, fig. 78.-Hargits, 1904, Bull. U. S. Bureau of Fisheries, vol. $24, \mathrm{p} .42$.

Zanclea cladophora, Hartlaub, 1907, Nordisches Plankton, Nr. 12, p. 121, fign. $112-115$.

Bell pyriform and about as broad as high. Apical projection solid, rounded, and domelike. There are 2 long, diametrically opposed tentacles from the outer sides of which arise a great number of slender filaments, each terminating in a knob-like body which contains 
nematocysts. These long tentacles are $\mathbf{I} .5$ times as long as the bell-diameter. There are also 2 small, conical tentacles $90^{\circ}$ apart from the long ones. The small tentacles do not give rise to side-filaments. No ocelli. A ridge of nematocyst-cells extends from the base of each tentacle about half-way up the side of the exumbrella. Velum broad. There are + broad radialcanals and a narrow circular tube. The outline of the bell-cavity does not follow that of the outer surface of the bell, but is widest at the inner apex. Manubrium conical, with a wide proximal base and regularly-narrowing sides. It does not extend quite to the level of the velar opening. The 4 lips are quite prominent, and the mouth is a rectangular opening. The mouth is surrounded by 2 or 3 rows of large nematocyst-cells, similar to those found upon the sides of the exumbrella. The gonad is developed upon the sides of the stomach, which it encircles. The tentacles are light-brown in color, and the entoderm at their bases contains orange pigment. There are bright-yellow pigment-spots at the bases of the two rudimentary tentacles. This species was found at Nahant, Massachusetts, in I862, hy Dr.

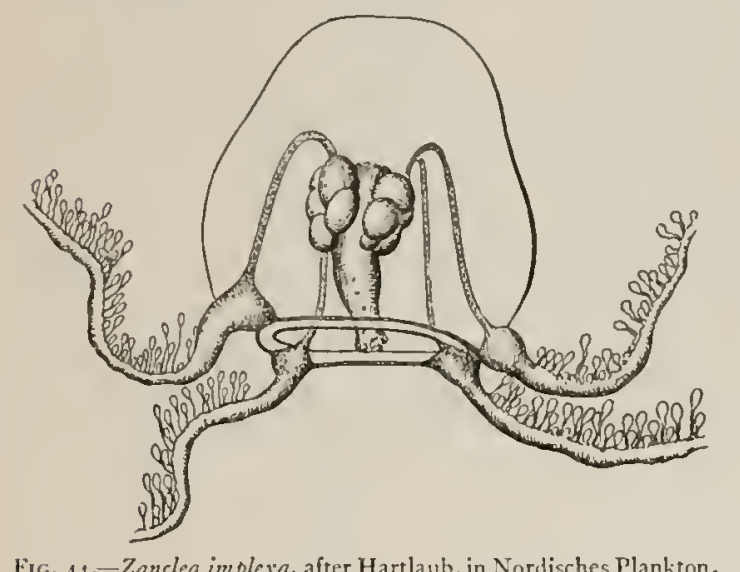

Alexander Agassiz. Nutting, 1901, oltained it at Woods Hole, Massachusetrs, in August, I 899. Neither of these observers states the dimensions of the medusa.

The peculiar outline of the subumbrella and the constriction above the lips figured by A. Agassiz may be due to unnatural contraction.

Many of the characters of this so-called "species" remain in doubt.

Zanclea nitida.

Gemmaria nirida, Hartlavb, 1905, Zoolog. Jahrbüchem, Suppl. 6, p. 527, fign. J, H (hydroid).

Polypites a bout $8 \mathrm{~mm}$. long. Club-shaped to cylindrical, with about 50 short knolhed tentacles, irregularly distributed. Hypostome short and flatly conical. Each polypite bears I to 3 clusters of small medusa-buds. These are borne upon short branching stems which arise between the tentacles near the lower, hasal part of the polypite. The condition of the medusa is not described. Found at Juan Fernandez Island, off the Pacific coast of South America.

Genus ZANCLEOPSIS Hartlaub, 1907.

Zancleopsis, Hartlaub, I907, Nordisches Plankton, Nr. 12, pp. 115, I16.

\section{GENERIC CHARACTERS.}

Cladonemidx related to Zanclea, but with large, stout, lateral branches on the tentacles. With ectodermal ocelli upon the tentacle-bulbs, and without meridional clusters of nematocysts upon the exumbrella.

The type species, and only known form, is Zancleopsis dichotoma, from Tortugas, Florida, described by Mayer under the name Gemmaria dichotoma.

This genus is distinguished from Zanclea ly the large lateral branches upon its tentacles. and by the absence of nettle-cell tracts upon the exumbrella. Also, it has ocelli, and these are not known in Zanclea.

Zancleopsis dichotoma Hartlaub.

$$
\text { Plate 8, fig. I. }
$$

Gemmaria dichotoma, MAyer, igoo, Bull. Mus. Comp. Zool. at Harvard College, vol. 37, p. 35, plate I7, fig. 40. Zancleopsis dichotoma, Hartlal'n, 1907, Nordisches Plankton, Nr. I2, p. II 5, fig. 105.

Bell miter-shaped, with thin walls, and solid apical projection. $3 \mathrm{~mm}$. high and about $2.5 \mathrm{~mm}$. wide. There are 2 rudimentary tentacle-bulls and 2 well-developed, diamerrically. opposed tentacles. These long tentacles are of unequal length, one heing about as long as 
the bell-height, while the other is only about two-thirds this length. Each of these tentacles terminates in a club-shaped, nematocyst-bearing end. The small tentacle gives rise to 2 to 3 side branches while the large one gives rise to 4 side branches. These side branches arise from the outer (aboral) side of the tentacle, and each one terminates in a knob-like end containing nematocysts as in the end of the main shaft itself. The youngest and least-developed side branch is always found nearest the side of the bell, whereas the oldest is nearest the outer end of the tentacle. The basal bulbs of the tentacles are large and swollen and contain each an ectodermal ocellus upon the outer (abaxial) side of the bulb. The ectodermal core of each tentacle and of the side branches is hollow. The nematocyst bulbs of the tentacles are provided with delicate bristles. The velum is quite narrow. There are 4 straight, simple radial-canals and a narrow circular vessel. The manubrium is flask-shaped, and cruciform in cross-section, with 4 small, cruciform, nematocyst-covered lips. The stomach-cavity does not project upward into the gelatinous apex of the bell. The gonads are developed upon the interradial sides of the stomach.

The entoderm of the manubrium and the circular and radial-canals is dull ocher-yellow, while the entodermal cores of the terminal bulbs of the tentacles is of a brighter $y$ ellow.

The 4 ocelli ( 2 on the bulbs of the well-developed tentacles and 2 on the rudimentary tentacle-bulbs) are dark reddish-brown.

This medusa is occasionally found at Tortugas, Florida, from May until July. It is taken each year upon the surface, but never in large numbers.

This species is widely separated from other medus $x$ of the genus Gemmaria by its welldeveloped ectodermal ocelli upon the 4 tentacle-bulbs and by the total absence of nematocyst tracts upon the exumbrella. The "filaments" arising from the abaxial sides of the 2 long tentacles are almost as thick as the main shaft of the tentacle itself, and in comparison with species of Gemmaria they are greatly reduced in number. This numerical disparity is, how. ever, counterbalanced by their great size.

\section{Genus PTERONEMA Haeckel, 1879.}

Microstoma, preoccupied by Cuvier, 1817, for Fishes.

Microstoma, LEsson, 1829, Voyage autour du monde sur la Coquille, tome 2, Zooph., p. 130.

Pteronema, Haeckel, i 879, Syst. der Medusen, p. IoI.-Vanhörfen, 1891, Zool. Anzeiger, Jahrg. I4, p. 445.

The first medusa to be described which belongs to this genus is Microstoma ambigua Lesson, from New Guinea.

Haeckel, I879, describes that which is probably the same medusa, in an expanded state, under the name Pteronema darwinii. This species is described from the coast of Australia, but the exact locality is not stated.

\section{GENERIC CHARACTERS.}

Similar to Zanclea, but distinguished by having a brood-sac above the stomach, the nature of which is unknown. If it be similar to that of Eleutheria it has no connection with the stomach. Haeckel considers it to be continuous with the stomach, but his studies do not demonstrate this to be true, for he cut no sections.

There are no meridional tracts of nematocysts upon the exumbrella in Pteronema.

\section{Pteronema darwinii Haeckel.}

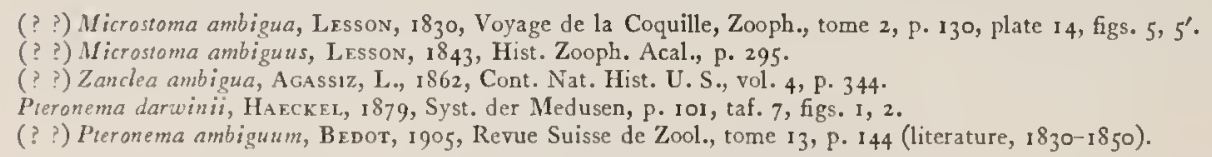

Haeckel describes his Pteronema darwinii from a single specimen preserved in glycerin. He states that the preservation was good, but that the tentacles were contracted and are represented in his figure as being of double the length observed in the preserved specimen. This medusa was obtained somewhere off the coast of Australia.

Lesson, 1830 , describes a medusa under the name Microstoma ambigua from Waigion, New Guinea, which may possibly be identical with $P$. darwinii. Lesson's description is, 
however, too vague to be of service, and his figure $5^{\prime}$ is almost equally hopeless. The spherical bell is apparently turned inside out, and there are 4 short, feathered, marginal tentacles and a flaring, conical manubrium, the tentacles and manubrium being bright yellow. His figure 5 is even worse for purposes of identification. I advise the dropping of Lesson's medusa from fut ure lists, for it will doubtless be impossible to determine it even generically.

In Haeckel's medusa the bell is $6 \mathrm{~mm}$. high, $+\mathrm{mm}$. wide, pyriform with a pointed

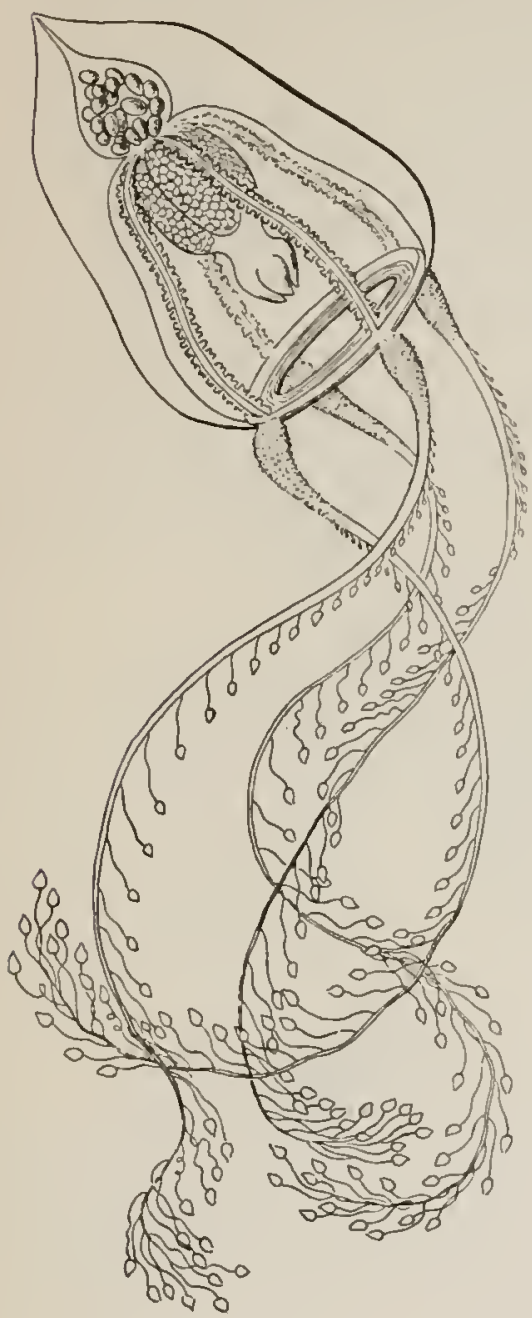

Fic. 45.-Pteronema darwinii, after Haeckel, 1879 . conical apex. There are no longitudinal lines of nematocysts over the exumbrella. There are 4 radially placed marginal tentacles, longer than the bell-height, and each provided with an abaxial row of filiform side branches, each one of which terminates in a spear-head-shaped capsule containing 5 to 10 nettle-cells. The basal bulbs of the tentacles are conical and lack ocelli. There are 4 straight, wide, jagged edged radial-canals and a narrower, smooth edged circular vessel. The stomach is spindleshaped, half to two-thirds as long as the depth of the bell-cavity, and provided with 4 simple lips. Gonads (?) on the adradial sides of the stomach.

The distinguishing characteristic of this medusa is the elongate, spindle-shaped brood-pouch above the stomach in the gelatinous apex of the bell. Haeckel observed ripe eggs and gastrulx in this brood-pouch. The anatomical relationships between this brood-pouch and the stomach are unknown, and it may have no connection with the stomach, but be ectodermal and connected with the subumbrella epithelium as it is in Eleutheria. Haeckel's description affords no solution of this problem. Color (?) Coast of Australia. Exact locality unknown. A single specimen described by Haeckel.

Genus ELEUTHERIA Quatrefages, 1842.

\begin{abstract}
Eleutheria, Quatrfacies, 1842 , Compt. rend. Acad. Sci., Paris, tome 15 , p. $168 ; 1842$, Annal. des Sci. Nat., série 2, tome 18, p. 270.

Chazatella (hydroid and medusa), Hiscks, 1861, Annals and Mag. Nat. Hist., ser. 3, rol. 7, p. 73 .

Eleutheria, Krons, 1861, Wiegemann's Archiv. für Naturges., Jahrg. 27, Bd. 1, p. 157.-CLaparèd F, 1863, Beobacht. über wirbellose Thiere, p. 4.Allman, 1872. Monog. Tubul. Hydroids, p. 384. Harckrt, 1879. Syst.der Medusen, p. I05.-Hartlaib, 1886, Zool. Anzeiger, Bd. 9. p. 707; Ibid., 1887, Bd. 10, p. 652; Ibid., Bd. 12, p. 665, 1889; 1907, Nordisches Plankton, Nr. 12, p. 126.-Browwr, 1902, Annals and Mag. Nat. Hist., ser. 7, vol. 9, p. 279.-Gïктн., 1903, Mitt. Zool. Sta. Neapel, Bd. 16, p. 57.-Kresarach, 1907, Zool. Anzeiger, Bd. $3 \mathrm{I}, \mathrm{P} \cdot 45^{\circ}$.
\end{abstract}

The type species of this genus is the extremely variable Fleutheria dichotoma of the Mediterranean and Atlantic coasts of Europe. Haeckel, 1879 , p. 106, records 12 subspecies of this medusa. The best description is by Hartlaub, $1886,1907$.

\section{GENERIC CHARACTIRS.}

Cladonemida with 4 or more simple radial-canals and an equal number of bifurcated tentacles. Terminal branches of tentacles end each in a knob-like.cluster of nematocysts. Manubrium a simple, + or more sided tube without oral tentacles or prominent lips. Velum well developed and there is an urticating ridge around the exumbrella side of the bell-margin below the ring-canal. There is a peculiar brood-pouch above the stomach, but this pouch is not connected with the gastrovascular cavity of the medusa. The cavity of this brood-pouch is, however, connected with the bell-cavity by means of simple, interradial openings. The genital products are developed exclusively in the epithelial lining of this brood-pouch, which is derived 
from the ectoderm of the subumbrella cavity of the bell. The medusa is hermaphroditic; ova develop in the ventral, and sperm in the dorsal (aboral) wall of the brood-pouch.

The hydroid is Clavatella of Hincks, i 861 (Annals and Mag. Nat. Hist., ser. 3, p. 73 , plates 7, 8; Ibid., 1868, British Hydroids, vol. 1, p. 73, plate 12, fig. 2). In Clavatella the polypites arise singly from a linear stolon. The polypites a re small linear, or clavate, with a zone of 8 slender tentacles which terminate each in a knob of nematocysts. The medusa-buds are borne only on two opposite sides of the body of the polypite near its base. The hydroid lives on Ulva in shallow tide pools, and the medusæ are produced in summer and autumn.

Hartlaub found that the entoderm of the planula of Eleutheria contains numerous nematocyst-cells. Krumbach, 1907 , believes that Trichoplax, F. E. Schulze, 1891 (Abhandl. Akad. Berlin), is the creeping planula of Eleutheria.

Eleutheria, Cladonema, and Amphogona are the only genera of hydromedusæ known to be hermaphroditic.
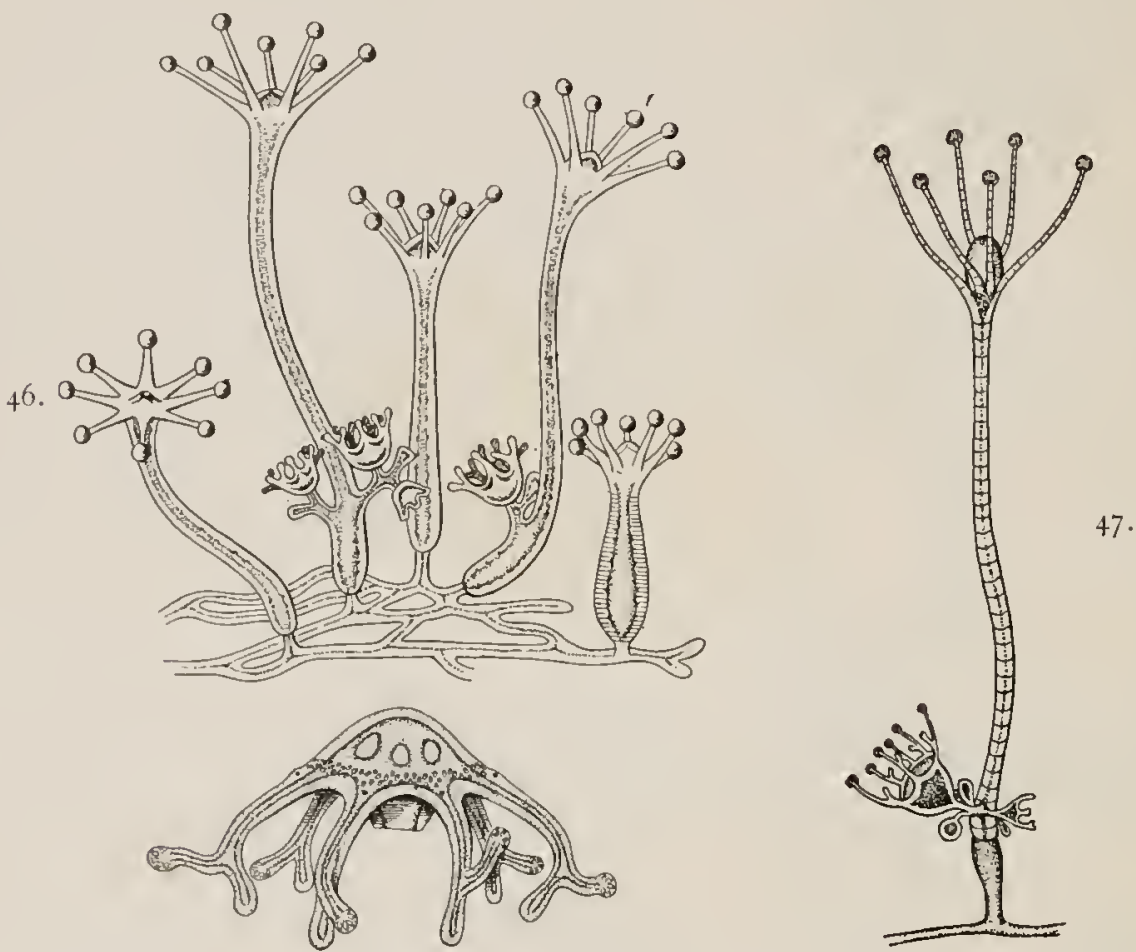

Fis. $f^{\text {h. }}$ - Hydroid (Clavalella prolifera) and its medusa (Fleutheria dichotoma), after Allman, in Ray Society, I871, 1872 . Fic. 47.-Clazatclla prolifera, after Hincks, in British Hydroid Zoophytes.

Eleutheria dichotoma Quatrefages.

Eleutheria dichotoma, Quatrefages, 1842 , Compt. rend. Acad. Sci., Paris, tome 15, p. 168 ; 1842, Annales Sci. Nat., Ser. 2, p. 270 , plate 18.-Kвона, 1861, Archiv. Naturgesch., Jahrg. 27, p. 157.

Clavatella prolifera (hydroid). Hincks, I861, Annals and Mag. Nat. Hist., ser. 3, vol. 7, p.73, plates 7, 8; 1868, Hist. British Hydroid Zoophytes, p. 73, plate 12, fig. 2.

Non Eleutheria dichotoma, Claparìde, 1863, Beob. Anat. und Entwick. wirbelloser Thiere, p. 4, taf. 1, fign. 4-10.

Claziatella prolifera (hydroid), Alzase, 1872, Monog. Tubul. Hydroids, pp. $31,212,3^{8} 4$, plate 18 .

Eleutheria dichotoma (non cla parède), HaECKEL, 1879, Syst. der Medusen, p. 106.

Eleutheria dichotoma, GrafFFe, 1884 , Arbeit. Zool. Inst. Wien, Bd. 5, p. 353.- Hartlaub, i 886, Zool. Anzeiger, Bd. 9. p. 706 ,

I fig. Also: Ibid., 1887, Bd. 10, p. 652; 1907, Nordisches Plankton, Nr. 12, p. 127, fign. 119, 120.-Bedot, 1905, Revue

Suisse de Zool., tome 13, p. 133 (literature cited to 1850).-MülLER, 1908, Zeit. für wissen. Zool., Bd. 89, pp. 34, 73, taf. 3 , fign. 3-7 (origin and structure of eggs). follows:

This medusa is exceedingly variable, but the normal form may be briefly described as

Bell irregularly hemispherical, with its lower surface more or less 6 -sided. 0.3 to $0.4 \mathrm{~mm}$. wide. There is a ridge of large nettling warts extending around the margin. There are 6 tentacles at the ends of the 6 short radial-canals, and not irregularly arranged in reference to the radial-canals as in E. claparedii Hartlaub $=E$. dichotoma Claparède. 
Each tentacle bifurcates and is twice as long as the bell-diameter. The 2 teminal branches end one in an adhesive disk, and the other in a large, knob-like cluster of nettle-cells. These branches are not quite as long as the basal shaft of the tentacle itself. An aloxial ocellus is found at the base of each tentacle.

The medusa is hermaphroditic, and the sexual products are developed in an ectodermal brood-pouch above, but not connected with, the stomach. The cavity of the hrood-pouch is connected with the bell-cavity by means of 6 simple, interradial openings which alternate with the 6 radial-canals. Sperm develops in the aboral, and ova in the oral (lower) wall of the brood-pouch.

Medusa-buds are also produced upon the exumbrella side of the ring-canal, and this process is usually associated with the sexual reproduction. The terminal suckers of the tentacles are orange or yellowish-brown. Stomach and canals yellowish.

This medusa is found clinging to green sea-weeds off the Atlantic coasts of Belgium, England, and France, and is widely distributed in the Mediterranean. Graeffe, 1884, found it to be common upon Ulva from July to September at Trieste, Adriatic Sea. The budded medusa become sexually mature in 3 to + weeks. The planula larva crecps over the seaweeds.

Detailed descriptions are given hy Quatrefages and Allman, and the hest modern account is that of Hartlaub, who discovered the remarkable character of the brood-pouch or ectodermal gonad.

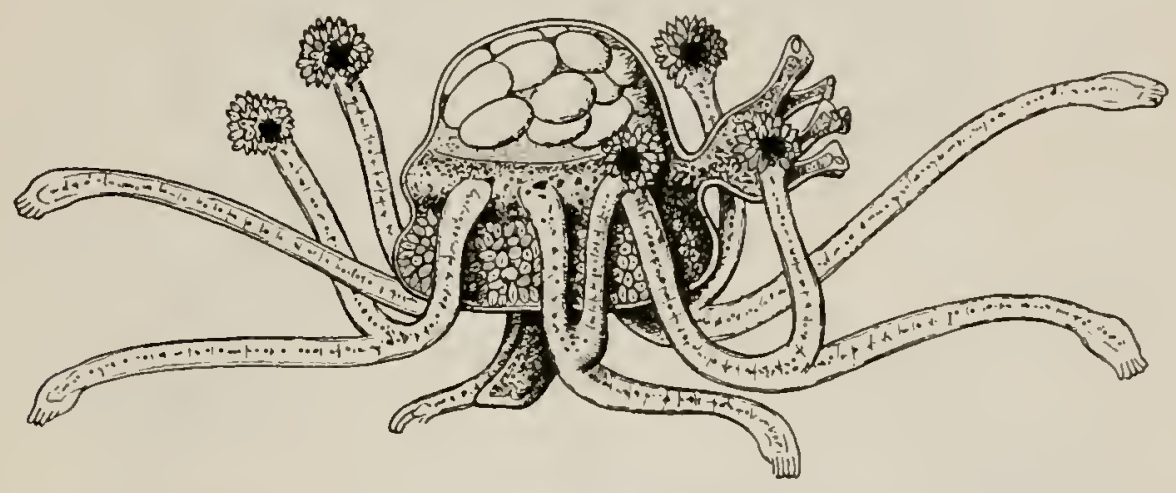

Fic. 48.-Eleutheria dichotoma, after Hartlauh, in Nordisches Plankton.

The hydroid is Clavatella prolifera Hincks (see definition of the genus Eleutheria).

Eleutheria dichotoma is apparently quite variable. The tentacles and radial-canals, although normally 6 , may range from 4 to 8 . Haeckel, 1879, p. 106. designates these aberrations as "subspecies," and gives specific names to twelve of them, although a number of these should be credited to Eleutheria claparcdii Hartaub and its variations. set free.

Hartlaub finds that the ova develop into planula larva within the brood-sac before being

Müller, 1908, studied the origin and structure of the eggs of this medusa. The eggs are small, numerous, and oval in outline, not amœeboid. There is no visihle distinction between exoplasm and endoplasm. The ooplasma is a network of very fine fibers. There are numerous small yolk-granules.

\section{Eleutheria claparedii Hartlaub.}

Eleutheria claparedii, Hartiaun, 1889, 7ool. Anzeiger, Bd.12, p. 665; 1907, Nordisches Plankton, Nir. 12, 13. 129, fig. 121. Elewheria dicholoma, Craparédf, 1863, Beobacht. Anat. und F.newicklungsges. wirbelloser Thicre, p. 4, taf. 1, figs. 4-10.Spagnolini, 1876, Catalogo Acalefi Mediterraneo, p. 24, tav. 4 , fig. 2.

Bell 0.4 to $0.5 \mathrm{~mm}$. wide, irregular in shape, usually more or less hemispherical (fig. 49 ). A ring of netrling warts on bell-margin. 8 to to tentacles, itregularly arranged in reference to the + to 6 radial-canals. A small abaxial ocellus at the hase of each tentacle. The tentacles are 3.5 times as long as the bell-diameter, and they bifurcate at their extrenities; onc branch ends in an adhesive disk, and the other in a nettling knoh. Ahout 6 or 7 medusa-lsuds are produced upon the subumbrella side of the ring-canal and project into the bell-cavity. 
This process of budding is independent of the sexual reproduction. The terminal suckers of the tentacles are orange. Found on Ulva in the Bay of Naples. Described in detail by Hartlaub. The structure of the reproductive sac is discussed in describing the character of the genus Eleutheria.

\section{Eleutheria vallentini Brown.}

Eleutheria vallentini, Browne, 1902, Annals and Mag. Nat. Hist., ser. 7, vol. 9, p. 279 .

Umbrella hemispherical, $3 \mathrm{~mm}$. wide, $2 \mathrm{~mm}$. high. 24 tentacles divided into two branches, the upper branch with clusters of nematocysts, the lower with a terminal sucker. "An ocellus on the extreme margin of the umbrella opposite each tentacle." Stomach-tube conical and small. Mouth a plain round opening without lips. The gonads occupy "the whole of the upper part of the umbrella above the stomach." A single specimen was found by Vallentin at

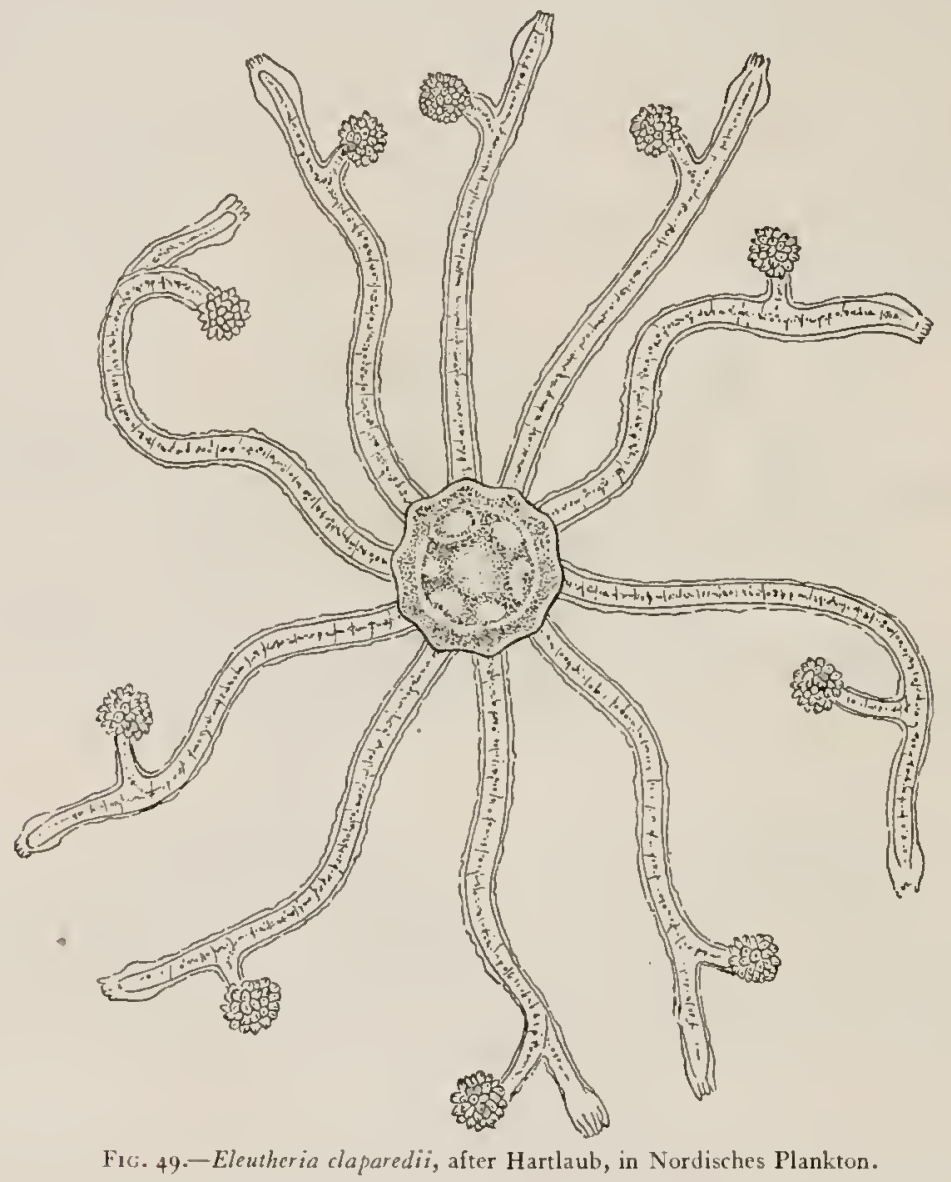

Stanley Harbor, Falkland Islands, and described by Browne. Color (?) Number of radialcanals (?) Brood-pouch (?) In the absence of a figure or a more detailed description it will probably be impossible to redetermine this form unless it be rediscovered in Stanley Harbor.

\section{Genus MNESTRA Krohn, 1853.}

Mnestra, Kroha, 1853. Archiv, für Naturges., Jahrg. 19, p. 278.-Güther, 1903, Mittheil. Zool. Sta. Neapel., Bu. 16, P. 35.

The type species is Mnestra parasites Krohn, from the Mediterranean.

GENERIC CHARACTERS.

Cladonemidx with 4 radial-canals and a ring-canal. No brood-sac above the stomach. 4 to o degenerate, hollow tentacles with a row of netting capsules along their aboral sides. With a ring of nettling cells around the margin and + linear tracts of nematocysts over the 
exumbrella, one above each of the + tentacle-bulbs. The throat of the medusa is blocked by a spongy mass of entoderm. There is a cup-like depression in the center of the exumbrella.

This medusa attaches itself by its suctorial mouth to the throat of the opisthobranch mollusk, Phyllirhö̈. It may be derived from some Zanclea-like form which has become degrenerate through its sessile habits. It can not swim, yet it has well-developed circular muscles in the subumbrella and a distinct relum.

\section{Mnestra parasites Krohn.}

Mnestre parasnes, krous, 1853 , Archiv. Naturges., Jahrg. 19, 19. 278.--Clats, 1875, Verhandl. \%oul. Butan. Ciesell., Wien,

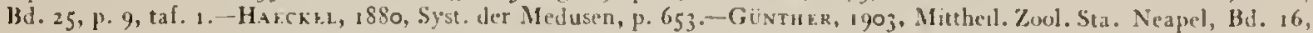
p. 35, plates $2,3,42$ figs.

Mnestra parasitica, Fewkes, 1884 , American Naquralist, vol. $18,1 \% 197$, figs. $4,5$.
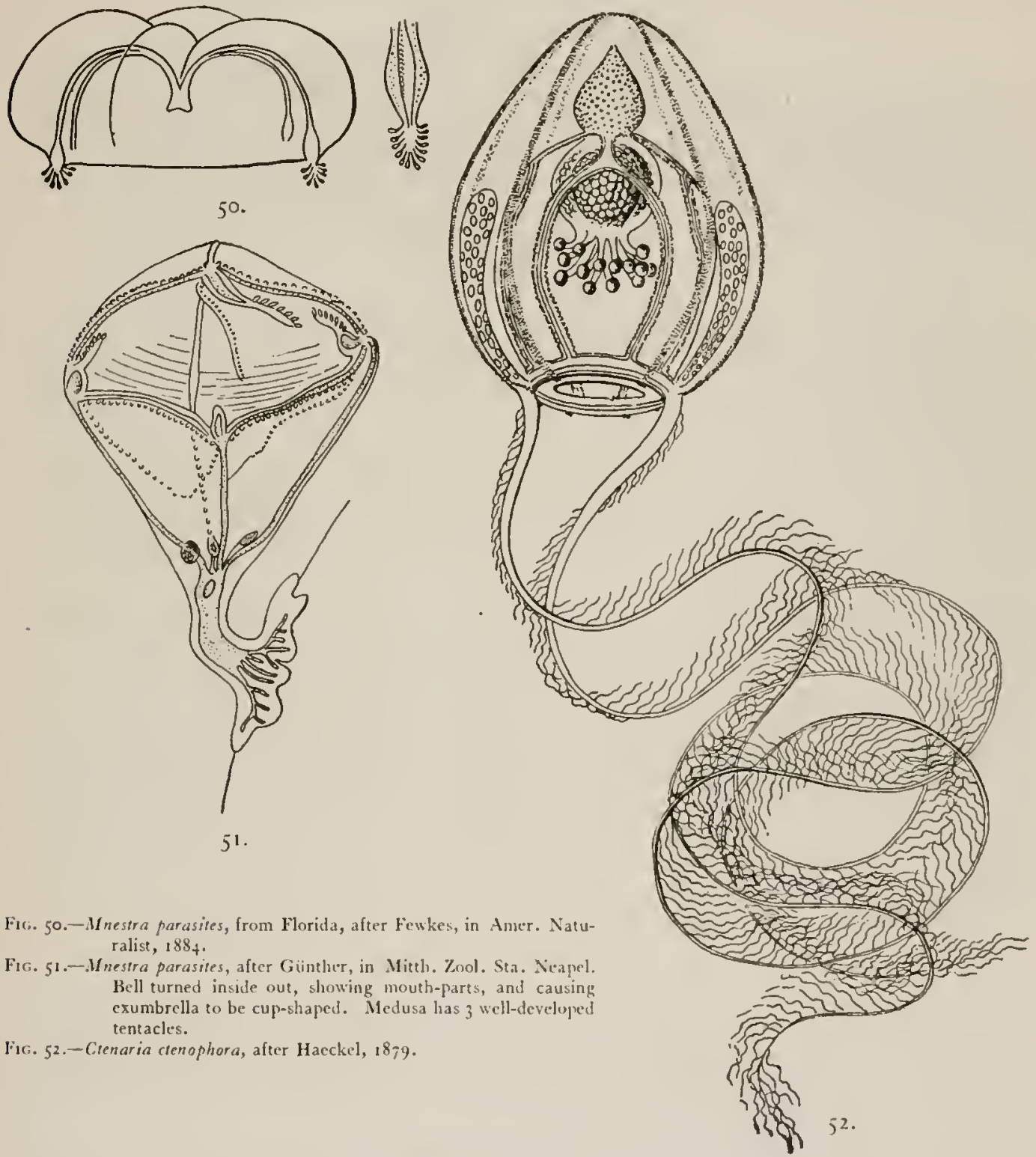

Fic. 50.-Mnestra parasies, from Florida, after Fewkes, in Anser. Naturalist, $188_{4}$.

Fig. 51.-.Mnestra parasites, after Gineluer, in Mitth. Zool. Sta. Nianel.

Bell turned inside out, showing mouth-parts, and causing exumbrella to be cup-shaped. Medusa has 3 well-developed tentacles.

Fig. 52.-Cienaria ctenophora, after Hacckel, $18,9$.

This minute, degenerate, highly variable medusa is parasitic or commensal upon the mollusk Phyllirhoë. Its germ cells appear to migrate into the hody of the Phyllirhoë where they develop. 
It has been rescued from scientific oblivion through an able paper by Günther, I903, who has carried out an elaborate study of its anatomy, life-history, and variations.

The characters of the medusa are those of the genus of which it is the sole representative (see genus Mnestra).

Fewkes, 1884 , describes this medusa upon Phyllirhoë on the Florida Reef. It is common at Naples and Messina, Mediterranean.

\section{Genus CTENARIA Haeckel, 1879 .}

Cienaria, Haeckel, I879, Syst. der Medusen, P. 107.-Gúnther, 1903, Mittheil.Zonl. Sta. Neapel, Bd. 16, J. 57.-Hartlatr, 1907, Nordisches Plankton, Nr. I2, p. 24.

The type species is Ctcnaria stenophora Haeckel, from the coast of Japan. This is the sole representative of the genus, and Haeckel had but a single preserved specimen.

GENERIC CHARACTERS.

Cladonemidxe with + hifurcated radial-canals. With 2 feathered marginal tentacles and simple. unhranched, oral tentacles. There are 8 adradial, meridional lines of nematocysts over the exumbrella, and a nematocyst tract above the base of each marginal tentacle. Gonads on the sides of the stomach. There is an apical cavity above the stomach, but it is not known whether this is an ectodermal brood-pouch, as in Eleutheria, or a mere extension of the stomach-cavity.

Ctenaria ctenophora Haeckel.

Cienaria clenophora, HaECKEL, I \$79, Syst. der Medusen, p. 108, taf. 7, figs. 5-7.-Hartiavi, I907, Nordisches Plankton, Nr. 12, p. 126, fig. 119.

Bell three-fourths-egg-shaped; $6 \mathrm{~mm}$. high, $5 \mathrm{~mm}$. wide. (Fig. 52.) Widest in a zone slightly below the middle. 8 adradial lines of nettling cells extend up the sides of the exumbrella from the margin nearly to the apex, and in addition to these there are 2 large club-shaped clusters of nematocysts extending from the bases of the 2 tentacles half-way up the sides of exumbrella.

The tentacles are each 2 to 4 times as long as the hell-height and they taper gradually from base to tip. There are no basal ocelli. A row of numerous, slender filaments arises from the abaxial side of each tentacle. These filaments superficially resemble those of Ctenophorx, and do not end in nematocyst capsules as in Zanclea. They are, however, covered with nematocysts throughout their lengths.

The velum is well developed. 4 main radial-canals arise from the stomach, but these bifurcate so that 8 canals join the marginal circular vessel in the 8 adradii. The edges of these radial-canals are serrated, being apparently beset with glands.

The stomach is almost spherical and about half as long as the depth of the bell-cavity. There are 16 short, simple, oral tentacles, each of which ends in a nematocyst-knob.

Haeckel describes 4 swollen, radially placed gonads on the sides of the stomach, but these are probably adradial or interradial (?) There is a well-developed apical cavity above the stomach, but it is not quite clear whether this is a brood-sac homologous with that of Eleutheria or whether it is simply an apical extension of the stomach. Haeckel supports the latter view, hut he made no sections, and the point can not be considered as determined. Color (?)

Haeckel describes this medusa from a single alcoholic specimen from Japan.

Genus CLADONEMA Dujardin, 1843 .

Cladonema, Dujardin, I843, Annal. des Sci. Naturelles, tome 20, p. 370.-Krohx, 1853, Müller's Archiv. für Anatomie und Phvsiologie, p. 420.-Gegenbale, 1856. Zeit. für wissen. Zool., Bd. 8, p. 230.-VAn Beneden, i866, Fauna Littor. Belgique, p. 139.-Hincks, 1868, British Hydroid Zoophytes, p. 62.-AllmaN, 1871-72, Monograph Tubularian Hydroids, pp. 216, 357.- Haeckel, 1879, Syst. der Medusen, p. Iog.-Perkins, Igoz, Johns Hopkins University Circulars, No. 155, p. 25, I908, Papers from Tortugas Laboratory Carnegie Institution of Washington, vol. I, P. I36.Hartlaue, 1887, Zool. Anzeiger, Bd. 10, p. 654; 1907, Nordisches Plankton, Nr. I2, p. 131.-Günther, Igo3, Mitt. Zool. Sta. Neapel, Bd. 16, p. 57.

Stauridium cladonema (hydroid), du Pl.sssis, 1888, Recueil Zool. Suisse, tome 4, P. 536.

\section{GENERIC CHARACTERS.}

Cladonemidx with 4 or 5 or more hifurcated radial-canals or 8 to 10 or more simple canals, or with some bifurcated and some simple canals. With 8 to 10 or more tentacles which 
give rise to sucker-bearing or nematocyst-bearing branches or both. With 4 or 5 simple, oral tentacles which terminate in nematocyst-knobs. There is no brood-sac ahove the stomach. The genital products develop within the entoderm of the stomach, and when mature are found in the ectoderm. The medusa is sometimes observed to be hermaphroditic.

The type species is Cladonema radiatum of the coasts of Europe. According to Haeckel this species is highly variable both in form and color (see Haeckel, 1879 , p. 109). The two American forms described by Perkins are, however, quite constant in their form, although one of them is somewhat variahle in color. "The hydroid stock of Cladonema helongs to the tubularian genus Stauridia of Dujardin. It is well described by Allman, 187 I (Tubularian Hydroids, pp. 216.357, plate xvir), and by Perkins, 1908 .

\section{Cladonema radiatum Dujardin.}

Cladonema radiaum, Dujaknin, 1843 , Compt. rend. Acad. Sci., p. 1134.

Stauridie (hydroid), Dujakdin, Ibid., p. 1133.

Cladonema radiatum and Stauridie, Dujardin, 1843, Annal. des Sci. Nat., tome 20, p. 370; 1845 , 16id., ser. 2 , tonie 4, pp. 271 272 , plate 14 , fig. C.

Cladonema radiatum, Krohn, 1853. Müller's Archiv. fur Anat. und Physiol., P. 420, plate 13.-Kirkrstrin ind Eht.ers, 1861. Zoologische Beiträge Neapel, Messina, p. 85, taf. 13, fig. 5. VAN BFnedrn, 1866, Mèm. Acad. Roy. Belgique, tome 36, p. 139, plate 12.-Hincks, 1868, Hist. British Hydroid Zooph., p. 62, plate 11.-Allman, 1872, Monog. Tubul. Hydroids, Pp. 216, 357, flate 17, figs. 1-10.-Hafckra, 1879, Syst. der Medusen, p. 109.-Wrismand, 1883, Entstehung Sexualzellen, bei Hydromedusen, Jena, pp. 119, 218 , taf. 12, figs. 2-5.- Jickelı, 1883, Morphol. Jahrbuch, Bd. 8, p. 602, taf. 26 (histology).-Hartuav B, 1887, Zool. Anzeiger, Bd. 10, p. 655, 1 fig.; 1907, Nordisches Plankton, Nr. 12, p. 132, fign. 123-125, (list of authors; excellent description of the medusa).-Bғрот, 1905, Revue Suisse de Zool., tome 13, pp. $58,{ }_{132}$ (references to 1850).-Billard, 1905, Bull. Musẻum d'Hist. Nat. Paris, tome 11, p. 500 (variations).-Míller, 1908, Zeit. für wissen. Zool., Bd. 89, pp. 30, 73, taf. 3, figs. 1, 2; taf. 4, figs. 8-11.

Bell half-egg-shaped or glohular and 2 to $3 \mathrm{~mm}$. wide. Ar Naples, Iraly, the medusa appears to be quite invariable, and according to Hastlauh, 1887 , the manubrium is spindleshaped and five-sided with 5 perradial oral tentacles and 5 perradial sac-like outgrowths upon the sides of the stomach. Thus in the Naples medusæ 5 main radial-canals, $72^{\circ}$ apart, arise from the stomach, but 3 of these bifurcate so that 8 canals, $45^{\circ}$ apart, join the circular vessel at the margin. These 5 main radial-canals are arranged as follows: 2 hifurcated canals $72^{\circ}$ apart; 2 simple, unbranched canals $144^{\circ}$ apart; I hifurcated radial-canal midway hetween the two simple canals, i.e., $72^{\circ}$ from each. Thus in glancing around the margin in the direction of the order of succession of the hour-numhers on the dial of a clock, we may hegin with a simple canal, then comes a bifurcated, then a simple, next a hifurcated, and finally another hifurcated canal. 2 of the hifurcated canals are thus side by side and the 2 simple canals are separated one from another by an interval occupied by the third hifurcated canal.

There are 8 tentacles upon the Naples medusx, one at the end of each terminal radialcanal. The hasal bulbs of these tentacles are heavy and swollen, and each bears an abaxial ocellus. I to 3 sucker-bearing filaments arise from the imner sides of the tentacles and their outer parts terminate in 4 to 6 branches which are armed with nettling warts and end in knobs.

The gonad encircles the stomach and is not confined to the sac-like protrusions, as was believed to be the case by Haeckel. According to Hartlaub, the genital products originate in the entoderm, but when mature are found in the ectoderm of the manuhrium; yet according to Weismann they originate and remain in the ectoderm.

The medusa exhihits a successive hermaphroditism, according to Hartlaub, although either sex may precede in the process. (See also Müller, 1908.)

The stomach, ring-canal, and tentacles are red to hrown.

This medusa is abundant off the Atlantic coasts of England, Holland, and France, and in the Mediterranean. Haeckel records a number of departures from the normal form. These are prohably only aberrations, but he gives specific names to each and every one of them. For example, the oral tentacles and the sac-like outgrowths on the stomach may range from 4 to 5 ; and there may he 10 simple, or 4 bifurcated radial-canals.

There appear indeed to be many local races of this medusa, and I am inclined to helieve that Cladonema perkinsii and $C$. mayeri of America may prove to be only varieties of $C$. radiatum. 
Billard has studied the variations of the medusa at the Bay de la Hougue near St. Vaast on the northwestern coast of France. Here he found that among 50 medusa 5 had 6 radialcanals, 4 had 7,39 had 8 , I had 9,0 had 10,1 had 1 I. In the case of the 39 medusx with 8 radial-canals, 36 had 2 simple and 3 bifurcated canals, as in the Naples medusa.

Müller, 1908, has studied the origin and structure of the ova in this medusa. The eggs are small and rounded and widely scattered in the gonad, for the successful eggs devour the weaker in the ovary. The ooplasma is sparsely vacuolated and there is very little yolk.

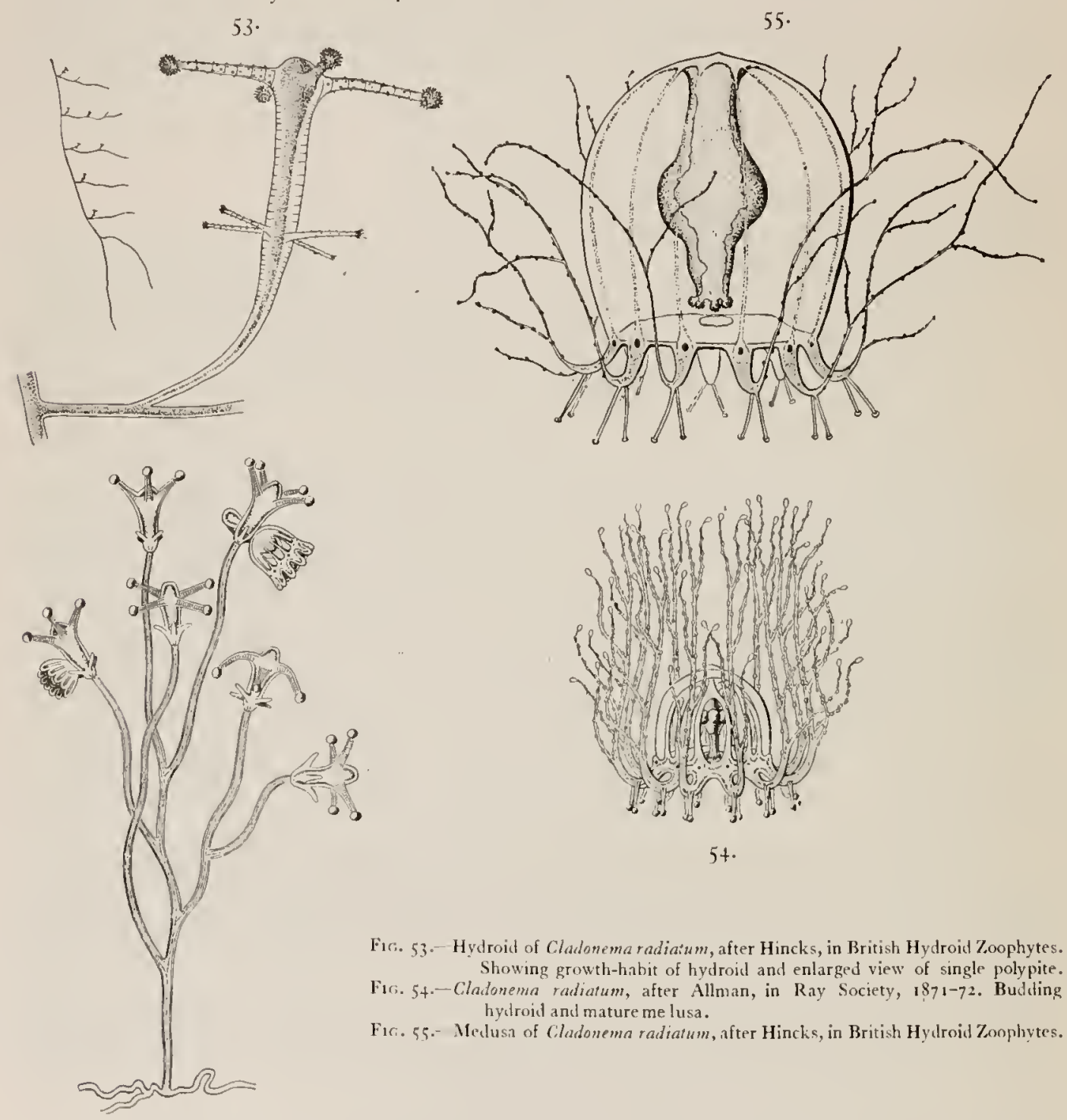

54 . Hincks.

The hydroid of Cladonema radiatum is Stauridia radiatum Dujardin = Cladonema radiatum

The hydrorhiza is a slender, creeping filament from which the hydranths arise at intervals. These hydranths are either simple, unbranched, and about $2.5 \mathrm{~mm}$. high, or are borne upon slightly branching stems I 2 to $25 \mathrm{~mm}$. high. The hydranths are club-shaped and have 2 alternating verticils, each circlet consisting of 4 tentacles. The circlet near the mouth is composed of long tentacles, each of which ends in a knob, while the circlet at the base of the hydranth consists of 4 very short, simple, unbranched, filiform tentacles which alternate with (i. e. are upon meridians $45^{\circ}$ apart from) the oral circlet. The medus $x$ bud out singly' from the sides of the polypite at a short distance above the basal circlet of tentacles. The 
hody of the hydranth is pale reddish and the perisarc bright yellowish-brown. The medusx are produced in spring and summer.

Dujardin's, 1843 , observations upon Cladonema radiatum are the earliest in which the complete life-history of the alternation of generations between hydroid and medusa was actually observed.

Cladonema perkinsii Mayer.

Plate 9, fig. 1.

Cladonema, sp., Perkins, tgoz, Johns Hopkins University Circulars, vol. 21, Nu. 155, §. 25, figs. in text.

Cladonema perkinsii, MaYfr, 1904, Menooirs Nat. Sci. Brooklyn Inst. Arts and Sci, vol. 1, No. 1, p. 8 . plate 4, fig. 35.- HarrLaub, 1907, Nordisches Plankton, Nr. 12, P. 135, fig. 126.

Bell half-egg-shaped; less than $2 \mathrm{~mm}$. in diameter, with thin, uniform walls. 8 large, stout, marginal tentacles. The inner and lateral parts of each of these tentacles bear 3 to 10 small, flexihle cirri, which a re besprinkled with wart-like clusters of nematocysts and terminate in a knob. There is a large, cup-like, ectodermal ocellus upon the outer side of each main tentacle shaft near the bell-margin. The velum is large and shows circular striations. Manubrium large and spindle-shaped, with about 6 rounded, protruding pouches at its widest part. The mouth is surrounded by a circlet of 5 simple, short oral tentacles each reminating in a knob-like mass of nematocysts. 8 simple radial-canals, $45^{\circ}$ apart, a rise from the stomach, and extend straight toward the simple circular ressel. The manubrium is thus 8 -sided at its proximal end, 6-sided in the middle, and 5-sided at the mouth. The genital products develop in the ecroderm of a large part of the manubrium and also in the hernia-like pouches. The ocelli are black and all other parts colorless. This species was discovered by Professor Perkins in Nassau Harbor, Bahamas, in July, 1902, upon the surface in shallow water at night.

\section{Cladonema mayeri Perkins.}

$$
\text { l'late } 9 \text {, figs. } 2 \text { and } 3 \text {. }
$$

Cladonema, sp., Frwkrs, $188_{3}$, Bull. Mus. Comp. Zool. at Harvard College, vol. 11, p. 87.

Ciladonema majeri, Prokiss, 1906, Year Bouk of the Carnegie Institution of Washington, No. 4, I905, P. I18.-1908, Papers from 'Tortugas Lab. Carnegite Inst. Washington, vol. 1, p. 136, plates 1 and 2, plate 4, figs. 21,22 . Hydroilt and medusa.

Bell thin-walled, higher than a hemisphere, and with small, solid, apical projection; top rounded and dome-like, and total height about $2.5 \mathrm{~mm}$. There are 9 marginal tentacles, one at the foot of each radial-canal. Each of these tentacles has a large, spindle-shaped hasal bulb, the entoderm of which contains a mass of white concretions. On the outer side of each hasal bulb near the circular canal there is a deep reddish-brown, ectodermal pigment spot. The distal, inner side of each basal buth gives rise to about 6 small tapering peduncles which terminate in small knoh-like adhesive disks. These enable the medusa to cling to the sides or botrom of the aquarium. The main shaft of each tentacle extends outward from the spindle-shaped end of the basal bulh. It is uniform, thread-like, and slender, and gives rise to 4 to 8 thread-like side hranches each of which, together with the central shaft, terminates in a knoh-like cluster of nematocysts. There are + to 6 nematocyst-warts upon each side hranch and a greater number upon the main shaft. Both the main shaft and the side branches are highly contractile and can be expanded so as to become longer than the bell-height, or contracted into a close bunch. The velum is very wide and its orifice small. 6 radial-canals arise from the stomach, but every alternate canal bifurcates near its point of origin, and thus 9 equally spaced canals reach the circular vessel. The manubrium normally extends to the level of the velar opening, but may contract somewhat at times, as is shown in our figure. The mouth is surrounded by 6 simple oral tentacles, each of which terminates in a large nematocyst-knoh. Near the middle of the stomach there is a circlet of 6 radially arranged, short, blunt, hernia-like projections. The genital products are developed in the ectoderm of the walls of the manubrium.

The color is quire variable. The entoderm of the basal hulbs of the marginal tentacles is milky-yellow streaked with dark-brown pigment-granules, while the entoderm of the manubrium is milky-yellow or dull-milky ocher, streaked longitudinally in each of the 6 radii by dark-brown, almost black, pigment-granules. The disposition and arrangement of this pigment is highly variable. Perkins, rgo8, gives the most complete account of this medusa and its hydroid. 
This medusa, together with its hydroid stage, was found in great numbers by Prof. Henry F. Perkins in the salt-water moat of Fort Jefferson, Tortugas, during the summer of 1905. The hydroid is a minute Stauridia which grows upon algx. The same medusa was described by Fewkes, $188_{3}$, as being in association with Cassiopea at Fleming's Key, near Key West, Florida.

Genus DENDRONEMA Haeckel, 1879.

Dendronema, Hafokr.., 1879. Syst. der Medusen, p. 110.-Gönther, 1903, Mitth. Zool. Sta. Neapel, Bd. 16, p. 57.

The only known form is Dendronema stylodendron Haeckel, from the Canary Islands, Arlantic Ocean.

\section{GENERIC CHARACTERS.}

Cladonemidx with branched oral tentacles and branched marginal tentacles, the branches ending in nematocyst-knobs or adhesive disks, or both. With bifurcated radialcanals. Gonads in the stomach-wall.

There is an apical cavity above the stomach, but we do not know whether this is a mere extension of the stomach itself, or a reproductive sac similar in anatomy to that of Eleutherin.

\section{Dendronema stylodendron Haeckel.}

Dendronema stylodendron, Ha Eckr.t, 1879 , Syst. der Medusen, p. I10, taf. 7 , fig. 8 .

Bell miter-shaped, with pointed conical apex. $9 \mathrm{~mm}$. high, $6 \mathrm{~mm}$. wide. Stomach spindleshaped. There are apparently 4 radially placed oral tentacles each of which branches dichotomously 6 to 7 times and terminates in ( 50 to 60 ) nematocyst-knobs in each quadrant. Haeckel's description is, however, vague upon this point. Haeckel states that there are 4 eggshaped "gonads" on the 4 perradial sides of the stomach. These may, however, he homologous with the protuberances seen in Cladonema (?) Haeckel's figure shows them distended with ova. + principal radial-canals, $90^{\circ}$ apart, leave the stomach and bifurcate so that 8 vessels reach the ring-canal $45^{\circ}$ apart. There are 8 marginal tentacles, one at the base of each radial-canal. There is an ectodermal abaxial ocellus at the base of each tentacle. Each tentacle gives off a stout, short branch on its inner (velar) side, and this hranch hifurcates twice and terminates in 4 nematocyst-bearing, knol-like "suckers," or adhesive organs. The main shaft of the tentacle also branches dichotomously many times and is besprinkled with nettling warts, and the ends terminate in large knobs. There is a spindle-shaped cavity in the apex of the bell, above the stomach, but its anatomical character is unknown. The mouth, stomach, apical cavity, and gonads are reddish-yellow. Tentacles, radial-canals, and ring-canal brownish-red. Ocelli black. 1867.

This medusa was found by Haeckel in the Canary Islands, Atlantic Ocean, in Fehruary,

Family OCEANID E, sens. Vanhöffen, I891.

Oceanida (in part), Eschscholtz, 1829 , Syst. der Acalephen, p. 96.-Forafs, 1848 , British Naked-eyed Medusa, p. $21 .-$

Gegendaur, 1856 , Zeit. für wissen. Zool., B1. 8, p. 219.

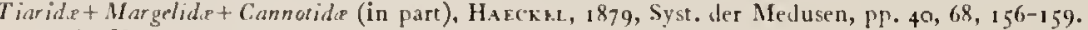

(Jceanilix, Vanhofrex, 1891, Zool. Anzeiger, BJ. 14. p. 443 .

FAMILY CHARACTERS.

Anthomedusx with 4 , or 4 pairs of, isolated gonads upon the interradial or adradial sides of the stomach. The marginal tentacles may arise singly or in clusters, but are neither branched nor feathered.

The Oceanidx constitute the third family of the Anthomedusæ, and they are more complex and more highly differentiated than the simple and more primitive Codonidæ. 
We distinguish three sulfamilies of Oceanidx.

I. Tiarine. Lips without oral tentacles. Simple unbranched radial-canals. Tentacles arise separately from the hell-margin and are not grouped in clusters.

2. Margelina. With oral tentacles. Simple, unbranched radial-canals. In some genera the marginal tentacles arise singly; in others they are grouped in clusters.

3. Dendrostaurine. Lips without oral tentacles. The radial-canals branch.

Direct development of the medusa from the egg is unknown in this family. "The following genera are known to develop through Tubularian hydroids: Stomotocn. Turris. Podocoryne. Sitylactis, Bougainvillia, Nemopsis, Lizzin, and Willia.

Medus $\boldsymbol{x}$ are produced asexually upon the interradial sides of the manubrium in Cyrcis, Podocoryne, Bougainvillia, and Rathkea. In some species of Bongninvillin the eggs undergo part of their development within the ectoderm of the parent medusa, and are discharged as well-developed planula. In $N$ iobia the tentacle-bulbs develop into new medusie, and are set free one after another to repeat this process. In Willia and Proboscidactyla, medusa-buds are produced upon hollow stolons which may arise from the corners of the stomach at the points of juncture with the radial-canals, or from the places where the canals fork, as in $P$. Anvicirrata, var. stolonifern, Maas.

Haeckel, 1879 , describes the gonads of the Oceanidx as being perradial in position and on the sides of the stomach in the same sectors with the radial-canals, but Vanhöfen, 1891 (Zool. Anzeiger, Bd. 14), showed that this is an error, for the gonads are almost universally adradial or interradial in position and alternate with the sectors of the radial-canals.

The specialized conditions displayed by the medusa of the Oceanida, such as the corrugated, folded gonads of the Tiarina, the clustered marginal tentacles and the oral tentacles of the Margelina, and the forked radial-canals and other peculiar structures in the Dendrostaurina, all indicate that the Oceanida are derived from simpler forms, such as the Codonidx. Indeed, the conditions seen in the Oceanidx are largely foreshadowed in the moredifferentiated Codonidx and in the Cladonemidx. In common with the Codonidx and Cladonemidx the Oceanida are derived from Tubularian hydroids.

\section{Subfamily TIARIN $Æ$ Haeckel, I879.}

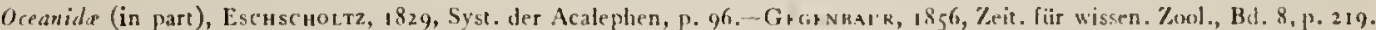
Nucleifere (in part), Lesson, 1843 , Hist. Nat. Zooph. Acal., p. 28, .

Tidride, Hafckir., 1879 , Syst. der Medusen, p. 40.

Sens. restr., Calomerinthia, Vanhört+n, 1891 , Zool. Anzeiger, Bd. 14, P. 443.

Tiaride, Haktlaun, 1892, Nachrichten kgl. Gesell. Wissenschaft. Univ. Götingen, 1P. 19-22; 1907, Nordisches 12lankton, Nr. 12, p. 5

Sens. restr., Tiaride, MaAs, 1904 , Result. Camp. Sci. Prince de Monacn, fase. 28, p. II

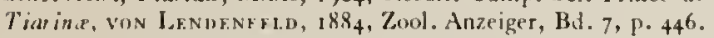

\section{CHARACI'ERS OF 'IHE TIARINA.}

Anthomedusa with 4 lips, without oral tentacles. With 4 or more unbranched radialcanals and with simple, hollow, unhranched tentacles which are not grouped in clusters, hut arise separately from the bell-margin. With interradial or adradial gonads forming swollen, corrugated regions in the walls of the stomach.

The following table shows the genera of the Tiarina.

1. Tribe Protiarid:

The outer surfaces of the four interradial gonads are smooth. Not corrugated or folded. There are 4 simple lips, 4 radialcanals, and a ring-canal, 4 or more tentactes.

Propiara Hakckel, 1879 . With 4 radial-canals and 4 radially situated marginal tentacles. 4 simple lips not com. plexly folded. Hydroid unknown.

Heserosiara MaAs, 1905 . With 4 radial-canals, and 8 marginal tentacles. Ring-canal gives rise to interradial, blindlyending, centripetal canals. Only species is H. anonyma, Mats, 1905. Craspedoten Mrdusen Siboga Fixpedition, Monog. 10, p. 19, taf. 3, figs. 19-21, Malay Archipelago. Hydroid unknown.

2. Tribe AMPHINEMIDI:

With 2 long and numerous rudimentary tentacles. There are 4 radial-canals.

Stomoroca 1. Afiassiz, $1862=$ Amphinema + Spomorocat Codonorchis, Harchri, 1879. With two well-developed tentacles. Manubrium may or may not be mounted upon a peduncle. Gonads corrugated, folded, swollen regions upon interradial or adradial sides of stomach.

Dissonema Ha Eckel, 1879. With 2 well-developed and numerous rudimentary tentacles. During their developnent gonads migrate outward from sides of stomach down the 4 radial-canals. 
3. Tribe Pandelol:

$\mathrm{With}_{4}$ or more well-developed tentacles. The gonads are interradial, corrugated, or folded ridges in the wall of the stomach 4 radial-canals.

Panden Lrssox, $1 \$_{43}\left(18_{37}\right.$ ?). 4 interradial gonads in stomach-wall, not completely separated in the 4 principal radii. Hydroid unknown.

Conis Brandr, 1838. Ocelli borne upon ends of special, short clubs which arise from bases of tentacles. Hydroid unknown.

Turris LEssos, $18_{43}=$ Tiara, Lfsson + Carablema, HAsch.l. With 4 interradial crescent-shaped gonads in the ectoderm of the stomach-wall. Fach crescent is composed of partially fused, swollen ridges. Hyclroid: Claz'ula (?), Campanidlava? or Perigonimus (?)

4. Tribe Calvopsion:

With more than 4 simple, unbranched radial-canals. Adradial, transversely folded gonads.

Calycopsis Frwk F.s, 1882 . With I 6 simple, separate, unbranched radial-canals, 4 radial, 4 interradial, 8 adradial.

Haeckel, i 879 , established the family Tiaridx for Anthomedusx with 4 wide, crenulated lips; with + separated or 8 cleft gonads in the stomach-wall; with + wide, hand-like radialcanals; and with simple, unbranched tentacles.

Vanhöffen, I 891 , showed that the gonads were interradial, not radial in position as was supposed to be the case by Haeckel; and in 1892 Hartlaub gave important details of the structure of the gonads, showing that Pandea had simpler gonads than either Tiara or T urris. For example, he showed that the gonads of Pander conica consist of 4 interradial, horseshoeshaped, network-like, swollen regions in the ectoderm of the stomach-wall. The gonads of Turris caca, however, consist not only in the interradial network, but chiefly in a double row of fused longitudinal swellings in each interradial quadrant of the stomach. In Tiara pileata, on the other hand, we find none of these network-like gonads, but instead a horseshoe-shaped gonad in each interradial quadrant, the apex being upward and the sides of the horseshoe being made up of a series of laterally-fused, horizontal swellings. Maas, 1904, loc. cit., gives clear figures of these conditions and supports Hartlaub's observations.

In the more complex and specialized Tiarinx, represented by the tribes Amphinemidi and Pandxidi, the gonads are thrown into complex folds or corrugations, and the lips have become recurved, with folded edges.

Vanhöffen concluded that Amphinema and Codonorchis of Haeckel are equivalent to Stomotoca L. Agassiz; and in this I concur. He also maintained that Pandea Lesson was identical with Tiara Lesson, but in 1892 Hartlaub showed that the gonads of Pandea were quite different in structure from those of Tiara; and Maas, 1904, supports this conclusion.

Maas, 1904, calls attention to the fact that there are no definite distinctions between Turris and Tiarn. He shows that the gonads of Turris consist of 4 interradial horseshoes, the sides of each horseshoe being made up of partially fused, transverse, branched, ectodermal ridges and the upper apex of the horseshoe heing composed of an open network of ridges. In Tiara the gonads are horseshoe-shaped, but commonly lack the network-like ridges. The transverse ridges do anastomose to some degree, however, in Tiara, so that a partial network is often found. See Maas, Igo4, loc. cit., plate 2, fig. II.

Maas describes the gonads of Catablema Haeckel as horseshoe-shaped and composed of partially fused, vertical ridges. In the fully-grown medusa, however, I find that the ridges tend to become transverse, as in $\mathcal{T}_{\text {urris }}$ or Tiara.

Maas, 1904, retains the genus Catablema of Haeckel to include medusx resembling Turris or Tiara, but with blindly-ending, lateral diverticula upon their radial-canal and ringcanal. As a matter of fact these diverticula a re highly variahle in different individuals of the same species and are seen in a more or less well-developed condition in the majority of Tiarinx. I therefore believe that confusion will be avoided if we combine the genera $\mathcal{T}_{\text {uris, }}$ Tiara, and Catablema to form a single genus. This should be called "Turris," for Lesson used this name on page 283 of his Hist. Zooph. Acal., and on page 17 of his "Prodrome," $18_{37}$ Tiara he defines later on page 286 of his "Histoire," I 843 , and on page 20 of his "Prodrome," 1837 .

I propose, therefore, following the lead of Vanhoffen, Hartlauh, and Maas, to reduce the 13 genera of Tiarina enumerated by Haeckel, 1879 , to 8, as follows: Stomotoca, Modecria, Protiara, Heterotiara, Pandea, Turris, Conis, and Calycopsis.

The Tiarine are widely distriluted, lut are abundant only along continental coasts, for in so far as is known, they arise by budding from Tubularian hydroids of the genera Perigonimus, Clavula (?), and Companiclava (?). Asexual budding or direct development in the medusa-stage is unknown. 
The medusa of the various genera of Tiarina hear a close resemhlance one to another. Their bells are usually miter-shaped; ectodermal ocelli are often found upon their hollow tentacle-bulbs, and their radial-canals are usually broad and Hat, and often with more or less jagged outlines.

All of the tentacles arise from the lower edge of the bell-margin when young, but as growth proceeds, the upper parts of the basal bulhs of the older ones are crowded and forced a short distance up the sides of the bell, while the smaller tentacles still remain upon the lower edge of the bell-margin. This gives the appearance of two rows of tentacles.

Hartlaub demonstrated that the so-called mesenteries of Haeckel, 1879 , are only the wide, funnel-like origins of the radial-canals, where they communicate with the stomach-cavity.

As Maas, 1904, has shown, the Tiarinxe have given rise to the more specialized Bythotiaridi, wherein the radial-canals have become branched, and the latter are probably related to the Williadi. The Tiarne are themselves derived, probalyly, from Codonidie in which the originally ring-like gonad has become radially' separated, so that it lies only in interradial positions on the wall of the stomach. They are thus, apparently, more highly specialized than the Codonidx. Calycopsis with its 16 simple, unhranched radial-canals may be regarded as a form intermediate between the Tiarinze and Bythotiaridi.

The Tiarinæe are distinguished from the Margelinx by the fact that oral tentacles are never found in the Tiarinx, hut are present in the Margelinie. Moreover, the tentacles of the Tiarina arise singly from the bell-margin, and are not grouped in clusters as is frequently the case in the more specialized Margelina. It seems not improluble that the Tiarina and Margelinx have arisen independently of each other from the Codonidx. A decided difference between the Tiarine and Margelinx is that in the former the entodermal cores of the tentacles are hollow, and in the Margelinx they are nearly, if not wholly, solid. When present the ectodermal ocelli in the Tiarina are on the outer sides of the tentacle-bullos, whereas in the Margelinæ they are on the inner (velar) sides.

Genus PROTIARA Haeckel, 1879.

Carminrothe beroe, SLA B ER, 1775 , Physikal. Belust., P. 64.

Protiara, Hafckel, 1879 , Syst. der Medusen, 1. 46.- Hakrite, 1902, Biological Bulletin, Boston, vol. 4, P. 17; 1904, Bull.

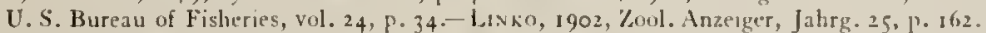

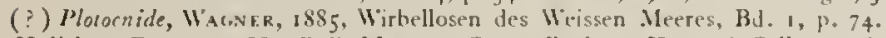

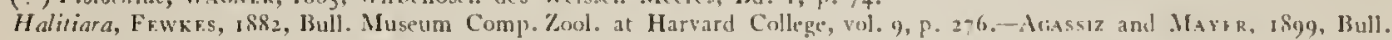
Museum Comp. Zool. at Harvard Collegr, vol. 32, p. 160.

GENERIC CHARACTERS.

Tiarinx with + well-developed, radially situated tentacles with hollow, basal bullos. With + Iongitudinal, swollen gonads on the + interradial sides of the stomach. The outer surfaces of these gonads are smooth, not folded, nor corrugated. The + lips are simple, not folded nor crenulated.

Haeckel, 1879 , founded this genus for $P$. totranema, which had been previously described by Slabber, 1775, under the name Carminrothe heroe from the North Sea and Finglish Channel. According to Vanhöften, 1891 (\%ool. Anzeiger, Bd. 14, p. 441), this medusa is only a young Corynitis. However this may be, Hargitt, 1902, discovered a medusa in Vineyard Sound, Massachusetts, which accords well with Haeckel's definition of Protiara. The gonads are described by Hargitt as being found in four separate, longitudinal, swollen regions in the interradial (radial?) sides of the stomach. Hargit cut no sections of the medusa, and consequently we must merely place this species provisionally in the genus Protiara, for if the gonads be developed so as to completely surround the stomach and are not separated radially, the medusa is one of the Codonida. If it he one of the Tiarina, it appears to constitute an interesting intermediate form between some Corynitis like member of the family Codonidx and the Tiarinx. It has the simple mouth, narrow canals, and smootlly rounded external surfaces of the manubrium characteristic of the Codonida, hut its 4 separated, interradial gronads, and its hollow, tapering tentacles ally it to the Tiarina.

Linko, 1902, secrioned a somewhat similar medusa from the Murman coast, between Russia and Norway, and demonstrated that the + gonads are interradial.

The medusa described by Fewkes as Malitiara formosa is evidenty a Protiara. 


\section{Protiara" beroe.}

Carminrothe beroe, SlabBer, 1775, Physikalische Belustingungen, Nürnherg, P. 64, taf. 14, fig. I. Oceania ietranema, Phron fit Lesurur, i 809 , Ann. du Mus. Hist. Nat., tome 14, p. 347 . Paris. Protiara tetranema, HAECkt.L, 1879 , Syst. der Medusen, p. 47.

(?) Protiara, Linko, 1902, Zool. Anzeiger, Bd. 25, p. 162, 2 figs.

(?) Protiara borealis= Plotocnide borealis, Colorless variety, Wacner, 1885 , Wirbellosen des Weissen Meeres, Bd. 1, p. 74, taf. 4, fign. 1, 2.

(?) (Syndiction?) incertum, Linko, 1900, Travaus Soc. Imp. Nat. de St. Pëtersbourg, tome 29, p. 151, fig. 1 (this is possibly Sarsia flammea?).

(?)Plotocnide incerta, Hartlaub, Nordisches Plankton, Nr. 12, p. 70, fig. 66.

Bell 6 to $15 \mathrm{~mm}$. high, 4 to $12 \mathrm{~mm}$. wide. Egg-shaped, with very thick walls, which in the upper part of the bell are one-third to one-fourth as thick as the bell-height. There are a few scattered nettle-cells over the exumbrella, these being more numerous in young than in old specimens. 4 tentacles, each 4 to 5 times as long as the bell-height, with thick basal hulbs about one-sixth as wide as the greatest width of the bell. No ocelli. The shafts of the tentacles bear garland-like pads of nettle-cells. There are 4 straight, narrow radial-canals with smooth edges. The nanubrium is short and even in mature medusa does not project beyond the velar opening. In young medus $x$ it is conical, in mature individuals very wide, but it narrows greatly at the neck immediately above the mouth. The neck is tubular, and the mouth is encircled with nematocysts. There are 4 longitudinal, interradial, ectodermal gonads, which project widely outward in the upper portion of the manubrium, hut do not extend to the mouth. The outer surfaces of the gonads are smooth.

Linko, Igo2, sectioned the manubrium and found that the entoderm forms 4 interradial partial septa which project inward in 4 longitudinal folds toward the axial center of the stomach, hut their inner edges do not fuse. The cells of these septa are digestive and they serve apparently to increase the area of the stomach-wall. The bell is colorless. Manubrium and tentacle-hulbs orange to yellow, radial-canals white.

Common in Barents Sea, North of Russia, between $68^{\circ} 54^{\prime}$ and $70^{\circ} 5^{\prime} \mathrm{N}$. lat.; and $33^{\circ} 30^{\prime}$ to $57^{\circ} 3^{8^{\prime}}$ long. E. from Greenwich. Rare in harbors and fjords.

(Syndiction?) incertum, Linko, 1900, may possihly he identical with $P$. beroe. It has a bell $3 \mathrm{~mm}$. high and somewhat more than $3 \mathrm{~mm}$. wide. The walls are thick and there is a rounded, dome-like apex sharply set off from the bell itself. The exumbrella is besprinkled with quite regularly and widely spaced nematocysts. There are 4 thick, tapering tentacles about one-third to one-half as long as the bell-height. These have large, spherical, nonocellated, basal bulbs. Velum well-developed. 4 straight, slender radial-canals. Stomach mounted upon a short, conical peduncle. The mouth does not reach the level of the velar opening. Mouth-opening round, without prominent lips. 'The gonad is figured as being much swollen ahove, tapering helow, and encircling the stomach. It is not wholly clear from Linko's description whether there are 4 interradial gonads or only one encircling gonad, for he states that the medusa resembles $P$. borealis $=(S y n d i c t i o n$ boreale Birula $)$ in some of its characters. Only about 10 very large eggs are produced by the fenale.

The manubrium is yellow to orange, tentacle-bullss red, and tentacles yellow. Other parts are colorless. Found in the White Sea, Northern Russia. It is probable that this form is a Sarsia, and is possibly $S$. fammea. See Hartlaub, 1903, 1907. There is, however, no peduncle in $S$. flammen.

\section{Protiara borealis.}

Plotocnide borealis, Wagner, 1885, WirbelJosen des Weissen Meeres, Bd. 1, p. 74, taf. 4, fign. 1, 2.

Syndictyon borenle, Birula, 1896 , Annuaire Musée Zool. Acad. Imp. Soc. St. Pétersbourg, tome I, p. 336 (Russian).

(?) Proitiara hackelii, Hargitt, 1902, Biological Bulletin, vol. 4, p. 16, fig. 4; 1904, Bull. U. S. Bureau of Fisheries, vol. 24 , P. 34 , I fig.

Plotocnide borealis, Hartlaub, 1907, Nordisches Plankton, Nr. 12, p. 69, fig. 65.

Bell is ahout $3 \mathrm{~mm}$. high and $1.5 \mathrm{~mm}$. wide, with simple rounded apex and thick walls. 4 radially situated tentacles, each about as long as the bell-height. These tentacles are besprinkled with nematocysts and have well-developed, conical, basal bulbs, without ocelli. Wagner's specimens were apparently much younger than Hargitt's and each tentacle terminated in a large knol-like cluster of nematocysts. In Hargitt's specimen the tentacles taper gradually to their tips. The velum is well-developed. There are 4 straight, narrow radial- 
canals, and a simple ring-canal. The nuanubrium is mounted upon a short, conical peduncle and is quite wide; rectangular above, hut nearly circular in cross-section near the mouth. There are 4 very small, simple lips. In Wagner's specimens the manubrium was only about

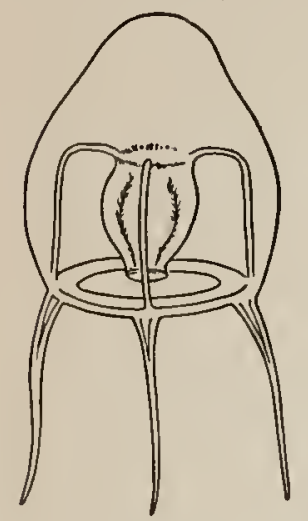

Fiti. 56.-Protiara "hackeli," after Hargitt, in Biological Bulletin. half as long as the depth of the bell-cavity, whereas in Hargitt's the mouth extended nearly to the level of the velar opening. This difference may he due to age(?) The gonads are + large, interradial, longitudinal swellings on the sides of the stomach. The outer surfaces of the gonads are smooth.

Wagner found a few specimens of this medusa in April, in the White Sea, north coast of Russia. Hargitt found an apparently identical medusa in summer near No Man's Land, an island off the southern coast of Massachusetts. The gonads and tentacle-bulls in Hargitt's medusa are milky in color, other parts heing transparent.

This species is distinguished from Protiara beroe (=l'. "tetruncma" Haeckel) by its absence of color and lack of ocelli.

Unfortunately no sections have been made of the manuhrium. Wagner's figure and description are unsatisfactory in that he leaves the position of the gonads in uncertainty and we can not tell whether there are 4 (interradial ?) gonads or only I encircling gonad.

\section{Protiara formosa. \\ Plate 6, figs. 4, 5, and 6; plate 13 , figs. 1 and 2.}

Halitiara formosa, Fewkes, 1882 , Bull. Mus. Comp.7.ool. at Harvard Coll., vol. 9, p. 276, plate 4, fig. 2.-MAYr. 1904, Memors Nat. Sci. Mus. Brooklyn Inst. Arts and Sci., vol. 1, No. 1, p. 8, plate 1, fig.8.-Ac.assiz, A., ANd MAYer, I8g9, Bull. Mus Comp. Zool. at Harvard Coll., vol. 32, p. I60.-Mayer, igoo, Bull. Mus. Comp. Zool. at Harvard Coll., vol. 37, p. 31 .

Bell ahout $3 \mathrm{~mm}$. high and pear-shaped with solid apical projection. There are 4 long, tapering, radially situated tentacles, about two-thirds as long as the hell-height. These tentacles a re hollow, with long, tapering, basal bulbs, and their ends are usually coiled in a close helix. In addition to these 4 long tentacles there are 24 to 35 short, solid tentacles, not onefourth as long as the large ones. These short tentacles are tightly coiled, their axial cells are chordate and they are more like cirri than tentacles. There are no ocelli or other marginal bodies. The velum is narrow. There are 4 straight, narrow radial-canals and a slender circular vessel. The manubrium is pyriform to conical and about half as long as the depth of the bell-cavity. The mouth is a simple, cruciform opening. The gonads are developed in the ectoderm on the interradial sides of the manuhrium and the ova are large and conspicuous. The entoderm of the manubrium and tentacle-bulbs in the female (plate 6, fig. 5) is green, but in the males light-brown (plate 6, fig. 4).

This medusa is very abundant at Tortugas, Florida, but is not so common in the Bahamas. An apparently similar form was found hy Agassiz and Mayer in the Fiji Islands, South Pacific, although the Pacific form was duller in color than is usual in Atlantic specimens.

Genus HETEROTIARA Maas, 1905.

Heterotiara, MAAs, 1905, Craspedoten Medusen der Siboga Exped., Monog. 10, p. 19.

The type species is Hetcrotiara anonyma Maas, from the Malay Archipelago. Only two imperfect specimens were found by the Siboga Expedition.

\section{GENERIC CHARACTERS.}

Tiarinze with 8 marginal tentacles ( 4 radial, 4 interradial). The riner-canal gives rise to one (or more?) hlindly-ending, centripetal diverticula. Gonads (?)

\section{Heterotiara anonyma Maas.}

Heterotiara anonyma, MAAs, 1905, Craspedoten Medusen der Siboga Exped., Monog. 10, p. 19, taf. 3, figs. 19-21.

Bell 12 to $16 \mathrm{~mm}$. high and slightly more than half as wide. Oval, dome-like, with very thick, gelatinous walls. 8 hollow marginal tentacles arise from the ring-canal and extend through the gelatinous sides of the bell so as to reach the exterior at a slight distance above the margin. The basal hulbs of these tentacles are small, and each one has a short, blunt, hollow, 
spur-like projection extending outward. There are no ocelli. All of the tentacles were broken off short and their normal length is thus unknown.

The ring-canal gives off a short, straight, blindly-ending diverticulum in one of the 4 interradii above the base of one of the interradial tentacles. 4 wide radial-canals as in other Tiarinx. They are straight-edged and lack the "glandular-pouches" seen in many Tiarinx.

The circular muscles of the subumbrella are very easily seen near the edges of the radialcanals and there are 4 interradial folds in the muscles which present the superficial appearance of radial-canals, but they are merely radial muscle furrows, in no way to be confused with the radial-canals.

The manubrium lacks a peduncle and is ahout half as long as the depth of the bell-cavity. It is 4 -sided at its base. The stomach part is urn-shaped, and there are 4 folded lips. Gonads(?) The tentacle-bulbs bear dense entodermal pigment granules. Color (?)

Two specimens were found by the Siboga expedition in the Malay Archipelago in vertical nets drawn from 500 fathoms depth to the surface, in lat. $0^{\circ} 17.6^{\prime} \mathrm{S}$., long. $129^{\circ}$ I $4.5^{\prime} \mathrm{E}$.

It is remarkable that in each of these specimens there was but one interradial diverticulum from the ring-canal. 4 interradial swellings are figured by Maas upon the sides of the stomach, but he does not mention gonads. Apparently both of his specimens were immature.
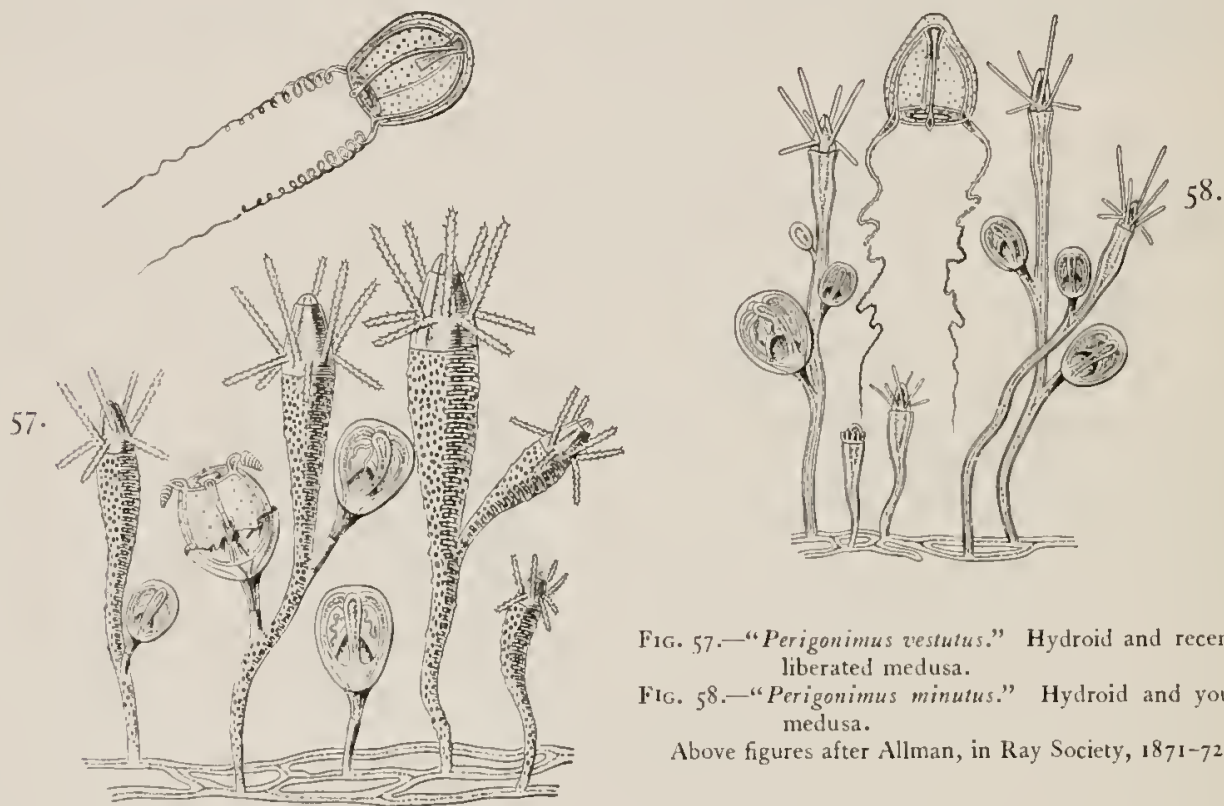

Fig. 57- "Perigonimus restutus." Hydroid and recently liberated medusa.

FIG. 58.- "Perigonimus minutus." Hydroid and young medusa.

Above figures after Allman, in Ray Society, $1871-72$.

Genus StomotocA L. Agassiz, 1862.

(?) Glalde betoe, StаввеR, 1775, Physikal. Belustig., p. $4^{6 .}$

Saphenia, Forbis (non Eschscholtz), 1848 , British Naked-eyed Medusa, p. 25, plate 2, fig.4.-Mic Cramy, 1857, Gymn. Charleston Harbor, p. 27.

Stomotoca, Agassiz, L., 1862 , Cont. Nat. Hist. U.S., vol. 4, p. 347.-A. Agassiz in L. Agassiz's, i 862, Cont. Nat. Hist. U. S., vol. 4, p. 347 (foot-note). -Agassiz, A., 1865 , North Amer. Acal.. p. 168.

Dinema, Van Benemfn, 1867, Mem. Acad. Roy. des Sci. Belgique, tom. 36, par. 2, p. 127.

Amphinemat Stomozoca, Ha Ecker., I879, Syst. der Medusen, PP. 49, 51 .

Codonorchis, HaECKF. I 1879 , Ibid., p. 51 .

Dinematella, Frwhes, 1881, Bull. Mus. Comp. Zool. at Harvard College, vol. 8, p. I51.

Stomotoca. Vanhör en, 189i, Zool. Anzeiger, p. 443.-MA.4s, i897, Mem. Mus. Comp. Zool. at Harvard Collegre, vol. 23, No. 1, p. I1.

This genus was founded by L. Agassiz, I862; the oldest species is possibly Stomotoca slabberi of the northem coasts of Europe. This species was first described by Slabber, 1775, under the name of Gladde beroe, and the hydroid and young medusa were described by Van Beneden, i 867, as Dinema slabberi. Slabber's description is, however, so unsatisfactory that we can not be certain that this medusa is actually a Stomotoca, and can not accept it as the type of the genus. Stomotoca dinema (Oceamia dinema) P'eron and Lesueur may be taken as the type of the genus. The grenus Saphenia Eschscholtz belongs to the Eucopidx. 


\section{Plate io.}

Fُig. I. Dissonema turrida. Tortugas, Florida, May 13, 1905. An abnormal specimen lacking ocelli and marginal cirri.

Fig. 2. Stomotoca dinema, female. Agassiz Laboratory, Newport, Rhode Island, July, I 892 .

Fig. 3. Stomotoca dinema, male. Agassiz Laboratory, Newport, Rhode Island, September 13, I 896 .

Fig. +. Stomotoca dinema, male. Agassiz Lahoratory, Newport, Rhode Island, July, I 896 .

Figs. 5 and 6. Stomotoca nugosa. Agassiz Lahoratory, Newport, Rhode Island, August 2 to I6, I 892 .

Drawn from life, by the author. 
PLATE 10

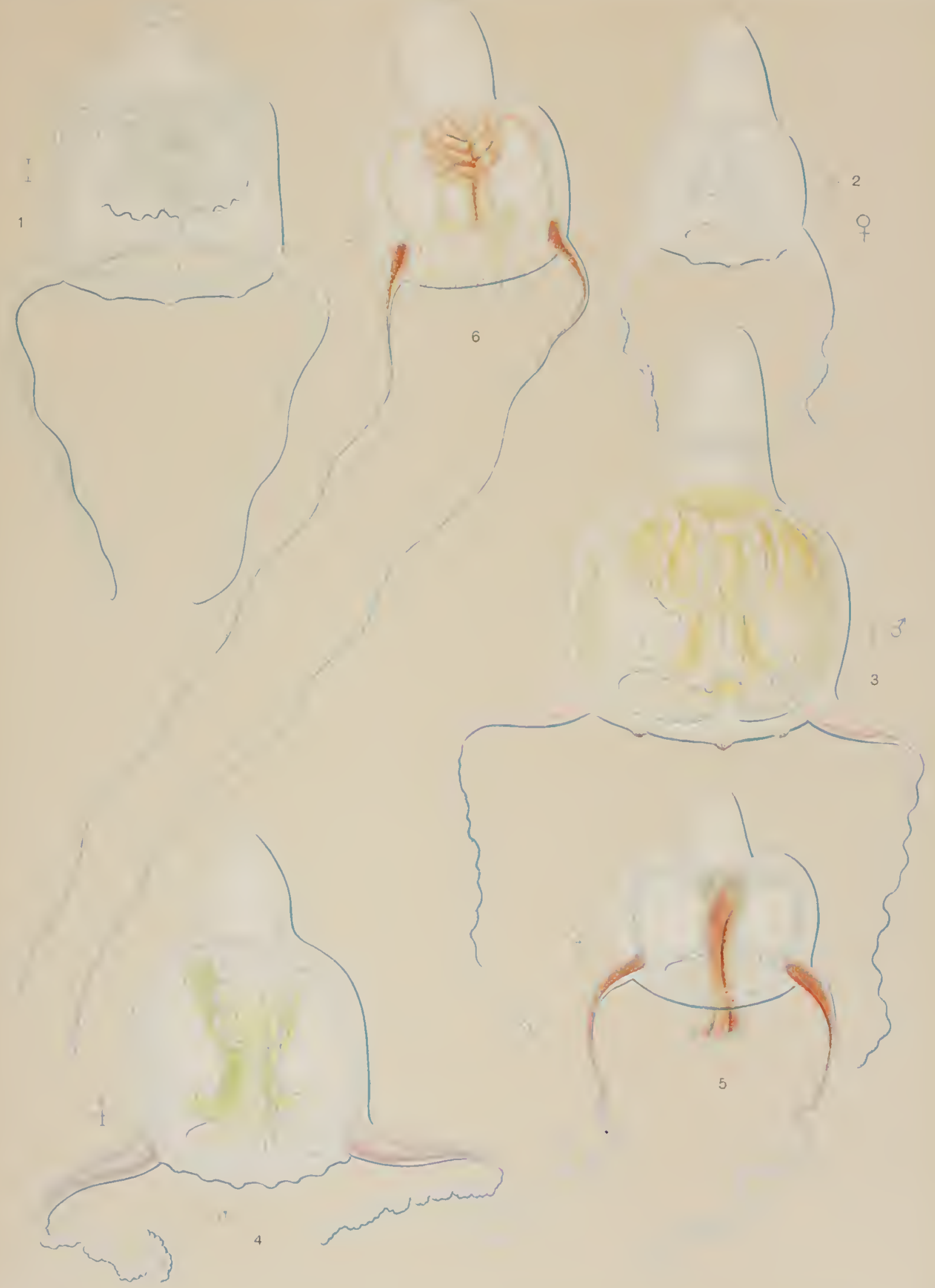



GENERIC CHARACTERS.

Tiarine with 2 long, diametrically opposed tentacles, and with more or less mumerous. rudimentary tentacles. The basal bulbs of the long tentacles are hollow. The t interradial gronads are complexly folded and are found in the ectoderm of the sides of the stomach. The + radial-canals are broad and flat and there is a well-developed circular canal. "The hydroid is Perigonimus.

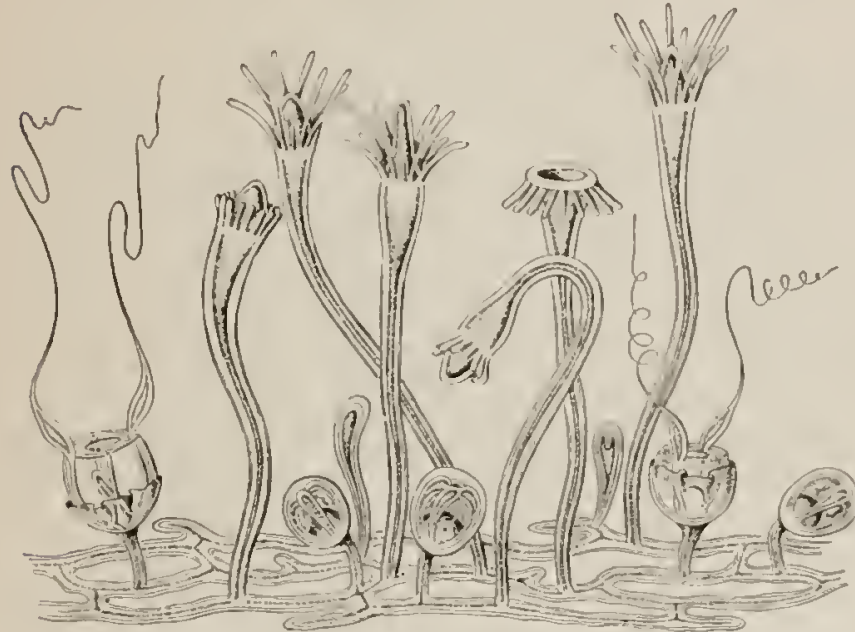

Fic. 59.-Perigonimus "serpens," after Allman, in Ray Society, i $871-72$.

There are a number of species of Perigonimus which probahly produce free (Stomotoca) medusa, but the medusa is as yet unknown. Such are: Perigonimus schncideri Motz-Kossowska, 1905. Archiv. Zool. Exper., ser. 4, tome 3, p. 72 , fig. vi; a red-colored Mediterranean hydroid which grows upon Membranipora and is distinguished by a cup-like expansion of perisare at the base of each hydranth. The clavate hydranths have about 10 tentacles. Another Mediterranean species is $P$. nopolitanus of Hargitt, 1904. Mitth. Zool. Sta. Neapel, Bd. 16, p. 57 I. taf. 22, fig. 25; also $P$. stcinachi Jickeli, 1883 , Morphol. Jahrb. Leipzig, Bd. 8, p. 617, taf. 27, figs. I-9, from Trieste, Adriatic. We present figures of various species of Perigonimus which produce free medusa, but in which the sexually mature medusa is undetermined. Perigonimus antarcicus (Hickson and Gravely, 1907, National Antarctic Expedition of I $901-04$. vol. 3, Nat. Hist., Hydroid Zoophytes, p. 4, plates I and 4 ) is found attached to the stems of Halecium in depths of o to I 30 fathoms in McMurdo Bay. South Victoria Land, Antarctic. It produces fixed gonophores, and is the only form of Perigonimus known from Polar seas.

Stomotoca dinema L. Agassiz.

Plate 9, figs. 8 to 10; plate 10 , figs. 1 to 4 .

Oceania dinema, Píros r.t Lestétr, 1809 , Ann. du Muséum d'Hist. Nat., tome 14, p. 346. Escuscuol.tz, 1829, Syst. der Acalephen, p. $9^{\&}$.

Saphenis dinema, Forbes, 1848 , British Naked-ered Medusx, p. 25, plate 2, fig. + (Excl. sin.).

Sapheris titania, Gosse, 1853 , Naturalists' Rambles, Devonshire Coast, p. 387 . plate 26, figs. 7-9.

Stomotoca dinema, Aciassiz, L., I S62, Cont. Nat. Hist. U. S., vol. 4, P. 347.

Amphinema titania, Hafcier, 1879 , Syst. der Medusen, P. 50.-BEDot, 1901, Revue Suisse de Zool., tome 9. p. 4 \$ $\$ 2 ; 16 i d$. Igo5, tome $1_{3}$, P. 131 (all papers to 1850 ).

Amphinema dinema, Brow's, 1896 , Proc. Zool. Soc. London, p. 475.

American variety $=$ Stamotoca apicata, L. Agassiz.

Male:

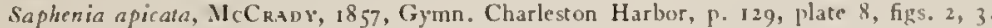

Stomotoca apicara, Aciassiz, L., 1862 , Cont. Nat. Hist. U.S., vol. 4, p. 347.-AGassiz, A., i865, North Amer. Acal., p. 168. Amphinema apicatum, Ha eckFl, 1879 , Syst. der Medusen, p. 50.

Female:

Dinemarella cavosu, Fewkes, 188 1, Bull. Mus. Comp. Zool. at Harvard College, vol. 8, p. I 51 , plate 11, figs. 2, 3; plate +, fig. $3 ; 1884$. Amer. Naturalist, vol. 19, p. 195, 1 fig.

Stomotoca apicata, Marer, 1900, Bull. Mus. Comp. Zool. Harvard College, vol. 37, p. 3, plate 2, figs. 3, 4. Harcitr, 1904 Bull. U.S. Bureau of Fisheries, vol. 24, P. 35, 2 figs. (Figure of male is $S$. apicata, but that of "female" is $S$.rugosa.)Nutring, 190I, Bull. U. S. Fish Commission for 1899 , vol. 19, p. 37 I, fig. 77.

EUROPEAN MEDUSA

Bell $3 \mathrm{~mm}$. long and $2 \mathrm{~mm}$. wide, with a narrow, elongate, sharp-pointed apex. 2 long tentacles, 2 to to times as long as the bell-height. Nhout $2+$ small tentacle-hulhs. "There are no ectodermal ocelli. Stomach oval, ahout half as long as the depth of the bell-cavity and square in cross-section. + well-developed, lanceolate lips. + simple, slender radial-canals and 
ring-canal. The gonads are 8 adradial, transversely folded, ectodermal regions on the sides of the stomach. Stomach yellowish-brown or green, tentacle-bulbs crimson or purplish.

Found off the coasts of Great Britain. Hydroid unknown.

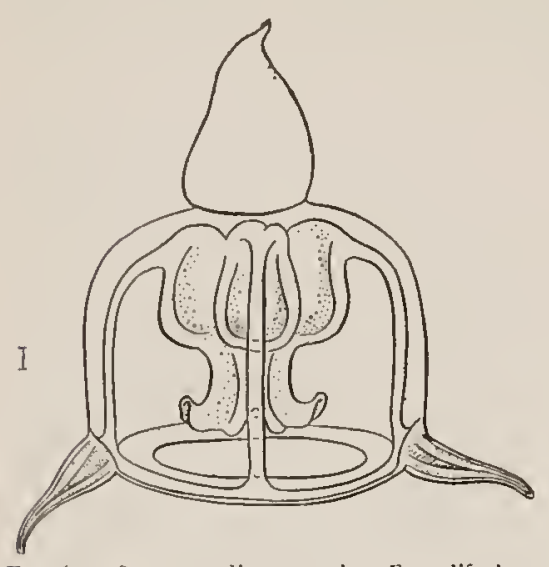

Fic. 6o.--Sromoroca dinema, male. From life, by the author. Mousehole, Cornwall, England, October 28, 1907.

I have seen medusx off the coast of Cornwall, England. which were identical with Stomotoca apicata of America.

\section{AMFRICAN MEDUSA.}

In the adult American medusa the bell is about 4 $\mathrm{mm}$. high and $2 \mathrm{~mm}$. wide. There is a large apical projection which is hollow in the female, hut usually solid in the male medusx. The bell-walls are thin and the sides vertical below, but sloping inward a bove to a pointed apex. There are 2 long, diametrically opposed tentacles, with large, tapering, hollow hasal bulbs. There are no ocelli. These long tentacles are highly contractile, but are usually about as long as the bell-height. Their shafts are covered with small wart-like clusters of nematocysts. In addition to the 2 long tentacles, there are 6 or more small rudimentary tentacle-bulbs upon the bell-

Synopsis of the Speries of Stomotoca.

\begin{tabular}{|c|c|c|c|c|c|c|c|}
\hline & $\begin{array}{l}\text { S. dinema } \\
\text { Haeckel. }\end{array}$ & $\begin{array}{l}\text { S. "apicata" } \\
\text { L. Agassiz. }\end{array}$ & $\begin{array}{l}\text { S. atra } \\
\text { L. Agassiz. }\end{array}$ & S. octaedra. & $\begin{array}{l}\text { S. rugosa } \\
\text { Mayer. }\end{array}$ & $\begin{array}{c}\text { S. pterophylla } \\
\text { Haeckel. }\end{array}$ & $\begin{array}{l}\text { S. divisa } \\
\text { Maas. }\end{array}$ \\
\hline $\begin{array}{l}\text { Size of bell } \\
\text { in } \mathrm{mm} \text {. }\end{array}$ & $\begin{array}{l}3 \text { long, } 2 \text { wide. } \\
\text { Apex solid. }\end{array}$ & $\begin{array}{l}4 \text { high, } 2 \text { wide } \\
\text { with solid } \\
\text { apex in male } \\
\text { and hollow } \\
\text { apex in } \\
\text { female. }\end{array}$ & $\begin{array}{l}25 \text { high, } 22 \\
\text { wide. Apex } \\
\text { solid. }\end{array}$ & $\begin{array}{l}2.5 \text { high, } 2 \\
\text { wide. Apex } \\
\text { solid. }\end{array}$ & $\begin{array}{l}5 \text { high, } 3 \text { wide. } \\
\text { Apex large, } \\
\text { solid. Sides } \\
\text { thin. }\end{array}$ & $\begin{array}{l}30 \text { wide, I } 2 \text { high. } \\
\text { Small apical } \\
\text { projection. } \\
\text { Flaring sides. } \\
\text { Thick gelati- } \\
\text { nous substance. }\end{array}$ & $\begin{array}{l}30 \text { wide, } 20 \\
\text { high. As in } \\
\text { S. ptero- } \\
\text { phylla. }\end{array}$ \\
\hline $\begin{array}{l}\text { Length of } \\
\text { tentacles } \\
\text { in terms } \\
\text { of bell-ra- } \\
\text { dius }(r) \text {. }\end{array}$ & 6 to 30. & 4 & $10 \pm$ & $5 \pm$ & $30 \pm$ & $20 \pm$ & $\begin{array}{l}\text { As in } S . \\
\text { pterophylla. }\end{array}$ \\
\hline $\begin{array}{l}\text { Number of } \\
\text { rudimen- } \\
\text { tary ten- } \\
\text { tacle- } \\
\text { bulbs. }\end{array}$ & 24 & 6 & 80 & 6 & 14 & 60 to 80. & $\begin{array}{l}\text { As in S. } \\
\text { pterophylla. }\end{array}$ \\
\hline $\begin{array}{l}\text { Ectodermal, } \\
\text { abaxial, } \\
\text { tentacular } \\
\text { ocelli. }\end{array}$ & None. & None. & None. & $\begin{array}{l}8, \text { orange- } \\
\text { colored. }\end{array}$ & None. & None. & None. \\
\hline $\begin{array}{l}\text { Shape of } \\
\text { manu- } \\
\text { hrium. }\end{array}$ & $\begin{array}{l}\text { Oval, half as } \\
\text { Jong as } \\
\text { depth of } \\
\text { bell-cavity. }\end{array}$ & $\begin{array}{l}\text { Flask-shaped. } \\
4 \text { folued, } \\
\text { cruciform } \\
\text { lips. }\end{array}$ & $\begin{array}{l}\text { Half as long as } \\
\text { depth of } \\
\text { bell-cavity. } \\
\text { Gonads } \\
\text { folded as in } \\
\text { Turris. }\end{array}$ & $\begin{array}{l}\text { As in } S . \text { api- } \\
\text { cata. }\end{array}$ & As in S, atra. & As in $S$.atra. & $\begin{array}{l}\text { As in } S . \\
\text { pterophylla. }\end{array}$ \\
\hline Color. & $\begin{array}{l}\text { Stomach } \\
\text { yellowish- } \\
\text { brown to } \\
\text { green. Ten- } \\
\text { tacle-bulbs } \\
\text { purple or } \\
\text { crimson. }\end{array}$ & $\begin{array}{l}\text { In male, stom- } \\
\text { ach green } \\
\text { and tenta- } \\
\text { cle-bulbs } \\
\text { purple. In } \\
\text { female, dull } \\
\text { milky-ye!low. }\end{array}$ & $\begin{array}{l}\text { Mouth dull- } \\
\text { yellow, } \\
\text { gonads very } \\
\text { darli-brown, } \\
\text { nearly black, } \\
\text { tentacles } \\
\text { light-brown. }\end{array}$ & $\begin{array}{l}\text { Stomach and } \\
\text { tentacles } \\
\text { green, with } \\
\text { orange cen- } \\
\text { ter in stom- } \\
\text { ach. }\end{array}$ & $\begin{array}{l}\text { Stomach, gon- } \\
\text { ads, and ten- } \\
\text { tacle-bulbs } \\
\text { brick-red } \\
\text { to nearly } \\
\text { black. }\end{array}$ & $\begin{array}{l}\text { Stomach and } \\
\text { tentacle-bulbs } \\
\text { brown. Radial- } \\
\text { canals and } \\
\text { gonads milky- } \\
\text { white. }\end{array}$ & $\begin{array}{l}\text { Gonads } \\
\text { orange to } \\
\text { cinnabar- } \\
\text { red. Stom- } \\
\text { ach and ten- } \\
\text { tacle-bulbs } \\
\text { yellow. }\end{array}$ \\
\hline $\begin{array}{l}\text { Where } \\
\text { found. }\end{array}$ & $\begin{array}{c}\text { Coast of Great } \\
\text { Britain. }\end{array}$ & $\begin{array}{l}\text { Atlantic coast } \\
\text { of United } \\
\text { States. } \\
\text { Probably } \\
\text { identical } \\
\text { with S.di- } \\
\text { nema. }\end{array}$ & $\begin{array}{l}\text { Port Town- } \\
\text { send, Wash- } \\
\text { ington. } \\
\text { Pacific coast } \\
\text { of America. }\end{array}$ & $\begin{array}{c}\text { Tortugas and } \\
\text { the Baha- } \\
\text { hamas, in } \\
\text { summer. }\end{array}$ & $\begin{array}{l}\text { Woods Hole to } \\
\text { Tortugas, } \\
\text { Atlantic } \\
\text { coast of } \\
\text { United } \\
\text { States. }\end{array}$ & $\begin{array}{l}\text { Bahamas, Tortu- } \\
\text { gas, West } \\
\text { Indies. }\end{array}$ & $\begin{array}{l}\text { Pacific coast } \\
\text { of Central } \\
\text { America. }\end{array}$ \\
\hline
\end{tabular}





\section{Plate i i}

Figs. I and 2. Stomotoca rugosa, young and mature. Newport, Rhode Island, August 4, I892.

Fig. 3. Young medusa of Perigonimus jonesii. Agassiz Laboratory, Newport, Rhode Island, August 22, I 896.

Fig. 4. Young medusa of Perigonimus jonesii. Agassiz Laboratory, Newport, Rhode Island, July, I896.

Fig. 5. Stomotoca octaedra, young medusa. Tortugas, Florida, July i7, I 898 .

Fig. 6. Stomotoca octacdra, Tortugas, Florida, June, 1897.

Fig. 7. Pandea violacca. Aboral view of gonads of the medusa shown in figure I, plate I 2 .

Drawn from life, by the author. 


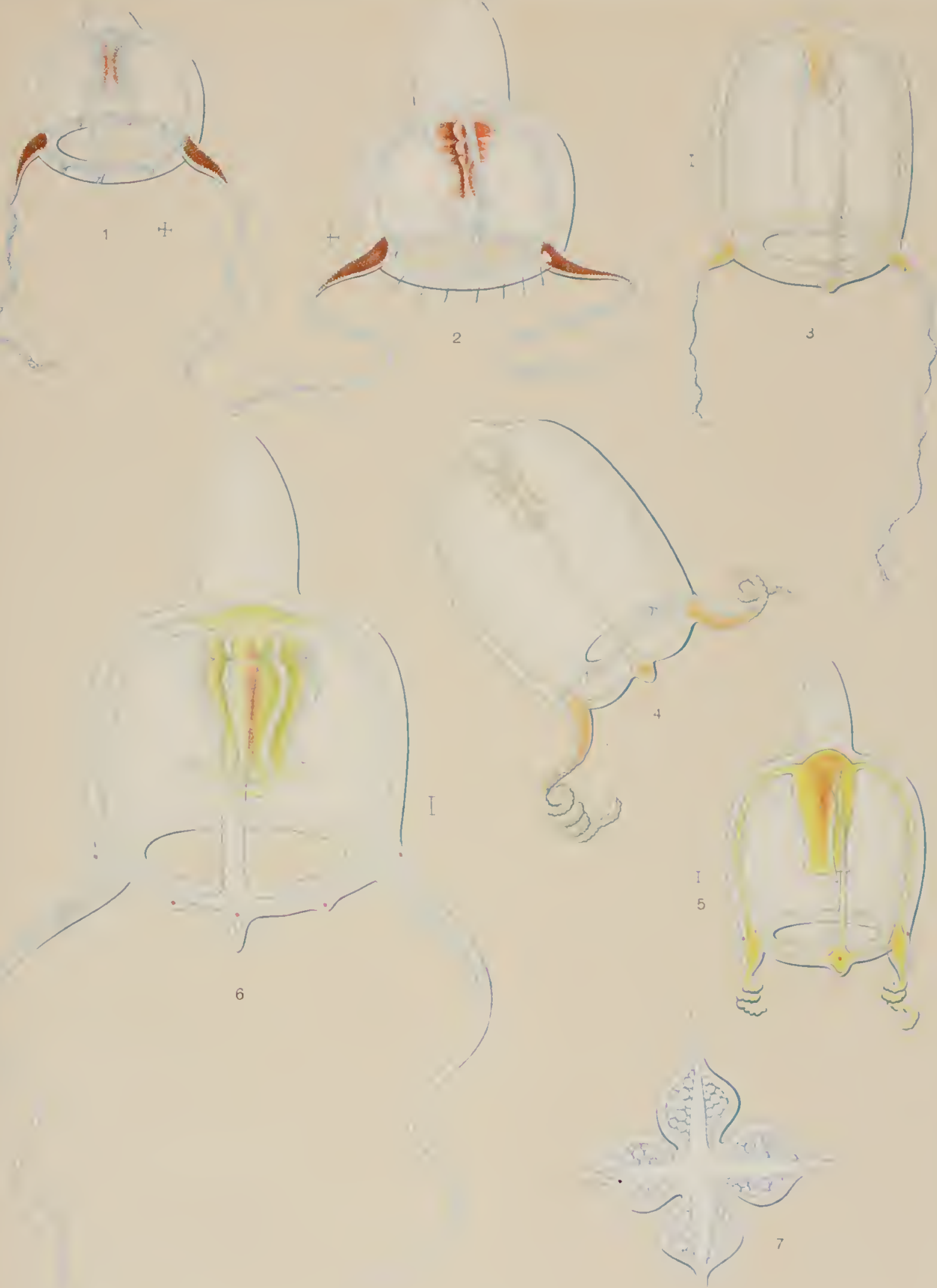



margin. These lack ocelli. The + radial-canals are wide and Aat. The houndaries of the radial-canals and of the ring-canal are often bluntly serrated. The manulurium is Aaskshaped; there is no peduncle and the + lips are cruciform, crenulated, and curve slightly: upward. The ectoderm of the upper part of the manubrium on both sides of the + radialcanals is thrown into interradial folds or convolutions and the gonads are developed in this region.

In the male the color of the manubrium varies from intense green to translucent ocheryellow or cream-color. The basal bulbs of the tentacles in the male vary from faint to deep purple. In the female the manubrium is usually translucent ocher-yellow or cream-colored, but occasionally straw-colored or faintly green. The tentacle-bults of the female are usually translucent milky or ocher, but occasionally one is found having faintly purple tentacte-luths. These sexually dimorphic color peculiarities are seen in the smallest and youngest medusa as well as in adults. In very young medusa the apical projection is small or absent. There are 2 tentacles and only 2 rudimentary tentacle-hulbs.

This medusa is common at Newport, Rhode Island, from July 15 to September. It is not common at Tortugas, Florida, and is not seen north of Cape Cod, Massachusetts. On Octoher 28, 1907, I found two male medusie of this species off Mousehole, Mounts Bay, Cornwall, England.

This species furnishes that which is probahly the most remarkahle instance of sexual dichromatism to be met with among the hydromedusa, the color differences affecting parts other than the gonads.

The two males found off the coast of Cornwall, England, were each $2.2 \mathrm{~mm}$. high and similar in all respects to the typical American form; with intense green manuhrium and purple tentacle-bulbs, without ocelli. The bell-apex was solid and getatinous. I believe that $S$. apicata of America is identical with $S$. dinema of Europe. The European medusa may have more rudimentary tentacle-bullos, but these are very variahle in number in the American form.

\section{Stomotoca atra Agassiz.}

Stomotoca atra, Acisssiz, 1.., 1862, Cont. Nat. Hist. U. S., vol. 4, 1. 347.-Acissiz, A., 1865, North Amer. Acal., p. I6u, figs. 271-273. Has.cki.1, 1879, Syst. dir Medusen, p. 53.

Bell 20 to $25 \mathrm{~mm}$. high, 20 to $22 \mathrm{~mm}$. wide. Bell-shaped, higher than a hemisphere. 2 long, highly contractile tentacles, and about 80 small rudimentary tentacle-bulbs. Stomach about half as long as the depth of the hell-cavity. Swollen, t-sided, and mounted upon a peduncle. 4 lips. The gonads are 8 adradial, linearcross-foldings upon the sides of the stomach, each gonad consisting of 12 to 5 folds as in Turris. The mouth is dull yellow. Gonads darkbrown to almost black. Tentacles light-brown.

Found by A. Agassiz in great numbers in Port Townsend, Washington, Pacific coast of the United States; from June until September.

\section{Stomotoca octaedra.}

Plate 11 , figs. 5 and 6.

Codonorchis oclaedrus, HaFCK:L, 1879 , Syst. der Medusen, p. 51.

Stomotoca australis, Mayre, 1900, Bull. Mus. Comp. Zool. at Harvard Collegr, vol. 37, p. 32, plate 1, fig. 2; Ibido, 1904, Mem. Nat. Sci. Brooklyn Inst. Museum, vol, 1, 1. 9, plate 1, fig. 9.

The following description is derived from studies of specimens found in the Bahamas, and at Tortugas, Florida.

Immature medusa (plate I I, fig. 6).-Bell ahout $2.5 \mathrm{~mm}$. high and with well-developed, sharp-pointed, apical projection upon aboral side. Bell-walls thin: There are 2 radially situated, diametrically opposed tentacles, each about as long as the bell-height and with long hollow, tapering basal bulhs. There is a single, ectodermal, orange-colored ocellus upon the outer side of each tentacle-bulh near its point of origin from the umbrella. In addition to the 2 long rentacles there are 2 short, rudimentasy tentacle-bulbs $90^{\circ}$ from the long tentacles. Each of these rudimentary tentacle-bulbs has an ectodermal, orange-colored ocellus upon its outer side, and there are + other ocelli upon the bell-margin in interradial positions. There are thus 8 ocelli in all, + on the tentacle-hulbs and + interradial ones on the hell-margin. "The 
velum is well developed. There are 4 straight-edged, wide radial-canals and a broad circular vessel. The manubrium is urn-shaped, quite wide, and with 4 cruciform, recurved lips. The mouth is at a point about half-way between the inner apex of the bell-cavity and the velar opening. The gonads are found in complexly folded regions upon the 4 interradial sides of the stomach. The manubrium and tentacle-bulbs are yellow or greenish-yellow. The entodermal core of the stomach is often orange.

When about I mm. high (plate 11 , fig. 5) the bell has a small apical projection. There are 2 large tentacles and 2 rudimentary tentacle-bulbs, each with an orange ocellus. There are no other ocelli upon the bell-margin. The manubrium is slender and urn-shaped, without gonads and with 4 simple, cruciform lips.

The young of this medusa are common at Tortugas, Florida, and in the Bahamas throughout the summer. Although the medusa has usually but 2 long tentacles, occasionally one is seen with + long, equally developed, radially situated tentacles. The mature medusa has not been seen and we must remain in doubt concerning its generic position, for it may he a young Turris. The presence of ocelli upon the tentacle-bulbs distinguishes it from all other American species of Stomotoca and is a character commonly seen in Turris.

I believe this medusa to be identical with Haeckel's "Codonorchis octaedrus," which he obtained off the Atlantic coast of France. Haeckel states that this medusa had 2 well-developed tentacles and ro tentacle-bulbs ( 2 perradial and 8 adradial). He described the ocelli as brownish-red. Apparently he found but a single specimen and the interradial tentacle-bulbs may have failed to develop. His medusa is described as having folded gonads, and is said to be $4 \mathrm{~mm}$. high and 2.5 wide.

Stomotoca rugosa Mayer.

Plate 10 , figs. 5 and 6 ; plate 11 , figs. 1 and 2.

Stomoloca apirata, Fewkes, iS8 r, Bull. Mus. Comp. Zool. at Harvard College, vol, 8, p. 152, plate 2, figs. I, 4, 9.-HargitT, 1901, American Naturalist, vol. 35, p. 581, fig. 40; 1904, Bull. U. S. Bureau of Fisheries, vol. 24, p. 35, 1 fig. (erroneously labeled Stomotoca apicala, female).-Rittensouse, 1907, Proc. Boston Soc. Nat. Hist., vol. 33, PP. 440, 445, 452,456 (embryology).

Stomotara rugosa, M+Yire, 1950, Bull. Mus. Comp. Zool. at Harvard College, vol. 37, P. 4, plate 2, fig. 5; Ihid., p. 32. Amplinema apjealum, Brooks, 1883, Studies Jolıns Hoplins Bıol. Lab., vol. 2, p. 473.

Bell $5 \mathrm{~mm}$. high and $3 \mathrm{~mm}$. broad. Solid, apical projection, in some individuals short and blunt, in others long and slender. Bell-walls of moderate thickness, and bell itself, exclusive of the apical projection, somewhat higher than a hemisphere, with relatively vertical, straight sides. There are 2 long, diametrically opposed tentacles, which a re of equal length, and when stretched are fully ten times as long as the bell-height. They are, however, highly contractile and may become not more than one-tenth as long as when fully expanded. The basal hullss of these long tentacles are large; hollow, and tapering and there are no ocelli.

In addition to the 2 long tentacles there are i 4 small, permanently rudimentary tentacles, 2 at the bases of 2 of the radial-canals and 3 in each interradial quadrant. These lack ocelli. The velum is well developed. There are 4 wide radial-canals and a ring-canal, all with jagged edges. The manubrium is quadratic and flask-shaped and the mouth in old medusa is about at the level of the velar opening. The mouth is cruciform and there are 4 prominent, recurved, crenulated lips. The mature sexual products are found in the ectoderm of the adradial walls of the stonach on both sides of the places of entrance of each of the 4 radialcanals where the surface is thrown into 8 series of complex folds and ridges, a double ridge of folds in each interradius.

The gelatinous substance of the hell is transparent, but the entoderm of the tentacle-bulbs and stomach is brick-red, often streaked with sooty brown. The radial and circular canals are faint red in color. Specimens from Tortugas, Florida, often show black streaks through the hrick-red color of the stomach and tentacle-bulbs, and medusx which have been confined in aquaria for some days often become wholly black in these parts.

IIydroid and young medusa.-Professor W. K. Brooks, $188_{3}$, describes the hydroid. It is a Prigonimus, very much like $P$. minutus Allman, $187 \mathbf{I}$ (Monog. Tubularian Hydroids, P. 324, plate xi, figs. 4-6). It was found at Beaufort, North Carolina, growing upon the lower 
surface of the shells of Limulus, fastened to the sand-tubes of Sabellaria. The stems are simple and unbranched and are only about $0.2 \mathrm{~mm}$. in height. They are covered for about twothirds of their length by a delicate, closely-adherent film of perisare to which foreign particles become attached. The stomach occupies about one-fourth or one-fifth of the length of the stem from which it is separated by a slight constriction. Each polypite has 10 tentacles which point alternately backwards and forwards, those pointing forwards being a little longer than the others. The medus $x$ are attached ly very short peduncles to the sides of the stems. When the medusa is set free it is about $0.5 \mathrm{~mm}$. in height and there is no trace of the apical projection, which develops in about eight days.

In an abnormal individual medusa of this species found at Newport, Rhode Island, in July, 1892 , there were + long tentacles, I at the base of each of the + radial-canals. This medusa was maintained alive in an aquarium for more than a month. When first found it had only 2 long tentacles which were diametrically opposite one another at the bases of 2 of the radial-canals. The other 2 tentacles developed later, after the first pair had attained their full length. The medusa had then 4 radially placed tentacles and 12 rudimentary tentacle-buds. This variation is interesting, as it illustrates the close relationship between Stomotoca and Turris.

Stomotoca rugosa is common on the southern coast of New Fingland in summer. It is found all along the coast to southern Florida, but is not very common at Tortugas or among the Bahama Islands. It has never been seen north of Cape Cod, Massachusetts.

Rittenhouse, 1907, finds that the eggs of this medusa are laid hetween $5^{\mathrm{t}}$ to $5^{\mathrm{h}} 30^{\mathrm{m}}$ in the morning. The egg is chalky-white. The entoderm is formed by cellular ingression. The planula settles down upon its side and becomes a hranched hydrorhizal from which the polypites bud out.

\section{Stomotoca pterophylla Haeckel.}

Plate 29, figs. 3 to 5 ; plate 30, fig. 7 .

Stomotora pierophylla, НАEcks.t, 1879, Syst. der Medusen, p. 52, taf. 4, fig. ro.

Stomotoca periphylla, lifwkes, 1889 , Report Commiss. Fish and Fisheries for 1886, p. 524.

Adult medusa.-Bell conical, with widely flaring sides and small, sharply-pointed apical projection. It is about 20 to $30 \mathrm{~mm}$. in diameter and 10 to $12 \mathrm{~mm}$. in height. "The gelatinous substance is very thick at the aboral pole, but becomes thin at the hell-margin. There are 2 long, tapering, marginal tentacles which are situated at the bases of 2 of the radial-canals, $180^{\circ}$ apart. When expanded these tentacles are fully 10 times longer than the bell-diameter. In addition to the long tentacles, there are about 60 to 80 small rudimentary tentacle-bullis, i 5 to 20 in each quadrant. The 4 radial-canals are wide, riblon-like, and Hat, with smooth, simple, outer edges. The ring-canal is narrow and its upper edge is smooth. There is a very wide, conical peduncle which extends about to the level of the velar opening. The gastric part of the manubrium is large and swollen and lies mainly outside of the bell-cavity. There are t prominent, complexly crenulated, lanceolate lips. The gonads occupy 8 adradially siruated, longitudinal swellings upon the sides of the stomach (plate 29, fig. 4). Each gonad consists of a row of swollen, leaf-like ridges which trend in a transverse direction. The stomach and tentaclebulbs are hrown. Radial-canals milky. There are no ectodermal ocelli.

This species is found in the West Indies and the warmer parts of the Gulf Stream. I found many specimens among the Bahamas and at the Tortugas during the spring and carly: summer of 1907 .

It is closely related to Stomotoca divisa, described hy Maas, from the west coast of Mexico (Men. Mus. Comp. Zool. at Harvard College, vol. 23, p. I1, taf. 1, figs. I 19, 1847), lut its rich-brown entoderm distinguishes it from the Pacific species.

Haeckel describes this medusa from preserved specimens, and this may account for certain errors in his description and figure. A small apical projection appears to be constantly present and there are no "ocelli." "The radial and circular muscles of the velum are very powerfully developed. In extreme states of contraction of the hell the peduncle may extend heyond the velar opening or fall short of reaching it. The long tentacles are highly contractile and when expanded are reduced to mere thread-like filaments. 
Stomotoca divisa Maas.

Siomoroca dizisa, MAas, 1897, Mem. Museum Comp. Zool. at Harvard College, vol. 23, p. 11, taf. 1, fign. 1-9.

Bell 20 to $30 \mathrm{~mm}$. wide, 15 to $20 \mathrm{~mm}$. high. Upper part of bell thick, solid, and domelike, and separated by an annular furrow from the thin-walled, marginal part of bell. This

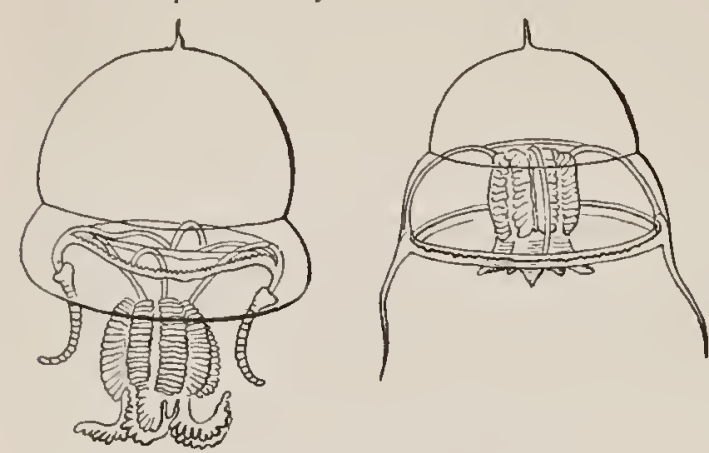

Fic. 61.--Stomotoca divisa, after Mas, in Mem. Museum Comp. Zool. at Harvard College, showing different states of contraction of the bell.

$S$. pterophylla of the West Indies by its brilliant coloration, $S$. pterophylla heing constanty dull-brown.

Perigonimus jonesii Osborn and Hargitt.

Plate 11 , figs. 3 and 4 .

Perigonimus jonesii, OsBorn and Hargitr, 1894 , Amer. Naturalist, vol. 28, p. 27, figs. 1-12.-HARGitr, 1895, Mittheil. Zool. Station Neapel, Bd.11, P. 479; 1904, Bull. U.S. Bureau of Fisheries, vol. 24, p. 33, I fig.; 1901, American Naturalist, vol. 35, p.308, fig. 4; p.579, fig. 37.-Netrins, 1901, Bull. U.S. Fish Commission, vol.19, pp. 331, 372, fig. 80.

Young medusa. - None of the specimens yet seen were mature. Bell of largest $2 \mathrm{~mm}$. in height and side walls extremely thin and flexible. There is a very small, dome-shaped apical projection. There are 2 well-developed, diametrically opposed tentacles, which are situated at the lases of 2 of the radial-canals. These tentacles are of unequal length and are at times carried curled in a close helix and at other times are extended to their full length, in which case one of them becomes about as long as the bell-height, while the other attains to about twice this length. The basal bulbs of these tentacles are long, conical, and hollow and have no ocelli, and the shafts of the tentacles are thickly covered with nematocyst-cells. In addition to these well-developed tentacles, there are 2 small tentacle-bulbs, situated at the bases of the 2 radial-canals $90^{\circ}$ away from the long tentacles. There are no ocelli. The velum is wide and Hexible. There are 4 straight, slender radial-canals and a narrow, circular tube. The nanubrium is short and simple, with a wide base and + simple, cruciform lips.

The ectoderm of the manubrium and tentacle-bulbs is of a dull ocher-yellow.

This medusa is very rare; only 3 specimens have been seen by me during 3 summers' study. All of my specimens were found in Newport Harbor, Rhode Island, during July and August.

Hydroid. - The hydroid has been described by Osborn and Hargitt, I894, from Cold Spring Harbor, Long Island, New York, where it is found very commonly upon the alodomen and upon the walking legs of the spider-crab (Iibinia emarginata). It is a Perigonimus. The stens arise from a creeping hydrorhiza and branch luxuriantly. The oldest polypite is found at the distal end of the stem. The stems are covered with a thick gelatinous perisarc which extends up the stems to the level of the tentacles, to which it is fastened. There are nomally i 6 tentacles in a single circlet around the base of the hypostome. These assume an alternately reflected position. The medusa-buds arise in clusters from near the center of the stems. They are covered with the thick perisarc and each one is attached to the stem by means of a well-developed peduncle. When set free the medusa has 2 diametrically opposed tentacles which are usually carried turned inward into the bell-cavity. The hydroid is fleshcolored.

The medusa can at once be distinguished from $S$. apicata by the extreme tenuity and Hexibility of the bell-walts. The bell is also higher and narrower than in $S$. apicata The 
medusa swims by the aid of a rhythmical series of wave-like contractions which travel one after another up the very flexible sides of the bell, from margin to apex. The efficiency of these movenents is greatly enhanced by the cooperation of the powerful velum.

The fully-developed medusa is unknown and it-is possible that this medusa may not he Stomotoca. It can not be referred to any $T$ urris known upon our coast, and the fact that the 2 long tentacles are of unequal length, one being considerably longer than the other, separates it at once from any other known species of Stomotocn. At present we place it provisionally in the grenus Stomotocn to which its hydroid appears to refer it. Were it not for the absence of ocelli upon the tentacle-bulbs I would be inclined to suspect that this medusa might prove to be the young of Turris pileatn.

(Stomotoca?) Perigonimus cidaritis Weismann.

Perigonimus cidaritis, Weis vavs, 1883 , Enestehung Sezualzellen bei Hydromedusen, PP. 117, 218, taf. 12, figs. 10, 11.

The stems of the hydroid are about $90 \mathrm{~mm}$. high and arise thickly one by the side of the other from a root-like hydrorhiza. The stems are often simple and unluanched, but they commonly branch dichotomously one or two times, the branches being set off at acute angles one with another. The hydranths have a circlet of about 20 tentacles. Perisarc thin and yellowish. The medusa-buds are borne upon pedicels in a zone at the bases of the hydranths. When set free the medusa is spherical, with + marginal tentacles and + radial-canals. The manubrium has + short, knobbed oral tentacles. The whole hydroid stock is invested with a thin layer of slimy mud, leaving only the mouth-ends of the hydroids projecting, and sometimes even those are covered, leaving only the tentacle rips free.

Found at Naples, Italy. Medusa set free in March.

The sex-cells originate in the ectoderm of the proximal part of the manubrium of the medusa-bud and develop in their place of origin, becoming mature in the free medusa. The mature medusa has not been determined.

Genus DISSONEMA Haeckel, 1879.

Disconema, Hafckf., 1879, Syst. der Medusen, P. 126.-MaYz., Igoo, Bull. Mus. Comp. Zool. at Harvard College, bol. 37 , 1\%.44.-Bariow, H. B., Igog, Bull. Museum of Comp. Lool. at Harvard College.

This genus was founded by Haeckel, 1879 , for Dissonema saphenella, of the coast of Australia.

\section{GFNERIC CHARACTERS.}

Tiarine with two hollow, diametrically opposite tentacles. The gonads extend from the manubrium outward along the canals. Without marginal sense-clulss. Cirri are sometimes present. With abaxial, ectodermal ocelli upon the hases of the tentacles.

Bigelow, 1908, finds that the adradial gonads begin to develop upon the sicles of the manuhrium and that afterwards they extend outward over the radial-canals. "The hollow rentacles, abaxial ectodermal ocelli, rudimentary tentacle-hulhs, and hollow bell-apex are all characteristic of the Tiarina, and it appears that this genus must be removed from the Thaumantiadx, in which Ilaeckel placed it.

Dissonoma bears the same relation to Stomotoca that Nemopsis does to Bongainvilliu. The hydroid is unknown.

Dissonema saphenella Haeckel.

Dissonema saphenella, Harckr., 1879, Syst. der Medusen, p. 126, tai. 8, fig. 3 .

Bell pyriform, with thick, solid apex and thin, hulging sides. $6 \mathrm{~mm}$. high, $4 \mathrm{~mm}$. wide. 2 well-developed tentacles, several times as long as the bell-height. These tentacles have large. swollen, conical hasal bulbs. There are 2 rudimentary tentade-hulbs $90^{\circ}$ apart from the long tentacles. There is an abaxial (ectodermal ?) "ocellus" of large size upon each of the 4 tentacle-bulbs. There are no marginal cluls, cirri, or other appendages.

The velum is well-developed and there are 4 straight, narrow radial-canals and a ringcanal. The manubrium is cylindrical, half as long as the depth of the hell-cavity and provided with + short, crinkled lips. The + folded, spindle-shaped gonads are developed upon the middle three-fourths of the radial-canals. Color (?) Coast of Australia. (See fig. 62.) 


\section{Dissonema turrida Mayer.}

Plate 10, fig. 1; plate 22, fig. I.

Dissonema "urrida, MAYER, I900, Bull. Mus. Comp. Zool. at Harvard College, vol. 37, p. 44, plate 2, figs. 3, 4; 1904, Mem. Nat. Sci. Brooklyn Institute Museum, vol. 1, p. 8, plate 2, fig. Io.

Adult medusa.-Bell bluntly cone-shaped with a hollow apical projection. It is 4 to 7 $\mathrm{mm}$. high and the side walls are thin and flexible. There are 2 long, hollow, gradually tapering

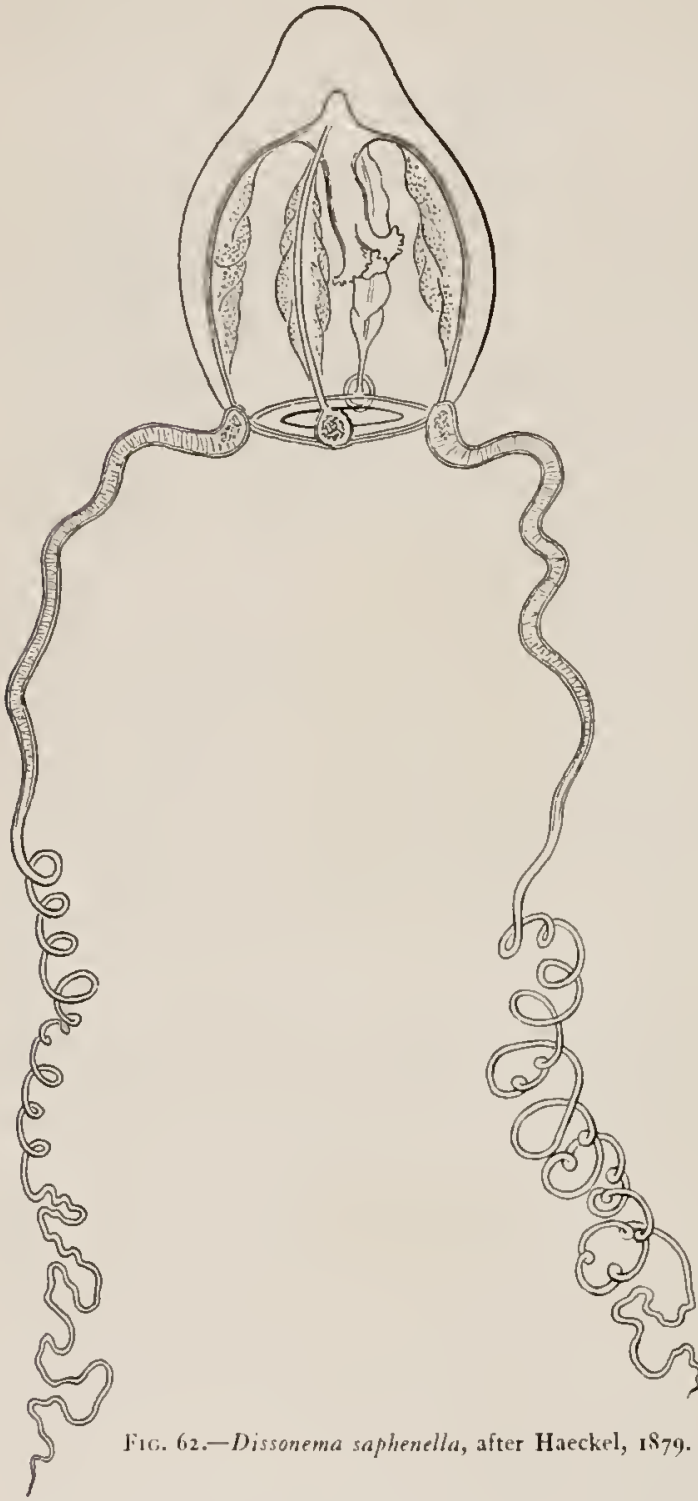
tentacles which are quite contractile, but when expanded are 3 to 4 times as long as the bell-height. Each of these tentacles has a minute, red ocellus in the ectoderm of its outer side near the bell-margin. In addition to the two large tentacles there are 12 to I4 small, solid cirri which arise separately, at equal intervals, from the bell-margin. Each cirrus has a red ocellus in the ectoderm of its outer (abaxial) side at the bellmargin. The velum is well developed. The circular vessel is narrow, but the 4 radial-canals are broad, and the 4 convoluted, bag-like gonads occupy three-quarters of their length and also lie upon the adradial sides of the manubrium. In the female each gonad contains 4 to 7 large eggs which project prominently over the surface of the organ. The manubrium is pyriform and the mouth projects beyond the velar opening. The stomach-walls are thin and flexible, and the mouth is surrounded by large recurved lips with crinkled edges. The entoderm of the manubrium and tentacles is a delicate green and the genital organs and circular canal are tinged with green or pink. The ocelli are red.

In young medusa there are but 2 large tentacles and 2 cirri. There are 8 ocelli. The 2 long tentacles have tapering, hollow basal bulbs, but their main shafts are at first solid, though later they become hollow.

This medusa is common on the surface in the Bahamas and at Tortugas, Florida, in summer.

Dr. H. B. Bigelow shows as a result of sectioning the medusa of Dissonema that the gonads begin to develop upon the adradial sides of the manubrium and later extend outward down the radial-canals. This fact, taken in connection with the abaxial ectodermal ocelli, the hollow tentacles, bell-apex, rudimentary tentacles and general form of the medusa, make it evident that Dissonema is one of the Tiarina.

Genus PANDEA Lesson, 1843.

Pandea, Lrsson, 1837, Prodrom. Monog. Meduses, Nn. 22 (not published); 1843, Hist. Zooph. Acal., p. 288.-AGassiz, L., 1862 , Cont. Nat. Hist. U. S., vol. 4 , P. 347 .

Pandera, Hakckri, 1879 , Syst. der Medusen, p. 53.

Pandea, Aciassiz and Mayer, 1899, Bull. Mus. Comp. Zool. at Harvard College, vol. 32, p. I6o.-Hartlaub, 1892 , Nachricht. kgl. Gesell. Wissenschaft. Univ. Göttingen, p.21.-Mass, 1904, Résult. Camp. Sci. Prince de Monaco, fasc. 28, P. 15. Dirman, Quoy et Gaimard, i827, Annal. des Sci. Naturelles, tome io, plate 6.

Non Dianca, Lamarck, 1816, Hist. Anim. sans Vert., tome 2, p. 505.

Pondien, Zoja, 1892, Boll. Sc. Paira, Anno 1891 , Nos. 3, 4, 3 pp.; 1892, Annals and Mag. Nat. Hist., ser. 6, vol. 9, p. 409. (Dendrodna dohrnii gives rise to a medusa resembling Pandea?) 
The type species of Pandea is $P$. conica Lesson, 1843. This medusa was previously described by Quoy and Gaimard (1827, Annal. Sci. Nat., tom. 10, p. 182, plate 6) under the name Diancaconica. It is found in the Mediterranean. Haeckel introduced the spelling "Pandea," although Lesson's original spelling is Pandea. The genus "Diana a" was founded by Lamarck (1816, Hist. Anim. sans Vert., tom. 2, p. 505), the type species being Dianca triedra, a medusa which had been previously described by Péron under the generic name of Lymnorea. Lamarck's genus Dianara also included various species of Geryonia, Oceania, Pelagia, and Medusa of previous authors, and is so hopelessly involved that in my opinion it must be dropped.

\section{GENERIC CHARACTFRS.}

Tiarina with 4 or more well-developed, marginal tentacles. There are 4 interradial, genital ridges in the ectodermal wall of the stomach, hut these gonads are only imperfectly. separated in the 4 principal radii; so that the stomach is completely encircled by the grenital organs, which are, however, better developed in the interradii than in the principal radii.

Dendroclava is possibly the hydroid of some species of Pandea, Conis, or Turris, but the mature medusa is unknown.

When set free the medusa of Dendroclava dohmii (Weismann, 1883, pp. 26, 216 , tiff. I2, fign. 6-9) has 8 marginal tentacles, 4 radial-canals, and a manubrium with 4 hand-like gonads

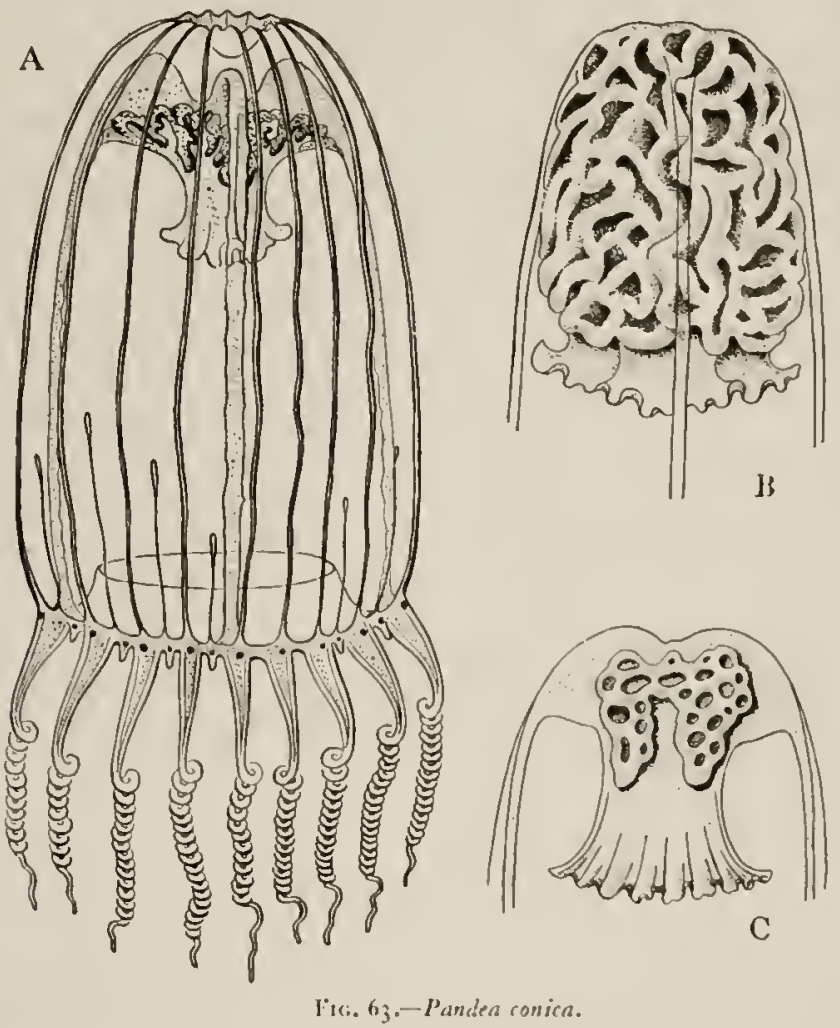

\footnotetext{
A. Side view of half-grown medusa. Bell $13 \mathrm{~mm}$. high. Gonads interradial.

13. Manubrium of mature medusa, with bell $21 \mathrm{~mm}$. high. Gonals confuent, surrounding stomach.

C. Manubrium of young medusa, showing interradial gonads. Bell $6 \mathrm{~mm}$. light. Fromt lift, by the author. Zoological Station, Naples. Winter of 1007-0.8
}

on its interradial sides. The sexual cells originate in the ectoderm of the manubrium of the medusa-hud and develop in the ectoderm of the free-swimming medusa, without wandering from their place of origin. The hydroid of Dendrodova dolurnii was found lyy. Weismann at Naples in the summer of 1881 , attached to a stock of $/$ sis which was dredged from a depth of 35 to 40 fathoms. The stems are about $35 \mathrm{~mm}$. high and arise from a short, creeping hydrorhiza, which together with the stems is covered by a smooth, horny perisarc. The main stems 
give rise to alternate side branches. The hydranths are club-shaped and bear 12 to 20 short, filiform tentacles, scattered over their whole sides. The medusa-buds arise singly from the side branches close under the neck of the lateral hydranths. Pictet, I893, found a very similar or identical hydroid at Amboina, Malay Archipelago. The principal references to this clavalike hydroid are as follows:

Dendroclava dohrnii, Weismann, 1893 , Entstehung Sexualzellen bei Hydromedusen, Jena, pp. 26, 215, taf. 12, fign. 6-9.-DU l'Lessis, 1888, Recueil Zool. Suisse, tome 4, p. 531 (from Villefranche).

Dendroclava dohrni, Piстет, 1893, Revue Suisse Zool., tome I, p. 6, plate 1, figs. 1, 2 (from Amboina).

It does not seem probable that Dendroclava dohrni produces a Pandea-like medusa, for it is well established by Brooks that Turritopsis nutricula comes from a Dendroclava hydroid.

\section{Pandea conica Lesson.}

Dianan conica, Quor f.T G.anmard, 1827, Annal. des Sci. Nat., tome 10, p. 182, plate 6 A, figs. 3, 4.

Pandea conica, Lesson, 184 ;, Hist. Zooph. Acal., P. 288. - Hackel, 1879, Syst. der Medusen, p. 54.-Mats, 1904, Result.

Camp. Sci. Prince de Monaco, fasc. 28, p. 16, plate 1, figs. 6, 7 (figures of gonads).-BEDot, 19o5, Revue Suisse de

Zool., tome 13, P. 141 (literature, 1827-50).-Lobıanco, 1903, Mitth. Zool. Sta. Neapel, Bd. 16, p. 217.

Oceania sedecimcostaia, Kölliker, 1853 , Zeit. für wissen. Zool., Bd. 4, p. 324.

Oceania conica, GegenBatr, 1856, Zeit. für wissen. Zool., Bd.8, p. 221, taf. 7, fign. 1-3.

Bell with barrel-shaped sides, and bluntly pointed or concave apex; $21 \mathrm{~mm}$. high, $10 \mathrm{~mm}$. wide. There are 8 to 24 well-developed, longitudinal rib-like ridges in the tentacular radii on the exumbrella, and an equal number of marginal tentacles with abaxial ectodermal ocelli. Stomach wide and short with 4 folded lips having sinuous margins. The gonads consist of 4 crescentic, reticulated, swollen.regions in the ectoderm of the 4 interradial sides of stomach, the convexity of the horseshoe pointing aborally. These gonads are not completely separated in the adult, in the 4 principal radii, so that they surround the stomach on all sides.

The best figures illustrating their structure are given by Maas, I904.

\begin{tabular}{|c|c|c|}
\hline $\begin{array}{l}\text { Height of } \\
\text { bell in } \mathrm{mm} \text {. }\end{array}$ & $\begin{array}{l}\text { No. of } \\
\text { tentacles. }\end{array}$ & Condition of the gonads. \\
\hline 6 & 16 & 4 small interradial. \\
\hline 8 & 16 & 4 larger interradial. \\
\hline 13 & 21 & $\begin{array}{l}4 \text { interradial nearly touching in the } \\
\text { perradii. }\end{array}$ \\
\hline 21 & 24 & $\begin{array}{l}\text { A unitary network of ridges sur- } \\
\text { rounding the stomacl. }\end{array}$ \\
\hline
\end{tabular}

Stomach brownish. Gonads and tentacle-bulbs hrownish-red. Tentacles yellowish-milky. Ocelli dark-purple.

Common in the Mediterranean.

This medusa was quite common during the winter of $1907^{-1} 908$ at Naples, Italy. When young the 4 interradial gonads are completely separated, but later they fuse more or less over the perradii, forming a complete, swollen network which girdles the stomach.

The prominent longitudinal ridges over the exumbrella arise after the tentacles begin to develop and extend upward from the bases of the tentacles toward the bell-apex. The table gives a growth-record obtained by the author from specimens of this medusa observed at Naples. (See fig. 63, page 117. .)

\section{Pandea saltatoria Lesson.}

Oceania saliatoria, SARS, 1835 , Beskriv og Jagtt., P. 25, plate 4, fig. $10 a-c$.

Pandea saliatoria, Lrsson, 1843 , Hist. Zooph. Acal., p. 290.-Hacket, i879, Syst. der Medusen, P. 54--Bedot, 19or, Revue Suisse de Zool., tome 9, P. $485 ;$ Ibid., 1905, tome 13, P. 141 (all literature to 1850 ).

Bell $8 \mathrm{~mm}$. high, $6 \mathrm{~mm}$. wide, with a pointed apex and rounded sides. Exumbrella with only 12 to 6 longitudinal lines of nettling-cells instead of about twice as many as in $P$. conica. 24 to 32 tentacles; twice as many as the lines of nematocysts, instead of being equal to these in number as in P. conica. Ocelli on outer sides of tentacle-bulbs. Stomach slender, lips small and simple. Immature (?) Color (?) Coast of Norway, Bergen.

Pandea minima von Lendenfeld.

Pandia minima, vos Lexpexfeld, $188_{4}$, Proc. Linnean Soc. New South Wales, vol. 9, p. 916, plate 42, figs. $10-12$.

Bell semi-ovate, $3 \mathrm{~mm}$. high, $2 \mathrm{~mm}$. wide. 8 tentacles about as long as bell is high. 8 adradial lines of nettle-cells upon the exumbrella. A bundle of nerve fibers is said to extend under each linear series of nettle-cells connecting the clusters one with another! The man- 
Plate I 2.

Fig. I. Pandea violacea, mature female. Tortugas, Florida, June 5, 1906. Fig. 2. Turris vesicaria, young medusa. Eastport, Maine, September 19, 1898.

Fig. 3. Turris vesicaria, half-grown medusa. Agassiz Laboratory, Newport, Rhode Island, June 24, I893.

Fig. 4. Turris pileata, half-grown medusa. Agassiz Laboratory, Newport, Rhode Island, July 13, 1895.

Fig. 5. Podocoryne fulgurans. Basal part of one of the marginal tentacles. Figs. 6 to 9. Podocoryne fulgurans. Views of manubrium showing medusabuds. Agassiz Laboratory, Newport, Rhode Island, September, I892.

Drawn from life, by the author. 


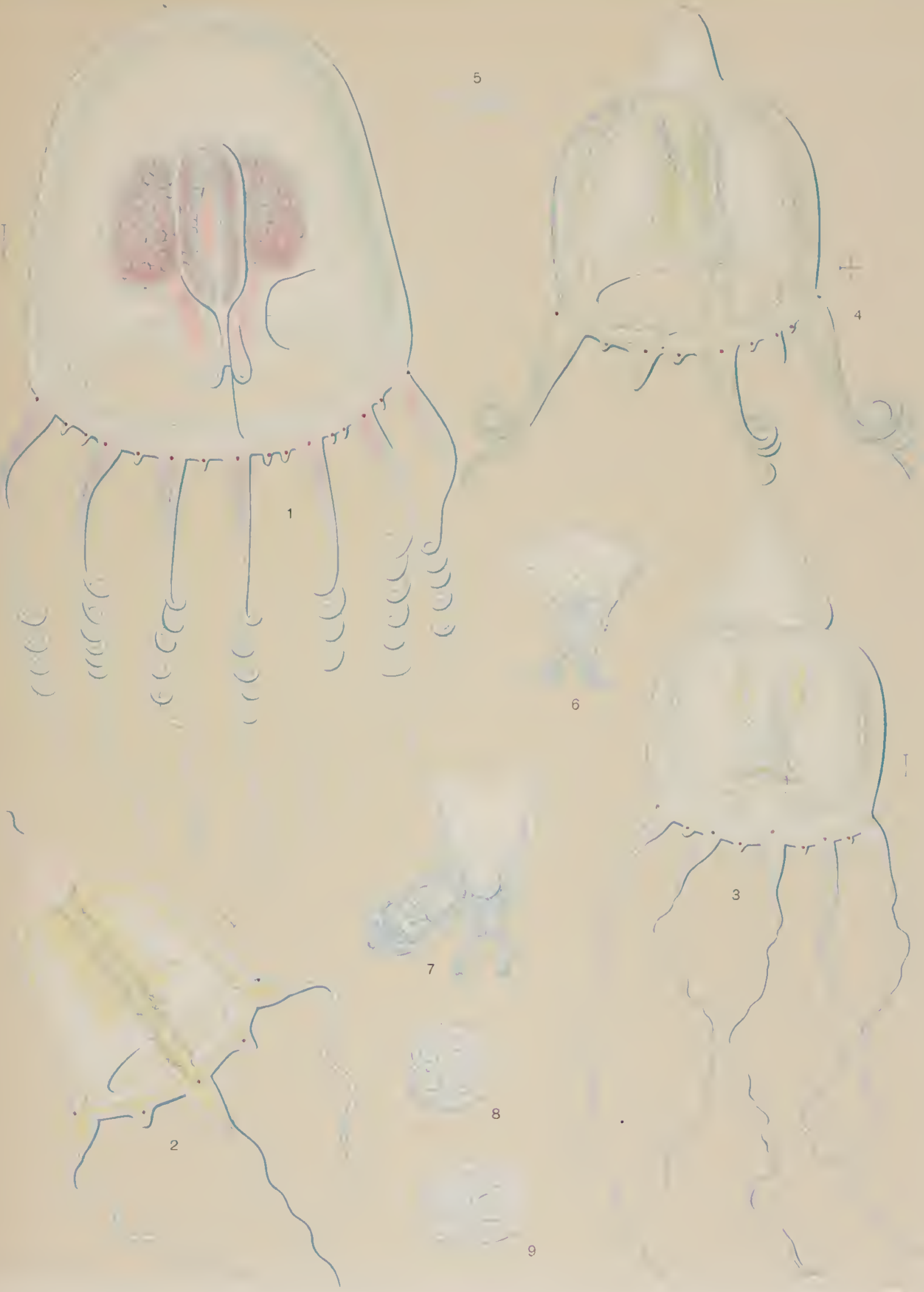



ubrium is slender and about half as long as the depth of the bell-cavity. 4 small lips. 4 longitudinal gonads on the stomach. These are narrow folds with smooth outer surfaces. Bell light-pink, with the 8 adradial lines of nematocysts more intense in color. Stomach and tentacle-hulbs light-brown.

Found in Sydney Harbor, New South Wales, Australia, in August and September.

$$
\begin{gathered}
\text { Pandea violacea Agassiz and Mayer. } \\
\text { Plate 11, fig. 7; plate 12, fig. 1. }
\end{gathered}
$$

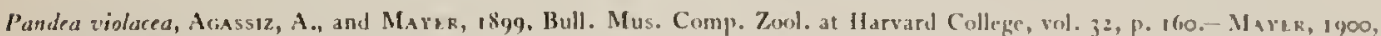
Bull. Mus. Comp. Zonl. at Harvard College, vol. 37, p. 34, plate 1, fig. 1.

I'andea, sp., Lobranco, 1903, Mittl. Zoolog. Sta. Neapel, Bd. 16, p. 217, tav. 7, fig. 1.

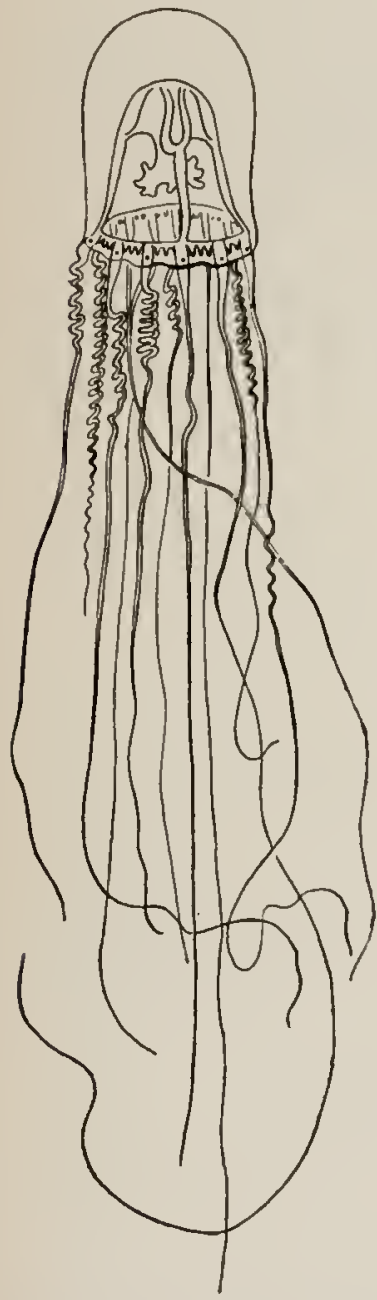

Firi. 64.-Pandea violacea, after Lobianco, Mitth. Zool. Sta. Neapel, 1903 .

Bell pear-shaped and $7.5 \mathrm{~mm}$. high, with moderately thick walls. There are about 32 tentacles. 8 to 12 of these are about 3 times as long as the bell-height and 24 are small and rudimentary. The long tentacles are all of equal length. Their basal hulbs are long, tapering, and hollow. There are 1 to 3 rudimentary tentacle-bulbs between each successive pair of long tentacles. There are about 32 ectodermal, purple ocelli, one on the outer side of each tentacle-bulb. The velum is well developed. The manubrium is flask-shaped and quadratic in cross-section. The outer surfaces of the adradial gonads are smooth and without corrugations (plate 11 , fig. 7). The mouth is at the extremity of a well-developed neck and is at about the level of the velar opening. There are 4 large, slightly recurved lips with smooth, simple edges. There are 4 straight, narrow radial-canals and a broad circular vessel. The entoderm of the manuhrium and tentacle-bulbs is delicate pink and in some specimens a green streak extends along the outer surface of the entodermal lining of the radial-canals. This medusa is common at the Tortugas, Florida, and among the Bahamas throughout the summer. An apparently identical species is found at Suva in the Fiji Islands, South Pacific, although the Pacific medusa is not so highly colored.

A closely related, if not identical, medusa is described by Lobianco, 1903, from two specimens drawn from depths of 500 to 600 fathoms near Capri, Bay of Naples, Italy. Dr. Lobianco kindly permitted me to study these specimens. The hell is $11 \mathrm{~mm}$. high, $7 \mathrm{~mm}$. wide; thick-walled, with dome-like apex. There are I 2 to 13 long tentacles, 4 to 5 times as long as the bell-height. These have long, hollow, tapering basal bulbs, each with an abaxial, dark-red ectodermal ocellus. In addition to the long tentacles there are ahout $2+$ to 36 very short rudimentary marginal tentacles, each with an abaxial ocellus. The $\&$ radial-canals are quite wide and with slightly jagged outlines. The manubrium is half as long as the depth of the bell-cavity. The + complexly folded lips are at the end of a well-developed neck. The outer surfaces of the adradial gonads are smooth. The entoderm is strawberry-pink. I can not separate this medusa from Panden violacea of Tortugas, Florida, some specimens of which are fully as pink in color as is the one shown in Lobianco's figure.

\section{Pandea maasi.}

Tiara, sp., MaAs, 1904, Résult. Camp. Sci. Prince de Monaco, fase. 28, p. 13. plate 2, fig. 11.

Bell ro to $13 \mathrm{~mm}$. high and only ahout half as wide as high, with a smooth exumbrella surface. Bell-walls quite thick, with an evenly rounded apex. without an apical projection. 4 thick, hollow tentacles at the bases of the 4 radial-canals. These have large, swollen hasal bulbs, but no ocelli were observed. The tentacles are about as long as the bell-height and 
their shafts are of about uniform width throughout, the outer ends being very hlunt, not tapering. There are no other tentacles or marginal appendages. The 4 radial-canals and the ringcanal are simple, narrow, and straight-edged; without glandular diverticula.

The stomach is wide and harrel-shaped to cylindrical and is about three-fourths as long as the depth of the bell-cavity. There is no peduncle and the 4 radial-canals run directly into the stomach without enlarging as they approach its base. The mouth is well developed, but the lips are simple, without the foldings commonly seen in other Tiarinæ.

The gonad is developed as an open network of more or less transverse folds over the ectodermal wall of the stomach, excepting only the neighborhood of the mouth. The gonad is not distinctly separated into 4 interradial parts, but is more or less fused over the perradial lines, thus encircling the stomach very much as in medusæ of the Codonidx or in Pandea conica.

The entoderm is yellow, the gonads being deep in color and the tentacles lighter. Other parts are transparent.

Found by the Prince of Monaco at Bear Island, between Norway and Spitzbergen, in July, 1898. It is well figured and described by Maas, 1904. Hartlaul, I907, considers this medusa to be identical with Sarsia flammea Hartlaub. The general proportions of the two medusa appear to be much alike, but the details of structure of the gonads and the color of $P$. maasi appear to distinguish it from other medusæ.

Genus TURRIS Lesson, 1843 , sens. amend.

Turris + Tiara (in part), Lesson, 1837, Prodrom. Monog. Meduses, Nos. 17, 20 (not published); 1843, Hist. Zooph. Acal., pp. $283,286$.

Turris Oceania (in part), Fonвes, 1848 , British Naked-eyed Medusx, pp. $21,26$.

Turris T Tiara, Agassiz, L., I862, Cont. Nat. Hist. U. S., vol. 4, pp. 346, 347.-Hartlaub, 1892, Nachricht. kgl. Gesell. Wissenschaft. Univ. Göttingen, pp. 20, 22.

Turris, Agiass12, A., 1865, North Amer. Acal., p. 164.

Tiarat Turris + Catablema, Ha ECKel, 1879 , Syst. der Medusen, pp. 56, 6o, 62.

Turris, Fewkes, 1881, Bull. Mus. Comp. Zool. at Harvard College, vol. 8, p. 147.

Tiara, WAGNer, 1885, Wirbellosen des Weissen Meeres, p. 78.-MAas, 1905, Craspedoten Medusen der Siboga Expedition, Monog. 10, p. 14.-Boveri, i 890 , Jena. Zeit. Naturw., Bd. 24, p. 339. (The egg gives rise to 2 polar globules.)

Catablema+Turrist Tiara, VANHÖFFEN, I891, Zool. Anzeiger, Bd. I4, P. 444.

Catablema + Tiara + Turris, Mass, 1904, Résult. Camp. Sci. Prince de Monaco, fasc. 28, pp. $12,15,16$.

\section{GENERIC CHARACTERS.}

Tiarinx with 4 or more marginal tentacles. With 4 interradial horseshoe-shaped gonads in the stomach-wall. Each horseshoe composed of partially fused swollen ridges.

Lesson, 1843 , describes three meduse under the name Turris, only one of which belongs to the genus as we define it. This one is T urris neglecta of the north Atlantic coasts of Europe. The name Tiara was also proposed by Lesson, 1843 , and is used to describe a medusa which was first observed by Forskål, 1775, under the name Medusa pileata. It is found off the Atlantic coast of Europe and in the Mediterranean.

I use Turris as equivalent to Turris Lesson + Tiara Lesson + Catablema Haeckel. Haeckel, I879, p. 62, establishes Catablema for a Greenland medusa which he calls Catablema campanula.

Maas, I904, who embodies the results of the studies of Vanhöffen, Hartlaub, and himself, defines Turris as having horseshoe-shaped interradial gonads, the sides of the horseshoe being made up of partially fused, transverse ridges while the arch connecting the two sides is composed of an irregular network of ridges. In Tiara the network is lacking, the entire horseshoe being composed of more or less transverse ridges. The ridges do, hovever, anastomose to some extent, so that an imperfect, partial network may be formed. Catablema he distinguishes by the jagged edges of its radial-canals and circular vessel. However, medusx of Turris and Tiara often display jagged edges upon their canals, and this character is very variable and subject to much individual irregularity in development. In the young medusa of Catablema the ridges forming its interradial horseshoe-shaped gonads tend more or less longitudinally, hut in later development they come to lie almost transversely as in Turris or Tiara. In order to terminate the confusion that has been introduced by these intergrading and too precise criteria for distinguishing the genera Turris, Tiara, and Catablema, I propose to unite them all under one genus and call it Turris, the name first used by Lesson to distinguish any of these medusæ. 
Tabular Synopsis of the Species of Turris.

\begin{tabular}{|c|c|c|c|c|c|}
\hline & T. papua Lesson. & $\begin{array}{l}\text { T. rotunda = Tiara } \\
\text { rotunda Haeckel.* }\end{array}$ & $\begin{array}{l}\text { T. prismatica }= \\
\text { Tiara prismatica } \\
\text { Maas. } t\end{array}$ & $\begin{array}{c}\text { T. reticulata } \\
\text { Haeckel. }\end{array}$ & $\begin{array}{l}\text { T. vesicaria } \\
\text { A. Agassiz. }\end{array}$ \\
\hline Size of bell in $\mathrm{mm}$. & $\begin{array}{l}28 \text { high, It wide. } \\
\text { Pointed apex. }\end{array}$ & $\begin{array}{l}20 \text { high, } 20 \text { wide. } \\
\text { Cubical. }\end{array}$ & 20 high, 12 widle. & 12 high, 10 wide. & 25 high, 12 wide. \\
\hline $\begin{array}{l}\text { Number of tenta- } \\
\text { cles. }\end{array}$ & 8 to 32 & 8 & 12 to 16 & 16 & 16 long, 48 short. \\
\hline $\begin{array}{l}\text { Ectodermal, ab- } \\
\text { axial ocelli on } \\
\text { tentacle-bulbs. }\end{array}$ & Present. & Present. & $?$ & Prescnt. & Present. \\
\hline $\begin{array}{l}\text { Character of edges } \\
\text { of radial-canals. }\end{array}$ & Scrrated. & Sinootl. & Serrated. & Smootls. & Jagged. \\
\hline $\begin{array}{l}\text { Character of } \\
\text { gonads. }\end{array}$ & $\begin{array}{l}4 \text { interradial horsc- } \\
\text { shoes of complex, } \\
\text { mainly transverse } \\
\text { swellings which } \\
\text { anastomose to } \\
\text { some extcnt. }\end{array}$ & $\begin{array}{l}4 \text { pairs of adradial } \\
\text { groups of cross- } \\
\text { folds. }\end{array}$ & As in $r$. pileata. & $\begin{array}{l}8 \text { separate triangular } \\
\text { areas in adradii of } \\
\text { stomach, with } \\
\text { complex anasto- } \\
\text { mosing ridges. }\end{array}$ & $\begin{array}{l}\text { Swollen, transverse, } \\
\text { papilliform, } \\
\text { anastomosing } \\
\text { folds forming nct- } \\
\text { work in } 8 \text { adradii } \\
\text { of stomach. }\end{array}$ \\
\hline Color. & $\begin{array}{l}\text { Tentacle-bulbs and } \\
\text { stomach pink to } \\
\text { dark-red. Gonads } \\
\text { pink to dark- } \\
\text { brownish-yellow. }\end{array}$ & $\begin{array}{l}\text { Tentacle-bulbs, } \\
\text { stomach, and } \\
\text { gonadscarmine. } \\
\text { Radial-canals and } \\
\text { ring-canal yellow. }\end{array}$ & ? & $?$ & $\begin{array}{l}\text { Stomacli and ten- } \\
\text { tacle-bulbs cin- } \\
\text { namon-brown. } \\
\text { Gonads dartier. } \\
\text { Ocelli dark-red. }\end{array}$ \\
\hline Where found. & $\begin{array}{l}\text { Pacific and Indian } \\
\text { Oceans in tropical } \\
\text { regions. }\end{array}$ & Straits of Gibraltar. & $\begin{array}{l}\text { Gulf strcam, At- } \\
\text { lantic. }\end{array}$ & $\begin{array}{l}\text { South Atlantic near } \\
\text { Tristan } \\
\text { d'Acunha. }\end{array}$ & $\begin{array}{l}\text { Arctic Ocean to } \\
\text { southern coast of } \\
\text { New England, } \\
\text { United States. }\end{array}$ \\
\hline
\end{tabular}

\begin{tabular}{|c|c|c|c|c|c|}
\hline & T. superba Mayer $\$$ & T. cœe a Hartlaub. & $\begin{array}{l}\text { T. pelagica Agassiz } \\
\text { and Mayer. }\end{array}$ & $\begin{array}{l}\text { T. conifera }=\text { Tiara } \\
\text { conifera Haechel. } \$\end{array}$ & $\begin{array}{l}\text { T.campanula }= \\
\text { Catablema cam- } \\
\text { panula Haeckel. }\end{array}$ \\
\hline Size of bell in $\mathrm{mm}$. & 5 high, 3.5 wide. & jo high, 20 wide. & 16 high, 9 wide. & 25 high, 20 wide. & 20 high, 20 wide. \\
\hline $\begin{array}{l}\text { Number of tenta- } \\
\text { cles. }\end{array}$ & 4 long, 12 short. & $\begin{array}{l}24 \text { to } 30 \text { of various } \\
\text { lengths. }\end{array}$ & $\begin{array}{l}\text { 30 short. All of } \\
\text { same length. }\end{array}$ & $24^{\text {to }} 4^{8}$. All long. & $24^{\text {to }} 4^{8 \text {. All long. }}$ \\
\hline $\begin{array}{l}\text { Ectodermal, ab- } \\
\text { axial ocelli on } \\
\text { tentacle-bulbs. }\end{array}$ & Prescnt. & Not present. & Not present. & ? & Not present. \\
\hline $\begin{array}{l}\text { Character of } \\
\text { edges of radial- } \\
\text { canals. }\end{array}$ & Smooth. & Jagged. & Jagged. & $?$ & Jagged. \\
\hline $\begin{array}{l}\text { Character of } \\
\text { gonads. }\end{array}$ & $\begin{array}{l}4 \text { interradial horsc- } \\
\text { shocs of partially } \\
\text { fused, mainly } \\
\text { transverse ridges. }\end{array}$ & As in T. superba. & As in T. vesicaria. & $\begin{array}{l}\text { Simple transverse } \\
\text { ritges across the } \\
8 \text { adradii of } \\
\text { stomach. }\end{array}$ & $\begin{array}{l}4 \text { crescent-shaped } \\
\text { gonads in the } 4 \\
\text { interradii of } \\
\text { stomach. Each } \\
\text { composed of } \\
\text { longitudinal } \\
\text { ridges sicle by } \\
\text { side. No trans- } \\
\text { verse folds. }\end{array}$ \\
\hline Color. & $\begin{array}{l}\text { Stomach emcrald- } \\
\text { green and pink to } \\
\text { rose. Tentacle- } \\
\text { bulbs rose-color. } \\
\text { Entire gelatinous } \\
\text { substance delicatc } \\
\text { pink. }\end{array}$ & $\begin{array}{l}\text { Stomach pink, } \\
\text { rose-colored, } \\
\text { wine-colored. } \\
\text { Tentacle-bulbs } \\
\text { yellow. }\end{array}$ & $\begin{array}{l}\text { All cntodermal parts } \\
\text { light port-wine- } \\
\text { colored. }\end{array}$ & ? & $\begin{array}{l}\text { Entodermal parts } \\
\text { yellow. }\end{array}$ \\
\hline Where found. & $\begin{array}{l}\text { Tortugas and } \\
\text { Bahamas in sum- } \\
\text { mer. }\end{array}$ & Mediterranean. & $\begin{array}{l}\text { Pacific coast of } \\
\text { Lower California. }\end{array}$ & $\begin{array}{l}\text { Arctic Ocean, } \\
\text { Russia, Grecn- } \\
\text { land. }\end{array}$ & Arctic Ocean. \\
\hline
\end{tabular}

* Probahly an abnormal or stunted $r$. pileatc. $\ddagger$ Probably identical with $T$, pileata.

IIs this an abnormal individual of $T$. pileates (?) 
According to Wright, 1859 (Edinburgh New Philosoph. Journ., plate 8, fig. I) and Hincks, 1868 (British Hyd. Zooph., p. 14, plate 3, fig. I), the egg of Turris neglecta develops into a Tubularian hydroid. Clavula gossei (see also Allman, 1871, Monog. Tubularian Hydroids, p. 259; also Metschnikoff, 1886, Arbeit. Zool. Inst., Wien, Bd. 6, p. 239) found that the eggs of Tiara pileata develop into a clava-like hydroid polyp. The hydroid polypites of Turris (Clavula) a rise singly from a creeping stolon. Each polypite is slender. elongated, and claviform with scattered, elongate tentacles. The conosare is invested by a polypary. It is possible that the hydroid described by Gegenbaur, 1854 (Verhandl. phys.-med. Gesell. Wiirzburg, Bd. 4, p. I65, taf. I, figs. 3,4) may prove to he the hydroid of Turris. The short. clavate polypites arise separately from a somewhat branching stolon, and each has 5 to 8 scattered, slender tentacles. The medusa-buds arise from the stolon and when set free each medusa has 2 long and 2 immature tentacles, and a line of nematocysts extends up from each tentacle-bulb to the top of the bell. Gegenbaur calls this form Clcodora tricuspidata or Syncoryna cleodora. Allman, I87 I (Monog. Tubularian Hydroids, p. 260) calls it Campaniclava.

It is prohahle that certain species of Perigonimus give rise to medusæ of the genus Turris.

Corydendrium minor Nutting, 1905 (U. S. Fish Commission Bulletin for 1903. p. 941, plate 2, fig. I; plate 7, figs. 8,9) from the Hawaiian Islands may he the hydroid of some Turris.

\section{Turris neglecta Lesson.}

Kermin beroe, Stabber, 1778 , Physilial. Belustig., Nürnberg. P. I Io, plate 13, fig. 3 .

Turris neglecta, Lrsson, 1843, Hist. Zooph. Acal., P. 284.-Forbes, I848, British Naked-eyed Medusa, p. 23, plate 3, figs. $2 a-2 i$.

Ocennia globulosa (young?). Forbes, 1848 , British Naked-eyed Medusa, p. 29, plate 3. fig. 3.

Turris neglecta (hydroid?), Gosse, 1853, Nat. Rambles Devonshire Coast, 1. 348, plate 13, figs. 6-10.

Clavula gossei, Wright, 1859 , Edinburgh New Phil. Journ, plate 8, fig. I.

Turris neglecta, Hincks, 1868, Hist. British Hydroid Zooph., P. I3, plate 3, fig. I.-Allman, 1872 , Monog. Tubularian Hydroids, p. 259.-Haeckel, 1879, Syst. der Medusen, p.62.- Bedot, 1901, Revue Suisse de Zool., tome 9, p. $488,16 i d ., 1905$, tome $13, \mathrm{p} .152$ (all literature to 1850 ).

Tabular Synopsis of the Species of Turris-Continued.

\begin{tabular}{|c|c|c|c|c|c|}
\hline & $\begin{array}{l}\text { T. eurystoma = Cat - } \\
\text { ablema eurystoma } \\
\text { Hacckel. }\end{array}$ & $\begin{array}{l}\text { T. pileata = Tiara } \\
\text { pileata L. Agas- } \\
\text { siz.* }\end{array}$ & T.neglecta Lesson-† & T. digitalis Forhes. & $\begin{array}{l}\text { T. brevicornis Mur- } \\
\text { bach and Shearer }\end{array}$ \\
\hline Size of bell in $\mathrm{mm}$. & 40 high, 20 wi e. & 40 high, 25 wide. & 6 high, + wide. & 40 high, 20 witle. & 45 high, 35 wille. \\
\hline $\begin{array}{l}\text { Number of tenta- } \\
\text { cles. }\end{array}$ & $\begin{array}{l}24 \text { to }{ }_{4} 8 . \text { All long } \\
\text { and } 24 \text { to } 32 \text { ten- } \\
\text { tacle-bulbs. }\end{array}$ & $\begin{array}{l}\text { I2 to } 4^{8} \text {. Usually } \\
24 \text { to } 32 \text {. All well } \\
\text { developed. }\end{array}$ & 60 to 70 short. & 50 to roo short. & I $40+$ \\
\hline $\begin{array}{l}\text { Ectodermal, ab- } \\
\text { axial ocelli on } \\
\text { tentacle-bulbs. }\end{array}$ & Not present. & Present. & Present. & $?$ & Not present. \\
\hline $\begin{array}{l}\text { Character of edges } \\
\text { of radial-canals. }\end{array}$ & Jagged. & $\begin{array}{l}\text { Slightly notched } \\
\text { and jagged. }\end{array}$ & & Jagged. & Jagged. \\
\hline $\begin{array}{l}\text { Character of } \\
\text { gonads. }\end{array}$ & $\begin{array}{l}\text { Developed in longi- } \\
\text { tudinal curtain- } \\
\text { like folds of in- } \\
\text { terradial sides of } \\
\text { short stomach. }\end{array}$ & $\begin{array}{l}+ \text { interradial horse- } \\
\text { shoes of mainly } \\
\text { transverse, some- } \\
\text { what anastomos- } \\
\text { ing ridges. }\end{array}$ & As in T.pileata. & $\begin{array}{l}8 \text { adradia rows of } \\
\text { transverse ridges. }\end{array}$ & As in $\mathbf{T}$. pileata. \\
\hline Color. & $\begin{array}{l}\text { Stomach and } \\
\text { gonads cherry- } \\
\text { red. Canals and } \\
\text { tentaclesbright- } \\
\text { red. }\end{array}$ & $\begin{array}{l}\text { Variable. Stomach } \\
\text { almost colorless, } \\
\text { yellow, red, purple, } \\
\text { brown. Radial- } \\
\text { canals colorless, } \\
\text { yellow, grcen. } \\
\text { Tentacles color- } \\
\text { less, pink. }\end{array}$ & $\begin{array}{l}\text { Stomach, gonads, } \\
\text { tentacle-bulbs } \\
\text { scarlet, purple. }\end{array}$ & $\begin{array}{l}\text { Stomach purple, } \\
\text { reddish-brown. } \\
\text { Tentacle-bulbs } \\
\text { yellow, orange. }\end{array}$ & $\begin{array}{l}\text { Tentacles, gonads, } \\
\text { and stomach dark- } \\
\text { red, purple. }\end{array}$ \\
\hline Where found. & Coast of Greenland. & $\begin{array}{l}\text { North Atlantic to } \\
\text { Mediterranean. }\end{array}$ & British coasts. & $\begin{array}{l}\text { Greenland to North } \\
\text { Sea, British } \\
\text { coasts. }\end{array}$ & $\begin{array}{l}\text { St. Paul Island, } \\
\text { Pribyloff Islands. } \\
\text { North Pacific. }\end{array}$ \\
\hline
\end{tabular}

* T. conifera rotunda, superba and prismatica are probably identical with $T$. pilecta. Hydroid: Perigonimus repens? $\dagger$ Hydroid: Clavula gossei Wright. 


\section{Plate 13.}

Fig. 1. Protiara formosa, mature medusa. Tortugas, Florida, May 21, 1907. Oral view of female.

Fig. 2. Protiara formosa. One of the marginal cirri showing the chordate entodermal cells.

Figs. 3 to 5. Podocoryne fulgurans. Agassiz Laboratory, Newport, Rhode Island, September, I 892.

Fig. 6. Turris pileata, young medusa. Agassiz Laboratory, Newport, Rhode Island, September 25, I896.

Fig. 7. Turris vesicaria, mature medusa. Eastport, Maine, August, 1897. Drawn from life, by the author. 


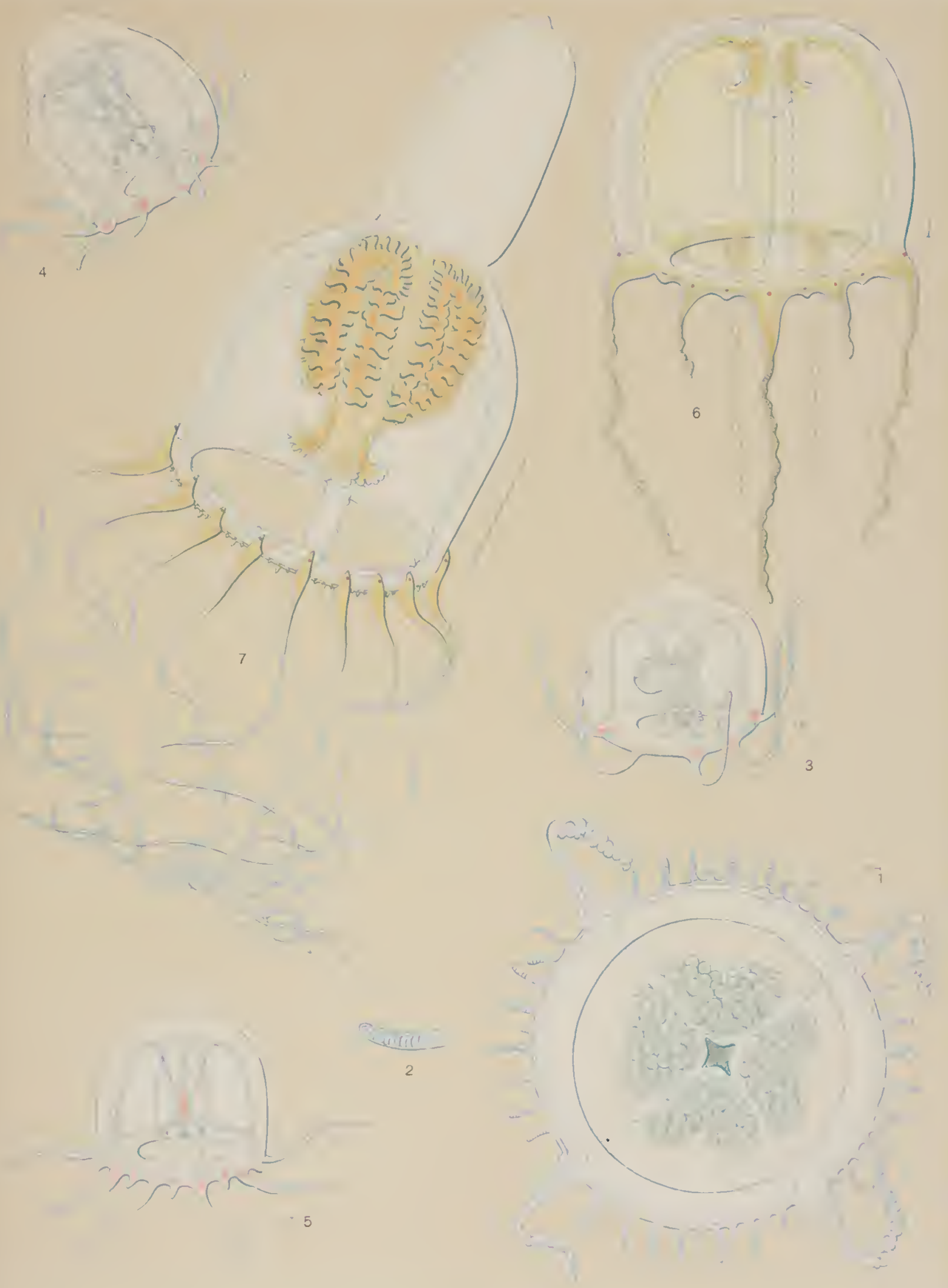



Bell 4 to $6 \mathrm{~mm}$. high, 3 to $4 \mathrm{~mm}$. wide. Glohular or with a conical apex and bulging sides; margin somewhat constricted. 60 to 70 short, crowded tentacles, shorter than the

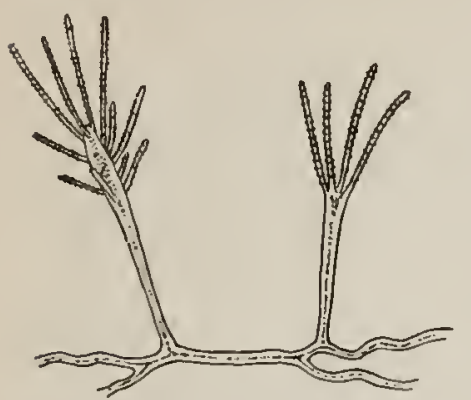

F16. 65.- Hydroid of Turris neglecia, after Hincks, in British Hyalroid Zoopliytes. bell-height, with abaxial ocelli. Stomach wide, cruciform in cross-section, and one-half to two-thirds as long as the depth of the bell-cavity. + simple lanceolate lips, not complexly folded. Gonads as in $T$. pilenta. Entoderm of stomach and tentacle-bulbs reddish-brown to rich purple. Found off the British coasts.

The hydroid was obtained by Grosse and Wright, who reared it from the egg. The planula is bright crimson. The hydranths a re club-shaped and only about $2.5 \mathrm{~mm}$. high. They arise singly at intervals from a creeping filiform hydrorhiza and have 12 or more scattered, filiform tentacles. The hydrocaulus and hydrorhiza are invested by a perisarc. Hydranths bright crimson.

Turris pileata.

Plate 12, fig. 4; plate 13, fig. 6.

Medusa pileaia, Forskis, 1775, Descriptiones Animal., p. I10; 1776, Icones rerum naturalium, plate 33, fig. I).

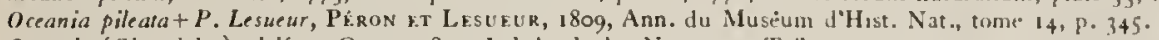

Oceania (Charybdea) pisifera, OKen, 1815 , Lehrbuch der Naturges., Teil 3, 1) 125.

Oceania ampullacea, StRs, 1835 , Beskriv og Jagttagelser, 1.22 , plate 4 , fig. 8 - $f$.

Tiara papalis $+T$. sarsii, Lesson, 1843 , Hist. Zooph. Acal., P. 287 .

Oceania turriat O. ocronat O. episcopalis, Forees, 1848, British Naked-eyed Medusa, 11). 27, 28, plate 2, figs. 1-3.

Oceania corcinea, Lruckart, 1856, Archiv, für Naturges., Jahrg. 22, p. 24

Phialidium ampullaceum + Tiara pileara, Aciassı, L., 1862, Cont. Nat. Hist. U. S., vol. 4, Pl. $352,347$.

Tiara smaragdina, Hakcket, 1864, Jena. Zeit. für Naturw., Bu. 1, p. 336.

Oceania pileata, Spacnolin1, 1876, Catalogo Acalefi Mediterraneo, p. 21, tav. 3, fig. 1, 2.

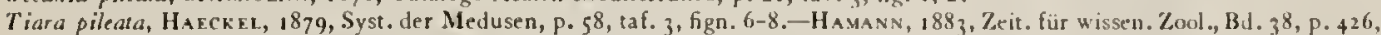
taf. 23 , fign. 16-20 (development of the planula larva).-Metschnikork, E., 1886, Embryol. Studien an Mejusen, pp. 29, 48, etc., taf. 1, fign. 1-17.-Hartlaub, 1894, Wissen. Meeresuntersuch. Komm. Meere Kiel, Helgoland, Neue Folge, Bd. 1, p. 189. - Forskål=Oceania episcopalis Forees; Browne, 1896, Irish Naturalist, p. 180; 1805, I’roc. and Trans. Liverpool Biol. Sac., vol. 9, p. 258.-BEnot, 1901, Revue Suisse de 7ool., toine 9, P. 487; 16id., 1905, tome 13, p. 150 (all literature to 1850).-Brownk, 1903 , Bergens Museums Aarbog, No. 4, P. 11.-MAas, 1904, Rẻsult. Camj Sci. Prince de Monaco, fasc. 28, p. 15 , plate 1, fig. 9.-Browne, 1905. Proc, Royal Soc. E.dinburgh, vol. 25, P. 760.

(?) Tiara insermedia, Browne, 19o2, Annals and Mag. Nat. Hist., ser. 7, vol. 9. p. 277 (Falkland Islands, South Atlantic). Ger yonia ociona, FlemiNG, 1823 , Edinburgh Philosoph. Journ., vol. 8, p. 299.

Ocearia octona, Forers, 1848 , British Nakel-eyed Medusa, p. 27, plate 2, figs. $3^{2-3} 3^{d .}$ The plate is wrongly labeled " $O$. episcopalis."

Oceania furrifa (young medusa), Forbes, 1848 , British Naked-eyed Medusa, p. 28, platt* 2, figs, 2a-2c.

Tiara octona, Ac.assiz, L., 1862, Cont. Nat. Hist. U. S., vol. 4, p. 347.

Oceania coronafa, Alluan, 1871, Monog. Tubularian Hydroids, 1. 33, fig. 8.

Tiara ocrona, Hakckk. 1879 , Syst. der Medusen, p. 57.

Non Tiara ocrona, Mats, 1904, Résult. Camp. Sci. Prince de Monaco, fasc. $28, p .13$, plate 2, fig. 11.

Bell about 15 to $40 \mathrm{~mm}$. high and 10 to $20 \mathrm{~mm}$. wide. Side walls quite thin, but there is usually a well-developed, solid, apical projection, although this may he absent. This projection may be conical or cylindrical, with a hasal constriction, or pineapple-shaped, etc. There are 12 to 48 , usually 24 to 32 , tentacles with hollow, laterally compressed, tapering basal bulbs. These tentacles are longer than the bell-height and there is an abaxial ocellus on the outer side of the base of each bulb. The velum is narrow and simple.

The 4 radial-canals and ring-canal are wide, flat, and ribbon-like and their edges are ofien more or less notched and jagged. As they approach the sides of the stomach the radial-canals widen out into funnel-like expansions, so that they embrace the upper halves of the sides of the stomach in the 4 principal radii.

The stomach is wide, balloon-shaped, and 4 -sided, and fills the upper one-half to twothirds of the bell-cavity. The 4 lips are at the end of a relatively narrow, short neck and are complexly folded, crenated and recurved upward.

The gonads are + horseshoe-shaped regions on the sides of the stomach, the sides of each horseshoe being adradial and the apex aboral and interradial. The horseshoe consists of an area of more or less transverse folds which, however, anastomose more or less so as to form a network of ridges. In young medusa the ridges of the gonads are more or less parallel and transverse, but in later life they anastomose to form an irregular network. 
This medusa is very variable in color. The stomach ranges from yellow to red, or from hrownish-red to purple. The radial and circular canals may be colorless, to yellow or green. The ocelli are red or dark brownish-purple. The tentacles range from colorless to light-purple.

It is widely distributed over the North Atlantic and in the Mediterranean, hut it appears to be much commoner on the European than along the American coast.

The development has been studied by Hamann, 1883 , and Metschnikoff, 1886 . Segmentation is total and equal and a single-layered, elongate, ciliated larva is found. The entoderm develops from cells which wander into the central segmentation cavity from the hinder end of the larva, so that finally a two-layered planula is formed. The planula attaches itself and the hinder end develops into a hydrorhiza, while the forward end becomes the polypite. The hydrorhiza hecomes invested with a thin perisarc and the polypite develops

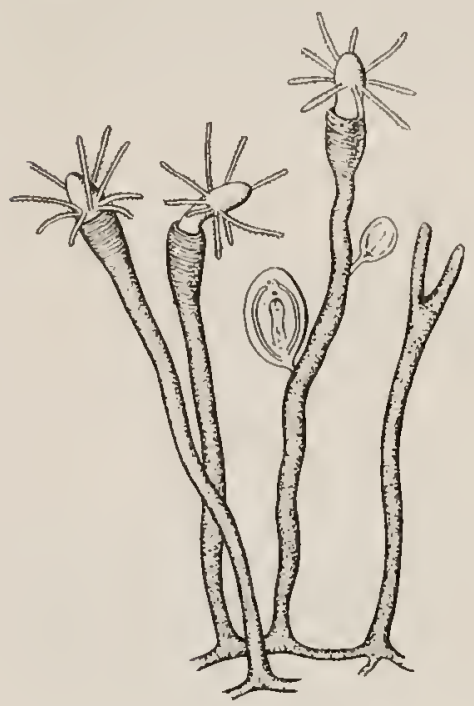

Fici. for.- Perigonimus repens, after Hincks, in l3ritish Hydroid Zoophvtes. a mouth and 2 or 3 long thin tentacles, which arise at the base of the conical throat-tube. This stage was reached at the end of 16 days in Metschnikoff's specimens, and apparently the hydroid is one of the Clavida.

This hydroid may possihly be the very abundant and widely distributed Periganimus repens (fig. 66) found off the Atlantic coasts of Europe from Russia southward, in the Mediterranean, off the Pacific coast of the United States, and at the Falkland Islands and Terra del Fuego, South America.

The stems of the hydroid branch and are covered with a gelatinous investment to which foreign bodies become attached. The polypites are spindle-shaped, with a single oral circlet of tentacles. The medusa-buds a rise singly from the sides of the stems.

According to Hartlaub and Browne the medusa is set free with but 2 tentacles and 2 small tentacle-bulbs. Forbes described the 4-tentacle stage as Oceania turrita, the 8-tentacle condition as $O$. octona, and the medusa with 12 tentacles as O.episcopalis.

Some of the recent literature relating to the hydroid $P$. reprns is here presented, though it must he borne in mind that this has not been proven to be the hydroid of the medusa in question.

Perigonimus repeus $+P$. minutus, Allman, 1872, Monog. Tubul. Hydroids, p. 321 , plate 11. Perigonimus repeus, Grafffe, 1884, A rbeit. Zool. Inst. Wien., Bd. 5, p. 350. (At Trieste, Adriat ic. Rare. Medusae produced in May).-Du Plessıs, 1888, Recueil Zool. Suisse, tome 4, p. 539.-Browne, 1896, Proc. Zool. Soc. London, p. 462 (P. minutus Allman=P. ve pens). Bonnevie, 1899, The Norwegian North Atlantic Expedition, 1876-1878, vol. 26, Hydroids, p. 4 (from Norway).-Calkins, 1899, Proc. Boston Soc. Nat. Hist., vol. 28, p. 339, plate I, figs. 3-3 D (from Puget Sound).-Torrey, 1902, California Univ. P'ub. Zool., vol. 1, p. 29 (Pacific coast, California to Washington).-Hartlaub, 1905, Zoolog. Jahrbüchern, Suppl. 6, p. 530, fign. K, L, M (from the Falkland Islands and Terra del Fuego).

\section{Turris rotunda.}

Dinnara rounda, Quoy et Gaimard, I827, Annal. des Sci. Nat., tome 10, p. I81, plate 6 A, figs. I, 2.

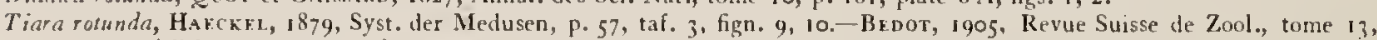
p. I5I (all literature to 1850 ).

Bell cubical without a pointed apex; $20 \mathrm{~mm}$. high, $20 \mathrm{~mm}$. wide. Bell-cavity only twothirds as deep as the bell-height. 8 tentacles much longer than the bell-height, with conical hasal bulbs. A large, dark-red ocellus on the outer side of each tentacle-bulb. Stomach small, swollen, globular, and confined to the upper third of the hell-cavity. The lips are short, much folded, and with a row of nettling warts around their edges. The gonads consist of 4 pairs of longitudinal, swollen areas, each thrown into 8 to to cross-foldings, on the adradial sides of the stomach. The stomach, gonads, and tentacle-bulhs are carmine, lips rose-red. 
Canals yellow. Found by Quoy and Gaimard, and later ly Haeckel, in the Straits of Gibraltar. Development unknown.

\section{Turris papua Lesson.}

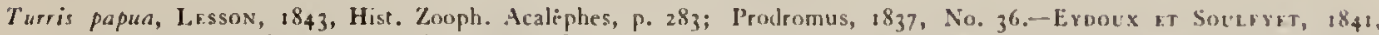
Voyage de la Bonire, tome 2, p. 639, plate 2, figs. 1-3.-Haeckil, 1879, Syst. der Medusen, p. 58.-11a.4s, 1905, Craspedoten Medusen der Siboga Expedition, Monog. 10, p. 14, taf. 2, fig. 13; 19ok, Kevue Suisse de Zool., tome 14, p. 8x. Bedot, 1905, Revue Suisse de Zool., tome 13, p. 150 (all literature to 1850 ).

Fiquoren mitra, Lrsson, 1829 , Voyage de la Coquille, Zool., P. 127, plate 14, fig. 4 .

(?) Tiara oceanica, Agassiz, A., and Mavre, 1902, Mem. Mus. Comp. Zool. at Harvard College, vol. 26, p. 141, plate 1, fig. 1.

(?) Tisra intermedin, Browsr, 1902, Annals and Mag. Nat. Hist., ser. 7, vol. 9, 1. 277.

Bell $28 \mathrm{~mm}$. high, $14 \mathrm{~mm}$. wide, with a solid a pical projection and thin vertical walls. The longest tentacles are about as long as the hell-height and have elongate, conical, basal hulbs, with dark-red ectodermal ocelli on their outer sides. According to Lesson and to Eydoux et Souleyet there are 8 tentacles: 4 radial, 4 interradial. Maas found 16 tentacles: 4 radial, 4 interradial, and 8 adradial. Agassiz and Mayer found 32 tentacles: 8 long radial and interradial, 8 short adradial, and 16 very short intermediate tentacles. These differences may he local variations, but can hardly he due to the medusa being in various stages of development, for Agassiz's specimen was only $5 \mathrm{~mm}$. high and had 32 tentacles, while Browne's and Mass's specimens were $7 \mathrm{~mm}$. high with only 16 tentacles. Moreover, Lesson's medusie were larger and had only 8 rentactes. The + radial-canals are quite wide and have serrated edges. The stomach is wide, swollen, and the lips complexly folded, and about at the level of velar opening. The gonads are in 4 interradial, horseshoe-shaped series of transverse swellings on the sides of the stomach, the open ends of the horseshoe heing directed downward toward the mouth and the apex heing near the aboral end of the stomach.

The entoderm of tentacle-bulhs and stomach is pink to dark-red. The gonads are pink to dark brownish-yellow.

Widely distributed over the Indian Ocean and tropical Pacific.

It is probable that this form displays considerable variability in the number of its tentacles and in the color of its gonads. It is closely allied to Turris superbu of Tortugas, Florida, and may be identical with $T$. intermedia Browne, from the Falkland Islands.

Turris prismatica.

Tiarn prismaticn, MA45, 1893 , Ergeh. der Plankion Exped., BJ. 2, K. c., P. 68, taf. 6, fign. 10, 1 .

Bell about $20 \mathrm{~mm}$. in height, $12 \mathrm{~mm}$. in diameter; 4 -sided and prismatic in shape. There is no apical projection and the bell-walts are remarkably thick. In the single specimen described hy Maas there are 12 tentacles, one at the foot of each of the 4 radial-canals. 3 others in one quadrant, 3 in another, and one in each of the other quadrants. It seems probable that the specimen is abnormal and that there are normally 16 tentacles. The tentacles arise at a slight distance above the bell-margin. Ocelli (?) The gonads are similar to those of $\mathcal{T}$ urris pilsata. In the preserved specimen the bell has a 4 -sided prismatic shape. Color ( :) A single individual of this species was found by the Plankton Expedition on August 4, 1889, in the Gulf Stream. May it not he an abnormal specimen of Turris pileata (?)

Turris reticulata Haeckel.

Tiara reficulata, Hafckel, 1879 , Syst. der Medusen, p. 60, taf. 3, fig. 3 .

Medusa bell-shaped, $12 \mathrm{~mm}$. high and $10 \mathrm{~mm}$. broad. There is a small, conical, apical projection, about 1.25 times as high as it is broad. The stomach is 4 -sided and pyranidal, widest helow, and its radial edges are bound throughout their length by the 4 radial-canals. The + lips are large and much folded. There are 16 tentacles which are longer than the width of the bell, and have large, laterally compressed bases, with ocelli on their outer sides. There are 8 separate, triangular gonads in the outer wall of the stomach. The surfaces of the gonads display complex anastomosing folds and swellings.

This species was descrihed by Haeckel from preserved specimens ohtained in the Sourh Atlantic near the Island of Tristan d'Acunha. 
Turris vesicaria A. Agassiz.

Plate 12 , figs. 2 and 3 ; plate 13 , fig. 7 .

Turris vesicaria, Agassiz, A., 1862, Proc. Boston Soc. Nat. Hist., vol, 9, P. 97; 1865 , North Amer. Acal., P. 164, figs. 261-268.Nutring, 1901, Bull. U. S. Fish Commission for 1899 , vol. 19, p. 375, fig. 86 (abnormal medusa).

Catablema vesicarium, Haeckr., 1879 , Syst. der Medusen, P.64.-GröNBERG, 1898 , Zool. Jahrb., Abth. Syst., Bd. II, P. 461. Turris episcopalis, Fewkes, 1881, Bull. Mus. Comp. Zool. at Harvard College, vol. 8, p. 147, plate 3, figs. 1-6.

Turris vesicaria, and T. episcopalis, HargiTT, 1904, Bull. U. S. Bureau of Fisheries, vol. 24, p. 36, 2 figs.

Catablema vesicar ium (young medusa), MaAs, $190_{4}$, Rẻsult. Camp. Sci. Prince de Monaco, fasc. 28, p. 12, planches I, 2.

Adult medusa (plate 13, fig. 7). - Bell about $25 \mathrm{~mm}$. in height and $12 \mathrm{~mm}$. in diameter. There is a large, solid, apical projection which varies greatly in shape. being globula $\mathrm{r}$ in some individuals, while in others it is cylindrical or conical. Its upper end is often seen to terminate in a small hutton-shaped projection. The side walls of the bell are quite thin and flexible. There are 16 well-developed tentacles, the basal bulbs of which are quite large and are Hattened in a radial direction, so that the tentacle appears to arise from the side of the bell slightly above the bell-margin. These well-developed tentacles are very Hexible, and when extended are ahout 2 to 4 times as long as the bell-height. These basal bulbs are hollow and bear each an abaxial ocellus. In addition to these long tentacles there are 48 very short, rudimentary tentacles, which arise from the bell-margin at a slightly lower level than the long tentacles. There are 3 of these rudimentary tentacles between each successive pair of long tentacles. There is a single dark-red ocellus upon the outer side of each and every tentaclebulb, 64 in all. The velum is narrow. There are 4 broad, flat radial-tubes and a broad, circular canal, all of which display jagged edges. The 4 radial-canals enter the stomach ly 4 wide, fumnel-like openings. The manubrium is large and urn-shaped and there is no peduncle. The mouth is surrounded by 4 prominent, crenulated lips. The gonads occupy 4 interradially situated, longitudinal regions upon the walls of the stomach. Each gonad consists of a pair of swollen, papilliform, adradial, ectodermal ridges, the outer surfaces of which are thrown into complex, but mainly transverse, folds and corrugations. The color of the manubrium and tentacle-bulbs is cinnamon-brown, the gonads being of a somewhat darker shade. The ocelli upon the tentacle-bulbs are dark-red.

Young medusa (plate I2, fig. 2).-In the youngest medusa observed the bell is about $2 \mathrm{~mm}$. in height. The walls are thin, and there is a short, conical, a pical projection. There are only 4 well-developed tentacles, one at the base of each of the radial-canals. These tentacles have large conical basal bulbs which are hollow. The axes of the tentacle-bulbs are at a slight distance above the bell-margin. In addition to the 4 well-developed, radial tentacles, there are 4 intermediate inter radial tentacles which arise from the bell-margin at a slightly lower level than the radial tentacles. The 4 radial-canals are broad and their edges are jagged. The manubrium is large and quadratic in cross-section. The lips are simple.

In a medusa $3 \mathrm{~mm}$. in height (plate $\mathrm{s} 2$, fig. 3 ), there were 8 well-developed and 8 immature tentacles. The apical projection was large and miter-shaped, and the lips had folded, notched margins.

This medusa is probably an Arctic species. It has been found but rarely south of Cape Cod, and then only in May and June. It is abundant, however, in the harbor of Eastport, Maine, in August, and ample opportunities for observing its growth were afforded.

The medusa is remarkable for its voracity and will devour Nanomia cara with great avidity. It is a common thing to observe the medusa in the act of devouring one of these large Siphonophores which may be many times its own size. Maas, 1904, records this medusa off Bear Island, between Norway and Spitzbergen, so that its distribution is probably circumpolar. Grönberg records it as being rare in August off the coasts of Greenland and Spitzhergen.

Turris superba (a variety of $T$. pileata).

Plate 27, fig. 8; plate 28, figs. 3 and 4 .

Tiara superba, Mayfr, 1900, Bull. Mus. Comp. Zool. at Harvard College, vol. 37, p. 34, plate 16, fig. 39; Memoirs Nat. Sci. Museum Brooklyn Inst. Arts and Sci., vol. I, No. I, p. 8, plate 2, fig. II.

Bell 5 to $7 \mathrm{~mm}$. high and with a well-developed apical projection. There are 4 long, hollow and 12 small, solid, rudimentary tentacles. The long tentacles are slender, with tapering basal bulbs. There is an ectodermal ocellus upon the outer side of the tentacle-bulb of 
each of the 16 tentacles. The velum is well developed. There are 4 broad, flat, smooth-edged radial-canals and a broad, simple, circular vessel. The + radial-canals enter the stomach ly + wide funnel-like openings. The manubrium is wide and fills the greater part of the belicavity. The 4 lips are recurved and their edges much folded. "The 4 gonads are developed on the interradial sides of the stomach. Each gonad is horseshoe-shaped, the apex of the horseshoe being uppermost, and the sides composed of partially fused, transverse ridges upon the ectoderm of the stomach-wall. The entire gelatinous substance of the medusat is of a delicate rose-pink.

The entoderm of the manubrium and tentacles is of a rich rose-color and the entodermal core of the stomach is emerald-green. This medusa is quite common at Tortugas, Florida, and among the Bahamas in the summer months. It is one of the most beautiful of American medusa.

Turris breviconis Murbach and Shearer.

Turris breviconis, Murbacil Ann Surakrk, 1902, Annals and Mag. Nat. Kist., ser. 7, vol. 9, P. 73; 1903, Proc. 7.ool. Snc. London, vol. 2, P. 190, plate 18, figs. 1, 2.

Bell cubical, $+5 \mathrm{~mm}$. high, $35 \mathrm{~mm}$. wide. More than 140 tentacles in douhle rows, with contractile muscles on their inner sides and enlarged ectoderm on their outer sides. No ocelli in preserved specimens. Gonads and stomach occupy less than half of the upper part of the hell-cavity. \& broad radial-canals with unbranched lateral diverticula. Bell bluish, tentacles, gonads, and stomach dark-red or purple.

St. P'aul Island, Pribytoff Islands, North Pacific.

Turris cœca Hartlaub.

Turris crea, Hartial:k, 1892, Nachrichten kgl. Gesell. Wissen. Güttingen, p. 19, fig. 1.-Ma+я, 1904, Résult. Camp. Scı. Prince de Monaco, fasc. 28, p. 17, planche 1, fig. 5.

Tinell a partheropaen, Tk1sc1, 1907, Archiv. Ital. Anat. Embr. Firenze, vol. 5. P. 533 (development and structure of oncytes).

Bell about $30 \mathrm{~mm}$. high and with $2+$ to 30 tentacles of various lengths. The tentacle-

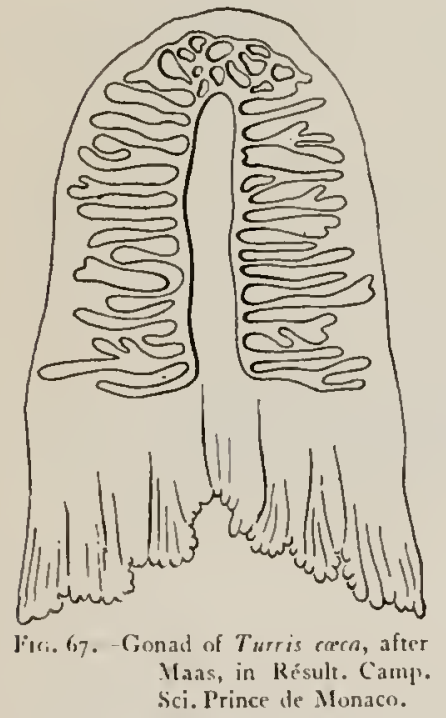
bulls lack ocelli. The radial-canals are wide and flat and there are a few globular tohes along their edges. The stomach is wide and the lips complexly folded. The 4 interradial gonads are composed of horseshoe-shaped swellings. The ridges are lateral cross-folds in the 8 adradii, but in the interradius at the apex of the horseshoe, near the base of the stomach, they form a reticulated network.

The stomach is rose-colored to wine-colored, and the tentacle-bulbs are yellow.

Found at Naples and Monaco, Mediterranean, in Fehruary and March.

Turris pelagica Agassiz and Mayer.

Turris pelagien, Agisssiz, A., and Maver, 1902, Mem. Museum Comp. Zool. at Harvard College, vol. 26, p. 142, plate" 1, fig. 2.

Bell $16 \mathrm{~mm}$. in height and $9 \mathrm{~mm}$. wide, and the sides are barrel-shaped, heing wider at the middle than at either end. 'There is a small, solid, apical projection. The bell-walls are very thin and quite Hexible. There are about 30 short tentacles, less than half as long as the hell-height, all heing of the same size. These tentacles all arise from the bell-margin and their bases are large and conical. There are no ocelli. The velum is well developed. There are 4 radial tubes which are flat and quite hroad, heing narrower near the circular canal than at any other place. Their outer edges are jagged, excepting in the narrow parts near the circular canal. The manubrium is large and fills the greater pant of the bell-cavity. It is joined to the + radial-canals by means of + wide funnel-shaped ducts. The gonads occupy 8 adradially situated rows which extend about two-thirds of the distance from the inner apex of the bell-cavity to the velar opening. The outer surfaces of the gonads are transversely folded and give rise to numerous papilla. There are 4 well- 
developed, complexly folded lips. The lips and tentacle-bulbs are of a light port-wine color and the gonads and radial-canals are of a still lighter shade. A single specimen of this medusa was found in a surface haul on August 26, 1899 , off the Pacific coast of Lower Califonia; N. lat. $3^{\circ} 10^{\prime}, W$. Iong. $125^{\circ}$. It is separated from $T$. papua and T. pileatu by the absence of ocelli.

\section{Turris conifera Haeckel.}

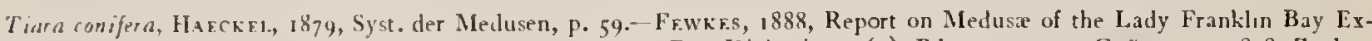
pedifion, P. 43--Lavissen, 1893. Vis. Meddel. Nat. For. Kjöbenhavn (5), Bıl. 4, P. 144.-GrönbfrG, 1898, Zoolog. Jahrb., Abth. Syst., Bal. 11, Pp. 454, 460.-LINko, 1904, Zool. Anzeiger, Bd. 28, p. 215.

Bell cone-shaped, with a large, conical, apical projection. It is about $25 \mathrm{~mm}$. in height and $20 \mathrm{~mm}$. in diameter. There are $2+$ to 48 tentacles which are longer than the bell-diameter and which have wide, conical bases. Ocelli (?) The manubrium is quadratic in crosssection and is somewhat longer than wide. The base is wide and cruciform, and the 4 radial corners are wide where the radial-canals enter the stomach. The + lips are very prominent and are thrown into complex crenulations and folds. The gonads are composed of about 10 pairs of regularly arranged, simple transverse or oblique ridges across each of the 8 adradial regions of the stomach and are separated in the 4 interradii.

This form is very closely related to Turris pileata, with which it may, indeed, prove identical. Haeckel says that it is distinguished from both $\mathcal{T}$. pileata and $\mathcal{T}$. reticulata by the regular feathered gonads and by the smallness of the 4 funnel-like origins of the radialcanals where they join the stomach. The oral lappets are smaller and less crenulated than in $\mathcal{T}$. pileata or $\mathcal{T}$. reticulata. The conical, apical projection is half as high as the bell. Color (:)

This species is found off the coast of Greenland. Linko, Igot, also found it in Barents Sea, north of Lapland, and its distribution is, therefore, probably circumpolar in common with other Arctic species of Turris.

\section{Turris campanula.}

Condema campanuda, Hafckfi, 1879, Syst. der Medusen, p. 63, taf. 4, fign. 4, 5.-Lrivinsan, 1893, Vid. Meddel. Nat. For.

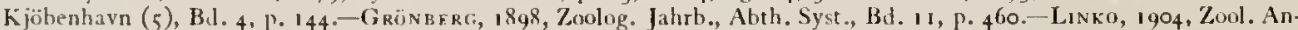
zetger, Bd. 28, P. 215.-B..not, 1901, Revue Suisse de Zool., tome 9, P. 482; 1bid., 1905, tome 13, p. I32 (list of references to 1.850$)$.

Bell about $20 \mathrm{~mm}$. wide and $20 \mathrm{~mm}$. in height. There is a well-developed, conical, apical projection, which is hollow and contains a prolongation of the gastric cavity. There are $2+$ to $4^{8}$ tentacles which are longer than the bell-diameter. Their bases are long and thick. No ocelli. The 4 radial-canals and the circular tube are wide and flat and have numerous complex, or simple, blindly-ending side branches resembling those of $\mathcal{T}$. eurystoma. The manubrium is wide and shallow and the 4 lips are thrown into complex crenulations and folds. The 4 gonads are found within 4 crescent-shaped swellings upon the 4 interradial sides of the stomach. A number of simple, straight, longitudinal folds or ridges extend across the crescent-shaped gonad; the horns of each crescent are directed downward, toward the velar opening. The manubrium, gonads, canals, and tentacles are yellow.

This species is found off the coast of Greenland and at Spitzhergen, and Linko found it in Barents Sea, north of Lapland.

\section{Turris eurystoma.}

Canablema eurvstoma, Hafckrt, 1879, Syst. der Medusen, p. 64, taf. 4, fign. 6, 7.-Lrvinsr.n, 1893, Vid. Meddel. Nat. For. Kjöbenhavn (5), Bd. 4, p. I44.- GrönBr. RG, 1898, Zoolog. Jahrb., Abth. Syst., Bd. 11, p. 462.

Bell about 20 to $25 \mathrm{~mm}$. in diameter, and spheroidal, being flatter than it is high. There is a spheroidal, apical projection which varies in size from alout one-fourth to almost as large as the bell itself. This apical projection is always solid. The sides of the bell are quite thin. There are about 24 to 48 well-developed tentacles which are much longer than the belldiameter. These rentacles have long, conical basal bulbs. In addition to the long rentacles there are usually $2+$ to 32 small, immature, or rudimentary tentacle-bulbs which alternate with the long tentacles. Ocelli (?) There are + radial-canals, each of which is about $3 \mathrm{~mm}$. wide in the middle and only $2 \mathrm{~mm}$. wide at either end. Both the radial-canals and the circular 
tube give rise to numerous simple or branched, blindly-ending side branches of 0.3 to $1 \mathrm{~mm}$. in length. Some of these side branches are simple sacs, but others give rise to secondary branches. The stomach is wide and cruciform, hut the side walls are remarkably' short, so that the mouth is a gaping, cruciform slit, reminding one of the mouth-opening of Staurophora. The + interradial sides of the stomach form + curtains within which the sperm or ova a re developed. The free, lower edges of these curtains are crenulated and thrown into complex folds. The stomach and gonads are cherry-red and the canals and tentacles are light-red in color. This species is found on the coast of Greenland.

\section{Turris digitalis Forbes.}

Turris diginlis, Foriss, 1848 , British Naked-eyed Medusa, p. 21, plate 3, figs. 1a-te.-Arasstz, I., t862, Cont. Nat. Hist

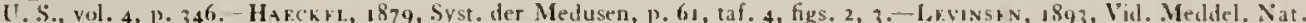
For. Kjöbenhavn (5), Bd. 4, p. 144.-Krín.Nurkt, 1880 , Vergleichend pliysiolog. Studien zu Turris, etc., Aht. 3, p. 124 (reactions to curare and strychnine).

Bell cylindrical, with a well-developed, conical, apical projection. It is 30 to $40 \mathrm{~mm}$. in height and 15 to $20 \mathrm{~mm}$. in diameter. There are 50 to 100 short tentacles, which appear as if arranged in two rows owing to the fact that the bases of the larger ones extend a slight distance up the sides of the bell above the margin.
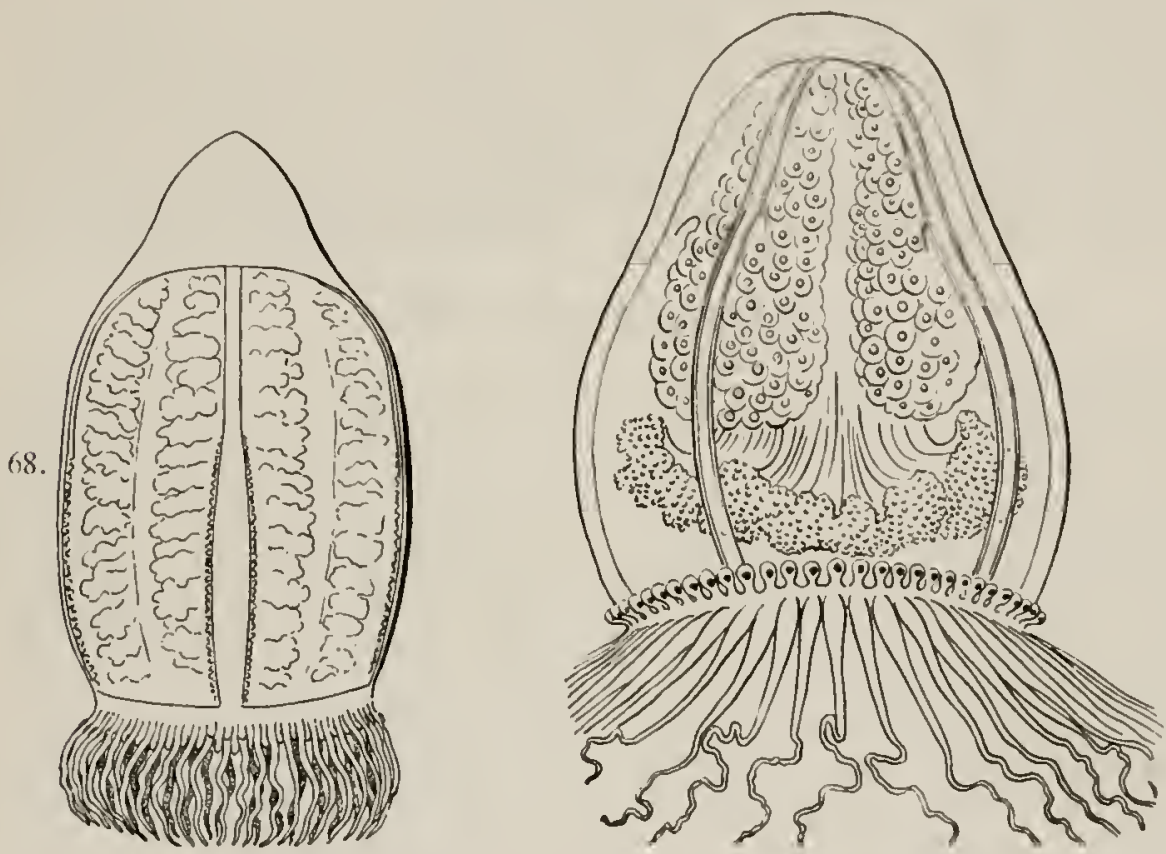

Fici. 68.-Turris digirolis, after Haeckel, 1879 .

Fig. 69.-Conis cyclophhalma, after Haechel, in Syst. der Medusen.

There are 8 strands of longitudinal inuscle fibers within the wall of the subumbrella. These strands lie close to, and upon both sides of, the + radial-canals. The radial-canals are broad and flat. In its upper half each radial-canal is a simple, Hat tube with a straight edge. In their lower halves, however, the canals become broader and give rise to many small side branches which end blindly. The manuhrium is very large and fills the greater part of the bell-cavity. The mouth extends to the level of the velar opening. There are + prominent crenulated lips. The gonads occupy + interradially situated, longitudinal regions upon the wall of the stomach. Each gonad consists of a double row of papilliform ridges, the outer surfaces of which are thrown into complex folds and corrugations.

The stomach is purple or reddish-brown and the lips are rose-colored. The gonads are darker in hue than the stomach. The tentacle-bulbs are orange or yellow and their outer ends are white. The bell is transparent. The 8 muscle-strands in the subumbrella are yellow. 
The species is found in the North Atlantic. It has heen taken off the Shetland Islands, between Greenland and Iceland, between Iceland and the Hebrides, in the North Sea, and off the west coast of Greenland. It is prohably an Arctic form, of circumpolar distrihution.

Genus CONIS Brandt, 1834 .

Comis, Brandt, 1834 , Recueil des Actes-séances publ., Acad. Imp. Sci. St. Pétersbourg, p. 19 (of the "separate"); $1838, \mathbf{M}_{3} \mathrm{em}$. Acall. Imp. Sci. St. Pètershourg, sér. 6, vol. 4, par. 2, p. 355.-HafckkL, 1879, Syst. der Medusen, p. 55.

The type species is Conis mitrata Brandt of the Bonin Islands, North Pacific.

\section{GENERIC CHARACTERS.}

Similar to Panden, but the tentacle-bulbs give rise to special ocellar clubs, which project nutward around the margin. The gonads consist of simple, longitudinal swellings on the sides of the stomach and have smooth outer surfaces. The hydroid is unknown.

\section{Conis mitrata Brandt.}

Conis mirran, Brandt, 1834 , Recueil Actes publique, Acad. Sci. St. Pètersbourg, p. 19 (separate); $183^{8}$, Mem. Acad. Imp. Sci. St. Pëtersbourg, sẻr. 6, vol. 4, par. 2, p. 355, pl. 2.-Hakckr., 1879, Syst. der Medusen, p. 55.-Briot, 1905, Revue Suisse de Zool., tome 13, P. 133 (literature $1834-50$ ).

Bell $50 \mathrm{~mm}$. high, $35 \mathrm{~mm}$. wide, with a short, conical apex. 64 short tentacles, each with a club-like ocellar hulb projecting from the outer side of the hasal hulb at the margin. The tentacles are shorter than the bell-height. The stomach is harrel-shaped, with + not very complexly folded lips, having their margins studded with nematocyst-warts. Lips are at a level about half-way between the velar opening, and the inner apex of the bell-cavity. Stomach light-red. Tentacle-hulhs blue. Ocelli hlack. Bonin Islands, North Pacific.

Conis cyclophthalma Haeckel.

Comis ryclophihalma, HaEckF1, 1879, Syst. der Medusen, P. 55, taf. 4, fig. I.

Bell pyriform, with thin sides and without an apical projecrion; $15 \mathrm{~mm}$. high, $12 \mathrm{~mm}$. wide. There are 52 tentacles with very elongate, conical basal hulbs, one-third as long as the rentacles themselves. The outer ends of the tentacles are thin and flexihle while the basal hulbs are stiff. The tentacles are longer than the bell-height. At the base of each tentacle on the abaxial side of the margin there is a short club-like projection which contains a black, ectodermal ocellus. There are 4 straight-edged radial-canals and a simple ring-canal. The stomach is very large and almost fills the hell-cavity. There are + very large, complexly folded lips with their margins studded with nematocyst-warts. The lips are at about the level of the velar opening. (See fig. 69.)

Haeckel figures and descrihes + longitudinal, swollen gonads on the "perradial" sides of the stomach. Their outer surfaces are smooth and they are filled with ova. He represents them as being completely separated in the interradii. The gonads are prohably adradial or interradial (?). Color (?)

Haeckel studied a preserved specimen in the Museum of Copenhagen. It was obtained near Gibraltar in latt. $36^{\circ} 29^{\prime} \mathrm{N}$., long. $2^{\circ} 23^{\prime} \mathrm{W}$.

\section{Genus CALYCOPSIS Fewkes, 1882.}

Colvenpsis, Fewres, 1882, Bull. Mus. Comp. Zool. at Harvard College, vol. 9, P. 304.

The type species is Calyropsis typa Fewkes, from the Gulf Stream off the coast of the United States.

\section{GENERIC CHARACTERS.}

Tiarina with 16 separate, simple, unhranched radial-canals; 4 radial, 4 interradial, and 8 adradial. Gonads are composed of a row of leaf-like, transverse foldings along each of the 8 adradial sides of the stomach. Lips ( $)$ Tentacles simple. Ring-canal simple, without blindly-ending diverticula. Development unknown. 
Calycopsis typa Fewkes.

Calycopsis typa, liwkes, 1882, Bull. Mus. Comp. Zool. at Harvard College, vol. 9, p. 304, plate 1, fig. 34

Bell higher than a hemisphere, with evenly rounded top and vertical sides. External surface smooth, bell-walls thin, thicker above than near the margin. Size (?) There are 16 radial-canals and 16 marginal tentacles, one at the base of each canal. These tentacles are

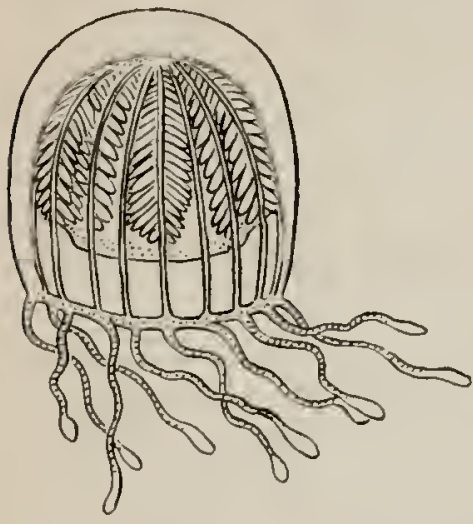

Fin. 70.-Calyropsis typa, after Fewkes, in Bull. Museum Comp. Zool. at Harvard College. about as long as the bell-height and are flexible with somewhat club-shaped outer ends and very small basal bulbs. No lithocysts or marginal bodies other than the 16 tentacles. The stomach is very wide and fills almost the whole of the inner half of the bell-cavity. The gonads are developed upon the sides of the stomach and appear as a series of transverse, leaf-like ridges on hoth sides of each of the 4 principal radial lines of the stomach. They are thus adradial in position and their manner of folding resembles the condition seen in the gonads of Turris. The sides of the stomach are bound to the suhumbrella hy 4 radially situated partitions. There are 16 straight, narrow radialcanals: 4 of these are perradial, 4 are interradial, and 8 adradial. In alcoholic specimens the ovaries were darkbrown. Tentacles and bell-walls white with a tinge of bluish color.

4 specimens were found by the Albatross, in 188081 , off the Atlantic coast of the United States, in deep water along the Gulf Stream.

Form of lips (?) Size (?) Ocelli (?)

\section{Subfamily MARGELIN $\notin$ Haeckel, 1879.}

Oceanidx with oral tentacles and with 4 simple, unbranched radial-canals. Gonads on the interradial, or adradial sides of the manubrium; the mature genital products are found in the ectoderm.

1. Tribe Cylcidi:

Marginal tentacles arise singly from bell-margin and are not grouped into clusters. Oral tentacles are unbranched, sinı̧le, or degenerate. They are found in all forms excepting in the degenerate medusæ of Siylactis.

Cylacis, Eschscholtz, 1829. Cytais + Cubogaster Haeckel. 4 marginal tentacles. Oral tentacles present. Hydroid unknown.

Podocoryne, SARs, $1846=$ Dysmor phosa + Cytarandra HaEckeL, 1879. 8 or more marginal tentacles. Oral tentacles present. When present the peduncle is solid. Hydroid: Podocoryne.

Turritopsis, McCrady, 1856. 8 or more marginal tentacles. Entodermal walls of the 4 radial-canals, above stomach, are composed of highly vacuolated cells forming a peduncle. Mouth studded with a row of nematocyst-bearing knobs. Hydroid: Dendroclara.

Ocearia, sens., Kölliker, 1853; Gegrnbaur, 1856. Medusa similar to Turrisopsis, but with a simple, solid, gelatinous (not vacuolated) peduncle. Hydroid: Clava-like.

Stylactis, Allman, 1864 , degenerate medusxe with 4 to 8 rudimentary marginal tentacles and no oral tentacles. Medusar mature upon liberation from hydroid. Hydroid: Seylactis; closely related to Podocoryne.

2. Tribe Thamnostomeidi:

With branching oral tentacles. With simple marginal tentacles, not grouped in clusters.

Thamnostylus, HaEckel, 1879. 2 diametrically opposed, marginal tentacles. Development unknown.

Thamnitis, HAECKEL, 1879. 4 radially situated, marginal tentacles. Development unknown.

Lymnorea, PÉron and Lesuevr, $1809=$ Limnorea + Thamnostoma, HAECKel, 1879. 8 or more marginal tentacles. Development unknown.

3. Tribe Bougainzillidi:

Marginal tentacles grouped into clusters. Each cluster consisting of 2 or more tentacles. The 4 oral tentacles may be simple or branched.

Bougainvillia, Lesson, $1836=$ Margelis + Lizusa + Hippocrene, НАвскr. L, 1879. With branching, oral tentacles. With 4 radially situated clusters of marginal tentacles, all of one sort. Hydroid: Bougainvillia.

Nemopsis, L. Agassiz, 1849. With branched oral tentacles. With 4 radially placed clusters of marginal tentacles, consisting of a median pair of club-shaped tentacles and a number of lateral filiform tentacles in each cluster. Hydroid: Bougainvillia.

Rathkea, Brandt, $1857=$ Margellium + Lizaia + Lizwella + Rathkea, Hakck.L, 1879 . With 8 clusters of marginal tentacles. Mature hydroid unknown.

Clinarella, MAas, 1897 . With 16 (8 double) clusters of inarginal tentacles. Circular canal gives off 4 interradial, blinilly ending, centripetal branches. 


\section{Genus CYT EIS Eschscholtz, 1829.}

Cylais, Eschscholtz, 1829, Syst. der Acalephen, p. 104.-Eyooux ex Souleyet, 1841, Voyage de la Bonile, tome 2, p.641.Gegenbaur, is 86 , Zeit. für wissen. Zool., Bd. 8, p. 228.- Maas, igo4, Résultats Camp. Sci. Prince Je Monaco, fasc. 28, p. 7; 1905, Craspedoten Medusen der Sibogr Expedition, Monog. 10, p. 8. -Agassiz and Mayer, IS99, Bull. MIus.

Comp. Zool. at Harvard College, vol. 32, p. 161.-Browne, 1905, Report Ceylon Pearl Oyster Fisheries, Roy. Soc.

London, Supplementary Report 27, P. 135.-СнuN, 1895, Bibliotheca Zoologica, Heft 19, p. 11 (law of budding). Coysis + Cubogaster, HaEcket, 1879, Syst. Jer Medusen, pp. 73, 75 .

Ton Cylás, Mayer, 1900, Bull. Mus. Comp. Zool. at Harvard College, vol. 37, p. 39.

Civeris, VANhÖFFen, IS91, Zool. Anzeiger, Bd. 14, P. 444.

Von Cveris, SARs, I\$35, Beskriv og Jagttag., p. 28.

Cubogaster, Hakckrt, 1864 , Jena. Zeit. für Naturw., Bd. 1, P. 341 (voung of Cyturis).

Vigrilina, Stefnstrup, 1837 , Acta et Catal. Musei Hafniensis, Haunide.

\section{GENERIC CHARAC'TERS.}

Margelina with + simple, radially situated, marginal tentacles and with + or more simple, unbranched oral tentacles. The hydroid is unknown.

The type species is Cytais tetrastyla Eschscholtz, 1829 , of the Mediterranean and eastern parts of the tropical Atlantic. Eschscholtz states that it has 8 simple oral tentacles and 4 marginal tentacles, but he figures at least 10 oral tentacles. More recently species of $C y t c i s$ have been found with 8 , I6, or even 32 oral tentacles.

Tabular Synopsis of the Medusa of Cytais.

\begin{tabular}{|c|c|c|c|c|c|}
\hline & $\begin{array}{l}\text { C.tetrastyla } \\
\text { Eschscioltz, } \\
\text { 1829.* }\end{array}$ & $\begin{array}{l}\text { C. atlantica }= \\
\text { C. macrogaster } \\
\text { Haeckel, } 1879 \\
=\text { C. tetrastyla } \\
\text { Eydoux et Soule- } \\
\text { yet, } 1841 \\
=\text { C. nigritina } \\
\text { Haeckel, } 1879 . \dagger\end{array}$ & $\begin{array}{l}\text { C. pusilla } \\
\text { Gegenbaur, } 185^{6} \text {. }\end{array}$ & $\begin{array}{l}\text { C. vulgaris } \\
\text { Agassiz and May- } \\
\text { er, } 1899 . \dagger\end{array}$ & $\begin{array}{l}\text { C. herdnani } \\
\text { Browne, I9o5. }\end{array}$ \\
\hline $\begin{array}{l}\text { Shape and size of } \\
\text { bell in } \mathrm{mm} \text {. }\end{array}$ & $\begin{array}{l}\text { Cubical to domelike. } \\
2 \text { to } 3 \text { high, } 2 \text { to } 3 \\
\text { wide. }\end{array}$ & $\begin{array}{l}\text { 'yriform. 5high, } \\
\text { 6 wi e. }\end{array}$ & $\begin{array}{l}\text { Oval. } 4 \text { high, } 3 \\
\text { wide. }\end{array}$ & $\begin{array}{c}\text { Prismatic, flat above. } \\
5 \text { high, } 3.5 \text { wide. }\end{array}$ & $\begin{array}{l}\text { Oval. } 3.5 \text { high, } 3.5 \\
\text { wide. }\end{array}$ \\
\hline $\begin{array}{l}\text { Character of the } 4 \\
\text { marginal tenta- } \\
\text { cles. Length in } \\
\text { terms of bell- } \\
\text { radius }(r) \text {. }\end{array}$ & $\begin{array}{l}\text { Similar each to each. } \\
2 r+\text { long. Basal } \\
\text { bulbs small. }\end{array}$ & $\begin{array}{l}\text { As in C. tetrastyla, } \\
\text { but with large } \\
\text { pyriform basal } \\
\text { swellings on ex- } \\
\text { umbrella above } \\
\text { each tentacle. }\end{array}$ & $\begin{array}{l}z r+\text { long. With } \\
\text { small basal bulbs. }\end{array}$ & $\begin{array}{l}2 r \text { long, with large } \\
\text { basal bulbs. }\end{array}$ & As in C.atlantica. \\
\hline $\begin{array}{l}\text { Shape and size of } \\
\text { nıanubrium. }\end{array}$ & $\begin{array}{l}\text { Flask-shaped, } \\
\text { mounted on } \\
\text { peduncle. Mouth } \\
\text { at level of velar } \\
\text { opening. }\end{array}$ & $\begin{array}{l}\text { Very large, Pask- } \\
\text { shaped. Two- } \\
\text { thirds to } 1.5 \text { tines } \\
\text { as long as deptlo of } \\
\text { bell-cavity. No } \\
\text { peduncle in } \\
\text { mature medusd. }\end{array}$ & $\begin{array}{l}\text { Stomach oval. } \\
\text { Mounted upon } \\
\text { conical peduncle } \\
\text { not quite as long } \\
\text { as stomach. } \\
\text { Mouth at middle } \\
\text { of bell-cavity. }\end{array}$ & $\begin{array}{l}\text { Stomach oval to } \\
\text { spindle-shape , } \\
\text { half to two-thirds } \\
\text { as long as depth of } \\
\text { bell-cavity. } \\
\text { Young medusa has } \\
\text { short peduncle, but } \\
\text { this is not seen in } \\
\text { mature animal. }\end{array}$ & $\begin{array}{l}\text { Wide flast-shaped, } \\
\text { on short peduncle. } \\
\text { Two-thirds as } \\
\text { long as depth of } \\
\text { bell-cavity. }\end{array}$ \\
\hline $\begin{array}{l}\text { Number of oral } \\
\text { tentacles. }\end{array}$ & 4 to 6 & 8 to 32 & 12 to 24 & 32 & so to 60 \\
\hline $\begin{array}{l}\text { Character of } \\
\text { gonads and } \\
\text { medusa-buds. }\end{array}$ & $\begin{array}{l}4 \text { interradial swell- } \\
\text { ings. }\end{array}$ & $\begin{array}{l}\text { Numerous incdusa- } \\
\text { buds on upper } \\
\text { half of manubrium. }\end{array}$ & $\begin{array}{l}4 \text { interradıal swell- } \\
\text { ings. }\end{array}$ & $\begin{array}{l}8 \text { adradial gonads } \\
\text { near base, on sides } \\
\text { of stomach. }\end{array}$ & $\begin{array}{l}4 \text { perradial? or } 8 \\
\text { adradial? gonads. } \\
\text { No medusa-buds. }\end{array}$ \\
\hline Color. & $\begin{array}{l}\text { Stomach and tenta- } \\
\text { cle-bulbs brown. }\end{array}$ & $\begin{array}{l}\text { Stomach yellowish. } \\
\text { Gonads and tenta- } \\
\text { cle-bulbs violet- } \\
\text { brown, red, or } \\
\text { nearly black. }\end{array}$ & $\begin{array}{l}\text { Stomach and gonads } \\
\text { vellowish-brown. } \\
\text { Tentacle-bulbs } \\
\text { black. }\end{array}$ & $\begin{array}{l}\text { Stomach and tenta- } \\
\text { cle-bulbs red and } \\
\text { green. Abaxial } \\
\text { entoderm red, } \\
\text { superficial green. }\end{array}$ & ! \\
\hline Where found. & $\begin{array}{c}\text { Mediterranean, and } \\
\text { tropical Atlantic. } \\
\text { Canary Islands. }\end{array}$ & $\begin{array}{l}\text { Mediterranean to } \\
\text { Atlantic to } \\
\text { Brazilian coast. }\end{array}$ & Mcditerrancan. & $\begin{array}{l}\text { Fiji Islands to Malay } \\
\text { Archipelago, trop- } \\
\text { ical Pacific. }\end{array}$ & Coast of Ceylon. \\
\hline
\end{tabular}


The gonads of Cytcis are developed upon the interradial sides of the stomach. In Cytais vulgaris, according to Maas, 1905 , they occur as 4 pairs of slightly swollen, corrugated regions, a pair being found on each interradial side of the stomach. The mature genirat products are found in the ectoderm of the stomach-wall. Many of the species develop medusabuds upon the interradial sides of their stomach. Haeckel's statement that the gonads are radial in position appears to be erroneous.

Cytcis is closely related to Podocoryne and is distinguished only by its smaller number (4) of marginal tentacles, whereas Podocoryne las 8 or more marginal tentacles. Moreorer there are commonly more than + oral tentacles in Cytris, whereas the majority of the species of Podocoryne have only + oral tentacles. Cytris is possibly the original genus from which Podocorync and more complex forms may have heen derived.

Cubogaster Hacckel, 1864, appears to be only the young of Cyrtis, excepting "Cubloguster gemmascens" which I take to be an abnormal young Rathkea octopuntata with only 2 wetldeveloped and 6 retarded marginal tentacles. Broch, 1905 (Bergens Museums Aarhogr, No. 11, p. 4), states that the marginal tentacle-bulbs may range from 4 to 8 , and that welldeveloped tentacles may be absent.

\section{Cytæis tetrastyla Eschscholtz.}

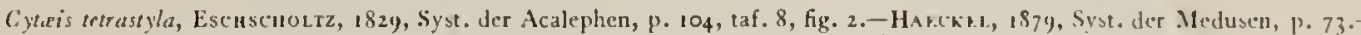
BEDOT, 1905, Revue Suisse de Zool., tome 13, P. 133 (literature, 1829-50).

Bougainvillea mediterranea, Busch, 1851, Beobach. wirbell. Scethiere, p. 21, taf. 2, fig. 10.

This medusa is recorded from the Mediterranean and the eastern parts of the tropical Atlantic. For details see tabular synopsis of the medusæ of $C y t a i s$.

\section{Cytæis atlantica.}

Nigritina atlantica, Str.knsteu, 1837 , Catal. Musei Hafniensis.

Ciyce is tetrastyla, Expoux et Souleyet, $184 \mathrm{I}$, Voyage de la Bonite, fomer 2, p. (741, plate 2, figs. 4 to 15.

Gyte is macrogaster, Harckel, 1879, Syst. der Medusen, 1. 74, taf. 6, fig. 1.-Citen, 1895, Bibliotheca 7oolugica, 11eft 19, p. 45 (budding of medusie from the manubrium).

Cylaris nigritina, Haeckel, 1879 , Syst. der Medusen, 1. 74, taf.6, fign. 2-5.-MaAs, 1904, Résult. Camp. Sci. Primce de Moltaco, fasc. 28, p. 8 , plate 1 , figs. 3,4 .

Bell bluntly conical or pear-shaped, about $6 \mathrm{~mm}$. high and $5 \mathrm{~mm}$. wide. There are 4 stout radially placed marginal tentacles longer than the hell-diameter. The hases of these tentacles are very thick and extend up the sides of the hell as large, bulbous, pear-shaped swellings. These swellings bear a large crescent-shaped mass of entodermal pigment on their lower, outer sides. These bulbous swellings are each about one-eighth to one-fourth as high as the bell. The velum is well developed. There are 4 simple, straight radial-canals and a simple ring-canal. The manubrium is large and lacks a peduncle. It is 0.5 to 1.5 times as long as the depth of the bell-cavity. Normally it is probably about as long as the depth of the hell-cavity. There are numerous medusa-buds upon the upper half of the stomachwall and these are seen in various stages of development. "Ihe mouth is surrounded ly a circlet of 8 to 32 short, slender, oral tentacles, each of which terminates in a nematocyst-knol. The stomach is reddish-brown and the tentacles brown, with tentacle-bullos nearly black. This medusa is found in the Mediterranean and Atlantic from the shores of Africa to the Brazilian coast.

Haeckel describes 4 gonads at the points of juncture of the + radial-canals with the stomach, but this is probably erroneous, for it is improbable that the gonads are in the principal radii.

Haeckel distinguishes $C$. nigritina with manubrium half as long as the depth of the bell-cavity, and with 16 to 32 oral tentacles; and $C$. macrogaster with manubrium 1.5 times as long as the depth of the bell-cavity and with 8 to 16 oral tentacles. In 1904, Maas descriles a very similar medusa, under the name of $C$. nigritina, in which the manubrium is about rwo-thirds as long as the depth of the bell-cavity and has 1 I oral tentacles. These medusie are so closely similar in all other respects that $\mathrm{I}$ am of the opinion that they are merely growth and contraction phases of one and the same species. Following the usual rule of precedence, it appears that the specific name should be "atlantica," this being the designation proposed by Steenstrup, 1837 . 


\section{Cytæis pusilla Gegenbaur.}

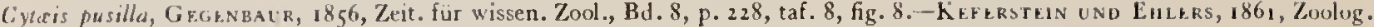
Beitrag., 1. 84 , taf. 13 , fign. 8, 9.- Hazcker, 1879 , Syst. der Medusen, p. 75 .

(?) Cubogasser dissonema (young medusa), HaEckes, Ibid., P. 76 .

This medusa is recorded from the Mediterranean. For details see tabular synopsis of the medusa of Cytais.

Haeckel describes "Cubogaster dissonema" a small medusa $2 \mathrm{~mm}$. high, with 2 welldeveloped and 2 immature or rudimentary marginal tentacles, and 8 oral tentacles. This he found at Croisic, Bretagne, Atlantic coast of France. It may be the young of C. pusilla (?)

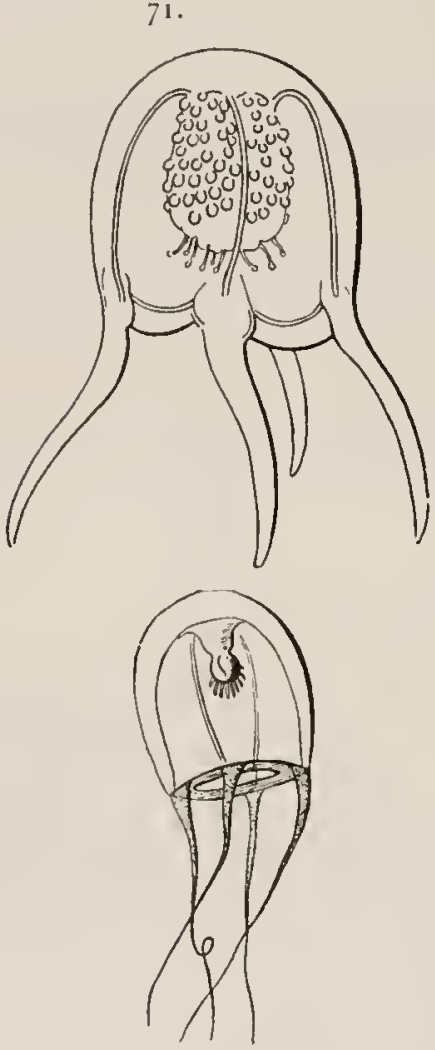

73 .

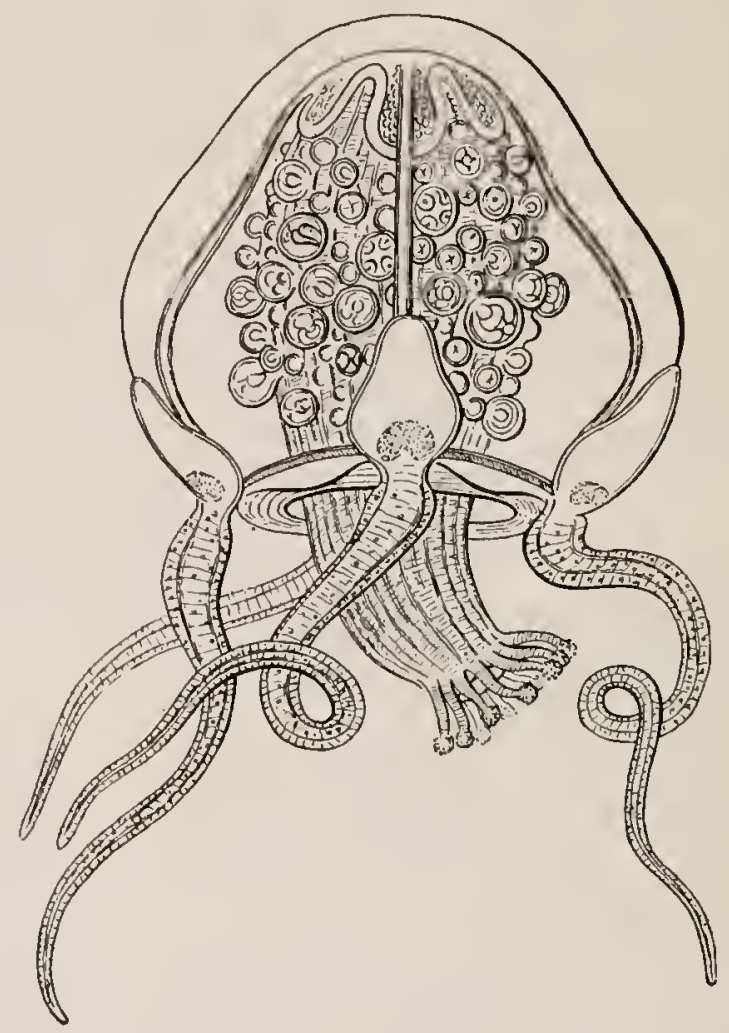

72.

FIG. 71.-Cvtcis atlantica, after Maas, in Result. Camp. Sci. Prince de Monaco.

Fig. 72.-Cytais "macrogaster" (C. atlantica), after Haeckel, 1879.

F1G. 73.-Cytcis pusilla, after Gegenbaur, in Zeit. für wissen. 7ool., Bd. 8.

Cytæis vulgaris Agassiz and Mayer.

Cylocis vulgaris, Agassiz and MaYer, 1899, Bull. Mus. Comp. Zool. at Harvard Coll., vol. 32, p. I61, plate 2, figs.3-5.-MAas, 1905, Craspedoten Medusen der Siboga Exped., Monog. 10, p. 8, taf. 1, fign. 4-7; 19o6, Revue Suisse de Zool., tome 4, p. 85 , fig. 3 , plate 2 .

Mature specimens of this medusa are described by Maas from the Malay Archipelago. Agassiz and Mayer described only half-grown medusæ from the Fiji Islands.

Mature medusa.-Bell $5 \mathrm{~mm}$. high, prismatic, 4-sided, and with a flat top. There are 4 thick, radially placed, marginal tentacles, each somewhat shorter than the bell-height. These tentacles end in blunt tips and have large hollow basal bulbs. Maas describes a thick lensshaped swelling on the abaxial side of each tentacle-bulb, but his specimens are somewhat contracted through preservation in formalin. The basal bulbs of the living medusx studied by Agassiz and Mayer were large and swollen, but lacked the lenticular, ectodermal swellings. On the other hand Agassiz and Mayer found only half-grown medusæ, and it is possible that the peculiar form of the basal bulbs described by Maas may be characteristic of the full-grown, 
but not of the half-grown, medusa. The velum is well developed. The 4 radial-canals and ring-canal are slender and simple. The manubrium is spindle-shaped and shorter than the depth of the bell-cavity. In the half-grown medusa there is a short conical peduncle, but this was not seen by Maas in his large specimens.

The mouth is at the extremity of a bluntly pointed, conical neck, and is a simple round opening. 32 or more short, slender, filiform, unbranched oral tentacles arise from a zone above the mouth. Each oral tentacle is solid and ends in a knob-like cluster of nematncysts.

The gonads are found on the upper interradial sides of the stomach and appear as a pair of longitudinal swellings in each of the 4 interradii. They are not developed on the 4 radial lines of the stomach. The eggs protrude over the surfaces.

In the formalin specimens studied by Maas, the gonads were yellow, the axial entoderm of the stomach dark-red, as were also the entodermal parts of the tentacle-loulhs. There is some green pigment in the ectoderm of the tentacle-bulbs. In the immature specimens from Fiji, studied from life by Dr. Agassiz and his assistant, the entoderm of the outer part of the manubrium and of the tentacle-tips was green, while there was red pigment in the axial part of the stomach and in the tentacle-bulbs and adjacent parts of the 4 radial-canals. In the young specimens from Fiji the oral tentacles ranged from 4 to 16 , while in those found by Maas in the Malay Archipelago, they ranged from 8 to 32.

Found in abundance on the surface among the Fiji Islands in November to January. Maas found numerous specimens in the Siboga collection from the Malay Archipelago, Sulu, Damar, Daram, Sabuida, Gisser, Manipa Straits, and Saleyer; and from Ámboina, Igo6.

Cytæis herdmani Browne.

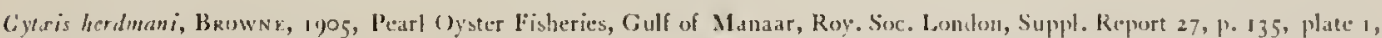
fig. I; plate 4 , fig. 12.

Umbrella about $3.5 \mathrm{~mm}$. in width and height. Somewhat hell-shaped with fairly thick walls. 4 marginal, long tentacles with very large, spear-head-shaped, basal bullos one-third as long as the hell-height. The ectodern of the tentacles is thickly crowded with nematocysts. The entoderm of the tentacles and basal butbs is pigmented. Velum narrow. 4 wide, straight radial-canals. Stomach about as wide as long placed upon a short peduncle and extending a little more than half-way down the cavity of the bell. A row of 50 to 60 short, equally spaced oral tentacles, each ending in a knob of nematocysts. Gonads form + (perradial?) swellings extending the entire length of the stomach. Color (?) Coast of Ceylon; Chilaw Paar, and Cheval Paar; March to November.

\section{Genus PODOCORYNE Sars, 1846 .}

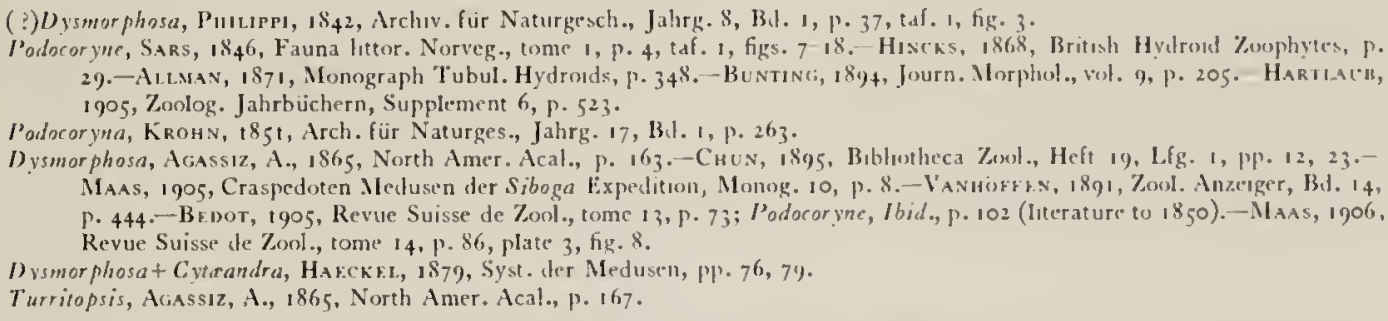

The name Dysmorphosa was first used by P'hilippi, 1842, in his description of $t$ ). contchiola, a hydroid polyp which may have been either a Podocoryne or a M vidractinia in the modern sense. In $18+6$, Sars described a closely related, medusa-bearing liydroid under the name Podocoryne carnea. The name Dysmorphosa was first applied to the free medusa hy $A$. Agassiz, 1865 . The great majority of authors have included both the hydroid and the free medusa under the generic name Podocoryne. In the ahsence of proof as to whether I'hilippi's hydroid develops medusx or not, we are unable to decide with certainty which name shonld stand, but there is no probability that Philippi's hydroid will ever be determined and we may alvoid confusion by considering it obsolete. 


\section{GENERIC CHARACTERS}

Margelinx with 4 or more simple, unbranched oral tentacles and with 8 or more simple marginal tentacles. When present the peduncle of the manuhrium is simple, solid, and gelatinous. The hydroid stock is Podocoryne.

Haeckel, 1879 , restricts the genus "Dysmorphosa" to include only those medusa which have 8 marginal tentacles. Medusx hearing more than 8 tentacles he places in a new genus "Cytcandra." Inasmuch as specimens of Podocoryme fulgurans and P. carnea are often found which have more than 8 tentacles, we consider Haeckel's definitions to be too restrictive. Vanhöffen, 1891 , defines Dysmorphosa, as we do Podocoryne, to include medusa, with 8 or more marginal tentacles.

Podocoryne may he distinguished from Lymmorea by its simple unhranched oral tentacles. In Turritopsis there are no oral tentacles, but only + simple lips studded with nematocystknols, and the presence of simple oral tentacles in Podocoryme at once distinguishes it from Turritopsis. It is distinguished from $C$ yteris by its having eight or more marginal tentacles, whereas $C y t$ if is is restricted to medusx bearing 4 marginal tentacles. In Cytais the oral tentacles are commonly more than 4 , whereas there are only 3 known species of Dysmorphosa bearing more than 4 oral tentacles. Podocoryne is possibly derived from the more simply organized Cytais.

\section{Podocoryne carnea Sars.}

Plate 14 , figs. 2 to 6 ; plate 15 , fig. 14.

SYNONYMS of THE Eeropran Fors.

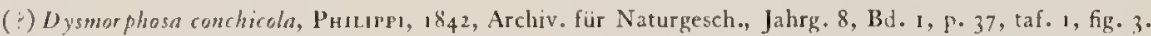

Podocoryne carnea, Saks, 1846, Fauna Littor. Norveg., p. 4, taf. 1, figs. 7-18. - Kronn, 1851, Archiv. für Naturgesch., Jahrg.

17, Bd. 1, p. 266.-Hincks, I868, British Hydroid Zooph., p. 29, plate 5, 6 figs. -Allman, 1871, Monograph Tubul. Hydroids. p. 349, plate 16, figs. 1-9.-OE VARENne, 1882, Archiv. de Zool. Expèr., tome 10, pp. 645, 674, 683, plate 33, figs. 6-15; plates 34, 36-38; 1882, Compt. rend. Paris, tome 94, p. 892.-W E.1s.ManN, 1883, Sexualzellen bei den Hydromedusen, pp. 63-72, taf. 19, fign. 1-13.-Brownk, 1896, Proc. Zool. Soc. London, P. 463.-DE VArennf, 1881, Annals and Mag. Nat. Hist., ser. 5, vol. 9, p. 134.-Havann, 1882, Jena. Zeitschrift für Naturwissen., Bd. 15, p. 517, taf. 20, fign. I,

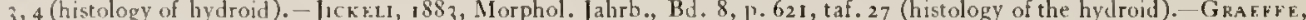
1884, Arbeit. Zool. Inst. Wien, Bd. 5, p. 347.-Ishikawa, 1888, 7.eit. für wissen. Zool., Bd. 47, p. 621, 6 fign. (origin of egg cells).-Bерот, 1905. Revue Suisse de Zool., tome 13, p. 103 (literature 1842-1850).-Ritchif, 1907, Trans. Roy.

Soc. Edinburgh, vol. 45 p. 523 (from Cape Colony, South Africa).

Dysmorphosa carnea, Hakckel., 1879 , Syst. der Medusen, P. 77

Cylicis exigula, HaEckel, Ibid., p. 634.

Padocoryne hackelii, Hatann, I882, Jena. Zcit. fur Naturwissen., Bd. I5, p. 519 (young stocks of $l$ '. carnea ?).

(?) Podocoryne conchicola (Philippi) in part, HaRo1TT, 1904, Mitth. Zool. Station Neapel, Bd. 16, p. 581, fig. 26, taf. 22.

\section{SYNONiMS OF THE AMERICAN REPRYSFNTATIVE.}

Turrizopsisnutricula, Agassiz, A., 1862, Proc. Boston Soc. Nat. Hist., vol. 9, p. 97, figs. 22, 23; 1865, North Amer. Acal.,p. 167, figs. 269, 270.-FEWkes, 1881, Bull. Mus. Comp. Zool., vol. 8, p. 153, plate 4, figs. 4, 7-10.

Calcydion formosin, Frivkrs, 1882 , Bull. Mus. Comp. Zool., vol. 9, p. 204

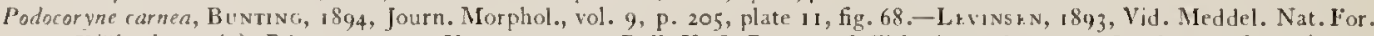
Kjöbenhavn (5), Bd. 4, P. 153.- HargitT, 1904, Bull. U. S. Bureau of Fisheries, vol. 24, p. 38 , plate 4, fig. 5 (figure labeled "Turriopsis mutricula," on p. 37).

Turrilopsis nutricula (in part), Netring, 1901, Bull. U. S. Fish Commission for 1899, vol. 19, p. 375 .

Porocoryne carnea, HargitT, 19ol, American Naturalist, vol. 35, p. 582, fig. 44.

Podocoryne, Hazen, 1902, Amer. Naturahst, vol. 36, p. 193 (regeneration).

\section{AMERICAN VARIETY.}

Adult medusa (plate 15, fig. I t). - Bell ellipsoidal in form and about $3.5 \mathrm{~mm}$. in height. Gelatinous substance not very thick, hut quite tough and rigid. There are about 2 to 32 marginal tentacles which are about as long as the bell-height. The tentacles are not very Hexihle, and are usually carried curled upward. The tentacle-bulbs are well developed and are filled with entodermal pigment granules. The velum is well developed. There are 4 straight and narrow radial-canals. The manubrium is flask-shaped and there is no peduncle. The mouth-opening is surrounded by 4 short, radially situated, unbranched, oral tentacles, each of which terminates in a knoh-shaped cluster of nematocysts. The ripe ova and spermatozoa are fonnd in the 4 interradii within the ectoderm of the nanubrium. According to Ishikava and 


$$
\text { • }
$$




\section{Plate it.}

Fig. 1. Podocoryne minuta, Tortugas, Florida, July I6, 1898.

Fig. 2. The hydroid of Podocoryne carnea. Agassiz Laboratory, Newport, Rhode Island, June 20, 1895.

Figs. 3 to 5. Podocoryne carnea. Stages in the growth of the medusa. Agassiz Laboratory, Newport, Rhode Island, July 20 to 24, 1892.

Fig. 6. Podocoryne carnea, young medusa. Agassiz Laboratory Newport, Rhode Island, July, 1895.

Fig. 7. Podocoryne dubia. Tortugas, Florida, July 20, 1898.

Fig. 8. Podocoryne dubia. Side view of oral tentacles.

Fig. 9. Podocoryne dubia. Side view of marginal tentacles.

Fig. 10. Turritopsis nutricula, mature male. Agassiz Laboratory, Newport, Rhode Island, July, I 892 .

Figs. 1 I to 13. Turritopsis mutricula, young stages of the medusa. Agassiz Laboratory, Newport, Rhode Island, July, 1892.

Drawn from life, by the author. 


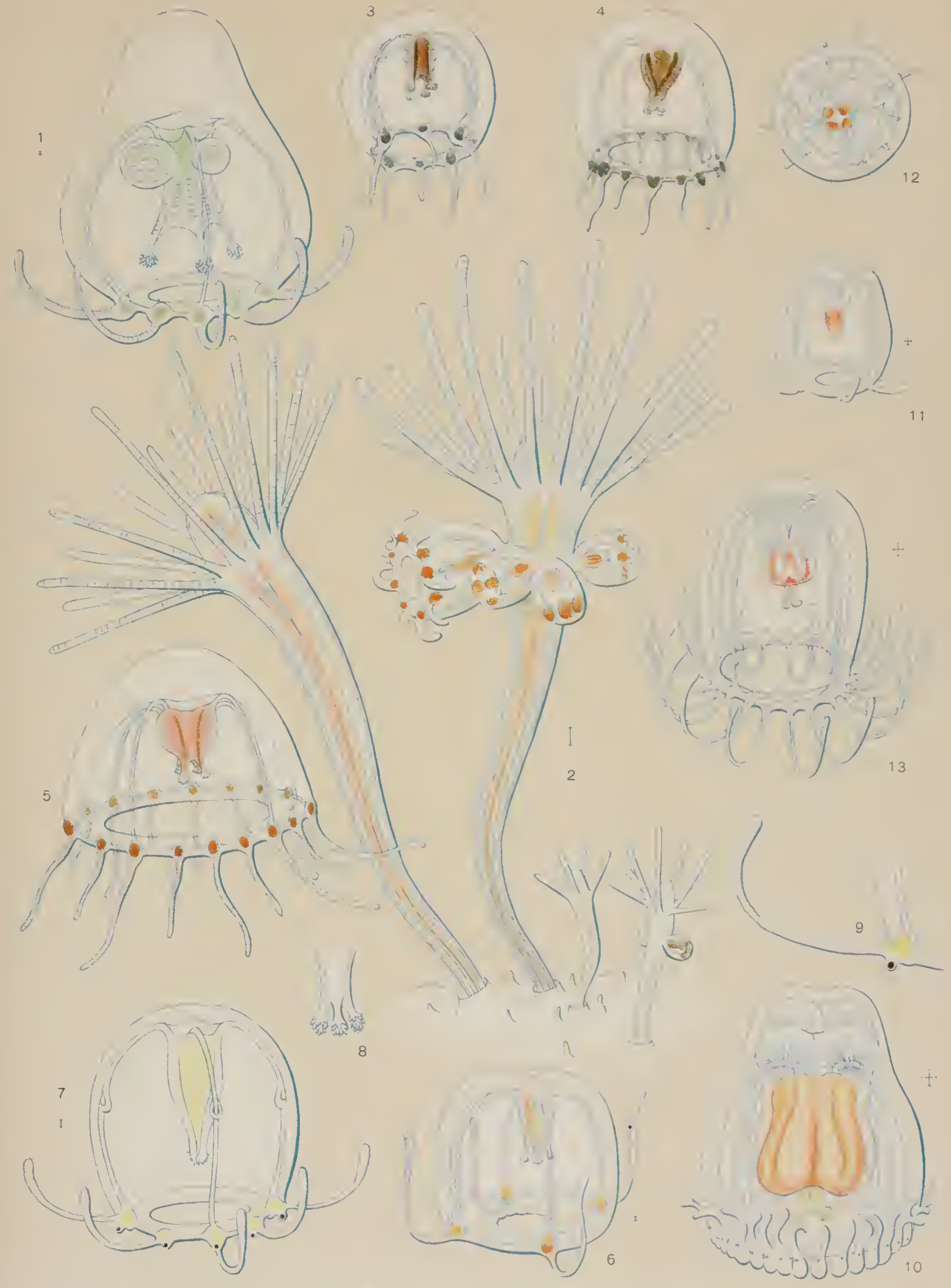



Bunting, the ova originate in the entoderm, but the sperm originates and remains in the ectoderm. When the medusa is mature both ova and sperm are found in the ectoderm of the stomach. In the female, the ova are large and prominent and are spherical in form. The entoderm of the manubrium and of the tentacle-butbs is red, or brown to red, in color.

Hydroid and young medusa. - No specific difference exists between the American and European hydroid stocks of Padocoryne. The hydroid (plate 14, fig. 2) is commonly found upon shells which are tenanted by the hermit-crab (Pagurus) and also upon the carapace of limulus. The polypites arise at somewhat irregular intervals from a hydrorhiza which clings to the surface of the shell, etc., upon which the stock is growing. In young colonies the hydrothiza consists of an open network of anastomosing fibers, which are covered by a thin, delicate perisarc, and externally by a Heshy hydrocaulus, or conosarc. As the colony becomes older. however, the fibers of the hydrorhiza form a closer network, and the chitinous perisarc fills in the spaces between them. Numerous short, chitinous spines are developed upon the crust which covers the fibers, and thus we find the polypites arising from a Aat, spinous base which adheres to the surface on which the colony is growing. The colony is composed of two kinds of hydranths: sterile feeding-polypites, and reproductive gonostyles. The sterite feedingpolypires are spindle-shaped, heing ahout twice as wide near the oral circlet of tentacles as they are at the base. They have 12 to 16 straight, stiff tentacles. The mouth is situated at the apex of a dome-shaped proboscis. They are very contractile and may vary in length from about 5 to $15 \mathrm{~mm}$. The reproductive polypires, or gonostyles, a re frequently exacrly similar in size and shape to the feeding-polypites, and, in fact, are probably merely feeding-polypires which

\begin{tabular}{|c|c|c|}
\hline & $\begin{array}{l}\text { Podocoryne carnea } \\
\text { Sars, of Europe. }\end{array}$ & $\begin{array}{l}\text { Pulocoryne carnea } \\
\text { var. americana. }\end{array}$ \\
\hline $\begin{array}{l}\text { Number of leniacles when liberaled } \\
\text { from hydroil. }\end{array}$ & 4 & 4 In 8. Isually 8. \\
\hline $\begin{array}{l}\text { Number of lenlacles possessed by } \\
\text { mature medusa. }\end{array}$ & $\begin{array}{l}\text { Usually } 4108 \text {, rarely } \\
\text { it, (Graeffe). }\end{array}$ & $\begin{array}{l}161032 \text {. I'sually } \\
\text { aboul } 24 \text {. }\end{array}$ \\
\hline $\begin{array}{l}\text { Metusa-buds on inlerradial sides of } \\
\text { slomach of medusa. }\end{array}$ & $\begin{array}{l}\text { Observed by Sars, } \\
18_{4} 6 \text {. }\end{array}$ & $\begin{array}{l}\text { No medusa-huds } \\
\text { observed. }\end{array}$ \\
\hline
\end{tabular}
have developed medusa-buds (see plate 14, fig. 2, g). In other instances the gonostyles are smalter and more stender. and possess not more than $t$ to 8 tentacles (see $g^{\prime}$. fig. 2). The medusa-buds arise from a zone which is slighty below the circlet of oral tentacles. From t to $S$ of these buds are usually to be seen upon each gonostyle. According to Martha Bunting, 1894 , it appears that the medusa-bud arises as an outpushing of both entoderm and ectoderm of the gonostyle. As the bud progresses in its development, we find the ova in the entoderm of the manubrium. When a later stage has been reached they migrate from the entoderm into the ectoderm. The spermatozoa, on the other hand, originate in the ectoderm of the manubrium, as was shown by Weismann, 1883 . When set free the medusa usually has 8 telltacles: + radial and 4 interradial. The radial tentacles are usually better developed than the interradial and in some individuals there are but + tentacles at the time of liheration, the interradial ones not yet being developed.

It is remarkable that while in some stocks of Podocorync the medusa are set free in an immature state, in others the medusa are mature when liberated, the manubrium being distended with sperm or ova, which are discharged almost immediately after the medusa is set free. It is possible, as Allman, 18,1 , suggests, that this difference may be the to the influence of local conditions, which may be favorable in the onc case and not so in the other to all advanced development of the medusa. Krohn, 1851 , and l.oven, 1857 , have olserved stocks of the European form of Podocorymo which were setting free mature medusa. Indeed, we appear to have a parallel case in Sarsia on the Massachusetts coast, where inmature medusa are liberated during the early spring months, whereas the medusa become ripe, discharge their genital products and wither upon the hydroid stock in May. Goond figures of Podocoryne stocks which are setting free immature medusa have heen given by Sars, $18+6$; Hincks, 1868 ; AHman, 1871 ; etc. When set free the medusa commonly have 8 tentacles, t radial and + interratial. "Whe radial tentacles are usually more advanced than the interradial, and in some few individuals 
there is no trace of interradial tentacles at the time when the medusa is liberated. The manubrium is short and fusiform and the mouth is surrounded by + radially situated, oral tentacles, each of which terminates in a knob-shaped cluster of nematocysts. When set free the medusa is about 0.5 to $0.6 \mathrm{~mm}$. in height.

In those medusx which are set free in an immature condition there are at first 8 tentacles, but these increase in number as growth proceeds and finally, when the medusa is about $3.5 \mathrm{~mm}$. in height, there are usually about 32 tentacles, $8 \mathrm{in}$ each quadrant. The manuhrium of the young, immature medusa is slender and fusiform, while in those medus $x$ which are set free in a

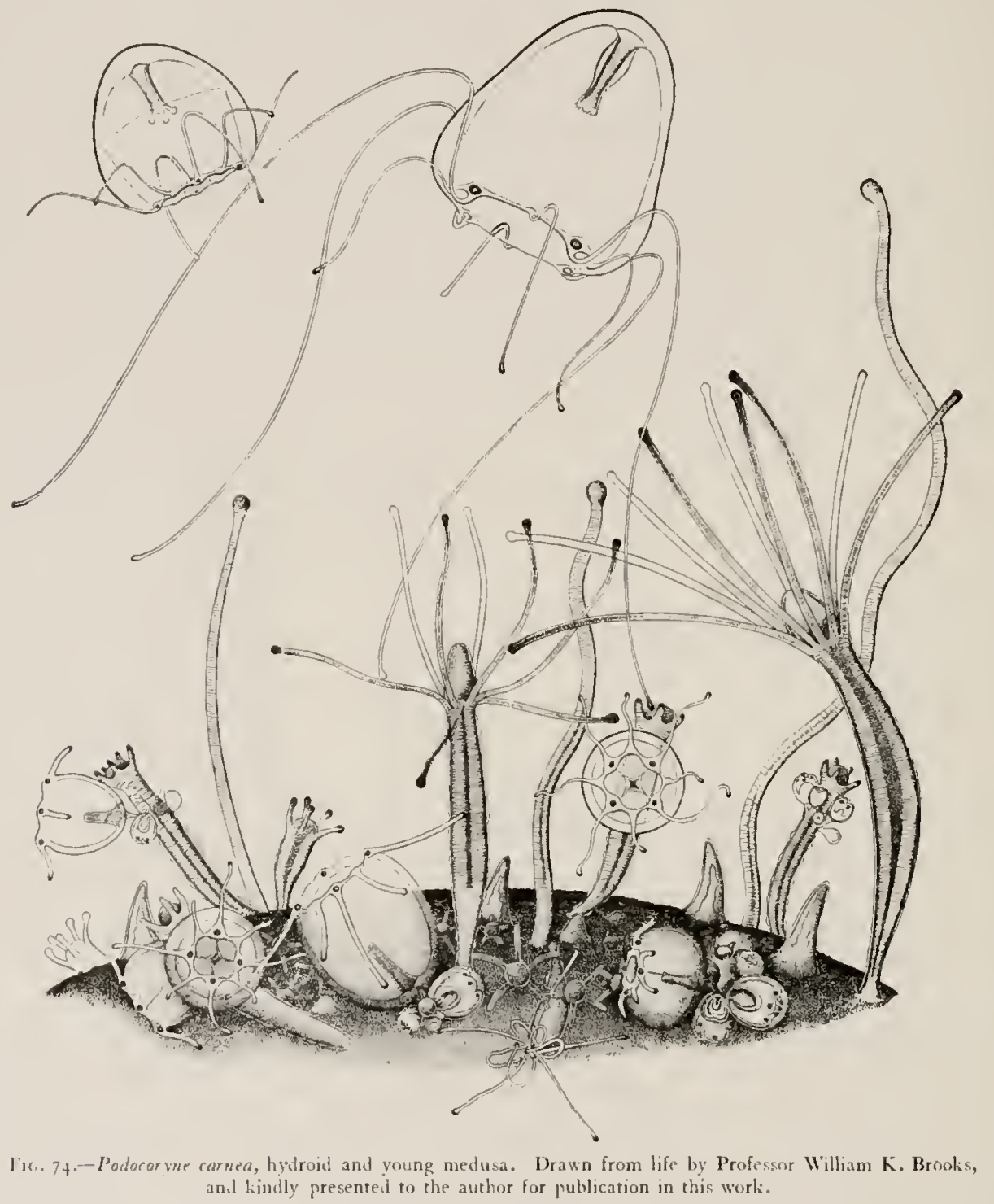

mature state it is globular and greatly distended with the genital products. The ectoderm of the hydroid is slightly bluish and translucent, while the entodem is creamy-pink, or silverywhite in color.

This species has been found upon the Arlantic coasts of Europe, in the Mediterranean Sea, and from Saldanha Bay, Cape Colony, South Africa. Levinsen, 1893 , records it from the west coast of Greenland, and we have found it in great ahundance in Narragansett and Buzzard's Bays, on the southern coast of New England. It has not been taken at Beaufort, North Carolina, nor at any' station farther south. 'The medusæ are very common in Narragansett Bay from the middle of June until Octoher, and I enjoyed exceptional opportunities 


\section{Plate 15}

Fig. I. Lymmore borealis. Eastport, Maine, September 19, 1898.

Fig. 2. Iymnoren borealis. Side view of the oral tentacles.

Fig. 3. I.ymnorea borealis. View of the nematocyst-capsules upon the oral tent acles.

Fig. 4. I.ymnorea alexandri, young medusa. Nassau Harbor, Bahamas, June, 1903 .

Fig. 5. L.ymmorea alexandri, mature medusa. Nassau Harbor, Bahamas, July, 1903 .

Fig. 6. L.ymurea alexandri. Cross-section showing the gland-cells of the mid-region of a radial-canal of the medusa shown in figure 5 .

Fig. 7. Lymmorea alexandri. Knob-like end of one of the oral tentacles showing the nematocysts.

Fig. 8. Lymnorea alexandri. Mouth parts of the young medusa shown in figure 4 .

Fig. 9. L.ymuorea alexandri. Marginal tentacle.

Fig. 10. Turritopsis mutricula, young medusa. Agassiz Laboratory, Newport, Rhode Island, August, I 892.

Fig. 11. Turritopsis mutricula, young medusa. Newport, Rhode Island.

Fig. 12. Turritopsis mutricula. View of the lips of a mature male medusa. Tortugas, Florida, April 6, 1906.

Fig. 13. Turritopsis nutricula. Ahoral view of manubrium showing the vacuolated entodermal cells surrounding radial-canals. Tortugas, Florida, April 6, 1906.

Fig. 14. Podocoryne carnea, mature female. Agassiz, Lahoratory, Newport, Rhode Island, July, I 895.

Drawn from life, by the author. 

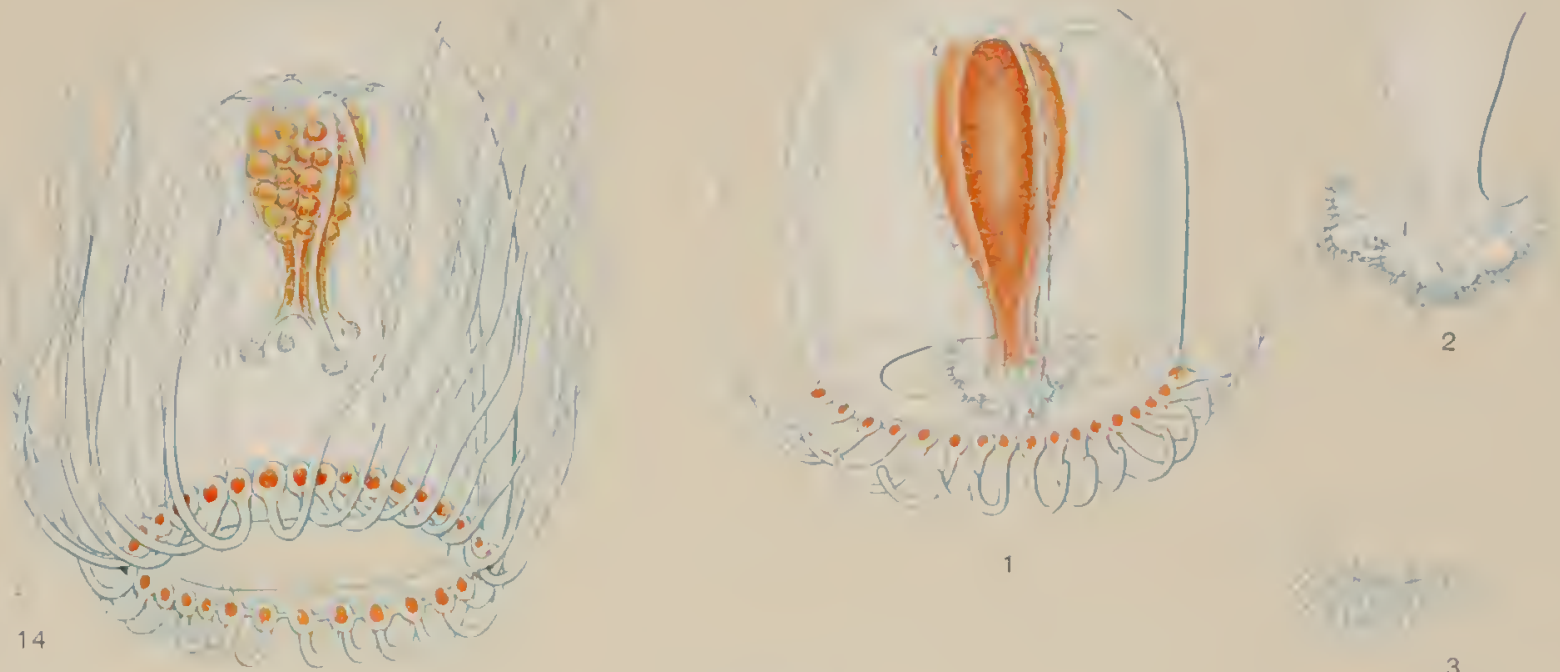

3
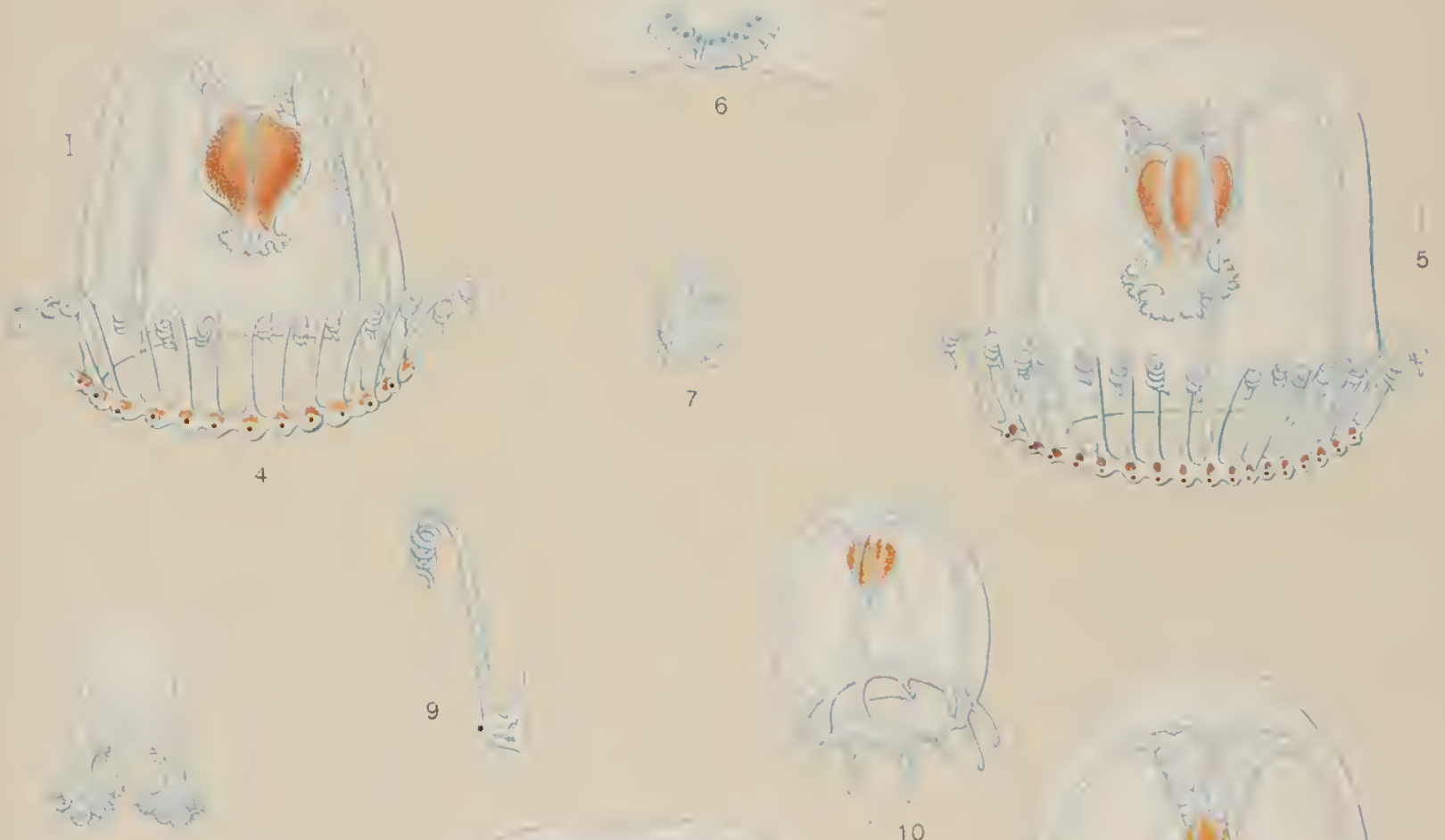

8
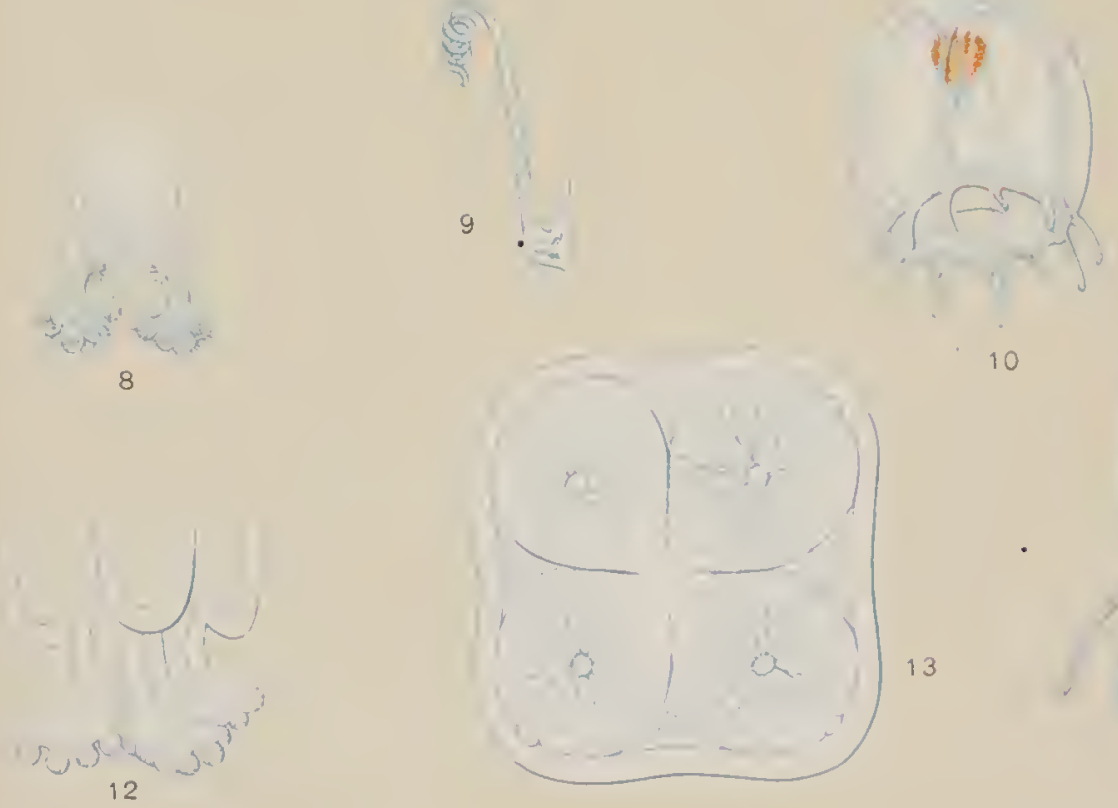

10

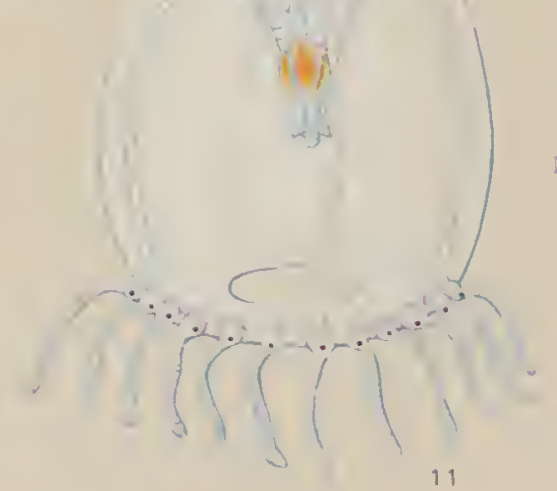



for observing their growth and development while studying at Dr. Alexander Agassiz's lahoratory at Newport, in $1892-96$.

In $1881-82$ de Varemne concluded that both eggs and sperm-cells originate in the entoderm of the coenosare of the hydroid and afterwards migrate into the medusa-bud. The more careful researches of Weismann, $188_{3}$, however, refuted this view, showing that the male germ-cells originate in the ectoderm of the budding medusa, but do not wander from their place of origin. On the other hand, the female germ-cells may possibly originate in the ectoderm; if so they soon wander into the entoderm of the hudding gonophore, then into the spadix of the medusa-bud and finally into the ectoderm of the manubrium of the medusa. According to the later studies of Ishikawa and of Bunting, however, the egg-cells originate in the entoderm of the medusa-bud and afterwards migrate into the ectoderm.

Podocoryne fulgurans.

Plate 12, figs. 5 to 9 ; plate 13 , figs. 3 to 5 .

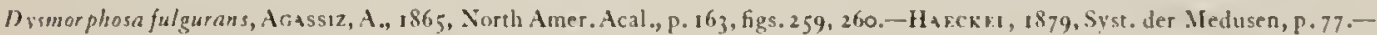

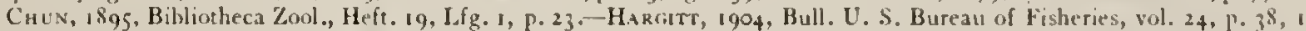

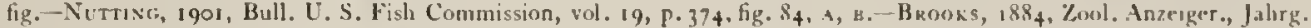
7. p. 711 (hydroid?)

(?) Mabella gracilis, Frwk rs, 188, Bull, Mus. Comp. Zool. at Harvard College, vol. 8, p. I 46.

Adult medwsa.-Bell usually somewhat pyriform in shape and about $\mathrm{I} \mathrm{mm}$. in height. Gelatinous substance very soft and flexible, so much so, indeed, that the medusa is often found to be much distorted and shriveled by the powerful contractions of the circular muscles. Very' frequently this contraction causes deep interradial furrows to appear upon the surface of the bell, in the meridian of the radiating muscles of the suhumbrella, and I believe that this appearance led Fewkes, I88 I, to describe one of these contracted medusx as a new genus: "Mabclla gracilis." There are usually 8 , hut sometimes 16 (plate 13, fig. 5), long, marginal tentacles with well-developed basal bulbs. These tentacles are quite stiff and are carried curled upward. The tentacle-hullos are large and are filled with entodermal pigment. The velum is wide. There are 4 straight, slender, radial tubes. The manubrium is furnished with a well-developed peduncle (plate 12 , figs. 6 to 9), which is quadratic in cross-section. The peduncle has the shape of a frustum of a pyramid, and it extends about one-third the distance from the inner apex of the bell-cavity toward the velar opening. The 4 radial tubes extend down the 4 angles of the pyramid into the gastric part of the manubrium. The gastric portion of the manubrium is short and the mouth-opening is situated at the lower extremity of a short tubular neck. There are no prominent lips. 4 radially situated, oral tentacles arise from the sides of the neck. These oral tentacles are quite flexible. They taper gradually and end each in a single, knoh-shaped cluster of nematocyst-cells. Medusa-buds are produced upon the sides of the stomach. These buds arise in the interradii (plate 12, fig. 7), and one usually sees 4 or 5 of them in various stages of development. The place and time of appearance of these medusa-huds appear to follow the law demonstrated by Chun, 1895 , in Rathken octopunctats. When set free the young medusa has 8 marginal tentacles. It is interesting to observe that while the medusx are still attached to the manuhrium of the mother they themselves hegin to develop medusa-buds upon the sides of their manubria (plate 12, fig. 7 ). The entoderm of the tentacle-bulhs is of a delicate salmon-red. The manubrium is sometimes colorless and sometimes salmon-red.

This medusa is very abundant at Newport, Rhode Island, late in the summer, when it occurs in vast swarms which cause the water, when disturbed at night, to glow with a bluish phosphorescence. A large swarm was found in the St. Mary's River, Maryland, near the mouth of the Potomac, in November, 1905; and I have also taken it at Beaufort, North Carolina, late in November. It has not heen seen at Tortugas. Florida.

This species is readily distinguished from Podocoryne carnea by its much smaller size. Also the mantshrium is provided with a well-developed peduncle, while in $P$. carnoa there is no peduncle. $P$. fulgurans is very delicate and flexible, while $P$. carnea is tough and relatively. inflexible.

A Podocoryne found at Beaufort, North Carolina, by Professor Brooks, is prohaloly the hydroid of this medusa. The tentacles are usually in whorls of 5 . 
Hvdractinia areolata, Ald F, I\$6I, Trans. Tyneside Nat. Field Club., vol. 5, P. 225, plate 9, figs. I-4 (hydroid).

Poidocoryne areolata, Hincks, 1868 , Hist. British Hydroid Zooph., p. 32, plate 6, fig. 1.

Cyecandra areolata, Ha ECKFL, 1879 , Syst. der Medusen, p. 79.

(?) Cyecandra areolata, Brownf, 1895, Trans. Liverpool Biol. Soc., vol. 9, p. 26z; 1897, Proc. Zool. Soc. London, p. 817, plate 48 , figs. I-z; 1903 , Bergens Museums Aarbog, No. 4, p. 12.

This medusa is liberated from Podocoryne areolata of the British coasts.

According to Browne, the medusa becomes about $4 \mathrm{~mm}$. wide and slightly less in height. The hell is pyriform with a thick, gelatinous apex. There are 25 to 30 marginal tentacles about as long as the bell-radius and with fairly large basal bulbs which lack ectodermal ocelli, but have entodermal pigment. The stomach lacks a peduncle and is about one-half to two-thirds as long as the depth of the bell-cavity. There are 4 long, narrow lips, each of which bifurcates and ends in 2 knoh-like clusters of nematocysts. The gonads are upon the sides of the stomach.

According to Browne, the entoderm of the stomach and tentacle-bulls is rich reddishbrown, darker than the stomach.

When set free from the hydroid the medusa has 16 marginal tentacles of various lengths. Browne has not observed the hydroid, which was obtained by Alder. I an inclined to believe that this medusa may prove to be identical with Lymnorea borealis, found at Eastport, Maine, on the American Atlantic coast. In Europe it ranges from British coasts to Norway, and is rare according to Browne.

Podocoryne octostyla.

Dysmorphosa octostyla, H+Eckit, 1879, Syst. der Medusen, p. 78, taf. 6, fig. 6.

Bell $0.4 \mathrm{~mm}$. high, $0.5 \mathrm{~mm}$. wide, with bulging sides and low, conical apex. 8 short. equally developed, marginal tentacles, about as long as the radius of the bell, with small hasal bulbs. Stomach mounted upon a conical peduncle as long as itself; both together about two-thirds as long as the depth of the bell-cavity. 8 simple, knobbed, oral tentacles about as long as the stomach. 4 swollen, interradial gonads on the sides of the stomach. When young, medusa-buds are produced upon the interradial sides of the stomach. Gonads and tentaclebullss nearly black.

Found in the Mediterranean. Two specimens were found by Haeckel.

Podocoryne polystyla.

Cytrandra polystyla, Ha ecket, 1879 , Syst. der Medusen, p. 79.

Bell nearly cubical, $1.5 \mathrm{~mm}$. wide, $1.5 \mathrm{~mm}$. high. 32 short, marginal tentacles (without ectodermal ocelli?). Stomach large, cubical, mounted on a short peduncle and filling nearly' all of the bell-cavity. I6 short, simple, oral tentacles. 4 gonads on the lower part of the stomach-wall. The gonads are "half-moon-shaped" with the convex side below. Stomach yellow. Gonads and tentacle-bulbs reddish-brown.

Found by Haeckel at Croisic, Atlantic coast of France.

Podocoryne minuta.

Plate 14 , fig. I.

Dismorphosa minura, M4rer, 1900, Bull. Mus. Comp. Zool. at Harvard College, vol. 37, p. 41, plate 18 , fig. 42. Dysmorphosa minuta, Trinci, 1904 , Monit. Zool. Ital., Anno 15, p. §04.

(?) Cyeis minima, Trinc1, 1903, Mittheil. Zool. Sta. Neapel, Bd. 16, p. 1, taf. 1, fign. 1-zo (young medusa?).

Bell pear-shaped and only $0.3 \mathrm{~mm}$. high. Bell-walls quite thick and the apex solid and bluntly pointed. In common with other species of Podocoryne, the gelatinous substance of the hell is very delicate and the medusa soon collapses into a shapeless mass when subjected to the abnormal conditions of captivity in a small aquarium. There are 8 solid, marginal tentacles with well-developed hasal bulbs without ocelli. The velum is narrow. There are 4 straight, narrow radial-canals and a slender ring-canal. The manubrium is mounted upon a short, wide peduncle, which is solid, and down the 4 radial corners of which the radialcanals extend into the stomach. The gastric portion of the manubrium is 4 -sided in crosssection. 4 well-developed, oral tentacles surround the mouth. The entodermal cores of these oral tentacles are composed of chordate cells, and each tentacle terminates in a bristling, 
. 
Plate i 6.

Figs. I to 3. Podocoryme gracilis. Successive stages in the growth of the medusa. Tortugas, Florida, June, 1899.

Figs. 4 to 5. Bougainvillia antumnalis, young and mature stages of the medusa. Agassiz Laboratory, Newport, Rhode Island, September, 1895 and July, I 896 .

Fig. 6. Bongainvillia fromlosa, showing planula upon the sides of the stomach. Tortugas, Florida, June, I 897.

Fig. 7. Bongainvillia carolinensis, young medusa. Agassiz Laboratory, Newport, Rhode Island, July, I892.

Fig. 8. Bongainvillia carolinensis. Cluster of marginal tentacles of a young medusa from Newport, Rhode Island.

Fig. 9. Bougainvillia carolinensis. Oral tentacle of a young medusa from Newport, Rhode Island.

Drawn from life, by the author. 


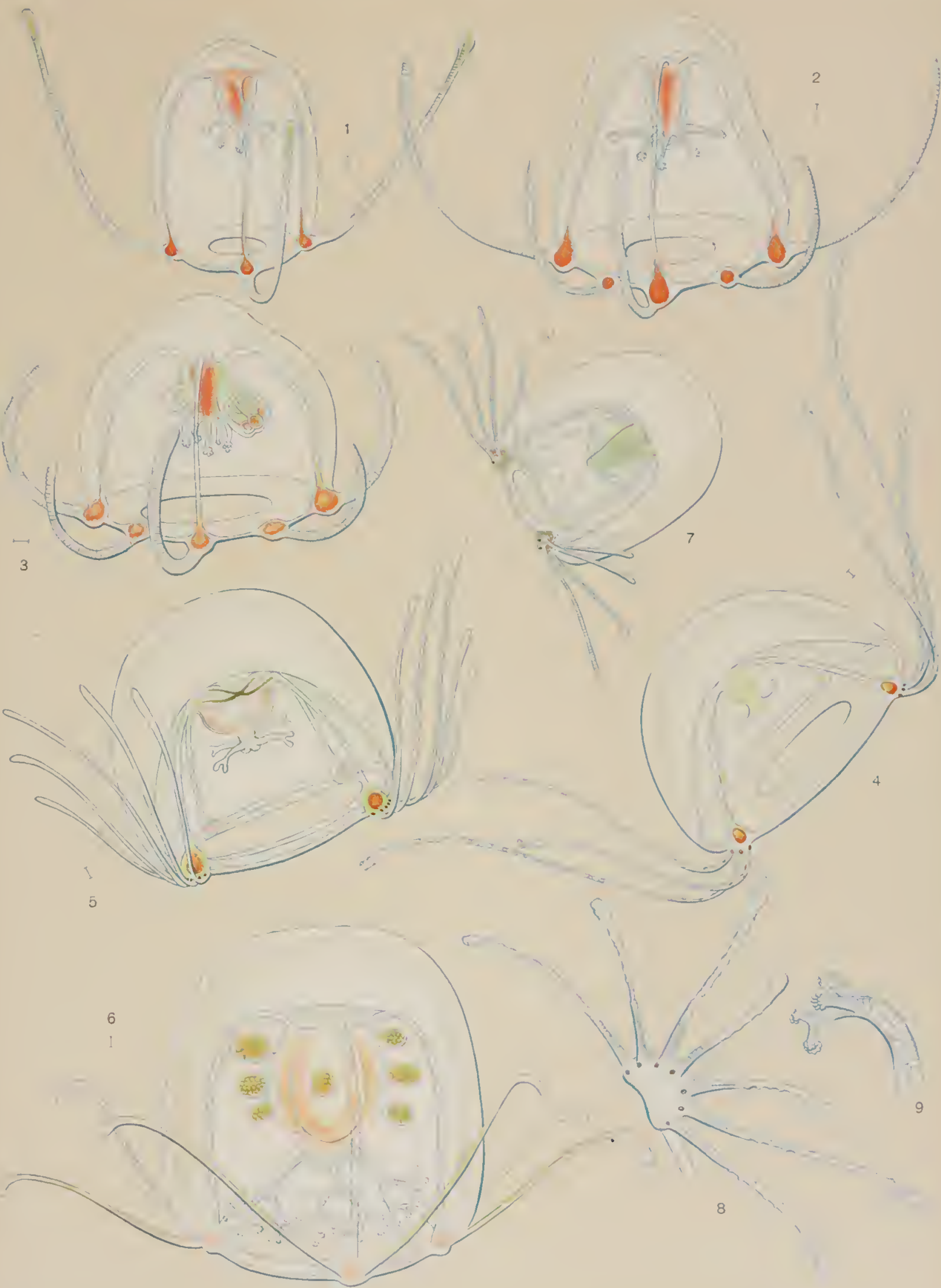



knoh-like cluster of nematocysts. Several medusa-buds in various stages of development are found upon the sides of the upper interradial regions of the stomach. "These budded medusa are set free as in $P$. fulgurans.

In some specimens the entoderm of the manubrium and tentacle-bulbs is turquoise-blue and in others it is lilac.

This medusa was abundant at Tortugas, Florida, in the middle of July, I 898 , and Trinci finds a very similar medusa at Naples, Italy. I am inclined to regard 'Trinci's Cytaris minima as the immature, 4-tentacled, medusa-budding stage of Podocoryne minuta. According to Trinci the hell is pyriform, 0.27 to $0.33 \mathrm{~mm}$. high and 0.2 to $0.24 \mathrm{~mm}$. wide. 4 perradial, marginal tentacles. each as long as the bell-diameter, with well-developed basal bulbs without ectodermal ocelli. Manubrium and tentacles yellowish-brown with blue in the entoderm. Medusa-huds develop upon the + interradial sides of the manubrium. These budding medusa are formed cntircly fiom the ectoderm of the parent medusa.

Trinci in the following year found a medusa similar to the above, but with 8 marginal tentacles.. Excepting for a slight color difference this 8-tentacled medusa is identical with P. minuta from Tortugas, Florida.

\section{Podocoryne tenuis.}

Dysmorphosa tenuis, Brownh, 1902, Annals and Mag. Nist. Hist., ser. 7, vol. 9, p. 277.

(? ?) Podocoryne humilis (hydroid), Hartat B, 1905, Zoolog. Jahrbuichern, Suppl. 6, P. 523, fig. k..

Umbrella somewhat conical, $2 \mathrm{~mm}$. high and 1.5 wide. There is a slight constriction above the level of the subumbrella cavity. 8 tentacles. Manubrium cubical and mounted upon a peduncle ahout as long as itself. Mouth with 4 lips having terminal clusters of nematocysts. Medusa-buds are found upon the interradial sides of the manubrium. Gonads not developed in the two specimens studied by Browne. Color (?)

Found at Stanley Harbor, Falkland Islands. Briefly described without figures ly Browne. This medusa appears to differ widely from the North American varicty of Podocorync carnca, but the hydroid described by Hartlaub bears a close resemblance to our North American $P$. carnca. Hartlaub's hydroid may not be the stock of $P$. temuis, however.

\section{Podocoryne dubia Mayer.}

Plate 14 , figs. 7 to 9 .

Dysmorphosa dubia, Mare., 1900, Bull. Mus. Comp. 7,ool. at Harvard College, vol. 37, P. 40, plate 22, figs.64t66.

Bell higher than a hemisphere, $1.5 \mathrm{~mm}$. high and three-fourths-egg-shaped, with thin. uniform, flexible walls. There are 8 stiff, marginal tentacles which are club-shaped, leing somewhat wider near their ends than they are near their hasal bulbs. The outer extremitics of the tentacles are thickly covered with nematocysts. Their hasal butbs are large and swollen. and a very large, black ocellus is found in the ectoderm of the under side of each bulb (plate 14. fig. 9). The velum is well-developed. There are 4 straight, narrow radial-canals and a ringcanal. At the middle point in the length of each radial-canal there is a small, hemia-like swelling, which is probahly glandular and similar in structure to the swollen parts of the radial-canals of Lymurea alexandri.

The manubrium is pear-shaped, quite slender, and extends about half the distance from the inner apex of the bell-cavity to the velar opening. "The mouth is surrounded by + short. radially situated, oral tentacles, each of which terminates in a bristling cluster of nematocysts (plate 14, fig. 8). Gonads (?) The entoderm of the manubrium and tentacle-hulbs is delicate custard-yellow. Only one specimen has heen found. This was taken on the surface at Tortugas, Florida, on July 20, 1898 .

\section{Podocoryne gracilis.}

Plate 16, figs. I to 3 .

Cytaris gracilis, Maver, 1900 , Bull. Mus. Comp. 7,ool. at Harvard College, vol. 37, 1\%. 39, plate 36 , figs. 122-124. Dysmorphosa gracilis, MaAs. 1905, Craspedoten Medusen der Siboga Expedition, Monog. 10, p. 8.

Mature medusa.-Bell pyriform or dome-like with a slight apical projection. It is about $3 \mathrm{~mm}$. in diameter and a little broader than it is high. The gelatinous substance is of only moderate thickness on the sides, although it is about twice this thickness at the apex of the 
bell. There are 8 stiff marginal tentacles with large basal bulbs. These tentacles are carried curled upward from the bell-margin. The 4 radially situated, marginal tentacles are about two-thirds as long as the bell-height, but the 4 interradial ones are only about half of this length. The basal bulbs of all of the tentacles are large, swollen, and hollow, with their entoderm deeply pigmented. The velum is broad. There are 4 simple, straight radial-canals and a simple circular vessel. The stomach is mounted upon a short, wide, solid peduncle. The stomach and mouth-parts are together only about half as long as the depth of the bellcavity. The mouth is a simple, round opening without prominent lips and is surrounded by 8 unbranched, oral tentacles, each of which terminates in a knob-like bristle of nematocysts. 4 of these oral tentacles are radial and 4 interradial in position. Their entodermal cells are chordate, and the nematocyst-capsules upon their free ends are spindle-shaped. Medusabuds develop upon the 4 interradial sides of the stomach. When set free each medusa has only 4 short, equally developed, marginal tentacles. The 4 interradial, marginal tentacles do not develop until the medusa is about half-grown and after it has acquired 8 oral tentacles. The entoderm of the manubrium is usually red in color, although of ten the inner core is red or pink and the outer annulus of entoderm is green. Each tentacle-bulb is provided with a dense mass of red, entodermal pigment, which in the case of the radial tentacle-bulbs extends a considerable distance up the radial-canals. This medusa was quite common on the surface at Tortugas, Florida, in June, 1899 and 1907.

This species and $P$. octostyla Haeckel are the only forms of Podocoryne having more than 4 oral tentacles. The remarkably late development of the 4 interradial, marginal tentacles and the presence of more than 4 oral tentacles indicate the close relationship between Cytcis and Podocorync. In Cytcis more than 4 oral tentacles are the rule. Although the medusa appears to begin life with but 4 , later it acquires 8 or more, Cytcis vulgaris having 32 tentacles.

Podocoryne humilis Hartlaub.

I'odocorne humilis, Hartlaub, 1905, Zoolog. Jahrbüchern, Suppl. 6, p. 523, fig. $x$.

(?) Dysmor phosa tenuis (medusa), Browne, 1902, Annal. and Mag. Nat. Hist., ser. 7, vol. 9, p. 277.

Hartlaub describes this hydroid from Terra del Fuego, and states that it may prove to be the stock of Podocoryne tenuis, which was briefly described by Browne, 1902, from the Falkland Islands.

The polypites arise in groups from the hydrorhiza. The feeding polypites are about $\mathbf{I}$ mm. long, club-shaped, with narrow bases, and a short, conical hypostome, which is encircled by a single zone of about 12 filiform tentacles about half as long as the body of the polypite.

The reproductive polypites are swollen, with only about 5 well-developed tentacles with a cylindrical proboscis, and with 3 to 4 large medusa-buds upon the basal half of the polypite below the zone of tentacles. These medusa-buds are mounted upon short pedicles, and when set free the medusa have no sexual products. The hydrorhiza forms an open network of thin branches bearing short, smooth, thorn-like processes. There are no spiral zooids or tentacular filaments. Color (?) Number of tentacles possessed by the medusa when set free?

Puerto Bridges, southern Terra del Fuego, January, 1893; from a depth of 7 fathoms.

This species appears to me to be closely allied to, if not identical with, the Podocoryne of the coast of New England. The number of the tentacles is very variable in our New England Podocoryne, especially in the reproductive polypites, and the colonies range considerably in size, apparently being influenced in this respect by conditions of nutrition. There is nothing in Hartlaub's description to prevent our considering the species from the southern end of South America to be identical with $P$. carnea of the coast of New England.

Podocoryne denhami Thornely.

Podocoryne denhami, Thonnely, 1905, Roy. Soc. Report Ceylon Pearl Oyster Fisheries, vol. 2, p. 110, plate 1, fig. 6.

Basal crust heset with numerous tall, stout, linear, reddish spines. Hydranths white, with about 24 tentacles on the barren ones, and only 4 or 5 on those bearing gonophores; and these latter are considerably swollen. A pair of large globule (medusiform ?) gonophores on each reproductive hydranth. Medusa unknown. Size (?)

Growing on a shell of Murex in Polk Strait, Ceylon. 
Genus TURRITOPSIS McCrady, 1856.

Oceania (Turrisopsis), Mc Crady, 1856, Proc. Elliott Suc. Charleston, p. 1.

Modeeria, Frwkes, 188 , Bull. Mlus. Comp. Zool., vol. 8, p. 149.

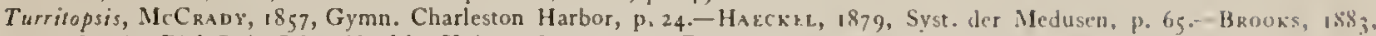

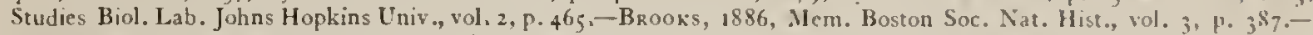
Hartlaub, 1897, Meeresuntersuch., Helgoland, Neue Folge, Bd. 2, Heft. 1, Abt. 2, p. $480 .-$ Fasirörzex, I8gi, \%oul.

Anzeiger, Bd. 14, P. 444.-Brook's and Ritresinouse, 1907, Proc. Boston Soc. Nat. Hist., vol. 33, 1. 436.

Ion Turriopsis, Ag.Assiz, A., 1865, North Amer. Acal., p. 167.

The type species of this genus is $\mathcal{T}$. mutricula McCrady, $1856 \quad 57$, from Charleston Harloor, South Carolina. It is common in summer from the West Indies to the southern coast of New England.

GENERIC CHARACTERS.

Margelina with $\&$ or more simple, marginal tentacles, which arise singly, not in clusters, from the bell-margin. The walls of the + radial-canals, above the stomach, consist of highlyvacuolated, entodermal cells, forming a peduncle for the gastric part of the manubriun. The 4 lips are studded with nematocyst-bearing knobs. The gonads are developed upon the 4 interradial sides of the stomach. The hydroid is Dendroclava.

Turrilopsis is peculiar in the remarkable development of vacuolated, entodermal cells lining the courses of the 4 radial-canals above the stomach. This condition is also displayed to a limited degree hy some, but not by all, of the medusa of the genus Lymorea. In Lymnorea, however, the mouth is surrounded by branched, oral tentacles, whereas in Turritopsis the lips display bead-like knobs of nematocysts, which 1 an inclined to regard as the remnants of the oral tentacles of the ancestral forms of Turritopsis. The tentacles of Turritopsis are solid and similar in structure to those of $L$ ymmorea. There is an ectodermal ocellus upon the inner (axial) side of each tentacle, adjacent to the basal bulb. In Tiarina, on the other hand. when ocelli are present they are found upon the outer (abaxial) sides of the tentacle-hullss. On account of the close similarity between the tentacles of T urrilopsis and those of Occaniu, I.ymuorca, Podocoryue, Cytais, and Cubogaster, we incline to Vanhoiffen's (1891) view that Turritopsis is related to the Margelina rather than to the Tiarina.

Turritopsis is closely related to Occania, but is distinguished by its vacuolated peduncle, that of Oceania being solid and gelatinous.

\section{Turritopsis nutricula McCrady.}

Plates 14 and 15 , figs. 10 to 13.

Oceania (Turrilopsis) nutricula, MICCRADY, 1856 , Proc. Elliott Soc. Charleston, pp. 1-36, plate 4, figs. 1-10.

Turritopsis nuericula, MCCRaDY, 1857 , Gymn. Charleston Harbor, p. 25, plate 8, fig. 1.-13 rooxs, i $88_{3}$, Studies Johus Hopkins Univ. 13iol. Lab., vol. 2, P. 465.-BRooks, 1886 , Mem. Boston Soc. Nat. Hist., vol. 3 P. 388 , plate 37. - HarcitT, 1904.

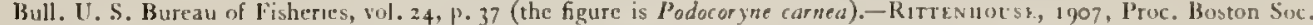
Nat. Hist., vol. $33, p .437$, plates $30-35$, figs. 1-55 (development).

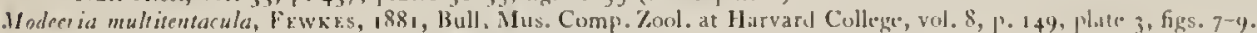

.Modecria nutricula, Frwkes, 1882 , Bull. Mus. Comp. Zool., vol. 9, p. 295.

non Turritopsis nutricula, Aciassiz, A., 1865, North Amer. Acal., p. 167, figs. 269, 270.

Turritopsis nutricula (in part), Haeckek, 1879, Syst. der Medusen, p. 66.-Nutrinci, 1901, Bull. U. S. Fisl Commission, vol. 19, P. 375 .

$$
\text { Fetroprax Mrutsa. }
$$

Occania polycirma, Kiterstein, 1862, Zeet. für wissen. \%oul., Bd 12, 13. 26, taf. 2, fign. 11 13.

Turrisopsis polynema, HaEckiL, 1\$79, Syst. der Medusen, 1) 66.

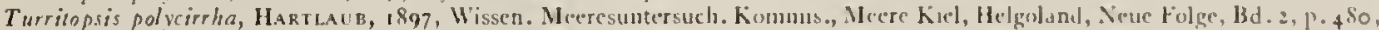
taf. $16 c$, fig. 2.

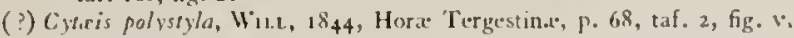

A merican medusa (plate 14 , fig. 10). - Bell usually stightly pyriform and about 4 to $5 \mathrm{~mm}$. in height. Bell-walls uniformly thin. There are to to 70 simple, marginal tentacles, which are all of ahout the same length and are somewhat shorter than the bell-height. These tentacles are capable of much contraction or extension. Their basal bullss are large and there is a single. ectodermal pigment-spot upon the lower (centripetal) side of each tentacle near its place of origin from the basal hulb. The surface of the tentacles is covered thickly with nematocystcells. The velum is well developed. There are + straight, narrow radial-canals and a narrow circular vessel. 'The manubrium is large and fills about half of the bell-cavity. The upper 
part of the manubrium near the base consists of 4 radially situated masses of large, highly vacuolated, entodermal cells, through the midst of which the 4 radial-canals extend downward into the stomach. These cells are indeed only the entodermal walls of the radial-canals (plate I 4, fig. I3). The stomach is large and quadratic in cross-section. The cruciform mouth is situated at the extremity of a short neck and is surrounded by a row of nematocyst-bearing knobs (plate I5, fig. I2). The gonads are developed upon the sides of the stomach, where they occur in the form of a double, longitudinal, swollen region in each adradius. Their outer surfaces are smooth. The entoderm of the stomach is dull-yellow or orange, or dullyellow streaked with orange. The tentacle-hulhs sometimes contain a little entodermal orange pigment. The ocelli upon the tentacles are dark-brown or orange.

Hydroid and young medusa.-The hydroid (fig. 76 ) was found by Brooks, i $88_{3}$, on piles of a wharf at Morehead City, North Carolina. It is a Dendroclava and closely related to $D$. dolmii Weismann. The stems of the hydroid are from 8 to $10 \mathrm{~mm}$. in height and hear large, terminal hydranths. There are also numbers of short, side branches which terminate in hydranths. The main stem and the side branches are incased in a loose, cylindrical perisarc, which is thick and becomes incrusted with foreign matter. The perisarc is not annulated, and terminates abruptly hy a sharp collar immediately below each hydrantl. The hydranth or feeding-polypite is long and fusiform and bears from 18 to 20 short, thick, filiform tentacles, which are arranged in three or more indefinite rows or whorls. The medusabuds originate upon the sides of the stem at the bases of the hydranths. Each medusa-bud is

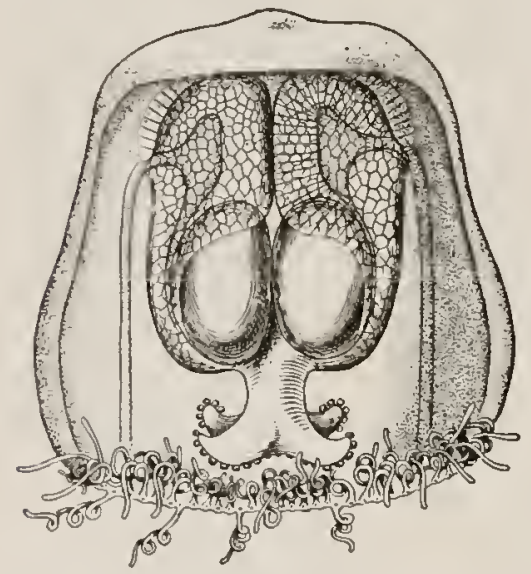

Fic. 75.--Turritopsis nutricula, after Brooks, in Mem. Boston Soc. Natural History. borne upon a short stalk or peduncle and is closely invested by a thin capsule of perisarc. When set free the young medusa has 8 tentacles. The manubrium is cone-shaped and there is a large peduncle formed of highly-vacuolated cells. 4 prominent, nematocyst bearing knobs surround the mouth. The hydranths are pale yellowish-red.

This medusa is found from the coast of Cuba to the southern coast of New England, being about equally ahundant in the northern and southern limits of its range. It is very common in the Bahamas and at Tortugas, Florida. In Charleston Harbor, South Carolina, it is commonly infested by larva of Cunoctantha octonaria McCrady, although it appears to be quite immune from this parasite in other places. I can detect no specific distinctions between this medusa and "T urritopsis polycirrha," which is occasionally seen off the Atlantic coast of France and Germany. This form is well figured by Keferstein, I862, and Hartlaub, I897, who are the only European students who have ohserved the medusa on the eastern side of the Atlantic.

Rittenhouse, 1907, has made an elaborate study of the development of $\mathcal{T}$. nutricula. The ova develop in the ectoderm of the 4 interradial sides of the manubrium. The primitive ova grow by the absorption of ovarian cells around them, as is common in other hydromedusa. The yolk-spheres in the ovum are formed from the ovarian cells which it ahsorbs. Ahout 20 to 35 , rarely 50 or more, eggs are discharged into the water by the muscular rupture of the ovarian walls between 5 and 60 'clock in the morning. The discharged eggs are spherical, o.I 6 $\mathrm{mm}$. in diameter and have no memhrane. They are yellowish-white, heavier than sea-water, and opaque. The outer layer of finely-granular ectoplasm is distinct from the coarsely granular, yolk-laden endoplasm. Soon after being discharged the egg gives off two polar bodies and is fertilized. Segmentation is total and approximately equal. The first two segmentation planes are meridional and the third equatorial. The hlastomeres remain quite far apart, touching only slightly. After this the cleavage becomes remarkahly irregular, recalling the extraordinary condition observed hy Hargitt in Pennaria. A solid morula is formed, which has no central segmentation cavity and which resemhles a looscly-connected mass of irregularly grouped cells rather than an emhryo of any mctazoan. The cleavages follow one after another at intervals of 20 to 30 minutes. 
As in Metschnikoff's Occania armata and Hargitt's embryos of Pcnnaria, this irregularly shaped morula gradually changes into an oval embryo, the surface of which hecomes ciliated, so that it swims upward from the bottom. This takes place at about 4 in the afternoon in egus which were laid hetween 5 and 6 in the morning.

Rittenhouse finds that during this period, when the loose, irregularly shaped mass of cells shapes itself into an oval embryo, the ectoderm and entoderm are formed. During this period "the cell-boundaries are lost for a short time and a syncyrium is formed. This syncytial structure is crowded with yolk-granules and nuclei are scattered throughout the protoplasm. The nuclei soon become more numerous near the periphery and the cell-walls hegin to appear"

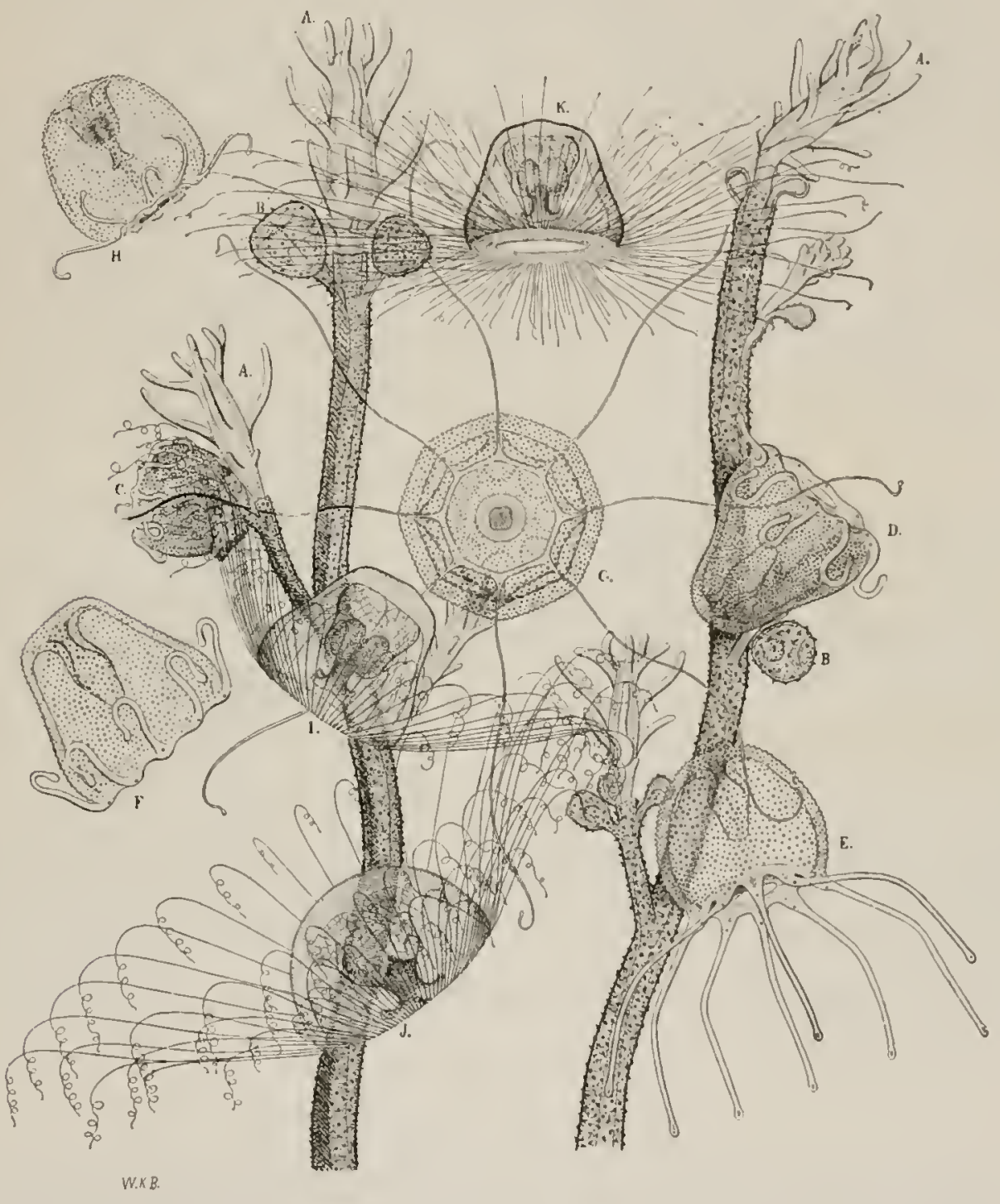

Fis. 76.- Turriopsis nutrirula, after Brooks, in Mrm. Boston Soc. Nat. Hist. Hydroid and young medusa.

between the peripheral nuclei. These peripheral cells are to become the ectoderm, which is soon separated from the inner, structureless mass by the development of the mesoglex. This inner mass afterwards acquires cell-boundaries between its nuclei, and still later a central cavity, the colenteric space, develops; and thus the entoderm is formed. This corlenteric cavity does not develop, however, until the larva is 48 to 60 hours old. The syncytium condition in T'urritopsis is much more complete than is seen according to Hargitt in P'cunariu, or in Bonganvillia, according to Gerd, 1892. 
Rittenhouse finds that during the early stages of cell-division in T urritopsis the multiplication is solely hy mitosis, but that later, when the embryo hecomes a mere irregularly arranged mass of loosely-compacted cells, some of the nuclei divide amitotically.

When about 50 hours old the elongate, oval larva ceases to swim through the water and settles down upon its side on the bottom. The larva then becomes the hydrorhiza, or root, of

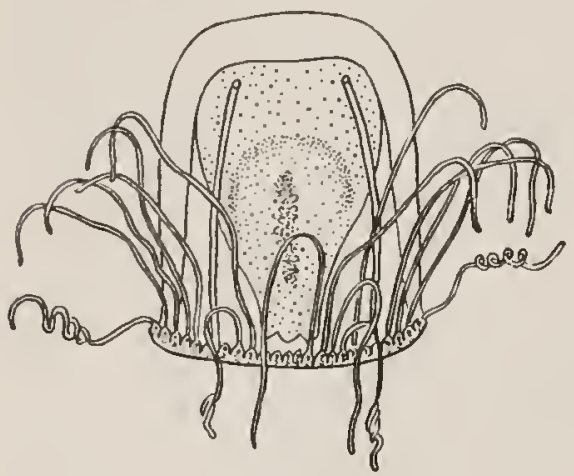

Fig. 77.-Turrtopsis, sp. (ऐ) $=$ (Oceanen polvcirrha), after Keferstein, $1 \$ 62$, Zeit. für wissen. Zool., Bd. 12, taf. 12, fig. 11 . the hydroid, and the first hydranth arises as a bud from about the middle of its length. The tentacles of the hydranth develop in indefinite whorls, with + tentacles in each whorl, the oldest tentacle being nearest to the mouth. In the mature hydroid the tentacles appear to be irregularly scattered rather than being arranged in whorls.

Turritopsis should be reared under more natural conditions than those of the ordinary laboratory in order to determine whether the remarkable, irregularly formed embryos descrihed hy Rittenhouse he normal or merely the result of pathological states induced hy adverse conditions; but Miss Beckwith has recently shown that the cleavage of Pennaria is normally irregular as is described by Hargitt.

Rittenhouse finds that when the embryo is in the loose-celled, morula stage it may he divided into two masses, each one of which produces a normal planula larva of small size.

\section{Turritopsis (?) lata von Lendenfeld.}

Turritopsis lata, von Lendenflld, 1884 , Proc. Linnean Soc. New South Wales, vol. 9, p. 588, plate 22, figs. 36, 36a. (??) Melicerts pleurostoma, Péron ex Lesuevr, 1809 . Ann. du Mus. Hist. Nat., Paris, tome 14, p. 353.

Mature medusa.-Bell $3.5 \mathrm{~mm}$. high, $3 \mathrm{~mm}$. wide, with a low, dome-like, apical projection. 60 to 130 marginal tentacles about as long as the bell-height. These have well-developed hasal bulbs, and there is an ocellus on the inner (velar) side of the hase of each tentacle. Velum well developed. 4 broad, straight radial-canals. The manubrium is mounted upon a peduncle, but von Lendenfeld does not state whether it be composed of vacuolated, entodermal cells or of the grelatinous substance of the bell, and his figures are ton vague to throw any light upon this point. Until this is settled we can not determine the systematic position of this medusa. The stomach is spindle-shaped, about two-thirds as long as bell-height. The mouth does not extend to the velar opening, and there are 4 lancet-shaped lips which are recurved and one-third as long as the manubrium. These lips have stalked nettling warts on their margins. There are 4 protruding gonads on the stomach-wall, each one being one-fourth spherical in shape. Gonads and entoderm of tentacle-bulhs intensely brown. Ocelli red.

This is the most abundant medusa in Port Jackson, New South Wales, during the Australian summer and autumn.

The young medus $x$ have but 4 marginal tentacles.

\section{Genus OCEANIA, sens. Kölliker, Gegenbaur.}

Oreania (in part), Péron ft Lesueur, 1809, Annal. du Mus. Hist. Nat. Paris, tome 14, Pp. $344^{-347 .}$

Oreania, Kölliker, 1853 , Zeit. für wissen. Zool., Bd. 4. . .323.-Gegenbaur, i856, Zeit. für wissen. Zool., Bd. 8, p. 223.Keferstein und Ehlers, I861, Zool. Beitr. Messina, p. 83.-Metschnikoff, 1886, Embryol. Studien an Medusen, Wien, pp. 23,25 , etc., to 78 .

Turritopsis (in part), HäCKé, 1879 , Syst. der Medusen, p. 65.

(?) Modeeria (young medusa), For B ES, 1848 , British Naked-eyed Medusa, p. 70.

Modeeriat Callitiara, HaEckkL, 1879 , Syst. der Medusen, pp. $47,4^{8}$.

Oceania = Callitiara, Vanhörren, 1892 , Verhandl. Gesell. Deutsch. Naturf. Arzte, 64 Vers., Abth. Syst., p. 121.

The generic name "Occania" of Péron and Lesueur has no definite modern meaning. for it was applied to many medusæ belonging to the Eucopidx, Tiarinæx, Thaumantidx, etc. In 1862 "Oceania" was restricted by L. Ágassiz to apply to a genus of the Eucopidx, but this same genus had already heen named Phialidium by Leuckart, 1856, and thus Agassiz's 
genus Oceania loses precedence. The type species of Occania in the modern sense is $O$. armata of the Mediterranean. It is possible that one of Péron and Lesueur's descriptions refers to this medusa (i. e., Occania flavidula?), but I am in much doubt upon this point. We must fall back upon Kölliker, 1853, and Gegenlaaur, 1856, for the definition of Occonir in the modern sense.

Haeckel suppresses Oceania and merges it with Turritopsis, but in Ocennia the perluncle is simple, solid, and gelatinous, whereas in McCrady's Turritopsis it is composed of large, vacuolated cells.

\section{GENERIC CIIARACTERS.}

Margelina with 8 or more marginal tentacles which arise singly from the bell-margin, and are not grouped in isolated clusters. There are ectodermal ocelli on the inner (velar) sides of the tentacle-bulbs. The manubrim is mounted upon a simple, solid, gelatinous peduncle. The 4 lips lack oral tentacles, hut their margins are lined hy a row of wart-like nematocysts. The hydroid is clava-like.

Following the lead of Agassiz, it has been the custom of American students to define Occania in a sense equivalent to Phiulidium of Leuckart, but as we have seen Phialidium, 1856, clearly takes precedence over Agassiz’s Occania, 1862.

In the system here proposed the genus Occania falls among the Oceanida instead of being among the Eucopida as it would be were Agassiz's definition admissihle.
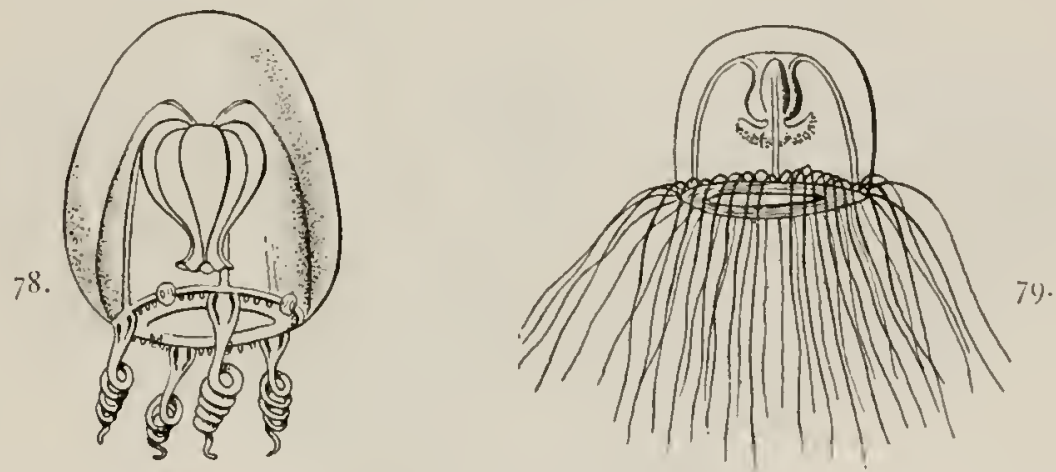

I'ic. 78 .- "Moderia formona," after Porbes.

Fig. 79.-Oceania "finidula" (O. armata), after Gegenbatir, in Zeit. für wissen. Zool., Bd. 8.

The generic name Modecria Forbes. 1848 , was applied to a very young and immature medusa which is so vaguely described that we can not state whether or not it had ectodermal ocelli. I consider that the name Modecria had best be dropped, having already led to nearly endless confusion.

The genus Occanio is closely related to Turritopsis, but is distinguished hy its simple, solid, gelatinous peduncle; whereas the peduncle in Turritopsis is composed of a mass of racuolated entodermal cells.

\section{Oceania armata Kölliker.}

(?) Modecria formosa (young medusa), Foknes, 184 , British Naked-eyed Medusd, p. 70 , plate 7 , fig. 1.

Oceania armata, Kölliker, 1853 , Zeit. für wissen. Zool., Bd. 4, p. 323.-Metscunikofr, 1886, Embryol. Studien an Medusen, Wien, pH. 23, 25 (egg); $36,37,47$ (segmentation); 75,78 (development of hydroid).

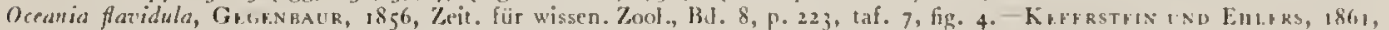
Zoolog. Beiträge, p. 83, Leipzig. -Sracinound, 1876 , Atti Soc. Ital. Sci. Nat.. tome 19, p. 22, tav. 3, fig. 3 .

Peardec faridula, Agassiz, L., 1862 , Cont. Nat. Hist. U.S., vol. $4, \mathrm{l} \cdot 347$.

Turritopsis armata, HAkekile, 1879, Syst. der Medusen, p. 65.

Callitiara polyopthalma, Harckel, 1879 , Syst. der Medusen, p. 67, taf. 3 , fign. 1-5.

Tiarella parthenopia, Trinc1, 1906, Monitore \%oologico Ltal. Anno 17, p. 208. 2 figs.

Bell pyriform, flat-topped, higher than a hemisphere, with uniform, thin walls. 8 to 10 $\mathrm{mm}$. high, 8 to $10 \mathrm{~mm}$. wide. 60 to 100 or more slender, tapering, marginal tentacles. 1.5 times as long as the hell-diameter. These tentacles are crowded into a double row. Their 
entoderm is solid and composed of chordate cells. There is an ectodermal ocellus on the velar side of each tentacle-bulb. Velum well developed. Well-developed circular muscles in the subumbrella. There are 4 jagged-edged, slender radial-canals and a simple ring-canal. The stomach is flask-shaped, cruciform in cross-section and mounted upon a short, pyramidal, 4-sided peduncle. This peduncle is a solid, gelatinous, truncated pyramid, only about onethird to one-fifth as long as the stomach itself. It is not vacuolated as in Turritopsis. The 4 lips are large and recurved and extend to the middle of the bell-cavity and their edges are studded with a single row of knoh-like nematocyst-ivarts. The 4 gonads are developed upon the interradial sides of the stomach and are longitudinal swellings with smooth outer surfaces.

The stomach and gonads a re yellow or brownish-yellow. Eggs pearly-white. Lips reddish-yellow, or port-wine colored. Radial-canals, ring-canal, and tentacles milky-yellow. Ocelli reddish-brown (see fig. 91).

Found in the Mediterranean. Quite common at Naples. (See figs. $78-81$. )

Vanhöffen ( I go2, Verhandl. Gesell. Deutsch. Naturf. Arzte, 64 Vers., Abth. Sitz., p. 121) maintains that this medusa is identical with Callitiara polyopthalma Haeckel of the Canary Islands, and with this I am in accord, having seen many specimens of the living medusa at Naples. Trinci, 1906, describes a medusa from Naples which resembles $O$. armata in all respects excepting that he finds no ocelli. He studied preserved specimens, however, and

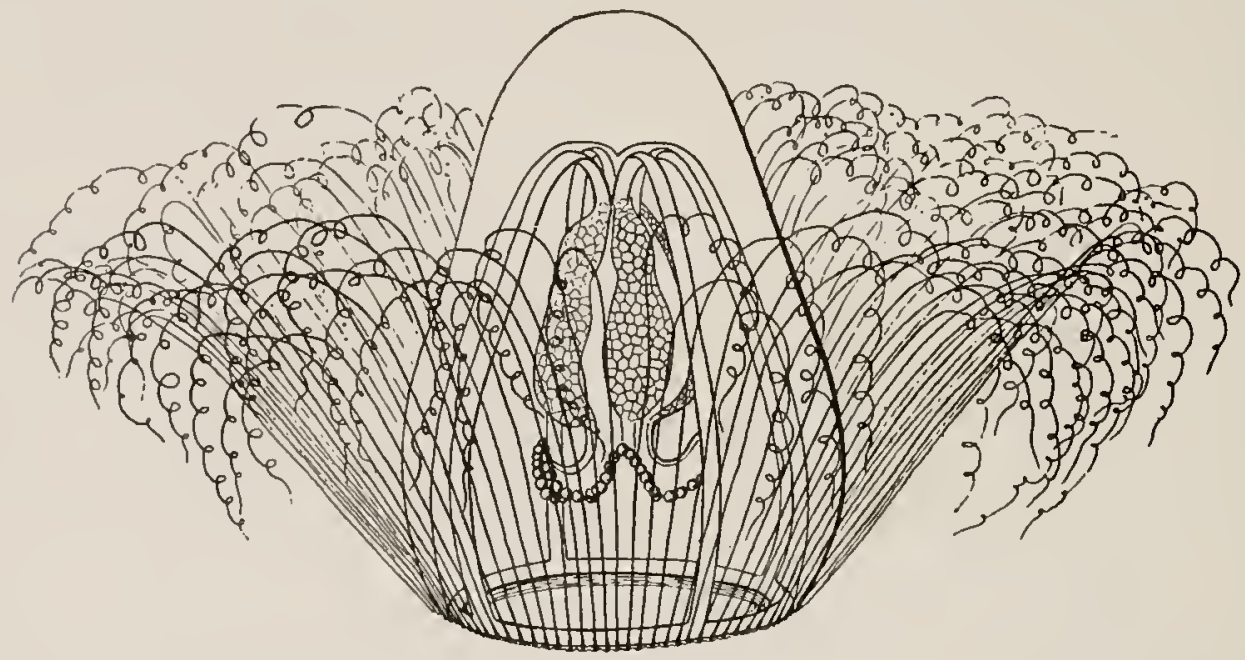

Fig. 80.-Oceania. "Callitiara polyophthihalma" (Ocennia ammata), after Haechel, 1879.

the ocelli may have faded. As Gegenbaur states, the ocelli upon the inner sides of the tentaclebulbs recall the conditions seen in Bongainvillia, and oblige us to place the medusa among the Margelinx. In the Tiarinx, on the other hand, the ocelli when present are always on the outer, abaxial sides of the tentacle-bulbs.

Gegenbaur (1854, Zur Lehre von Generationswechsel, p. 28, taf. 2, fign. 10-16) reared the larva from the egg, and later Metschnikoff carried out a similar series of studies.

Metschnikoff, 1886 , finds that the egg of this medusa is milky-white and $0.28 \mathrm{~mm}$. in diameter. It is laid between 6 and $70^{\prime}$ clock in the afternoon during December, in the Mediterranean. The segmentation is total, but not equal, and the resulting hlastomeres form a very irregularly shaped, I-layered mass, inclosing a large segmentation cavity. Finally, a symmetrical, egg-shaped, ciliated, planula larva is formed. The planula attaches itself and becomes a branched hydırhiza, from which the spindle-shaped clava-like hydranths arise. These develop in about 18 days after the egg is laid. The polypite has 13 tentacles arranged alternately in 3 whorls.

In its irregularly shaped larva and in its mode of attachment this medusa resembles Turritopsis, to which indeed it is evidently closely related, the only distinction between Turritopsis and Occania heing that in the former the peduncle is vacuolated and in Occania it is solid and gelatinous. 
Genus STYLACTIS Allman, 1864.

Stylacris, Allman, 1864, Annals and Mag. Nat. Hist., ser. 3, vol. 13, p. $353 ; 1871$, Monograph Tubularian Hydroids, 1). 302. Clarke, 1882 , Mem. Boston Soc. Nat. Hist., vol. 3 , P. 138 .- Sicikroos, 1889 , American Naturalist, vol. 33 , P. 801.

These are Margelinx in which the medusa is degenerate, and indeed in the European species of Stylactis no medusæ are set free, mere sporosacs heing developed on the hydranths. The two American forms, however, produce free-swimming, although degenerate medusa.

The medusa has 8 rudimentary tentacle-bulbs, + radial and + interradial; + simple radialcanals and a ring-canal. The manubrium is sac-like without a mouth, and without oral tentacles. The gonad encircles the sac-like manubrium, and the mature eggrs or sperm are found in the ectoderm. The sexes are separate.

The hydroid, Stylactis, hears a resemblance to both Hydractivia and Podororyme, but unlike the two last named the hydrorhiza is not covered with a fleshy layer of cornosate

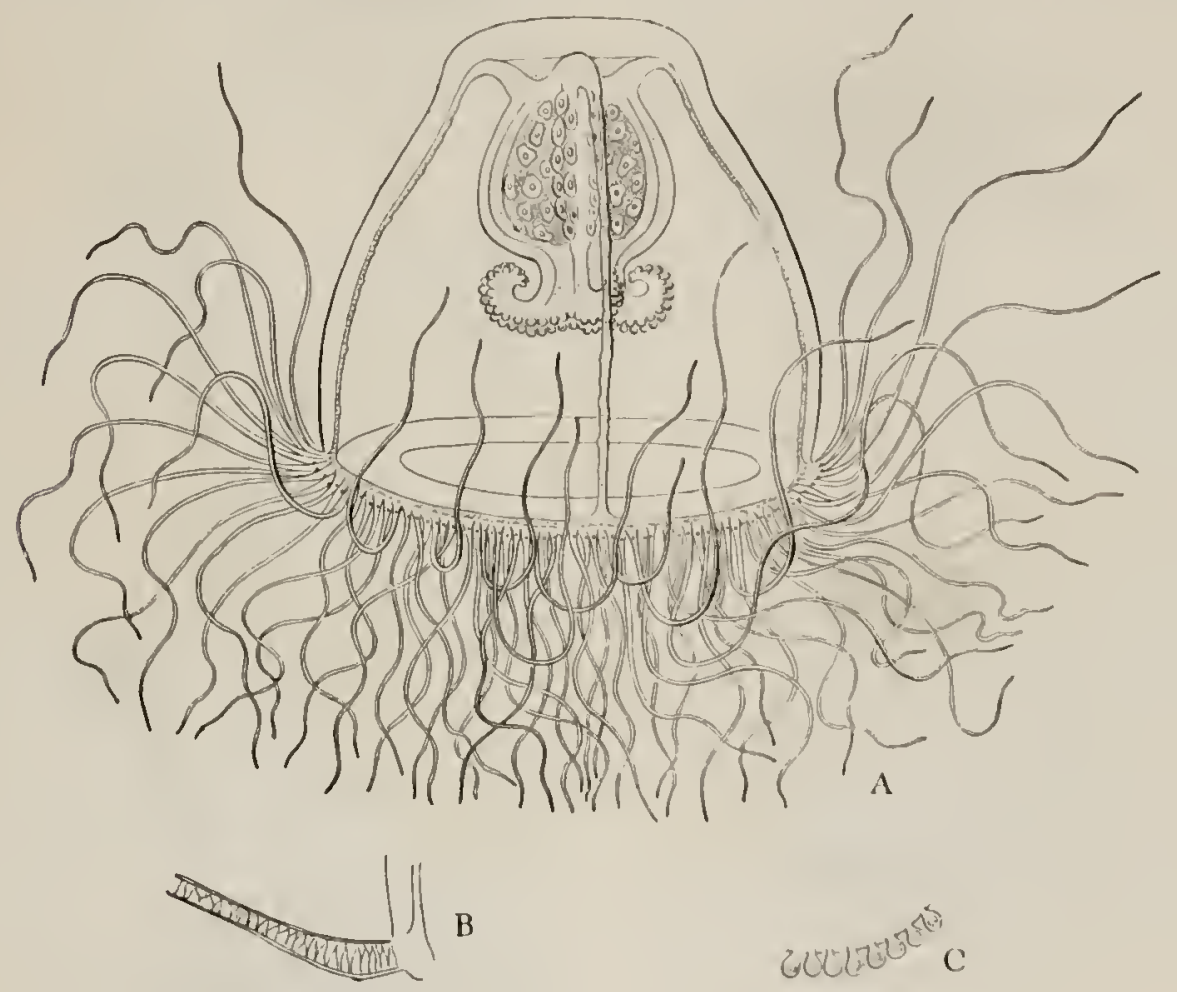

Fici. 81.-Oceania armasa, from life, by the author. Naples \%oological Station, December $18,1407$.

A. Mature female.

B. Basal part of tentacle showing ectodermal occllus on its velar sids.

C. Part of lip, showing row of nettling-warts.

(hydrocaulus). The hydrorhiza of Stylactis is formed of a network of anastomosing stolons invested with a chitinous perisarc, hut are without a superficial layer of naked coenosarc. The hydranths are simple, claviform, or cylindrical, with one or two circles of filitorm tentacles around the oral zone. The hydranths arise singly from the hydrorhiza and are of two sorts, reproductive and nutritive. Spines also arise from the hydrorhira. The sporosacs, or medusa-buds, are horne upon the sides of the reproductive hydranths in an irregular circlet below the tentacles.

The type species is Stylactis fucioln of the Mediterranean (see Allman, 1864) which was first described by M. Sars (1857. Nyt. Magr. Naturvid., 9), under the name Podocoryur fuciola. Allman pointed out its peculiar characters and distinguished it from Podocoryme.

One of the most remarkable species is Stylactis minoi Alcock (1892, Annals and Mag. Nat. Hist., ser. 6, vol. 10, p. 207, I fig.). This is commensal upon a fish Minous inermis. Sporosacs, but no medusa-buds, are produced by the hydroid of this species. 
Stylactis hooperi Sigerfoos.

St Whatis hooperi, Sigrarnos, 1899, American Naturalıst, vol. 33, p. 8ol, 5 figs.-Nutrinri, 1901, Bull. U. S. Fish Commission for 1899 , vol. 19, pp. 335, 374, figs. 13, 85.-HargitT, 1904, Bull. U. S. Bureau of Fisheries, vol. 24, P. 41.

Medusa. - The medusa is degenerate and intermediate in its character between the

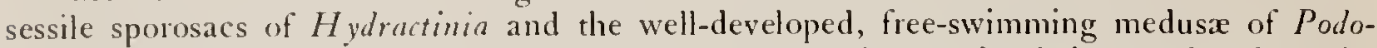
coryue. The medusa of Stylactis hooperi live only a few hours after being set free from the hydroid, and die soon after setting free their genital products. The sexes are separate, the mature genital products being developed within a large part of the ectoderm of the manubrium, so that the gonad encircles it as in the Codonidx. The evident relationship of the hydroid to Podocoryme, however, necessitates the medusa's being classified in connection with Podocoryne.

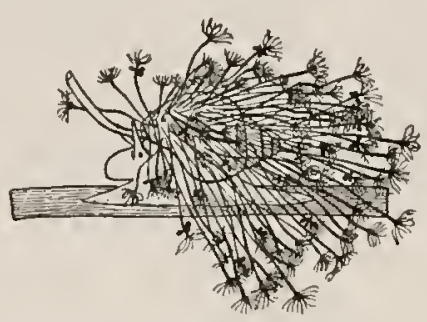

A

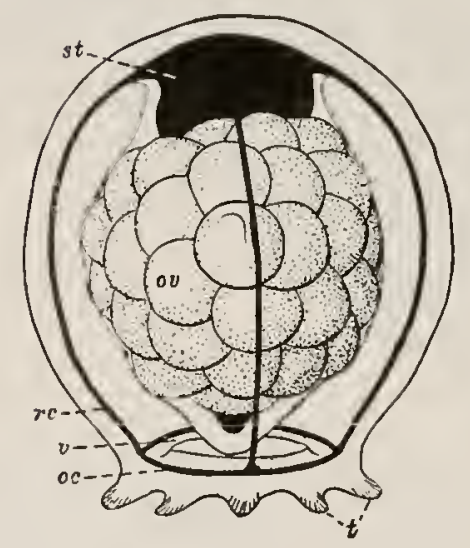

F1t. 82.-Stylactis hooperi, after Sigerfoos, in American Naturalist.

A. Colony shell of living Il vanassa obsoleta, represented as crawling over a blade of eelgrass. Natural size.

13. Part of colony magnified 6 diameters. (1) large nutritive hydranth fully expanded; (2) same slightly contracted; (3) same fully contracted ; (4) large reproductive hydranth fully expanded ; (5) smaller reproductive hvelranth, slightly contracted; $h r .$. tubes of lyctrorhiza; sp., spines.

C. Recently liberated female medusa, before extrusion of eggs. ce., circular canal; rr., radial-cinal; st. stomach; $t$., tentacles; v., velum; 02 ., ova. $\times 50$.

The bell is somewhat fuller than a hemisphere, with thin, uniform walls. There are 8 short, marginal tentacles, 4 radial and 4 interradial. The velum is well developed. There are 4 straight, slender radial-canals and a ring-canal. The manubrium is wide and spindleshaped and fills the greater part of the bell-cavity. There is no mouth-opening and there are no oral tentacles. The ectoderm around the middle region of the manubrium is much distended with the genital products.

Hydroid.- The hydroid was found by Sigerfoos growing upon the living shells of Iyomassa, especially upon snails found crawling upon eelgrass. It was found in Lloyds Harbor. Huntington Bay, in Long Island Sound, New York, during the summers of 189899. 
There is no hydrocaulus. The hydrorhiza is a network of tubes lying in one plane, from which arise a few small, simple spines and many sessile hyclranths. "The hydrantlis are of two kinds, nutritive and reproductive. The nutritive hydranths are about $25 \mathrm{~mm}$. Long and a re elongate, simple, and unbranchert. Their oral ends taper gradually, being widest at the circlet of tentacles. There are usually about $20 \mathrm{long}$, slender tentacles arranged in a single whorl, but specimens are found with as many as 35 and as few as 15 tentacles. The entodermal cores of these tentacles are solid and consist of a single row of cells. The tips of these tentacles are not appreciably swollen or knob-like, although they are well provided with nematocysts.

The reproductive hydranths are slightly smaller than the nutritive ones. They have only 6 to ro tentacles and are only one-third to three-fourths as long as the nutritive hydranths. but they have functional mouths. There are usually + to 5 medusa-huds arranged in a circlet immediately below the circle of tentacles. The entoderm of the hydroid is white or pinkishwhite. The meduse appear to be set free soon after dark, and the breeding season extends throughout July and August.

There are no spiral protective zooids such as are found in Hydractimia and there is no conosare layer over the hydrorhiza such as is found in Hydractinio and Podocoryue.

\section{Stylactis arge Clarke.}

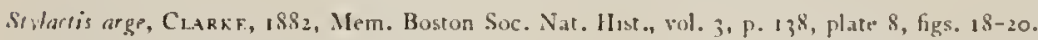

The medusiform gonophores of this species often become mature while attacherl to the hydroid stock. In other cases, however, the gonophores become free, although they are sexually mature at the time of liberation.

Free medusa.-The bell is ellipsoidal and the gelatinous substance thin. There are 8 small rudimentary tentacle-bulbs, + radial and + interradial. + simple, narrow radial-canals. The manubrium is globular and greatly distended by the contained genital products.

Hydroid.-The hydranths are very much elongated and slender. Each hydranth is provided with 10 to 30 tentacles which arise in 2 circlets close together below the hypostome. 'The tentacles of the lower circlet are somewhat shorter than those of the upper one, although in some individuals all of the tentacles are of equal length. There are usually + sporosics or medusa-buds developed upon the sides of the body of the hydranth beneath the circlets of tentacles, 2 being first developed on opposite sides of the hydranth, and then 2 others appear at points $90^{\circ}$ from the first pair. The entire colony is of a delicate opaque white.

It is remarkahle that in this species a constriction sometimes appears around the hody of a hydranth, from a point just above which two or three cylindrical, stolon-like processes are developed. The constriction then becomes complete and the distal end of the hydranth becomes free. This then settles down in a new locality and the stolon-like processes give rise to a hydrorhiza and a new colony is thus developed asexually.

This species has been found by Clarke in Chesapeake Bay.

\section{Genus THAMNOSTYLUS.}

Thamnostylus, HaF(Kk1, 187\%, Syst. der Medusen, P. 85; 1881, Report H. .1. S. Challenger, Zool., vol. \&. P. I.

The only known species is Thammostylus dimema Haeckel, from the Antarctic Ocean.

GI:NIRIC CHARACIIRS.

Margelinæ with hranched orat tentacles and 2 marginal tentacles $180^{\circ}$ apart. Development unknown.

\section{Thamnostylus dinema Haeckel.}

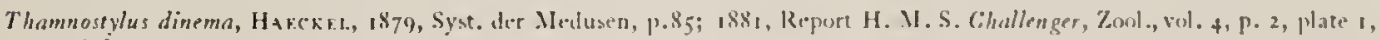
8 figs.

Bell hemispherical, $16 \mathrm{~mm}$. wide, $8 \mathrm{~mm}$. high, with thick gelatinous substance, but thin at margin. The margin is thickly studted with nematocysts and the exumbrella is also hesprinkled with isolated nettling cells. 2 cliametrically opposite, radially situated, hollow, 
marginal tentacles about 3 times as long as the bell-diameter and ringed at frequent intervals with swollen masses of nematocysts. The basal bulbs of these tentacles are swollen and conical and each one bears a dark-red abaxial ocellus. There are 2 rudimentary, ocellated tentacle-bullss upon the margin $90^{\circ}$ a part from the long tentacles. Velum wide. 4 straight, narrow radial-canals and a simple ring-canal.

The stomach is a wide, 4 -sided pyramid, as long as the depth of the bell-cavity. It extends below into a 4 -sided, elongated throat-tube, twice as long as the stomach itself. This throattube projects beyond the velar opening and the mouth is a simple, 4-sided opening studded with nematocysts.

4 large, radially placed, oral tentacles arise from the distal end of the stomach and branch dichotomously 6 to 8 times, their ends terminating in nematocyst-knobs. The gonads are swollen, leaf-like, lobular, folded ridges in the 8 adradii of the stomach. They are blunt ahove, but more pointed below, and each gonad exhibits about 5 double transverse folds. The ova are prominent. The gonads, oral tentacles, nematocysts of bell-margin and of the tentacles and tentacle-bulbs are blood-red.

Antarctic Ocean, south of the Kerguelen Islands, at a depth of 120 fathoms. Beautifully figured by Haeckel, 1881.

\section{Genus THAMNITIS Haeckel, I879.}

Thamnitis, Hafcker., 1879, Syst. der Medusen, p. 84.-Vanhöffen, 1891, Zool. Anzeiger, Bd. 14, p. 444.-Browne, 1905 , Proc. Royal Soc. Edinburgh, vol. 25, p. $75^{8}$.

The first described species of this genus is Thammitis nigritella, first made known by Forbes, 1848 , under the name Bougaimvillea nigritella. The first species mentioned by Haeckel is a newly-described form, Thammitis tetrella. T. migritella comes from the Shetland Islands, while T. tetrella was obtained off the coast of Brazil.

\section{GENERIC CHARACTERS.}

Margelinx with branched oral tentacles and 4 simple, radially placed, marginal tentacles.

It is possible that Thamnitis may be simply an immature or damaged Bougainvillia which has lost all but one marginal tentacle of each radial cluster, but we are not yet justified in concluding that this is the case. Forbes, $18+8$, describes and figures the tentacle-bulls of Thammitis nigritello as being bean-shaped, containing a single large ocellus (?) or mass of very dark pigment, and having a single short tentacle arising from one side of the bulb, not from the middle. Haeckel, 1879 , p. 84 , describes $\mathcal{T}$. tetrella as having small, pear-shaped tentacle-bulbs with a single tentacle arising from the middle of each bulb. He does not mention ocelli, but his description is brief and unaccompanied by a figure. Further study is required before we can be certain that Thammitis actually exists in nature. Vanhöffen, 1891, accepts it with some hesitation, and I share his view in this respect.

Browne, 1905 (Proc. Roy. Soc. Edinburgh, vol. 25, p. 758), is the only recent author who has seen a specimen of Thammitis. He found two small, immature medusæ in the Firth of Clyde, Scotland, in September to Octoler. They were 1 to $1.5 \mathrm{~mm}$. wide and had 4 simple, marginal tentacles. No ocelli. 4 oral tentacles 2 to 3 times dichotomously branched. No gonads. Stomach yellow to orange, tentacle-bulbs orange.

"Thammitis nigritella" Forbes, 1848 (British Naked-eyed Medusx, p. 63, plate 12, fig. 2) is probably an immature Bongainvillia which has lost all but one tentacle in eacli marginal cluster.

Thamnitis tetrella Haeckel.

Thammitis tetrella, HAECkEL, 1879 , Syst. der Medusen, p. $s_{4}$.

Bell egg-shaped, being $6 \mathrm{~mm}$. in height and $4 \mathrm{~mm}$. in diameter. There are 4 radially situated, marginal tentacles which are longer than the bell-height. Each tentacle arises from the middle of a large basal bulb. An ocellus is situated at the base of each tentacle. There are 4 radial-canals. The manubrium is culsical with a wide quadratic base. There are 4 radially situated, oral tentacles, each of which branches dichotomously three times. The gonads are found in 4 interradial(?) swellings upon the wall of the stomach. Color (?) This species is found upon the coast of Brazil. 


\section{Genus LYM NOREA Péron et Lesueur.}

(?) Favonia, Pérox ex Itesurur, 1809 , Hist. Gín. des Meduses, p. 16.

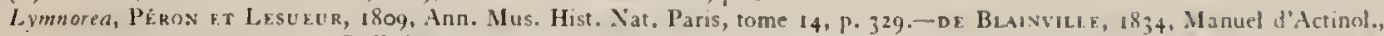
p. 290.-Marer, 1900, Bull. Mus. Comp. Zool. at Harvard College, vol. 37, p. 6; 1904, Mem. Nat. Sci. Brooklyn Inst.

Ifuseum, vol. 1, p. 10.-Agassiz and Marer, 1902, Mem. Mus. Comp. Zool. al Harvard College, vol. 26, p. 144.

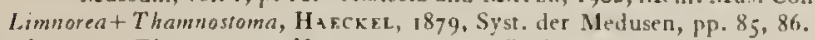

Lomnorea + Thamnosioma, VAмнöf FN, 1891, Zool. Anzeiger, Bd. 14. P. 445.

Macradia, Brooks and Rittfnhousf, 1907, Proc. Buston Soc. Nat. Hist., vol. 33, p. 437.

The oldest species of this genus is Lymmorea tricdra, described by P'cron and Lesueur, and first figured by de Blainville, 1834 . It occurs on the southern coast of Australia. The figures and description leave much to be desired, but the branching oral tentacles are clearly represented. The marginal tentacles are small and numerous.

\section{GENERIC CHARACTIRS.}

Margelina with branched oral tentacles and with 8 or more marginal tentacles which arise separately, not in clusters, from the bell-margin. The hydroid is unknown.

Haeckel, 1879, would call medusx with 8 marginal tentacles Thamnostoma, and those with 16 or more Limnorea. He introduced the spelling Limmorca, but Péron and Lesueur spell it Lymnorea. Owing to the very incomplete description of Péron and Lesueur it is impossible to determine whether Favonia is or is not equivalent to Lymmorea. Judging from de Blainville's, 1834 , copy of Péron and Lesueur's unpublished figure, it appears to be closely allied to Lymnorea, but its relationships must remain uncertain. Favonia takes precedence over Lymnorea, should it be equivalent, for it precedes Lymmoren in Péron and Lesueur's description.

\section{Lymnorea dibalia.}

Limin dibalin, Busch, 1851, Beobach. wirbellos. Seeth., p. 23, taf. 1, fign. 7-9.

Thamnostoma dibalis, Hafckrt, 1879. Syst. der Medusen, p. $86 .-$ Graffrk, 1884 , Arbeit. Zool. Inst. Wien., Bul. 5, P. 348.

Bell oval, $7 \mathrm{~mm}$. high, $6 \mathrm{~mm}$. wide. 8 marginal tentacles, those at the bases of the + radial-canals being longer than the 4 interradial tentacles. The ocelli are borne upon projecrions, one of which arises from each tentacle-bulb. The stomach is cubical and lacks a peduncle, and the throat-tube is as long as the stomach. There are + oral tentacles which branch dichotomously twice. + swollen gonads on the interradial sides of the stomach.

Found at Trieste, Adriatic Sea, Mediterranean. Graeffe states that the mature medusa are found in October, and the young first appear in September.

\section{Lymnorea macrostoma.}

Thannostoma macrostomi, Hafck F.1, 1S79. Svst. der Medusen, p. 86.

Bell cubical, $8 \mathrm{~mm}$. high, $8 \mathrm{~mm}$. wide. 8 similar marginal tentacles, each longer than the bell-diameter. A simple, abaxial ocellus at the base of each tentacle. Stomach gloloular without a peduncle. The throat-tube is 3 times as long as the stomach and extends beyond the velar opening. There are + short, oral tentacles, each of which branches dichotomously 6 to 8 times, thus giving rise to 80 to 100 terminal branches in each quadrant. + gonads on sides of stomach. Color (?) Indian Ocean, Singapore.

\section{Lymnorea ocellata Agassiz and Mayer.}

L.ymnorea ocellato, Acissiz, A., and MaYer, 1902, Mem. Museum Comp.Zool. at Harvard Coll., vol. 26, p. 144, plate 2, figs. 9-I2. (?) Lymmorea triedra, Pikon k. L.sukur, 1809, Annal. du Mus. Hist. Xat. Paris, tome 14. p. 329; de Blanville, 1834. Man. Actinologle, 1'. 290, plate 40, fig. 2; Harckel, 1879 , Syst. der Meolusen, p. 87.

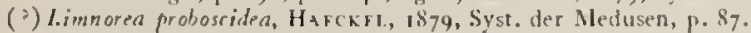

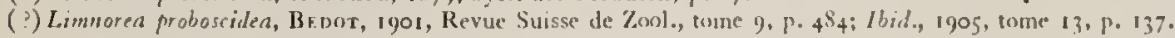

The top of the bell is flat and the sides flare outward in a bell-shaped manner. The bell is about $+m m$. in diameter and is about as high as it is broad. The walls are thin and guite Hexible. There are about 50 short, stiff tentacles which are each about half the length of the bell-height. These tentacles are usually carried curled upward and their entodermal cores are solid and composed of vacuolated chordate cells. The basal bulls of the tentacles are large 
and each contains a mass of red entodermal pigment. In addition to this there is a prominent ectodermal ocellus upon the velar side of each tentacle at a short distance outward from the basal bulb. The velum is narrow. There are 4 straight, narrow radial-canals and a slender circular vessel. The peduncle of the manubrium is wide and quadratic in cross-section and its lower portion near the stomach consists of highly vacuolated, entodermal cells. The stomach is pear-shaped and the mouth is a simple, round opening. The entire manubrium extends about

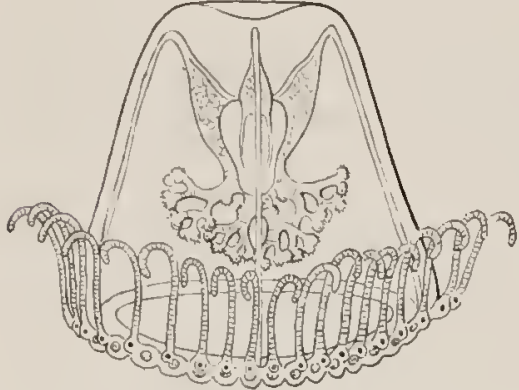

Fico. $S_{3}-$ Lummorea ocellata, after Agassiz and Mayer, in Mens. Museum Comp. Zool. at Harvard College. half the distance from the inner apex of the bell-cavity to the level of the velar opening. There are 4 welldeveloped, radially placed, oral tentacles, each one of which is about half as long as the height of the manubrium. Each oral tentacle branches dichotomously 4 times, thus giving rise to 16 distal knohs. Each knob is thickly covered with a bristling cluster of fusiform nematocyst-cells. In addition to these there are several patches of nematocystic bristles upon the sides of the main shaft of each oral tentacle. The gonads are developed in 4 interradial regions on the walls of the stomach. The entoderm of the tentacle-bulbs and of the stomach is brick-red. The ectodermal ocelli are black. A number of these medusæ were ohtained on the surface in the lagoon of Makemo Island, Paumotus, South Pacific, on October 23, I899.

This species may be identical with Lymnorea triedra Péron et Lesueur $=L$. probosciden Haeckel, but the published drawing of this medusa is evidently inaccurate and the description so brief and vague that it will probably never be possible to redetermine the species. L. triedra is described from Bass Strait, between Australia and Tasmania.

\section{Lymnorea borealis Mayer.}

Plate 15, figs. I to 3 .

Lvmnorea borealis, MAYer, 1900, Bull. Mus. Comp. Zool. at Harvard College, vol. 37, F. 6, figs. 16-18, plate 5.

(?) Limnarea nowegica, Broch, 1905, Bergens Museums Aarbog, No. 11, p. 5 .

(?) Cypranda areolata, Brownr, 1897, Proc. Zool. Soc. London, p. 817, plate 48, figs. 1, 2. (Podocoryme?)

Bell $3 \mathrm{~mm}$. high. It is higher than a hemisphere and is acorn-shaped, with a low, blunt apical projection. The bell-walls are thin. There are 32 marginal tentacles, each about half as long as the bell-height. They are quite stiff and a re carried curled upward, a bove the margin. Their basal bulbs are large and densely pigmented. The velum is well developed. There are + straight, narrow radial-canals and a slender, simple, circular vessel. The manubrium is slender and pyriform and mounted upon a very short, solid peduncle. It is cruciform in crosssection. The mouth is flanked on its 4 radial comers by 4 short dichotomously branching oral tentacles (plate 15, fig. 2). Each oral tentacle branches dichotomously twice, thus giving 4 tentacle tips in each quadrant. These tentacle tips a re knob-like and armed with long spindleshaped nematocysts (plate 15, fig. 3 ) very much as are the oral tentacles of Lymnoren ocellata. The 4 gonads are found in four longitudinal, interradial, swollen regions in the ectoderm of the stomach-wall. The immature eggs are transparent and give a reticulate appearance to the surface of each gonad. The entoderm of the manubrium and tentacle-bulbs is bright-red. There are no ocelli.

Three specimens were taken on the surface at Eastport, Maine, on September 19, 1898 .

Broch, igo5, gives a brief description of a Lymmorea from the coast of Norway which may he identical with this species. He states that there is a pair of very short, oral tentacles at each of the 4 corners of the mouth and that each of these forks dichotomously twice, thus giving 8 terminal knobs at each radial comer of the mouth. There are 16 to 22 tentacles. In other respects his description accords with that of $L$. borealis, allowance heing made for contraction due to preservation in Broch's specimen. He gives no figures and does not mention the color.

Lymnorea alexandri Mayer.

Plate I5, figs. 4 to 9.

L.vmnoren alexandri, MayrR, I906, Mem. Nat. Sci. Museum Brooklyn Institute, vol. I, p. 10, plate 1, figs. I-5a. Mecradia, sp., Brooks and Ritrt.nhousf, 1907, Proc. Boston Soc. Nat. Hist., vol. 33, p. 435, plate 31 , fig. 8 . 
Bell $4 \mathrm{~mm}$. high, $3 \mathrm{~mm}$. hroad, with vertical sides, flat top, and thin walls. 32 stender tentacles with tightly coiled ends and large basal bulls. A black, ectodermal ocellus lies upon the velar side of each tentacle-hutb (plate 15, fig. 9). The velum is well developed. The 4 radialcanals are straight and slender, but slightly swollen in the mid-region of their lengths, where their inner sides are lined with gland-cells (ptate 15, fig. 6). "The manubrium is Hask-shaped, and ahout half as long as the depth of the bell-cavity. "The distal part of the manubrium adjacent to the points of entrance of the + radial-canals is composed of highly vacuolated cells. The mid-region of the manubrium is cruciform in cross-section and the mature genital products are found in the ectoderm of the + interradial sides of the stomach. The mouth is at the extremity of a short neck and is surrounded by + oral tentacles, each of which branches dichotomously 3 times and terminates in 8 nematocyst-bearing knobs, making in all 32 of these knobs surrounding the mouth (plate 15 , fig. 5 ). The entoderm of the manubrium and tentaclebulbs is dull, Hesh-colored pink. In the youngest medusa seen the hell was $0.6 \mathrm{~mm}$. in diameter and had only + oral tentacle-knobs, + marginal tentacles, and + rudimentary tentacle-bulbs. This is one of the most abundant medusie upon the surface in summer, among the Bahama Islands. A single specimen was found at Tortugas, Florida, in July, 1905. Named in honor of Dr. Alexander Agassiz.

\section{Genus BOUGAINVILlia Lesson, 1836 .}

Cyanua bougainzilli, I,esson, 1830 , Voyage de la Coquille, Zonl., tom. 2, part. 2, 2e div., p. 118 , plate 14,700 phytes, figs. 3. $\mathrm{D}, \mathrm{D}^{\prime}, \mathrm{D}^{\prime \prime}, \mathrm{D}^{\prime \prime \prime}$.

Bougainullia, L,rsson, 1836. Ann. des Sci. Nat., Zool., sér. 2, tom. 5, P. 262.

Hippocrene, Brasnt, (Mertens), 1835. Mém. Acad. Imperiale des Sci. St. Péterstourg, Sci. Nat., sér. 6, tome 2, p.229. Preoccupied by Okfn, 1817 , for Mollusca.-Acissiz, L., 1849, Mem. Anner. Acall., New Series, vol. 4 , P. 250.

Bougaimillen, Forers, 1848 , British Naked-eyed Medusa, p. 6I.

Bougainvillia, Agassiz, L., 1862, Cont. Nat. Hist. U.S., vol. 4. p. 344.-Acatssiz, A., 186is, North Amer. Acal., P. 152.

Lizusa (young medusa), Hazckel, 1879 , Syst. der Medusen, p. 80.

II ippocrene, Hackic, 1879 , Syst. det Medusen, p. 90.

Bongaineillia, Hartlatb, 1897 , Wissen. Meeresuntersuch. auf Helgoland, Heft 1, Abe. 2, p. 455.

Bongainzillea, Mias, 1905, Craspedoten Medusen der Siboga Expedition, Monog. 10, P. 10.

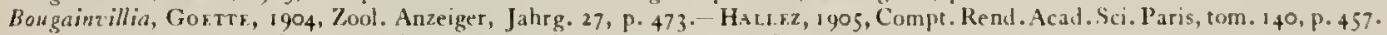
Margelis. St fenstrue 1850 , Videnskab. Meddel. fra den Nat. For., Kjöbenhavn, Nr. 1-3, p. 35.

Margelis, Agiassiz, L., 1862 , Cont. Nat. Hist. U.S., vol. 4, P. 344.-Acissiz, A., 1865, North Amer. Acal., P. 155.-114rekri, 1879, Syst. der Medusen, p. 87.-Hartiate, 1897, Wissenschaft. Meresuntersuch. But. Anstalt auf Hejgolani, Bi. 2. Heft 1 , Abt. 2, pp. 472,473 .

Bongainvillia, Hargitt, 1904, Bull. U.S. Bureau of Fisheries, vol. 24, p. 37.

Bongainzillea, GrRD, 1892 , Zool. Anzeiger, B1. 15, 1). 312, 5 fign. (cell-division, development of morula).

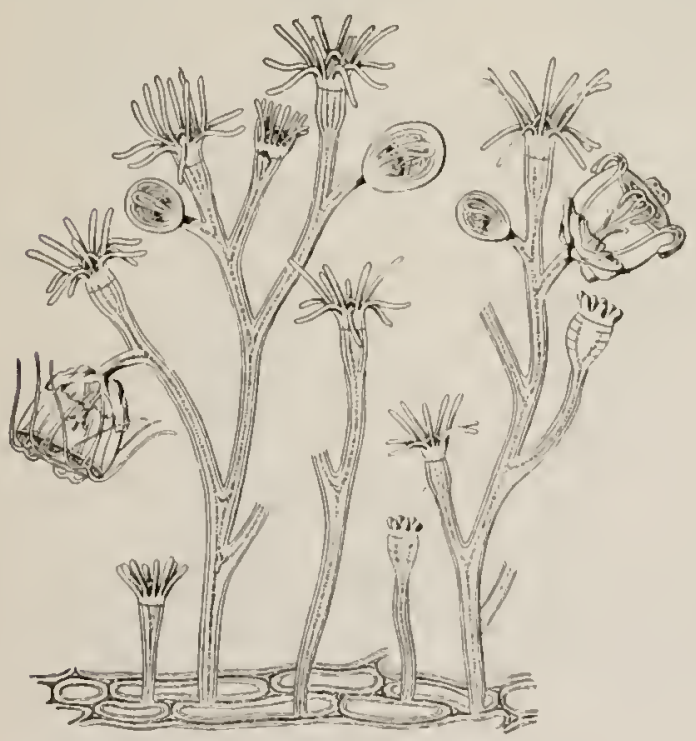

Fir. $8_{4}$,- Bougaimzillia "muscus," after Allman, in Ray" Suciety, $1871-1872$.

GINFRIC CIIARACTERS.

Margelina with + radially placed clusters of marginal tentacles, the tentacles of each cluster being all of one kind and similar in structure each to each. Hydroid: Bongainvillia.

There are 4 radially placed, dichotomously branching, oral tentacles, a quadratic manubrium, + radial-canals, and gonads on the interradial or adradial sides of the stomach as in orher Bougainvillidi.

The type species of the genus is Bougainrillia macloviana Lesson, 1836 , from the lialkland lslands. This medusa was first described and figured by. Lesson, in $1 \$ 30$, under the name Cyancabougainallii. The generic name "Cyanca" was, however, previously used by Péron and Lesueur, 1809 . for Discomedusx. Also the name Hippocrene of Brandt (Mertens), 1835 , was preoccupied in 1817 hy. Oken

for Mollusca and can not be applied to Medus:e. It therefore becomes necessary to adopt the generic name Bougainvillia. 
The name "Margclis" was first proposed by Steenstrup, 1850, and applied to designate Margclis principis of the North Sea, and this name was adopted by Agassiz and Haeckel. They would designate "Margelis" as being similar to Bougainvillia, but with a manubrium having a narrow base devoid of a peduncle and with the 4 radial-canals opening close together into the 4 corners of the narrow stomach. Bougainvillia, on the other hand, they would restrict to designate medusa with a wide quadratic stomach and often with a peduncle, the 4 radial-canals arising far apart from the 4 corners of the wide cruciform stomach. While these distinctions serve adinirably to distinguish "Margelis" principis or " $M$." carolinensis from Bongainvillia superciliaris, they fail completely to classify medusæ in which the manubrium is of moderate width, neither wide nor narrow. It is my object to retain only positive,

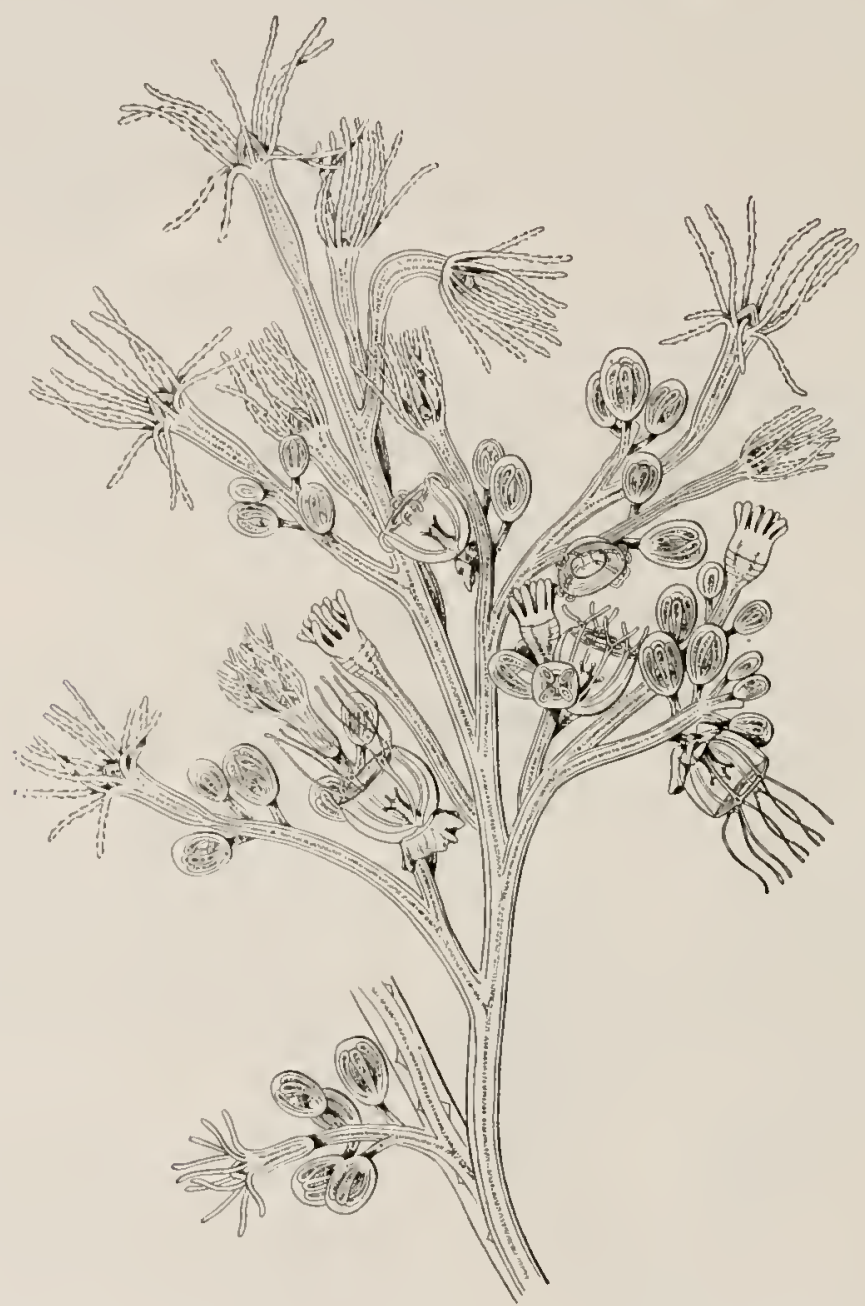

Fuc. 85-- Bougainaillin "fruticosn," after Allman, in Ray Society, $1871-72$.

not relative, characters as of generic value. It is futile and confusing to attempt to separate genera upon such intergrading differences as "wide or narrow stomach," "long or short manubrium," etc., for we generally find that species will be discovered allied evidently to both these so-called "genera," but strictly intermediate in essential characters. Bongainvillia takes precedence over Margelis and should therefore supplant it.

Forbes, 1848 , introduced the spelling Bongainvillea, but Lesson's original proposition is Bongainvillia.

Haeckel, 1879, p. 90, confuses the hydroid of Bougainvillio with Eudendrium, but in Eudendrium no free medusx are produced and there are other distinctions separating it from Bougainvillia. 
Nemopsis is separated from Bougainvillia by the tentacles, composing its + radially situated, marginal clusters, being of two distinct kinds (cluhbed and simple-ended). The marginal tentacles of Bougainvillia a re all of one sort and do not terminate in knobs. Vanhöffen. 189 I, shows that we can not separate $N$ emopsis from Bougainvillia upon the mere length of the radial pouches of its stomach, for some medusx of Bougainvillia display pouches of considerable length.

Tabular Synopsis of the Medusa of Bougninvillia.

\begin{tabular}{|c|c|c|c|c|c|c|c|}
\hline & $\begin{array}{l}\text { B. macloviana } \\
\text { Lesson. }\end{array}$ & $\begin{array}{l}\text { B. principis = } \\
\text { Margelis } \\
\text { principis } \\
\text { Steenstrup. }\end{array}$ & $\begin{array}{l}\text { B. fulva } \\
\text { Agassiz and } \\
\text { Mayer. }\end{array}$ & $\begin{array}{l}\text { B. britannica } \\
\text { Forbes. }\end{array}$ & $\begin{array}{c}\text { B. superciliaris } \\
\text { L.Agassiz. }\end{array}$ & $\begin{array}{l}\text { B. dinema } \\
\text { Greene } \\
=\text { B.super- } \\
\text { ciliaris (?)* }\end{array}$ & $\begin{array}{l}\text { B. multicilia } \\
\text { l.izusa } \\
\text { multicilia } \\
\text { Haeckel. } †\end{array}$ \\
\hline $\begin{array}{l}\text { Shape and size } \\
\text { of bell in } \\
\mathrm{nm} \text {. }\end{array}$ & $\begin{array}{l}\text { Cylindrical, } \\
\text { with round- } \\
\text { ed top. 15 } \\
\text { high, 13 } \\
\text { wide. }\end{array}$ & $\begin{array}{l}\text { Nearly spheri- } \\
\text { cal. } 7 \text { wide, } \\
6 \text { high. }\end{array}$ & $\begin{array}{l}\text { Cylindrical, } \\
\text { with flatly } \\
\text { rounded } \\
\text { top. 1t } \\
\text { high, II } \\
\text { wide. }\end{array}$ & $\begin{array}{l}\text { High, done- } \\
\text { like. Thick- } \\
\text { walled. }\end{array}$ & $\begin{array}{l}\text { Dome-like, with } \\
\text { bulging } \\
\text { sides. 10 } \\
\text { high, 10 } \\
\text { wide. }\end{array}$ & $\begin{array}{l}\text { Dome-like, } \\
\text { with bulging } \\
\text { sides. 12 } \\
\text { high, } 8 \\
\text { wide. }\end{array}$ & $\begin{array}{l}0.75 \text { splierical. } \\
6 \text { high, } 5 \\
\text { wide. } \\
\text { Thin uni- } \\
\text { form bell- } \\
\text { walls. }\end{array}$ \\
\hline $\begin{array}{l}\text { Number of } \\
\text { tentacles } \\
\text { upon each } \\
\text { of the } 4 \text { mar- } \\
\text { ginal bulbs. }\end{array}$ & $\begin{array}{l}35 \text { to } 65 \text { in } \\
\text { double row. }\end{array}$ & $\begin{array}{l}25 \text { to } 30 \mathrm{in} \text { sin- } \\
\text { gle row. }\end{array}$ & $\begin{array}{l}15 \text { to } 20 \text { in sin- } \\
\text { gle row. }\end{array}$ & $\begin{array}{l}16 \text { to } 20 \text {. Very } \\
\text { short, in } \\
\text { single row. }\end{array}$ & $\begin{array}{l}10 \text { to } 15 . \\
32 \text { in the } \\
\text { variety } \\
\text { B. aurea. }\end{array}$ & $\begin{array}{l}101012(?) \\
\text { Only } 2 \text { per- } \\
\text { fect tenta- } \\
\text { cles seen. }\end{array}$ & 10 to 12 \\
\hline $\begin{array}{l}\text { Shape of mar- } \\
\text { ginal bulbs. }\end{array}$ & V-shaped. & $\begin{array}{l}\text { Long, linear; } \\
\text { wider than } \\
\text { spaces be- } \\
\text { tween them. }\end{array}$ & $\begin{array}{l}\text { F.paulet- } \\
\text { shaped. }\end{array}$ & $\begin{array}{l}\text { Epaulet- } \\
\text { shaped. }\end{array}$ & $\begin{array}{l}\text { F.longate, oval } \\
\text { basal bulbs, } \\
\text { of small size. }\end{array}$ & $\begin{array}{l}\text { Kidney- } \\
\text { shaped. }\end{array}$ & $\begin{array}{l}\text { Kiilney- } \\
\text { sliaped. }\end{array}$ \\
\hline $\begin{array}{l}\text { Shape and } \\
\text { size of man- } \\
\text { ubrium. }\end{array}$ & $\begin{array}{l}\text { Small, cubical. } \\
\text { On broad, } \\
\text { conical } \\
\text { peduncle. }\end{array}$ & $\begin{array}{l}\text { Short, wide. } \\
4 \text {-sided. } \\
\text { Only one- } \\
\text { third as long } \\
\text { as depth of } \\
\text { bell-cavity. }\end{array}$ & $\begin{array}{l}\text { Wide. Half } \\
\text { as long as } \\
\text { depth of } \\
\text { bell-cavity. } \\
\text { No pedun- } \\
\text { cle. }\end{array}$ & $\begin{array}{l}\text { 4-sided, wide, } \\
\text { urn-sliaped. } \\
\text { No pelun- } \\
\text { cle. Only } \\
\text { about half } \\
\text { as long as } \\
\text { depth of } \\
\text { bell-cavity. }\end{array}$ & $\begin{array}{l}\text { Wide, } 4 \text {-sided, } \\
\text { and flask- } \\
\text { shaped. } \\
\text { Mounted on } \\
\text { peluncle i-5 } \\
\text { to two-thirds } \\
\text { as long as } \\
\text { depth of bell- } \\
\text { cavity. }\end{array}$ & $\begin{array}{l}\text { Snall, balloon- } \\
\text { shapeel, } \\
4 \text {-sided, } \\
\text { hardly one- } \\
\text { fourth as } \\
\text { long as bell- } \\
\text { height. }\end{array}$ & $\begin{array}{l}\text { Globular to } \\
\text { Hask-shapesl } \\
\text { with con- } \\
\text { stricted } \\
\text { base. No } \\
\text { peduncle. }\end{array}$ \\
\hline $\begin{array}{l}\text { Number of } \\
\text { dichotonous } \\
\text { branchings } \\
\text { of each of } \\
\text { the toral } \\
\text { tentacles. }\end{array}$ & 6 to 7 times. & flogtimes. & 8 times. & 6 to 7 tines. & $\begin{array}{l}\text { About } 5 \text { times. } \\
7 \text { tines in } \\
\text { the variety } \\
\text { B. aurea. }\end{array}$ & $f^{\text {to }} 5$ times. & $\begin{array}{l}\text { Simple, un- } \\
\text { branched. }\end{array}$ \\
\hline $\begin{array}{c}\text { Character of } \\
\text { gonads. }\end{array}$ & $\begin{array}{l}\text { + wide, folded, } \\
\text { interradial } \\
\text { swellings. }\end{array}$ & $\begin{array}{l}+ \text { spherical, } \\
\text { interradial. }\end{array}$ & 8 adradial. & $\begin{array}{l}8 \text { adradial. } \\
\text { No planulie } \\
\text { remain } \\
\text { att ached to } \\
\text { stomach. }\end{array}$ & $\begin{array}{l}4 \text { interradial. } \\
\text { Planuls } \\
\text { develop in } \\
\text { capsules } \\
\text { upon sides of } \\
\text { stonach. }\end{array}$ & 4 interradial. & 8 adradial. \\
\hline Color. & $\begin{array}{l}\text { Stomach and } \\
\text { tentacle- } \\
\text { bulbs yel- } \\
\text { low. Gon- } \\
\text { ads and } \\
\text { ocelli } \\
\text { brownish- } \\
\text { black. }\end{array}$ & ? & $\begin{array}{l}\text { Stomach and } \\
\text { tentacle- } \\
\text { bulbs } \\
\text { orange, yel- } \\
\text { low, brown- } \\
\text { ish-yellow: } \\
\text { Ocelli } \\
\text { black. }\end{array}$ & $\begin{array}{l}\text { Stomach and } \\
\text { tentacle- } \\
\text { bulbs } \\
\text { golden-yel- } \\
\text { low. Ocelli } \\
\text { black. }\end{array}$ & $\begin{array}{l}\text { Stomach and } \\
\text { tentacle- } \\
\text { bulbsrosin- } \\
\text { yellow to } \\
\text { redelish- } \\
\text { hrown. Ocel- } \\
\text { li black. }\end{array}$ & $\begin{array}{l}\text { Stomach and } \\
\text { tentacle- } \\
\text { bulbs yel- } \\
\text { low. Ocelli } \\
\text { black. }\end{array}$ & $\begin{array}{l}\text { Stomach light- } \\
\text { yellow: } \\
\text { Jentacle- } \\
\text { bulbs } \\
\text { orange- } \\
\text { yellow: } \\
\text { Ocelli dark- } \\
\text { red. }\end{array}$ \\
\hline Where found. & $\begin{array}{l}\text { Falkland } \\
\text { Islands, } \\
\text { South At- } \\
\text { lantic. }\end{array}$ & $\begin{array}{l}\text { North Sea, } \\
\text { coast of } \\
\text { Scotlanil. }\end{array}$ & $\begin{array}{l}\text { Tropical } \\
\text { Pacific, } \\
\text { Piji to } \\
\text { Malay } \\
\text { Archipelago. }\end{array}$ & $\begin{array}{l}\text { North Atlantic } \\
\text { coasts of } \\
\text { Europe and } \\
\text { America. }\end{array}$ & $\begin{array}{l}\text { Arctic Ocean, } \\
\text { northern } \\
\text { coasts of } \\
\text { Europe and } \\
\text { America. }\end{array}$ & $\begin{array}{l}\text { E.ast coast of } \\
\text { Irelansl. }\end{array}$ & $\begin{array}{l}\text { Straits of } \\
\text { Gibraltar. }\end{array}$ \\
\hline Hydroid. & Unknown. & Unknown. & Unknown. & $\begin{array}{l}\text { Hydroid has } \\
\text { been com- } \\
\text { monly call- } \\
\text { ed B. "ra- } \\
\text { mosa." }\end{array}$ & B. superciliaris: & & \\
\hline
\end{tabular}

* This medusa appears to be $B$. superciliaris which has lost some tentacles. H. aured, linkon, 1904, is prebably a variety of B. superciliaris from Arctic Ocean.

tAn immature medusa? 
The definitions of Bougainrillia and Nemopsis here proposed are identical with those of Hargitt, 1904, P. 37 .

Species of Bougainvillia are widely distributed in all seas, but are especially abundant in the cold waters of the northern hemisphere, a remarkably large number being found in the North Sea near Helgoland, by Hartlaub, 1897. Many of the species are very closely related and their distinctions may be due in part to environmental influences. Hallez found that

Tabular Synopsis of the Medusa of Bougainvillia.-Continued.

\begin{tabular}{|c|c|c|c|c|c|c|c|}
\hline & $\begin{array}{l}\text { B. platygaster } \\
\text { Haeckel. }\end{array}$ & $\begin{array}{l}\text { B. Xanthi } \\
\text { Hartlaub.* }\end{array}$ & $\begin{array}{l}\text { B. carolinen- } \\
\text { sis= Hip- } \\
\text { pocrene } \\
\text { carolinensis } \\
\text { McCrady. }\end{array}$ & $\begin{array}{l}\text { B. niobe } \\
\text { Mayer. }\end{array}$ & $\begin{array}{l}\text { B. pyramidata } \\
=\text { Hippo- } \\
\text { crene pyra- } \\
\text { midata } \\
\text { Forbes. }\end{array}$ & $\begin{array}{l}\text { B. nordgaardii } \\
=\text { Margelis } \\
\text { nordgaardii } \\
\text { Browne. }\end{array}$ & $\begin{array}{l}\text { B. flavila } \\
\text { Hartlaub. }\end{array}$ \\
\hline $\begin{array}{l}\text { Shape and size } \\
\text { of bell in } \\
\mathrm{mm} \text {. }\end{array}$ & $\begin{array}{l}\text { Cubical. } \\
12 \text { high, } 12 \\
\text { wide. }\end{array}$ & $\begin{array}{l}\text { Dome-like, } \\
\text { walls very } \\
\text { thick. } 6 \\
\text { high, } 5 \text { wide. }\end{array}$ & $\begin{array}{l}\text { Dome-like. } \\
\text { Very thick } \\
\text { walls. } 4 \\
\text { high, } 4 \text { wide. }\end{array}$ & $\begin{array}{l}\text { Cylindrical, } \\
\text { with flatly- } \\
\text { rounded } \\
\text { apex. } 6.75 \\
\text { high, } 4.8 \\
\text { wide. Bell- } \\
\text { walls thick. }\end{array}$ & $\begin{array}{l}\text { Semi-globular. } \\
6 \text { high, } 6 \text { wide. } \\
\text { Walls thick. }\end{array}$ & $\begin{array}{l}\text { Oval. } 4 \text { high, } \\
4 \text { wide. } \\
\text { Walls only } \\
\text { fairly thick. }\end{array}$ & $\begin{array}{l}\text { Oval. } 3 \text { wide, } \\
2 \text { high. } \\
\text { Walls thick. }\end{array}$ \\
\hline $\begin{array}{l}\text { Number of } \\
\text { tentacles } \\
\text { upon each } \\
\text { of the } 4 \text { mar- } \\
\text { ginal bulbs. }\end{array}$ & 10 to 12 & yto 10 & $\begin{array}{l}7 \text { to } 9 \text { very } \\
\text { long and } \\
\text { slender. }\end{array}$ & 8 & 6 to 8 & $\begin{array}{l}5 \text { to } 7 . \text { No } \\
\text { ocelli. }\end{array}$ & $\begin{array}{l}\text { Not more than } \\
6 .\end{array}$ \\
\hline $\begin{array}{l}\text { Shape of mar- } \\
\text { ginal bulbs. }\end{array}$ & $\begin{array}{l}\text { Triangular, } \\
\text { wider than } \\
\text { spaces be- } \\
\text { tween then. }\end{array}$ & $\begin{array}{l}\text { Small, oval to } \\
\text { globular. }\end{array}$ & $\begin{array}{l}\text { Small, thick, } \\
\text { bulbous. }\end{array}$ & Small, oval. & Small, globular. & $\begin{array}{l}\text { Small, globu- } \\
\text { lar. }\end{array}$ & $\begin{array}{l}\text { Swollen, fairly } \\
\text { large, bul- } \\
\text { bous. }\end{array}$ \\
\hline $\begin{array}{l}\text { Shape and size } \\
\text { of manu- } \\
\text { brium. }\end{array}$ & $\begin{array}{l}\text { Flat, 4-sided. } \\
\text { No pedun- } \\
\text { cle. }\end{array}$ & $\begin{array}{l}\text { Spindle-shap- } \\
\text { ed. Noped- } \\
\text { uncle. }\end{array}$ & $\begin{array}{l}\text { Narrow, } \\
\text { widest near } \\
\text { mouth. } \\
\text { Half as long } \\
\text { as depth of } \\
\text { bell-cavity. }\end{array}$ & $\begin{array}{l}\text { Flask-sliaped. } \\
\text { Cruciform } \\
\text { in cross- } \\
\text { section. } \\
\text { Half as long } \\
\text { as depth of } \\
\text { bell-cavity. }\end{array}$ & $\begin{array}{l}\text { Flat, cruciform, } \\
\text { mounted } \\
\text { upon pedun- } \\
\text { cle. }\end{array}$ & $\begin{array}{c}\text { Half as long as } \\
\text { depth of } \\
\text { bell-cavity. }\end{array}$ & $\begin{array}{l}\text { Small, conical. } \\
\text { about half } \\
\text { as long as } \\
\text { depth of } \\
\text { bell-cavity. } \\
\text { No pedun- } \\
\text { cle. }\end{array}$ \\
\hline $\begin{array}{l}\text { Number of di- } \\
\text { chotomous } \\
\text { branchings } \\
\text { of each of } \\
\text { the } 4 \text { oral } \\
\text { tentacles. }\end{array}$ & 3 or + times. & $\begin{array}{c}\text { About } 2 \text { or } 3 \\
\text { times. }\end{array}$ & 2 times. & 4 times. & 2 times. & 4 or 5 times. & 3 times. \\
\hline $\begin{array}{c}\text { Character of } \\
\text { gonads. }\end{array}$ & + interradial. & 4 interradial. & 4 interradial. & $\begin{array}{l}\text { Meclusa-buds } \\
\text { arise from } 8 \\
\text { adradial } \\
\text { sides of } \\
\text { stomach. }\end{array}$ & $\begin{array}{l}\text { Gonads on base } \\
\text { and lobes of } \\
\text { stomach. }\end{array}$ & 4 interradial. & 4 interradial. \\
\hline Color. & $\begin{array}{l}\text { Stomach and } \\
\text { tentacle- } \\
\text { bulbs red- } \\
\text { dish-yellow. } \\
\text { Occlli? }\end{array}$ & $\begin{array}{l}\text { Stomach and } \\
\text { tentacle- } \\
\text { bulbs gold- } \\
\text { en-yellow, } \\
\text { reddish-yel- } \\
\text { low. Ocelli } \\
\text { small, } \\
\text { brownish- } \\
\text { violet. }\end{array}$ & $\begin{array}{l}\text { Variable, us- } \\
\text { ually stom- } \\
\text { ach and } \\
\text { tentacle- } \\
\text { bulbs green } \\
\text { or grecn and } \\
\text { red. Ocelli } \\
\text { black. }\end{array}$ & $\begin{array}{l}\text { Stomach and } \\
\text { tentacle- } \\
\text { bulbs rosin- } \\
\text { yellow. }\end{array}$ & $\begin{array}{l}\text { Stomach and } \\
\text { tentacle- } \\
\text { bulbs orange } \\
\text { to yellow to } \\
\text { redilish- } \\
\text { brown. }\end{array}$ & $\begin{array}{l}\text { Gonads and } \\
\text { tentacle- } \\
\text { bulbs yel- } \\
\text { lowish- } \\
\text { brown (in } \\
\text { formalin). } \\
\text { No ocelli. }\end{array}$ & $\begin{array}{l}\text { Stomach and } \\
\text { tentacle- } \\
\text { bulbs } \\
\text { orange-yel- } \\
\text { low. Ocellı } \\
\text { black. }\end{array}$ \\
\hline W'here found. & $\begin{array}{l}\text { Eastern parts } \\
\text { of tropical } \\
\text { Atlantic. } \\
\text { Cape Verie, } \\
\text { Canary } \\
\text { Islands. }\end{array}$ & $\begin{array}{c}\text { Helgoland, } \\
\text { German } \\
\text { Ocean. }\end{array}$ & $\begin{array}{l}\text { Atlantic coast } \\
\text { of United } \\
\text { States, } \\
\text { Woods } \\
\text { Hole to } \\
\text { Tortugas. }\end{array}$ & $\begin{array}{l}\text { Bahana } \\
\text { Islands, } \\
\text { tropical } \\
\text { Atlantic. }\end{array}$ & $\begin{array}{l}\text { West coast of } \\
\text { Scotland, } \\
\text { south of } \\
\text { Ireland. }\end{array}$ & $\begin{array}{c}\text { Near Bergen, } \\
\text { Norwav. }\end{array}$ & $\begin{array}{l}\text { Helgoland, } \\
\text { German } \\
\text { Ocean, } \\
\text { August to } \\
\text { September. }\end{array}$ \\
\hline Hyilroid. & Unknown. & Unknown. & $\begin{array}{l}\text { Hydroil: B. } \\
\text { carolinensis. }\end{array}$ & Unknown. & Unknown. & Unknown. & $\begin{array}{l}\text { Hydroid: B. } \\
\text { flavida } \\
\text { Hartlaub. }\end{array}$ \\
\hline
\end{tabular}


B. fruticosa Allman is a form of B. ramosa Van Beneden, which grows in agitated water. The observations of Graeffe, $188+$ (Arbeit. Zool. Inst. Wien., Bd. 5, p. 349), are interesting in the same connection, for he found that five distinct forms of Bougainvillia medusa arise from a hydroid apparently identical with Bougainvillia muscus Allman. It is therefore probable that many of our so-called "species" of Bougainvillia are merely envirommental races. "The hydroids of most of them remain unknown, or are not associated with any known medusa, and many of the species are imperfectly descrilied. The following descriptions must be considered as only tentative attempts to unravel the confusion which prevails at present and which can not be dissipated until the hydroids of all or most of the species are discovered.

Haeckel's 1879 , genus "Lizusa" appears to apply only to immature specimens of Brongaimvillia in which the oral tentacles have not yet hecome hranched.

Tabular Synopsis of the Medusa of Bouganevillia.*-Continted.

\begin{tabular}{|c|c|c|c|c|c|c|}
\hline & $\begin{array}{l}\text { B. autumnalis } \\
\text { Hartlaub=B. } \\
\text { gibbsi Mayer. }\end{array}$ & $\begin{array}{l}\text { B. proliferd- } \\
\text { Lizusa prolif- } \\
\text { era von Len- } \\
\text { denfeld. }\end{array}$ & $\begin{array}{l}\text { B. maniculata } \\
\text { Haectiel. }\end{array}$ & $\begin{array}{l}\text { B. rugosa } \\
\text { Clartic. }\end{array}$ & $\begin{array}{l}\text { B. trinema = } \\
\text { Margelis tri- } \\
\text { nema von } \\
\text { Lendenfeld. }\end{array}$ & $\begin{array}{l}\text { B. frondosa } \\
\text { Majer. }\end{array}$ \\
\hline $\begin{array}{l}\text { Shape and size } \\
\text { of bell in mm. }\end{array}$ & $\begin{array}{l}\text { Dome-like. } \\
2.5 \text { high, } 2 \\
\text { wide. } \\
\text { 'Thick walls. }\end{array}$ & $\begin{array}{l}\text { Dome-like. } \\
3 \text { high, } 2.5 \\
\text { wide. }\end{array}$ & $\begin{array}{l}\text { Neariy spherical. } \\
\text { 1.5 high, } 1.5 \\
\text { wide. } \\
\text { Thin walls. }\end{array}$ & $\begin{array}{l}\text { Pyriform. } \\
\text { I.5 high. }\end{array}$ & $\begin{array}{l}\text { Oval. } \\
3 \text { wide. }\end{array}$ & $\begin{array}{l}\text { Dome-like with } \\
\text { vertical sides. } \\
2 \text { ligh, } 1.25 \\
\text { wide. Walls } \\
\text { thick. }\end{array}$ \\
\hline $\begin{array}{l}\text { Number of ten- } \\
\text { tacles upon } \\
\text { each of the } 4 \\
\text { marginal } \\
\text { bulbs. }\end{array}$ & 3106 & 5 & $\begin{array}{l}\text { \& sluort, finger- } \\
\text { shaped. }\end{array}$ & 3 & 3 & 2. No ocelli. \\
\hline $\begin{array}{l}\text { Shape of mar- } \\
\text { ginal bulbs. }\end{array}$ & $\begin{array}{l}\text { Rounded, bul- } \\
\text { bous, fairly } \\
\text { large. }\end{array}$ & $\begin{array}{c}\text { Large, "scrota. } \\
\text { shaped." }\end{array}$ & Smadl, globular. & Small, glubular. & Suall. & $\begin{array}{l}\text { Simall, without } \\
\text { ocelli. }\end{array}$ \\
\hline $\begin{array}{l}\text { Shape and size } \\
\text { of manubrium. }\end{array}$ & $\begin{array}{l}\text { Short urn-shap- } \\
\text { ed, wide, } 4^{-} \\
\text {sided. Not } \\
\text { lialf as longas } \\
\text { dephth of hell- } \\
\text { cavity. No } \\
\text { peduncle. }\end{array}$ & $\begin{array}{l}\text { Sinali, nearly } \\
\text { cubical. }\end{array}$ & $\begin{array}{l}\text { Flask-sliaped. } \\
\text { Narrow hase, } \\
\text { spherical } \\
\text { stomacl. } \\
\text { Long, conical } \\
\text { throat. }\end{array}$ & $\begin{array}{l}\text { Short, thick, } \\
\text { flask-shaped. }\end{array}$ & Small. & $\begin{array}{l}\text { Cruciform, sliort, } \\
\text { thick, flask- } \\
\text { sliaped. Half } \\
\text { as long as depth } \\
\text { of bell-cavity. }\end{array}$ \\
\hline $\begin{array}{l}\text { Numher of di- } \\
\text { chotomous } \\
\text { branchings of } \\
\text { each of the } 4 \\
\text { oral tentacles. }\end{array}$ & 2 or 3 times. & $\begin{array}{l}\text { Simple un- } \\
\text { branched. }\end{array}$ & $\begin{array}{l}\text { Twice. Only } \\
\text { tips branched. }\end{array}$ & $\begin{array}{l}\text { Unbranclied, } \\
\text { simple. }\end{array}$ & $\begin{array}{c}\text { Each ends in } 3 \\
\text { branches. }\end{array}$ & 2 or 3 times. \\
\hline $\begin{array}{c}\text { Character of } \\
\text { gonads. }\end{array}$ & + interradial. & $\begin{array}{l}\text { Medusa-buds on } \\
\text { sides of stom- } \\
\text { ach. }\end{array}$ & + interradial. & $\begin{array}{l}\text { Not developed } \\
\text { (immature). }\end{array}$ & Not developed. & $\begin{array}{l}8 \text { adradial. Plan- } \\
\text { ulae develop } \\
\text { upon sides of } \\
\text { stomach. }\end{array}$ \\
\hline Color. & $\begin{array}{l}\text { Stomach green- } \\
\text { brown. Ten- } \\
\text { tacle-bulbs } \\
\text { yellowish- } \\
\text { greenish-yel- } \\
\text { low. Ocelli } \\
\text { black. }\end{array}$ & $\begin{array}{l}\text { Stomacls and } \\
\text { tentacle-bulbs } \\
\text { brown. }\end{array}$ & $\begin{array}{l}\text { Stounach and } \\
\text { tentacle-bulbs } \\
\text { violet-gray. }\end{array}$ & $\begin{array}{l}\text { Stonach an:l } \\
\text { tentacle-bulbs } \\
\text { yellow, brown. }\end{array}$ & $\begin{array}{l}\text { Strmach and } \\
\text { tentacli-bulbs } \\
\text { tark-ycllow. }\end{array}$ & $\begin{array}{l}\text { Simmich and ten- } \\
\text { tacle-bulbs } \\
\text { pinkish-white. } \\
\text { rentacle-tips } \\
\text { turquoise. }\end{array}$ \\
\hline Where found. & $\begin{array}{l}\text { Newport, United } \\
\text { States. Helgo- } \\
\text { land, German } \\
\text { Ocean. Aug- } \\
\text { ust to Noven- } \\
\text { ber, and off } \\
\text { Britisl coasts. }\end{array}$ & $\begin{array}{l}\text { Port Jackion, } \\
\text { New South } \\
\text { Wales, March } \\
\text { to April. }\end{array}$ & Mediterranean. & $\begin{array}{l}\text { Virginia to South } \\
\text { Carolina, } \\
\text { Atlantic coust } \\
\text { of United } \\
\text { States. }\end{array}$ & $\begin{array}{l}\text { Pori Jackison, } \\
\text { New South } \\
\text { Wales, Aus- } \\
\text { tralia. } \\
\end{array}$ & Tortugas. \\
\hline Hydroist. & $\begin{array}{l}\text { Hyilroid un - } \\
\text { known. }\end{array}$ & $\begin{array}{l}\text { An inmature } \\
\text { form? In- } \\
\text { known. }\end{array}$ & Cuhnown. & $\begin{array}{l}\text { IIyslroid: } 13 . \\
\text { rugosa Clarke. }\end{array}$ & L'uknown. & lnknown. \\
\hline
\end{tabular}

* For B. obscura Bunnevie and $B$. gloriella Torrey, see text. 
There is considerable variability in coloration among individuals of the same species in many forms of Bougainvillia. The preceding tables present a synopsis of the so-called "species," although it is probable that some of the small medusx listed near the end are only the young of those described higher up on the table.

Gerd, 1892 , finds that the segmentation in the egg of Bougainvillia is at first total and equal and a central segmentation cavity is formed. Then the cells divide tangentially and the nuclei take up a peripheral position. Later there is multipolar ingression into the segmentation cavity and thus a solid morula is formed, having all cells similar each to each. The peripheral layer of cells forms the ectoderm of the planula larva. Before the formation of the ectoderm the cell boundaries become indistinct as in $\mathcal{T}$ urritopsis, but later they reestablish themselves.

Bougainvillia macloviana Lesson.

Cyanea bouguinvillii, Lesson, 1830, Voyage de la Coquille, Zool., tome 2, part 2, 2ul div., Zonphytes, p. 118, plate 14, figs. 3, D- D"ll.

Boupainvillea macloviana, Lesson, 1843, Hist. Zooph. Acal., p. 290.-AGassiz, L.., 1862, Cont. Nat. Hist. U. S., vol. 4. 1'. 344. Hippocrene macloviana, Ha Ecker, 1879, Syst. der Medusen, p. go, taf. 5, fign. 1, 2.-Browne, 1902, Annals and Mag. Nat. Hist., ser. 7, vol. 9, p. 278.-ВЕдот, 1905, Revue Suisse de Zool., tome 13, p. 135 (literature 18,0-50).

Adult medusa.-Umbrella a little higher than broad, about $15 \mathrm{~mm}$. high, with a quadrangular margin, and with longitudinal furrows on the exumbrella. There are $4 \mathrm{~V}$-shaped, radially situated tentacle-bulbs, each giving rise to about 35 to 65 tentacles arranged in a double row. There is a single ocellus at the base of every tentacle. The stomach is small, cubical, and situated upon a broad, cone-shaped peduncle. 4 narrow, perradial lobes extend outward from the stomach along the whole length of the peduncle. The mouth is small, with 4 short, perradial lips placed at a point about two-thirds down the depth of the umbrella-cavity. There are 4 closely and thickly branched tentacles, each with 80 to 100 terminal branches ending in knob-like clusters of nematocysts. The gonads are developed upon the interradial sides of the stomach and extend over the sides of the perradial lobes of the stomach, hanging down in a folded band from the peduncle. The stomach and tentacle-bulbs are yellow, while the gonads and ocelli are brownish to black. This species is abundant at the Falkland Islands. Mature specimens were recently obtained by Vallentin hetween November and Felruary at Stanley Harbor and described by Browne. Haeckel's specimens appear to have been immature.

\section{Bougainvillia principis.}

Margelis principis, Steenstrup, 1850 , Vidensk. Meddel. Nat. For. Kjöbenhavn, p. 35 .

Bougainillea fruticosa + B. Allmani, Romanes, 1876-77, Journal Linnean Soc. London, Zool., vols. 12, 13, pp. 526, 190.

Margelis principis, HAECKEL, 1879 , Syst. der Medusen, P. 88, taf. 6, fign. 14-16.-Browne, 1895 , Proc. and Trans. Liverpool Biol. Soc., vol. 9, p. 266.

Bell nearly spherical, 6 to $7 \mathrm{~mm}$. wide, $5.6 \mathrm{~mm}$. high. Bell-walls only moderately thick and quite uniform. 4 marginal clusters of tentacles. Each cluster arises from an epauletshaped base, and contains 25 to 30 short tentacles, shorter than the bell-radius. There is an ectodermal ocellus on the velar side of each tentacle near its base. The basal epaulets of the tentacles are somewhat wider than the interradial parts of the margin between them.

The stomach is short, swollen, and without a peduncle. It is not half as long as the depth of the bell-cavity, and its interradial sides are occupied by 4 swollen gonads. The 4 oral tentacles each branch dichotomously 4 to 5 times, thus giving 20 to $30 \mathrm{knoh}$-shaped, terminal branches in each quadrant. Color (?)

Found off the eastern coast of Scotland and in the North Sea, at Far-Oer Island.

The hydroid is unknown.

This medusa is distinguished by its short stomach and the remarkable length of its marginal tentacle-epaulets, which are linear, not triangular, in outline.

\section{Bougainvillia fulva Agassiz and Mayer.}

Bougainzillea fulva, Aciassız, A., and Marre, 1899, Bull. Mus. Comp. Zool. at Harvard College, vol. 32, p. I6z, plate 2, fig.6; Ibid., 1902, Mem. Mus. Comp. Zool. at Harvard Coll., vol. 26, 1. 145, plate 2, fig. 8.- Mas, 1905, Craspedoten Medusen der Siboga Exped., Monog. 10, p. 10, taf. 1, fig. 8; taf. 2, fign. 9, ro: Igoh, Revue Suisse de Zonl., tome 14, 1) 87, plate 2, figs. 4, 5.- Bignlow, H. B., 1909, Mem. Mus. Comp. Zool. at Harvard College, vol. 37, p. 195, plates 6 alind 44 . 


\section{.}




\section{Plate i 7 .}

Fig. I. Bongainvillia superciliaris. Showing planula developing upon the interradial sides of the manubrium. Woods Hole, Massachusetts.

Fig. 2. Bongainvillia rngosa, young medusa. Charleston Harbor, South Carolina, December 17, 1904 .

Fig. 3. Bongainvillia antummalis, young medusa. Agassiz Laboratory, Newport, Rhode Island, July, 1902.

Fig. 4. Bongainvillia autumnalis, mature female. Agassiz Laboratory, Newport, Rhode Island, August, 1892.

Fig. 5. Nemopsis bachei. One of the median marginal tentacles of the medusa shown in figure 6 .

Fig. 6. Nemopsis bachei, mature male. Hampton Roads, Virginia, November I, 1904 .

Fig. 7. Bongainvillia carolinensis, mature male. Charleston Harhor, South Carolina, September ro, i $\$ 97$.

Fig. 8. Bongainvillia britannica, mature female. Eastport, Maine, September 19,1898 .

Drawn from life, by the author. 


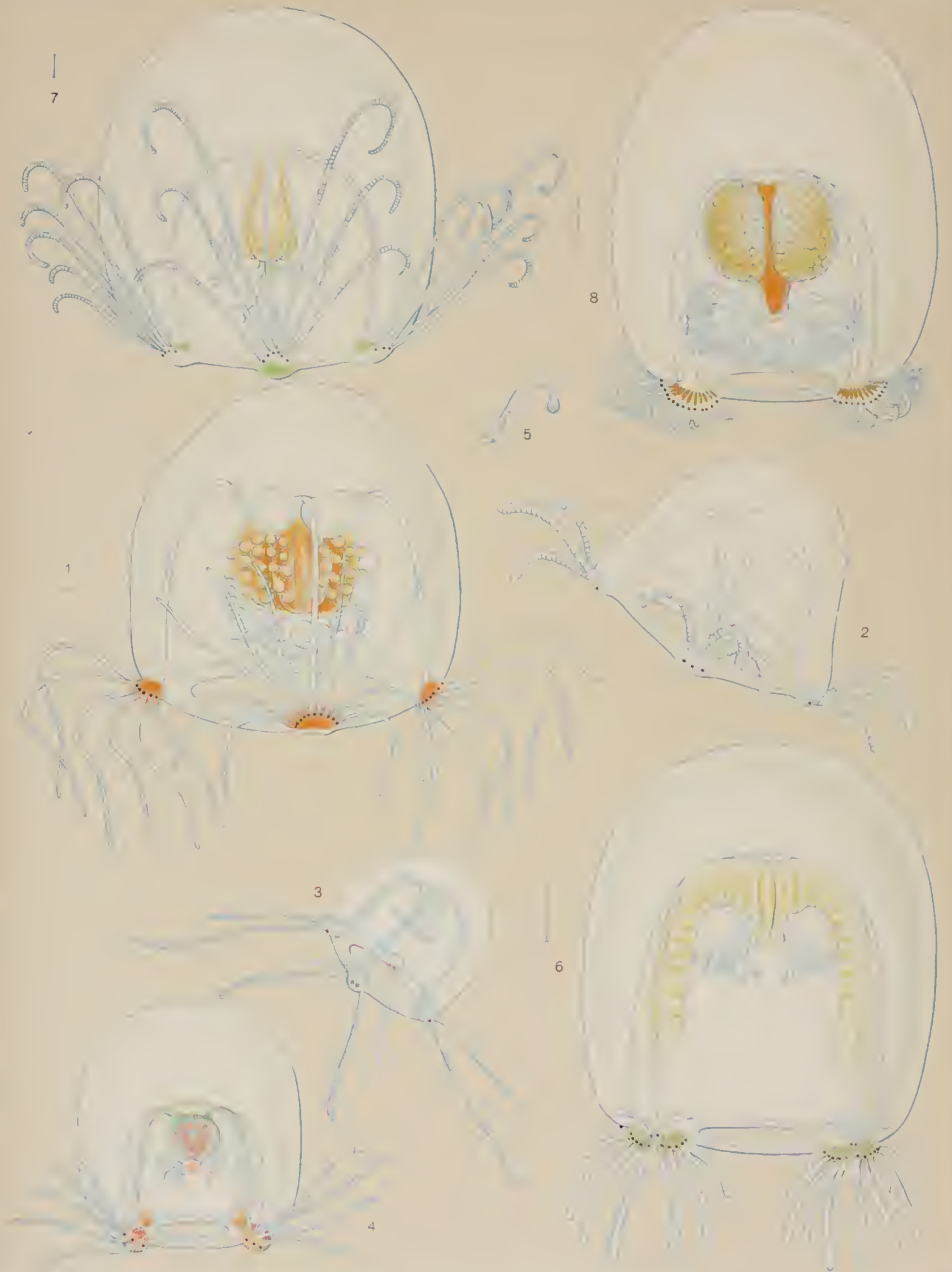



The mature medusa is described by Maas, Dr. Agassiz and his assistant having found only immature specimens.

Mature medusa.-Bell 8 to $14 \mathrm{~mm}$. high, with thick, vertical sides and Hatly rounded top, + radially placed clusters of marginal tentacles with about 15 to 20 tentacles in cacl cluster. These tentacles are not half as long as the bell-height and are clavate and Hexible. There is an ocellus on the velar (imner) side of the hase of each tentacle. There are + straight radialcanals which widen as they join the 4 corners of the stomach. The manubrium is wide at its base and lacks a peduncle. It is about half as long as the bell-height. The + oral tentacles branch dichotomously $\$$ times, and their tips end in knoh-like cxpansions, almed with bristling nematocysts. There are thus $25^{6}$ tips to the oral tentacles in each quadrant.

There are 8 gonads, 2 upon each interradial side of the stomach. These gonads are distinctly separated in the + principal radii.

The entoderm of the stomach and tentacle-bulbs is orange-yellow or yellowish-green to hrownish-yellow. The gonads are dark-yellow to brown. This medusa is abundant over the western parts of the tropical Pacific, Fiji, Ellice Islands, Malay Archipelago W $\mathrm{C}$ est Coast of Mexico, Aca pulco Harbor.

\section{Bougainvillia britannica Forbcs.}

Plate 17, fig. 8.

Hippoerene britannica, linkars, $18_{4} 1$, Annals and Mag. Nat. Hist., vol. 7, p. 84 , plate 1, fig. 2

Bougainvillea britannica, For Bes, 1848 , British Naked-eyed Medusa, 1. 62, plate 12, fig. 1.

Eudendrium ramosum, Van Beneoss, 1844 , Mèm. Acad. Belgique, tome 17, p. 56, plancle 4; 1866, Fauna I.ittor. Belgique, p. 112 , plates 6,7 .

Bougainvillea ramosa, Allman, 1871, Monog. Tub. Hydr., p. 311, plate 9, figs. 5-7 (hydroid and medusa).-Bonlls, 1878, Jena. Zeitsch. für Naturw, Bd. 12, p. 189, taf. 6, fig. 6 .

Margelis ramosa, HaEckeL, 1879 , Syst. der Medusen, p. 88.

(?) Lizusa octocilia (young medusa), HarckF., Ibid., p. 80.

Bougainvillia ramosa, Wersmann, 1883 , Entstehung Sexualzellen bei Hydromelusen, Jena, pp. 113, 218.-Biltarn, 19o6, Bull. Mus. Hist. Nat. Paris, No. 5 , p. 330.

(?) Bougainvillia ramosa, Pictet, 1893 , Revue Suisse Zool., tome I, p. I (hyelroid from Amboina, Mala Archipelago).

Lizusa octocilia Dalyell = Bougainvillia ramosa Böhm, HartlavB, 1894 , Wissen. Mecesuntersuclı. Konm. Meere Kiel, Helgoland, Neue Folge, Bd. 1, p. 190.

Margelis brilannica (Forbes), Browne, 1895, Trans. Livernool Biol. Soc., vol. 9, p. 267

Bougainvillia ramosa, Browne, 1898 , Journ. Marine Biol. Assoc., N. S., vol. 5. p. 187 (hydroid).

Margelis ramosa, Bzoot, 1905, Revue Suisse de Zool., tome 13, P. 138 (citation of papers to 1850).

Margelis britannica, Browne, 1905, Proc. Roy. Soc. Edinburgh, vol. 25, p. 754 .

Bougainvillia benedenii, Bonnevie, 1898 , Zeit. für wissen. Zool., Bd. 63, p. $4_{4}^{8}$, taf. 26, fign. 34 , 35 (degenerating hydroil).

(?) Bougainvillia obscura, Bonvevte, 1898 , Bergens Museums Aarbog, No. 5, p. 7 (perisarc unringed, is tentacles of various lengths).

Bougainvillia bella, Hartlaub, 1897, Wissen. Mecresuntersuch. Kommis. Meete Kiel, Helgoland, Neue Folge, Bd. 2, p. 470, taf. 15, fig. 7; taf. 16a, figs. 6, 11=B. brisannica, Forbes, Hartlaub, 1904, Ibid., Bd. 5, p. 103.

(? ?) Bougainvillia nuscus, Thorvely, 1900, Zoological Results, A. Willey, Part 4, p. $45^{2}$ (hydroid from tropical Pacific).

Bell about $12 \mathrm{~mm}$. high and $10 \mathrm{~mm}$. wide. High, dome-like, rounded, with very thick walls. Each of the 4 radially placed, marginal tentacle-bullos gives rise to 16 to 24 short tentacles, ahout one-fourth as long as the bell-diameter. Each tentacle is provided with a basal ocellus on its inner (velar) side. The ocelli are black in the adult, but may be red in the young medusa.

4 quite wide radial-canals. Manubrium short and wide without a peduncle. The 4 oral tentacles hranch dichotomously 6 to 7 times. There are 8 adradial gonads in the ectoderm on the sides of the stomach. The ripe eggs are not inclosed in nematocyst capsules

Distinctions between $B$. britunnica and $B$. superciliaris.

\begin{tabular}{|c|c|c|c|c|c|}
\hline & $\begin{array}{l}\text { Marginal tenta- } \\
\text { cles in each of } \\
\text { the } 4 \text { radial } \\
\text { clisters. }\end{array}$ & $\begin{array}{c}\text { Character of } \\
\text { stomach. }\end{array}$ & Cloaracter of gonads. & Color. & $\begin{array}{l}\text { Length of mar- } \\
\text { ginal tentacles } \\
\text { in terms of } \\
\text { bell-radius }(r) .\end{array}$ \\
\hline $\begin{array}{l}\text { B. superciliaris } \\
\text { L. Agassiz. }\end{array}$ & 10 to 15 & $\begin{array}{l}\text { Mounted on short, } \\
4^{\text {-sided, prismat- }} \\
\text { ic peduncle. }\end{array}$ & $\begin{array}{l}\text { + wide interradial. The } \\
\text { eggs develoj into plan- } \\
\text { ula on sides of } \\
\text { stomacls. }\end{array}$ & $\begin{array}{l}\text { Rosin-vellow to } \\
\text { reddish-brown. }\end{array}$ & $1.5102 r$ \\
\hline $\begin{array}{l}\text { B. britannica } \\
\text { Forbes. }\end{array}$ & 16 to 24 & No peduncle. & $\begin{array}{l}8 \text { narrow adradial. Do } \\
\text { planule on sides of } \\
\text { stomacli. }\end{array}$ & Golden-yellow: & $0.5 r$ \\
\hline
\end{tabular}


and do not develop into planulx while still attached to the medusa. The entoderm of the stomach and tentacle-bulbs is golden-yellow. This species is found off the North Atlantic coasts of France, Great Britain, and Germany. It was taken by Hartlaub at Helgoland, German Ocean, in June, and by Browne in the Firth of Clyde, Scotland, in June and July.

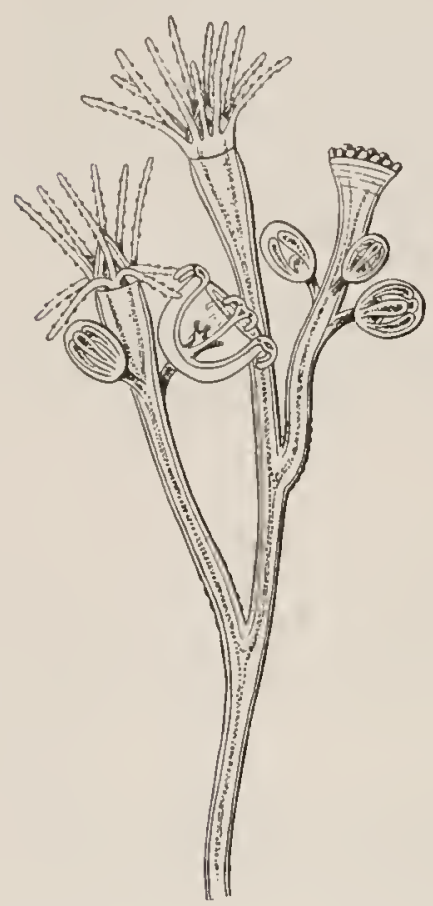

Fir. 86.-Hydroid of Bougamvillio britannica, after Allman, in Ray Society, $1871-72$. I found a single mature specimen in the harbor of Eastport, Maine, on September 19, 1898 . It appears, therefore, to he widely distrihuted over the North Atlantic. Pictet, 1893 , states that he identifies the hydroid of this form from Amboina, Malay Archipelago.

The hydroid of B. britannica has been commonly called B. ramosum, and has been well described by Van Beneden and Allman. The stems are much branched and are 25 to $75 \mathrm{~mm}$. high; the ultimate branches are for the most part alternate. The hydrorhiza is branched and root-like, the branches not anastomosing. The perisarc of the stems exhibits shallow annulations at the origin of the branches. The perisarc extends in a cup-like form over the sides of the hydranths almost to the hases of the tentacles, so that the hydranth may be almost completely withdrawn into the hollow of the cup. There are about 12 tentacles which are filiform and not very long and arise in a single zone at the base of the conical hypostome. The tentacles are carried nearly straight, with every alternate one elevated and depressed. The medusa-buds are borne singly on moderately long pedicels which arise from the bases of the hydranths upon the terminal branches of the stems. There are I to 2 medusa-buds at the base of each hydranth. When set free the medusa has a bell higher than a hemisphere, with fairly thick walls. There are 8 marginal tentacles, 2 in each radial cluster, and 4 short-knobbed, oral tentacles. Browne, i 898 , had a hydroid of this species from the Eddystone, English Channel, which liberated 4,450 medusx in 3 days.

Wiesman, 1883, finds that the germ-cells of both sexes originate in the ectoderm of the manubrium of the budding medusa and they do not wander from their place of origin, hut remain there and become mature in the free-swimming medusa.

Bougainvillia superciliaris L. Agassiz.

Plate 17, fig. 1.

Hippocrene bougamvillit, Gov's, 184 1. Report on Invertebrates of Massaclusetts, p. $34^{8}$.

Hippocrene superciliar is, Agassiz, L., 1849, Mem. Amer. Acad., New Series, vol. 4, p. 250, plates 1-3, 53 figs.-Stimfson, 1853. Maine Invert. Grand Manan, P. 11.

Bougainvillia superciliaris, AGAsst2, L., 1862, Cont. Nat. Hist. U.S., vol. 4, pp. 289, 291, figs. 37-39; p. 344, plate 27, figs. 1-7.Agassiz, A., 1862, Proc. Boston Soc. Nat. Hist., vol. 9, p. 97, figs. 24, 25; 1865, North Amer. Acal., p.153, figs.232-240.VERR1L, 1873, Report Commiss. Fish and Fisheries U.S., for 1871-72, PP. 328, 733, plate 37, fig. 276.

Hippocrene superciliaris, HaEckel, 1879 , Syst. der Medusen, p. 92.

Bougainvillea superciliaris, WaGner, 1885, Wirbellosen des Weissen Meeres, P. 73, taf. 2, fign. 5, 8, 9; non 6, 7.--LEvınsen, 1893, Vid. Meddel. Nat. For. Kjöbenhavn, ser. 5, Bd. 4, P. 144.-Mass, 1893 , Ergeb.der Plankton Exped., Bd. 2, K. c., p. 69.-Hartlax' B, 1897, Wissen. Meeresuntersuch. auf Helgoland, Heft. 1, Abt. 2, p. 466, taf. xv1a, fign.1, 5, 7-9, 12; taf. xvib, fig. 3 ; taf. xvic, fign. $3,4,11-13$; taf. xv, fig. I.

Hippocrene superciliaris, Schlater, 1891 , Rèvue des Sci. Naturelles, St. Pétersbourg, tome 2, p. 342.-Birula, 1896, Annuaire du Mus. Zool. de l'Acad. Impériale des Sci., St. Pètershourg, tome 1, No. 4, pp. 330, 339.-Grönberg, 189R, Zoolog. Jahrb., Abth. Syst., Bd. $11, \mathrm{p} \cdot 462$, taf. 27, fign. 5, 6.

Hip pocrene superciliarist H. aurea, Linko, 1904, Zool. Anzeiger, B.1. 28, p. 216; 1900, Mën. Acad. Sci. St. Pẻtersbourg, sèr. 8, tome 10, No. 3, p. 6, taf. 1, fign. 13-18, taf. 2, fign. 19-21 (histology of the ocelli).

Bougainvillia supereiliar is, HargitT, 1904, Bull. U. S. Bureau of Fisheries, vol. $24, \mathrm{P} .40,1$ fig.

Bougainvillia superciliaris, Nutting, 1901, Bull. U. S. Fish Commission, vol. 19, pp. 330, 376, fig. 90.

Bongaimvillea paradoxica, Mfreschkowskv, 1879, Annals and Mag. Nat. Hist., ser. 5, vol. 3, p. 177, plate 20.

(?) Hippocrene bougainzilli, Brandt, 1834 , Récueil Actes sẻances publiques Acad. Imp. Sci. St. Pétersbourg, F. 29 (of the "separate"); 1853, Mèm. Acad. Imp. Sci. St. Peitersbourg, sẻr.6, vol. 4, part 2, p. 393, plate 20=Bougainzillea mertensii, L. Agassiz, 1862 .

Adult medusa.--Bell about $10 \mathrm{~mm}$. in height and alout same in diameter. Gelatinous substance very thick, so that bell-cavity is only about lialf as deep as the hell-height. "There are 4 clusters of marginal tentacles which are situated at the hases of the 4 radial-canals. 
Each cluster of tentacles arises from a large bulhous swelling upon the bell-margin. There are 10 to 15 tentacles in each cluster. The tentacles are highly contractile and are normally: about two-thirds as long as the bell-diameter. There is a single, very dark-brown ocellus within the ectoderm of the inner (velar) side of the hase of each tentacle. The velum is well developed. There are + straight, narrow radial-canals, which arise from the + radial comers of the stonach. The stomach is wide and quadratic in cross-section and Hask-shaped in longitudinal outline. It is mounted upon a $t$-sided peduncle which is ahout half as long as the stomach itself. There are + radially situated, oral tentacles, each of which branches dichotomously about 5 times. The mouth is situated at the extremity of a short, simple tule and the lips are not prominent. The mature genital products are situated within the ectoderm of the $f$ interradial sides of the stomach. There are thus $f$ interradial gonads, above the zone of the oral tentacles. This species is thus separated from B. bella hy having + interradial instead of 8 adradial gonads. In the female, according to Hartauh, 1897 , the large eggs may be seen lying within the ectoderm close to the supporting lamella. As they grow larger they approach the surface, and finally hecome inclosed in epithelial, nematocyst-bearing capsules, derived from the ectoderm cells of the stomach-wall. These capsules finally protrude from the sides of the manubrium, hut each one remains attached to it by a narrow stalk. In this situation the egg develops into a planula which finally breaks through the walls of the

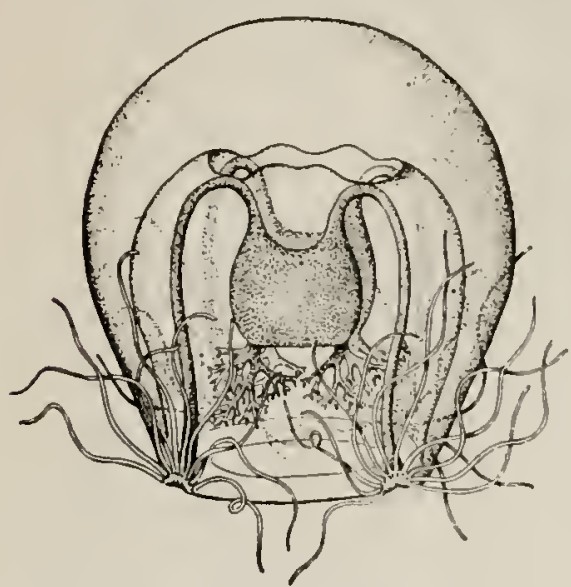

lisi. 87.-Bougainzillia superriliaris, afuer I.. Agassiz in Mem. Amer. Acat. Arts and Sci. 18+9. Si:k virw of medusa. capsule and escapes into the water. Hartlaub showed that although the large eggs were found in the ectoderm they were derived from the entoderm of the young medusa. In the young and immature medusa the supporting lamella does not completely. separate the ectoderm from the entoderm, and the egg-cells then migrate from the entoderm into the ectoderm (see Hartaub, 1897 , pp. $+69+70)$.* "The sperm originates in the ectoderm and there develops without migration.

The entoderm of the manubrium and tentaclebulbs is rosin-yellow or reddish-brown, and the gelatinous substance of the bell often has a decided yellowish tinge.

Hydroid and young medusa. - The hydroid is usually found attached to rocks, and lives in the purest sea-water. It grows in clusters, not more than $50 \mathrm{~mm}$. high. The stems give rise to primary and secondary branches, which arise somewhat irregularly, though more or less altemately'and spirally. "The hase of every branch is ringed with from 5 to 10 annulations. The chitinous sheath which incloses the stem thins out as it passes on to the polypites and disappears entirely helow the circlet of tenticles. Each polypite has fiom 15 to 20 long, slender tentacles which arise from a single circlet near the distal end of the polypite. Each tentacle is ringed at regular intervals by clusters of nematocyst-cells. The medusahuds arise singly and somewhat irregularly from the sides of the stem, neall the proximal bases of the polypites. Each medusa-bud is inclosed in a thin capsule formed from the chitinous ectosare of the stem. When set free the young medusa usually has 8 marginal tentacles, 2 at the hase of each radial tube. The young tentacles are each provided with a centripetal, ectodermal ocellus. The manubrimm is short and tubular and there are + short, knol-shaped, unhranched, oral tentacles.

In common with other Arctic medusa this species appears upon the southern coast of New England early in April and soon disappears. It is found throughout the summer, however, north of Cape Cod, and mature individuals are occasionally taken at Lastport, Maine, in August. This species has been found hy Levinsen, 1893. off the west coast of Greenland, and according to Birula, 1896 , it is the most ahundant medusa in the White Se:a in July. Hartlaub, 1897, found it at Helgoland, and L.inko. 1904, found it in Barents Sea,

* It is interesting to observe that other species of the Bougainvillidi, such as Cviris, also retain the emhryos within the ectoderm of the manubrium until the planula stage. This was first observed hy Mereschowsty, i\$74, and lias since hecn con. firmed by N. Wagner, $188_{5}$, and by Hartlaub, 1 iny 7 . 
where it commonly occurs in the fjords from November until June, but during the summer it is found about a degree northward of Ekaterinen Harbor, in the cold water. At Helgoland the medusa is most abundant in February and March.

"Hippocrene anrea" Linko is only an Arctic form of Bougainvillia superciliaris in which the oral tentacles branch dichotomously 7 times, instead of 5 to 6 times as is commonly observed.

I am inclined to believe that Hippocrene bougaimvillii Brandt (= Bougainvillea mertensii L. Agassiz) from Behrings Sea is identical with $B$. superciliaris.

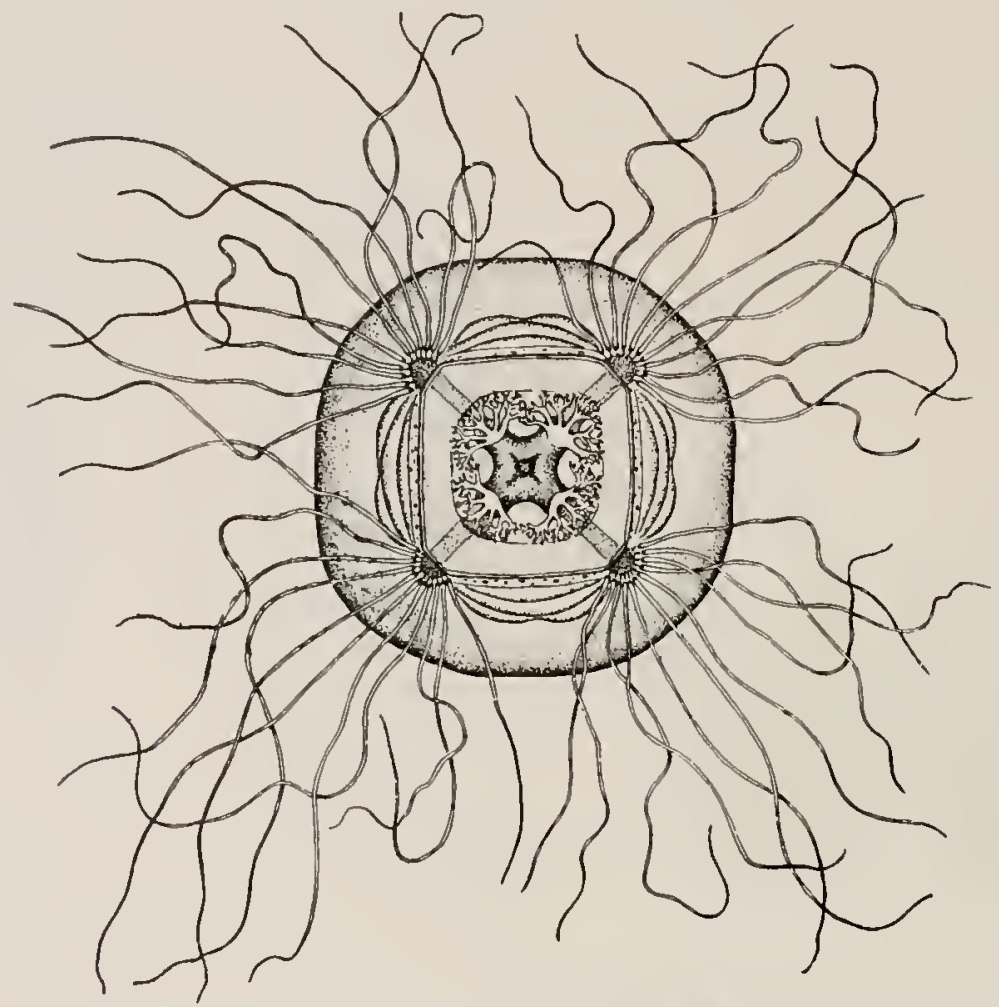

Fic. 88.-Bonganvillia supercilan is, after I.. Agassiz in Mem. Amer. Acall. Arts and Sci., $18_{49}$. Oral view of medusa.

Bougainvillia dinema-B. superciliaris (?).

Bongainvillea dinema, GRFFNE, 1857, Nat. Hist. Review, vol. 4, p. 246, plate 15, fig. 6.

Margelis zygonema, Harcki, 18So, Syst. der Medusen, p. 635.

I helieve this medusa to be identical with B. snperciliaris. (See tabular synopsis.)

Bell oval with a constricted margin, 10 to $12 \mathrm{~mm}$. high, 6 to $8 \mathrm{~mm}$. wide. The 4 marginal tentacle-bullos are kidney-shaped and only half as wide as the intervals between them. Each bulb bears 10 to 12 ocelli. Only 2. tentacles were observed by Greene and Haeckel on each lullb, but the others had probably lieen broken off. The 2 were at the ends of the bulb.

The stomach is roundish, 4 -sided, smaller than the tentacle-bulbs, and hardly one-fourth as long as the bell-height. The 4 oral tentacles branch dichotomously 4 or 5 times. The gonads are 4 interradial, triangular to egg-shaped swellings on the sides of the stomach. Stomach, gonads, and tentacle-bulbs yellow.

East coast of Ireland.

Bougainvillia multicilia.

Lizusa multicilia, Hafckr., 1879 , Syst. der Medusen, P. 81, taf. 6, fig. 13.

Bell three-fourths spherical, with thin, uniform walls, evenly rounded, $6 \mathrm{~mm}$. high, $5 \mathrm{~mm}$. wide. + wide, kidney-shaped, marginal tentacle-bulbs, wider than the intervals between them; ach with 10 to 12 tentacles with ocelli, and about as long as the bell-radius. 4 straight, 
narrow radial-canals. The velum is narrow. The stomach is glolutar with a constricted base, but no peduncle. 4 simple, unbranched oral tentacles, each ending in a single nematocystknob. 4 pairs of gonads on the adradial sides of the stomach. Stomach light-yellow. Gonads and tentacle-bulhs orange-yellow. Ocelli dark-red. Straits of Gibraltar in March. This may be a young form, the shape of the bell and unbranched condition of the oral tentacles being indications of immaturity.

\section{Bougainvillia platygaster.}

Hippocrene platygaster, Harckr.L, 1879 , Syst. der Medusen, p. 91.

Bell cubical, flat above. $12 \mathrm{~mm}$. high, $12 \mathrm{~mm}$. wide. The + radially placed, marginal tentacle clusters arise from wide, triangular, basal swellings, which are wider than the interradial spaces between them. Each basal swelling gives rise to to to 12 tentacles, which are shorter than the bell-diameter. The tentacles arise in a single row from their basal bullis. Ocelli (?) Stomach flat and 4 -sided. It is 4 times as wide as high, and without a peduncle. The + short, oral tentacles hranch dichoromously 3 or + times, giving 8 to 16 short, terminal ramuli in each quadrant. The 4 wide, rectangular gonads are on the interradial sides of the stomach. The stomach, gonads, and tentacle-bulbs are reddish-yellow.

Atlantic Ocean, Cape Verde, and Canary Islands.

Distinguished by the wide, triangular, hasal bulls of its marginal tentacles, and its short, wide, t-sided stomach.

\section{Bougainvillia xantha Hartlaub.}

Bougainzillia xamtha, Hartlaub, 1897, Wissen. Meeresuntersuch. Kommis, Mrere Kiel, Helgoland, Neue Folge, 13d. 2, p.46́r, taf. 15, fign. 2, 3; taf. 16a, fig. 3; tal. 16b, fig. 19.

Young medusa.-Bell rounded, somewhat higher than wide, with thick gelatinous walls. Height 4 or $5 \mathrm{~mm}$. Bell-margin 4 -sided. Each of the 4 radially situated, marginal tentaclehulbs gives rise to 9 or to tentacles, with small, indifferently developed, brownish-violet ocelli. 4 quite wide radial-canals. Manubrium small, with 4 branching oral tentacles longer than the manubrium. The oral tentacles branch dichotomously ahout + times and each ends in about I6 nematocyst-knobs. These terminal branches of the oral tentacles are very short in comparison with the length of the main shaft of the tentacle. The + interradial gonads begin to develop in specimens about $+\mathrm{mm}$. wide. The tentacle-bulbs and stomach are light goldenyellow to reddish in color. The interradial entodermal tamella is translucent greenish-yellow. Common at Helgoland from March until the end of June. No mature specimens have leen seen and the hydroid is unknown. It is closely allied to $B$. flavida and may be only a variety of the latter form. It appears, however, to have more marginal tentacles in corresponding stages of growth than is seen in $B$. flavida and there are slight color differences.

\section{Bougainvillia carolinensis Allman.}

Plate 16 , figs. 7 to 9 ; plate 17 , fig. 7 .

II ipporrene carolimensis, MCCRady, 1857, Gymn. Charleston Harbor, p. 62, plate 10, figs. 8-10.

Margelis carolinensis, Acassiz, 1.., 1862, Cont. Nat. Hist. U.S., vol. 4. P. 344.-Agassiz, A., 1865, Nortl Amer. Acal., P. 156, figs. $241-24$. - Ha E.CkEL, 1879 , Syst. der Medusen, p. 89 .

Bougainvillie carolinensis, Al.tuan, 1871, Monog. Tubul. Hyctroids, p. 316.

Bougainz illia carolinensis, Nutring, 1901, Bull. U. S. Fish Commission Cor 1899, vol. 19, Pp. 330, 376; figs. 5, 89.-Hakrate, 1 yo4, Bull. U. S. Bureau of Fisheries, vol. 24. p. 39 , plate 2, fig. 4 ; 1901, American Naturalist, vol. 35 , p. 583 , fig. 46.

Adult medusa (plate 17, fig. 7).-Bell dome-shaped and + mm. in height. Bell-walls, especially at apex, very thick. There are + radially arranged clusters of marginal tentacles that arise from 4 small, hulhous, hasal swellings. 7 to 9 tentacles in each cluster. The longest of these tentacles attain a length ahout equal to the hell-height. The tentacles are slender and quite stiff, and their tips are usually curled downwards in a semicircle. A large ectodermal ocellus is situated at the hase of each tentacle upon the ventral (centripetal) side. The velum is well developed. There are + straight, narrow, radial tubes. The manubrium is long and narrow, and extends for about half the distance from the inner apex of the bellcavity to the velar opening. Near its distal end it is somewhat wider than at its hase. The mouth part, however, is a simple, narrow tuhe. 4 oral tentacles arise from the 4 radial sides 
of the mouth-part of the manuhrium. Each one of these hranches twice dichotomously, thus giving rise to 4 tentacle tips in each quadrant. The gonads are found in the ectoderm of the manubrium, where they occupy longitudinal, interradially situated, swollen regions.

In the Tortugas and Charleston Harbor examples of this species, the entoderm of the tentacle-bulbs and of the manubrium is of a delicate sage-green. The gonads are creamcolored, and the tentacular ocelli dark-brown or hlack. In northern examples of this medusa, found at Newport, Rhode Island, and Naushon, Massachusetts, according to A. Agassiz, the tentacle-bulbs are colored with brilliant red, surrounded by a green edge bordered with brightyellow, and the digestive cavity is brick-red or green. No such brilliant coloration has been observed by me in southern examples of this species.

The hydroid stock has been figured by A. Agassiz, 1865, p. I 58 . It occurs very commonly upon Fucus vesiculosus, where it grows in dense clusters. The main stems are often 230 to $270 \mathrm{~mm}$. in length. They taper gradually from base to summit and branch profusely and pinnately. The side branches do not often give rise to secondary hranches. Great numbers of ringed pedicels, which terminate in polyp-heads, arise from the sides of the main stem and also from the branches. The polypites are fusiform and possess a single circlet of ahout 15 long, slender tentacles near the distal extremity. The mouth is situated at the apex of a slight, conical proboscis. Medusa-buds make their appearance anywhere all over the stems, where they appear either singly or in clusters. When set free the young medusa is about $1.7 \mathrm{~mm}$. in height. The bell is pyriform in outline, and the gelatinous substance quite thick. There a re 8 tentacles, 2 at the hase of each of the 4 radial tubes. The tentacles are all provided with basal ocelli. The manuhrium is small, slender, and tuhular, and there are 4 short, unbranched, oral tentacles.

The general color of the stems of the hydroid is of a horny green and the polypites are often of a delicate rosy tint.

This medusa is very ahundant throughout the summer in Charleston Harbor, South Carolina. It is much rarer at the Tortugas, Florida. The brilliantly colored, northern variety is said to he quite common upon the southern coast of New England, but it has never been found north of Cape Cod, Massachusetts.

Hargitt, rgor (Biol. Bulletin, Woods Hole, vol. 2, p. 228), discovered a remarkahle twin sport, apparently of this medusa. It had 2 manubria fused at a common base so as to form a common stomach. Each "twin" had a complete bell-margin, only the sides of their bells being fused one to the other.

Bougainvillia niobe Mayer.

Plate 18 , figs. 1-3.

Bougainvillin niobe, Mayfr, 1894, Bull. Mus. Comp. Zool. at Harvarel College, vol. 25, p. 236, plate 1, fig. 2: Ibid., vol. 37, p. 42; 1904, Mem. Nat. Sci. Brooklyn Institute Museum, vol. 1, p. 11, plate 2, figs. 14-15r.

Adult medusa (plate 18 , fig. 1 ).- Bell $6.75 \mathrm{~mm}$. high and $4.8 \mathrm{~mm}$. in diameter, with vertical sides and thick, gelatinous walls. 4 radially situated clusters of marginal tentacles, each composed of about 8 tentacles about as long as the bell-height. On the velar side of each tentacle, near the hulbous base, there is a dark-colored ocellus. 4 straight, narrow radial-canals. Manubrium wide, flask-shaped, and cruciform in cross-section. Ahout half as long as the height of the hell-cavity. 4 radially situated clusters of oral tentacles, each of which hranches dichotomously 4 times. These are very flexible and their distal ends are knolbed.

Medusa-buds arise from the 8 adradii of the manubrium, the youngest buds being inmediately under and on both sides of the point of entrance of each radial-canal, while older ones are found farther down the sides of the stomach. The young huds are small, ovoid vesicles contained entirely in the ectoderm. The limiting memhrane, between the entoderm and ectoderm of the manuhrium in the neighborhood of these buds, is entire (plate I 8, fig. 3), and I can find no evidence of cells passing through it. Indeed, throughout the future development of the buds, the entoderm remains inert and its limiting membrane unbroken. The wall of the vesicle consists of 2 layers of cells: an outer epithelium of ectodermal cells, destined to give rise to the ectoderm of the hud, and an inner layer of somewhat larger cells destined to give rise to the entoderm of the budding medusa (plate 18, fig. 2). These latter cells are entirely incased by the ectoderm of the parent. They may, however, have heen 


$$
\text { . }
$$




\section{Plate i8.}

Fïg. 1. Bougainvillia niobe, Nassau Harbor, Bahamas, March 18, I893.

Fig. 2. Bongainvillia miobe, section of a young medusa-bud upon the ectoderm of the manubrium. $c$, central mass of degenerating cells: $c c t$, ectoderm of the manubrium of the parent medusa; $e n t$. (brown) entoderm of the parent medusa; $e c t b$, (gray) ectoderm of the budding medusa; $e n t b$, (green) entoderm of the budding medusa; $s l$, limiting membrane between the ectoderm and entoderm of the manubrium of the parent medusa.

Fig. 3. Bongaimvillia niobe. Cross-section of the medusa showing the budding region of the manubrium. Successive stages in development of buds are shown in bi-b4. Colors as in figure 2 .

Fig. 4. Rathkea elegans, mature male. Tortugas. Florida, July I, 1899. Fig. 5. Ratlikea octopunctata var. grata. Newport Harbor, Rhode Island, April 24, 1897 .

Drawn by the author from living and preserved specimens. 


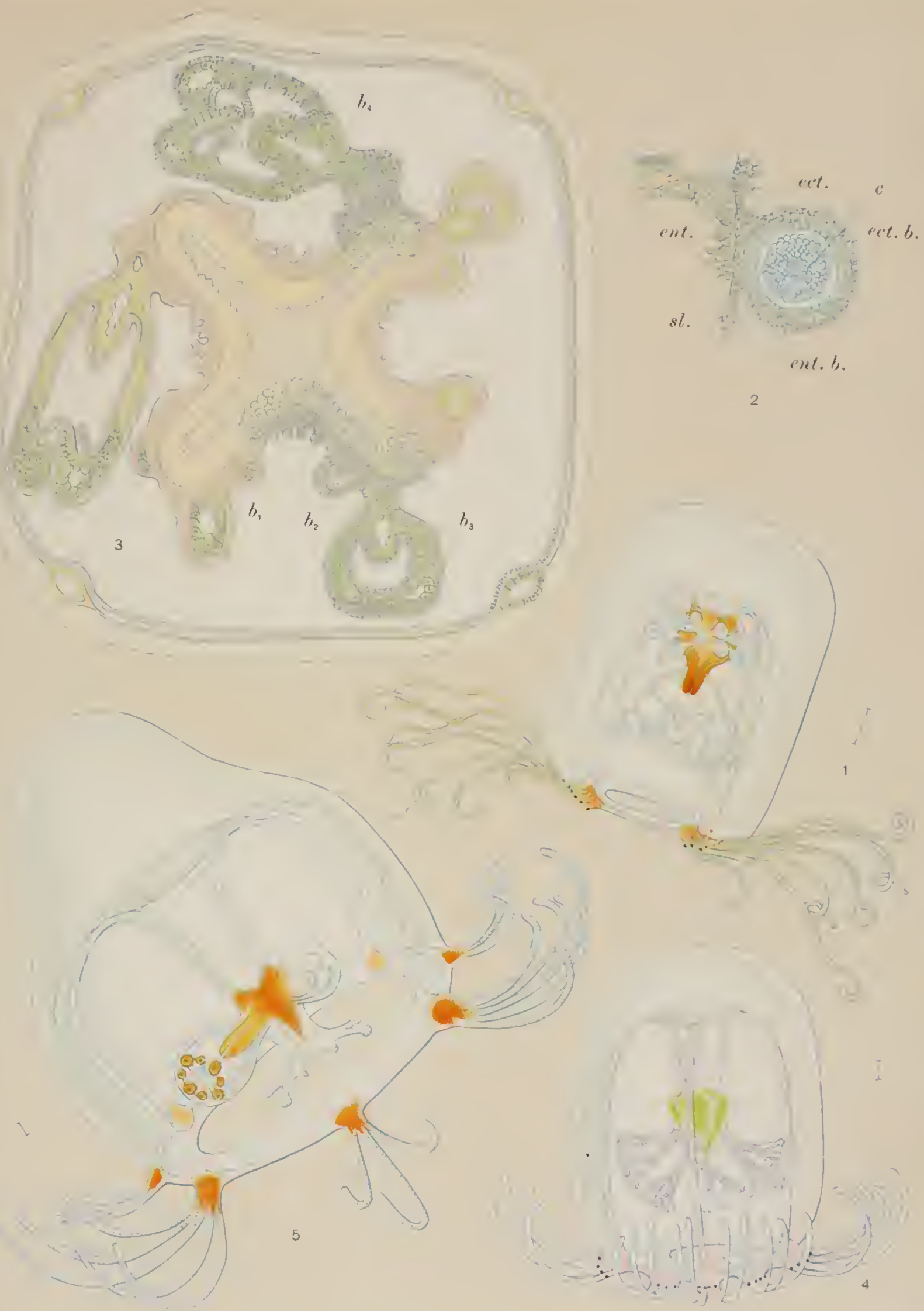



derived at an earlier stage from the entoderm of the parent medusa and have migrated into the ectoderm. Careful search has, however, failed to reveal evidence of any such migration, and in default of evidence to the contrary, we assume that these cells may he ectodermal in origin, although destined to produce the entoderm of the bud.

The central cavity of the vesicle is partially filled with a loose mass of nuclei and cell material showing little or no trace of cell boundaries $(c$, plate 18 , fig. 2$)$. These are present at all stages of the developing bud, partially filling the gastrovascular cavity, but they appear to degenerate in later stages, and it seems possible they serve to nourish the bud in its growth. This supposition appears the more probable from the fact that the gastrovascular cavity of the hud is never in connection with that of the parent medusa.

We have, therefore, a graded series of phenomena in the asexual production of medusabuds by hydromedusx. Where the ectoderm and entoderm are both thin-layered and of about equal thickness, such as in Sarsia and Eucheilota paradoxica, both entoderm and ectoderm take an equal share in the formation of the bud. In forms such as Ruthea oitopunctata and

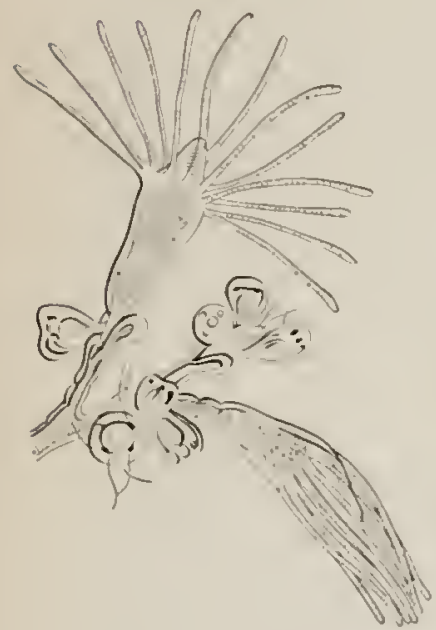

So.

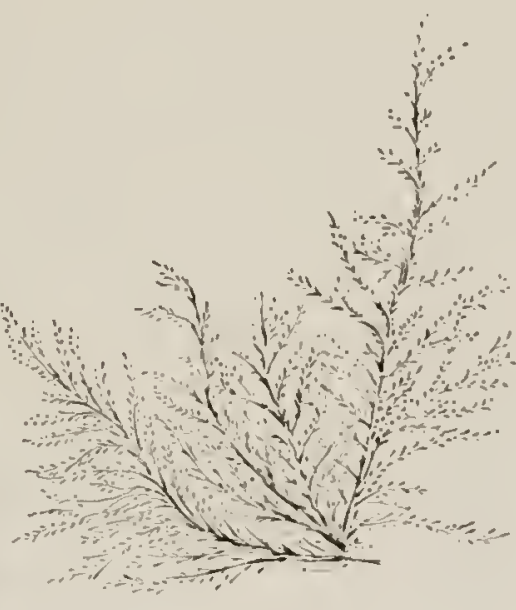

So.

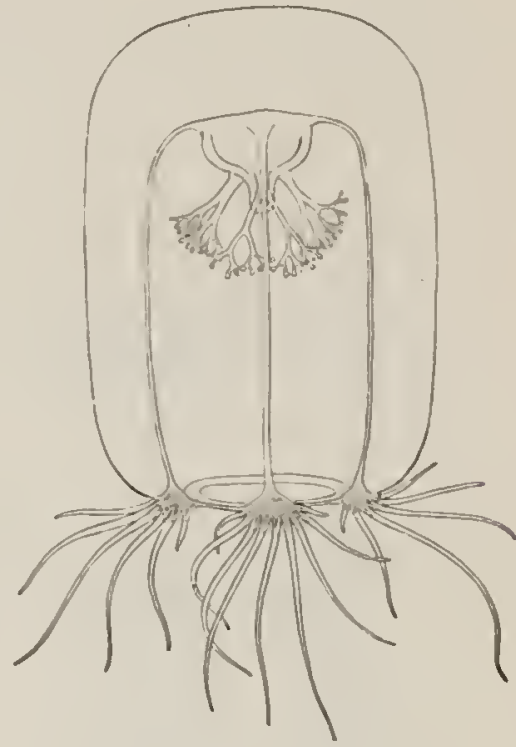

yo.

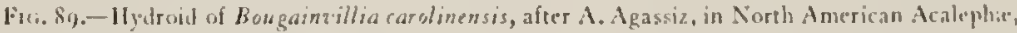
showing an enlarged viek of a part of stem bearing medusa-buds.

Fic. 90.-Bougainvillia niobe, from life, hy the author. Tortugas, Forieta, June 27, 1908.

Lizzin clapardei, according to Chun, Bihliotheca Zoologica, 1895 , a different condition is olserved, for the medusa-buds are formed entirely within the ectoderm of the parent, although the gasturascular carity of the bud finally acquires a connection with that of the parent, the entoderm of the bud hecoming continuous with that of the parent manubrium.

In Bongainvillin niobe, however, the ectoderm is very thick and the hudding medusic are developed within it alone, the entoderm of the parent medusa remaining inct and passive during the growth of the bud, and no connection ever being estahlished between the gastrovascular cavities of the bud and the parent. This result may be regarded as due to a gradual process favored by the thickness of the ectoderm, which prevented the deep-lying entoderm from taking an equal share in the formation of the bud, until fivally it remains passive throughout the period of the formation of the bud. Medus $x$ produced from ectoderm alone may, therefore, be phylogenetically homologous with medusie produced by the more primitive and universal cooperation of both ectoderm and entoderm.

The entoderm of the manubrium and tentacle-bulbs of $B$. niobe is rosin-colored, all other parts heing transparent. There is a dark-colored ocellus on the velar side of each tentacle near the basal bulb. This medusa is found in Nassau Harhor, Bahamas, in April. 


\section{Bougainvillia pyramidata.}

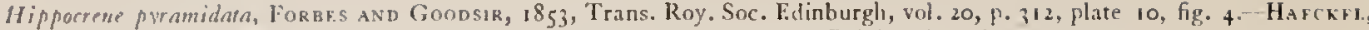
isio, Syst. der Medusen, P. 635.-Browne, 1905, Proc. Roy. Soc. Edinhurgh, vol. 25, P. 751.

Bell semiglobular, 2.5 to $6 \mathrm{~mm}$. wide and equally high. Bell-walls thick and gelatinous substance at apex well developed. The 4 marginal tentacle-bulhs are very small and globular, and each one hears 6 to 8 tentacles which have ocelli and are somewhat shorter than the bell-diameter. The stomach is mounted upon a short, conical peduncle. It is cruciform and its + lohes extend along the entire length of the peduncle. The mouth is a circular opening. The $f$ oral tentacles branch twice dichotomously. The gonads are upon the basal margin of the stomach and its lobes. The radial-canals are straight and narrow. Stomach, gonads, and tentacle-bulbs orange-yellow to reddish-brown. Tentacular ocelli black. Found off the west coast of Scotland and off the soutl coast of Ireland.

Bougainvillia nordgaardii.

Margelis nordgnardii, Browvf, 1903. Bergens Museums Aarbog, No. 4, p. 14, plate 2, fig. 1, plate 3, figs. 5, 6.

Bell $4 \mathrm{~mm}$. wide, $4 \mathrm{~mm}$. high. Bell-walls uniform and of moderate thickness. Bell dome-like, evenly rounded. 5 to 7 tentacles in each of the 4 radial bulbs. No ocelli. Ten-

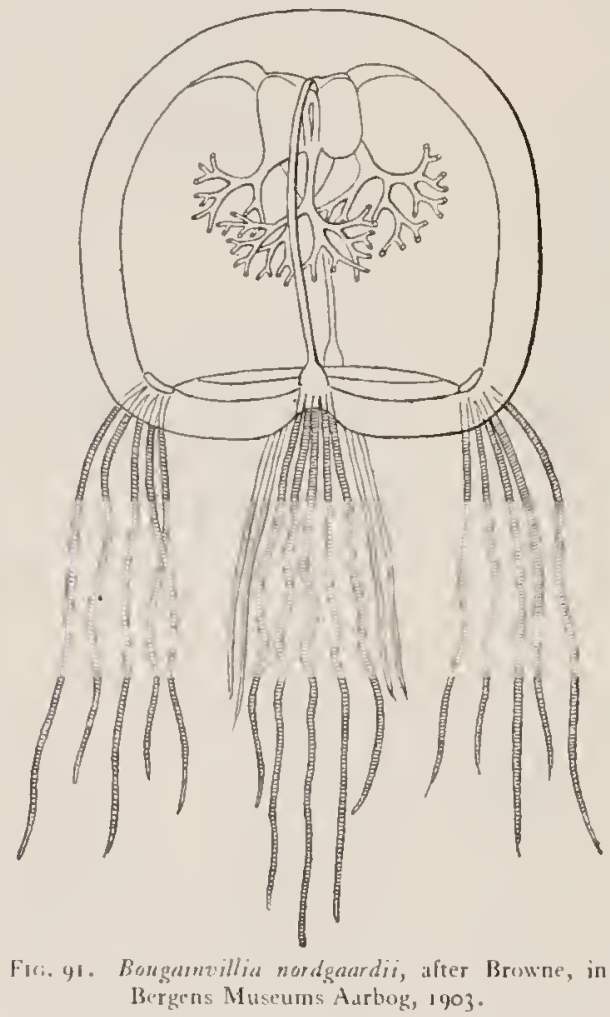
tacles somewhat longer than the bell-diameter. Velum narrow. Stomach half as long as the depth of the bell-caviry. 4 oral tentacles, 4 or 5 times dichotomously branched. 4 wide, interradial, gonads on the sides of the stomach. Gonads and tentacle-bulbs yellowish-brown (in formalin). Byfjord, near Bergen, Norway. Distinguished by its lack of ocelli.

For details see tabular synopsis of medusx of Bougainvillia.

\section{Bougainvillia favida Hartlaub.}

Bougainzillia flarida, HartLaUB, 1897 , Wissen. Meeresuntersuch. Kommis. Deutsch. Meere Kiel, Helgoland, Neue Folge, B.l. I, P. 456, taf. 14, figs. 1-10; taf. 15 , figs. $4^{-6,8}$.

The mature medusa is slightly higher than a hemisphere with an evenly-rounded bell. The gelatinous substance is thick, so that the bellcavity is only a little more than half as deep as the bell-height. The bell is 2 or $3 \mathrm{~mm}$. wide. There are 4 radially placed clusters of marginal tentacles with not more than 6 tentacles in each cluster. These tentacles are about as long as the belldiameter and each one has a large ocellus upon its velar side near the base of the cluster. The $4 \mathrm{com}-$ mon, hasal bulbs are swollen, semiglobular, and well developed. 4 quite wide, straight radial-canals and a narrow, simple, circular vessel. Manubrium small, conical, half as long as the depth of the hell-cavity. Without a peduncle. The 4 oral tentacles branch dichotomously about 3 times. With interradial, undivided gonads. Entoderm of manubrium and tentacle-bases orange-yellow.

The mature medusx are found at Helgoland, German Ocean, in August and September.

Hydroid.-The hydrorhiza is net-like, creeping, and yellowish-brown in color. The stems arise at cquite infrequent intervals and are unbranched, very slender below and swollen above at the polypite. They are 5 to $7 \mathrm{~mm}$. high and light gray-brown in color. The hydranths are elongate, club-shaped, with 8 to ro tentacles in a single zone around the mouth. The medusa-buds are produced upon branching processes which arise from the sides of the stem near the hase of the polypite, or from points lower down upon the side of the polypite 
itself. There may be as many as 6 medusa-buds upon one of these branches, and there are usually several branches producing medusx. The huds are oval at first, but later they become spherical.

When set free the medusa's hell is only 0.3 to $0.6 \mathrm{~mm}$. wide. It is irregularly grlobular with very thick walls and an irregularly shaped bell-cavity. There are 4 perradial hasal bulbs, each of which gives rise to a single, marginal tentacle. These are long and lack vecelli. 4 simple, unbranched, oral tentacles, and 4 wide radial-canals, with an axial canal above the stomach. The exumbrella is hesprinkled with nemarocysts as is usual in young medusa. The tentacle-bulbs and manuhrium are reddish-brown by reflected light.

The hydroid is found at Helgoland attached to living or dead shells during the summer. Both hydroid and medusa are described in detail hy Hartlaub, 1897 .

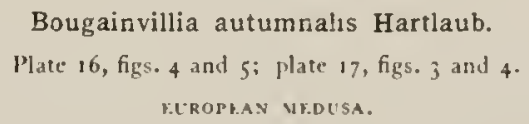

Bougumvillia autummalis, Hartlaub, 1897, Wissen. Meeresuntersuch. Kommis. Mecre Kirl, Helgoland, Neue liolge, Bul. 2, p. 465, taf. 15 , fign. 11-13.

Margelis autumitis, Browne, igo6, Trans. Linnean Soc. London, ser. 2, Zool., vol. 10, p. 170.

ANERTCAN MBDLSA.

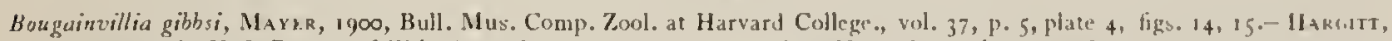
1904 , Bull. U. S. Bureau of Fisheries, vol. 24, P. 40; 1901, American Naturalist, vol. 35, P. 583 .

Bell rounded, $2.5 \mathrm{~mm}$. wide, somewhat higher than a hemisphere, with thick, gelatinous walls. 4 bulhous, rounded, marginal tentacle-bulbs, each of which gives rise to 3 to 6 ienracles. 4 narrow, straight radial-canals. Manuhrium short, wide, 4 -sided, urn-shaped; not half as long as the depth of the hell-cavity. 4 oral tentacles which turn upwards and branch dichotomously 2 to 5 times. The ends of the oral tentacles are simple, without terminal knobs. 4 interradial gonads in the ectoderm of the stomach-wall. Tentacle-bullos vellowish to greenish-yellow. Manubrium green or brown. Hydroid unknown.

Found by Hartaub at Helgoland, German Ocean, from the end of August to the end of November. Browne found it off the west coast of Ireland and in the English Channel.

1 consider this medusa to be identical with B. gibbsi Mayer, of the southern coast of New England. It is possibly separated by uncertain and variable color differences. A description of the American form is herewith presented:

Adult medusa (plate 16 , fig. 5; plate 17 , fig. 4).-Bell alout 4 mm. in height and $3.8 \mathrm{~mm}$. in diameter. Gelatinous substance very thick, so that the hell-cavity is only ahout half as deep as the height of the animal. There are 4 chusters of marginal tentacles which arise from 4 large, hulbous swellings situated at the hases of the 4 radial-canals. Each bulbous swelling gives rise to 4 or 5 slender tentacles. There is a single, dark-brown ocellus at the hase of each tentacle upon the centriperal (velar) side. The velum is small. There are 4 straight, narrom radial-canals. The manuhrium is wide and cruciform in cross-section, and the radial-canals arise from the 4 corners of the cross. The manuhrium is short and does not extend quite half the distance from the inner apex of the betl-cavity to the velar opening. The mouth is situated at the extremity of a short, tubular neck and there a re no prominent lips. + radially situated, oral tentacles a rise from the sides of the neck of the manubrium. Each of these branches dichotomously about twice. The gonads are developed upon the 4 interradial sides of the stomach, and in the female the ova are large and prominent. The manubrium is pearl-colored or of a deticate green. The entodermal cores of the tentacte-hullos are red, surrounded by a delicate yellow-green. The supporring lamella of the bell often displays a faint greenish tinge.

Foung medusa. - In the young medusa there are but 8 tentacles, 2 from each tentackbulb. The bell is a little higher than a hemisphere and the gelatinous substance is not very thick, being of about uniform thickness everywhere, instead of heing very thick at the ahoral pole as in the adult. The manubrium is short and quadratic and there are 4 short, unhranched, knob-shaped, orat tentacles. When the medusa is ahout $3 \mathrm{~mm}$. in height, the bell is still hemispherical. The manubrium is wide, shallow, and puadratic, and the oral tentacles branch once dichotomously. Ahout 3 to 5 marginal entactes arise from each tentacle-bulls. 
This medusa is found in Newport Harbor, Rhode Island, United States, from July until (octoher. I consider it to be identical with Hartlaub's B. autumnalis from Helgoland, German Ocean.

This species is distinguished from Bongainvillia carolincnsis by the greater height and lesser width of its bell. Also in B. carolinensis the manubrium is long and slender, while in B. antmmolis it is short and wide. The manubrium of $B$. carolinensis is widest at about the middle of its length, while that of $B$. autumnalis is widest at its proximal base.

\section{Bougainvillia prolifera.}

Lizusa prolifera, von Lb.ndr.nr k.ld, 1884 , Proc. Linnean Soc. New South Wales, vol. 9, p. 589 , plate 23, figs. 38 , 39.

Bell evenly rounded, $3 \mathrm{~mm}$. high, $2.5 \mathrm{~mm}$. wide. 4 radial clusters of marginal tentacles which arise from large, "scrota-shaped" basal bulbs; 5 tentacles upon each bulb, 20 in all. These tentacles are about half as long as the height of the bell. 4 simple radial-canals. Stomach small, nearly cubic, with 4 unbranched, simple, oral tentacles about two-thirds as long as the length of the stomach. These end each in knob-like clusters of nematocysts. Medusa-buds develop at the base of the manubrium and these give rise also to medusa which appear as buds at the time when the originally budding medusa are set free. Tentaclebullos and stomach brown, other parts colorless.

Port Jackson, New South Wales; March to April.

This medusa exhibits every indication of immaturity, and it is probable that the oral tentacles finally become branched.

\section{Bougainvillia maniculata Haeckel.}

Bonganvillea maniculata, Ha eckr., 1864, Jena. Zettsch. für Naturw., Bd. 1, P. 340; 1879, Syst. der Medusen, P. 8y, taf. 5, fign. 4,5 .

Bell almost spherical, $1.5 \mathrm{~mm}$. wide, $1.5 \mathrm{~mm}$. high with uniform, fairly thin walls. Velum very wide. The 4 marginal tentacle clusters are hand-shaped; each with 4 very short,

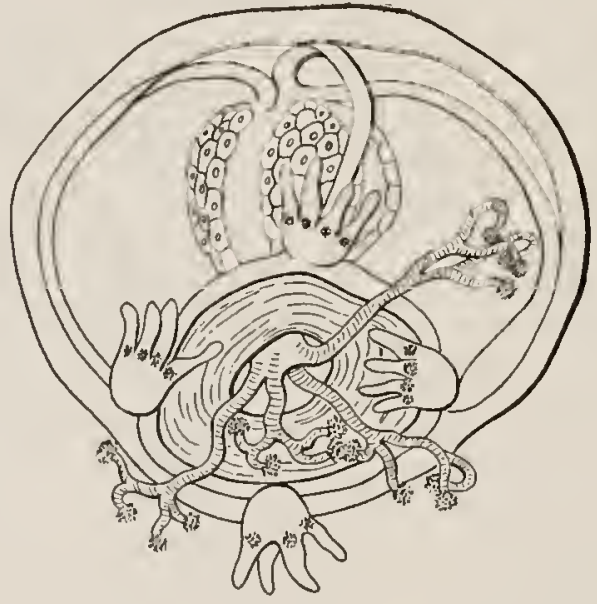

92.

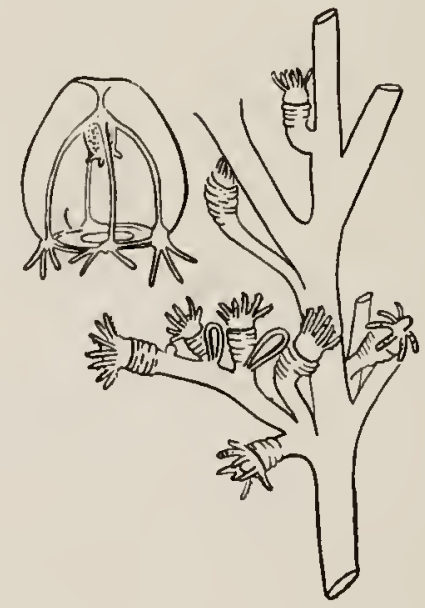

93.

Fic. 92.-Bougainvillia maniculata, after Haeckel, 1879.

Futi. 93.-Bongaimillia rugosa, after S. F. Clarke, in Men. Boston Soc. Nat. Hist.

finger-like tentacles, with an ocellus on the inner side of each. The stomach is spherical, with a narrow hase, and a long, conical throat-tube which projects beyond the velar opening. There are 4 long, slender, oral tentacles, which branch twice dichotomously at their outer ends, thus ending in 4 very short, knobbed tips. These oral tentacles are each about as long as the manubrium itself.

There are 4 interradial gonads on the sides of the stomach. The stomach, gonads, and tentacle-bulbs are violet-gray. Found by Haeckel in the Mediterranean at Villafranca and Nizza. 
The medusa is distinguished by its thin-walled, almost spherical bell, its wide vilum, and its very long oral tentacles which branch only at their outer ends. The flask-shaped stomach and small size are also characteristic. On the whole it presents the appearance of a degenerate form.

\section{Bougainvillia rugosa Clarke.}

Plate 17, fig. 2 .

Bougainvillia rugosa, Clarkt, 1882, Mem. Buston Suc. Nat. Hist., vol. 3, P. 140, plate 8, figs. 21-24.

Foung medusa (plate 17, fig. 2).-Unblolla somewhat pyriform. 12 marginal tentacles, 3 at the base of each radial tube. Tentacles all of equal size. According to Clarke, ocelli are developed only at the bases of those 2 tentacles which are first and second as one passes around the bell from left to right, but I found a specimen with 12 ocelli, one at the hase of each tentacle. The velum is well developed. There are 4 straight, narrow, radial tulses. The manuhrium is short and thick, and there are + short, unbranched, oral tentacles.

Hydroid. - The hydroid stock attains a height of $75 \mathrm{~mm}$. There are numerous irregularly arranged hranches. Some of the branches which a rise near the proximal end are about as long as the main stem, but most of them a re short and delicate. The branches bear secondary branches which give rise to 3 or 4 terminal ramuli. The hydroict is rooted by a creeping stolon. The polypites are fusiform and are protected by an expansion of the perisare which bears a number of annulations. There are $S$ to 10 short tentacles. The medusa-buds are borne upon the ultimate branches immediately below the proximal bases of the polypites. The hydroid is light-brown.

It was found hy Clarke, 1882, growing upon Alcyonidium at Ilampton Roads, Virginia, and in the southern parts of Chesapeake Bay. A medusa believed to he of this species was found by me in Charleston Harbor, South Carolina, on December 17, 1904.

Bougainvillia trinema.

Margelis trinema, von Lende.NFeld, $188_{4}$, Proc. Linnean Soc. New South Wales, vol. 9, p. 918, plate 41 , fig. 1 ;

An immature medusa from Sydney Harbor, New South Wales, Australia. The hell is oval, rounded, 2 to $3 \mathrm{~mm}$. wide. There are only 3 tentacles in each of the 4 clusters of marginal tentacles. These are about half as long as the bell-height. Each of the 4 oral tentacles ends in 3 (?) snall, equal branches a hout one-third as long as the shaft of the oral tentacle. Entoderm of stomach and tentacle-bullos dark yellow. This may possibly be the young of $B$. fulva Agassiz and Mayer, 1899, but von Lendenfeld's description and figure are too imperfect to) determine this point.

Bougainvillia frondosa Maycr.

Plate 16, fig. 6.

Bougainvillia frondosa, MaYr.r, 1900, Bull. Mus. Comp. Zool. at Ilarvard College, vol. 37, 5.41 , fig. 5, plate 3 .

The bell is higher than a hemisphere with relatively straight, vertical sides, and about $2 \mathrm{~mm}$. high. There are 4 radially placed clusters of marginal tentacles, which are situated upon hulbs at the ends of the 4 radial-canals. Each bulb gives rise to but 2 tentacles, so that there are only $8 \mathrm{in}$ all. There are no ocelli at the hases of the tentacles. The velum is narrow. There are 4 straight, narrow radial-canals and a simple, narrow ring-canal. The manubrium is cruciform in cross-section. short, thick, and Hask-shaped. It extends ahout half the distance from the inner apex of the bell-cavity to the velar opening. "There are + radially placed, oral tentacles, each of which branches dichotonously 2 or 3 times. Planula develop upon the sides of the stomach near, and on hoth sides of, the 4 principal radii. I at first considered these to be parasitic Zooxanthellax, but further studies have shown that they are planule. Hartlaub, 1897 , observes a similar phenomenon in Bougaimeillia superciliaris, etc., and Maas, I904, cites it in Cytris nigritina (Résult. Camp. P'rince de Monaco, fasc. 28, p. S. plate 1, figs. 3,4 ).

The entoderm of the manubrium and tentacle-bulbs is pinkish-white and the rentacle tips are turquoise. This medusa is occasionally found at Tortugas, Florida, in June to July. 
Bougainvillia obscura Bonnevie.

Bougainvillia ahscura, Bisnseste, 1899 , Bergens Mus. Aarbog for $1898, \mathrm{No} .5, \mathrm{l} \cdot 7, \mathrm{taf}$. 1, fig. 4, 4a.

The hydroid is small, a bout $20 \mathrm{~mm}$. high. The hydrocaulus of the trophosome is about $3 \mathrm{~mm}$. high, with almost opaque perisare without foldings or rings. The polypites are about $2 \mathrm{~mm}$. long, nearly cylindrical and with about 15 very long tentacles. The medusa are set free, and are produced either singly or in small clusters upon branched processes immediately under the liydranths.

Found at Christiania. Color (?) Hydrorhiza (?) Description of medusx (?) The species is said to differ from orher Bougainvillix in its smooth, opaque perisare, and in its long tentacles. It will be difficult to rediscover this form from its very meager description.

\section{Bougainvillia glorietta Torrey.}

Bouganvillia gloriena, Torrfy, 1904, Univ. California Publications, Zuol., vol. 2, No. 1, P. 7, figs. 2, 3 .

Stems branched, rising from a creeping hydrorhiza in clusters to the height of 20 to $30 \mathrm{~mm}$. The stems and branches often twine about each other. Perisare smooth, or wavy, covered with particles of detritus. Terminal polypites largest, with 20 to 25 tentacles in 2 or 3 irregular whorls, the outermost being the shortest. Tentacles highly contractile. Gonophores in groups of 2 or 3 on branches or hydranth stalks, mounted on short pedicels. The well-developed medusx within the gonophores have 4 pairs of marginal, 4 simple, oral tentacles, and 8 ocelli. Color (?) Found at San Diego, California.

Distinguished by its smooth, unannulated perisarc and twining stems. Free medusa is unknown.

\section{Genus NEMOPSIS L. Agassiz, I849.}

Nemopsis, Agassiz, L.., I849, Mem. Amer. Acad., New Series, vol. 4, p. 289 ; 1862, Cont. Nat. Hist. U. S., vol. 4, p. 345.

Mc.Crady, 1857, Gymn. Charleston Harbor, P. 58.-Agassiz, A., i862, Proc. Boston Soc. Nat. Hist., vol.9, p.98; 1865.

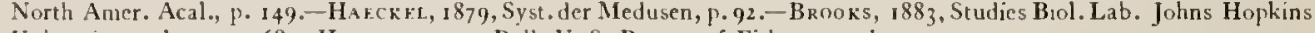
University, vol. 2, p. $468 .-$ HargitT, 1904 , Bull. U. S. Bureau of Fisheries, vol. 24, P. 37.

This genus was founded by L. Agassiz, 1849 , for Nemopsis bachei of the Atlantic coast of the United States south of Cape Cod.

\section{GENERIC CHARACTERS.}

Margelinæ with 4 clusters of marginal tentacles, one at the extrenity of each of the radialcanals. There are two sorts of tentacles in each cluster, a median pair of club-shaped tentacles with swollen extremities studded with nematocysts; and on both sides of this median pair there are number of simple, filiform tentacles. The 4 radial lohes of the stomach exrend outward along the radial-canals and the gonads are developed along the sides of these lobes. The hydroid is a Bongainvillia. In the Ncmopsis hydroid, however, the medusæ arise from the sides of the naked polypites, not from the branches of the stems of the hydroid, as is usual in other species of Bougainvillia.

In common with Bougainvillia the medusa of Nemopsis has 4 dichotomously branching, oral tentacles. Its most striking feature is the wide extension of the 4 radial pouches of the stomach along the 4 radial-canals. This is, however, not of generic value, for it occurs to a greater or less degree in Bougainvillia. The sole distinctive generic feature of Ncmopsis is the presence of two distinct sorts of tentacles upon each marginal bulb. L. Agassiz, in his first brief notice of this genus in 1849 . called attention to its peculiar club-like median pair of tentacles and presents a good figure of them, but his description is not wholly correct, for the ocelli are not upon the ends of the tentacles, but are on the axial (inner) side of each tentacle adjacent to the pad-like base.

Haeckel, 1879, considers $N$ cmopsis to be identical with Favonia of Péron and Lesueur, 1809; nevertheless he adopts the name Nemopsis, although maintaining the precedence of Favonia. I agree with Vanhöffen, 1891, and consider that Favonia is certainly not equivalent to Nemopsis. Blainville's (1834, Man. d'Actinologie) copy of P'éron and Lesueur's figure of 
Favonia and his brief and unsatisfactory description are only confusing. It is evident that the figure is very erroneous, and it appears to bear a closer relationship to l.ymnorca than to Nemopsis. No marginal tentacles are shown, and the flat, bell-shaped disk is wholly unlike any known species of $N$ rmopsis.

Favonia octonema Péron et Lesueur is probahly an inperfect specimen of some species of Lymmorea. Haeckel calls this "Nomopsis faronia."

I can distinguish no difference between Haeckel's Nemopsis "hotcroncma" and $N$. bachci of our coast. It was described from an isolated specimen found on the coast of Norway, and falls within the common limits of variahiliry of $N$. bachei in all respects. It is possibly an individual which may have drifted across the Atlantic in the trend of the winds and currents.

The genus Nomopsis is evidently derived from the more generalized Bongaimillin in which the marginal tentacles have hecome specialized into two sorts and the + radial conners of the stomach have extended far outward along the radial-canals. "lhe hydroid remains identical with that of Bongainvillia.

Nemopsis is one of those exceptional Anthomedusa in which the gonads have migratcd outward from the sides of the stomach along the radial-canals. Dissoncma among the "Tiarinac is another instance of the same sort. In the medusa we frequently find that the hard and fast distinctions which Haeckel attempts to apply to the separation of familics do not hold in nature. Thus the gonads are often more or less interradial in the Codonida, or more or less upon the sides of the manubrium in the Thaumantiadx; the lithocyst-bearing medusa Futima arises from a hydroid having the superficial appearance of one of the Tubularian order, and Rathksa fasciculata is the only medusa of the Oceanida with + perradial gonads.

\section{Nemopsis bachei L. Agassiz.}

$$
\text { Plate } 17, \text { figs. } 5 \text { and } 6 .
$$

Nemopsis barhei, Agassiz, I.., 1849, Mem. Amer. Acad., New Series, vol. 4, p. 289, I fig.-186z, Cont. Nat. Hist. U. S., vol. 4, p. 345.-Agassiz, A., 1862, Proc. Boston Soc. Nat. Hist., vol. 9, p. 98, figs. 26, 27.-1865, North Amer. Acal.,

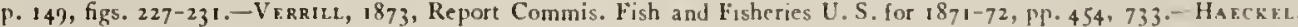
1879 , Syst. der Medusen, p. 93.-Brooks, 1883 , Studies Johns Hopkins Univ. Biol. Lab., vol. 2, p. 468 (hylloid and young medusa).-Brooks, 1890, Handbook of Invert. Zool., p. 40, fig. 21.-Nurtixc, 1901, Bull. U. S. Fish Commission for 1899 , vol. 19, P. 375, fig. 88.-HarGits, 1904, Bull. U. S. Bureau of lisheries, vol. 24, P. 41, 1 fig.; 1901, Anierican Naturalist, vol. 35, p. $5^{8} 3$, fig. 47 ; 1901 , Biol. Bulletin, Woods Hole, vol. 2, p. 227.

Nemopsis gibbesii, MсCяарr, $1857, G y m n$. Charleston Harbor, p. 58, plate ro, figs, $1=3$, non figs. $4=7$.

Favonia bachei, Ha ccker, 1877, Prodrom. Syst. Medusen, No. 103 (unpublished).

Nemopsis heteronema, Ha feckl, 1879 , Syst. der Medusen, p. 93, taf. 5, fign. 6-9 (isolated specimen from coast of Norway).

Adult medusa (plate 17, fig. 6).-Bell about II $\mathrm{mm}$. high, being higher than a liemisphere, with relatively straight sides and flat top. There are 4 radially situated clusters of marginal tentacles. Each cluster arises from a cleft, pad-like base and contains about it tentacles. The median pair of tentacles are short, slender, and terminate each in a knollike cluster of nematocysts (plate 17 , fig. 5). These median tentacles are flanked by a long. highly contractile pair which contain reddish-hrown pigment in their ectoderm. On either side of these brown tentacles there are 5 transparent, highly contractile, filiform tentacles. When swimming the medusa often carries its tentacles with their shafts cxtending straight outward at an acute angle with the sides of the bell, while the extremity of each tentacle bends sharply downward at a right angle, recalling the appearance presented by the tentacles of Gonioncmus. There is a dark-colored ectodermal ocellus at the base of each tentacle on the lower (velar) side. The bell-cavity is about three-quarters as deep as the bell-height. There are 4 straight, narrow radial-canals and a slender circular vessel. The velum is well developed. The gonads are flat and ribbon-like, with curtain-like folds, and they extend down the radialcanals, along the sides of the 4 stomach-pouches, which project ahout two-thirds the distance from the sides of the manubrium to the tentacle-bulbs. The manubrium is short, with 4 simple, quadratic lips, and with 4 radially situated clusters of oral tentacles. Each of these oral clusters arises from a single shaft which bifurcates from 5 to 7 times, terminating in 32 to 128 small, nematocyst-covered knolss. The entodermal cores of the oral tentacles consist of chordate cells. Gonads, stomach, and tentacle-bulbs dull milky-yellow to orange. "This 
medusa is very abundant in autumn and winter along our Atlantic coast near the mouths of large hays into which pure ocean water has free access. It is not usually found in brackish water far from the ocean. It is found at Woods Hole, Massachusetts, and is common in Long Island Sound as far west as New Haven; in the mouth of the Chesapeake; in Pamlico Sound, especially near the inlets, and in the mouths of all southern harbors, in winter, as far south as Fernandina, Florida. It is also found off the coast in the ocean. It has not been seen north of Cape Cod, nor upon the southern Florida coast. Very often the medusa is seen with all of its marginal tentacles broken off short, leaving only rounded stumps, this condition being commonly found in animals living in brackish water or far from the ocean. N. "heteronema" Haeckel, 1879, appears to be identical with our American $N$. bachei.

IIydroid and young medusa.-McCrady, 1857 , is mistaken in his identification of the hydroid of this medusa, for his hydroid is Margelopsis. The hydroid stock was found hy Brooks, $188_{3}$, in Newport River, North Carolina, growing upon a piece of submerged wood. It is a Bongainvillia. The stems of the hydroid are about $25 \mathrm{~mm}$. in height. Each main stem gives rise to 3 or 4 short alternating branches, and these as well as the main stem end in hydranths, which are sharply separated from the stem by means of a fold or collar. The stems are covered by a thin, transparent, horny ectosarc which extends almost, but not quite, up to the basal collar of the polypites. There are 2 or 3 irregular annulations upon the ectosarc of the side branches, close to the main stem. Each polypite bears 24 long, slender tentacles, which arise in a single circlet near the distal end of the hydranths. The mouth is situated at the extremity of a well-developed proboscis which is funnel-shaped and sharply distinguished from the body of the hydranth. 6 or 8 medusa-buds, in various stages of development, are arranged in a circlet situated upon some of the hydranths between the distal base and the circlet of tentacles. The terminal hydranths and those near the free end of the main stem bear no medusa, for these appear to be developed upon the old hydranths. The hydroid of Nemopsis is thus a Bougainvillia, but the medusa arise from the sides of the polypites, not from the stems.

When set free the medusa is flattened and folded so that the manubrium projects beyond the velar opening. In about an hour, however, it expands and begins to swim. It is then about $0.5 \mathrm{~mm}$. in height, and the bell is globular, being about as broad as high. The manubrium is short and tubular and without oral tentacles. In some individuals there are 8 tenracles, 2 at the base of each radial tuhe. In others there are but 4 primary tentacles, one upon each tentacle-bulb at the base of the 4 radial tubes.

As development proceeds the marginal tentacles increase in number, those which are nearest the middle of the basal bulbs being the oldest. The new tentacles appear at the sides near the base of the cone-shaped basal bulb. The 4 oral tentacles develop upon the 4 radial sides of the manubrium, and finally the gonads begin to develop upon the 4 radial-canals adjacent to the sides of the manubrium and finally extend down almost the entire length of the radial-canals.

According to Hargitt, Igor, about 5 per cent of the medusa of $N$. bachei display variations of a numerical nature in the radial-canals, manubrium, gonads, and tentacles.

\section{Nemopsis crucifera Haeckel.}

Ilippocrene crucifera, Forses, 1853, Trans. Roy. Soc. Edinburgh, vol. 20, $\mathrm{P} \cdot 313$. plate 10, fig. 5 . Vemapsis crucifera, HakckrL, 1880 , Syst. det Medusen, p. 635 .

This species is distinguished from $N$. bachei by its dark-red color and possibly by its more nearly spherical bell.

Bell oval, $4 \mathrm{~mm}$. wide, $4 \mathrm{~mm}$. high. Each of the 4 marginal tentacle-bulbs bears a median pair of short, stiff, club-shaped tentacles, flanked on either side by 2 to 3 longer filiform tentacles. There are thus 6 to 8 tentacles upon each marginal hulb. The stomach is cruciform. and its sides extend half-way down the 4 radial-canals. The oral tentacles a re short and branch twice dichotomously. The gonads are as in $N$. bachei. Forbes shows the stomach, gonads, and tentacle-bulbs of a darker red color than has been observed in N. bachci. The tentacular wcelli are black. Found by Forbes and Haeckel at Tobermory and Handa Island, off the west coast of Scotland. 
Genus RATHKEA Brandt, 1837 , sensu Vanhöffen.

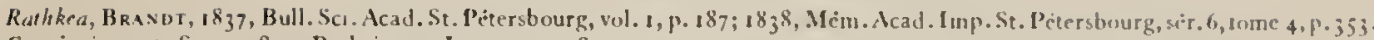
Cyeris, in part, S.ARs, 1835 , Beskriv. og Jagttag, p. 28 .

Lizzia, Furaes, 1846, Annals and Mag. Nat. Hist., ser. 1, vol. 18, p. 286; 1848, Britush Naked-eved Melustr, p. 64,Claparéde, 1860, Zeit. für wissen.Zool., Bd. 10, p. 401, taf. 32, fign. 1-3.-Aciassiz, L., I862, Cont. Xat. Hist. U.. S.

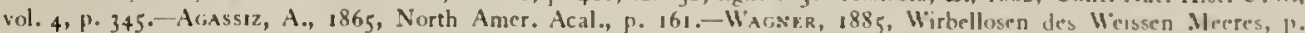
73.- Garstane, 1904, Journ. Marine Biol. Association, Plymouth, New Series, vul. 3, p. 213.-MAas, I897, Mein. Mus. Comp. Zool. at Harvard College, vol. 23. P. 14--Hargitr, 1904, Bull. U. S. Bureaul of f'isheries, vol. $24.1 \% 37$.

Rathkeat Margellium + Lisaia, С HuN, 1895 , Bibliotheca Zoologica, Heft 19, 1.fg. 1, Pp. 13, 16, 24, 36, etc.

Margellium, Beowst, 1895, Proc. and Trans. Liverpool Bul. Soc., vol. 9, p. 270; 1896, Proc. Zool. Soc. Lonslen. Margellium, P. 477 ; Limaia, D. 475 .

Lizaia + Lizullat Margellium+Ratlikea, Hatckв, 1879 , Syst. der Medusen, pp. 72, 82, $83,94,96$.

Rathker, Let'Tken, 1850, Vidensk. Meddel. Nat. Foren. Kjöbenhavn, Pp. 18, 25. Agassiz, 1.., i86z, Cont. Nat. Hist. [1. S., vol.

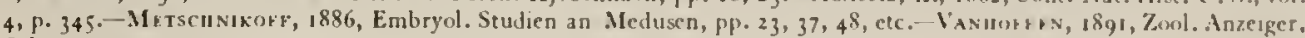
Jahrg. I $4, p .445$.

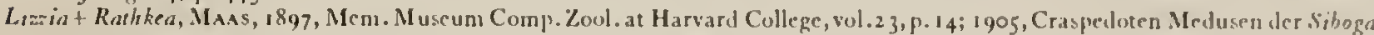
Expedition, Monog. 10, p. 12.-BF Dot, 1905, Revue Suisse de \%ool., tome 13, pp. 137, 144 (citation of references to 1850 ).

The type species is Rallikea blumenbachii Brandt, of the Black Sea. I believe future studies will show that this medusa is identical with Ralhker oclopunctala.

In $1846-48$ Forbes introduced the generic name "Lizzia," applying it to loizzin oclopunclata, which Browne and Garstang have shown to be identical with Cylcris ocropuncrala of Sars, 1835 .

Haeckel, 1879 , defines the following genera:

\begin{tabular}{|c|c|c|c|c|}
\hline & \multicolumn{4}{|c|}{ Haeckel's name. } \\
\hline & L.izzia. & Margellium. & Lizzella. & Rathkea. \\
\hline Condition of oral tentacles. & Unbranched. & Branched. & Unbranclicd. & Branched. \\
\hline $\begin{array}{l}\text { Condition of the } 8 \text { clusters of } \\
\text { marginal tentacles. }\end{array}$ & $\begin{array}{l}4 \text { radial clusters have } \\
\text { more tentacles than } \\
\text { the } 4 \text { interradial. }\end{array}$ & $\begin{array}{l}4 \text { radial clusters have } \\
\text { more tentacles than } \\
\text { the } 4 \text { interradial. }\end{array}$ & $\begin{array}{l}\text { All } 8 \text { tentacular } \\
\text { clusters alike. }\end{array}$ & $\begin{array}{l}\text { All } 8 \text { tentacular } \\
\text { clusters alike. }\end{array}$ \\
\hline
\end{tabular}

Vanhöffen, I89I, shows that "Lizzia, Margellium, and Lizzellı" are stages in the growth of Rallika.

Much confusion has thus been introduced by the too narrow definition of genera, as restricted by Haeckel, and it seems well to broaden the genus so as to make it apply to these medusx in all stages of their free life.

\section{GENERIC CHARACTERS}

Margelinæ with simple or branched oral tentacles and 8 clusters of marginal tentacles. 4 radial and 4 interradial.

There are perradial, adradial, or interradial gonads on the sides of the stomach and the oral tentacles terminate in knob-like clusters of nematocysts.

In Rathkea medusa-buds are commonly developed upon the sides of the manubrium. Chun, 1895 , has shown that these buds are produced entirely from the ectoderm of the parent medusa. A short time before the young medusa is set free, however, a connection is established between the gastrovascular cavity of the bud and that of the mother medusa. Claparide, 1860, describes a "Lizzia" from Scotland in which the embryos are developed upon the outer walls of the stomach very much as is the case with the planula of Bouganvillin superciliaris. In the case of this "Lizzia," however, the eggs, or embryos, are set free inclosed in capsules and then develop directly into medusx. This remarkable observation awaits confimation.

According to Browne, 1896 (Proc. Zool. Soc. London, p. 477), the medusa of Lizzia (Rallikea) octopunctata first reproduces itself by means of medusa-huds upon the manubrium, and when it reaches the adult condition either ova or spermatozoa develop within the ectodermal wall of the stomach, the sexes being separate; and the same statement applies to Raliken blondina.

It is highly probable that the very variable $R$. oclopunctala is found in the Mediterranean and along the Atlantic coasts of Europe and America, and that R. hlumenbachii and $R$. blendina are unly synonyms. $R$. fasciculate is the only known Anthomedusa in which the gonads are restricted io the perredial sides of the manubrium. 
Tabular Synopsis of the Species of Rathkea.

\begin{tabular}{|c|c|c|c|c|c|c|c|c|}
\hline & $\begin{array}{l}\text { Rathkea blumen- } \\
\text { bachii Brandt, } \\
18_{37} \text { to } 18_{3} 8 \text {. }\end{array}$ & $\begin{array}{l}\text { R. formosissi- } \\
\text { ma=Lizzia } \\
\text { formosissima } \\
\text { Browne. }\end{array}$ & $\begin{array}{l}\text { R. octopunctata } \\
=\text { Cytxis octo- } \\
\text { punctata Sars, } \\
1835 \text { to } 1846= \\
\text { Lizzia octo- } \\
\text { punctata } \\
\text { Forbes, } 1848 \text {. }\end{array}$ & $\begin{array}{l}\text { R. octopunc- } \\
\text { tata var. } \\
\text { grata }=\text { Liz- } \\
\text { zia grata A. } \\
\text { Agassiz, } 1862 \\
\text { to } 1865 .\end{array}$ & $\begin{array}{l}\text { R. fasciculata }= \\
\text { Melicerta fasci- } \\
\text { culata Péron et } \\
\text { Lesueur. Liz- } \\
\text { zia köllikeri } \\
\text { Gegenbaur, } \\
1854 \text { to } 1856 \text {. }\end{array}$ & $\begin{array}{c}\text { R.octonemalis } \\
\text { Maas, } 1905 .\end{array}$ & $\begin{array}{l}\text { R. elegans } \\
=\text { Lizzia } \\
\text { elegans } \\
\text { Mayer, } \\
\text { \$900. }\end{array}$ & $\begin{array}{l}\text { R. blon- } \\
\text { dina }= \\
\text { Lizzia } \\
\text { blondina } \\
\text { Forbes. }\end{array}$ \\
\hline $\begin{array}{l}\text { Shape } \\
\text { and } \\
\text { size of } \\
\text { bell in } \\
\mathrm{mm} \text {. }\end{array}$ & $\begin{array}{l}\text { Bell-shaped. } \\
6 \text { high, } 4 \text { wide. }\end{array}$ & $\begin{array}{l}\text { Bell-shaped. } \\
3 \text { high, } 2.5 \\
\text { wide. }\end{array}$ & $\begin{array}{l}\text { Pyriform. } 5 \text { high, } \\
4.5 \text { wide. }\end{array}$ & $\begin{array}{l}\text { Pyriform. } \\
3 \text { to } 5 \text { high, } 3 \\
\text { wide. }\end{array}$ & $\begin{array}{l}\text { Globular. } \\
\text { Widest at up- } \\
\text { per two-thirds } \\
\text { of bell. } 15 \text { high, } \\
12 \text { wide. }\end{array}$ & $\begin{array}{l}\text { Globular, } \\
\text { dome-like. } \\
6 \text { high, } 5 \\
\text { wide. }\end{array}$ & $\begin{array}{l}\text { Apex } \\
\text { dome- } \\
\text { like, sides } \\
\text { vertical. } \\
6 \text { high, } 5 \\
\text { wide. }\end{array}$ & $\begin{array}{l}\text { Pyriform. } \\
6 \text { high, } 4 \\
\text { wide. }\end{array}$ \\
\hline $\begin{array}{l}\text { No. of } \\
\text { tenta- } \\
\text { cles in } \\
\text { each of } \\
\text { the } 8 \\
\text { nargin- } \\
\text { al clus- } \\
\text { ters. }\end{array}$ & $\begin{array}{l}3 \text { in each cluster } \\
(2+\text { in all }) \text {. }\end{array}$ & $\begin{array}{l}5 \text { in each ra- } \\
\text { dial, } 3 \text { in each } \\
\text { interradial } \\
\text { cluster. }\end{array}$ & $\begin{array}{l}4 \text { to } 5 \text { in each ra- } \\
\text { dial cluster. } 3 \text { in } \\
\text { each interradial } \\
\text { cluster. When } \\
\text { half-grown there } \\
\text { are } 3 \text { tentacles } \\
\text { in each of the } 8 \\
\text { clusters. }\end{array}$ & $\begin{array}{l}5 \text { in radial, } 3 \text { in } \\
\text { interradial } \\
\text { clusters. As } \\
\text { in R.octo- } \\
\text { punctata. }\end{array}$ & $\begin{array}{l}15 \text { to } 20 \text { in each } \\
\text { of the } 8 \text { clusters } \\
\text { when mature. } \\
\text { When only } 3 \\
\text { mm. high there } \\
\text { are } 7 \text { in radial } \\
\text { and } 5 \text { in inter- } \\
\text { radial clusters. }\end{array}$ & $\begin{array}{l}7 \text { to } 9 \text { in } \\
\text { radial, } 5 \text { to } \\
7 \text { in interra- } \\
\text { dial clusters. }\end{array}$ & $\begin{array}{l}4 \text { in radial, } \\
3 \text { in inter- } \\
\text { radial } \\
\text { clusters. }\end{array}$ & $\begin{array}{l}3 \text { in each } \\
\text { radial } \\
\text { cluster. } 4 \\
\text { small iso- } \\
\text { lated in- } \\
\text { terradial } \\
\text { tentacles. }\end{array}$ \\
\hline $\begin{array}{l}\text { Condi- } \\
\text { tion of } \\
\text { oral } \\
\text { ten- } \\
\text { tacles. }\end{array}$ & $\begin{array}{l}4 \text { oral tentacles, } \\
\text { each with } 3 \text { pairs } \\
\text { of simple lateral } \\
\text { branches. }\end{array}$ & $\begin{array}{l}4 \text { oral tentacles, } \\
\text { each with a } \\
\text { simple ter- } \\
\text { minal cluster } \\
\text { and } 3 \text { to } 5 \\
\text { pairs of nem- } \\
\text { atocysts. }\end{array}$ & $\begin{array}{l}4 \text { forked oral ten- } \\
\text { tacles, each } \\
\text { with pair of } \\
\text { nematocyst- } \\
\text { knobs at its } \\
\text { base. }\end{array}$ & $\begin{array}{l}\text { As in R. octo- } \\
\text { punctata. }\end{array}$ & $\begin{array}{l}\text { Each of } 4 \text { oral } \\
\text { tentacles, } \\
\text { branches dichot- } \\
\text { omously } 6 \text { to } 8 \\
\text { times. }\end{array}$ & $\begin{array}{l}\text { Each of } 4 \text { or al } \\
\text { tentacles } \\
\text { branches } \\
\text { dichoto- } \\
\text { mously }+ \text { to } \\
5 \text { times. }\end{array}$ & $\begin{array}{l}\text { Branched, } \\
\text { dichoto- } \\
\text { mously } \\
3 \text { to } 4 \\
\text { times. }\end{array}$ & $\begin{array}{l}4 \text { simple, } \\
\text { unbranch- } \\
\text { ed. }\end{array}$ \\
\hline $\begin{array}{l}\text { Form } \\
\text { and } \\
\text { size of } \\
\text { manu- } \\
\text { brium. }\end{array}$ & $\begin{array}{l}\text { A short, conical } \\
\text { peduncle about } \\
\text { half as long as } \\
\text { stomach. Both } \\
\text { together half to } \\
\text { two-thirds as } \\
\text { long as depth } \\
\text { of bell-cavity. }\end{array}$ & $\begin{array}{l}\text { Peduncle } \\
\text { about as long } \\
\text { as stomach. }\end{array}$ & $\begin{array}{l}\text { Peduncle about as } \\
\text { long as stomach. } \\
\text { Both together } \\
\text { about half as } \\
\text { long as depth of } \\
\text { bell-cavity. }\end{array}$ & $\begin{array}{l}\text { Peduncle } 1.5 \\
\text { times as long } \\
\text { as stomach. } \\
\text { Both to- } \\
\text { gether about } \\
\text { two-thirds as } \\
\text { long as depth } \\
\text { of bell-cavity. }\end{array}$ & $\begin{array}{l}\text { Peduncle not } \\
\text { quite as long as } \\
\text { stomach. }\end{array}$ & $\begin{array}{l}\text { Peduncle } \\
\text { about as long } \\
\text { as stomach. } \\
\text { Both together } \\
\text { about half as } \\
\text { long as } \\
\text { depth of bell- } \\
\text { cavity. }\end{array}$ & $\begin{array}{l}\text { As in } \mathrm{R} \text {. } \\
\text { octone- } \\
\text { malis. }\end{array}$ & $\begin{array}{l}\text { As in } R \text {. } \\
\text { octopunc- } \\
\text { tata. }\end{array}$ \\
\hline Gonads. & $\begin{array}{l}8 \text { (?) interradial. } \\
\text { No medusa-buds } \\
\text { observed. }\end{array}$ & $\begin{array}{l}4 \text { interradial. } \\
\text { When young, } \\
\text { medusa pro- } \\
\text { duce medusa- } \\
\text { buds. }\end{array}$ & $\begin{array}{l}\text { When young, } \\
\text { medusa-buds } \\
\text { developed in } \\
\text { the \& interradii } \\
\text { of stomach. } \\
\text { When older, this } \\
\text { budding ceases } \\
\text { and sexual pro- } \\
\text { ducts develop. }\end{array}$ & $\begin{array}{l}\text { As in R.octo- } \\
\text { punctata. } \\
\end{array}$ & $\begin{array}{l}4 \text { perradial gon- } \\
\text { ads, each gonad } \\
\text { forming a cres- } \\
\text { cent around } \\
\text { place of en- } \\
\text { trance of radial- } \\
\text { canal into } \\
\text { manubrium. }\end{array}$ & $\begin{array}{l}4 \text { interradial } \\
\text { horse-shoe- } \\
\text { shaped. No } \\
\text { medusa- } \\
\text { buds. }\end{array}$ & $\begin{array}{l}\text { Interradial } \\
\text { No } \\
\text { medusa- } \\
\text { buds. }\end{array}$ & $\begin{array}{l}\text { As in R. } \\
\text { octopunc- } \\
\text { tata. }\end{array}$ \\
\hline Color & $\begin{array}{l}\text { Tentacle-bulhs } \\
\text { brownish-yellow. } \\
\text { Stomach straw- } \\
\text { colored. Gonads } \\
\text { and tentacles } \\
\text { nilky-white. }\end{array}$ & ? & $\begin{array}{l}\text { Entoderm of } \\
\text { stomach and } \\
\text { tentacle-bulbs } \\
\text { ranges from } \\
\text { brownish-green } \\
\text { to black. }\end{array}$ & $\begin{array}{l}\text { Entoderm of } \\
\text { stomach and } \\
\text { tentacle- } \\
\text { bulbs ranges } \\
\text { from brown- } \\
\text { isb-green to } \\
\text { orange. }\end{array}$ & $\begin{array}{l}\text { Entoderm of } \\
\text { stomach and } \\
\text { tentacle-bulbs } \\
\text { red to brown- } \\
\text { ish-red. }\end{array}$ & $\begin{array}{l}\text { Brownish-red } \\
\text { as in R.fasci- } \\
\text { culata. }\end{array}$ & $\begin{array}{l}\text { Stomach } \\
\text { bright- } \\
\text { green, } \\
\text { tentacles } \\
\text { and canal } \\
\text { system } \\
\text { pearly- } \\
\text { pink. }\end{array}$ & $\begin{array}{l}\text { Stomach } \\
\text { and ten- } \\
\text { tacle- } \\
\text { bulbs } \\
\text { amber to } \\
\text { yellow. }\end{array}$ \\
\hline $\begin{array}{l}\text { Where } \\
\text { found. }\end{array}$ & $\begin{array}{l}\text { Black Sea, Russia. } \\
\text { Sebastopol, } \\
\text { April. }\end{array}$ & $\begin{array}{l}\text { Falkland } \\
\text { Islands, } \\
\text { Atlantic coast } \\
\text { of South } \\
\text { America. }\end{array}$ & $\begin{array}{l}\text { Arctic Ocean and } \\
\text { North Atlantic } \\
\text { coasts of Europe } \\
\text { and America. }\end{array}$ & $\begin{array}{l}\text { Atlantic coast } \\
\text { of North } \\
\text { America, } \\
\text { north of New } \\
\text { Jersey. }\end{array}$ & Mediterranean. & $\begin{array}{l}\text { Malay Archi- } \\
\text { pelago. }\end{array}$ & $\begin{array}{c}\text { Tortugas, } \\
\text { Florida. }\end{array}$ & $\begin{array}{l}\text { Coasts of } \\
\text { Great } \\
\text { Britain, } \\
\text { France, } \\
\text { and Ger- } \\
\text { many. }\end{array}$ \\
\hline $\begin{array}{l}\text { Distinct- } \\
\text { ive } \\
\text { char- } \\
\text { acters. }\end{array}$ & $\begin{array}{l}\text { Distinguished by } \\
\text { pinnate, oral ten- } \\
\text { tacles and short } \\
\text { peduncle. These } \\
\text { may be errone- } \\
\text { ously described } \\
\text { by Ratbke, and } \\
\text { medusa is proba- } \\
\text { bly identical witl } \\
\text { R. octopunctata. }\end{array}$ & $\begin{array}{l}\text { Pinnate, oral } \\
\text { tentacles, } \\
\text { and large } \\
\text { number of } \\
\text { marginal ten- } \\
\text { tacles. Is } \\
\text { this identical } \\
\text { with R. octo- } \\
\text { punctata? }\end{array}$ & $\begin{array}{l}\text { Oral tent acles } \\
\text { forked, and pro- } \\
\text { vided with later- } \\
\text { al nematocyst- } \\
\text { knob; thus con- } \\
\text { bining charac- } \\
\text { ters of pinnate } \\
\text { and dichoto- } \\
\text { mous tentacles. }\end{array}$ & $\begin{array}{l}\text { An American, } \\
\text { local variety } \\
\text { of O.octo- } \\
\text { punctata. }\end{array}$ & $\begin{array}{l}\text { Dichotomous, } \\
\text { oral tentacles. } \\
\text { Large number } \\
\text { of marginal } \\
\text { tentacles. }\end{array}$ & $\begin{array}{l}\text { Very small } \\
\text { basal stalks } \\
\text { of dichoto- } \\
\text { mously } \\
\text { branched } \\
\text { oral tentacles. } \\
\text { Small num- } \\
\text { ber of mar- } \\
\text { ginal tenta- } \\
\text { cles. }\end{array}$ & $\begin{array}{l}\text { Brilliant } \\
\text { green } \\
\text { colora- } \\
\text { tion. } \\
\text { Dichoto- } \\
\text { mous } \\
\text { oral ten- } \\
\text { tacles. }\end{array}$ & $\begin{array}{l}\text { Simple, un- } \\
\text { branched } \\
\text { oral ten- } \\
\text { tacles. }\end{array}$ \\
\hline
\end{tabular}


According to Gegenbaur, 1854 (Generationswechsel Polypen und Medusen, pp. 22-28, Taf. 2, fign. I-9), the egg of Rathkea fasciculata develops into a solitary polyp covered with a horny peritheca and provided with 4 tentacles. The segmentation stages were studied by Metschnikoff, I 886.

The oral tentacles in the young medusx are unbrancbed, but in the majority of the species they become forked as growth proceeds. In Rathkea blondina (Ioizzia blondina Forbes) they remain simple and unbranched throughout life. It appears hest, however, not to separate Lizzia from the older genus Ratikea on the ground that lizzia has simple tentacles throughout its life, for all of these medusæ have simple oral tentacles when young and their forked character in later life may better be considered specific rather than generic.

\section{Rathkea blumenbachii Brandt.}

Oceania blumenbachit, Ratнкё, 1835 , Mém. Acal. Imp. Sci. St. Pétersbourg, tome 2, p. 321, taf. 1, fign. 1-4.

(?) Cvfiris ocropunctata, SARs, 1835 , Beskriv og Jagttag, p. 28 , plate 6, figs, $14 a^{-1} 4$ g.

Rathkia blumenbachiana, Brandt, 1837 . Bull. Sci. Acad. St. Petersbourg, vol. 1, No. 24, p. 187. Also: R. oreaniablumenbachii, 18,8 , Mèn. Acad. Imp. Sci. St. Pétersbourg, sér. 6, tome 4, p. 353.

Rathkea blumenbachii, Haccsis, 1879 , Syst. der Medusen, p. 96.

Rathkea blumenbarhi, Bгоnт, 1905, Revue Suisse de Zool., tome 13, p. 144 (literature 1835-50).

This medusa has a pyritorm hell with thick, gelatinous walls. Bell-cavity about two-thirds as deep as the bell-height. 8 marginal clusters, eacb with 3 tentacles all of equal length and as long as the bell-height. 4 radial-canals. Stomach mounted on a short, conical peduncle. Stomacb and peduncle together are about one-half to two-thirds as long as the depth of the bell-cavity. 4 radially placed, oral tentacles, each of which forks at its end and gives rise also to 4 sbort, side brancbes, 2 on each side of the tentacles. 8 gonads (?) No medusa-buds. Stomacb and tentacle-bulbs brownish-yellow. Sebastopol, Russia, in April.

For further description, see synoptic table of species of Rathkea.

Rathke's drawing is inaccurate in showing 8 radial-canals. The + interradial radiating muscle strands were doubtless mistaken for radial-canals. I am inclined to suspect that this medusa may be identical with the better-known Rathken ortopunctata.

\section{Rathkea formosissima.}

Lizzia formosissima, Browne, 1902, Annals and Mag. Nat. Hist., ser.7, vol. 9, p. 278.

Umbrella bell-sbaped, $3 \mathrm{~mm}$. high and $2.5 \mathrm{~mm}$. hroad, with a sligbt, transverse constriction level with the top of the subumbrella cavity and a solid mass of jelly above it. 5 tentacles in each radial, and 3 in each interradial, cluster. Stomach small, somewhat cubical, a hout as long as broad, and situated on a broad peduncle about as long as the stomach. Mouth with a plain, simple margin, somewhat quadrangular in shape. There are + oral tentacles, each with 7 to 11 clusters of nematocysts consisting in a terminal cluster and 6 to Io lateral clusters in a double row. Gonads on the stomach in + interradial, roundish swellings or masses. The young medusa have medusa-buds upon the stomacb and only 3 tentacles in each group. Color (?) Found at Stanley Harbor, Falkland Islands, South Atlantic coast of South America.

\section{Rathkea octopunctata Haeckel. \\ Plate 20, fig. 11.}

(?) Oceania blumenbachii, Ratık $5,18_{35}$, Mèm. Acad. Imp. Sci. St. P'tersbourg, tome 2, p. 321,4 figs.

Cytuis (?) ocropunctata, SARS, 1835 , Beskriv og Jagttag, p. $2 R$, plate 6, figs. $14 a^{-1} 4$.

Cyceis octopunctata, SARs, 1846, Fauna Littor. Noveg., tome 1, P. 10, plate 4, figs. 7-13.- I.1Nko, 1900, Travaux Soc. IInp. des Nat. de Si. Peitersbourg, tome 29, p. 152, fig. 2.

Hippocrene octopunctata, For b.s, 1841 , Ann. and Mag. Nat. Hist., vol. 7,1 . 84 .

Bougainzillia ocropunctafa, lesson, 1843. Hist. Zooph. Acal., p. 292.

Lizmia octopunctata, Foraes, 1848 , British Naked-eyed Meduse, p. 64, plate 12, figs. 3 a to 3e.-Ariassiz, 1.., 1862 , Cont. Nat. Hist. U.S., vol. 4, P. 345.-VAN BENEDEN, 1867 , Mém. de l'Acad. Belgique, tome 36, p. 94 , plate 3, figs. 7-13 (?Circe hyalina, p. 95, plate 3 , fig. 14).-Bонм, 1878 , Jenaische Zelt. fur Naturw., Bd.12, p. 186, taf. 4-6, fign. 1-4.- Frwkrs, 188, Mem. Mus. Comp. Zool. at Harvard College, vol. 9. No. 3, plate 5, figs. 20-22.-M'Intosis, 189o, Ann. and Mag. Nat. Hist., ser. 6, vol. 5. p. 298.

Margellium ortopunctatum + Rathkea oclopunctata, Hafckri, 1879. Syst. der Medusell, pp. 95, 97.

Lizaia grala, Frwkrs, 1881, Bull. Mus. Comp. Zool. at Harvard College, vol. 8, p. 142, plate 1, figs. 1-7.

Rathkea octopunctata, Chun, 1895, Bibliotheca \%oologica, Atlantis, Heft 19, I.fg. 1, pp. 15, 17, 24, taf. 2, fign. 1-13.

Margellium ociopunctatum, Browne, 1896, Proc. Zool. Soc. London, p. 477; 1895, P'roc. and Trans. Liverpool 13iol. Soc., vol. 9. p. 270.-Linko, 1904, Zool. Anzeiger, Bd. 28, p. 216. 
Rathken octopunctata, GiARd, I888, Bull. Sci. France Belg., sẻr. 3, année I, p.317, plate 21.-Chun, I896, Bronn's Thier-Reichs, Bd. 2, Abth. 2, p. 253, taf. 12 (development of medusa-buds).-BeDor, 1905, Revue Suisse de Zool., tome 13, P. 145 (all papers cited to 1850 ).

Margellium octopunctarum, Brow:ve, 1903, Bergens Museums Aarbog, No. 4, p. 15; 1905, Proc. Royal. Soc. Edinburgh, vol. 25, p. 755 .

Cubogaster gemmascens, Ha हckel, 1879, Syst. der Medusen, P. 76, taf. 6, figs. 8-1 I (young budding medusa with only 2 marginal tentacles).

Adult medusa.-Bell pyriform, with solid, apical projection, and about $5 \mathrm{~mm}$. in height and $4.5 \mathrm{~mm}$. in diameter. Gelatinous suhstance thick at the apex of the bell, hut thin upon sides of bell-cavity. There are 8 clusters of marginal tentacles. 4 of these are radial and are situated at the bases of the 4 radial-canals, and the 4 others are interradial and are situated $45^{\circ}$ from the radial clusters. In the fully-grown medusa there are usually about 4 or 5 tentacles in each radial cluster, while the interradial clusters are each composed of not more than 3 tentacles. When the medusa is not yet fully grown, however, there a re normally 3 tentacles in both radial and interradial clusters. Tentacle-bulbs large and swollen and filled with entodermal pigmentgranules. Velum well developed. There are 4 straight, narrow radial-canals. The manubrium is provided with a distinct peduncle which, however, does not extend more than onethird of the distance from the inner apex of the bell-cavity to the velar opening. The gastric portion of the manubrium is short and quadratic in cross-secrion. The mouth is surrounded by 4 prominent lips. Each lip terminates in a pair of oral tentacles each of which ends in a knob-shaped cluster of nematocysts. In addition to these there is also a pair of knob-shaped clusters of nematocysts upon the sides of each lip, centripetal to the terminal knobs. Medusabuds are developed upon the sides of the manubrium about the region of the stomach. These medusa-buds appear on interradially situated positions on the stomach-wall. According to Chun (1895. Bibliotheca Zool., pp. 20, 21) the order of development of the medusa-buds follows a very definite law. The oldest buds appear nearest the peduncle of the manubrium and the youngest are found lower down nearer the oral tentacles. The accompanying diagram will serve to illustrate the law of succession in position and in time of the various buds upon the manubrium ( 1 ) being the oldest bud and (16) the youngest (newest).

3, 7, 11, 15, $16,12,8,4 \quad$ The oldest buds are developed near the proximal base of the stomach, and the newest and youngest are found near the hases of the oral tentacles. Even before they are set free the young medusa begin to develop buds on their stomach-walls, and these secondary medusa-buds follow the same laws of time and place of development as do the primary medusa-buds (see Chun, 1895, p. 23). Chun, 1895, showed that the medusa-huds were formed entirely from the ectoderm of the manubrium, the entoderm taking no part in their development. As the bud becomes older, however, a connection is formed between its gastrovascular cavity and that of the mother medusa. The developing medusa-bud has, at first, only 4 radial tentacles, one at the base of each radial-canal. When set free, however, it possesses 16 tentacles: 4 clusters each of the 3 tentacles at the bases of the 4 radial-canals; and also + simple interradial tentacles. The color of the entoderm of the manubrium and tentacle-bulbs varies from hrowngreen to black.

This medusa is common in the north Atlantic, where it has heen taken off the coasts of Norway, Barents Sea, Helgoland, England, Ireland, Scotland, and New England. Fewkes found it in Narragansett Bay, Rhode Island, and it is common on the southern coast of New England in March. Browne records this species from Valencia Harbor, coast of Ireland. Levinsen, 1893 , found it off the west coast of Greenland. I helieve that future studies will show that $R$. Bumenbachii of the Black Sea is identical with $R$. octopunctata. The drawing of the oral tentacles of $R$. blumenbachii in Rathke's memoir is evidently diagrammatic and probably quite erroneous. $R$. blumenbachii appears to be merely an $R$. octopunctato in an intermediate stage of growth wherein it has 3 tentacles in each of its 8 marginal clusters. 
Rathkea octopunctata var. grata A. Agassiz.

Plate 18, fig. 5 .

Lizzia grafa, Agassiz, A., 1862, Proc. Boston Soc. Nat. Hist., vol. 9, p. 100, figs. 28, 29; 1865, North Amer. Acal., p. 16i,

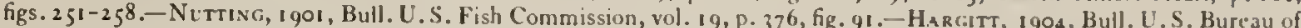
Fisheries, vol. 24, p. 39, plate 1, fig. 4 .

Non Lizzia grata, Fewkes, 1881, Bull. Mus. Comp. Zool. at Harvard College, vol. 8, No. 8, p. 142, plate 1, figs. 1-7.

Margellium gratum, Hafckel, 1879 , Syst. der Medusen, p. 95.-L. Fvivsen, 1893. Vut. Meddel. Nat. For. Kjöbenhavil (5), I3d. 4, P. 145 .

Adult medusa (plate 18 , fig. 5).- Bell about $3.5 \mathrm{~mm}$. in height and $3 \mathrm{~mm}$. in diameter; pyriform in shape, and with well-developed apical projection which is solid. The gelatinous suhstance is thick at the apex of the bell, but thin upon the sides. There are 8 clusters of marginal tentacles, + radial and + interradial. The radial clusters are each composed of 5 tentacles, while the interradial clusters contain only 3 tentacles each. The tentacles are long and Hexible and are usually carried curled upward. The basal bulbs are large and filled with entodermal pigment-granules. The velum is well developed. There are + slender, straight radial-canals. The peduncle of the manubrium is long and extends about two-thirds of the distance from the apex of the bell-cavity to the velar opening. The gastric portion of the manubrium is small, and quadratic in cross-section. There are + prominent lips, each of which terminates in a pair of oral tentacles which end in knob-shaped clusters of nematocyst-cells. There is also found a pair of knol)-shaped nematocystic clusters upon the sides of each lip.

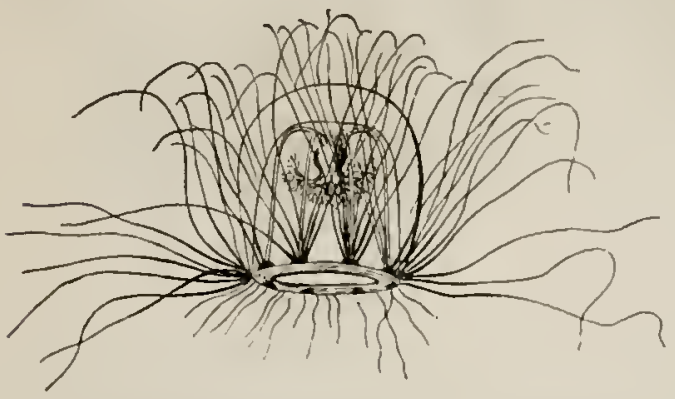

Fic.93.-Rathkea"kollikeri," = R. fasciculata, after Gegenbaur, in Zeit. für wissen. 7.0ol., Bal. $\$$. Medusa-buds are developed in the interradii upon the sides of the manubrium. The entoderm of the tentacle-bulbs and manubrium is usually intense orange, but in some cases the stomach is sage-green and the tentaclebulbs russet.

Young medusa.- In a medusa $1.2 \mathrm{~mm}$. in height there are 16 tentacles: + radial clusters each consisting of 3 tentacles and 4 simple, interradial tentacles. The peduncle is long and has the shape of the frustum of a cone. The stomach is short and there are $t$ simple lips which terminate each in a single knob-shaped cluster of nematocyst-cells. No medusa-buds are yet to be seen upon the manubrium.

The medusa-buds upon the manubrium of the adult have at first only + simple tentacles. one at the foot of each radial-canal. At this stage there are also + small interradial tentaclehulbs, which lack tentacles. It is not known what condition the medusa-buds may le in at the time of their liberation from the parent.

This variety is probably an Arctic form. It appears in Newport Harbor, Rhode Island, and in Massachusetts Bay during February, and disappears before June.

It is distinguished from the European and American I.. octopunctata by its color and the great length of the peduncle of the manubrium. Also the medusa-buds do not seem to make their appearance until some time after the liberation of the young medusa, while in lizzin octopuntatn they develop upon the stomach of the roung medusa while it is ret attached to its mother.

\section{Rathkea fasciculata Haeckel.}

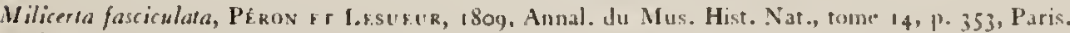

Köllikeria fasciculata, AGassiz, I.., 1862, Cont. Nat. Hist. 17. S., vol. 4, P. 345.

Rathkea fasciculata, Hafckel, 1879, Syst. der Medusen, p. 97.-Metschisikuf, F... 1886, Arbeit. Zool. Inst. Wien, Bil. 6, P. 239.- Metschniknz', 1886, Embryol. Studien an Medusen, Wien, pp. 23 (egg), 37 (segmentation), 48 (formation of entoderm), taf. 1, fign. 18-31.-Mses, 1897, Mem. Mus. Comp. Kool. at Harvard College, vol. 23, p.16; 19o4, Result Camp. Sci. Prince de Monaco, fasc. 28, p. 10.-Bfbot, 1901, Revue Suisse de Zool., tome 9, P. +86 ; Ibid., 1905, tome 13, p. 145 (all literature to 1850 ).

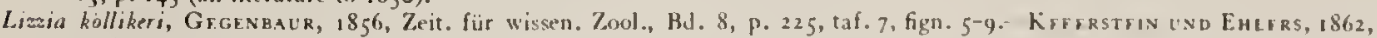
Zoolog. Beitrag, p. 84 , taf. 13, fig. 10.

Bougainvillia källikeri, Lfucx a RT, 1856 , Archiv. fur Naturgesch., Bd. 22, p. 24. taf. 2, fig. 2. 
This large Mediterranean form is described in the synoptic table of species of Rathkea. Gegenbaur, 1854 (Generationswechsel und Fortplanz. bei Medusen, etc., p. 22, taf. 2, fign. I-9), raised the larva until it developed into a solitary hydroid, $0.5 \mathrm{~mm}$. long, with 4 tentacles, each beset with a row of nematocysts. A horny perisarc covered the hydrorhiza.

The stages of segmentation were studied by Metschnikoff, I 886 . The egg is $0.1 \mathrm{~mm}$. wide and yellowish to white in color. The segmentation is total and equal, and results in the formation of an elongated, ciliated, one-layered blastula with a large, central, segmentation cavity. The ectoderm is formed by the cells which wander into the segmentation cavity by ingression from the hinder end of the larva.

The medusa is quite common at Naples, Italy, during the winter. The bell is barrelshaped with a flatly-rounded apex. It is $8 \mathrm{~mm}$. high and $9 \mathrm{~mm}$. wide. The marginal tentacles are highly contractile. There are 10 to 13 tentacles in each of the 8 clusters. Each

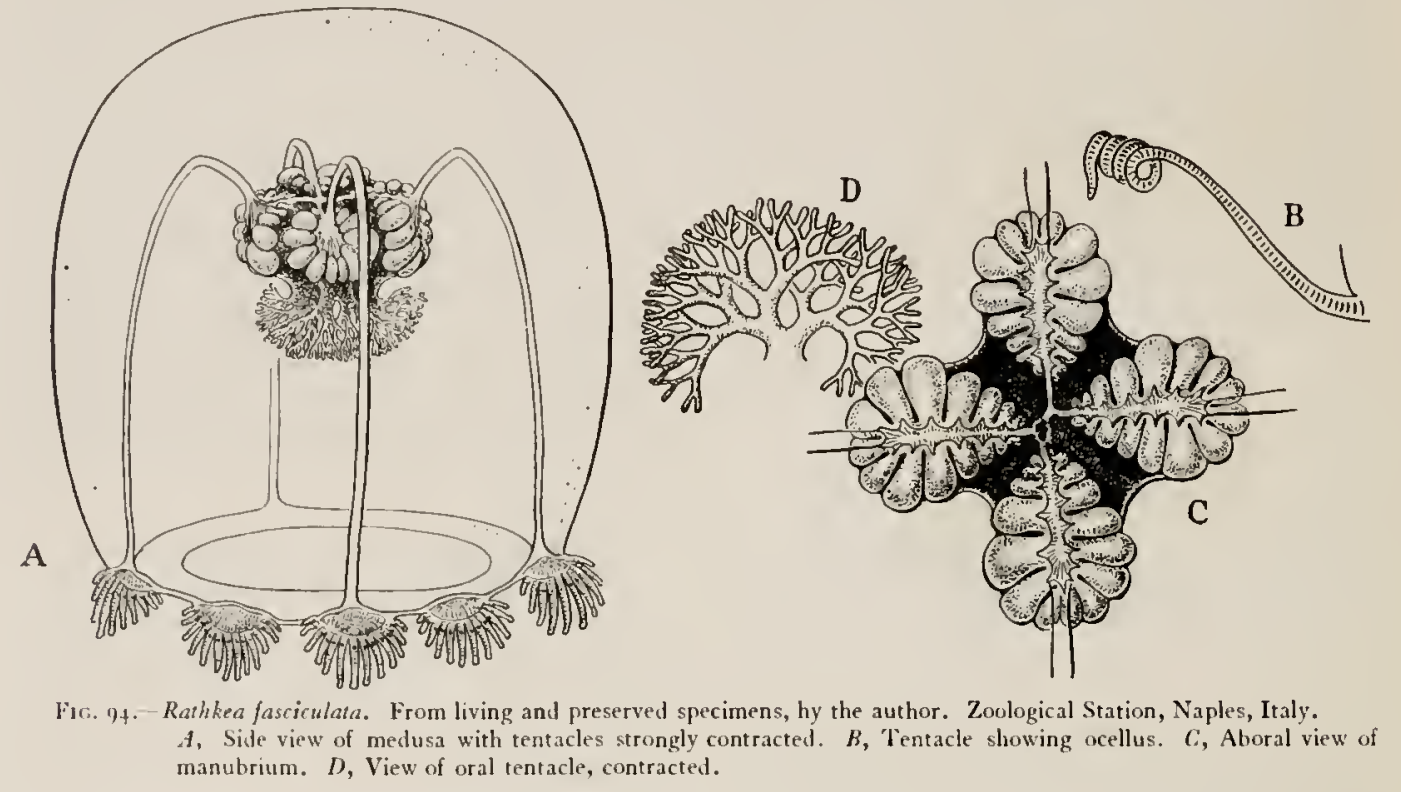

tentacle bears an ocellus on its inner side. The oral tentacles branch dichotomously 7 times. Whenever the medusa is disturbed by a mechanical shock the oral tentacles suddenly expand to their full extent, forming a network of filaments around the mouth, and thus it is seen that through this fortuitous reaction the medusa captures its prey. Such a reaction is remarkable, for in common with other medusx all other parts of the animal contract when disturbed.

The 4 gonads form horseshoe-shaped, swollen crescents with transwerse furrows. Each crescent surrounds the point of entrance of the radial-canal into the stomach and the horns of the crescent are directed aborally. There are thus 4 perralial gonads. This heing the only instance of perradial gonods seen in the anthomedusx.

Rathkea octonemalis Maas.

Rahkea octonemalis, MaAs, 1905, Craspedoten Medusen der Siboga Expedition, Monog. 10, p. 12, 1af. 2, fign. $11,12$.

(? P) Lizzella octella, Hafckel, 1879, Syst. der Medusen, p. 84 .

Bell 5 to $6 \mathrm{~mm}$. high, 4 to $5 \mathrm{~mm}$. wide, with thick, gelatinous walls, hulging sides, and flat top. There are 8 clusters of marginal tentacles. 7 to 9 tentacles in each of the 4 radial, and 5 to 7 tentacles in each of the 4 interradial clusters. These tentacles are not one-fourth as long as the bell-height, and there is a black ectodermal ocellus upon the inner side of each tentacle near the point of origin of the tentacle from the basal butb.

The 4 radial-canals and the ring-canal are straight, narrow, and simple. The stomach is mounted upon a short, wide, conical peduncle. The mouth is surrounded by 4 clusters of oral tentacles. Each cluster arises from a short hasal stalk and branches dichotomously 4 to 5 times. The basal stalks of these clusters are so short and the forked branches so long that the mouth appears at first sight to be surrounded by 8 clusters of tentacles. This impression is, however, erroneous, for there are but 4 clusters of oral tentacles. The mouth does not 
extend to the level of the velar opening. The gonads are on the 4 interradial sides of the stomach. They are doubly cleft in each interradius so as to present the appearance of 4 longitudinal bands below, but are fused above, forming a double horseshoe. The tentaclebulbs have decided red, entodermal pigment. The stomach is reddish-brown and the eggs appear as flecks of yellow.

Found in the Malay Archipelago, Ternate, $3^{\circ} 46^{\prime} \mathrm{S}$. lat., $127^{\circ} 47^{\prime}$ long. E. from Greenwich.

It is possible that Lizzella octella Haeckel may be identical with this species. Haeckel gives a very brief description of this medusa as follows: Bell egg-shaped, $15 \mathrm{~mm}$. high, $10 \mathrm{~mm}$.

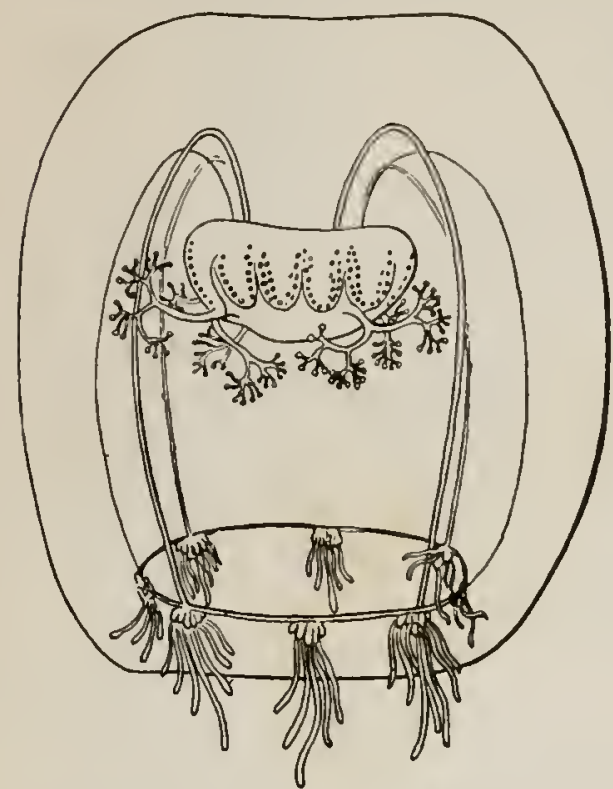

Fic. 95.-Rathee occonemalis, after Maas, in Hydromedusen Siboga Expedition. wide. Stomach globular or almost cubical, about as long as its conical peduncle. Gonads 4 -feathered leaves in the stomach-walt. 8 simple, unbranched, oral tentacles as long as the stomach. (Broken?) 8 marginal tentacle clusters, each with 8 long tentacles. Coast of Japan. Color (?)

\section{Rathkea elegans.}

Plate 18, fig. 4 .

I.izzin elegans, Marrr, 1900, Bull. Mus. Comp. Zool. at Harvaral College, vol. 37 , P. 44 , plate $3^{8,}$ fig. 127 .

Bell 3 to $7 \mathrm{~mm}$. in height and gelatinous substance of moderate and nearly uniform thickness. The sides of the bell are almost straight and vertical and the top is dome-shaped. There are 8 groups of marginal tentacles, 4 radial and 4 interradial. Each radial group is composed of 4 , and each interradial of 3 tentacles. The tentacles are quite stiff and curve upward and are only ahout half as long as the bell-height. There is a small, darkbrown, ectodermal ocellus upon the under (velar) side of each tentacle near the basal bulb. The velum is wide and provided with strong muscles. There are 4 straight, narrow radial-canals and a simple circular vessel. There is a well-developed, conical peduncle above the stomach, down which the radial-canals lead in their course to the gastric sac. The gastric part of the manubrium is cruciform in cross-section and pear-shaped in general longitudinal contour. The mouth is a simple opening without prominent lips. The oral tentacles arise from + radial sides of the stomach at a short distance above the mouth. Each tentacle branches dichotomously 3 times, and then each tip terminates in 3 small branches which are covered with nematocysts. The entodermal cells of the oral tentacles are chordate. The genital products are situated upon the four interradial sides of the stomach.

The entoderm of the tentacle-bulbs and radial-canals is of an intense, opaque, pearlywhite color, often displaying a tinge of pink. The entoderm of the stomach is of an intense green, and the oral tentacles a re pearly-pink. "The intense opaque color of the radial-canals contrasting with the hyaline transparency of the bell renders this medusa one of the most beatutiful found at the Tortugas, Florida. Several specimens were captured early in July, 1899.

\section{Rathkea blondina.}

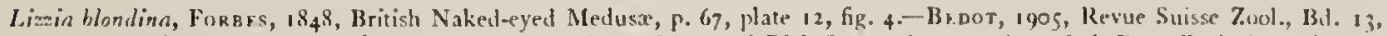
P. 137 (literature $1848-50$ ). - Browne, 1895 , Trans. Liverpool Biol. Soc., vol. 9. p. 265 ; 1896, Proc. \%oul. Suc. of 1.ondon for $1896, \mathrm{p} .47 \mathrm{~S}$ (review of recent literature, etc.); 1898 , Journal Marine Biol. Assoc., N. S., vol. 5, p. 188.-(Fornas), Browni, 1896, Proc. Zool. Soc. London, p. 475

Lizia, sp., Claparipe, i860, Zeit. für wissen. Zool., Bd. 10, P. 401, taf. 32 , fign. I-3.

Dysmorphosa minima (young stage) + Lizzia cluparedeit L. blondina, Hafckfi, 1879. Syst. der Medusen, pp. $78,82$. taf. 6, fig. 7 .

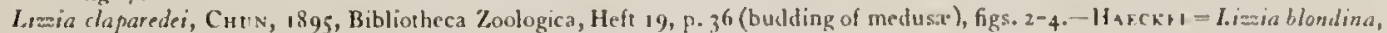
Fornes, Brownf, 1905 , Proc. Roy. Soc. Edinburgh, vol. 25, p. 754 .

(?) Lizia elizabethie, Harckri, 1879 , Syst. der Meducen, p. 83 , taf. 6, fig. 12.

D) ysmorphosa minima (young medusa), Brownf, 1895, Trans. Livernool Brol. Soc., vol. 9, p. 260.

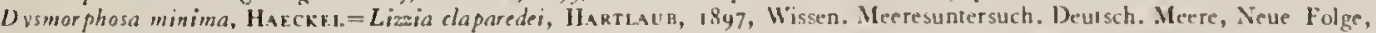
Abtl. Helgoland, Bul. 2, p. 455.-Hafckrt=Lizia claparedei, Broch, 1905, Bergens Museum Aarbog, vol. II, P. 5 . 
Mature medusa.-Bell $6 \mathrm{~mm}$. high, $4 \mathrm{~mm}$. wide. Pyriform. There are 3 tentacles in each of the 4 radial, marginal clusters and only one tentacle in each interradius. The stomach is mounted upon a short peduncle, and both together are hardly half as long as the depth of the bell-cavity. There are 4 radially placed, simple, unbranched, oral tentacles, each of which terminates in a knob-like cluster of nematocysts and is as long as the stomach itself. When immature the medusa produces medusa-buds upon the interradial sides of the stomach, but later, when there are 3 tentacles in each radial cluster, the budding ceases and ova or sperm develop. Claparède discovered that the eggs are inclosed in nenratocyst-bearing capsules, reminding one of the condition observed in Bongainvillia superciliaris. Browne states that the medusa may become sexually mature when the bell is only $1.5 \mathrm{~mm}$. high. The stomach, gonads, and tentacle-loulbs are amber-yellow. Found off the coasts of England. Ireland, Scotland, Germany, and Norway.

When the medusa is young there are only 8 marginal tentacles, 4 radial and + interradial. Later there are + radial clusters, each consisting of 2 tentacles, and 4 smaller, isolated, interradial tentacles. Medusa-buds are produced upon the interradial sides of the stomach, when the medusa has only 8 tentacles. The 4 oral tentacles remain simple and unbranched throughout life.

Lizzia clizabether Haeckel resembles $R$. blondina in all respects excepting that there are + tentacles in each radial, and 2 in each interradial cluster. Haeckel found this at Jersey, English Cliannel. May it not be $R$. blondina with more than the usual number of tentacles?

Browne found a 3 -rayed specimen of $R$. blondina, with 3 radial-canals, 3 oral tentacles 3 clusters of "perradial "tentacles each containing 2 tentacles and 3 single interradial tentacles

Genus CHIARELLA Maas, 1897.

Chiarella, Mats, 1897, Mem. Mus. Comp. Zool. at Harvard College, vol. 23, p. 15.

The type species and the only known form is Chiarella centripetalis Maas, from the Gulf of California, Pacific coast of Mexico.

\section{GENERIC CHARACTERS.}

Margelinx in which the ring-canal gives rise to lolindly ending, centripetal diverticula, There are 8 cleft tentacle-clusters, so that the tentacles arise from i 6 epaulet-shaped. marginal swellings. 4 of these cleft tentacle-clusters are radial, and 4 interradial in position. The oral tentacles are dichotomously branched.

This genus is chiefly distinguished by the hlindly-ending diverticula of the marginal ring-canal. The deeply-cleft tentacle-epaulets are quite characteristic, but this tendency is also seen in some species of Bongrinvillia and can not be considered as being a distinguishing characteristic of Chiarella, although it appears in a more marked degree in Chiarella than in Bongaimeillin.

\section{Chiarella centripetalis Maas.}

Chiarella centripetalie, MA45, 1897, Mem. Mus. Comp. Zool. at Harvard College, vol. 23, p. I5, taf. 2, fign. 1-4; 1905, Craspeduten Medusen der Siboga Expedition, Monog. 10, p. 1,3.

Bell high and dome-like, I 5 to $20 \mathrm{~mm}$. high, 10 to $15 \mathrm{~mm}$. wide. Gelatinous substance of slight consistency and fairly thick at apex, hut thin at margin. Velum small. Bell-margin exhihits 8 adradial, lappet-like emarginations which alternate with the radial and interradial clusters of tentacles. The tentacles are very short, not more than one-tenth as long as the bell-height and arising from 8 medianly cleft, marginal, epaulet-shaped swellings. The median cleft in each tentacle-epaulet is so deep that the epaulet seems divided. 4 of these divided epaulets are radial and + interradial in position. In the mature medusa there are somewhat more than 40 tentacles in a single row on each double-epaulet, the medusa having altogether about 320 tentacles. These tentacles arise side by side from the margin of the epaulets, and the line of tentacles is continuous and not interrupted at the median cleft. There is an ocellus upon the margin of the epaulet, on the velar side, at the base of each tentacle.

There are 4 straight-edged, narrow radial-canals and a ring-canal. This ring-canal gives off a short, pointed, blindly ending, centripetal diverticulum in each interradius above the median cleft of each interradial tentacle-epaulet. 
The stomach is barrel-shaped and about one-fifth as wide as the bell-diameter. It is not quite half as long as the depth of the bell-cavity and is mounted upon a very short peduncle down which the 4 radial-canals extend to the base of the stomach. There are 4 radially placed clusters of oral tentacles. Each cluster arises from a single stalk which branches dichotomously 5 to 6 times, thus giving somewhat more than 32 terminal ramuli in each

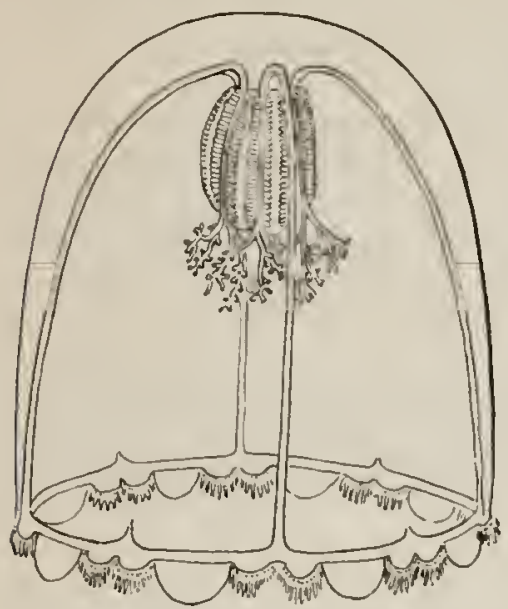

Fic. 96.-Chiarella centripetalis, after Maas, in Men. Museun Comp. Zool. at Harvard College.

4 lips are without oral tentacles. the stomach. quadrant. These terminal branches end in nematocystknobs.

The gonads are 8 adradial, linear swellings along the sides of the barrel-shaped stomach.

The entoderm of the radial-canals and tentacle-bulls is rose-red, as is also the deep-lying entoderm of the stomach. The gonads are dark-carmine and the ocelli dark-brown.

Found in the Gulf of California. Pacific coast of Mexico, by the Albatross in the spring of 1891 .

Subfamily DENDROSTAURINÆ, nov. subfam.

Buthotiaridat $/$ illiade, MA+5, 1904, Sitzungsber, math-phys. Klasse kul. Bayer. Akad. Wissenschaft., Bd.34,PP.437.438; Craspedoten Medusen der siboga Expedition, Monog. 10, pp. 15, 19.-Bigelaw, 1yon. Men.

Mus. Comp. Zool. at Harvard College, vol. 37, p. 212.

Cannotide (in part), Hickrt, 1879 , Syst. der Medusen, p. 140

\section{SUBFAMIII' CHARACIERS}

Dendrostaurinx: Anthomeduse with 4 or more primary radial-canals, some or all of which branch. The The gonads are upon the interradial, or actradial, sides of

There are two tribes, Brthotiaridi and Williadi.

The tribe Bythotiaricli was established by Maas, 1904, as the family Bythotiarida (Sit zungsber. math.-phys. Klasse kgl. Bayer. Akad. Wissenschaft., Bd. 34, p. 437; also, Craspedoten Medusen der Siboga Expedition, Monog. 10. p. 15). Maas pointed out its relationship to the Tiarina, which are exhibited most completely in the genus Bythotiara Gïnther, wherein the gonads are exactly similar to those of the "Fiarina, the only essential difference being the branched radial-canals.

The tribe Williadi as we define it is equivalent to the family. Williada of Forbes, Agassiz, Haeckel, Browne, Maas, and others.

In In04, loc. cit., Maas showed that the Cannotidxe of thaeckel, 1879 , was a heterogeneous group composed of both Anthomedus:e and Leptomedusa, and is, therefore, purely artificial and must be abandoned.

We will now proceed to define the tribes Bythotiaridi and Williadi and their genera.

CHARACIERS OF THE TRIBF, BYTIIOTIARIDI.

Dendrostaurine with branching radial-canals and a ring-canal. Without chusters of nematocysts upon the exumbrella above the margin between the tentacles. With hollow tentacles situated at the ends of the branches of the radial-canals. The conads are confined to the interradial sides of the stomach.

The Bythotiaridi are separated from the Williadi by the presence of a ring-canal and the absence of clusters of nematocysts upon the exumbrella.

In the genera Bythotiar and Sibogita the gonads are similar to those of the Amphinemidi and Pandardi of the Tiarina, for they consist of ridges in the ectoderm of the interradlial sides of the stomach. Unfortunately the development of these medusx is unknown, although a peculiar process of budding takes place in the tentacle-bullos of $N$ iobia and the same medusa is known to cast its eggs out into the water.

The genera of the tribe Bythotiaridi are as follows: Bythotiara Gïnther, 1903: with 4 radial-canals which bifurcate so that $\$$ canals reach the circular vessel. 8 marginal tentacles, 
one at the end of each terminal branch of the radial-canals. Gonads in 4 interradial ridges on the sides of the stomach. Manubrium with 4 simple lips. A single specimen found by Günther at a depth of 1,610 fathoms, N. lat. $52^{\circ} 18.1^{\prime}$, W. long. $15^{\circ} 53.9^{\prime}$.

Sibogita Maas, I904; with 4 principal radial-canals. Centripetal vessels arise from the ring-canal and fuse with the 4 radial-canals. These canals are of various calibers. The tentacles are hollow. The gonads are developed upon the 4 interradial sides of the manubrium in the form of a double row of transverse ridges in each quadrant. There are 4 simple lips.

S. geometrica Maas, 1905 (Craspedoten Medusen der Siboga Expedition, Monog. 10. p. 17, taf. 3, fign, 16-18.) A single specimen was found near the Celebes, Malay Archipelago. S. simulans Bigelow, I gog, from the Eastern Pacific.

Niobia Mayer, I900; with 4 main radial-canals, 2 of which bifurcate so that 6 radialcanals reach the circular vessel. The 4 gonads are developed upon the interradial sides of the stomach. The marginal tentacles develop into free-swimning medusæ. The only species is $N$. dendrotentacula of Tortugas, Florida.

Maas, 1904 , is inclined to include the genera Netocertoides and Dichotomia among the Bythotiaridi, but in these genera the gonads extend outward along the radial-canals and there are solid interradial cirrus-like tentacles upon the bell-margin; they appear, therefore, to be Leptomedusx.

\section{CHARACTERS OF THE TRIBE. WILIIADI.}

Williadre, Forres, 1848, British Naked-eyed Medusx, p. 19.-Agrassiz, A., 1865, North Amer. Acal., p. 171.-Harcker, 1879, Syst. der Medusen, p. I 56. - Brown F, 1904 l'auna and Geog. Maldive and Laccadive Archipelagoes, vol. 2, Pt. 3, p. 724 .MAas, 1904, Sitzungsber. math.-phys. Klasse kgl. Bayer. Akad. der Wissenschaften, Bd. 34, p. 43; 1905, Craspedoten Medusen Siboga Expedition, p. 19.-Hartlavk, 1907, Nordisches Plankton, Nr. 12, p. 5 .

Berenicidit' (sens. restr.), Agassiz, I.., I 862 , Cont. Nat. Hist. U.S., vol. 4, p. 345.

Hydrolaride, Allman, 1871, Monog. Tubularian Hyudroids.-D frage. et Herolard, 1901, Traité de Zool. Concrète, tome 2, Par. 2, Les Curlentėrés.

Dendrostaurinx with 4 or more primary radial-canals which, during the growth of the medusa, give rise to one or more side branches. Stomach with 4 to 6 or more lobes upon the interradial sides of which the gonads are situated. The tentacles are simple and hollow and are situated at the ends of the main radial-canals and their branches. There are clusters of nematocysts upon the exumhrella above the margin between the tentacles, and there is no ringcanal. These last two characters serve to distinguish the Williadi from the closely allied trihe Bythotiaridi.

The tentacles are never grouped into clusters, but arise singly from the bell-margin. There are neither cirri nor sensory clubs upon the bell-margin. The successive development of side branches which arise from the main radial-canals is a distinguishing feature of this tribe.

It has been shown by Hincks, 1872 , and Browne, 1896 , that the medusa of Willsia stellata Forbes develops by alternation of generations from the hydroid Lar sabcllarnm of Gosse, 1857 .

Brandt, 1838 , and Browne 1904 , found that there is no circular canal in Proboscidactyla and IIillsia, and in 1904 Browne showed that there is a tube under the clusters of nematocysts of the exumbrella. Isolated nematocysts move along the bell-margin and then enter one of these tubes and stop, and thus a cluster is formed by the accumulation of nematocysts.

For the Williadi we adopt the classification of Browne and Maas in the sense in which they define the Williadre. Thus:

Proboscidactyla, BRANDT, 1835. Williadi in which 4 primary radial-canals leave the stomach.

Willsia, FORB Es, 1846 , with 6 or more primary radial-canals leaving the stomach. The hydroid of $H$ '. stellato is Lar sabellarum.

It appears from researches of Hincks 1872 , Browne 1896 , 1904, and Maas 1904, that the Williadi belong among the Anthomedusa and not, as stated by Haeckel, among the Leptomedusa. For Browne, 1896 (Proc. Zool. Soc. London for 1896, p. 468), demonstrates that the medusa of Willsia stellata Forhes is derived from a hydroid which was first descrihed by Gosse, 1857, under the name of Lar sabellarum. The best description of Lar sabsllarum has however, been given by Hincks, 1872 (Ann. and Mag. Nat. Hist., ser. 4, vol. 10, p. 313, plate 19). The polypites are of two sorts and arise from a creeping hydrorhiza which is found grow- 
ing upou the tuhe of $S_{a b c l l a}$. The sterile feeding-polypites are fusiform and have but 2 tentacles, which arise from one side of the body. The reproductive polypites, or blastostyles, are mouthless and cylindrical in shape. Their free distal end terminates in a knob-like cluster of nematocysts. Several medusa-buds arise in a cluster from the side of the blastrostyle. The medus $x$ become free and develop into I'illsia stcllata of Forles, 1848 (p. 19, plate 1, fig. 1).

Tribe BYTHOTIARIDI.

Genus BYTHOTIARA Ginther, 1903.

Bybhotiara, Gunther, 1903, Annals and Mag. Nat. Hist., ser.7, vol. 11, P. 424.-MAss, 1yo5, Craspedoten Medusen der Siboga Exped., Monog. 10, p. 18.

The type species is Bythotiara murrayl Giinther, from a depth of 1,610 fathoms, off the southwest coast of Ireland.

\section{GENERIC CHARACTERS.}

With 4 (to 5 ?) radial-canals some or all of which bifurcate so that 8 (to) 10 ?) canals reach the circular vessel at the margin. Tentacles at the extremities of the terminal branches of the radial-canals. 4 interradial gonads, in the form of swollen ridges on the sides of the stomach. 4 (or 5 ?) simple lips. No longitudinal nematocyst tracts upon the exumbrella.

Bythotiara murrayi Ginther.

Bythotiara murayi, Güther, 1903, Annals and Mag. Nat. Hist., ser. 7, vol. 11, P. 424, plate 10, figs. 4, 5.

Medusa $7 \mathrm{~mm}$. in diameter. 8 long tentacles at the bases of the 8 terminal branches of the radial-canals. 4 radial-canals which bifurcate close to the manubrium, giving 8 terminal

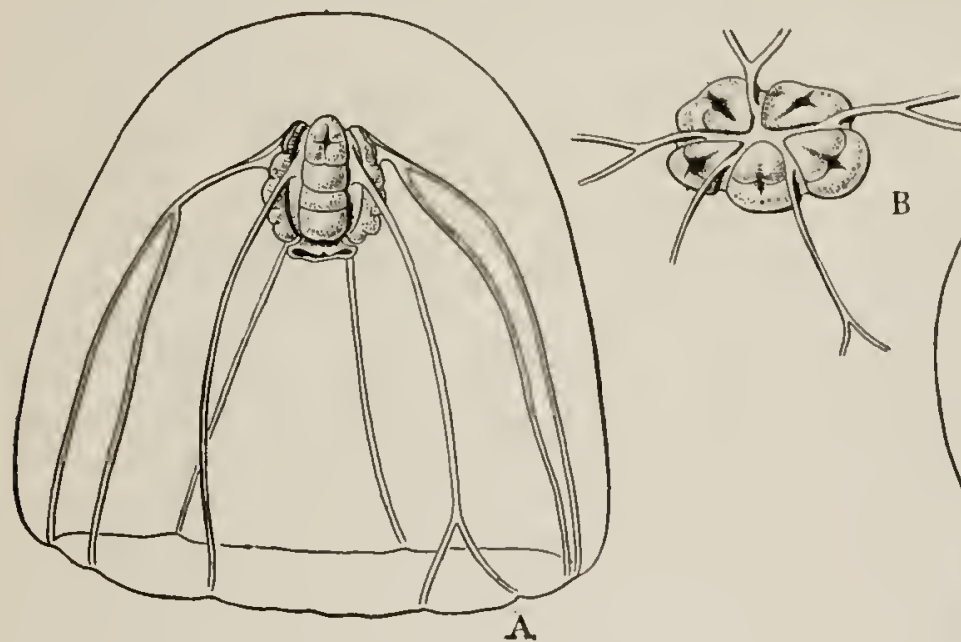

98.

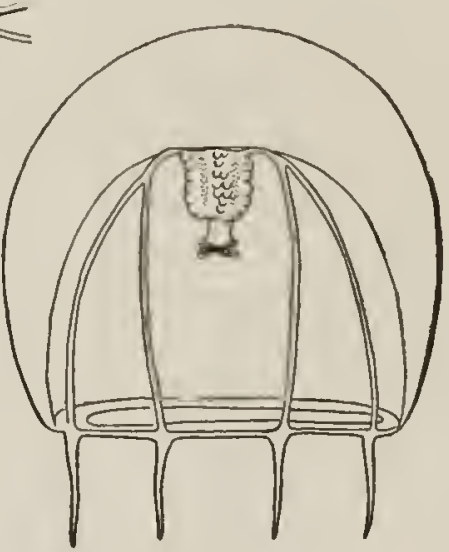

97.

Fic, 97--Byhotiara murrayi. After Günther, Annals and Mag. Nat. Hist.

Fig. 98.-Bythotiara murrays. A. Side view. B. Aboral view of manubrium. From a specimen in the P'uritan collection, No.46, 1902; at the Stazione Zoologica, Naples. Drawn by the author.

branches. 4 lips. Gonads in 4 ridges along the interradial angles of the stomach. Color (!) A single specimen from a depth of 1,610 fathoms in N. lat. $52^{\circ} 18.1^{\prime}$, W. long. $15^{\circ} 53.9^{\prime}$, oft the southwest coast of Ireland. Dr. Lobianco of the Naples Station kindly permitted me to study a specimen of this, or a closely allied medusa which was ohtained lyy the Krupp yacht Puritan from a depth of 1,000 fathoms near Capri, Bay of Naples, and is now preserved in alcohol at the Naples Zoological Station (fig. 98). The hell is dome-shaped, 12 mm. high and $14 \mathrm{~mm}$. wide and flattened laterally. The bell-margin is destroyed. 5 primary radial-canals arise from the stomach and 4 of these hifurcate, the orher canal being simple. Thus 9 canals extend to the periphery of the bell. The stomach is $2.5 \mathrm{~mm}$. long and there are 5 inter- 
radial, swollen gronads, with transverse furrows and a longitudinal median groove. I believe this to be identical with Günther's medusa. Having 5 primary radial-canals it may be abnormal.

Genus SIBOGITA Maas, I905; sens. emend Bigelow, 1909.

Sibogita, Mass, 1905, Craspedoten Medusen der Siboga Expedition, Monog. 10, p. 16.-Bul,elow, H. B., 1909, Mem. Mus. Comp. Zool. at Harvard College, vol. 37, p. 213.

The type species is Sibogita geometrica Maas, from the Malay Archipelago.

GIENIRIC CHARACTERS.

Bythotiaridi with + main radial-canals. The marginal ring-canal gives off a number of centripetal canals which in young specimens end blindly, hut in later stages they connect with the cruciform base of the stomach. The gonads consist of a pair of ridges with cross furrows on each of the 4 interradial sides of the stomach. The tentacles are hollow and are situated at the ends of the larger canals. medusa.

It is probable that this genus has been phylogenetically derived from some Turris-like Sibogita geometrica Maas.

Sibogita geometrica, MaAs, 1905, Craspedoten Medusen der Siboga Exped., Monog. 10, p. 17, taf. 3, fig11. 16-18.

Bell is $40 \mathrm{~mm}$. high, $20 \mathrm{~mm}$. wide; with bulging, laterally flattened, barrel-shaped sides and flatly rounded top. Gelatinous substance uniform and quite thick. There are 16 slender, hollow tentacles, with swollen, club-like outer ends. These tentacles arise from the ring-canal at the bases of the $\mathbf{r} 6$ larger canals and they project from the sides of the bell at a short distance above the margin, as in Narcomedusx. The entodermal cores of the tentacles extend through

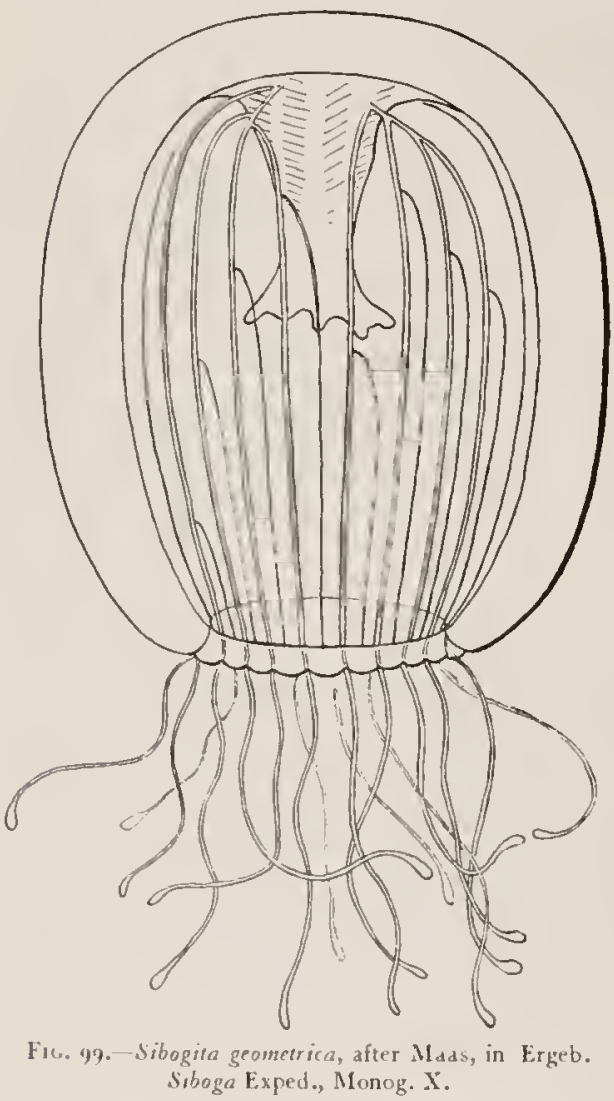
the gelatinous substance of the bell to the ringcanal, and the margin between the tentacles is thrown into i 6 gelatinous "lappets." The tentacles are about three-fourths as long as the bell-height, lut are highly contractile. Their hases are only slightly swollen and there are no ocelli.

There is a marginal ring-canal which gives rise to centripetal branches. According to Maas, 4 wide, main radial-canals arise from the + corners of the stomach and proceed straight to the ring-canal. 2 or 3 alternately arranged branches fuse with the sides of each of these main radialcanals. The largest (oldest?) hranches are nearest the corners of the stomach, while the branches which fuse with the more peripheral parts of the main canals are smaller as we proceed outward. Altogether about 28 centripetal vessels a rise from the ring-canal. The 4 main radial-canals are of large caliber, hut the centripetal vessels are narrower in accordance with their age, the latest formed being narrowest. Dr. H. B. Bigelow has shown that the "side branches" of Maas are actually centripetal vessels which arise from the ringcanal and only later in life join the radialcanals.

The stomach lacks a peduncle and is narrow and about half as long as the depth of the bellcavity. It is 4 -sided at its hase and the + lips are Haring with folded edges. There is a throat-tube 


\section{Plate I9.}

Fig. I. Niobia dendrotentacula. young medusa immediately after being set free from the parent. Tortugas, Florida, May, 1899.

Fig. 2. Niobia dendrotentacula. Side view of medusa showing the manner in which the tentacles develop into medusæ.

Fig. 3. Niobia dendrotentacula. View of manubrium of mature medusa after the budding process has ceased and the ova become mature.

Fig. 4. Niobia dendrotentacula. Diagram showing the sequence in which the medusa buds are set free from the parent medusa; "I " is set free first, " 7 " last.

Fig. 5. Niabia dendrotentacula. Oral view showing the order in which medusa buds are developed at the tentacle-bases. Tortugas, Florida, May 25, 1899.

Drawn from life, by the author. 
PLATE 19

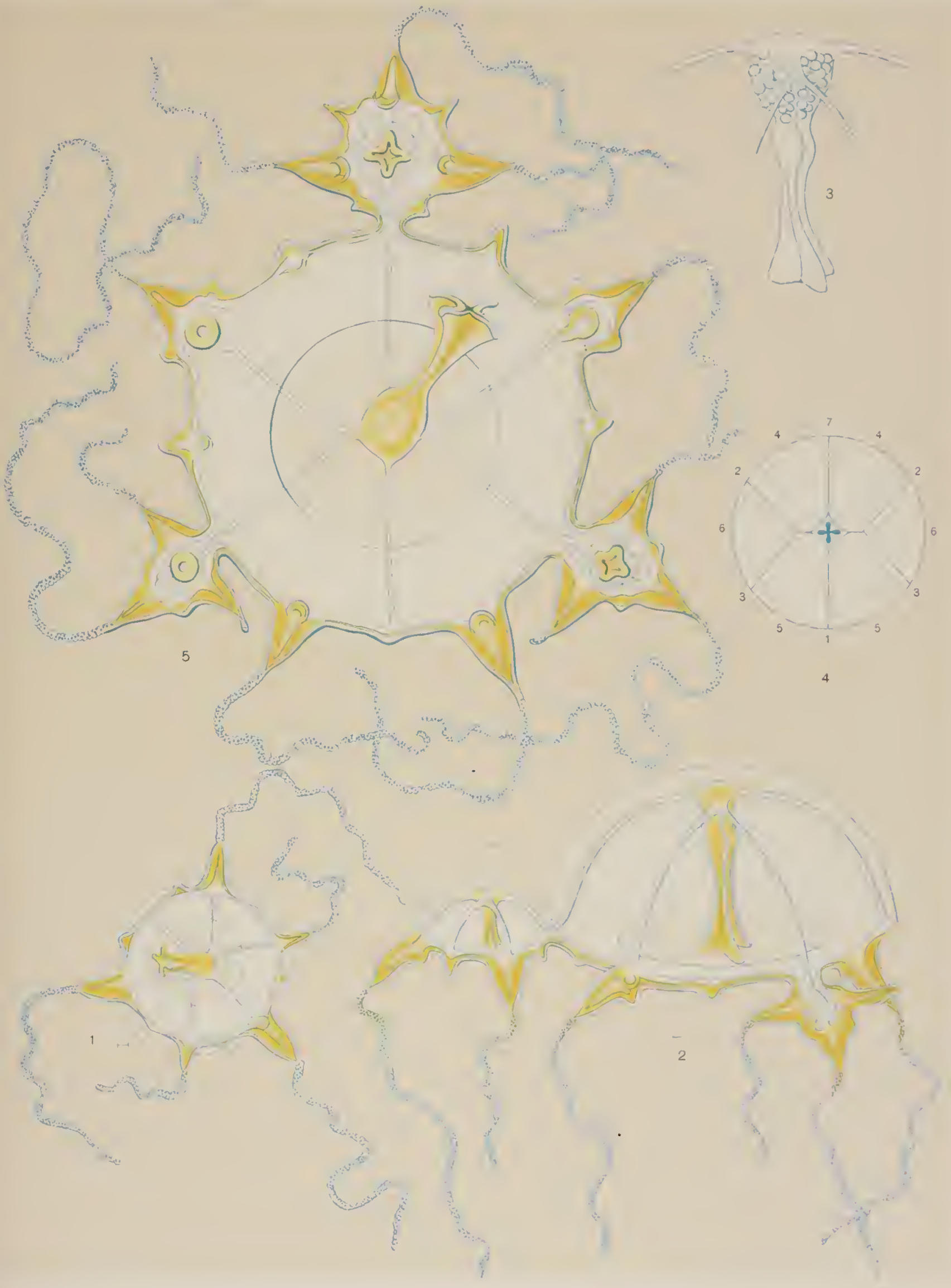



above the mouth and the stomach is urn-shaped and cruciform in cross-section. The 4 gonads are on the interradial sides of the hasal part of the stomach and consist of 2 bowlike longitudinal ridges in each interradius. These ridges are crossed by furrows as in Tiarina.

The entodermal parts are brown or almost black, but this color may be due in some measure, if not wholly, to the method of preservation.

A single preserved specimen is described by Mas. It was captured in an open vertical net hetween 450 fathoms and the surface, in the Malay Archipelago, near the Celebes, in $1^{\circ} 3^{\prime}$ N. lat., $124^{\circ} 28.2^{\prime}$ E. long.

Sibogita simulans Bigelow.

Sibogica simulans, Buciplow, H. B., 1909, Mem. Mus. Comp. Znul. at Harvard College, vol. 37. J. 21 i, plates 50 41, and 43.

This medusa may prove to be identical with $S$. gemetrica Maas.

Bell $30 \mathrm{~mm}$. high, $22 \mathrm{~mm}$. wide, laterally flattened, apex donc-like and rounded, grelatinous substance thick. Manubrium barrel-shaped, one-third as long as depth of bell-cavity. Its base is 4 -sided. 4 interradial gonads each consisting of a double, transverse row of folds on the sides of the stomach. Lips well developed. There are 4 main radial-canals. In young medusx the ring-canal gives rise to 8 adradial, blindly ending centripetal vessels. In later life these adradial vessels connect with the stomach and 4 new interradial vessels make their appearance and also connect with the stomach. Thus the medusa has 4 radial-canals and I 2 vessels which arise from the marginal ring-canal and secondarily connect with the cruciform arms of the stomach. When mature there are 30 tentacles, one opposite each canal and the others somewhat irregularly arranged. The tentacles are long, hollow, and flexible and terminate in a knob of nematocysts. They have no basal bulhs and no ocelli.

The gonads are reddish-brown; bell faint blue.

2 specimens were found on the surface in the tropical Pacific hetween the Galapagos Islands and Panama; another from Behring Sea, 121 fathours.

Genus NIOBIA Mayer, 1900.

Niobia, Mayr , 1900 , Bull. Mus. Comp. \%ool. at Harvard College, vol. 37, p. 36.

GENIERIC CHARACTERS.

Dendrostaurine with + main radial-canals, 2 of which bifurcate, so that 6 canals reach the circular vessel at the bell-margin. The gonads are developed on the 4 interradial sides of the stomach. The mature genital products are found in the ectoderm. There are + simple lips, but no oral tentacles. The marginal tentacles develop into medusa by a peculiar process of budding combined with fortuitous growth and are set free into the water as independent animals similar to the parent medusa.

The only known species is Niobia dendrotentacula of the Tortugas, Florida.

Niobia dendrotentacula Mayer.

Plate 19, figs. 1-5.

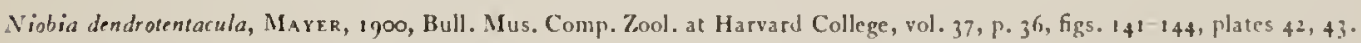

Adult medusa (plate 19, fig. 5).- The hell is slightly flatter than a hemisphere and about $4 \mathrm{~mm}$. in diameter. The outer surface is smooth and there is no apical projection. The gelatinous substance of the bell is quite thin and uniform, but not very Hexible.

+ radial-canals arise from the + corners of the stomach; but 2 of these canals, which are diametrically opposite each other, bifurcate so that 6 radial-canals reach the circular vessel at the margin, $60^{\circ}$ apart.

There are 12 marginal tentacles, one at the foot of each radial-canal and one intermediate hetween each successive pair of radial-canals. These 12 tentacles are arranged in a bilatcrally symmetrical manner in accordance with age. The oldest and the youngest tentacles are situated at the ends of the 2 simple radial-canals and the remaining ro tentacles are arranged in bilateral symmetry in accordance with their various ages, the axis heing in the diameter of the 2 simple radial-canals and the oldest and youngest tentacles. Each half of the margin is thus a reflection of the other, and the order in age of each tentacle is shown in plate 19, fig. 4, where (I) represents the oldest. (2) the next oldest, and (7) the youngest 
and least-developed tentacles. Thus tentacles ( 1 ) and (7), the oldest and youngest, are situated at the ends of the two simple radial-canals, while tentacles $(2,2)$ and $(3,3)$, the second and third in order of age, are found at the bases of the two forked canals. In addition to these there are the interradial sets of tentacles $(4,4),(5,5)$ and $(6,6)$ in order of age; and thus the medusa has 12 tentacles, 6 radial and 6 interradial.

It is remarkable that through a peculiar process of growth and budding each tentaclebulb is successively developed into a small medusa which resembles the adult and is set free into the water. The oldest tentacle is the first to develop into a medusa and be set free, and the others follow in the order of their age until all of the tentacles have been cast off. They are immediately replaced, however, by new tentacles, but after every one of the original 12 tentacles has been developed into a new medusa, the process of forming medusa declines and finally ceases, and then the parent medusa becomes sexually mature.

The first stage in the transformation of a tentacle-bulb into a new medusa is the appearance of a hernia-like outgrowth upon the floor of the subumbrella close to the tentacle-bulb. This hernia-like projection, which is composed of both ectoderm and entoderm and has its cavity connected with a radial-canal or the circular vessel of the medusa, is destined to form the manubrium of the new medusa. Soon after it begins to develop 2 pointed outgrowths appear on the sides of the adjacent tentacle-bulb and these soon develop into new tentacles. These outgrowing tentacles become larger and soon a still younger pair appear farther out on the side of the original tentacle-bulh and these are soon followed by another pair of tentacles, hetween the original pair of side branches and the margin of the medusa. Before this has taken place, however, 4 short canals (the bifurcated radial-canals of the future medusa) develop and the circular canal completes its circuit by coalescence.

An opening then appears in the velum of the parent medusa immediately below the manubrium of the developing medusa and this constitutes the velar opening of the new animal. The manubrium becomes cruciform in cross-section and finally the new medusa is constricted off and is set free with 6 radial-canals, 5 well-developed and 6 small, immature tentacles and a velum (plate 19, fig. I). Even before the young medusa is cast off a hernia-like outgrowth has developed near the hase of its oldest tentacle preparatory to a repetition of the process of budding. In this remarkable process of hudding we see that the simple radialcanals, the ririg-canal, the velum, and the oldest tentacle are stolen directly, so to speak, from the parent medusa. The forked canals, manubrium, and younger tentacles are new growths, and thus the bud is not compelled to develop all of its organs anew. The budded medusa are very hardy when detached and swim actively about, and soon develop new medusæ out of their tentacle-bulbs.

The manubrium of the mature medusa is about as long as the depth of the bell-cavity. There is an enlargement near the middle of its length; the 4 simple lips are well developed and cruciform. The gonads occupy 4 interradial situations in the upper part of the ectodermal wall of the stomach. After the budding medusx have been set free the gonads become mature and the ova are large and project from the interradial surfaces of the stomach. They are finally dehisced into the water. The entoderm of the manubrium, tentacle-bulbs, and circular canal is ocher-yellow, all other parts being transparent.

This medusa was abundant at Tortugas, Florida, from May 21 to June 4, 1899; and a few have been found early in June of every subsecquent year. It is very active and thrives well in confinement.

Tribe WILLIADI.

\section{Genus PROBOSCIDACTYLA Brandt, 1838}

I'roboscidaetyla, Brandt, 1838 , Mém. Acad. Imp. St. Pétersbourg, Sci. Nat.. sér. 6, tome 4, p. 390.--Brownr, 1904, Hydromedusx Maldive Islands, P. 725: 1905, Ceylon Pearl Oyster Report No. 27, Medusæ, p. 135.-MaAs, 1904, Sitzungsber, math.-phys. Klasse kgl. Baver. Akad. Wissenschaften, Bd. 34, F. 438; 1905, Hydromedusen der Siboga Expedition. P. 20 -Bigelow, H. B., 1909 , Mem. Museum Comp. Zool. at Harvard College, vol. 37, p. 218.

Willsia, MCCRAD $\%, 1857$, Gymn. Charleston Harbor, p. 47.

Willia, Agassiz, L., 1862, Cont. Nat. Hist. U.S., vol. 4, p. 346.-Aciassiz, A., i865. North Amet. Acal., p. 171.-Verrili, 1873, Report Commiss. Fish and Fisheries for $1871-72, p .735$.

Dyscannolat Dicranocannat Hillena + Proboscidactyla, Ha eckel, 1879, Syst. der Medusen, pp. 151, $156,157,159$.

Willia, Frwkes, $1 \$ 82$, Bull. Mus. Comp. Zool. at Harvard College, vol. 9. No. 8, F. 299; i884, Mem. Mus. Comp. Zool. at Harvard College, vol. 9. No. 3, plate 5 , fig. 19.

Willsia, Huxerr, 189i, Anatomy of Invertebrated Animals, P. 120. 


$$
\text { . }
$$


PLATE 20.

Figs. 1, 2, and 3. Proboscidactyla ornatn, young medusx. Agassiz Laborarory, Newport, Rhode Island, June, 1892.

Fig. 4. Proboscidactyla ormata, young medusa with rentacles expanded. Agassiz Laboratory, Newport, Rhode Island, July 3, 1893.

Fig. 5. Part of a tentacle of the medusa shown in figure 4 .

Fig. 6. Proboscidactyla ornata, young medusa having 8 terminal branches to the radial-canals. Agassiz Laboratory, Newport, Rhode Island, July, 1892.

Figs. 7 and 8. Proboscidactyla ornata, young medusæ showing variations in color. Agassiz Laboratory, Newport, Rhode Island, July 26, 1895 .

Fig. 9. Proboscidactyla ornata, mature female in which the radial-canals have 12 terminal branches. Agassiz Laboratory, Newport, Rhode Island, Seprember 17, 1896 .

Fig. 10. Proboscidactyla ornata. Oral view of a mature female in which the radial-canals have 16 terminal branches. Agassiz Laboratory, Newport, Rhode Island, September 12, 1892.

Fig. 11. Rathkea octopunctata. Half-grown budding medusa. Abundant among masses of floating ice in the harbor. Woods Hole, Massachusetts, March 4, 1907.

See page 178 for description of figure 11 .

Drawn from life, by the author. 


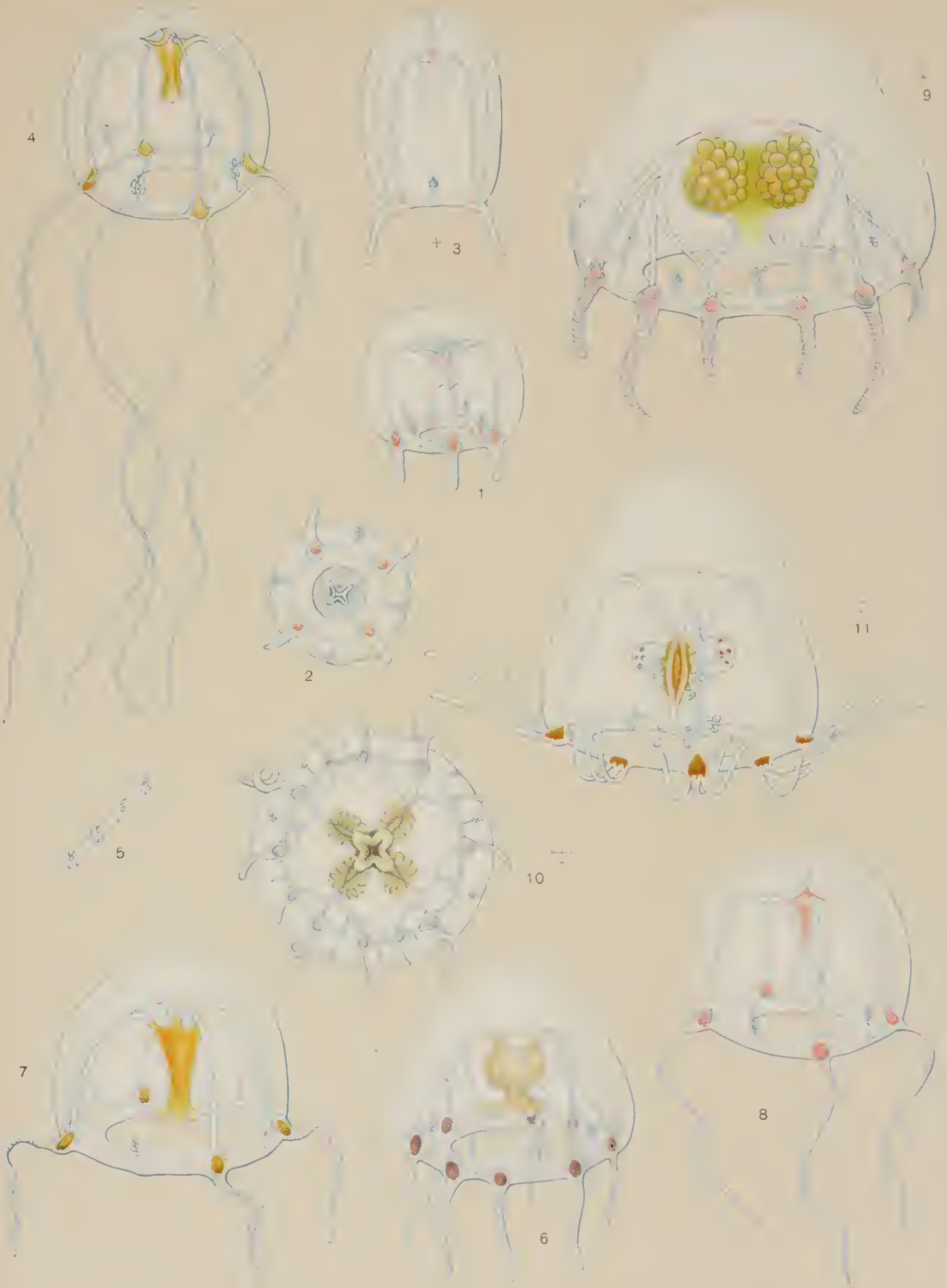



The rype species of this genus is Proboscidactyla flavicirrata Brandt, from the North Pacific. Its 4 main radial-canals branch more profusely than in any other species of the genus.

The American species, $P$. ornat , was first described hy McCrady under the name Willsia ornata from Charleston Harbor, South Carolina.

\section{GENERIC CHARACTFRS.}

Proboscidactyla: Dendrostaurina having + primary radial-canals which give rise to simple, or hranched, side branches during the growth of the medusa. The tentacles are simple and hollow and are situated at the extremities of the radial-canals and their branches. Upon the exumhrella there are clusters of nematocysts which alternate in position with the tentacles. There are no marginal cluhs or cirri and there is no circular canal. The gonads are upon the 8 adradial sides of the stomach extending outward along the sides of the + radial-canals. as follows:

Haeckel, 1879 , separates that which we here designate as Probossidactyla into \& genera

1. Dicranocanna, in which the 4 radial-canals branch once, giving 8 radial vessels which reach the bell-margin.

2. Dyscannota, in which the 4 primary radial-canals give rise each to 2 side hranches, and thus 12 canals reach the bell-margin.

3. Willerta, in which the 4 original radial-canals give rise each to 2 sicle branches, and the first-formed side branch of each quadrant itself gives rise to a side hranch, so that 16 canals reach the bell-margin.

4. Proboscidactyla, in which the 4 canals that rise from the stomach branch complexly, and branches arise from the primary branches, etc., so that 32 or more radiating canals reach the hell-margin.

It is evident that medusx of the genus Proboscidactyla may successively pass through stages represented by the genera Dicranocamna, Dyscannota, and IVilletta.

The American, Atlantic Proboscidactyla ornata is sexually mature in the " "illetta" stage, but its southern variety gemmifera gives rise to medusa-buds while in the "Dyscannota" stage.

Psythia prolifera, Agassiz and Mayer, 1902, Mem. Museum Comp. Zool. at Harvard College, vol. 26, p. 143, plate 1 , fig. 3 , may be a young hudding Proboscidact yla?

\section{Proboscidactyla flavicirrata Brandt.}

Proboscidartyla flatirirrata, BRandt, 1834, Recueil Actes seances puhliques Acad. Inm. Sci. St. Peetersbourg, p. 28 (of the "Separate"); 1838, Mèm. Acad. Imp. Sci..St. Pètersbourg, Sci. Nat., sér.6, tome 4, Par.2, p. 390, plate 19.-A6Assiz, A., 1865 , North Amer. Acal., P. 173, figs. 280-282,-Browns, 1y04, Fauna and Geography Maldive and Laccadive Archipelagoes, vol. 2, P.725.-Bг̈ot, 1905, Revue Suisse de Zool., tome 13, P. 144 (all papers to 1850).

Proboscidactyla favicirrata+P. brezicirrata, Hakcks., 1879, Syst. der Medusen, pp. 159, 160.

Proboscidartyla brevicirrata, Muraach and Sнkakrk, 1903, Proc. Zoot. Soc. London, vol. 2, p. 178.

Bell thick-walled and dome-like to glohular. About $12 \mathrm{~mm}$. wide and $10 \mathrm{~mm}$. high. 4 main radial-canals arise from the stomach, but these fork near their points of origin and each branch gives rise to side branches, from one side only and these again give off similarly arranged hranches so that ahout 54 to $70+$ terminal branches reach the hell-margin. There is a short tentacle at the end of each terminal branch of the radial-canals. There are clusters of nematocysts on the exumbrella alternating with the tentacles. There is no ring-canal. Stomach small, with 4 recurved lips. Gonads upon the sides of the 4 radial pouches of the stomach. There are neither medusa-luds nor stolons.

Stomach, gonads, and tentacle-bulbs dull yellow. North Pacific, coast of Kamtschatka and Puget Sound, Washington.

This species is distinguished by the profuse and peculiar hranching of its radial-canals.

Proboscidactyla ornata Browne.

Mate 20 , figs. 1-10.

W'illsia ornata, MCCrady, 1857, Gymn. Charleston Harbor, p. 47, plate 9, figs. 9-11.

W'illia ornata, Agassiz, 1.., 1862, Cont. Nat. Hist. U. S., vol. 4, p. 346.-Agiassiz, A., 1862, Proc. Boston Soc. Nat. Hist., vol. 9. p. 96 , figs. 20, 21; 1865 , North Amer.Acal., 1. 171, figs. 274a-279.-V rkritl, 1873, Report Commiss. Fish and Fisheries U. S. for 1871-72, pp. 455, 735. - Frwkes, 1882, Bull. Mus. Comp. \%oul. at Harvard College, vol. 9, p. 299, figs. 22, 23, non fig. 24; 1884, Mem. Mus. Comp. Zool. at Harvard College, vol. 9, No. 3, plate 5, fig. 19.-Marrr, 1904, Mem. Nat. Sci. Museum Brooklyn Inst. Arts and Sci., vol. 1, No. 1, p. 13, plate 2, fig. 12.-Nutrinc, 1901, Bull. U. S. Fish Commission for 1899 , vol. 19, P. 377.- Harcitt, 1904, Bull. U. S. Bureau of Fisheries, vol. 24, P. 40, plate 1, fig. 5 . Dyscannota dysdipleura, HaErikr., 1879, Syst. der Medusen, p. 152.

Hilletta ornata, HAEckEL, 1879 , Syst. der Medusen, p. 157.

Proboscydactyla ornata, Browne, 1904, Hydromedusae Maldive Islands, p. 726.- -MA4s, 1904, Sitzungsber, math.plyys. K'lasse kgl. Bayer. Akad. Wissenschaft., Bd. 34, P. 439.

(?) Dicranocanna furcillata, HaEckel, 1879, Syst. der Medusen, p. 156. 
Serually-mature medusa (plate 20, figs. 9 and 10 ).-Bell about $5 \mathrm{~mm}$. in diameter and slightly' higher than a hemisphere with flaring, bell-shaped sides. Gelatinous substance thick and rigid. There are 16 marginal tentacles, one at the foot of each terminal hranch of the radial-canals. 4 of these tentacles are at the ends of the 4 primary radial-canals. 4 younger tentacles are at the extremities of the secondary, 4 still smaller tentacles at the ends of the tertiary, and 4 more at the ends of the quartemary canals. There are thus 16 marginal tentacles, 4 in each quadrant. The tentacle-loulbs are large and hollow and their entoderm is densely pigmented. The shafts of the tentacles are very contractile and capable of great elongation. They are covered with ring-like clusters of nematocysts, which become apparent only during periods of contraction. There are neither marginal clubs nor cirri, but midway hetween the tentacles, immediat ely under the surface of the exumbrella, are 16 slender, centripetal canals which alternate with the tentacular radii in position. One or more clusters of nematocyst-cells are found upon the exumbrella immediately over each of these canats, and according to Browne, 1904, these nematocysts travel singly up the canals from the hell-margin and hecome lodged at intervals, forming accumulations.

4 main radial-canals arise from the + radial corners of the stomach. Each of these canals gives rise to 2 side branches and the longest and oldest of these side branches also gives rise to a side branch. Thus there are 16 terminal branches each one of which ends in the cavity of a tentacle-hulb. There is no ring-canal, but only a solid cord of entodermal cells connecting the tentacle-bulbs one with another. The manubrium is flask-shaped and the mouth is nearly at the level of the velar opening. There are + radially arranged, recurved lips with crenated edges. The 4 gonads are developed upon the 4 interradial sides of the

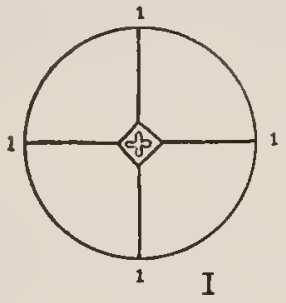

Fıc. 100.-Diagrammatic oral views showing order of development of radial-canals in Proboscidactyla ornata. I, youngest stage; IV, mature condition.

stomach. In the female the mature ova are large and prominent. The entoderm of the stomach and gonads is ocher-yellow or greenish-yellow, while the entoderm of the tentaclebulls is crowded with brownish pigment granules. In the very young medusa, however, the entoderm of the manubrium and tentacle-bulbs is often pink.

Young medusa. - The lydroid of our American species has not been observed. In the youngest medusx seen by ne, the bell is about $0.7 \mathrm{~mm}$. in diameter (plate 20, figs. 1-4). The gelarinous substance is relatively thinner than it is in the adult. There are $t$ equally developed tentacles, capable of much expansion (fig. 4 ), but these are usually seen contracted in captive specimens. These tentacles are situated at the hases of the 4 primary radial tubes. 4 slender, blindly-ending, centripetal canals arise from the margin midway between the 4 tentacles, and there is a cluster of nematocyst-cells upon the exumbrella immediately over each canal. The manubrium is a simple, short tube with 4 well-developed, quadratic lips. The condition of the medusa in this stage is represented in text-figure I0o, I, which represents an oral view of the animal.

When the medusa is about $1.25 \mathrm{~mm}$. in diameter (plate 20, fig. 6), a side hranch arises from each of the 4 primitive radial-canals, and at the same time a second set of tentacles (2222, text-figure 100,11 ) make their appearance. These new tentacles are about $22^{\circ} 30^{\prime}$ away from the primary tentacles (IIII). If one face the oral surface of the medusa, as is shown in text-fig. I00, it will be seen that the secondary tentacles (2222) lie in positions spposite to that of the hands of a watch relatively to the primary tentacles.

The third set of radial-canals (333.3, fig. 100,111 ) arise from the 4 primary canals beyond the origins of canals 2222. This takes place when the medusa is about $2 \mathrm{~mm}$. in diameter. 
The fourth set of radial-canals (444, fig. 100, iv) arise from the sides of the second set of canals. At the completion of this stage, the medusa has 16 canals and 16 marginal tentacles which are about $22^{\circ} 30^{\prime}$ apart. 'This does not occur until the medusa is isbout $3.5 \mathrm{~mm}$. in diameter (plate 20, fig. 4 ) and some individuals appear to become sexually mature before this stage is reached (plate 20, fig. 3 ).

This medusa is common in Narragansett and Buzzard's Bay's on the southern coast of New England. It is rare, according to Brooks, at Beaufort, North Carolina. McCrady found a single mature specimen and I have found several in Charleston Ha rhor, South Ca rolina, and in the Bahamas and Tortugas. It has not been taken north of Cape Cod on the New England coast, but is found along the entire coast of North America from the Bahamas to southern New England. Bigelow, 1909, has demonsirated that there is a closely related budding variety in the tropical Pacific.

It is possible that "Dicranocanna furcillata," found hy Hateckel off the Atlantic coast of Morocco, may lie identified with $P$. ormata.

From South Carolina southward our $P$. amata gives rise to a variety which produces medusa-buds upon stolons at the + radial corners of the stomach near the points of entrance of the + radial-canals, and Haeckel's medusa has stolons in these positions.

Proboscidactyla ornata var. stolonifera Bigelow.

(?) Willsia, sp., Huxur.r, 1877 , Manual of Anatomy of Invertebratect Anmals, 1.ondon, p. 120, fig. 17.

(?) Proboscidactyla tropica, Browng, 1904, Fauna and Geog. of Maldive and I.accadive Archipelagoes, vol. 2, part 3, Hydromedusa, $\mathrm{p} .727$.

Proboscidactyla flavicirrata var. stolonifera, MAas, 1905. Craspedoten Medusen der Siboga Eirpedition, p. 21, taf. 4. fign. $24-2 \$$; 1906, Revue Suisse de \%oul., tome 14, J. 8y.

Pryboscidactyla ornata, zar. stolonifera, Bigelow, H. B., Iyou, Mem Mus. Comp. 7aol. at 11arvard College, vol. 37, P. 220, plates 6,41 .

Bell rounded, $5 \mathrm{~mm}$. wide, $+\mathrm{mm}$. high, with a low, dome-like, apical projection and thin walls. 12 to 20 or more tentacles, one at the base of each terminal branch of the + main radial-canals. These tentacles are about as long as the belf-radius and havelarge, spherical

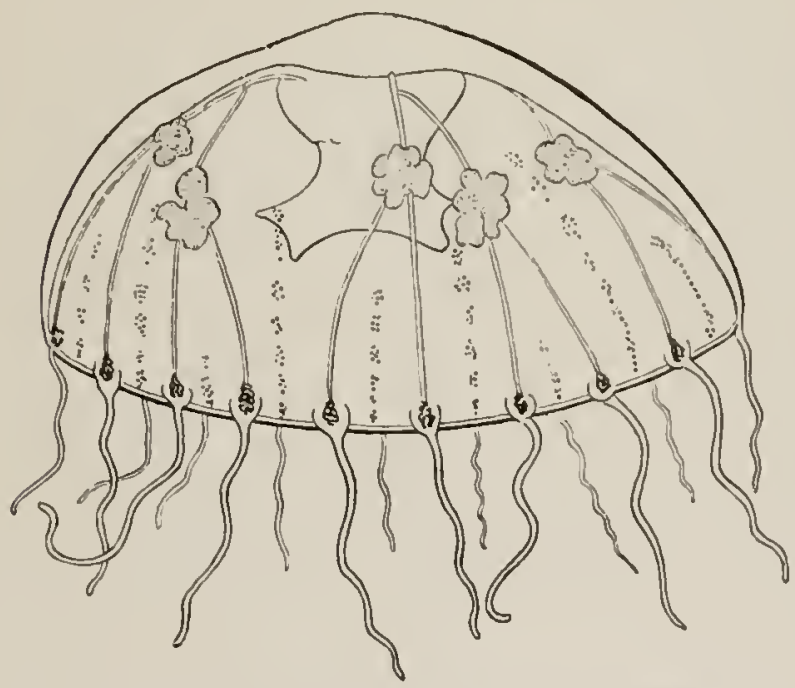

Fir. 101.-Proboscidactvla ornata var. stolonifera, after Ma:1s, in Ergeb. Siboga Exped., Monog. X. hasal bullos which hear entodermal pigment-granules. An equal number of meridional lines of nematocysts alternate with the tentacles. These are upon the exumbrella and extend from the margin about one-fifth to one-half the clistance up the sides of the bell. There are a number of clusters of nettling cells upon each line. The axial line is composed of al core of entodermal cells which branch off from the solid cord of entodermal cells which constitute the degenerate "ring-canal."

The + main radial-canals branch quite irregularly after the second forking, so that 12 to 20 , or more, canals reach the margin. The general mode of forking is, however, similar to that of $P$. ornala.

Medusa-bearing stolons develop at the second and third forkings of each of the + radial-canals. There are thus 8 of these stolons, 2 in each quadrant. These stolons do not all develop at one and the same time. The two oldest appear at the second forks of the canals of one diameter, then the next two at the second forks of the diameter $90^{\circ}$ apart from the first, and then the 4 others follow in the same order at the third forkings of the canals.

The stomach is wide, cruciform, and um-shaped, as in other species of the genus. The + lips are recurved, and the manubrium is not longer than one-half to two-thirds the depth 
of the bell-cavity. The gonads may be pale green or colorless. The entoderm of the tentacle-hulbs is black, or pale green, or colorless. The gonads are upon the sides of the stomach and extend even beyond the first bifurcations of the radial-canals. It is found in the Malay Archipelago, and at Acapulco, Pacific coast of Mexico.

This is identical with the medusa found by Huxley in the Louisiade Islands, North Pacific, and called P. tropica by Browne, 1904. In P. "tropica," however, the medusahearing stolons arise from the first branchings of the 4 main canals and not from the second and third points of forking as in Maas' and Bigelow's form. Bigelow's studies have shown, however, that the two are identical, P. tropica being only a young stage.

$P$. "tropicn" has 16 terminal branches to its 4 main radial-canals. 16 short tentacles, 4 stolons at the points of origin of the first hranches of the 4 main radial-canals. These stolons are long and end in a knob of nematocysts. On one side the stolon gives rise to a series of medusa-buds, the oldest being nearest the free lower end of the stolon. When about to be set free the budding medusa has 4 simple, unbranched radial-canals and 4 tentacles.

Proboscidactyla ornata var. gemmifera.

Plate 21 , figs. $\mathrm{I}-3$.

Hillin ormata, Brooks, 1880, American Naturalist, vol. 14, p. 670; 1881, Studies Johns Hopkins Univ. Marine Lab., vol. 2, P. 144.

I"illia gemmifera, Frwess, I882, Bull. Mus. Comp. Zool. at Harvard College, vol. 9, p. 300 , plate 1, fig. 24.

l'roboscidactyla gemmifera, MAas, 1904 , Sitzungsber. math.-phys. Klasse kgl. Bayer. Akad. der Wissenschaften, Bd. 35, P. 439.Browns, 1904, Hydromedusæ Maldive Islands, p. 727.

D) yscamnota gemmifera, MAyre, 1900, Bull. Mus. Comp. Zool. at Harvard College, vol. 37, P. 47, plate 8, fig. 17.

This variety of $P$. ornato is peculiar in that it gives rise to medusa-buds which are borne upon + stolons that arise from the radial corners of the stomach near the points of origin of the 4 main radial-canals. Several medusa-buds in various stages of development may usually be seen upon each stolon. When set free, each medusa has 4 simple, unbranched radial-canals, + well-developed, radially situated tentacles, and 4 small, interradial tentacle-bulbs. There are also $\delta$ centripetal canals alternating with and int ermediate in position between the tentaclebulls and tentacles. There are no medusa-buds or stolons upon the medusæ when set free from the parent.

All of the budding specimens of Proboscidactyla which have thus far been observed were in the Dyscammota stage, having 12 terminal branches to the radial-canal system and 12 marginal tentacles. Each of the + canals which leave the stomach gives rise to 2 side branches, and thus there are 3 terminal canals in each quadrant; 12 in all. It is possihle that after the medusa has ceased budding the canals may increase in number so as to become 16 . On the other hand, $P$. ornata var. gemmifera, may never develop sex-cells or possess more than 12 canals. The common $P$. ornata, which lacks medusa-buds and has 16 tentacles and terminal canals, is found wherever the hudding variety has been observed, alt hough the hudding variet $y$ is not known north of Beaufort, North Carolina, while the sexual form is abundant upon the southern coast of New England. For many years it was believed that in this gemmifera form there was constantly but a single cluster of nematocysts over each centriperal canal of the exumbrella, between the tentacles, whereas in the sexual $P$. ornat there might he 1,2 , or occasionally 3 , clusters over each canal. In 1903 , however, I found two specimens of the gemmifern form which had I, 2, or 3 clusters of nematocysts over each centripetal canal, and therefore resembled the condition seen in the sexual $P$. ornata. No gonads have been ohserved upon the manubrium of the gemmifera form and the stomach is therefore smatler and more slender than in the sexual P. ornatn.

$P$. ornata var. gemmifera is found from Beaufort, North Carolina, southward to the Bahamas. On the whole its close similarity to $P$. ornato in the Dyscrnnotn stage leads me to believe that it is only an immature or budding variety of Proboscidactyla ornata.

Proboscidactyla "minima" Browne.

Proboscidactyla minima, Browne, 1905, Pearl Oyster Fisheries, Gulf of Manaar, Suppl. Report, Roy. Soc. London, 27, p. 136, plate 2, fig. 3 .

Bell hemispherical(?), 0.75 to $1 \mathrm{~mm}$. wide, with fairly thin walls. + main radial-canals with lateral branches. Numher of lateral branches (?) 10 to 20 short tentacles $0.25 \mathrm{~mm}$. long with globular basal bulbs. Stomach with 4 longitudinal lobes with the gonads upon their sides. Mouth with a sinuous margin. Clusters of nematocysts on the exumbrella near the 


\section{Pi.ATE 2I.}

Fig. I. Proboscidactyla ornata var. gemmifera, showing a budding medusa about to be set free. Tortugas, Florida, June, 1897.

Fig. 2. Proboscidactyla ornata var. gemmifera, showing unusually dark pigment in the tentacle-bulbs. Beaufort, North Carolina, November 21 , I904.

Fig. 3. Proboscidactyla ornata var. gemmifera, showing small immature medusa buds at the + radial angles of the stomach. Tortugas, Florida, June I2, I 897 .

Figr. 4. Laodicea cruciata ("calcarata"), young medusa. Agassiz Laboratory, Newport. Rhode Island.

Figr. 5. Laodicea cruciata ("calcarata"), half-grown male medusa. Agassiz Laboratory, Newport, Rhode Island, September $17,1896$.

Drawn from life, by the author. 

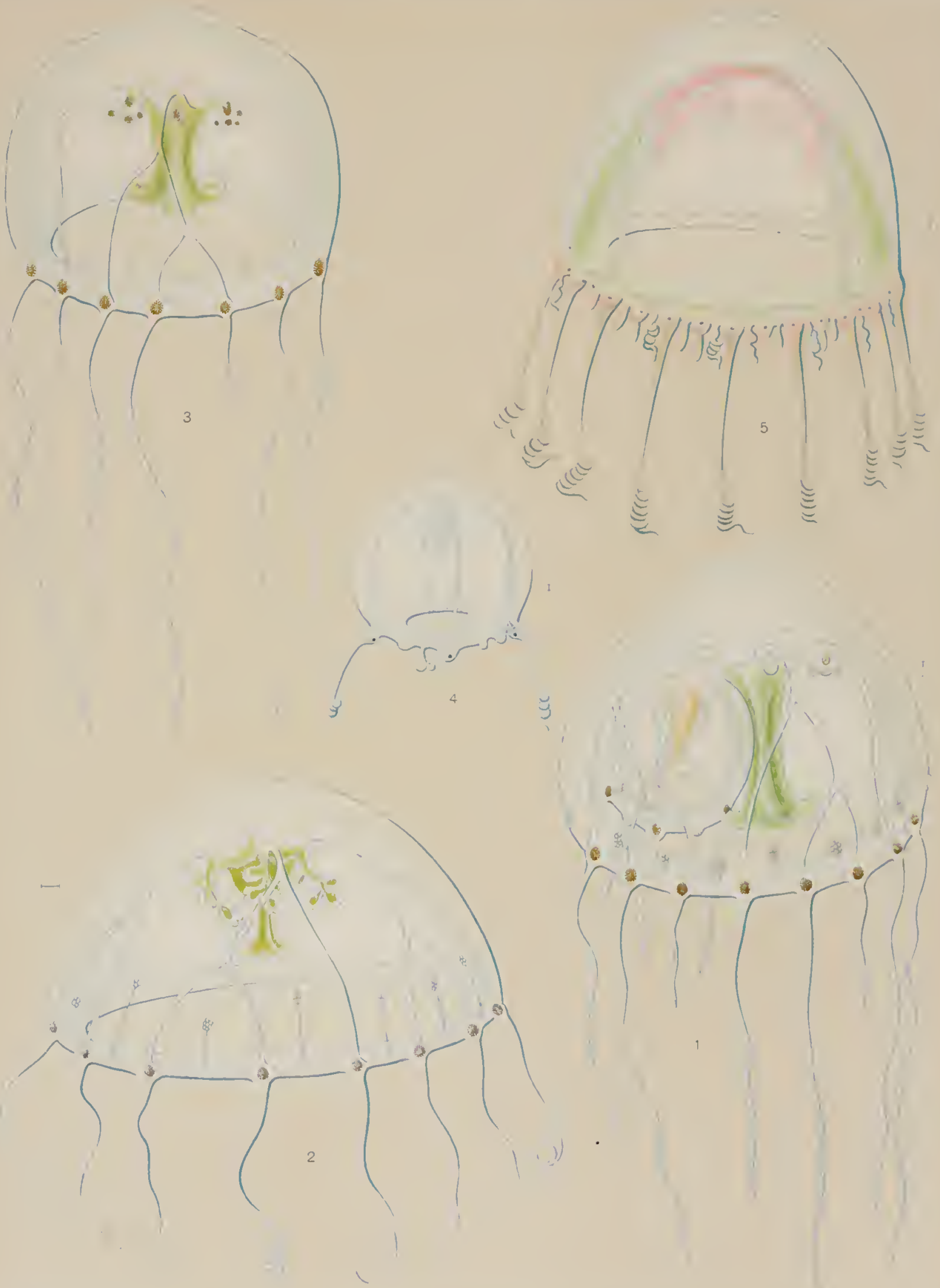

margin between the tentacles. Gulf of Manaar, near Ceylon, in February. Color (?) Distinguished by its small size (when mature?).

\section{Proboscidactyla "occidentalis" Browne.}

II illin ofcidentalis, Frwks, I889, Bull. Essex Inst., Salen, vol. 21, No. 7, p. 109, plate 5, fig. 3 .

Probosridartyld occidentalis, Brows. 1904, liauna and Geog. Malive and Laccadive Archipelagoes, vol. 2, p. 726.

Size (?) Bell pyriform, gelatinous suhstance thick. + main radial-canals, each of which gives rise to 2 side hranches, which also branch; thus each main radial-canal reaches the marfin hy 5 vessels. 20 tentacles with reddish hasal bulbs. Gonads on the marginal sides of the stomach. + lips. A single cluster of nematocyst-cells on the exumbrella between each successive pair of tentacles. Island of Sinta Cruz. California. Color (!) Is this only a youngr stage of $P$. Alavicimatn?

\section{Genus WILLSIA Forbes, 1846 .}

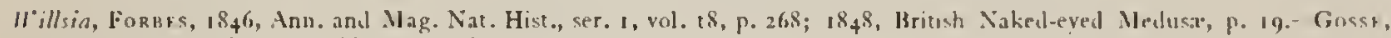
1853, Naturalıst's Rambles Deronshire Coast, p. 359. IIillia, Acisssiz, I... 1862, Cont. Nat. Hist. U. S., vol. $\$$, $\left.\right|^{\circ} \cdot 34^{6}$. II illsia, Peach, 1867, Journ. Roy. Institute, Cornwall, p. 357.

II'illia, Harckrl, 1879, Syst. der Medusen, P. 158.-Browve, 1902, Annals Mag. Nat. Hist., ser. 7, vol. 9, p. 280; 1904,

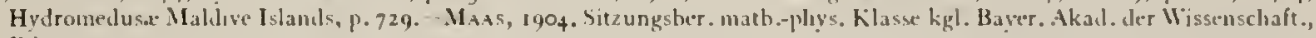
13.1. $34,8.439$.

\section{GENERIC CHARACTI:RS.}

Williadi with 6 or more primary radial-canals, each of which gives rise to one or more side hranches all of which extend to the bell-margin.

The type species is IIIlsin stellata Forbes, of the northern coast of Europe. Its hydroid stock is lar subellarmm Gosse.

\section{Willsia stellata Forbes.}

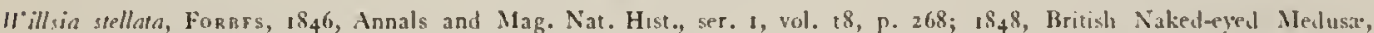
13. 19, plate t, fig. 1.-Brdot, 1905, Revue Suisse de Zool., tome 13, P. 152 (litırature to 1850). Bkownk, 1904, Fauna and Geog. Maldive and laccadive Archipelagoes, vol. 2, 1.729.

"Iillid stellata, Harckri, 1879 , Syst. der Medusen, p. 158 .

Iar sabellarum (hydroid), Gossf, i857, Trans. Linnean Soc. London, vol. 22, p. It3, plate 20.

Lar subellorum, Hincses, 1872 , Annals and Mag. Nat. Hist., ser. 4, vol. 10, p. 313, plate 19.

(?) II illia furcata, H+s.ckel, Ibid., p. 158.

17 illsin stellata, Forbes = Lar sabellarum Gosse, Brow:ve, 1896, Proc. Zool. Soc. Lonlon, 13. 4618; 1897, Proc. Zool. Soc. I.ondon, P. 818,9 figs. (the best modern description).

I.ar sabellarum, Brownf, 1905 , Proc. Ray. Soc. Edinburgl, vol. 25 , p. 753 (medusa only).

Bell dome-like, about $9 \mathrm{~mm}$. wide and $8 \mathrm{~mm}$. high, with thick gelatinous walls, evenly: rounded. Stomach 6-sided, with well-developed, lateral lobes upon the sides of which the gonads are situated.

When the medusa is set free from the hydroid there are 6 straight, simple radial-canals, $60^{\circ}$ apart, but when about $1 \mathrm{~mm}$. wide a side branch grows out from each of the 6 original canals. These side branches grow out from near the middle points of the original canals, and the original canals then bend so that 12 vessels reach the bell-margin nearly $30^{\circ}$ apart. In the next stage another side branch arises, farther out than the first and on the opposite side from each of the 6 original canals, and finally a third branch grows out from the inner side of the first branch. Thus each of the 6 original radial-canals gives rise to 3 branches, and hence $2+$ terminal canals reach the bell-margin. Owing to the bending of the radial-canals the terminal branches are spaced with a fair degree of symmetry, but the intervals hetween the ends are not constantly $15^{\circ}$, for the space between the main canal and the last-formed branch is apt to remain wider than the other intervals. (See Browne 1905.)

There are $2+$ short tentacles, one at the end of each terminal branch of the radial-canals. These tentacles have well-developed, hasal hulhs and are tapering and shorter than the belldiameter. 24 short, blindly-ending, centripetal canals extend upward from hell-margin under the surface of the exumbrella, alternating with the tentacles; and there is a cluster of nematocysts upon the exumbrella over each one of these centripetal vessels. There is no ring-canal.

The 6-sided stomach is short, not being longer than one-half to two-thirds the depth of the bell-cavity and there are 6 simple recurved lips. The stomach differs from the Amer- 
ican I'illsia discovered by Professor Brooks, in being 6-rayed at its center, whereas the center of the stomach of the American medusa is only 3-rayed.

The stomach and gonads are yellow to reddish-yellow and the tentacle-bulbs are dark yellowish-brown or purple-brown. This medusa is found off the coasts of Great Britain and Ireland. It is abundant at Valencia Island off the southern coast of Ireland.

A summary of its stages in growth may be presented thus:

\begin{tabular}{|c|c|c|c|}
\hline & Radial-canals. & Tentacles. & $\begin{array}{l}\text { Exumbrella } \\
\text { clusters of } \\
\text { nematocysts. }\end{array}$ \\
\hline Earliest stage. & 6 unhranched. & 6 & 6 \\
\hline Second stage. & $\begin{array}{l}\text { I side branch to each } \\
\text { canal. }\end{array}$ & 12 & 12 \\
\hline 'Third stage. & $\begin{array}{l}2 \text { opposite branches } \\
\text { to each canal. }\end{array}$ & 18 & 18 \\
\hline $\begin{array}{l}\text { Fourtli and adult } \\
\text { stage. }\end{array}$ & $\begin{array}{l}\text { The first-formed side } \\
\text { hranch branclies. } \\
\text { Thus eacl main } \\
\text { canal gives off } 3 \\
\text { branclies. }\end{array}$ & 24 & 24 \\
\hline
\end{tabular}

The hydroid is "Lar sabellarum" of Gosse and Hincks. It grows upon the tube of Sabella. The polypites arise at intervals from a creeping hydrorhiza. The fusiform feeding polypites are larger than the reproductive ones and have each 2 tentacles which both arise from one side of the body. The reproductive polypites have no tentacles and their free upper ends are somewhat globular and devoid of a mouth, although they are armed with many nematocysts. The medusa-buds arise in clusters of 3 to 4 on the upper sides of the body of the polypite. When set free the bell is somewhat higher than a hemisphere and the medusa has 6 radial-canals and 6 tentacles alternating with 6 clusters of nematocysts upon the exumbrella. The stomach is 6-lobed and has 6 lips.

Haeckel, 1879 , p. 158 , describes a "Willia furcata" from St. Nazaire, Atlantic coast of France. This may be identical with $W$. stellat $n$, but it is said to have the gonads isolated upon the radial-canals. The lower edge of the stomach is said to be folded or crinkled and without true lips. In other respects the medusa is evidently identical with $W$. stellata. I suspect this of heing merely a specinten of $W$. stcllatn in which the central part of the stomach has been lost through accident and is in process of regeneration.

Willsia (?) varians.

Proboscidactyla varinns, Brownf, 1902, Fauna and Gengraphy Maldive and Laccadive Archipelagoes, vol. 2, p. 728 , plate 54. figs. i, 2 .

Browne describes this medusa from a single specimen with an irregular, 6-lobed stomach.

The medusa was $3 \mathrm{~mm}$. wide, $2 \mathrm{~mm}$. high. 6 main radial-canals, each with 1 to 3 lateral branches. 17 tentacles, one at the end of each terminal branch of the radial-canals. No ring-canal. Clusters of nematocysts on the exumbrella. Stomach very irregular with 5 (?) lips. No gonads, hut with 2 medusa-buds upon 2 of the radial-canals near the stomach. Tentacle-hullos dark brown. Maldive Islands, Indian Ocean. This may be an abnormal specimen of Proboscidactyla ornata var. stolonifera.

\section{Willsia mutabilis Browne.}

W'illin mutabilis, Browne, 1902, Annals and Mag. Nat. Hist., ser. 7, vol. 9, p. 280; 1904, Fauna and Geog. Maldive and Laccadive Archipelagoes, vol. 2, P. $72 \%$.

Bell slightly conical, $6 \mathrm{~mm}$. high and $6 \mathrm{~mm}$. wide. Margin of bell slightly inverted and summit broad and round. There are 24 or more tentacles. 6 or 8 radial-canals arise from the stomach and each gives rise to 3 or more branches. The stomach is small, with 6 or 8 lolves, and the margin of the mouth is complexly folded. The gonads surround the stomach and its lohes. This species is very variable. Found by Vallentine at Stanley Harbor, Falkland Islands and briefly described by Browne. Color (?)

Willsia brooksii, sp. nov.

Beautiful drawings of a young stage and also of the adult condition of this medusa were made by the late Prof. William K. Brooks, while he was at Beaufort, North Carolina, and were found among his unpublished figures, after his death. They were kindly pre- 


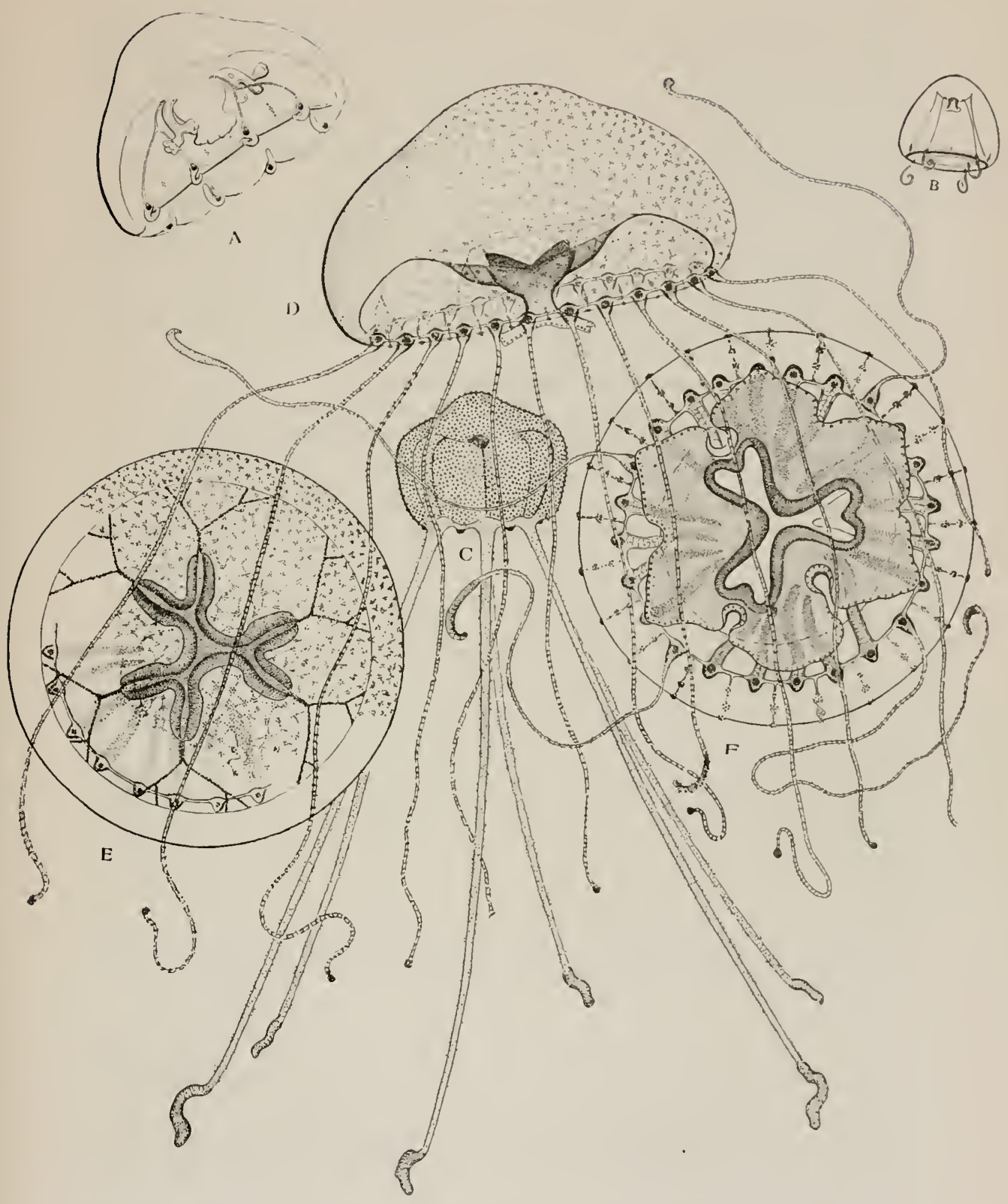

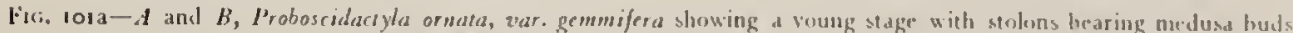
C to F", young and mature stage of W'illsia brooksii sp. nov of having fo primary radial-cands, 24 (erminal ramuli. From Beaufort, North Carolina. Drawn from life, by l'rofessor Broxks. 
sented to me by the Department of Biology of Johns Hopkins University for publication in this work, and it seems but fitting that the species should be named in honor of the great naturalist who discovered it. It is closely allied and possibly identical with the European I'illsia stellata, although the 3 -rayed center of the stomach appears to distinguish it.

In the young stage there are 6 simple, slender radial-canals, $60^{\circ}$ apart. The belt-walls are relatively thin and the bell somewhat higher than a hemisphere with a bluntly pointed apex. The 6 tentacles are 5 to 6 tinies as long as the bell-diameter and have swollen, nematocyst-bearing, outer extremities.

In the mature medusa the bell is flatter than a hemisphere, thick walled, with a sliallow bell-cavity. Twenty-four tentacles alternate with 24 exumbrella, nematocyst tracts each with several clusters of netrling cells. The manubrium has 6 lips. Stomach 3 -rayed at center, but each ray forks, giving 6 ramuli, 6 primary radial-canals which bifurcate twice giving 24 terminal branches. The gonads extend along the sides of the stomach. The size and color can not be determined from Professor Brooks's drawings. Found at Beaufort, North Carolina. (See page I95.)

\section{Order LEPTOMEDUS $Æ$ Haeckel, 1866.}

Lepromedusc, Haserkel, 1866, Generellen Morphologie, Bd. 2, p. Ivii; 1879, Syst. der Medusen, 1'. 111.-Bigrtow, 19on, Mem. Mus. Comp. Zool. at Harvard College, vol. 37, p. 147.-Torrey, 1909, Publications University California, Zoul., vol. 6, p. 12.

CHARACTERS OF THE ORDER LEPTOMEDUSA.

Hydromedusæ which arise by alternation of generations from Campanularian hydroids. The gonads are developed upon the radial-canals. When present the lithocysts are of ectodermal origin.

We may distinguish three families as follows:

I. Thaumantiadx Gegenbaur, 1856. Without lithocysts, but with marginal sensoryclubs or cordyli.

2. Eucopidx Gegenbaur, 1856 . With lithocysts and with less than 8 radial-canals.

3. Equoridx Eschscholtz, 1829 . With lithocysts and with more than 8 radial-canals.

The Leptomedusæ are probably descended from the more simply organized Anthomedusx; this is shown hy the fact that when first set free from the hydroid some of the Eucopida, such as Phortis, lack lithocysts, which develop later. Also the hydroid of Eutina called Campanopsis has nearly all of the characters of the Tubularian hydroids. Asexual production of medusa-buds is extremely rare in the medusx of the order Leptomedusx being known only in Eucheilota paradoxica and Eirene medusifern. These medusa are therefore creatures of the coasts and are rarely found far out at sea, for they can not maintain themselves in situations unsuited to the growth of their hydroids.

\section{Family THAUMANTIADÆ Gegenbaur, 1856.}

Thammantiade, Gerinbaur, 1856, Zeit. für wissen. Zool., Bd. 8, pp. 218, 236, 268. -MAas, 1893, Ergeb.der Plankton Exped., Bd. 2, K. c., pp. 64-65; 1897, Men. Mus. Conp. Zool. at Harvard College., vol. 23, No. 1, P. 19; 1905, Craspedoten Medusen der Siboga Expedition, Monog. 10, p. 23.

Thaumantiada + Cannotida, Ha Ecké, 1879 , Syst. der Medusen, Pp. $120,140$.

\section{FAMILY CHARACTERS.}

Leptomedusæ without lithocysts. The gonads are developed upon or extend outward over the radial-canals and are not confined exclusively within the walls of the stomach.

In so far as is at present known the Thaumantiadx develop through alternation of generations from Campanularian hydroids. For our knowledge of the development of the species constituting this family we are indebted to the researches of Wright, 1862, on Thaumantias; A. Agassiz, 1865, on Melicertum; Metschnikoff, 1886, on Loodicea; and Browne, 1900, on Diplcurosoma.

It is evident, indeed, that the Thaumantiadxe are very closely related to the Eucopidx. They resemble the Tubularian medusx (Anthomedusx), however, in the absence of lithocysts and the prevalence of ectodermal ocefli upon the tentacle-bulls. Indeed, all authorities agree in considering the Thaumantiadx as more lowly organized than the Eucopidx and Equoridie, 
and probably nearly related to the forms from which the Campanularian medusac have developed (see A. Agrassiz, 1865, pp. 124, 125; O. and R. Hertwig, 1897, Nervensyst. und Sinnesorgane der Medusen, p. 155; Haeckel, 1879, pp. 121, 125; Brooks, 1895, pp. 301-303). Haeckel goes so far as to state that the medusa of his genus Tetranema (Thaumantias) are the primitive forms from which the Campanularian medusa (Leptomedusa) have been developed!

Asexual budding of medusa upon the gonads is unknown in the Thaumantiadx.

Brooks, 1895 , shows that the marginal sense-clulss of Landicea contain no trace of concretions. Their cores are entodermal and they arise from the level of the exumbella nervering, above the velum, and are identical in all their anatomical relations with the sense-clubs of the Narcomedusx and Trachymedusx.

Haeckel, 1879, includes Gonionemus and the Williadi among the Thaumantiadie. Gonioncmus is certainly not one of the Thaumantiadx, for it has marginal lithocysts; and according to the researches of Hincks, 1872 , and Browne, 1896 , the Williadi are derived from Tubularian hydroids and should be placed among the Anthomedusx.

The Thaumantiadx may be conveniently, although somewhat arrificially divided into three subfamilies:

1. Melicertina, with simple, unloranched radial-canals.

2. Polyorchina, in which the radial-canals give rise to blindly-ending side hranches, and these side branches do not fuse with the circular vessel.

3. Berenicina, in which the radial-canals give rise to side branches, and these side branches connect with the circular vessel.

A description of the genera of the Thaumantiada follows:

Subramily Mrlicrertins: With simple, unbranched radial-canals upon which the gonals are developed. The lips are as numerous as the radial-canals. Ocelli, marginal sense-clubs, cordyli, and cirri dre often present. There are no oral tentacles.

Thaumantias Eschscholtz, $1829=$ Tetranemat Thaumamias HAEck r., 1879. 4 or more tentacles, 4 radial-canals, and 4 simple lips. No marginal clubs or cirri. Hydroid: Thaumantias.

Leiadicea LESSON, 1843=Ocromemat Ladice HAECKEL, 1879. 4 or more tentacles, with marginal clubs or cirri or both between tentacles. 4 radial-canals, 4 simple lips. Hydroid: Cuspidella.

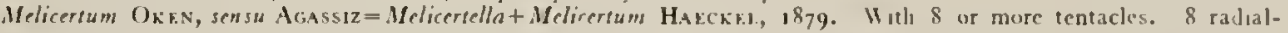
canals, 8 simple lijss, and without marginal sense-clubs and cirri. Hydroid: Melicertum.

Melicerlissa HaEckrL, 1879. With 8 or more tentacles. 8 radial-canals and 8 lips. With marginal sense-cluhs or cirri. This is equivalent to Melicertussat Melicertidium Hafek $2 \mathrm{~L}, 1879, \mathrm{p}$. 124.

Orchistoma Hascers., 1879 . More than 8 radial-canals and the same number of lips. With or without margnal sense-clubs and cirri. Development unknown.

Timoides Bigelow, 1904. 4 radial-canals. Ring-canal gives rise to blindly-ending, centripetal canals. Stomach upon a peduncle. 4 gonails on the radial-canals. Numerous tentacles and cirri. Development unk nown.

Sthranly Polyorchina: 4 or more radial-canals which give rise to blindly-ending side branches that do not reach the eircular vessel. Gonads upon radial-canals, or upon their side branches. Ocelli, marginal sense-clubs, and cirri are often present.

Sinurodiseus Hanckni, 1879 . 4 radıal-canals, each of which gives rise to 2 blindly-ending side hranches. Gonads upon 4 main radial-canals, also upon side branches. There are marginal sense-clubs. Manubrum tubular, with 4 sinple lips. Development unknown.

I'tychogena A. Agassız, 1865. 4 radial-canals, which give rise to numerous blindly-rnding side branches upron which gonads are developed. Manubrium wide and shallow. Mouth simple, large, cruciform opening. Developnent unknown.

Polyorehis A. Acassiz, 1862-65. 4 radial-canals, which give rise to nany blinelly-ending side branches. A number uf free sack-shaped gonads arise from radial-canals. Bell-margin simple. Manubrium long and tubular, and there are 4 simple lips. The ring-canal is simple without centripetal hranches.

Serippsia, Torrey, 1yog. Sinilar to Polyorchis, hut with a gastric peduncle and without pinnate branches on the ralial-canals distal to the gonads. (Sec Appendix.)

Spirocodon Harckel, $187 y=$ Goneomeandrus KurkPatrick, 1903. Similar to Polvorchis, but rung-canal gives rise to blindly-ending centripetal branches and bell-margin divided into lappets. Developunent untinowil.

Subranily Beranicina: Radial-canals branch and all branches connect witl circular vessel. Laps as numerous as main radial-cansls. Occllı, marginal clubs, and cirri often present.

Cannota Harckel, 1879 . 4 main radial-canals each of which gives rise to 2 simple side hranches, and thus 12 canals connect with the circular vessel. There are 12 gonads, 1 upon each terminal branch of the radial-canals.

Curieria Prikon, $1807=$ Berenice Hakckis., 1879. The 4 main radial-canals give rise to non-lichotonous sule branches, and the side branches also branch. Gonads on the terminal branches of the ralial-canils.

Dichotonia Brooks, I903. 4 main radial-canals all of which divide dichotomously two or more tuntes. The gonals extend outward from the sides of the stomach over the radial-canals and their branches.

Dipleurosoma Axf. Bufck, $1866=$ Tetracannota MAYr. 1900 . 3 or more man radial-canals, some or all of which give rise to non-dichotonous branches. Gonads on the canals adjacent to the in anubrium. According to Browne, the hydroid appears to be Cuspidella?

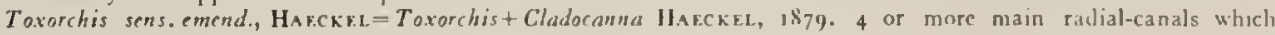
hranch dichotomously one or inore times. The gonads are upon the outer branches of the radial-canals near the circular canal.

Vetocertoides MaYre, 1900. 8 main radial-canals, which branch dichotumously. '17he gonads extend outward frem the sides of the stomach along the radial-canals. 
Thummuntios (in part), Escuscholtz, 1829, Syst. der Acal., 1. 102.-OKen, 1835 , Allgemeine Naturgesch., Bd. 5, p. 226.Lesson, 1843 , Hist. Zeroph. Acal., p. 176. -Foraes, 1848 , British Naked-eyed Medusa, p. 45 , etc.

Thaumanias. Gegrabaur, 1856, Zeit. fuir wissen. Zool., Bd. 8, p. 237.-Wricht, 1862, Quart. Journ. Microscop. Sci., N. S., vol. 2, pp. 221, 308.-Hincks, 1868, British Hydroid Zoophytes, P. 178. - Browne, i896, Proc. Zool. Soc. London, Pp. 4 So, $4 \$ 9$.- Hartlaub, 1905 , Zoologische Jahrbücher, Supplement 6, p. 567 .

Telranemat Thammantias, Ha Eckel, 1879, Syst. der Medusen, Pp. 125, 127.

Halmomises, von KeNNEL, 1891 , Sitzber. Nat. Ges. Dorpat, Bd. 9, p. 282.

The oldest species is "Thammantias hemispherica" Eschscholtz, $1829=$ Medusa hemisphtrica Gronovius, 1760 ; hut Browne, 1896 , shows that this is undoubtedly a Phialidium, and has lithocysts which former observers had overlooked. "Thaumantias acronautica" Forbes, 1848 , is probably a Phialidium, and the type species appears to be Thammantias collularia Haeckel=L,aodice cellularia A. Agassiz, I862, 1865.

\section{GENERIC CHARACTERS.}

Thaumantiadx with 4 gonads upon the 4 radial-canals. With 4 or more tentacles. Manubrium without a peduncle and with 4 simple lips. No marginal sense-clubs or cirri. The hydroid is Thaumantias.

Haeckel, 1879 , would restrict Thaumantias to include medusæ with 16 or more tentacles, and he proposed a new genus $\mathcal{T}$ ctrancma for medusæ with 4 tentacles. We adopt a broader definition and restore the older interpretation of Forbes and others, and include medusx with 4 or more tentacles under Thaumantias.

Thaumantias is separated from Laodicen by the fact that there are no marginal senseclubs or cirri in Thaumantias, whereas these structures exist in Laodicea.

The hydroid of Thaumantias was first descrihed by Wright, 1862 (Journ. Microscopical Science, vol. 2, p. 221). The stem is simple (or branched?) and rooted by a thread-like stolon; lydrothecx campanulate; polypites with a prominent funnel-shaped proboscis. The stem is sometimes ringed throughout, sometimes only at the base and summit. The calycles of the polypites are denticulate, the edge having ahout 7 teeth. There are 16 or more tentacles in a single ring. Wright reared the hydroid from the eggs of Thaumantias inconspicua Forbes.

Thaumantias is unfortunately a receptacle for all the medusx of Phialidium in which lithocysts have not been observed. The older authors, previous to Gegenhaur's researches published in 1856 , generally failed to ohserve the lithocysts; hence our heritage of numerous "species" of "Thaumantias." Browne, a most assiduous student of European medusx, recently stated that he had never found a $\mathcal{T}$ haumantias. I have never taken one in thousands of surface-tows made along the Atlantic coast of the United States from Eastport, Maine, to Tortugas, Florida, nor did I find a single specimen of Thaumantias in cruising over the

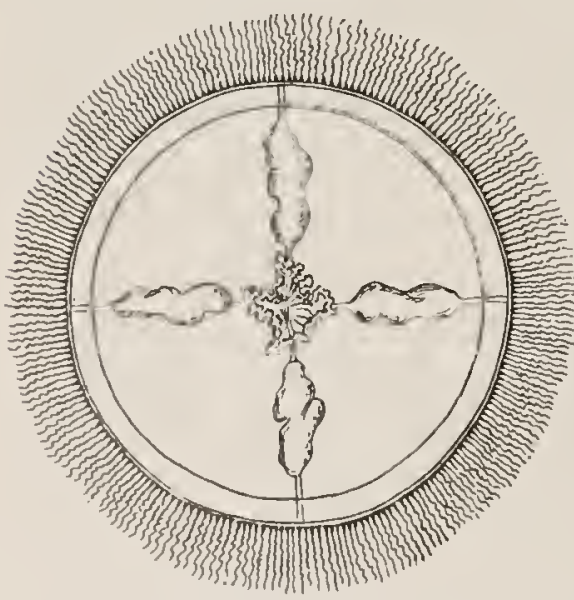

Iis. 102. Thaumantias eschscholizii, after Hacckel, 1879 . Pacific while serving as assistant to Dr. Alexander Agassiz. Dr. Lobianco, however, kindly permitted me to study some well-preserved specimens of a medusa collected by him at Naples, which I believe to be a T'haumantias.

Thaumantias eschscholtzii Haeckel.

Thaumanias esrhscholrzii, НАEскEL, 1879 , Syst.der Medusen, $\mathrm{p} .129$ tal. 8, fig. 4.-LEvinsen, 1893 , Vid. Meddel. Nat. Foran. Kjöbenhavn, ser. 5 , Bd. 4 , p. 145.

Bell flat and watch-glass-shaped, and 3 to 4 times as broad as high. About 10 to $12 \mathrm{~mm}$. in diameter. There are 240 to 280 slender tentacles with globular hasal bulbs which are provided with ocelli. The tentacles are ahout half as long as the radius of the bell. There are no sense-clubs or cirri upon the hell-margin. The velum is well developed. There are 4 straight, narrow radial- 
canals. The manubrim is very shalkow and there are 4 prominent, crinkled lips. The $t$ gonads are thick and cylindrical and oceupy the middle regions of the + radial-canals. Lach gonad is about half as long as the radial-canal upon which it is situated. Color-:) This medusa is found upon the western coast of Greenland.

Thaumantias rubrum.

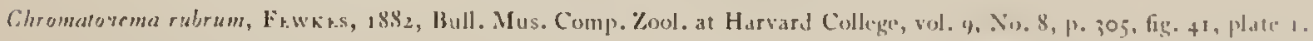

Bell hemispherical and gelatinous suhstance thick. There are 12 to 16 short tentacles. Nolithocysts, marginal clubs, or cirri. There are + straight, ladial tubes. Manubrium slort and there are + slightly crenulated lips. Gonads developed upon radial-canals aljacent to manubrium. Each gonad is about one-third as long as the radial tube upon which it is situated. 1he owa are very conspicuous. The gonads and tentacles are red in alcoholic specimens.

Found off the New England coast hy the United States lish Commission in 1880 and 188. Were the lithocysts destroyed by preservation in alcohol? Size (?)

Thaumantias cellularia Haeckel.

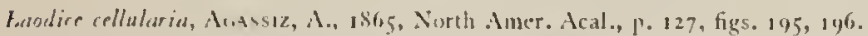

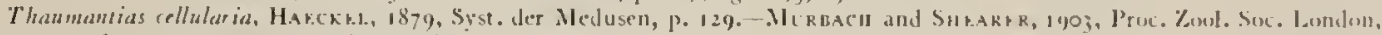
vol. 2, p. 172, plate 17, figs. 2-2b.

Bell thick, dome-like, about $30 \mathrm{~mm}$. wide, $20 \mathrm{~mm}$. high. Ahout 100 tentacles with welldeveloped basal bullos set closely" one hy the side of the other. "lentacles about as long as the bell-diameter. Stomach very small and with 4 long, slender, folded lips. 5 to 6 times as long as the diameter of the stomach. + folded linear gronads nearly as long as the f radial-cintials upon which they are developed. Stomach, gonads, and tentacle-hulbs violet.

Abundant off the l'acific coast of Washington during the summer and autumn.

Thaumantias forbesii Haeckel.

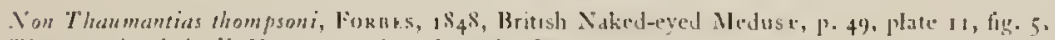

Thaumantias forbesii, Harcket, 1879, Syst. der . Medusen, p. 129.

Telranema encopium (voung or abortive medusa?), Harckel, Ibid., p. 125, taf. 8, fig. 1, 2.

Bell flat, $16 \mathrm{~mm}$. wide, 5 to $8 \mathrm{~mm}$. high. I6 tent acles longer than the bell-diameter with large, glohular hasal bulbs, separated by wide intervals. Ocelli upon the tentacle-bulls. Stomach small, globular. Mouth with 4 large folded lips, 2 to 3 times as long as the diameter of the base of the stomach. + ellipsoidal gonads upon the outer thirds of the + radial-canals, touching the margin. Mouth and stomach light-violet. Gonads and tentacle-bulbs dark violet. Ocelli hlack. Coast of Norway, near Bergen, Haeckel, September, i 860.

Tetranema cucopium Haeckel, 1879 , appears to be the same medusa, only 8 mm. wide with only + tentacles, and with 4 folded, spindle-shaped gonads over the greater parts of the t radial-canals. Found in the Straits of Gibraltar, by Haeckel, in March.

Thaumantias lacustris.

Halmomises lacustris, vos Kinsel, 1891 , Sither. Nat. Ges. 1)orpat, I3J. 9, 12. 282.

Halmomises lacusaris, won Kennb., Ann. and Mag. Nat. Hist., ser. 6, vol. 8, p. $25 \%$.

Bell about 2 to $2.5 \mathrm{~mm}$. in diamerer and slightly higher than a hemisphere. There are 16 to 24 very long tentacles with well-developed hasal bulbs, which contain a simple ring of pigment upon their outer (centrifugal) sides. There are no marginal cirri. The velum is well developed, being hroad and thin. The manubrium extends from the inner apex of the hellcavity to the level of the relar opening. It is cruciform in cross-section, with a wide proximal base. The mouth is simple, with + small, bluntly rounded lips. The + radial-canals are sinuous for the first three-fourths of their length from the + corners of the stomach. In the last quarter of their length, near their point of junct ure with the circular tuhe, they are straight and narrow. The canals are hroad in the sinuous region and here the gonads are situated. Fach gronad is longer than the portion of the canal upon which it is situated, and it is therefore thrown into frills and wisted sinuously. The hell is haline or faintly vellowish. The tentacles and hellmargin are slightly milkv. The gonads are yellowish-brown. 
This medusa was discovered by von Kennel in a fresh-water lagoon on the east coast of Trinidad, south of Mayaro Point, in a cocoanut plantation. The water in which it was living was apparently perfectly fresh, not heing salt to the taste. The lagoon was in communication with the sea during the rainy season.

Thaumantias mæotica Ostrooumoff.

Thaumantias marotica, Ostrooumurf, 1896, Bull. Acał. Impériale des Sci. St. Pétersbourg, sèr. 5, tome 4, p. 401, plate 1, figs. $2,4,5$.

Bell fuller than a hemisphere, with very thick gelatinous substance; $18 \mathrm{~mm}$. wide, $10 \mathrm{~mm}$. high. 32 filiform, slender tentacles, twice as long as bell-diameter, with well-developed basal

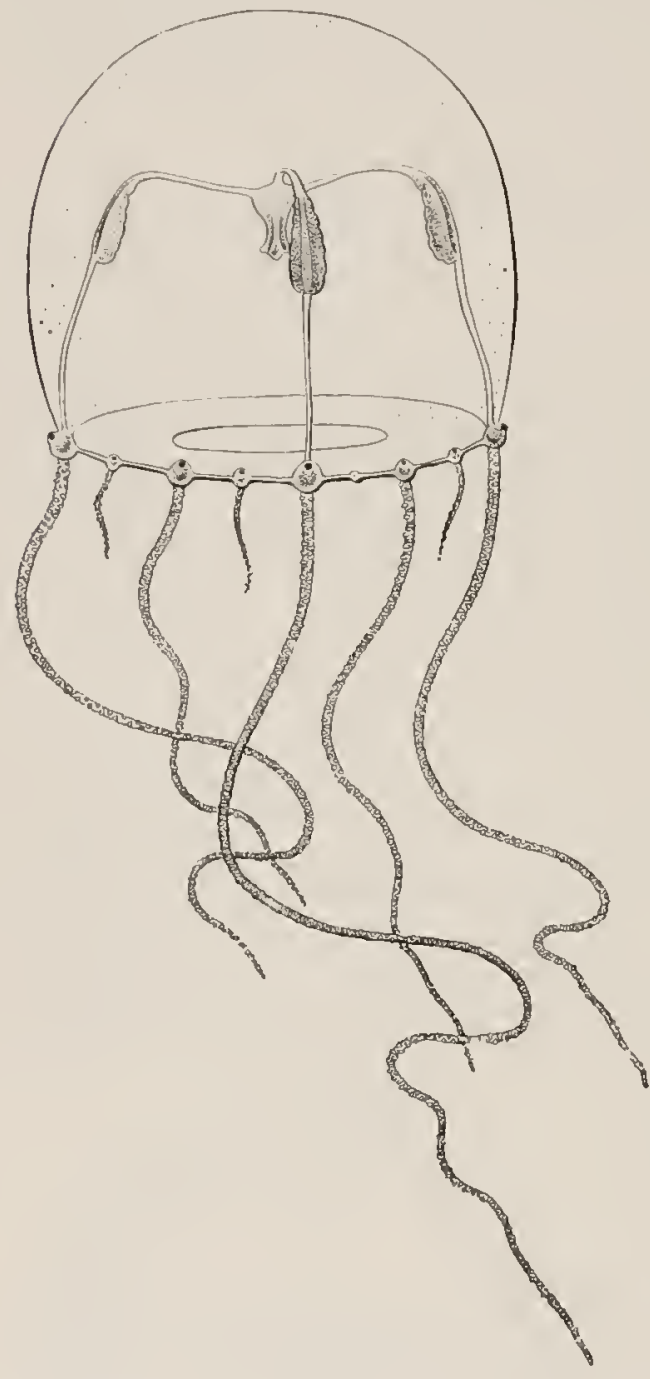

Fis. 103.-Thaumantias matica?

bulbs. Dark-colored ectodermal ocellus on each tentacle-hull. Velum narrow. 4 straight, slender radial-canals. Manubrium 4-sided, prismatic, with 4 simple lips. About half as long as depth of bell-cavity. No peduncle. 4 spindleshaped gonads on the middle thirds of the 4 radial-canals. Sea of Azov, Russia.

Dr. S. Lobianco of Naples kindly permitted me to study some very well-preserved specimens of a Thaumantias which he collected in the Bay of Naples. At first I was inclined to regard these as a new species, but now helieve that they may represent a young stage of $\mathcal{T}$ haumantias merotica. I herewith present a cut (fig. 103) representing the largest of Dr. Lobianco's specimens together with the following description:

Bell $4 \mathrm{~mm}$. high and of about an equal width. A pex evenly rounded and exumhrella smooth. Gelatinous substance thick at apex, but thin at lell-margin. Bell-cavity ahout two-thirds as deep as the height of the bell.

There are not more than 16 tentacles; the number among six specimens observed by me ranged from 8 to $\mathrm{I} 2$. The 4 perradial tentacles are about twice as long as the bell-diameter, the 4 interradial about half this length, and the adradial tentacles are not more than one-third as long as the interradial. All of the tentacles taper gradually to their tips and are sharply set off from their globular, swollen, basal bulbs. There is a black, abaxial, ectodermal ocellus upon each basal bulb. The shaft of each tentacle is regula rly hesprinkled with small, isolated, wart-like patches of nematocyst-cells, which do not form rings.

Velum very wide. There are 4 straightedged, narrow ra dial-canals and a simple, slender ring-canal. Manubrium small, flask-shaped, and with 4 simple lips. It is not more than one-fourth as long as the depth of the bell-cavity. The 4 spindle-shaped gonads are developed along the 4 radial-canals from their proximal thirds to their middle points. They are apparently immature.

The collection of the Stazione Zoologica at Naples, Italy, contains six well-preserved, alcoholic specimens of this medusa, which were gathered by Dr. Lobianco in the Bay of Naples.

This medusa bears some resemblance to Thaumantias quadrata Forbes, 1848, British Naked-eyed Medusa, p. 43, plate 9. fig. 2; from Loc Fyne, Scotland. In this British medusx, however, there are apparently no true ocelli, the so-called ocelli of Forbes being orangecolored cutodermal pigment in the tentacle-bulbs. 


$$
\text { - }
$$


PLATI: 22.

Fig. 1. Dissonema turrida, mature male. Tortugas, Florida, June 21, 1907. Figs. 2 to 4 . Ladiced cruciata ("calcarata"). Successive stages in the development of the medusa. Agassiz Laboratory, Newport, Rhode Island, June to September, 1892.

Fig. 5. Laodicea cruciata ("calcarata"). Part of the bell-margin of the medusa shown in figure + .

Fig. 6. Laodicen cruciate ("calcarata"). Details of the gonads and manubrium of the medusa shown in figure 4 .

Fig. 7. Staurodiscns tetrastaurus, young medusa. Charleston Harbor, South Carolina, September 14, 1897 .

Fig. 8. Staurodiscus tctrastaurus, young medusa. A sense-club from the bell-margin.

See page 116 for description of figure 1 .

Drawn from life, lyy the author. 


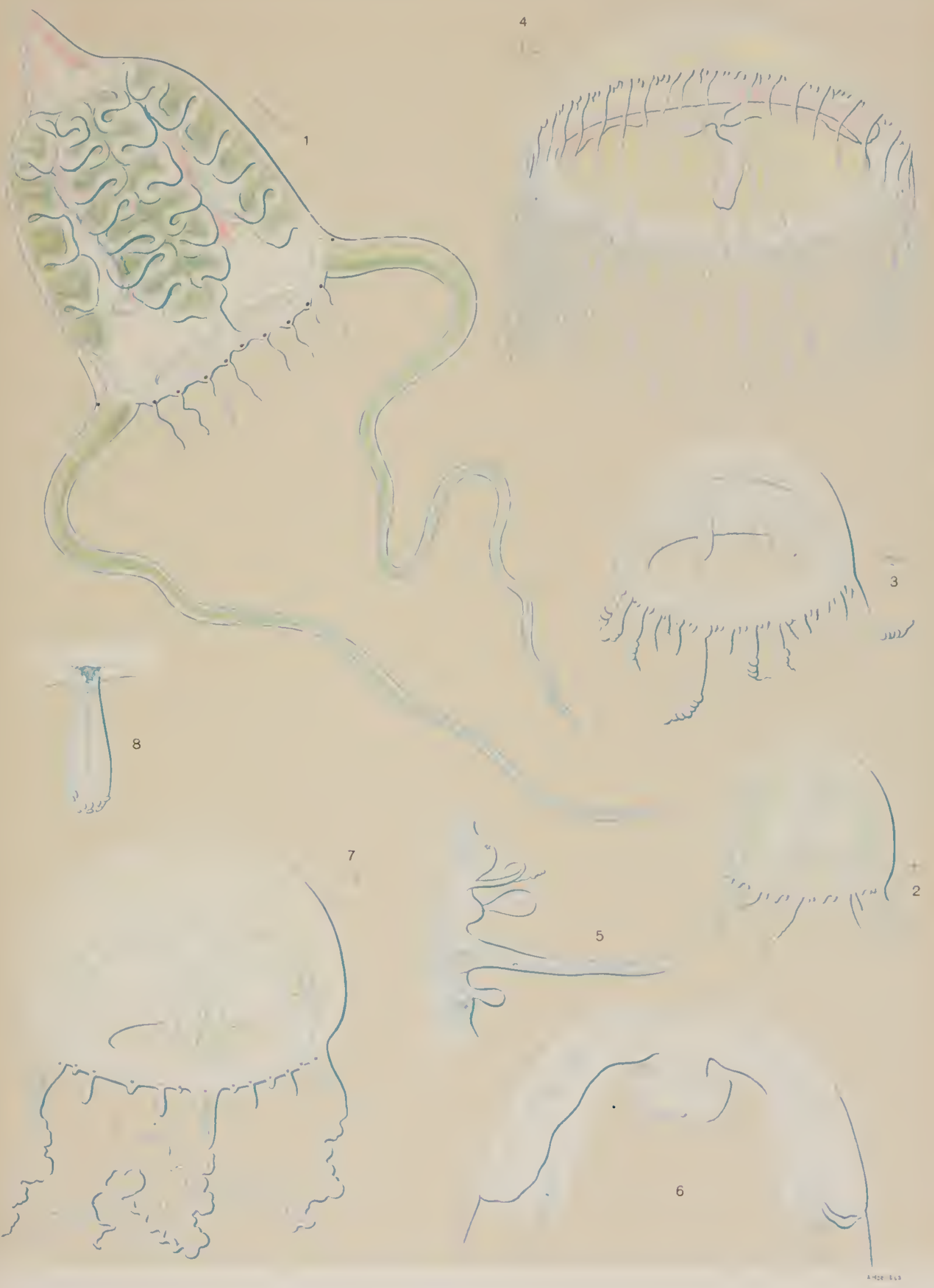



Genus LAODICEA Lesson, 1843 .

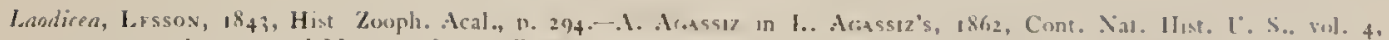

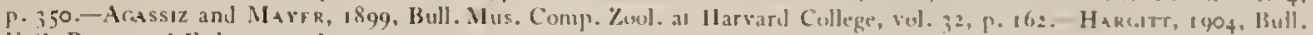
L'.S. Bureau of Fisheries, vol. $24, \mathrm{r} .43$.

Cosmetira, Forнis, 1848 , British Naked-eyed Medusa, p. $4^{2}$.

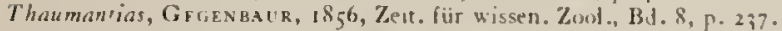

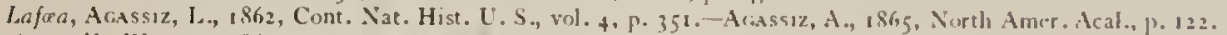

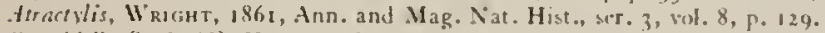

Ciuspidella (hydroid), Hixexs, 1868 , British Hvilroid Zooph., J. 209, plate to.

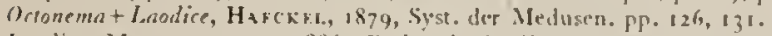

I.colice. Mrtschisork, 1886, Emhryol. Studien an Medusen, 11 ien, P. 23, etc. (development). Broosis, 1S95, Journal

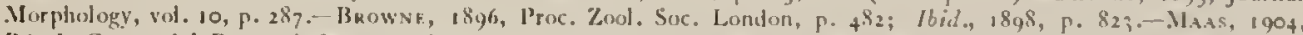

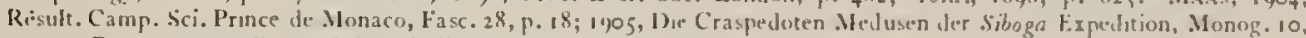

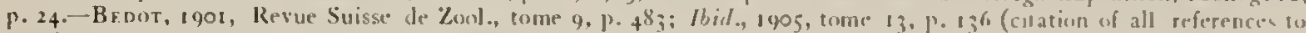
1850).-Browis, [907, Annals and Mag. Nat. Hist., vol. 20, ser. 7, p. $45 \%$.

Cienue $x, \mathrm{M}+\mathrm{s}, 1893$, Hydromedusen Plankton Expedition, p. 65.

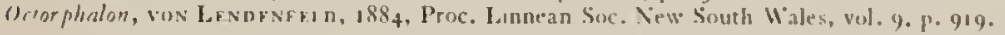

This genus was founded by Lesson, $18+3$, for Ladicea crucinta, of the coast of Europe. which appears to have been previously described by Forskil, 1775, under the name of ./Cdus crucinta.

\section{GI:NERIC CIIARACTERS.}

Thaumantiadx with + gonads upon the + radial-canals. With + or more tentacles. The tentacle-bulhs often bear ectodermal ocelli. Sensory-clubs (cordyli) and cirri are situated hetween the tentacles. The stomach is without a peduncle. There are + simple, cruciform lips. The hydroid is Conspidclla Hincks.

Brooks, 1895 , shows that the sensory-clubs of l.nodicen are situated upon the ecrodermal neve-ring, which is found on the exumbrella side of the hell immediately above the velum. The core of each sense-club is composed of entodermal cells which are in direct connecrion with the entoderm of the circular canal. The sense-clubs contain no concretions. Anatomically the sense-clubs of Lnodics are strikingly similar to the embryonic sense-clubs of the Narcomedusa and Trachymedusie. but they lick concretions. On the orher hand there can be no doubr that Laodicon is closely related to the lithocyst-hearing Leptomedusa or Vesiculatx of the Herrwig brothers.

Haeckel introduced the spelling Lanodice, but Lesson's original name is spelled Janodicon. Our Iandicen is equivalent to Laodice Octonoma Haeckel. The medusa of Ladicen are extremely variable in color and in the arrangement of their tentacles, cirri, ocelli, and marginal sense-clubs. I am inclined to helieve that L. ulothrix. J. calcarata of the Atlantic, I.. indica of Ceylon, and I. marama of the Fiji Islands are only local races of L. crucinen of the Mediterranean and Atlantic coasts of Europe. All of these so-called species are possibly only imperfectly differentiated local races of Ladicen crucinta. Browne, 1896,1898 . has shown that the common Mediterranean, European, and Anerican Jonodiced are probably one and the same species, and my own studies serve only to convince me of the conrectness of his vicw.

As in Tiarrpsis the species of Iandicen fall into two well-defined groups: Those with + to 8 rentacles, represented by L. cucope. fertilis. neptuna, and golatinosa, and those with 32 to 300 tentacles, represented by $L$. cruciatu, chapmani, and pulchra.

Metschnikoff, 1886, made elaborate studies of the development of the egor of the Larodicen crucinn of the Mediterranean; and he succeeded in rearing the larva until they developed into small hydroids of the genus Couspiddlen Hincks.

\section{Laodicea cruciata L. Agassiz.}

Plate 21, figs. 4 and 5 ; plate 22, figs. 2 to 6i plate 23, figs. 1 in i.

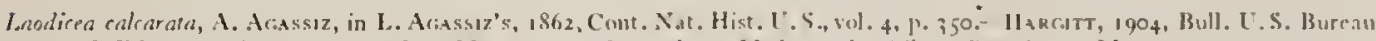

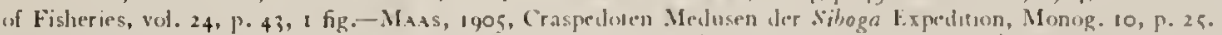

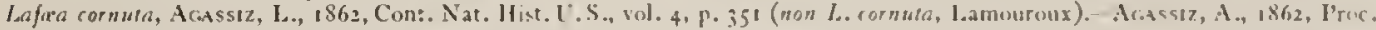
Boston Soc. Nat. Hist., vol. 9, p. 91, fig. 4 .

Campamularia dumosa, I.Fidr, 1859 , Marine Invert. Fauna of R. I. and N. J., J. 6.

Laffra rulcarata, Acassiz, A., 1865 , North Amer. Acal., F. 122, figs, 184, 194.

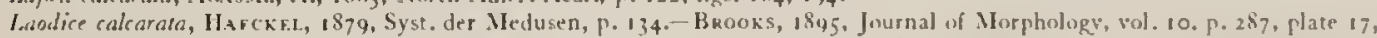

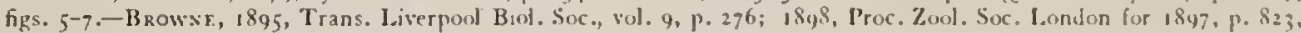
plate 49, fig. 4; 1900, Proc. Royal Irish Acad. Duhlin, ser. .., vol. 5, p. 720.

Lafoia calearata, V'FrRIL, 1873 , Report Commiss. Fish and Fisheries for $1871-72$, p. 729. 
Helhella calcarata (liyclroid and medusa), Nutring, 1901 , Bull. U. S. Fish Commission for 1899, Pp. 353, 378, figs. 56, 94.

Laodice indica, Brownf, 19o5, Pearl Oyster Fisheries Gulf of Manaar, Suppl. Repurt 27, Roy. Soc. Lomdun, P. 136, plate 1, fig. 5; plate 4 , figs. 7-11 (Ceylon).

Ianodice wothrix, Hakcker, 1879, Syst. der Medusen, p. 133, taf. 8, fign. 5-7.--Bkooks, 1895, Amer. Journal Morphology, vol. 10, P. 304 , plate 17,7 figs.

Locodicea uloshrix, Mayr., 1900, Bull. Mus. Comp. Zool. at Harvaral Coliege, vol. 37, p. 49; 1904, Mem. Nat. Sci. Brooklyn Institute Museum, vol. 1, P. 14, fig. 30, plate 4.

Iandicra marama, Agassiz, A., and Mayr.r, 1899, Bull. Mus. Comp. Zool. at Harvard College., vol. 32, p. ifuz, plate 3, figs.7, 8 (Fiịi Islands).

(?) Medusa aquarea, Bast F. R, 1759, Opuscula subseciva, 11, P. 55, taf. 5, fign. 2, 3 .

(?) Medusa cruciata, Forskis., 1775 , Descript. anim., p. 110, taf. 33, fig. A.

Thaumantias undulata, Forkfs and Goods1R, 1853 , Trans. Koy. Soc. Edinhurgh, vol. 20, p. 313, plate 10, fig. 7.

Thaumanias mediterranea, Gegrnbauk, 1856 , Zeit. für wissen. Zool., Bd. 8, p. 237, taf. 8, fign. 1-3.

l.aodice cruciata, Agassiz, L., 1862, Cont. Nat. Hist. U.S., vol. 4, p. 350.- HA EckF.L, 1879, Syst. der Medusen, p. 132 (a list of bubliography).-Browne, 1896 , Proc. Zool. Soc. London, p. 483 (a good discussion of the literature).- Graf.Fff, 1884 , Arbeit. Zool. Inst. Wien, Bd. 5, P.357.-M mtschisikoff, E., 1886, Embryologische Studien an Medusen, Wien, Pp. 23 (egg), 37 (segmentation), 57 (formation of entoderm), 83 (polypute), taf. 4, fign. 17-31; taf. 5, fig. 1.

(?) Loodice pulchra, Browne, 1902, Annals and Mag. Nat. Hist., ser. 7, vol. 9, p. 280 (Falkland Islands).

daodicea cruciata L. Ag. = Thaumantias mediterranea Gegindiatr; Metschnikoff, E., 1886, Arbeit. Zool. Inst. Wien, Bal. 6, p. 239.

Cosmetira salinarum, du Prfssis, 1879 , Annal. Mag. Nat. Hist. London, vol. 3 , P. 385 (= L. cruciata).

Iocodice salinarum, Hafckf, 1879 , Syst. der Medusen, p. 636 (from the salt ditches of Montpellier, Mediterranean coast of France).

Laodice craciala, BFDot, 1901, Revue Suisse de Zool., tome 9, P.483; Ihid., 1905, tome 13, p. 136 (all papers cited to 1850 ). llebella calcurata. Thornfir, 1905, Report Pearl Oyster Fisheries of Ceylon, Roy. Soc. Lonılon, Part 2, p. 116 (hydroid from the Gulf of Manaar, Ceylon).

Laodice calcarata, elc., BroWNe, 1907, Annals and Mag. Nat. Hist., vol. 20, ser. 7, p. $4_{60}$; Cuspidella (hydroid), Ibid., p. $4^{6} 3$.

It is difficult to determine the correct name of this medusa. Mednsa crucrata Forskåt, 1775 , is so vaguely described and figured that it will never be possible to determine its true relationships, and this is also true of Medusa crquoreo Baster, 1759.
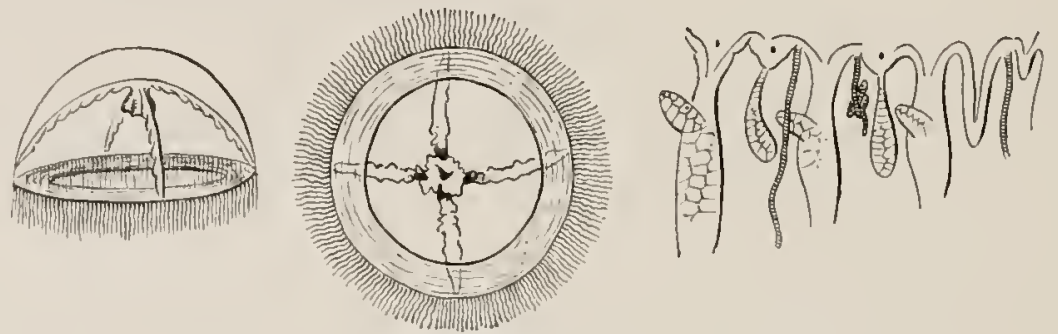

Fic. 104.-Laodicen "mediterramea," after Gegenbaur, in Zeit. für wissen. Zool., Bd. 8.

Oral and side views of medusa and part of bell-margin showing tentacular spurs.

Thammantias meditcranea Gegenbaur, 1856 , is evidently a Laodicea, and is the same medusa which L. Agassiz, 1862, and Haeckel, 1879, call Laodice crmciata. Browne, 1896, 1898 , inclines to the opinion that L. calcarata, I. ulothrix and Thaumantias mediterramea = L. cruciato L. Agassiz and Haeckel. and are one and the same species. My studies of Laodicen "calcarata," which is very abundant along the Atlantic coast of the United States south of Cape Cod, has convinced me that it is identical with Laodicen cruciata of Europe, and is also distributed widely over the Pacific, where it has been called L. marama and $L$. indica. The extreme variability in color and in the development of the marginal appendages has caused much confusion in the naming of this most abundant and widely spread medusa. The old name $L$. crmciata takes precedence over "calcarata" and should supersede it, being, indeed, synonymous with it, but nevertheless the identity between this medusa and "Medursa crucinta" of Forskål must remain in doubt. It seems advisable, however, to retain an old and familiar name rather than to reinstate an unfamiliar one such as L. indulota, which is the specific name given to this medusa by Forbes and Goodsir, I 853 .

Adnlt medusa (plate 22, fig. 4).- The bell is about 20 to $25 \mathrm{~mm}$. in diameter, and when fully expanded it is somewhat flatter than a hemisphere. Being very flexible, however, it assumes all sorts of distorted forms under the influence of contraction. The gelatinous substance is not thick at the apex and becomes regularly thinner toward the margin. There are 70 to 150 , or more, long tentacles, the ends of which are usually coiled in a close helix, while the main shaft of each tentacle is quite straight and rigid. The basal bulbs of the tentacles are large and hollow and often have abaxial spur-like projections; and there is a dark-hrown or 


\section{Pilate 23.}

Figs. 1 and 2. Lodicen crmcinta var. nothrix. Successive stages in the development of the mednsa, Toriugas, Forida, June, 1897.

Fig. 3. Inodicen crncinto var. ulothrix. Oral view of gonads of a female medusa. Nassau Harbor, Bahamas, June, 1903.

Fig. 4. Melicertum campanula, young medusa. Nahant, Massachusetts, May 6, 1898.

Fig. 5. Melicertmm camponuln, mature male. Marblehead, Massachusetrs, July 6. 1900 .

Drawn from life, by the author. 


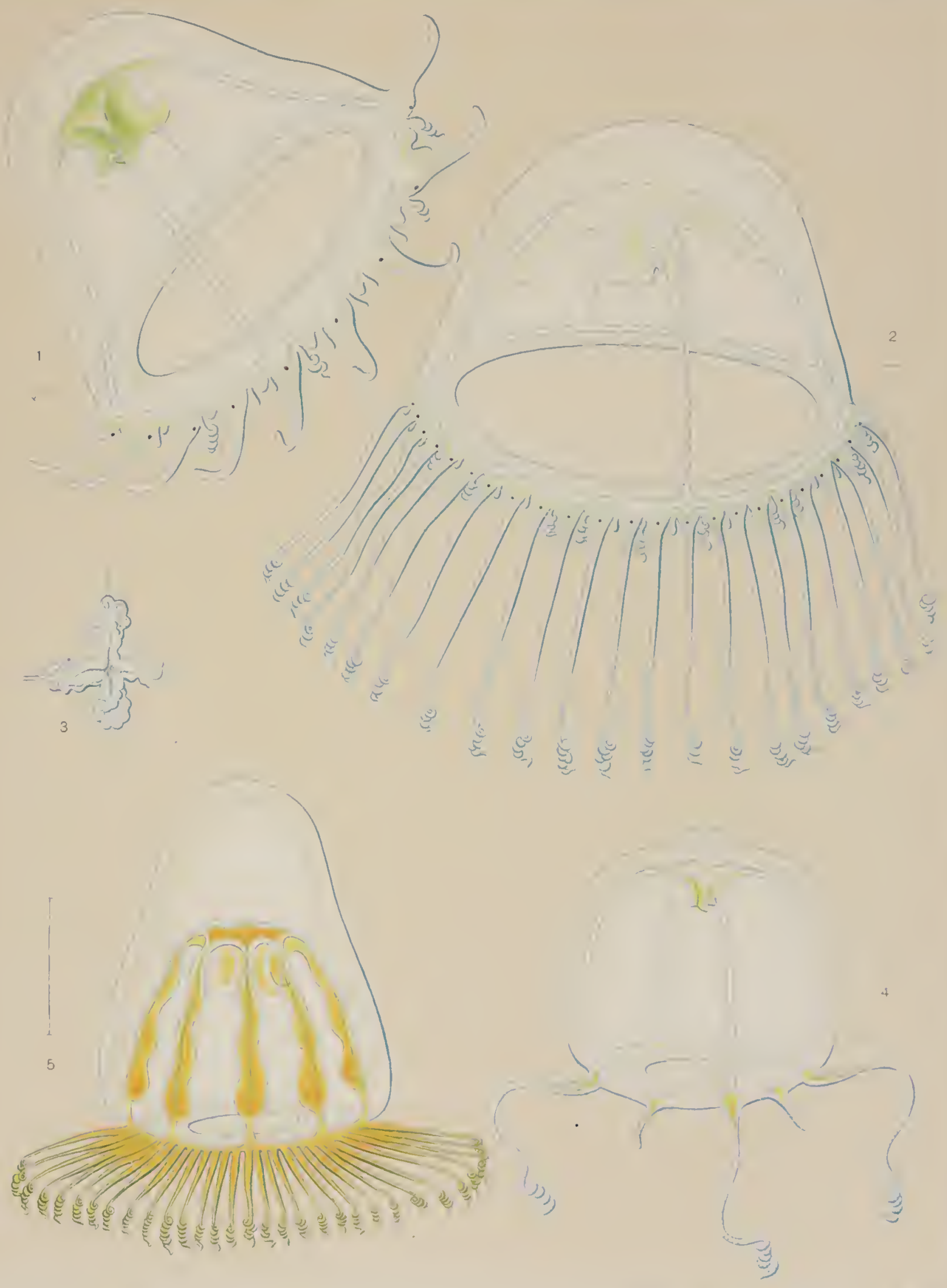



purple ocellus situated within the ectoderm of the inner (centriperal) side of most of the tentacle-bulbs. There are a number of coiled cirri scattered between the tentacle-bulls (plate 22. fig. 5). 'These are usually somewhat less numerous than the tentacles. "They' arise at a short distance above the bell-margin on the exumbella side of the hell. The core of each cirrus is made up of highly vacuolated entoderm-cells which are continuous with the entoderm of the circular canal.

Numbers of spindle-shaped nematocyst-capsules are found in the ectoderm at the distal end of each cirrus. In addition to the cirri there are one or two clubs, or cordyli, hetween each successive pair of tentacles. The distribution of these cordyli is very irregular, but they are usually somewhat more numerous than the tentactes. Each club is flask-shaped and united to the hell-margin by means of a narrow neck. They arise from the side of the exumbrella at the level of the upper nerve-ring, a very" short distance above the level of the velum. "The core of each sense-cluh is composed of large, highly vacuolated. entodermal cells which are directly. continuous with the entoderm of the circular-canal (see Brooks, 1895 , plate 17. fig. 5). 'The

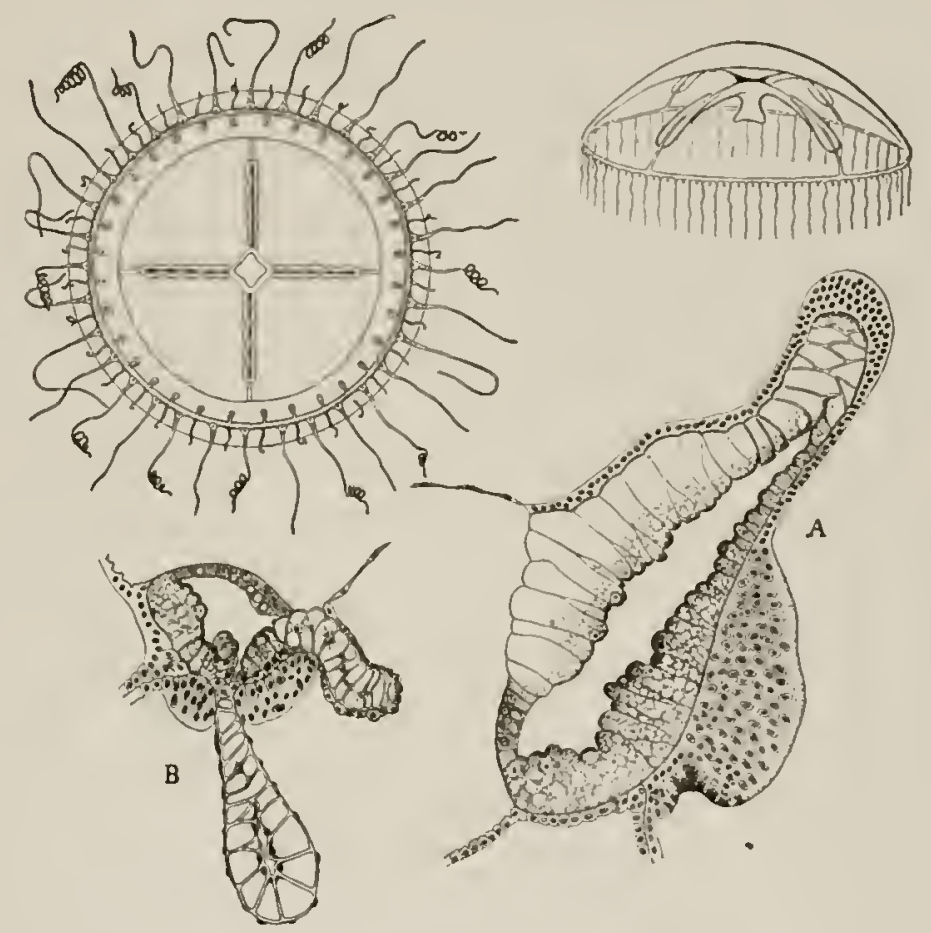

Fic. 105.- Lnodicen crucinta (ulothrs), after Bronlis, in Journal of Morphologv, vol. 10.

1. Section of tentacle. B. Section of one of the marginal clubs.

clubs are not solid for there is usually a smatl intercellular humen in the axis of the broad distal end of the club. There are noconcretions. The velum iswell developed. There are tstraight. narrow radial-canals. The stomach is short and quadrangular in cross-section, and there are + recurved, shighty crinkled lips. In fully grown individuals the gonads extend from the sides of the stomach down nearly, if not quite, the entire length of the radial-canals. The medusa is very variable in color, some individuals being nearly colorless. In others the entoderm of the manubrium, gonads, and rentacle-hulbs is green or pink. and the entodermal lamella of the betl is of a delicate green, while in others the entoderm is milky or dull translucent yellow.

This medusa is common along the coast of the United States from June to early winter. along the southern shores of New England to Cuba and the West Indies, hut it has not heen taken north of Massachusetts Bay. It ranges into more northerly latitudes off the European coast, however, for Browne took it in Valencia Harbor on the southern coast of Ireland. It is seen in the Mediterranean from Octoler to December, and is found in the Fiji lslands, 
and Ceylon, in the Pacific and Indian Oceans. It is common only near coasts, not being a creature of the open ocean. It appears to be far more abundant off the coast of America than in European waters. I found it only occasionally at Naples during the winter of I907-08.

The development has been studied by Metschnikoff. The early stages are descrilied for the Mediterranean L. cruciata. The egg is $0.18 \mathrm{~mm}$. in diameter and is laid between 4 and 5 in the afternoon from November to December. Segmentation is total and equal; and an oval, hen's-egg-shaped, ciliated, one-layered blastula is formed. Sometimes one sees a slight temporary invagination at the narrow hinder end of the blastula, but this is not the beginning of the formation of the entoderm. The entoderm on the contrary is formed from numerous cells which migrate individually into the large central segmentation cavity from the hinder end of the blastula. The resulting planula swins about for a time, but finally it attaches itself and becomes a creeping, root-like, slightly branched hydrorhiza, from which there arise unbranclied polypites "resembling Cuspidella lumilis or Cuspidella costata Hincks."

The liydrotheca is long and subcylindrical, and the margin is provided with sharp-pointed teeth, and the polypite may withdraw within the hydrotheca and close the opening by the folding together of these teeth. The polypites have flaring, open, urn-shaped peristones, below which there is a zone of $10 \mathrm{long}$, slender, fliform, nematocyst-studded tentacles, all of alout the same length.

Browne, 1907, states that Miss M. Delap, of Valencia Island, off the southern coast of Ireland, maintained a colony of Cuspidella costata Hincks alive, and obtained from it young medusa which resemble the youngest stages of Laodicea calcarata found in the Ocean. It is probahle, therefore, that the hydroid described by A. Agassiz, I865, as Lafaca calcarata and which he believed to be the nurse of Laodicea is not such. It lacks the toothed operculum found in Cuspidella and the margin of the hydrotheca is simple and entire. The direct embryological evidence demonstrates that the hydroid of Laodicen is Cuspidella I lincks.

Tabulnr Synopsis of the "Varicties" of Laodicen crucintu.

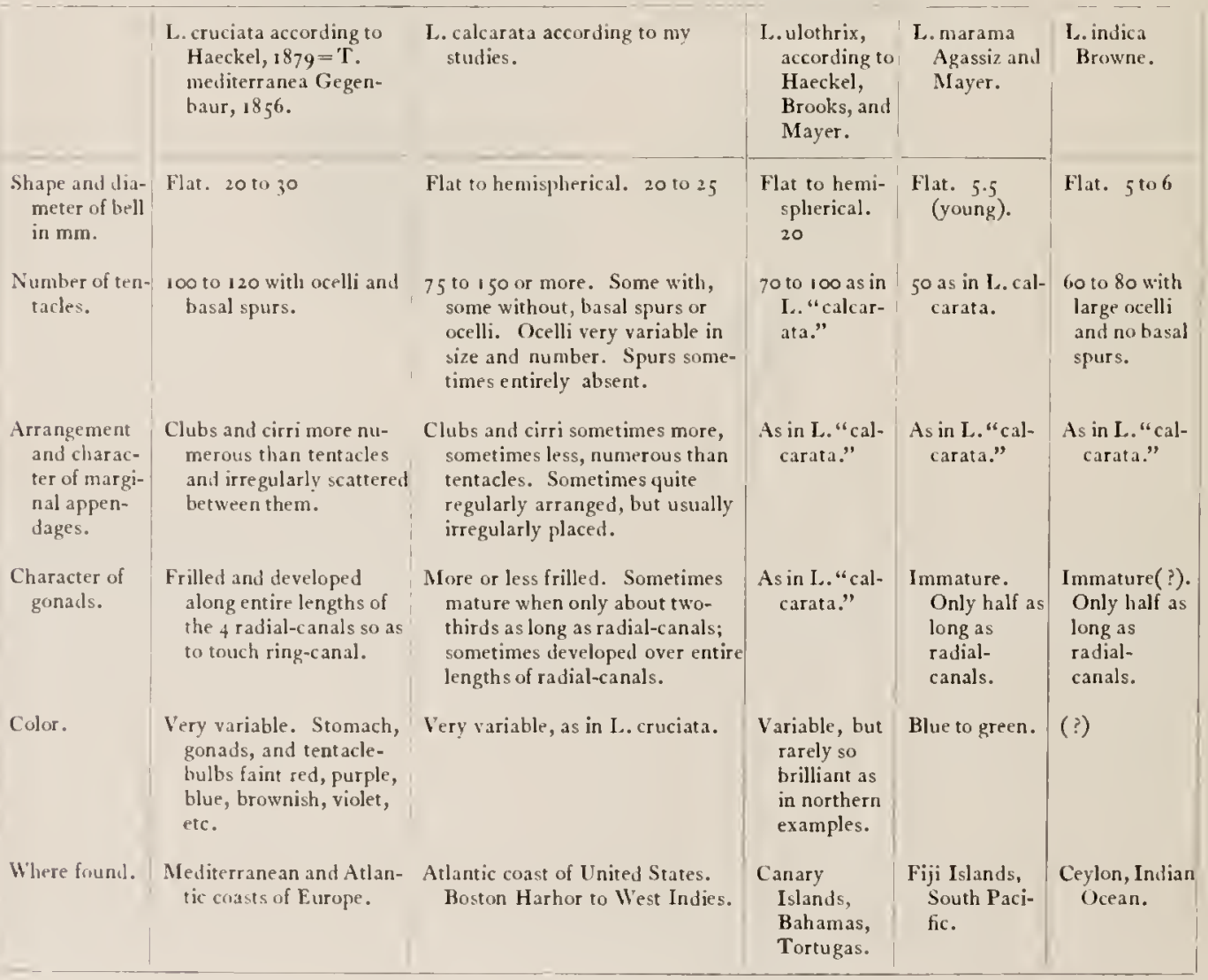


When set free the medusa usually has 2 long tentacles, 2 well-developed hasal hulls, and + small interradial swellings upon the bell-margin. At this time the bell is about $1 \mathrm{~mm}$. in height and about $0.7 \mathrm{~mm}$. in diameter (plate 22, fig. 2). Its outer surface is covered with nematocyst-cells. There are only one or two marginal clubs or cirri in the young medusx. There are, however, well-developed ocelli within the ectoderm of the inner (centripetal) side of each tentacle-bulb. The + radial tubes are straight and narrow and the gonads are repre. sented by + scarcely perceptible swellings adjacent to the sides of the manulnium. "The manubrium is a simple tube with + small cruciform lips.

As development proceeds the tentacles increase in number, as do also the cluhs and cirri. The bell becomes relatively flatter until it approaches a hemisphere. 'The gonads hegin to develop at the angles of the manubrium and soon grow down the radial-canals until they extend to the circular canal. The manuhrium acquires 4 recurved folded lips.

A synopsis of the so-called varieties of $L$. cruciata such as is given on page 204 , may be of service in illustrating that we have here only one species.

\section{Laodicea fijiana Agassiz and Mayer.}

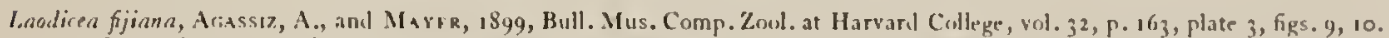

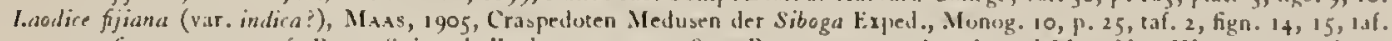
5, fign. 32-35; 1906, Revue Suisse de Zool., tome 14, P. 89.- Browvi, 1907, Annals and Mag. Nat. Hist., ser. 7, vol. 20, P. 4 6.7; L. massi, p. 466 .

Bell i 2 to $20 \mathrm{~mm}$. wide, + to $5 \mathrm{~mm}$. high. Bell-walls, although thin, quite rigid. 160 tentacles. These are flexible, tapering, with coiled ends, and are about as long as the bell-radius. Ahout half to three-fourths of the tentacles have a dark-hrown ectodermal ocellus upon the inner (axial) sides of their basal bulbs. "There a re a few clubs on the margin hetween the tentacles; about 12 to 15 in each quadrant in a large medusa, but only about 2 in each quadrant in specimens $6 \mathrm{~mm}$. wide. There are no cirri hetween the tentacles.

The stomach is square in cross-section, very Hat, and without a peduncle. It is about onefourth as wide as the bell-diameter and the lips are widely open, their folded edges inclosing an open square.

The gonads are developed upon the proximal parts of the + radial-canals and grow outward from the angles of the stomach, so that in large medusx they may extend over two-thirds to seven-eighths of the length of each radial-canal, nearly touching the ring-canal. They are developed upon numerous short side branches of each of the + radial-canals, so that they are complexly folded and quite wide. In the female the ova stand out prominently over the surface of the ectoderm. The outer portions of the + radial-canals, which lack gonads, are straight and narrow and of the same width as the circular vessel. color.

The entoderm of the stomach, tentacles, and radial-canals is opaque and milky-hlue in

Common on the surface in the tropical Pacific, Fiji, and Malay Archipelago. It apparently does not descend into deep water.

In large meduse the wide, flat, open stomach recalls that of Ptychogena. Maas found a single specimen with 5 lips and 5 radial-canals, and others hat 5 or 6 canals. This variahility recalls the condition characteristic of Diplenrosoma.

\section{Laodicea pulchra Browne.}

Iandire pudehra, Browns, 1902, Annals and Mag. Nat. Hist., ser.7, vol. 9, p. 280 ; Ihid., vol. 20, p. 4 fr6.

Unbrella Alatly curved, $25 \mathrm{~mm}$. wide, $15 \mathrm{~mm}$. high. About 50 tentacles without hasal spurs. No marginal cirri, but 3 or + clulss (cordyli) between every two tentacles. Each cordylus situated on a small bulb. An ocellus is usually found at the base of every tentacle and cordylus. The stomach is very large with + large perradial lohes extending nearly to the margin of the umbrella. The mouth has + large lips. "The gonads extend from near the stomach to within a short distance of the ring-canal. Found at Stanley Harbor. Falkland Islands, from November to February. Color (?) Briefly described, without figures, by Browne from specimens obtained by Vallentin. May this not be identical with latodicen cruciata? 
Laodicea? neptuna Mayer.

Plate 26, figs. 1-3.

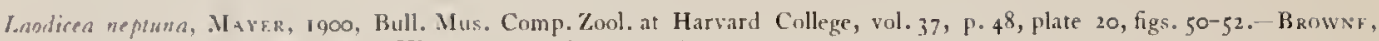
1907, Annals and Mag. Nat. Hist., ser. 7 , vol. 20, P. $4^{\text {frg. }}$

Immature medusa (?). - Bell little higher than a hemisphere and $2.5 \mathrm{~mm}$. in diameter. There are 8 short tentacles with large basal bullos and 8 small, rudimentary tentacle-hullss. Tentacles thickly covered with nematocysts and usually carried coiled and contracted. A single, large, black ocellus is found at the base of each tentacle (plate 26, fig. 3). There are numerous small nematocyst-bearing cirri but no sensory-clubs upon the bell-margin between the tentacles. The velum is well developed. There are 4 straight, radial tuhes, the upper regions of which, adjacent to the manuhrium, are occupied by the gonads. The manuhrium reaches slightly beyond the velar opening and the lips are surrounded by + prominent clusters of nematocyst-cells. The color of the entoderm of the manubrium, tentacle-bulbs, and circular and radial tuhes is pearly-iwhite. The entodermal lamella of the hell is of a delicate shade of green. This medusa was occasionally found at the Tortugas, Florida, during July and August, I 898 . It has not been seen since that time. I can not be certain that this medusa is a Laodiccu and share the douhts expressed by Browne, 1907, upon the subject.

\section{Laodicea? eucope.}

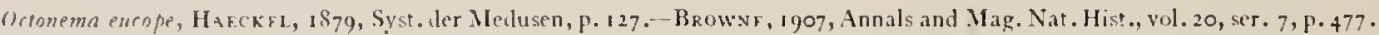

Bell hemispherical, $8 \mathrm{~mm}$. wide. 8 equal tentacles, somewhat Ionger than the belldiameter and with thick, glohular. hasal bulbs sharply set off from the long. delicate shafts of the tentacles. An abaxial ocellus with a subspherical lens on each tentacle-bulb. 60 to 80 marginal clubs. 30 to to spiral cirri as in Laodicen cruciata. 4 radial-canals. Stomach with 4 short, slightly-folded lips. 4 ribbon-like, folded gonads extending along the entire lengths of the + radial-canals. Color (?) Honolulu, Hawaiian Islands. The presence of abaxial ocelli may necessitate the removal of this medusa from the genus Laodica.

\section{Laodicea? fertilis.}

Oerorhopalon ferislis, vnn Lendenferd, 1884 , Proc. Linnean Snc. New Snuth Wales, vol. 9, p. 919 , plate 42, figs. 14-15.BRowvF, 1907, Annals and Mag. Nat. Hist., ser. 7, vol, 20, p. $47^{8}$.

Bell semi-ovate, $2.5 \mathrm{~mm}$. high, $2 \mathrm{~mm}$. wide. Stomach a 4 -sided pyramid, widest in the middle, "octaedral." 4 simple lips. 8 tentacles, + radial and 4 interradial; longest tentacles two-thirds as long as bell-height; interradial ones shorter. Tentacle-bulbs elongate. but narrow and conical. There are 8 adradial clubs upon the bell-margin. These are longer than the tentacle-bulbs. The gonads are complexly folded and extend over the entire lengths of the + radial-canals and fuse one with another on the sides of the stomach. Gonads orangeyellow, other parts colorless. Sydney Harbor, New South Wales, Australia, in September.

$A$ more detailed description is required before we can be certain of the actual aftinities of this medusa, which appears to have heen described from immature specimens?

\section{Laodicea? chapmani Günther.}

Lnodicen chapmani, Ginterk, 1903, Ann. and Mag. Nat. Hist., ser. 7, vol. 11, P. 425, plate 9, figs. 1-3. North Atlantic, nff the Irish const.

Iadodice (?) chapmani, MaAs, I905, Craspedoten Medusen der Sihoga Expedition, Monog. 10, p. 25. Brownr, 1907, Annals and Mag. Nat. Hist., ser. 7, vol. 20, p. 4 forg.

Bell $17 \mathrm{~mm}$. wide, $12 \mathrm{~mm}$. high. 32 rentacles, only 4 of which have ocelli. These 4 are at the hases of the + radial-canals. Marginal clubs (?) Cirri (?) 4 fimbriated, protrusive gonads on restricted parts of the + radial-canals somewhat nearer to the sides of the stomach than to the bell-margin. A single specimen taken between 1,070 fathoms and the surface off the Irish coast in N. lat. $52^{\circ} 18^{\prime}, \mathrm{W}$. long. $15^{\circ} 5 t^{\prime}$.

The gonads do not touch the sides of the stomach. Is this an abnormal specimen of I. cruciata or does it betong to some genus other than Laodicea? 



\section{PLATE 24.}

Fig. I. Orchistoma tentaculata, young medusa. Agassiz Laboratory, Newport, Rhode Island, August 18,1896 .

Fïg. 2. Mclicertissa clavigcra Haeckel, Tortugas, Florida, June 2, 1906.

Fig. 3. Mclicertissa clavigera Haeckel. One of the marginal sense-clubs of the medusa shown in figure 2.

Fig. 4. Laodicea cruciata var. ulothrix. Part of the bell-margin of the medusa shown in figure 2, plate 23 .

Fig. 5. Meliccrum campanuln, half-grown medusa with the 4 secondary radial-canals beginning to develop. Nahant, Massachusetts, May 6, 1897 .

Drawn from life, by the author. 


Meliceria, preoccupied by Schkaxk, 1803, for Rotilers.-Oken, 1815, Lehrbuch der Naturgesch., Bd. 1, Register p.4. 1'. 125 . Pbron et Lisurur, 1809 , Ann. du Mus. Hist. Nat. Paris, tome 14, P. 352.-I.esson, 1843, Hist.7ooph. Acal., p. 324. Meliertum, Okr.N, 1835, Allgemeine Naturgesch. für alle Stande, Bd.5, p. 226.-Escuscuoltz, 1829 , Syst. der Acalephen, P. 105.-Ehresberg, 1837 , Abhandl. Akad., 1835 , Berlin, P. 255.-Aciassiz, 1.., 1862, Cont. Nat. Hist. U. S., vol. 1. pp. 349, 352.-Agassiz, A., 1862, Proc. Boston Soc. Nat. Hist., vol. 9, p. 96; 1865, North Amer. Acal., p. 130.

Mass, 1897, Mem. Mus. Comp. Zool. at Harvard College, vol. 23, p. 19.-L1sko, 1904, 7ool. Anzeiger, 13d. 28, p. 218. Campanella, MӧRсн, 1857 , Beskriv af Grönland, P. 95.

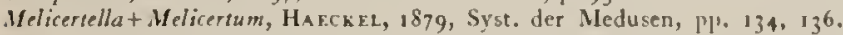

Melicertidium, Browne, 1905, Proc. Royal Soc. Edinburgh, vol. 25, 1. 764.

The name Mclicerta appears, inadequately defined, in Oken's Lehrbuch, 1815, on page iv of the index and page 125 of the text. The same medusa is apparently described by Oken. 1835. under the name of Mcliccrum campaunla from Greenland. In Oken's Meliccrum there are but 4 radial-canals( ?) and the stomach is tubular and quadratic in cross-section with 4 short lips. The marginal tentacles are of unequal length. It seems impossible to determine whether the medusa described by (Oken is or is not the young of the $1 /$. crmpanula of Agassiz. The name "Mclicerta" is preoccupied, and "Mclicrtum" would have been hopelessly lost through inadequate definition had it not been clearly defined by A. and L. Agassiz, 1862, I865.

\section{GFNERIC CHARACTERS.}

Thaumantiada with 8 gonads upon the 8 radial-canals. 8 or more tentacles. Without marginal sense-clubs or cirri. With or without a gastric peduncle. The hydroid is M/clicertum.

Mclicertum as here defined is equivalent to Mclicctum Mclicctella of Haeckel, 1879.

Hartlaub, 1894, and Browne, 1905 , have discovered that Oceanin octocostala Sars, 1835. lacks marginal cirri and has all of the characters of Agassiz's Meticerlum. Haeckel labored under the false impression that this medusa had marginal clubs and he therefore established his new genus "Melicertidiun" especially for this species. Browne would therefore amend Melicertidium and define it in the sense of the older genus Mclicetum, doing away with Mclicortum. But it appears that Ehrenherg, 1837 , placed Sars's species in the genus $1 /$ clicettum, and I think it should remain there and he considered a cotype of that genus.

\section{Melicertum campanula Oken(?), Agassiz.}

Platc 23 , figs. 4 , 5; plate 24 fig. 5 .

(2) Melicertum campanula, (GEN, 1835, Allgemeine Naturg. für Alle Stande, Bd. 5, p. 226.

Melicertum campunula, Agassaz, L.. 1862, Cont. Nat. Hist. U. S., vol. 4, Pp. 349.352-Agass16, A., 1862, P'ruc. Buston Sur. Nat. Hist., vol.9, p. 96, figs. 18, 19; 1865 , North Anier. Acal., 1.130, figs. 202-214.-HAseks.1, 1879, Svist. der Meduse11. p. 137.-Nitring, 1901, Bull. U.S. Fish Commission for 1899, p. 382, fig. 104.-Hareitt 1904, Bull. U.S. Burcau uf Fisheries, vol.24, P. 47. - L.1:ko, 1904, Zool. Anzeiger, 13d. 28, p. 218 .

Melicertidium campanula, Browne, 1905, Proc. Royal Soc. Edinburgh, vol. 25. 1). 766 .

Adult modusa (plate 23. fig. 5).-Bell pyriform in outline and about $25 \mathrm{mmm}$. in height and $25 \mathrm{~mm}$. in diameter. The gelatinous substance is quite thick, especially at the aboral pole. There are about 70 long, flexible tentacles with hollow, conical, basal bulhs. The tentacles arise from the bell-margin and are all longer than the bell-height. There are no marginal cirri or lithocysts between the tentacles, nor any ocelli. The velum is well-developed. There are 8 simple, straight, quite broad radial tubes. The manubrium is wide and shallow and does not extend quite half the distance from the inner apex of the bell-cavity to the velar opening. There are 8 simple, recurved lips. The 8 gonads occupy the entire lengths of the 8 radial-canals. These are longer than the canals upon which they lie and are reflected from one side to the other of the radial-canals in sinusoidal curves. The entoderm of the manubrium. gonads, and tentacle-hulbs is ocher-yellow, and the bell often displays a faint yellow ringe.

Hydroid and poung undusa.-The eggs are cast into the water and levelop into pearshaped planula. The planula are ciliated and swim ahout near the hotom of the aquarium. They soon attach themselves by the hlunt (foremost) end, and the narrow (hindermost) end then develops into a long, narrow trunk, which becomes the main stem of the hydroid. The distal extremity of the stem expands and forms the first polypite. The polypites are long. cylindrical, and protected by a small, funnel-shaped hydrotheca at their proximal ends. 
There is a circlet of 10 to 12 short, stout tentacles, the bases of which are connected by a wel). It the end of six months the hydroid colonies were about $8 \mathrm{~mm}$. in height.

In the youngest medusa observed the bell is about twice as high as broad and the bellwalls are thin and flexible. There are 2 well-developed, diametrically opposite tentacles and 2 small, undeveloped rentacle-bulbs. There are + straight, radial tubes. The manubrium is very small and there are 4 simple lips.

When the medusa is $1.5 \mathrm{~mm}$. in diameter (plate 23, fig. 4) the bell has become relatively flatter and broader. There are now 8 tentacles, 4 long radial and 4 short interradial ones. There are, as yet, but 4 radial tubes and 4 lips. The bell-walls are still thin.

When the medusa is about $4 \mathrm{~mm}$. in diameter (plate 24 , fig. 5), the bell has become pyriform in shape and the gelatinous substance has greatly increased in thickness. There are 32 tentacles in several stages of development. There are 8 radial-rubes, 4 of which are hroad, and 4 very narrow and almost thread-like. The 4 thread-like tubes are new and arise from the periphery of the stomach and extend down toward the circular vessel. The manubriun is shallow and there are 8 simple lips. The gonads begin at this stage upon the 4 broad radial-canals. The other 4 radial-canals acquire them later. The gonads first appear near the periphery of the stomach and extend down the radial-canals until they reach the circular tube.

This medusa is common on the New England coast, north of Cape Cod, during May and early June. It has not been taken south of Cape Cod. It is exceedingly abundant on the surface in Salem Harbor, Massachusetts, early in the summer, but disappears about the middle of July. The medusa is very constant to its type, individuals having more or less than 8 radial-canals being exceedingly rare. Linko finds it to be rare off the Murman coast, Northern Russia, near Norway.

Mrlicertum octocostatum ( = Occanin octocostata Sars) of the northern Atlantic coasts of Europe is closely allied to, if not identical with, our American medusa.

\section{Melicertum octocostatum Haeckel.}

Oreania orlocostala, SARS, 1835 , Beskriv og Jagttag, p. 24 , plate 4 , fig. $9 a-d$.

Melicetum campanulatum, EHRFBerti, 1837, Abhandl. d. k. Akad. Wissen. 24 Berlin (1835), pp. 190, 255, taf. 8, fign. 5-7. Thaumantias milleri, LANDSBorovch, 1847 , Arran, a poem, p. 265.

Somobrachium octocostatum, Fories, 1848 , British Naked-eyed Medusæ, p. 3o, plate 4 , fig. 1.- Romaves, 1876 , Journal Linnean Soc. Londun, vol. 12, p. 526.

Melicertum octocostatum, Melicertidium octocostatum, Hakekrt, 1879 , Syst. der Medusen, p. 138.

Meliceridium oclocostainm, Hartlath, 1894, Wissen. Meeresuntersuch. Komm. Meere Kiel, Helgoland, Neue Folge, Bd. 1, P. 192.-Browne, 1905 Proc. Roy. Soc. Edinburgh, vol. 25, p. 762.-BEDot, 1905, Revue Suisse de Zuol., tome 13. p. 138 (literature $1835-50)$.

Bell somewhat conical to pyriform, with thick, solid apex and thinner sides. About $\mathbf{t}$ to $13 \mathrm{~mm}$. high and 10 to $11 \mathrm{~mm}$. wide. There are about 64 large, alternating with 64 small, tentacles having laterally compressed basal bulbs and no ocelli. No clubs or cirri. Velum narrow. There are 3 to 5 fine, longitudinal lines of nematocyst (?) cells upon the subumbrella, extending from stomach to margin between each successive pair of radial-canals. These lines occasionally branch or anastomose. In large medusie these lines are usually confined to parts near the margin, extending upward for a short distance only. Such lines have never been observed in the American M. campanula.

The stomach is octagonal, prismatic, one-fourth as long as the depth of the bell-cavity. It has 8 slightly crinkled lips. A short, broad peduncle is sometimes present. The 8 radialcanals are broad and straight, and the sinuous linear gonads extend along their outer twothirds, reaching the bell-margin.

Color of gonads, stomach, and basal bulbs of large tentacles, yellow to yellowish-brown.

Found off the northern Atlantic coasts of Europe, Norway. Helgoland, Scotland. The best modern descriptions are given by Browne and Hartlaub.

This medusa appears to differ from the American $M$. companula Agassiz in having fine radiating lines of nematocysts over its subumbrella. The gonads appear to be more restricted in their position upon the radial-canals, and the tentacles to he more markedly of two sizes in the European form. Nevertheless the two "species" are evidently closely related and may eventually prove to be identical. This is rendered probable on account of the Arctic range of 11 . campanula Agassiz. 
Melicertum georgicum A. Agassiz.

Melicertum georgicum, Agassız, A., in L.Agassiz's, 1862, Cont. Nat. Hist. U.S., vol. 4, P. 349; 1865, North American Acalephar, p. 135, figs. 215, 216.-HAECKFL, 1879, Syst. der Medusen, p. 137.

Bell pointed above; $20 \mathrm{~mm}$. high, $20 \mathrm{~mm}$. wide. About 30 to to tentacles with large basal bulbs. No peluncle. Stomach wide, flat, and octagonal. Mouth long, with + ( 8 gonads covering nearly the entire lengths of the 8 radial-canals, but not touching the ringcanal. Manubrium, gonads, and tentacle-bulbs yellow.

Pacific coast of North America, State of Washington, in July.

Distinguished by its small number of tentacles and $+(?)$ lips. Is it identical with.$M$. campanula Agassiz?

Melicertum panocto.

Meliceriella panocio, Hasckel, 1879 , Syst. der Medusen, p. 135.

Bell is high, rounded, nearly barrel-shaped, $10 \mathrm{~mm}$. high, $8 \mathrm{~mm}$. wide. No marginal clubs or cirri. 8 tentacles longer than bell-diameter, with very large, globular basal bullss. A black ocellus on each tentacle-bulb. The ocellus is flanked by a half-moon-shaped black spot on both sides. Stomach octagonal, prismatic, half as long as bell-height. $8 \mathrm{long}$, much folded, crinkled lips. 8 spindle-shaped gonads developed upon entire lengths of 8 radialcanals. Color (?) Azores, Atlantic.

Described by Haeckel from a preserved specimen. May it not be a specimen of Mclicertissa clavigera which has lost its marginal clubs?

\section{Melicertum (?) Aglantha (?) proboscifer Maas.}

Melicerium proboscifer, MAAs, 1897 , Mem. Mus. Comp. Zool. at Harvard College, vol. 23, p. 19, taf. 2, fign. 5-7.

Bell rounded, $40 \mathrm{~mm}$. wide, $15 \mathrm{~mm}$. high; bell-walls quite thin. No a pical projection. About 160 or more short, slender, tapering tentacles, nearly all of which were broken off short in the specimen studied by Maas. No lithocysts observed. Velum weakly developed. 8 straight, narrow radial-canals and a simple, marginal ring-canal. Stomach small, urnshaped, and mounted upon a narrow, long, cylindrical peduncle as long as depth of bellcavity so that the stomach projects beyond velar opening. There are 8 short, recurved, somewhat folded lips. 8 sausage-shaped gonads arise from middle of subumbrella lengths of the 8 radial-canals and project outward into bell-cavity.

Entodermal parts, including interstitial lamella of bell, intense carmine; tentacles rose-colored. Albatross.

Found in the Gulf of Panama, Pacific coast of Central America, in March, i 89 I, by the

I beliere that future studies will show that this medusa is one of the Aglaurida, possihly Aglantha. Its slender (solid?), brittle tentacles. S sausage-shaped gonads, and long. cylindrical peduncle are all characters of $A$ glantha. The lithocysts of $A$ glauridae are often difficult to observe owing to their heing readily lost, even in living medusa, and in preserved specimens they are rarely detected. All known species of Aglantha have + lips, but this medusa is said to have 8; however, its general appearance is wholly unlike that of any other Mclicertum, but closely resembles that of the known species of Aglantha.

Genus MELICERTISSA Haeckel, I879, sens. emend.

Melicertissat Melicertidium, Hakckr., 1879, Syst. der Medusen, pp. 124, 135, 137.

Meliceridium, Mas, 1905, Craspedoten Medusen der Siboga Expedition, Monog. 10, p. 27.

Melicertissa, Brownf, 1907, Annals and Mag. Nat. Hist., ser. 7, vol. 20, p. 476 .

\section{GFNERIC CHARAC'IERS.}

Thaumantiada with 8 simple radial-canals upon which the 8 gonads are developed. 8 lips and 8 or more marginal tentacles. Marginal sense-clubs or cirri, or both, are present. Development unknown. 
Our Melicertissa is equivalent to Melicertissa +Melicertidium of Haeckel, 1879 . Haeckel would restrict Melicertissa to include medusa with only 8 tentacles, while Melicertidium would apply to medusx with more than 8 tentacles. It is probable that Melicertissa as defined by Haeckel is only the young of his Melicertidium. His name Melicertissa precedes that of Melicertidium and should therefore designate the genus.

Melicertissa is closely related to Melicertum, but is distinguished by its rudimentary marginal sense-clubs or cirri which are absent in Melicertum.

\section{Melicertissa clavigera Haeckel. \\ Plate 24 , figs. 2 and 3 .}

Melicertissa elavigera, Ha f.ckel, 1879 , Syst. der Medusen, p. 135, taf. 8, figs. 8-12.

(?) Meliceriella panocto, Ha zCKel, Ibid. p. 135 (a damaged specimen without marginal clubs?).

Bell $7 \mathrm{~mm}$. in diameter, flatter than a hemisphere, with moderately thin walls becoming thinner toward margin. I 6 marginal tentacles with long, hollow, tapering basal bulbs and coiled lash-like ends. When contracted these tentacles are each about half as long as the belldiameter. 8 of the tentacles are radial and 8 interradial. There are $\mathbf{6} 6$ sense-clubs (plate 24, fig. 3) midway between the tentacles. There is a well-developed, black, entodermal, cup-like mass of pigment at the base of each tentacle and sense-club, 32 in all. In some specimens one or more of the interradial tentacles are replaced by a marginal sense-club. Haeckel, indeed, describes only 8 radial tentacles and 24 marginal sense-clubs, there being no interradial tentacles. His specimens were obtained in the Canary Islands. At Tortugas, Florida, however, we find specimens with interradial tentacles, but which conform in all other respects to Haeckel's medusa.
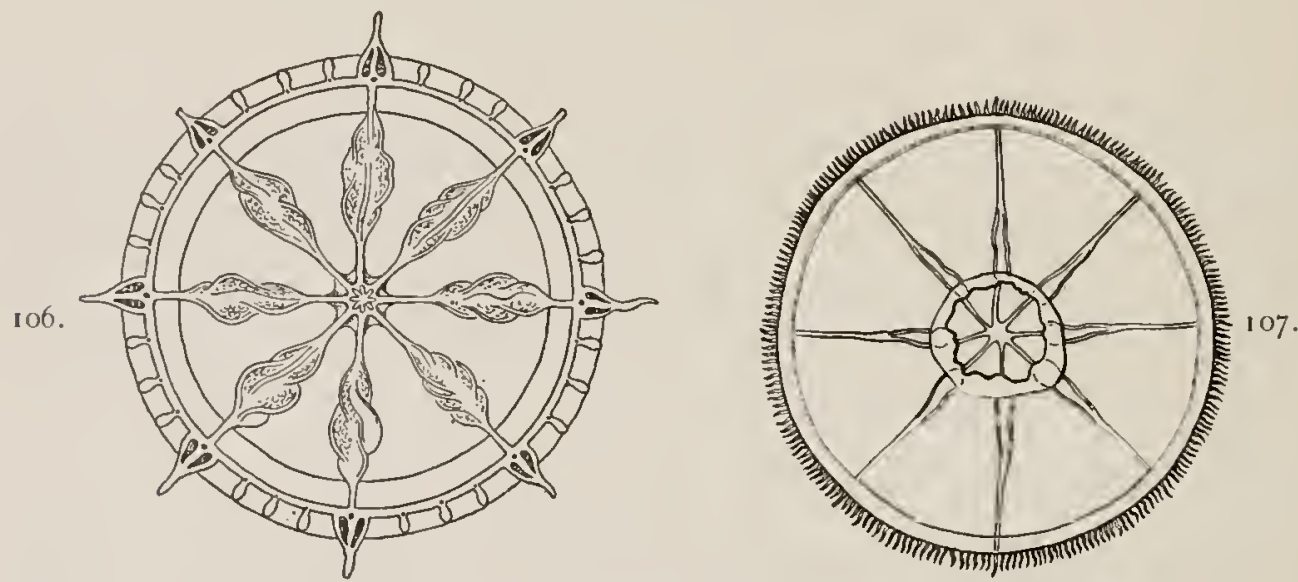

Fig. 106.-Melicerissa clavigera, after Haeckel, 1879 .

F16.107.-Melicertissa malayica, after Maas, in Hydromedusen Siboga Expedition.

Velum well developed. There are 8 straight, narrow radial-canals and a simple, circular vessel. Stomach about one-fourth as wide as bell-diameter and the 8 radial-canals arise singly from its periphery $45^{\circ}$ apart. Stomach flat and entire manubrium short and not over onethird as long as depth of bell-cavity. There are 8 short, simple lips. The gonads are linear, somewhat sinuous, and occupy the middle halves of the radial-canals, not touching the circular canal or edge of stomach.

Entoderm of stomach, radial and circular canals, and tentacle-bulbs dull yellow in specimens from Tortugas, Florida; the entodermal marginal ocelli black. Hacckel describes the color of the entoderm in the Canary Island specimens as being bronze-colored, brownish, or greenish-yellow.

Haeckel found this medusa at Lanzerote, Canary Islands, in January, 1867. We found it on the surface at Tortugas, Florida, early in June, Igo6.

The American specimens are interesting, for they show that there is no natural distinction between the genera Meliccrtissa and Melicortidium of Haeckel. Parts of the bell-rim are 
usually in the "Melicertissa" condition with only 2 tentacles and 3 sense-clubs in each octant, while other parts of the rim of the same medusa are in the "Melicertidium" condition with 3 tentacles and 2 sense-clubs in each octant.

\section{Melicertissa malayica Browne.}

Melicertidium malayicum, MAas, 1905, Craspedoten Medusen der Siboga Expedition, Monog. 10, p. 28, taf. 5, fign. $29-31$. Melicertissa malayica, Browne, Ig07, Annals and Mag. Nat. Hist., ser. 7, vol. 20, p. 477.

Bell flat, $32 \mathrm{~mm}$. wide, 20 short tentacles in each octant, 160 in all. These tentacles are only about one-tenth as long as the bell-radius and their outer ends are coiled. They have slightly swollen basal bulbs. At the base of about every fourth tentacle there is an abaxial, ectodermal, swollen ocellus. Altogether there are 40 to $4^{8}$ of these ocelli.

A number of small clubs arise from the margin between the tentacles. These are about half as numerous as the tentacles and are irregularly' scattered around the margin. The cores of these clubs are filled with entodermal cells, as in Laodicea. A few small, coiled cirri, much fewer than the clubs, arise from the margin, each containing an axial core of entoderm.

Velum narrow. There are 8 straight, narrow radial-canals and a simple, slender ringcanal. Stomach flat, without a peduncle and with 8 simple, folded lips. Gonads linear and developed upon the sides of the proximal thirds of the 8 radial-canals, adjacent to stomach. The gonads begin to develop when the medusa is $18 \mathrm{~mm}$. wide. The ocelli at the bases of the tentacles are black. (See figure 107, page 210.)

Malay Archipelago, Ternate. 2 specimens found by the Siboga expedition.

Genus ORCHISTOMA Haeckel, 1879.

Orchistoma, Hakckrt, 1879 , Syst. der Medusen, p. 138. -KFller, 1884, Recueil Zool. Suisse, tome 1, Pl? 417,418 .

The type species of this genus is Orchistama pileus, described by Lesson ( $1843, \mathrm{p} .31 \%$, plate 6, fig. I) under the name of Mesonema pileus. This species is believed to have come from the west coast of Africa.

\section{GENERIC CHARACTERS.}

Thaumantiadx with more than 8 simple radial-canals which arise separately from periphery of stomach. The gonads are situated upon the radial-canals. Numerous tentacles. Cirri or marginal sense-clubs may or may not be present.

Mesonema of Eschscholtz, I829, is one of the Fquoridx, and hence this generic name can not be applied to the type species of Orchistoma.

\section{Orchistoma pileus Lesson. \\ Plate 25 , figs. 1 to 4 .}

Mesonema pileus, I. F.s5on, 18 \$3, Hist. Zooph. Acal., p. 317, planche 6, fig. 1.

Orchistama steenstrupii, Hafckel, 1879, Syst. der Medusen, p. 139, taf. 15, fign. 3-5.-KLtLer, $188_{4}$, Recucil \%ool. Suisse, tome I, P. $\$ 17$.

Bell flat-topped with vertical sides, 30 to $40 \mathrm{~mm}$. in diameter. Gelatinous substance thick. 64 short tentacles with well-developed, hollow, basal bulbs; these tentacles are shorter than the bell-radius and are flat and ribbon-like, with hollow bulbs. About 100 small, solid, straight cirri from the side of exumbrella at a short distance above the bell-margin (plate 25, fig. 2). The entodermal cores of these cirri are connected with the entoderm of the circular canal. There are about 400 dark-brown, entodermal ocelli upon the circular canal. Each ocellus is provided with an ectodermal lens (plate 25, fig. 3).

Velum narrow. There are 32 straight, narrow radial-canals. The manubrium is provided with a large peduncle fully half as wide as bell-diameter and not quite as long as wide; it extends a short distance beyond the velar opening. The stomach is wide and shallow, and there are 32 long, complexly crenated lips (plate 25, fig. 4). There are 32 short, swollen, linear gonads, one upon each radial-canal very near its point of juncture with the stomach.

In the female the gonads are cinnamon-color, lips sage-green, tentacles ocher-yellow, and ocelli black. Other parts colorless. In the male, however, gonads, lips, and tentacle-bults are dull blue-gray. 
Lesson first found this medusa off the west coast of Africa (?). Haeckel describes it from the West Indies, and I have taken it upon the surface of the Gulf Stream off the Bahamas and near Tortugas, Florida, from March to July. The males greatly outnumber the females.

Distinguished from $O$. agariciforme Keller, from the Mediterranean, by having 32 lips instead of only 7 , as in $O$. agariciforme.

Usually very rare, hut ahundant during the spring and summer of 1907 , at Tortugas, Florida.

\section{Orchistoma agariciforme Keller.}

Orchistoma agariciforme, KEILER, 1884 , Recueil Zool. Suisse, tome 1, p. +18 , taf. 21 , fign. 1-3.

Found by Keller at Naples, Italy. Similar to Orchistoma pileus in all respects except that there are but 7 lips instead of 32 , as in the Atlantic species. The color is not described by Keller, who found only one mature and one young specimen. Like the Atlantic form, it is very rare. I 9 or more (ahout 32 ?) radial-canals. Keller states that the gonads are diverticula from the stomach which extend outward along the radial-canals.

Orchistoma tentaculata Mayer.

Plate 24. fig. I.

Orchistoma tentaculata, MAY ER, 1900, Bull. Mus. Comp.Zool.at Harvard College, vol. 37, p. 8, plate 5, fig. 19.-Nutring, Igo1, Bull. U.S. Fish Com. for 1899, p. 377, fig. 92.- HargitT, 1904, Bull. U. S. Bureau of Fisheries, vol. 24, p. 44, 1 fig.

Young medusa.-Bell $6 \mathrm{~mm}$. in height. Sides near margin slightly flanged outward. Gelatinous substance of upper part of hell rery thick, so that concavity is shallow. 32 marginal tentacles in various stages of development, the longest being about 1.5 times as long as bell-height. Tentacles with long, hollow basal bulbs. No marginal sense-organs. I 6 functional radial tubes and $\mathrm{r} 6$ others in process of development. Radial tubes straight with no traces of gonads upon them. Velum well developed. Manubrium flat and shallow, 8 lips.

The entoderm of the basal bulbs of the tentacles delicate green.

Only one immature specimen of this medusa has ever been seen; no gonads were visible. It was found on the surface at Newport, Rhode Island, August 18, I896.

Nutting states that the tentacle-bulbs are red. They are certainly green hy reflected light, but probably red by transmitted light. Descriptions of color in this work are based upon the appearance presented by reflected light. Professor Nutting's figure and mine are drawn independently from the same specimen while yet alive.

The differences between this medusa and $O$. pileus are so considerable that it does not seem possible that the one can be the young of the other.

Genus TIMOIDES Bigelow, 1904.

Timoides, Bigelow, 1904, Bull. Mus. Comp. Zool. at Harvard College, vol. 39, p. 254 . Ocean.

The only known species is Timoides agassizii Bigelow, of the Maldive Islands, Indian

\section{GENERIC CHARACTERS.}

Thaumantiadre with 4 radial-canals and a ring-canal which gives rise to hlindly ending, centripetal canals. Stomach mounted upon a peduncle. Tentacles numerous, without lateral cirri. Numerous cirri upon bell-margin. There are no lithocysts. 4 gonads on the 4 radialcanals. Dr. Bigelow, upon re-examining his 'specimens, tells me that the medusa has no lithocysts.

Timoides agassizii Bigelow.

Timoides agassizii, Bigerow, 1904, Bull. Mus. Comp. Zool. at Harvard College, vol. 39, p. 254, plate 3, figs. 10, 11.

Medusa hell-shaped with rounded dome and flaring sides; $20 \mathrm{~mm}$. wide, $14 \mathrm{~mm}$. high, with very thick gelatinous suhstance at apex, hut thin at margin. 32 tentacles, 4 radial, 4 interradial, 8 adradial, and 16 intermediate. The 4 radial tentacles are at the ends of the 4 radial-canals. The 4 interradial and 8 adradial tentacles are at the bases of the $\mathrm{I} 2$ interradial 
and adradial centripetal canals which arise from the ring-canal and end blindly in the gelatinous substance of the bell. The remaining 16 tentacles alternate with the radial and centripetal canals. All of these tentacles are exceedingly flexible and contractile; when contracted they are usually coiled helically, this coiling being more or less local and usually not affecting the entire length of the tentacle. When expanded, the tentacles are about 300 $\mathrm{mm}$. long. In addition to the tentacles there are numerous cirri along the bell-margin, but no cirri arise from the sides of the tentacle-bulbs. No lithocysts upon the bell-margin.

The 4 radial-canals are straight and slender. There is a marginal ring-canal which gives off 12 blindly ending, centripetal vessels, the 4 interradial ones being about two-thirds as long as the bell-height, and the 8 adradial ones are only half this length. Velum well developed.

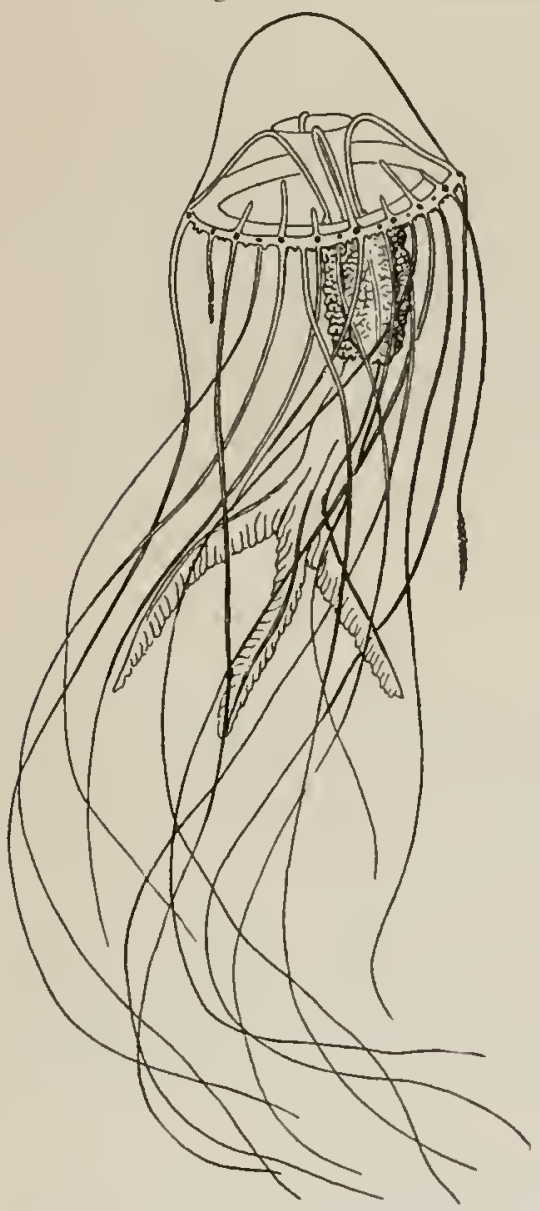

Fic: 108.-Timoides agassizii, after Bigelow, in Bull. Museum Comp. Zool. at Harvard College.

Peduncle nearly cylindrical, flaring at its base, and twice as long as depth of bell-cavity. The barrel-shaped stomach is almost as long as the peduncle and bears 4 lancet-shaped lips with complexly folded margins. These lips may be longer than the combined lengths of stomach and peduncle.

The + gonads are upon the lower half of the peduncle on the + radial-canals, above the stomach. They consist of a great number of simple and hranched papilliform processes on hoth sides of the 4 radialcanals, thus forming + prominent, double ridges.

The gelatinous substance of the bell is faintly tinged with blue. The radial-canals and tentacles are rosepink and there is a pink pigment-spot at base of each tentacle. Stomach and lips pink-violer. Gonads rich Indian yellow, changing in some lights to ruddy-orange.

This beautiful medusa was found by 1)r. Bigelow in abundance in IJaddummati Atoll, Maldive Islands, Indian Ocean, on January 8, 1902. It appears upon the surface at alrout $+\mathrm{p}$. $m$.

\section{Genus STAURODISCUS Haeckel, 1879.}

Stauradiseus, Hacckel, I 879 , Syst. der Medusen, p. 145.-Brow:N, 1907, Annals and Mag. Nat. Hist., ser. 7, vol. 20, p. 475 .

Non Staurodiscus, Agassiz and Marzr, 1899 , Bull. Mus. Comp. Zoul. at Harvard College, vol. $32, \mathrm{p} .164$.

Staurodiseus (in part), Mass, 1904, Sitzungsber. math.-phys. Klasse kgl. Bayer. Akad der Wissenschaften, Bd. 34, P. 440.

This genus was founded by Ilaeckel, 1879, for Staurodiscus tetrastaurus found at the Canary Islands and off the Florida coast.

\section{GINERIC CHARACTERS.}

Thaumantiada with + radial-canals, each gising rise to 2 side branches which end blindly. The gonads are upon the + principal radial-canals and their side hranches. There may or may not he marginal sense-clubs hetween the tentacles. Development unknown.

Staurodiscus is closely related to Cammota, but in Cammota the side branches of the radialcanals fuse with the circular vessel, whereas in Staurodiscus they end hlindly. Maas, 1904, considers Staurodiscus to be the young of Commota, and believes that the side hranches of the radial-canals eventually fuse with the ring-canal. I have seen hundreds of meduse of Staurodiscus tetrastaurus, evidently mature, but have never found the side branches fused with the ring-canal. Cammota doubtless passes through a "Staurodiscus stage," but on the other hand there appear to be medusx which do not attain to the Camota condition and must be called Stamrodiscus. "Staurodiscus" migricans Agassiz and Mayer shoukl he called Commotu 
nigricans. It is probable that Dipleurosona brooksii is derived from a Staurodiscus ancestor by the new formation of 4 interradial canals and the growing outward of the side branches of the perradial canals until they join the ring-canal.

Staurodiscus tetrastaurus Haeckel.

Plate 22, figs. 7 and 8 ; plate 25 , fig. 5 ; plate 26 , figs. 10 and $\mathrm{n} 1$.

Staurodiscus tetrastaurus, Haechre, i 879, Syst. der Medusen, p. 145, taf. 9, fign. I-3.-Marer, igoo, Bull. Mus. Comp. Zoul. at Harvard College, vol. 37, p. 46, plates 18, 19, figs. 47-49.-MAAs, I904, Sitzungsber. math.-phys. Klasse kgl. Bayer.Akad. der Wissenschaft., Bd. 34, p. 440.-BRowne, 1907, Annals and Mag. Nat. Hist., ser. 7, vol. 20, p. 475 .

Octonema gelainosa (young medusa), MAYER, 1900, Bull. Mus. Comp. Zool. at Harvard College, vol. 37, p. 8, plate 6, figs. 20,21 .

Bell $4.5 \mathrm{~mm}$. in diameter, and about twice as wide as high. In adult medusæ there are 8 long, flexible tentacles with hollow basal bulbs. Some specimens have 24 , others 16 sensoryclubs upon the bell-margin. 32 black entodermal ocelli, one at the base of each tentacle-bulb and sensory-club. Velum is well developed. Only 4 radial-canals reach the circular vessel. From the middle points of each of these canals there arises a pair of equally developed side branches that end blindly. The gonads are upon these side branches and on the distal part of each radial-canal. The manubrium bears 4 prominent lips. Entoderm green or yellow.

In the youngest specimen observed, the bell was I mm. in diameter and about as high as broad. There were 4 well-developed tentacles, 4 rudimentary tentacle-bulbs, and 8 marginal cluhs. The medusa is common on the surface at Tortugas, Florida, in July and August. Haeckel found this species in the Canary Islands, at Lanzerote. I have seen hundreds of specimens at Tortugas and the side branches of the 4 radial-canals appear never to extend to the circular vessel.

\section{Staurodiscus heterosceles Haeckel.}

Staurodiscus heterosceles, HAECKEL, 1879 , Syst. der Medusen, p. 146.

This medusa resembles $S$. tetrastaurus Haeckel, excepting that the two side branches from each of the 4 radial-canals do not arise opposite one another from the middle of the radialcanals, lut one branch is long and arises from the main canal near the stomach, while the other side branch is short and arises from the main canal beyond the middle point near the bellmargin. The long hranches arise constantly from one, and the short branches from the opposite sides of the main radial-canals as one glances around the bell.

Bell hemispherical, 6 to $8 \mathrm{~mm}$. wide. There are 8 to 32 , usually i6, long tentacles with globular basal bulbs, and 40 to 80 marginal clubs between the tentacles. There is an ocellus at the base of each tentacle-bulb and marginal club. 12 club-shaped gonads, one at the outer end of each of the 4 main radial-canals, and one upon each side branch. Stomach, gonads, and tentacle-bulbs yellowish-brown. Ocelli black. Canary Islands, January, 1867, Haeckel. Development unknown.

\section{Genus PTYCHOGENA A. Agassiz, 1865.}

Ptychogena, Aciassiz, A., 1865, North Amer. Acal., p. 137.-Hafck El, 1879, Syst. der Medusen, p. 147; 1881, Report on Deepsea Medust, Challenger Report, Zool., vol. 4 , part xil, p. 7 .

Non Prychogena, MAas, 1893 , Ergeb. der Plankton Exped., Bd. 11, K. c., p. 64.

Ptychogena, Lrvinsen, 1893 , Vid. Meddel. Nat. For. Kjöbenhavn, ser. 5, Bd. 4, p. I45.-Linko, A., 1904, Zool. Anzeiger, Bıl. 28, p. 217.-Browne, 1907, Annals and Mag. Nat. Hist. ser. 7, vol. 20, p. 473.-Bigflow, 1909, Mem. Mus. Comp. Zool. at Harvard College, vol. 37, p. 149.-Torrex, 1 gog, University California Publications, Zool., vol. 6, p. 13.

This genus was founded by A. Agassiz, i 865, for Ptychogena lactea, found in Massachusetts Bay.

\section{GENERIC CHARACTERS.}

Thaumantiadæ with 4 radial-canals which in the mature medusa give rise to numerous, short, blindly ending side hranches. The gonads are situated upon the radial-canals in the interspaces between the side branches, close to the subumbrella. The stomach is a wide, Hat pouch and the mouth is a simple cruciform slit. The tentacles have no ocelli, and differ in this respect from those of Inodicen. 


$$
\text { . }
$$




\section{Plate 25.}

Fig. I Orchistoma pileus, mature medusa, female. Gulf Stream, Tortugas, Florida, July 4, 1906.

Fig. 2. Orchistoma pileus. Part of the bell-margin.

Fig. 3. Orchistoma pileus. One of the ocelli showing the ectodermal doubly convex lens and the entodermal pigment.

Fig. 4. Orchistoma pileus. One of the lips.

Fig. 5. Staurodiscus tetrastaurus. Side view of mature male. Tortugas, Florida, August, 1898.

Fig. 6. Staurophora mertensii, young medusa. Nahant, Massachusetts, May 7,1897 .

Figs. 7 and 8. Dipleurosoma collapsa, young stage in the growth of the medusa. Tort ugas, Florida, and Nassau, Bahamas, July, I902-03.

Drawn from life, by the author. 


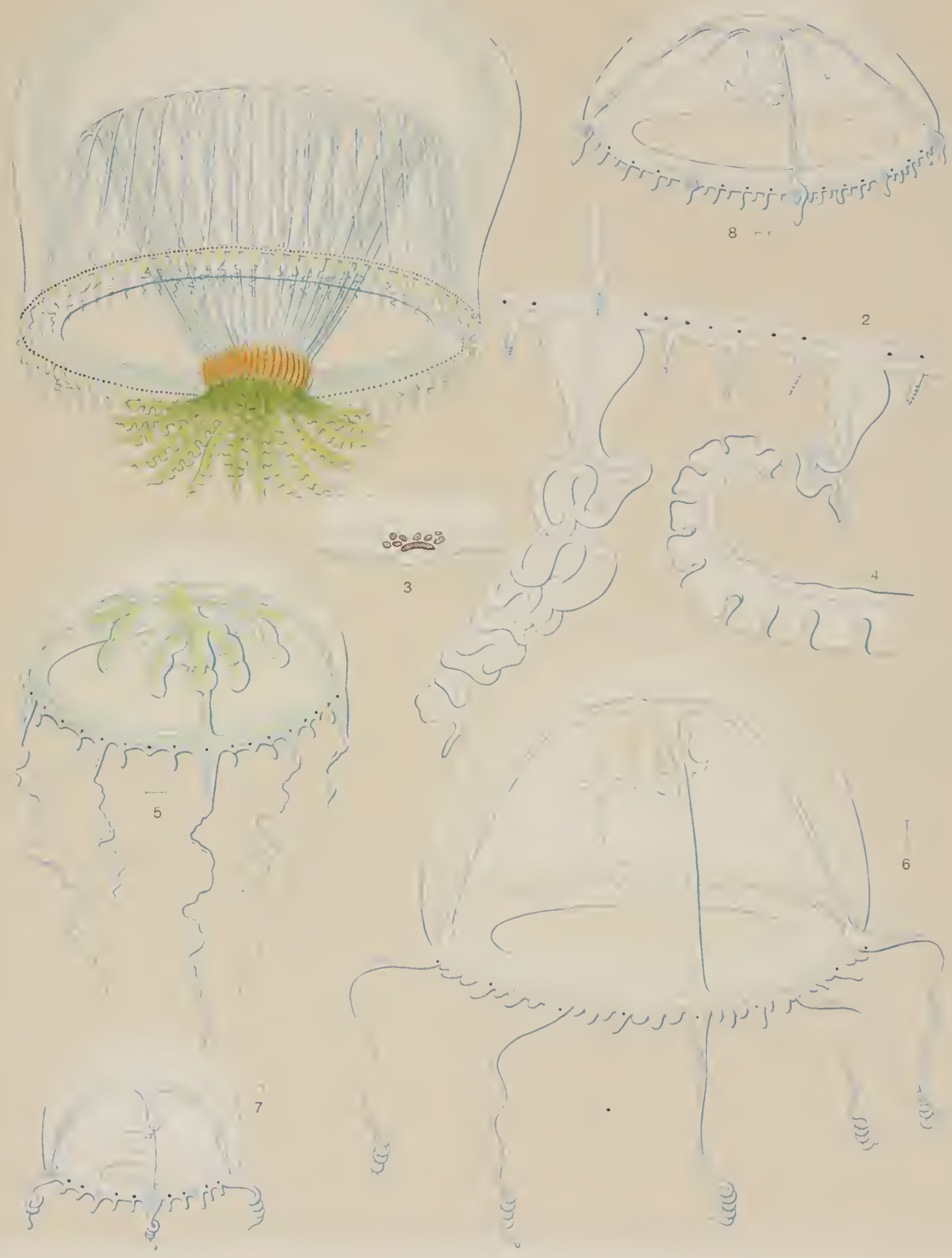



Ptychogena lactea A. Agassiz.

Peychogena laciea, Agassiz, A., 1865 , North Amer. Acal., p. 137, figs.220-224; 1888, Bull. Mus. Comp. Zool.at Harvard College, vol. 15, P. 128, fig. 422.-HAECKEL, 1879, Syst der Medusen, p. 147.- BrowXE, 1907, Annals and Mag. Nat. I1ist., ser. 7, vol $20, \mathrm{p} \cdot 473$.

Ptychogena pinnulata, Haeckr.L, 1879, Syst. der Medusen, p. 148; 1881, Report on Decp-sea Medusa, Reports H. M. S. Challenger Zool., vol. 4, part 12, p. 7, plate 2, figs. 1 to 8.-Lwvissen, 1893 . Vid. Meddel. Nat. For. Kjübenhavn, ser. 5, Bd. 4, p. 145.-Grönвerg, 1898, Zoolog. Jahrb., Abrh. Syst., Bd. 11, P. 465.

Ptychogena pinnulate var. intermedia Linko, 1904, Zool. Anzeiger, Bd. 28, p. 217.

Adult medusa.-Bell about 50 to $70 \mathrm{~mm}$. in diameter and 20 to $30 \mathrm{~mm}$. in height. Sides of bell Hange slightly outward. The gelatinous substance is about $10 \mathrm{~mm}$. thick at aboral pole of bell, but diminishes constantly in thickness towards the margin. Substance of bell transparent, but quite rigid. There are more than $300 \mathrm{long}$, slender, highly contractile tentacles, with hollow, finger-shaped basal bulbs. When expanded these tentacles are about as long as the bell-diameter. Their free extrenities ofren become entangled and this causes the tentacles to droop in graceful festoons from the hell-margin. There are 25 to 200 or more marginal sense-clubs. They arise on the inner (centripetal) side of the tentacle hases near the origin of the velum. These sense-clulss are elongate and pyriform, with a narrow basal stalk. They are between a third and a half as long as the basal bulbs of the tentacles. Each sense-club is hollow and connected with the lumen of the circular canal. In some places the sense-clubs are as numerous as the tentacles and often alternate with them in position, but on other parts of the bell-margin they are much less numerous than the tentacles. Velum very wide and thin. The 4 radial-canals a re wide near their proximal ends, adjacent to manubrium, but straight and narrow near the circular vessel. These radial-canals are pinnated in their proximal halves, adjacent to the stomach. In this region they give rise to about 20 to 30 hlindly ending, pinnate side branches, upon which the genital organs are situated. The genital organs consist of leaf-shaped sacs attached to the side branches of the radialcanals. The free outer edges of these sacs are serrated or split up into a number of fingershaped points. Thus each genital gland consists of 20 to 30 leaf-shaped sacs or lamellæ, all connected with the main axis of the radial-canal. Manubrium wide and shallow. The 4 corners of the fundus of the stomach are prolonged into + conical fumnels, whose ends extend to the middle of the genital organs and occupy the proximal halves of the + radial-canals. Mouthopening quadrate and about one-third as wide as hell-diameter. Lips irregularly frilled and extend at the + radial corners into 4 short, wavy, oral lobes. 4 narrow, ciliated grooves extend along umbrella wall of the 4 radial-canals and meet at center of stomach on gastral surface of gelatinous umbrella, forming a cross. The gonalds and tentacle-hulbs are milky in color and the marginal sense-clubs are white. All other parts of the medusa are transparent.

This medusa appears to be an Arctic form. It was first found by A. Agassiz swimming at considerable depth in Massachusetts Bay. Since then specimens have been described by Haeckel, under the name of Ptychogena pinnulata, from the North Atlantic Ocean between Ireland and Iceland (lat. $50^{\circ} 7^{\prime} \mathrm{N}$, long. $13^{\circ} 32^{\prime} \mathrm{W}$. from Greenwich). The Challenger also dredged a specimen between 1,250 fathoms and the surface near Halifax, Nova Scotia. Levinsen, 1893 , records this medusa from Jakobshavn and Ritenbenk on the west coast of Greenland, and Linko found it in Barents Sea in $72^{\circ} 30^{\prime}$ N. lat, both in the eastern and western parts of the sea north of Lapland.

I believe that $P$. pimmulata of Haeckel, 1879 , is identical with $P$. lactea of A. Agassiz, 1865. Upon comparing Agassiz's original figures (some of them unpublished) with those of Haeckel, it appears that the only difference which may exist between the two forms is that in $P$. pinnullata the free, outer edges of the leaf-like gonads are serrated, whereas in P. Incten of Agassiz they appear to be entire and smooth. Also in Agassiz's figures some of the side branches of the radial-canals give rise to secondary branches, and this appears not to be the case in Haeckel's $P$. pimnlata. Agassiz's specimens were, however, Irrger than those described by Haeckel, and probably they mal have been more mature.

Linko, 1904. found a medusa in Barents Sea which he considers to be intermediate between $P$. lacte'l and $P$. pinmulata, but nearer to $P$. pinmulata.

It is possible that this medusa is an inhabitant of the deep-sea and that it comes to the surface only occasionally. 


\section{As A. Agassiz says:}

"The action of the light and increase of temperature of the surface is sufficient to kill them in the course of half an hour; the moment they are brought to the surface, the bell loses its transparency, the genital organs become dull and the medusa is soon completely decomposed. This action is much more rapid than anything of the kind which I have noticed, even in Ctenophorx, Mertensia being the only genus in which the decomposing effects of light and heat are at all equal to what is produced here. This jelly-fish must be a deep-water species, as they have only been found during a single autumn, and then only for a few days, when they seemed quite abundant."

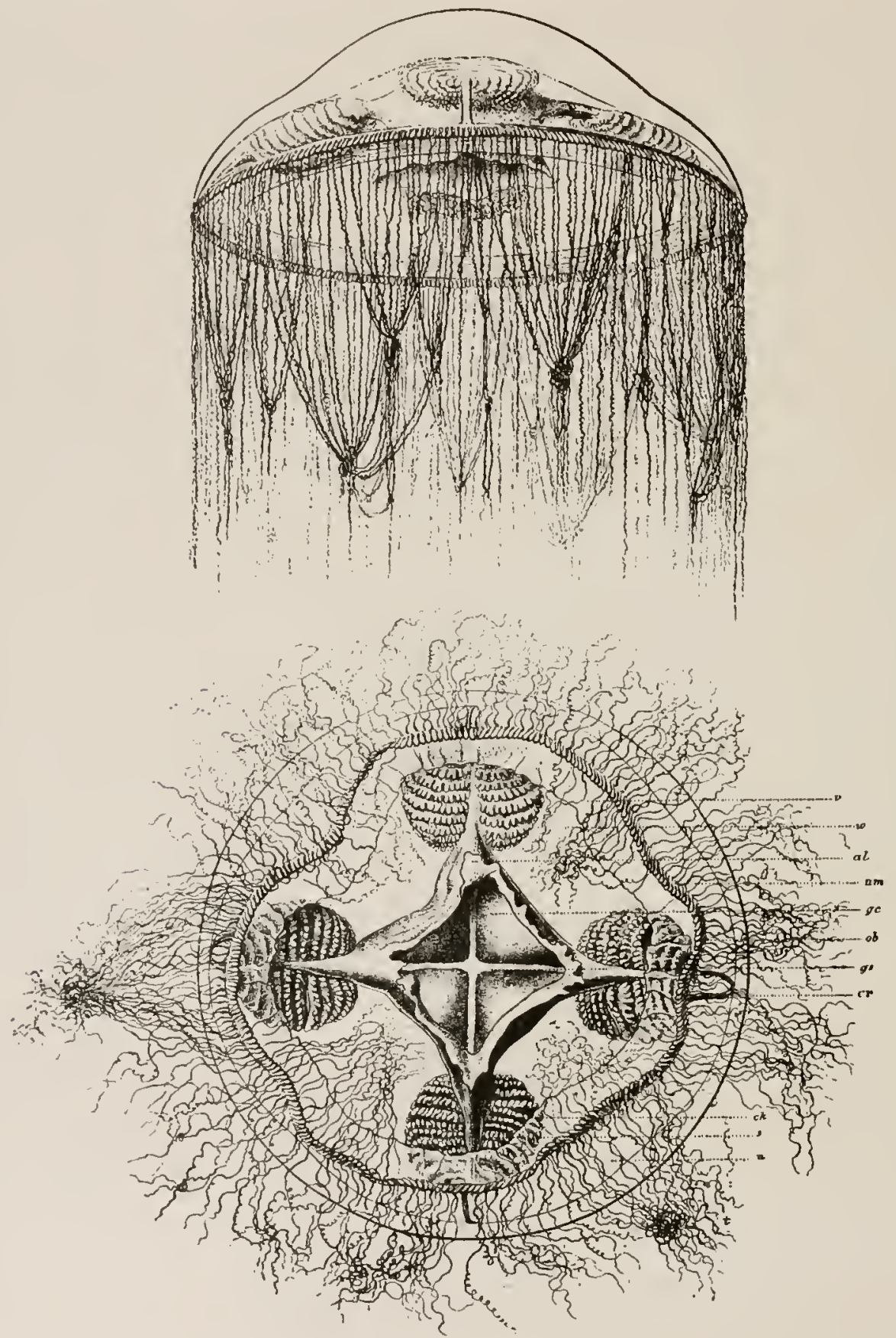

Fic. 109.--Ptychogena "pinnulata" = P. lactea, after Haeckel, in Report. Challenger Expedition, Deep-Sea Medusæ. $v$, velum; $w$, subumbrella; $a$, lips; $u m$, umbrella-margin; $g c$, stomach cavity; ob, marginal clubs; gs, ciliated perradial cruciform furrow in the aboral wall of the central stomach; $c n$, outer part of one of the radial-canals; $c k$, distal funnel-like part of one of the radial-canals; $s$, gonad; $u$, umbrella; $t$, tentacles. 
Linko also considers Ptychogena to be a deep-sea form; as Browne, 1907, and Bigelow, 1909, state, however, we have no trustworthy evidence upon this point and it is not improbable that the medusa is merely a rare and somewhat variable Arctic species which lives constantly at or near the surface.

\section{Ptychogena longigona Maas.}

Ptychogena longigona, MAas, 1893 , Ergeb. der Plankton Exped., Bd. 2, K. c., pp. 64, 97, taf. 6, fign. 7-9.

Prtychogena (?) longigona, Browne, 1907, Annals and Mag. Nat. Hist., ser. 7, vol. 20, P. 474.

Bell $25 \mathrm{~mm}$. wide, Alat, with firm gelatinous substance. About roo tentacles very closely set side by side so that they form an outer row around the margin, on the outer side of which is a row of marginal clubs. Circular canal simple, but the 4 wide radial-canals have numerous, indistinct, unbranched diverticula along their sides, the spaces between the lateral branches of the canals being nearly filled in by the gonads. Stomach shallow and 4 -cornered and about one-fourth as wide as the diameter of the bell. The mouth is a wide cruciform opening with lips turned back as in Ptychogena, so that the water may enter the wide openings of the 4 radial-canals at the corners of the stomach. The gonads cover the entire lengrths of the 4 radial-canals and their lateral surfaces give rise to hollow, evaginated, sac-like elevations or papilla, which are neither so complex nor so regularly arranged as in Piychogena. These

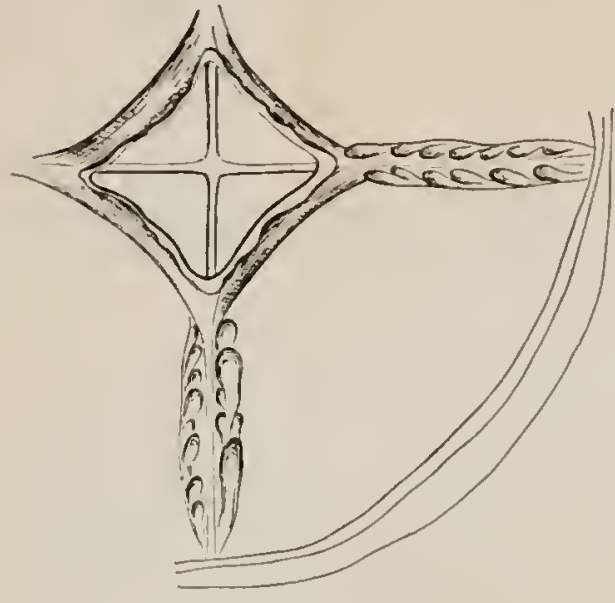

Fig. IIo.- Plychogena longigona, after Mas, in Ergeb. Plankton Expedition. papillæ occur along either side of each radialcanal, but not in the median line. The mature genital products are in the ectoderm. The grooves of the 4 radial-canals extend along the upper wall of the stomach and meet in the middle. Color (?)

The species was found by the Plankton expedition in the North Atlantic at a depth of 100 to 200 fathoms, but Maas does not give the exact locality. As he states, it may prove to be only a local variety of Ptychogena pinmulata (lactea). It differs from Ptychogena lactea, however, in the simple side branches upon the radial-canals and in that the gonads extend along the entire length of the sides of the radial-canals, not being restricted to their middle parts as in Ptychogena lactea. The hollow elevations upon the gonads are also simple and not so regularly arranged as in P. lactea.

Medusa somewhat similar to $P$. longigona were found by the Plankton expedition near the Cape Verde Islands.

\section{Ptychogena? antarctica Browne.}

Peychogena antartica, Browne, 1907, Annals and Mag. Nat. Hist., vol 20, ser. 7, p. 474 .

The basal bulbs of the tentacles are laterally compressed and without ocelli. They resemhle those of $P$. lactea. Number of tentacles(?) Sensory-clubs(?) The 4 radial-canals have wavy outlines, but no lateral branches. The wavy outlines of the radial-canals correspond with those of the gonads, which are broad, lateral folds extending only part way along the radialcanals. The stomach was lost in the single specimen studied by Browne. The tentacles are red. Size of medusa(?)

Found off Cape André, Victoria Land, Antarctic Ocean.

\section{Ptychogena erythrogonon Bigelow.}

Ptychogena erythrogonon, Birelow, H. B., 1909, Bull. Mfus. Comp. Zool. at Harvard College, vol. 37, p. 150, plates 5, $3^{8}$, and 39.

This medusa is beautifully figured and well described by Bigelow.

Bell $3^{8} \mathrm{~mm}$. wide, $25 \mathrm{~mm}$. high with very thick gelatinous subsiance and shallow bellcavity. 40 to 60 tentacles about one-fourth as long as bell-diameter and with tapering. conical basal bulbs. There are only' a very few cirri between the tentacles and these ter- 
ininate in a knob-like cluster of nematocysts. Some of the medusæ lack cirri and Bigelow never saw more than 3 upon a single medusa. The cordyli or clubs upon the bellmargin are more numerous than the tentacles. There are no lithocysts and no ocelli. When young the outlines of the 4 broad radial-canals are plain. Later they develop short, simple, lateral diverticula and then the gonads develop in the interspaces of these branches close to the subumbrella as in $P$. longigona. The manubrium is quadrate basally and its side walls are short and barrel-shaped with a widely open mouth.

Basal parts of radial-canals, manubrium, and tentacle bulbs are brilliant opaque brickred; gonads and outer parts of canal system and tentacles lighter. A pale colored line extends along the central line of each radial-canal forming a cross at the middle of the stomach. The entoderm cells contain red, yellow, and black granules, and the ectoderm cells minute, red granules.

This medusa is one of the intermediate fauna found at depths of about 300 fathoms in the Humboldt Current off the coast of Peru. Torrey describes another species of Ptychogena from the California coast. (See appendix.)

\section{Genus POLYORCHIS A. Agassiz, 1862.}

Polyorchis, A. Agassiz in I. Agassiz's, 1862, Cont. Nat. Hist. U.S., vol. 4, p. 349; 1865, North Amer. Acal., p. 119.-Haeckel, I 879 , Syst. der Medus n, p. 149.-Murbach and Shearer, 1903, Proc. Zool. Soc. London, vol. 2, p. 174. States.

The type species is Polyorchis penicillata A. Agassiz, from the Pacific coast of the United

GENERIC CHARACTERS.

Thaumantiadx with 4 radial-canals which give rise throughout their lengths to many blindly ending side branches. Marginal ring-canal simple and bell-margin not divided into lobes. Numerous sac-like, sausage-shaped gonads attached to the radial-canals and their side branches. Stomach long, tubular, and with 4 simple lips.

\section{Polyorchis penicillata A. Agassiz.}

(?) Medusa campanulata, de Chamsso ft Evsenharnt, 1820, Nova Acta Phys. Med. Leop. Car., tome ro, p.359, plate 30 , fig. 1. Melicertum penicillatum, Escuscuoliz, 1829, Syst. der Acalephen, p. Io6, taf. 8, fig. 4 .

Aglaura penicillata, DE Blainville, 1834 , Man. d'Actinologie, p. 283 , plate 33 , fig. 4 .

Polyorchis penicilleta, A. Agassiz in L.Agassiz's, 1862, Cont. Nat. Hist. U. S., vol.4, p. 349.-Agassiz, A., i 865, North Amer. Acal., p. II 9, figs. 179-183.-FEwKEs, 1889, Amer. Naturalist, vol. 23, p. 593, figs. 3, 4; I889, Bull. Essex Inst. Salem, vol. 21, No. 7, p. I03, plate 4, figs. 6, 7.-Banckoft, 1904, Journ. Exper. Zool., Baltimore, vol. I, p. 289 , 4 figs. (reactions to galvanic currents).-BAncroft, 1906, University of California Publications, Physiol., vol. 2 , p. 43,4 figs.

Polyorchis pinnatust P. penicillatus, HaEckel, 1879, Syst. der Medusen, pp. 149, 150, taf. 8, fig. 13.

Polyorchis - LorB, 1906 , Journ. Biological Chemistry, New York, vol. 1, No. 6, p. 427 (physiological).

Polyarchis campanulata + P. penicillata, BE Dot, I905, Revue Suisse de Zool., vol. I 3, Pp. 143, I 44 (citation of all papers to 1850 ). Polyorchis — Loeb, I906, Dynamics of Living Matter, Columbia Univ. Biol. Series, No. 8, Pp. 87, $91,141$.

Polyorchis - Maccallusi, 1907, The Journal of Biol. Chemistry, vol. 2, No. 4, p. $3^{8} 5$, New York.

Bell about 50 to $60 \mathrm{~mm}$. high, 30 to $40 \mathrm{~mm}$. wide, with a slight, solid, apical projection and almost vertical, slightly bulging sides. Gelatinous substance quite thin. 36 to 40 tentacles arise in a single row from the bell-margin. They a re equal each to each and a re longer than the bell-height. Their basal bulbs are large, elongate, and spindle-shaped, and have dark-purple pigment. There are no other marginal appendages. Velum narrow. Ring-canal simple and unbranched, bur the 4 radial-canals give rise each to 15 to 25 pairs of simple, short, unbranched, blindly ending, lateral diverticula. Stomach prismatic with a very short peduncle, and nearly as long as depth of bell-cavity. There are 4 short lips with sinuously folded margins. A row of + to 8 elongate, sac-like, sausage-shaped gonads arises from the sides of each of the 4 radial-canals between the sides of the stomach and the feathered (branched) parts of the canals, there being in all 16 to 32 of these suspended gonads.

Stomach, gonads, tentacle-bulbs, and radial-canals reddish-brown to purple.

Found on the Pacific coast of California to Washington, and as far westward as the Hawaiian Islands.

Fewkes found the medusa ahundant in hays along the California coast in March and April. He states that when the medusa has 16 tentacles the 4 radial-canals were merely leginning to exhibit notches along their sides and the gonads were beginning to appear at the + corners of the stomach. When mature, the medusa has about $3^{6}$ tentacles. 



\section{Plate 26.}

Figs. I and 2. Laodicea? neptuna. Tortugas, Florida, July, I 898 .

Fig. 3. Laodicea? neptuna. Part of the bell-margin.

Fig. 4. Staurophora mertensii, half-grown medusa. Nahant, Massachusetts.

Fig. 5. Staurophora mertensii. Part of the bell-margin of the medusa shown in figure 4 .

Fig. 6. Staurophora mertensii, mature medusa, natural size. Agassiz Laboratory, Newport, Rhode Island, June 9, I895.

Fig. 7. Staurophora mertensii. Portion of the bell-margin of the medusa shown in figure 6.

Fig. 8. Staurophora mertensii. Aboral view of the mid-region of one of the radial-canals of the medusa shown in figure 6 .

Fig. 9. Staurophora mertensii. Oral view of the mid-region of one of the radial-canals of the medusa drawn in figure 6 . This shows the curtain-like folds of the gonads.

Fig. Io. Staurodiscus tetrastaurus, young medusa. Tortugas, Florida, July, 1898.

Fig. I I. Staurodiscus tetrastaurus. Oral view of female. Tortugas, Florida, July, I 898 .

See page 206 for description of figures 1 to 3 .

Drawn from life, by the author. 


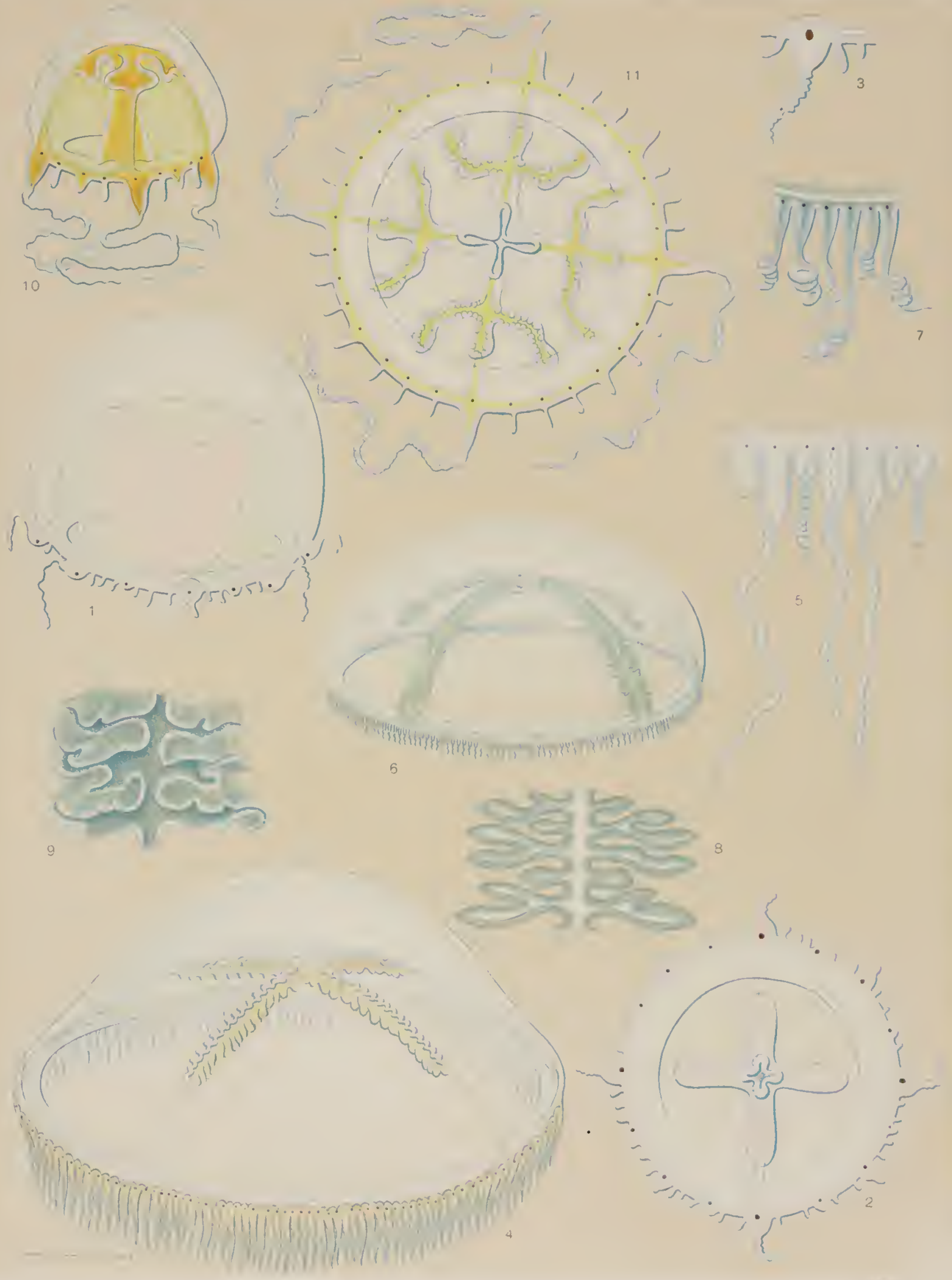



Bancroft, $194^{-06}$, carried out an interesting series of observations upon the galvanotropic reactions of the medusa, showing that the tentacles and manuhrium respond definitely to the current, even detached parts of the tentacles reacting. The maximum response is at the anode side in sea-water, whether acid or alkaline. The tentacles and nunubrium turn and point toward the cathode. The tentacles may be caused to contract slowly and irregularly in a constant current. They contract when the current is made and relax when it is broken.

Loeb, 1906, finds that the magnesium of the sea-ivater serves to relax the muscles of the bell, stomach, and tentacles of Polyorchis; and that the remaining salts of sea-water produce a state of contraction, so that if we place the medusa in any solution resembling sea-vater, but lacking magnesium, pulsation is impossible and the tentacles and stomach are contracted. If we add magnesium, however, pulsation is resumed, but this effect of magnesium can he inhibited by addition of an equivalent amount of calcium or potassium.

The isolated center of the hell will not beat in sea-water or in a sugar solution, but beats commence in these solutions if we add calcium, strontium, or barium chlorides. No

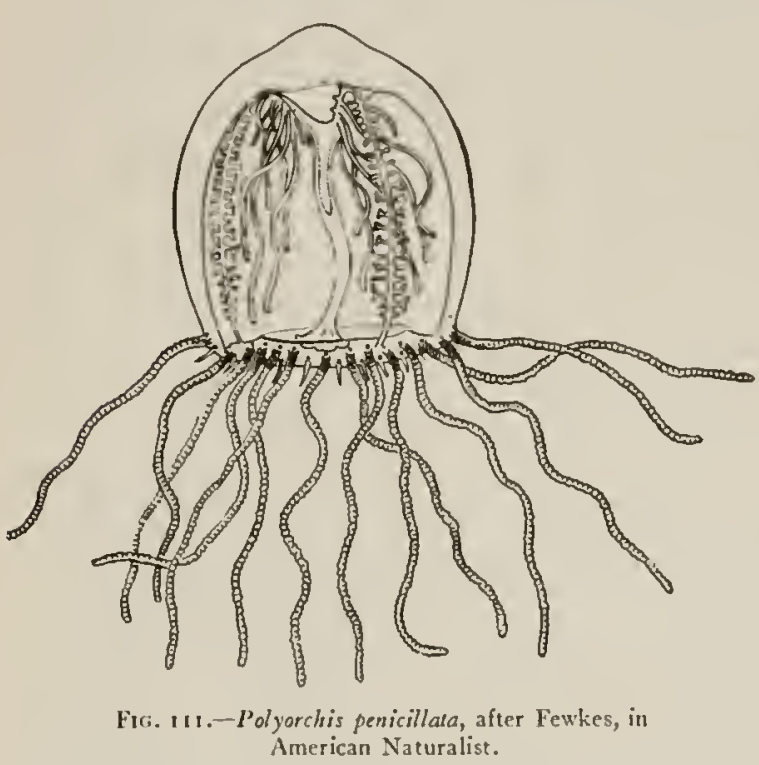
heats occur, however, if we add magnesium chloride. The isolated center will beat for 3 to 4 hours in any decalcifying salts, such as oxalates, fluorides, oleates, citrates, etc. Acids cause the center to beat, while alkalies inhihit such beats.

The center does not beat until some hours after being placed in $\mathrm{NaCl}$; but then rlyythmical pulsations set in and may last 2 or 3 day's. But pulsation may be at once produced in $\mathrm{NaCl}$ hy adding salts which precipitate calcium, such as sodium citrate, tartrate, or oxalate. A trace of $\mathrm{HCl}$ or $\mathrm{CO}_{2}$ added to $\mathrm{NaCl}$ will also cause beats, as will pure solutions of $\mathrm{CaCl}_{2}, \mathrm{BaCl}_{2}$, or $\mathrm{SnCl}_{2}$. Beats are inhilited more by ${ }^{\prime} \mathrm{Mg}$ than by $\mathrm{Ca}$. We have thus the anomaly that contractions occur in an excess or a deficiency of $\mathrm{Ca}$.

Maccallum, 1907, finds that solutions of cascara sagrada, rhubarl, aloin, podophyllin, and colocynth produce temporary pulsations in the isolated center of Polyorchis.

Polyorchis minuta Murbach and Shearer.

Polyorchis minula, Murbach and Shearer, 1903, Proc. Zool. Soc. London, vol. 2, p. 174, plate 19, fig. 3; plate 22, fig. 1; 1902, Annals and Mag. Nat. Hist., ser. 7, vol. 9, p. 72.

Bell $15 \mathrm{~mm}$. high, $12 \mathrm{~mm}$. broad. Truncated, oval, with thick walls; only $9 \mathrm{~mm}$. wide at velar margin. There are 55 or more tentacles. Yellow ocelli on outer sides of tentacle hases on elevations. 4 narrow radial-canals with short, lateral diverticula. Stomach mounted on a long peduncle extending to level of velar opening. + crenated lips. Gonads long. finger-shaped. arising from the 4 radial-canals near base of peduncle.

Gonads and tentacles pale yellow in preserved specimens, other parts colorless.

Found in Puget Sound, British Columbia.

Genus SPIROCODON Haeckel, 1880 .

Spirocodon, HAECKeE, 1880 , Syst. der Medusen, p. 636.

Goneomeandrus, KirkPatrick, 1903, Annals and Mag. Nat. Hise., ser. 7, vol. 12, p. 6i6.

The type species and only known form is Spirocodon saltatrix of the Inland Sea. Japan. This was first described hy Tilesius, 1818 , as Medusa saluatrix. Hacckel, 1880 , estahlished it as a type of the genus $S$ pirocodon. 


\section{GENERIC CHARACTERS.}

Thaumantiadxe with 4 radial-canals and a ring-canal, all of which give off blindly ending, dendritic side branches. Bell-margin cleft into lappets. Stomach mounted upon a peduncle, and with 4 lips. Gonads sac-like, complexly folded, and developed upon the radial-canals adjacent to sides of stomach.

This genus resembles Polyorchis, hut ring-canal gives off blindly ending, centripetal branches, and margin is cleft into lappets.

\section{Spirocodon saltatrix Haeckel.}

Meduse saltatrix, Tilestus, 1818 , Mém. Acad. St. Pétersbourg, tome 6, p. 554, taf. 18.

Polyorchis saltastix $=$ Spirocodon saltatrix, HaEckel, 1880 , Syst. der Medusen, p. 636.

Spiracodon saltatrix, Goette, 1886, Sitzungsber. kgl. Preussisch. Akad. Wissenschaft. zu Berlin, Jahrg., 1886, p. 832.

Goneomeandrus chrysoste phanus, Kirkp.atrick, 1903, Annals Mag. Nat. Hist., ser 7, vol. 12, p. 6I6, plate 33, figs. 1-4 (this is spirocodon saltatrix. Haeckel; see Kirkpatrick, Ig04, Annals and Mag. Nat. Hist., ser. 7, vol. 13, p. 80).

Bell with octagonal sides and dome-like, rounded top, angles of side-walls radial and interradial in position, 30 to $60 \mathrm{~mm}$. wide, 50 to $80 \mathrm{~mm}$. high. 8 adradial, semicircular, marginal lappets. The clefts between the lappets pass obliquely upward and outward from below and extend much higher on the exumbrella than on the subumbrella side, so that only the outer third of each lappet is free. The lappets alternate in position with the angles of the sides of the bell. Velum quite hroad, its inner edge circular.

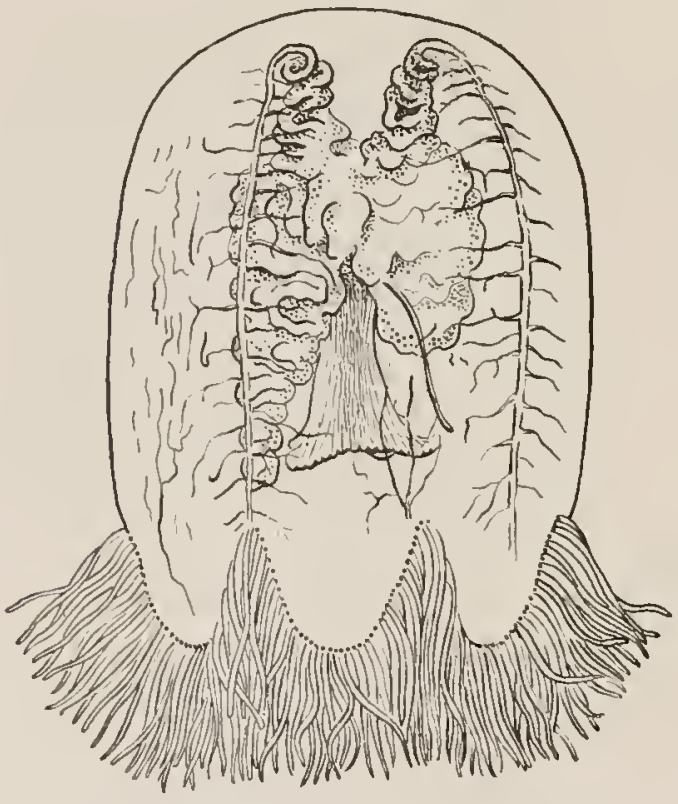

I 12 .

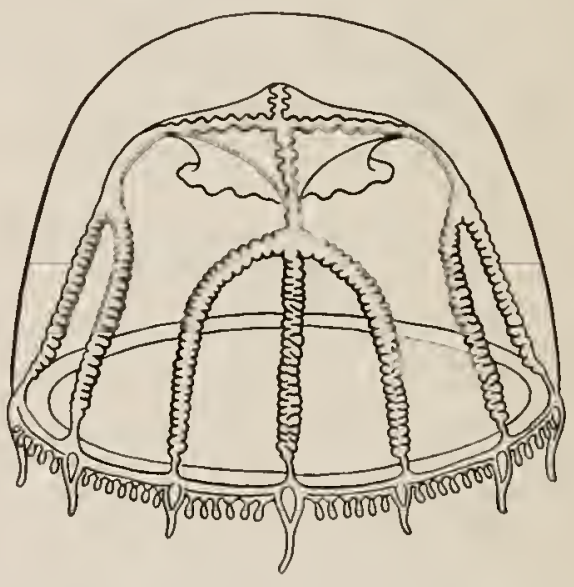

113.

FiG. 112.-Spirocodon saliatrix, after Kirkpatrick, in Annals and Mag. Nat. Hist.

Fig. 113.-Canmoia dodecantha, after Agassiz and Mayer, in Bull. Museum Comp. Zool. at Harvard College.

There are about 40 to 80 tentacles on each of the 8 lappets, 320 to $640 \mathrm{in}$ all. These tentacles arise in a single row from the margin, and are about one-third as long as bell-diameter. Their bases are hollow and narrower at margin than at some distance out. There is an orange-brown ocellus above the hase of each tentacle and there are no other marginal senseorgans. There are 4 radial-canals and a ring-canal which extends around the margins of the lappets. All of these canals give off numerous hlindly ending, dendritic side branches, which do not anastomose. 4 main centripetal vessels arise from the interradial angles of the marginal ring-canal and smaller ones arise from the ring-canal in adradial and other positions.

The stomach is set upon a short, gelatinous peduncle which is one-third as wide as the bell itself and as long as wide; it is cruciform in cross-section, 4 -sided, and about half as long as 
bell-height. There are + slightly recurved lips with sinuously folded margins. The gronads are complexly folded, swollen, projecting masses on proximal parts of the 4 radial-canals, upon the peduncle adjacent to the stomach. The hell is colorless, gonads pale yellow, ocelli orange to brown. Found at Nagasaki, Inland Sea, Japan.

Genus CANNOTA Haeckel, 1879.

Cannota, HafCKel, 1879 , Syst. der Medusen, p. 15 :.

Siaurodiscus (in part), MaAs, 1904, Sitzungsber. math.-phys. Klasse kgl. Baver. Akad. Wissenschaft., Bd. 34, p. $4+0$.

The type species is Cannota dodecantha Haeckel, from New Guinea, tropical Pacific.

GFNIRIC CHARACTERS.

Thaumantiadi with 4 main radial-canals, each giving rise to 2 simple, unbranched side hranches which, together with the main radial-canals, connect with ring-canal at margin. Gonads upon the 4 main canals and side branches. Marginal cluls and cirri may or may not be present. 12 or more tentacles.

This genus is closely relared to Stanrodiscus, but is distinguished by the fact that the side branches of the radial-canals join the marginal ring-canal, whereas in Stourodiscus they end blindly.

Maas, 190., would regard Stanrodiscns as a young stage of Haeckel 's Camnota, but my studies of numerous specimens of Staurodiscus at Tortugas. Florida, convince me that the medusa become mature with blindly ending side branches upon the 4 main radial-canals.

\section{Cannota dodecantha Haeckel.}

Cannota dodecan:ha, Harckel, 1879 Syst. der Medusen, p. 151.

Staurodiscus nigricans, Agassız, A., And MAYkR, 1899, Bull. Mus. Comp. Zool. at Harvard College, vol. 32 , p. 16 4 , plate 4. figs. 11, 12.-Browne, 1907, Annals and Mag. Nat. Hist., vol. 20, ser. 7, p. 475 .

Bell thin and flexible, $14 \mathrm{~mm}$. in diameter. 12 short tentacles with well-developed hasal bulbs. The 4 tentacles at the bases of the 4 main canals are about wice as long as the 8 which arise from the ends of the lateral branches. The longest tentacles are, however, only ahout onesixth as long as bell-diameter. Between each successive pair of tentacles there are 7 small protuherances upon the bell-margin, each one of which bears a sensory-club. V'elum narow. Each of the 4 radial-canals gives rise to a pair of opposed lateral hranches and thus 12 canals reach the circular vessel $30^{\circ}$ apart. "The gonads are developed upon these 12 tridentlike terminal canals. Manubrium is very short, mouth-opening wide. Gelatinous substance and entodermal lamella of bell of a hrownish tinge. Genital organs, hasal bullos of tentacles, and manubrium are light-sepia in color. Bulhs of sensory-clubs are dark-brown.

This medusa was found near Suva Harhor, Fiji Islands, Sourh Pacific, in 1)ecember, i 897. Haeckel descrihes a small specimen 4 mm. wide from New Guinea. (See fig. 113.)

\section{Genus CUVIERIA Péron, 1807 .}

Cutieria (in botany), Kübreutre, 180z; De. Candolle, 1807 .

Cuvieria (medusa), Péron, 1807, Voyage aux terres australes, plate 30, figs. 2, 2a.-Acassiz, L.., 1\$62, Cont. Nat. Hist. U. S., vol. 4, p. 345 .

Curvieria (echinoderm), Péron, 1817.

Cuvieria (crustacean), DesMarest, 1825.

Cuvieria (mollusk), RAnG, 1828 .

Berenix, Pfron et Lesurur, 1809 , Annal. du Mus. Hist. Nat. Paris, tome it, P. 327.

Berenice, OkEn, 1815, Lehrbuch der Naturgesch., Teil 3, Zool., p. 114.-Eschscroltz, 1829, Syst. der Acalephen, p. 120.-

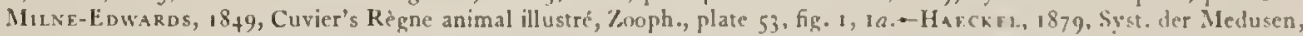
p. 152.-MA.4s, 1904, Sitzungsber. math.-phys. Klasse kgl. Bayer. Akad. Wissenscliaft., Bd. it, p. +40.-Br.0ot, 1901, Revue Suisse de Zool., tome 9, p. $482 ; 16$ id., 1905 , tome $13, \mathrm{P} .131$ (list of all references from $1807-1850$ ).

As is apparent from the ahove, the name Civieria was first used in botany in $1 \$ 02$, and in zoology for a medusa in 1807 . Its previous use in botany does not interfere with its use in zoology. The type species is Curieria carisochroma of l'éron from the tropical Atlantic. 


\section{GENERIC CHARACTERS.}

Thaumantiadx with 4 principal radial-canals which branch, and the branches again branch, and all unite with the circular vessel. The gonads are developed upon the outermost branches of the radial-canals near the ring-canal. Tentacles numerous. There may or may not be marginal clubs or cirri. Development unknown.

Modern authors have commonly followed Péron and Lesueur, isog, and Eschscholtz, 1829 , in calling this genus Berenice, but if we follow the rule of precedence the name Cuvieria must stand. It is rarely a pleasant duty to revive an unfamiliar name to supplant one well

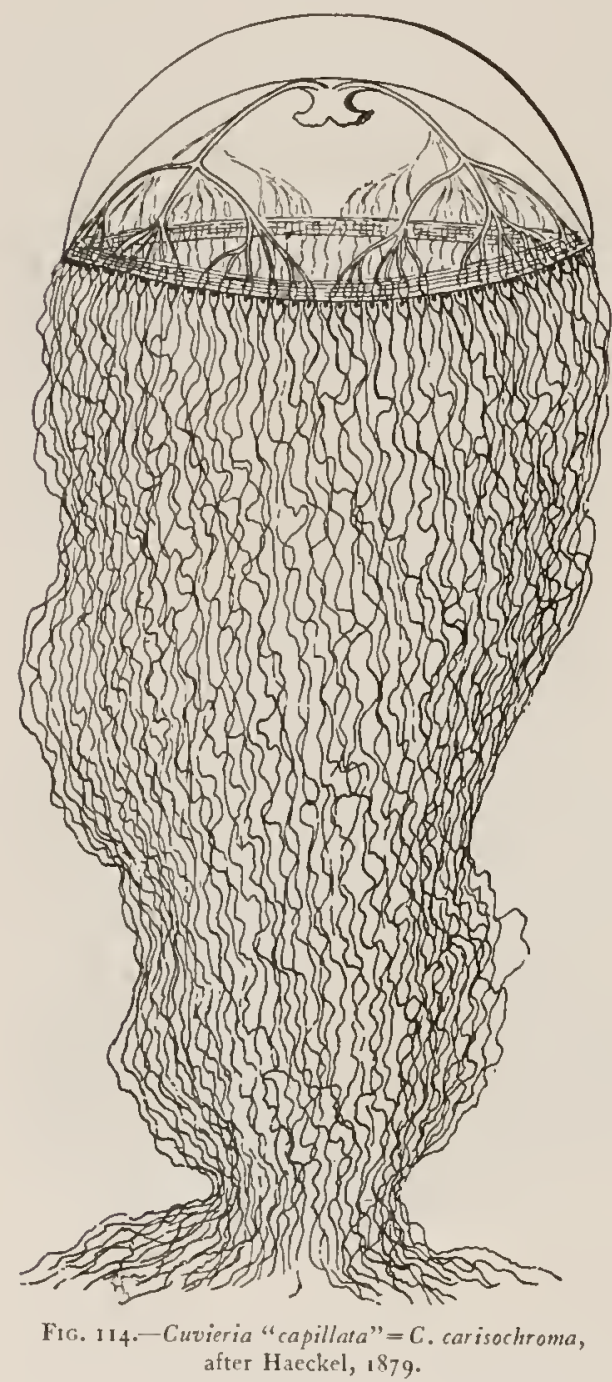
known to literature, but happily in this case the name of one whose memory we all delight to honor may once more be associated with a genus in that branch of science which his labors ably advanced.

\section{Cuvieria carisochroma Péron.}

Cuvieria carisochroma, Ṕ́ron, 1807 , Voyage aux terres australes, plate 3o, figs. 2, $2 a$.

Equorea cuchroma and Equorea rosea, de LAsarck, 1817, Anim. sans vertèbres, tome 2, p. 497.

Berenice rosea, Еsснісног.tz, 1829 , Syst. der Acalephen, р. $120 .-$ Hasckel, i879, Syst. der Medusen, p. 153.-Веdot, 19o1, Revue Suisse de Zool., tome 9, p. 482; Ibid., 1905, tome 13, p. 131 (list of papers to 1850 ).

(?) Berenice capillata, Hazckel, I879, Syst. der Medusen, p. 154, taf. 9 , fig. 5 .

According to Péron, bell is flat and shieldshaped, about $50 \mathrm{~mm}$. wide and $10 \mathrm{~mm}$. high. There are 50 to 60 very long thin tentacles with very large, hemispherical basal bulbs. Each of the 4 principal radial-canals gives rise to two opposed side branches, and these side branches as well as the principal canals give rise to 3 to 5 terminal branches which reach the circular canal. Thus 50 to 60 canals reach the circular vessel. The 50 to 60 gonads are developed on terminal branches of canals. Bell, gonads, and tentacles rose-red, and tentacle-bulbs yellow. This species is found in the tropical Atlantic.

I am inclined to regard Haeckel's Berenice capillata as being identical with this medusa. According to Haeckel the bell in B. "capillata" is hemispherical, $20 \mathrm{~mm}$. wide, 100 to I 20 long tentacles, with well-developed globular, spindle-shaped basal bulbs. There are no marginal clubs or cirri.

The 4 main radial-canals and their 2 side branches each and all give rise to 4 to 8 terminal branches, so that 50 to 100 vessels reach the marginal ring-canal. Small, spindle-shaped gonads are developed upon the terminal branches of the radial-canals near the ring-canal. Stomach small, with 4 simple, recurved lips. Color (?)

Cape Verde Islands, Atlantic Ocean.

\section{Cuvieria huxleyi.}

Berenice huxleyi, HaECKEL, I879, Syst. der Medusen, p. 154, taf. 9, fig. 4.

Bell flat, $16 \mathrm{~mm}$. wide, $0.4 \mathrm{~mm}$. high. 16 long tentacles with globular to spindle-shaped basal bulbs with ocelli. 80 to 100 marginal clubs, 2 to 6 between each successive pair of ten-. tacles. Stomach small, flat, with 4 simple, short, cruciform lips. The 4 main radial-canals 
each give rise at their middle points to 2 opposite side branches. These main canals and their 2 branches each end in 5 to 7 terminal branches, and thus about 70 vessels reach the ringcanal. Gonads spindle-shaped, on terminal hranches of the canals near the ring-canal.

Color (?) Found off Azores, Atlantic Ocean. Distinguished by its large number of marginal clubs and few tentacles. Is it only a variety of Cuvieria carisochroma l'éron (?).

\section{Genus DICHOTOMIA Brooks, 1903.}

Dichotomia, Brooks, 1903, Proc. American Philosophical Society, Philadelphia, vol. \$2, p. 11. - MAas, 1904, Sitzungsber. math.phys. Klasse kgl. Bayer. Akad. der W'issenschaften, Bd. 34 , Heft 3 .

\section{GENIERIC CHARACTIRS.}

Berenicidx with 4 main radial-canals which divide dichotomously 2 or more times and open into the circular vessel by 16,32 , or more distal branches. Tentacles of two sorts hollow ones and solid ones-all arising from bell-margin. Mouth sinple without prominent lips. The gonad encircles the stomach and extends outward over the radial-canals and their branches.

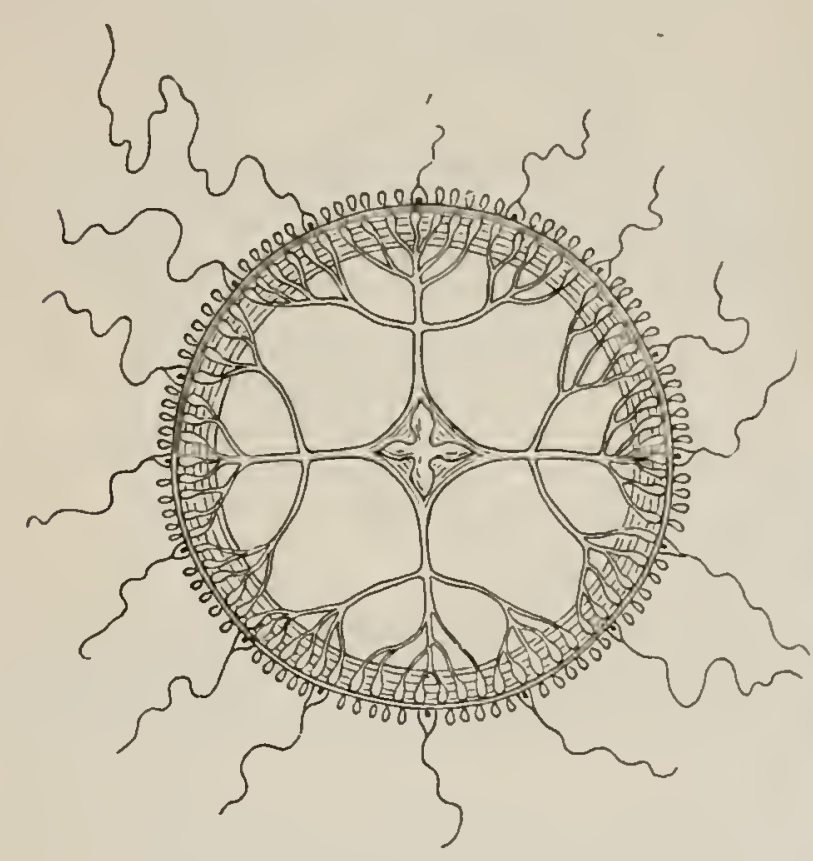

115.

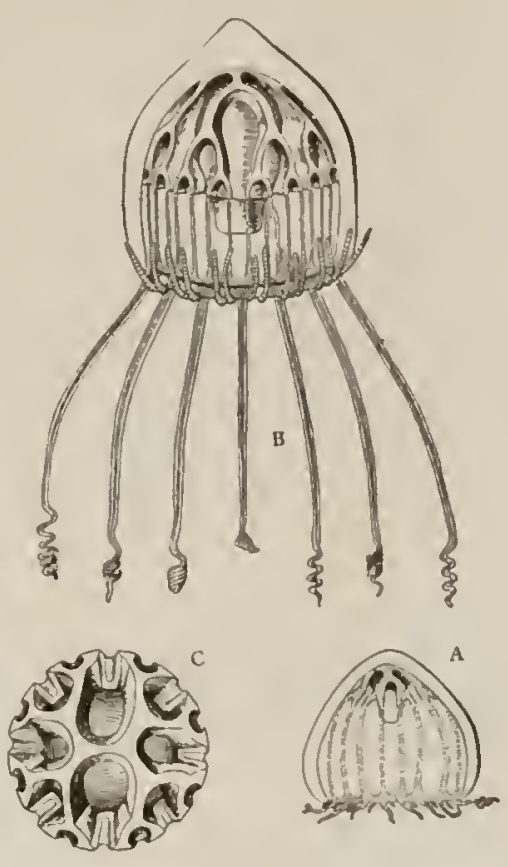

116.

Fig. 115.-Cuvieria haxleyi, after Hacckel, 1879.

F1ci, 116.-Dichotomia cannoides, after Brooks, in Proc. American Philosoph. Soc., vol. 42.

$A$, young medusa. $B$, adult medusa. $C$, model showing arrangement of radial-canals.

The type species is Dichotomia cannoides, described by Brooks from the Bahama Islands. This is the only known species.

\section{Dichotomia cannoides Brooks.}

Dichotomia cannoides, Brooks, 1903, P'roc. American Philosophical Soc. Philadelphia, vol. $\$ 2$, No. 172, p. 12, plate 1, 3 figs.Mans, 1904, Sitzungsber. math.-phys. Klasse kgl. Bayer. Akad. der Wissenschaft., Bd. 34. p. $43^{8}$.

Bell about $8 \mathrm{~mm}$. high and $6 \mathrm{~mm}$. wide, subcylindrical, and with conical apex. The 4 main radial-canals do not arise independently and directly from aboral end of stomach, but in pairs from the ends of a short transierse canal, so that the only planes which divide the medusa into symmetrical halves are the two primary interradial planes. When thus divided each half is bilaterally symmetrical, and the halves are reversed copies of each other (fig. $116 \mathrm{c}$ ). "The + primary radial-canals branch dichotomously' at least 3 times, so that 32 terminal branches 
reach the circular vessel. The radial-canals of older medusa maj branch more profusely. The subumhrella consists of two strongly contrasted regions: An upper opaque part, nearly hemispherical, contains the arches formed by the gonad, which spans space between proximal parts of radial-canals and stomach in a system of groined arches. The lower half of the subumbrella is transparent and without these arches.

There are 16 long, hollow, contractile tentacles with tightly coiled tips. In the young medusa, with only i6 terminal radial-canals, these tentacles arise from margin at base of each canal; but in older medusx, with 32 terminal branches of radial-canals, the hollow tentacles are in the radii of dichotomy. In addition to the long, hollow tentacles, there are a number of short, stiff, solid tentacles, which remind one of the solid tentacles of Geryonidie, and are carried turned upward from bell-margin. These short, stiff tentacles are equal in number to the terminal branches of radial-canals.

There are no marginal sense-organs, clubs, or cirri. The manubrium is a truncated cone, extending about two-thirds the distance from inner apex of bell-cavity to margin.

The gonads and manubrium in old medusæ are opaque white. The radial-canals, circular vessel, and axes of hollow tentacles in young medusæ are colored by brownish to orange pigment-granules. The bell, subumbrella, and tentacles are nearly colorless in old medus $x$.

This interesting medusa was found by Professor Brooks at Nassau, Bimini, and Green 'Turtle Key' among the Bahama Islands, and was described by him in derail.

\section{Genus DIPLEUROSOMA Axel Boeck, I866, sens. emend.}

Dipleurosoma, Axz Bozck, 1866, Forenings Vidensk. Meddelelser, Nos.10, I1, Pp. I31, I 36. -Hackel, I879, Syst.der Medusen, pp. 155, 636.-Ariassiz A. and Mayer, 1902, Mem. Mus. Comp. Zool. at Harvard College, vol. 26, p. 148.-Browne, 1898 , Proc. Zool. Soc. London for I 897, p.826; 1900, Proc. Royal Irish Acad., ser. 3, vol. 5, p. 715.

Tetracannota, Marer, i goo, Bull. Mus. Comp. Zool. at Harvard College, vol. 37, p. 46 ; 190+, Mem. Nat. Sci. Brooklyn Inst. Mus., vol. 1, p. 12.

Tetracannola + Dipleurosoma, MAAs, 1904, Sitzungsber. math. phys. Klasse kgl. Bayer. Akad. der Wissenschaften, Bd. 34 , Pp. $440,4+1$.

Ametrangia, Allman, 1873 , Nature, vol. 9, p. 73 .

The type species is Dipleurosoma typicum Axel Boeck, i 866, from the coasts of Norway, Newfoundland, and northern Atlantic generally.

\section{GENERIC CHARACTERS.}

Thaumantiadxe with 3 or more main radial-canals, some or all of which branch irregularly (not regularly and dichotomously) and connect with the circular vessel. Gonads are upon the radial-canals adjacent to manul,rium. Tentacles numerous, and marginal clubs, cirri, and ocelli may be present. The hydroid appears to be Cuspidella.

The radial-canals vary greatly both in number and arrangement in $D . t y$ picum, and are hest described by Browne, 1900. This extreme variability has caused the species to be descrihed under various names. Judging from the irregular arrangement in the single specimen of $D$. pacifica found hy Agassiz and Mayer, near Tahiti, the canals may be equally variable. In $D$. collapsa they appear to be more regular, mature specimens having 16 canals arranged in + groups of 4 canals each.

\section{Dipleurosoma typicum Axel Boeck.}

Dipleurosoma typicum, Axet Bozcк., I866, Forenings Vidensk. Meddelelser, Ňos. 10-11, p. 131, fign. 1-3; Ibid., D. sturitzi, pp. 136, 137. figs. 1-4.-Browne, 1900, Proc. Royal Irish Acad., ser. 3, vol. 5, pp.696, 715, plates 20, $21 .-$ MaAs, 1904, Sitzungsber. math.-phys. Klasse kgl. Bayer. Akad. der Wissenschaft., Bd. 3t, p. $4 t_{1}$.

Ametrangia hemispherica, Allmax, 1873 , Nature, vol. 9. p. 7 ;.

Dipleurosoma typicum + amphihhectum + irregulare, Haxckel, i\$79, Syst. der Medusen, pp. 155.636, taf. 9, fig. 9.

Dipleurosoma hemispharica, HAdnon, 1885 , Proc. Roy. Irish Acad., ser. 2, vol. t, p. 526.-Browne, I898, Proc.Zool.Soc. London, for 1897, p. 826 , figs. $10-12$.

Bell usually flatter than a hemisphere and about $15 \mathrm{~mm}$. wide. Marginal tentacles very numerous, more than I00. Each tentacle has a bulbous base with an ocellus upon its inner side. There appear to be no marginal clubs in D.typicum, but these occur in D. pacifica of the tropical Pacific. Velum well dereloped. Stomach is flat and watch-glass-shaped, with an irregular outline, and there are + lips. In 217 specimens studied hy Browne from Valencia 
Harbor, Ireland, the number of radial-canals arising from the periphery of the stomach ranged from 5 to 18,43 of the medusa having 9 canals. Canals exccedingly irregular in position and in mode of hranching, so that it is impossible to define a normal type. but they appear normally to connect with the circular vessel. The gonads are developed upon radial-canals adjacent to the stomach and may be upon all or on only a few of the canals. They vary in number from I to 12, and 5 is the most frequent number. The females are in excess of the males in the proportion of about 4 to 3 . "The ova remain attached to the ovary until the planula stage is reached. They were partially reared by the Misses Delap, and developed into hydroids apparently belonging to the genus Cuspidilla (see Browne, igoo, p. 6g6).

The gonads, stomach, and tentacle-bullos are said to he brownish (Haeckel. 1879 ).

The changes which the medusa undergoes in its growth are unknown, but Browne believes that the stomach is primarily regular in shape and that it becomes irregularly elongated into lobes by development of the radial-canals.
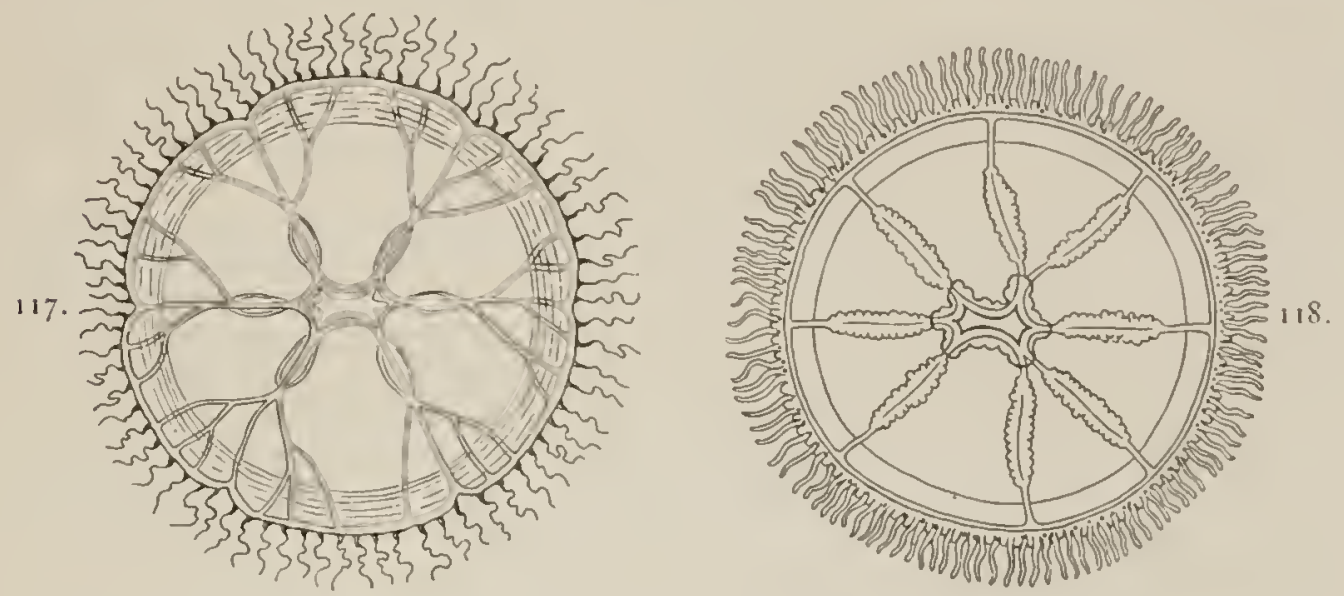

Ha. $117 .-$ Dipleurosoma ("amphiehectum"), after Hackel, 1879.

Fic. IIS.-Dipleurosama pacifica, after Agassiz and Mayer, in Mem. Museum Comp. Zool. at Harvard College.

D. typicum of the North Arlantic may prove to be identical with D. pacifica from Tahiti, South Pacific. The only distinctions between the North Atlantic and the tropical Pacific species are their wide geographical separation and the presence of marginal clubs in $D$ ). pacifica. Dipleurosomn typicum has heen taken off the northern coasts of Europe and off Newfoundland.

Dipleurosoma pacifica Agassiz and Mayer.

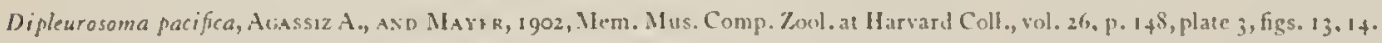

Bell very flat, about 3 times as broad as high, $23 \mathrm{~mm}$. in diameter. Surface of exumbrella reticulated by a regular system of hexagonal elesations bounded by shallow furrows. About 100 short tentacles with narrow, bulbular bases. Entodermal core of these tentacles is solid and composed of chordate cells. At the bases of most tentacles upon the lower (subumbrella) side, there is a single black ocellus. Slender, club-shaped, sensory bodies are scattered at frequent and irregular intervals between the tentacles. Entodermal cores of these hodies are solid and very similar to those of the tentacles. No concretions. Velum narrow. 6 radial-canals arise in groups of 3 from diametrically opposite sides of the stomach. In the single specimen examined, 2 of these canals hifurcate, and 8 canats thus reach the circular vessel. The gonads are linear and occupy the middle regions of the 8 canals. Their surfaces are slightly papillate and the ova stand out as hemispherical protuberances. Stomach elongated in the direcrion of the two opposed groups of radial-canals. Manuhrium very short, 6 small, slightly folded lips.

Tentacle-bulhs, genital organs, and manubrium milky white, all other parts of the medusa being transparent. A single specimen was obtained in a surface haul about 50 miles north of Tahiti, South Pacific. 
Dipleurosoma is exceedingly variable in the number and arrangement of its radial-canals. The Pacific species is distinguished by having marginal clubs between its tentacles, these being absent (?) in the Atlantic Dipleurosoma typicum.

\section{Dipleurosoma collapsa Mayer.}

Plate 27 , figs. 1 to 3 , and 7 .

Tetracannoia collapsa, Mayer, 1900, Bull. Mus. Comp. Zool.at Harvard College, vol.37, p. $4^{6}$, plates 7, 8, figs. 14-16; Memoirs Nat. Sci. Mus. Brooklyn Inst. Arts and Sci., vol. 1, No. 1, p. 12, plate 4, fig. 32.-MAas, 1904, Sitzungsber. math.-phys. Klasse der kgl. Bayer. Akad. Wissenschaft., Bd. 34, p. $4 \neq 0$.

Adult medusa (plate 27, fig. 3).-Bell $7 \mathrm{~mm}$. in diameter and about as high as broad. Top dome-shaped, side walls vertical. 16 well-developed tentacles are carried tightly coiled in close helices, and besides these there are 112 very small rudimentary tentacles. Dark-brown entodermal pigment-spots are found within the base of each tentacle. There are 16 radialcanals, arranged in 4 groups of 4 each (plate 27, fig. 7 ). The gonads are found in proximal parts of the 16 radial-canals very near the point where they branch off from the stomach. Peduncle of manubrium wide and prominent. The mouth has 8 slightly crenated lips. Entoderm of manubrium in some specimens is green, in orhers it is pearly-white or yellowish. Fintodermal pigment-spots at bases of tentacles are dark-brown.

Stages in development.-The youngest medusa observed had a bell $1 \mathrm{~mm}$. in diameter (plate 27 , fig. I). It had 4 slender radial-canals and 24 tentacles, 4 well-developed and 20 rudimentary. Velum prominent; 4 lips, and as yet no peduncle. No trace of genital organs. In the next older stage (plate 27 , fig. 2 ), we find 4 new radial-canals beginning to develop. A still older stage (plate 27, fig. 7) has 16 radial-canals and 8 lips, but as yet no peduncle and no trace of gonads, nor have radial tubes grouped themselves into 4 bundles as in the adult.

This medusa is very common at the Tortugas and Bahamas in June, and ample opportunity for observing its transformation was afforded. It exhibits the curious habit of collapsing into an almost shapeless mass, in which condition it may remain for several hours and then "straighten out" and swim about in excellent condition.

Fewkes, i $88_{3}$ ("On a Few Medusx from the Bermudas," Bull. Mus. Comp. Zool., vol. 11, No. 3, figs. $7,7 a)$, has evidently figured the young of this species under the name of "Larva of an unknown Tubularian."

Dipleurosoma ochracea sp. nov.

Plate 29, figs. 1 and 2 .

Immature medusa.-Bell thin-walled, somewhat flatter than a hemisphere and $8 \mathrm{~mm}$. in diameter. About 12 to 16 well-developed tentacles and about 35 immature or rudimentary tentacle-bulbs. The well-developed tentacles are in the radii of radial-canals. They have hollow, conical, basal bulbs and filiform, contractile, lash-like shafts, which are about as long as the bell-radius. Each tentacle-bulb is flanked by a pair of large, sausage-shaped, marginal clubs, and in addition to these there is a single sausage-shaped diverticula from the ring-canal on the subumbrella side above each tentacle-bulb. There are no marginal cirri or appendagres other than those described above. Velum very wide. Central stomach is flat and about one-fifth as wide as bell-diameter. About 6 to 9 radial-canals arise in a very irregular manner from margin of stomach; some of these give rise to side branches. Manubrium very shallow, 6 or more very irregularly arranged, folded lips with plain margins. No gonads are observed, though they may develop later upon the broad, expanded middle regions of the radial-canals. Stomach, radial-canals, and marginal clubs of this medusa are crowded with masses of yellow algx. or Philozoon, apparently similar to that which infests the medusa of l'elella. These plant-cells develop between the cells of the medusa and give a dense, opaque, brilliant yellow coloration to the marginal clubs, and in a lesser degree to the stomach and canals. All other parts are colorless.

The medusa are remarkable for their very active, incessant pulsation.

Large swarms of this medusa appeared at Tortugas, Florida, between July 5 and 24, 1907 , but no mature specimens could be found. 


$$
\text { . }
$$




\section{Plate 27.}

Fig. 1. Dipleurosoma collapsa, young medusa with 4 simple radial-canals. Tortugas, Florida, June, I 897 .

Fig. 2. Diplcurosoma collapsa, half-grown medusa with 16 simple, separate, radial-canals.

Fig. 3. Diplcurosoma collapsa, mature female, with i6 radial-canals grouped into clusters of 4 canals each. Tortugas, Florida, July, I 898 .

Figs. 4 and 5. Netocertoides bracliatum. Successive stages in the growth of the medusa. Tortugas, Florida; and Nassau, Bahamas, July, I 898 and 1903 .

Fig. 6. Netocertoides brachiatum. Oral view of medusa shown in figure 4 .

Fig. 7. Dipleurosoma collapsa. Aboral view of the stomach showing the grouping of the radial-canals into 4 radial clusters of 4 canals each. Tortugas, Florida.

Fig. 8. Turris superba. Aboral view of the stomach showing the interradial positions of the gonads.

See page 126 for description of figure 8 .

Drawn from life, by the author. 

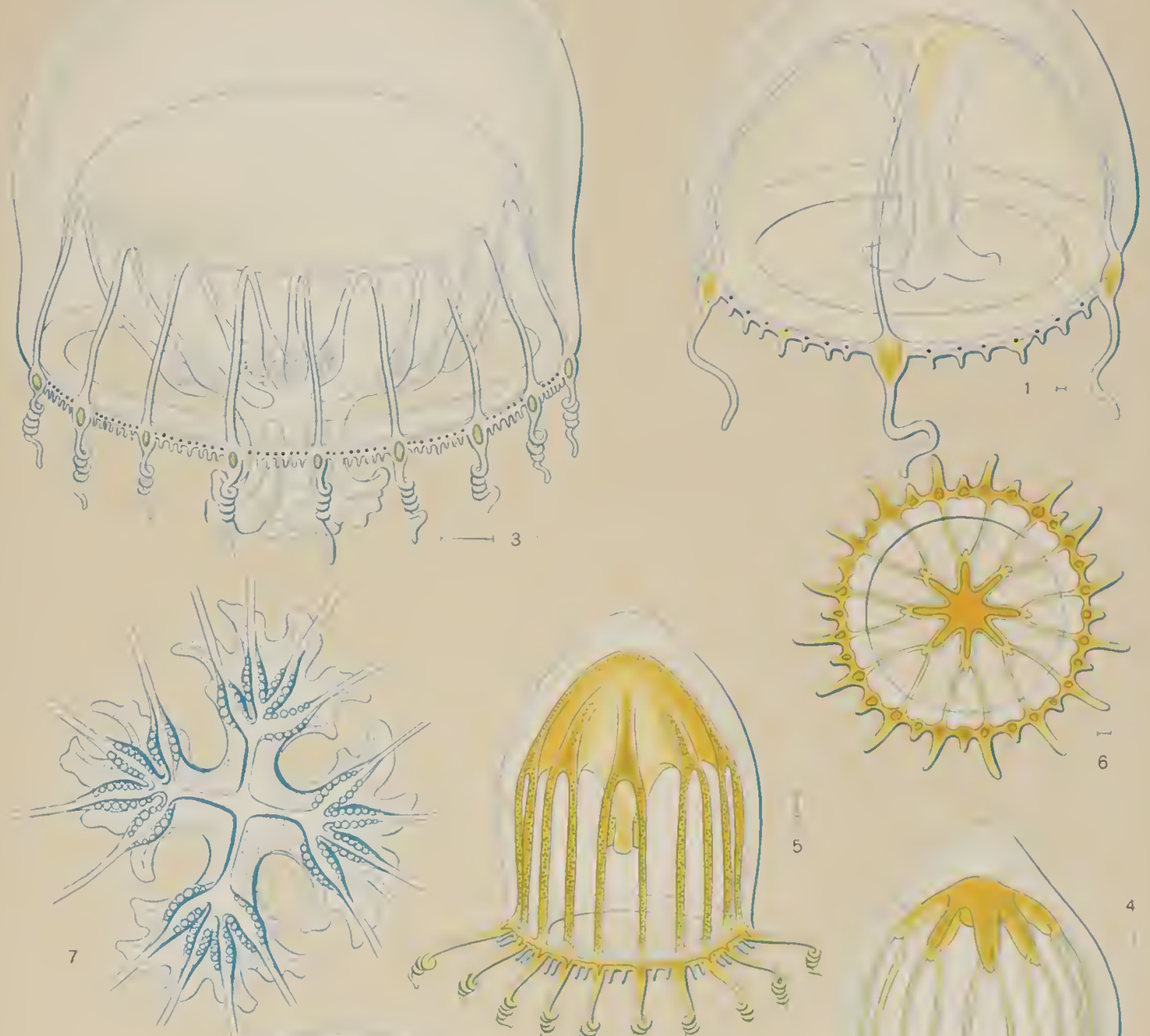

(13)
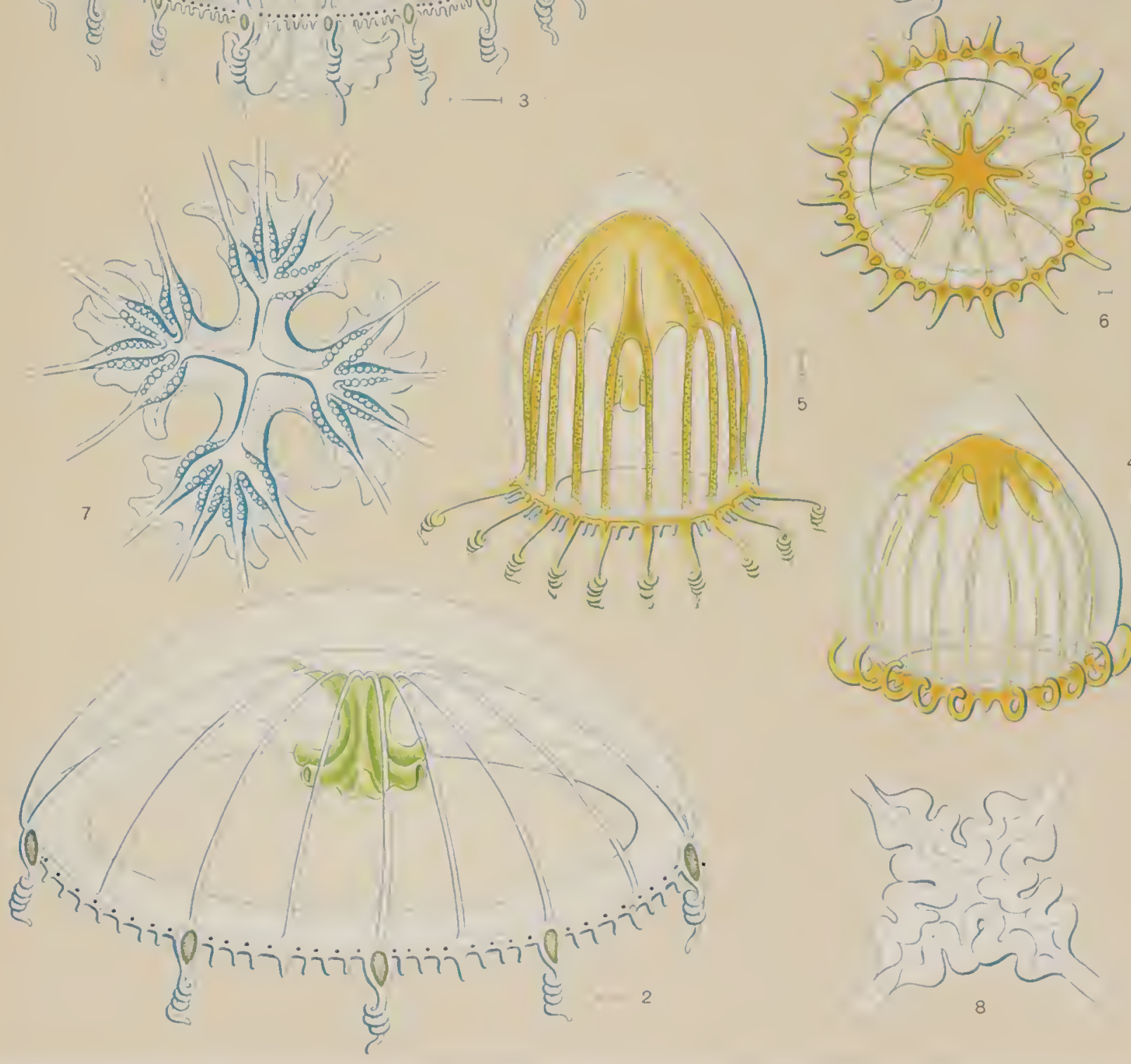

$\left(6 \cos 2 \sin ^{3}\right)^{2}$
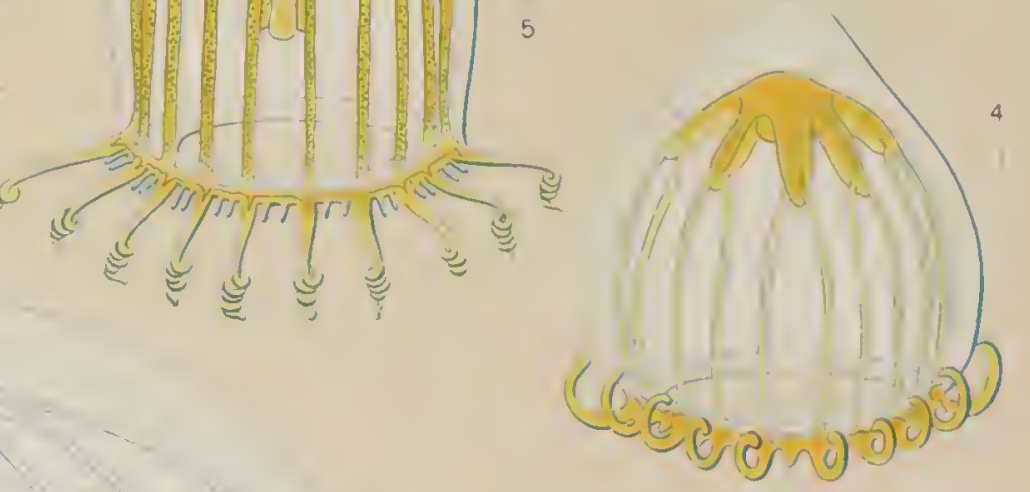

Dipleurosoma brooksii sp. nov.

This form is described from drawings made by the late Prof. William K. Brooks, and found after his death among his unpublished figures. The drawings were generously presented to the author by the Department of Biology of the Johns Hopkins University for reproduction in this work.

Bell Hatter than a hemisphere, evenly rounded, thin walled. Manubrium small, short, and 8 -sided. 8 simple lips, 4 long and 4 short. 8 radial-canals arise from the stomach, the $t$ in the radii of the long lips are trident-shaped, each giving rise to 2 side branches. The 4 canals in the radii of the short lips are simple. Thus 16 teminal branches reach the circular vessel. In the specimen figured by Professor Brooks only 14 canals joined with
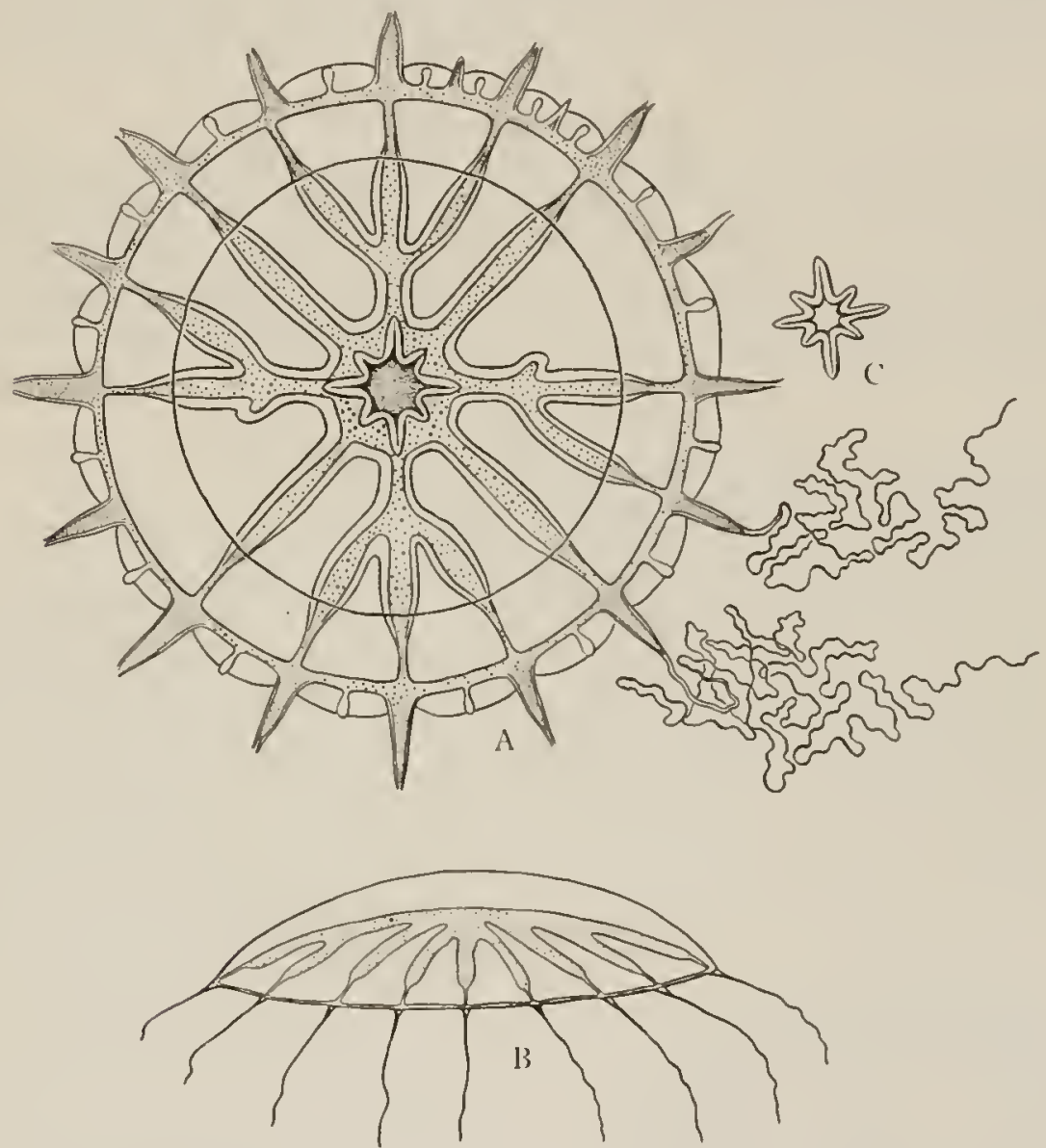

Fic. $118 \mathrm{a} .-$ Dipleurosoma brooksii, sp. nov. $\mathrm{A}$, oral view; $\mathrm{B}$, side view with tentacles cut off short; $c$, oral view of lip̧s. Drawn from life by Professor Brooks.

the circular vessel, for two of the side branches of the main radial-canals failed to develop. There appear to be typically 16 tentacles, one at the base of each terminal branch of the radial-canals, although in two intervals there aresmall additional tentacles thus giving 18 tentacles in the specimen figured by Professor Brooks. The tentacles have long, conical, tapering basal bulbs, which are hollow and very long, lash-like shafts, longer than the belldiameter and very flexible. No ocelli are figured by Professor Brooks. The gonads are upon the sides of the 16 radial-canals, not touching the ring-canal but extending from the sides of the stomach outward. The velum is a wide, annular diaphragm. The size and color of the medusa can not be determined from Professor Brooks's drawings. The medusa was found at Nassau, Bahama Islands. 
Were it not for the ahsence of ocelli I would be inclined to regard this medusa as a hypertrophic specimen of Staurodiscus tetrastaurus in which the side branches of the 4 primary radial-canals had reached the circular vessel and 4 intermediate canals had developed. I have, however, never observed such a condition among many hundreds of apparently mature medusx of $S$. tetrastaurus found at Tortugas, Florida; and it seems probable therefore that Professor Brooks's medusa is a new species which may have been derived from a Staurodiscus-like ancestor.

Genus TOXORCHIS Haeckel, I879, sens. ampl.

Toxorchis + Cladocanna, HAfcke I, 1879 , Syst. der Medusen, Pp. 156, I 60 .

Toxorchis, MaAs, 1904, Sitzungsber. math.-phys. Klasse kgl. Bayer. Akad. Wissenschaft., Bd. 34, P. 441 .

Haeckel, 1879 , founded this genus for Toxorchis arcuatus of the Canary Islands, Atlantic Ocean; but the first known species is T. thalassina = Berenix thalassina Péron and Lesueur, 1809, from Northern Australia.

\section{GENERIC CHARACTERS.}

Thaunantiada with 4 , 6 , or more main radial-canals which branch regularly and dichotomously one or more times. The gonads are upon the outermost hranches of the radial-canals, near the ring-canal. Numerous tentacles, cirri, and marginal clubs. Hydroid unknown.

Haeckel restricts Toxorchis to include medusx having radial-canals branched once dichotomously, while his Cladocanna applies to medusa having radial-canals with 2 or more dichotomous branchings.

Toxorchis thalassina Maas.

Berenix thalassina, Péron et Lesurctr, 1809, Annal. du Mus. Hist. Nat. Paris, tome 14, P. 327. Berenice euchroma, DF. Blainitleze, 1834, Mantuel d'Actinologie, p. 276, plate 32, fig. I.

Curieria euchroma, Lest'EUR, $1 \$ 39$, in Cuvier's Le Règne animal, plate 53, fig. 2.

Cladocanna thalassina $+C$. polyclada, HAECKEL, 1879, Syst. der Medusen, pp. I6o, 161.

Cladocanna polyclada, von Lendenfeld, 1884 , Proc. Linnean Soc. N. S. Wales, vol. 9, p. 581 .

Toxorchis thalassina, MaAs, 1904 , Sitzungsber. math.-phys. Klasse kgl. Bayer. Akad. Wissenschaft., Bd. 34 , p. 44 I.

Cladocanna thalassina. Bedot, 1901, Revue Suisse de Zool., tome 9, P. 482 ; Ibid., I 1905, tome 13, P. 132 (list of papers to 1850 ).

Bell flatter than a hemisphere to hemispherical, about $50 \mathrm{~mm}$. wide. About 100 or more long tentacles with marginal cluhs and cirri between them. Stomach shallow, with 6 wide lips. 6 wide radial-canals arise from stomach. For one-third the distance between stomach and margin these canals are simple and unbranched, but outwardly they branch dichotomously and somewhat irregularly 3 to 4 times, so that there are about roo terminal branches which reach the circular canal at the margin. The sac-like, spindle-shaped, folded gonads are developed upon the outermost branches of canals. The entire medusa is light sea-green.

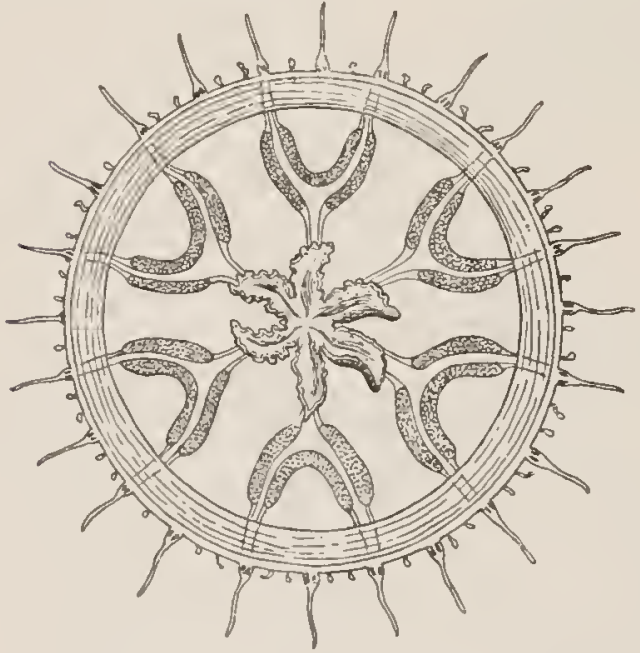

Fig. II9.-Toxorchis archatus, after Haeckel, i $\$ 79$. Found off the coasts of New Guinea and Northern Australia. Development unknown.

\section{Toxorchis arcuatus Haeckel.}

Toxorchis arcuatus, HAECKEL, 1879, Syst. der Medusen, P. 157, taf. 9, figs. 6-8.

Bell flat to hemispherical, $6 \mathrm{~mm}$. wide. Stomach small and flat, with 6 much crinkled, lanceolate lips. 6 main, wide radial-canals which fork at their middle points, so that 12 canals, $30^{\circ}$ apart, reach the circular vessel at bell-margin. There are 24 long tentacles with bulbous bases, each bearing a reddish-brown ocellus. Numerous clubs and cirri on bellmargin between the tentacles.

The gonads are developed upon the edges of the forked ends of radial-canals, there being a crescentic gonad upon the concave side of the crotch of each fork, and a pair of linear gonads upon the convex sides of the forks. There are thus 3 gonads upon each main canal at its forking, 18 gonads in all. 


$$
\text { . }
$$


Plate 28.

Fig. 1. Toxorchis kellneri. Side view of female medusa. Tortugas, Florida, July 8,1907 .

Fig. 2. Toxorchis kellneri. Oral view of the medusa.

Fig. 3. Turris superba (a variety of $T$. pileata). Tortugas, Florida; July 4, I907. Mature male medusa.

Fig. 4. Turris superba (variety of $T$. pileata). Side view of manubrium showing the foldings of the interradial gonads.

See page 126 for description of figures 3 and 4 .

Drawn from life, by the author. 


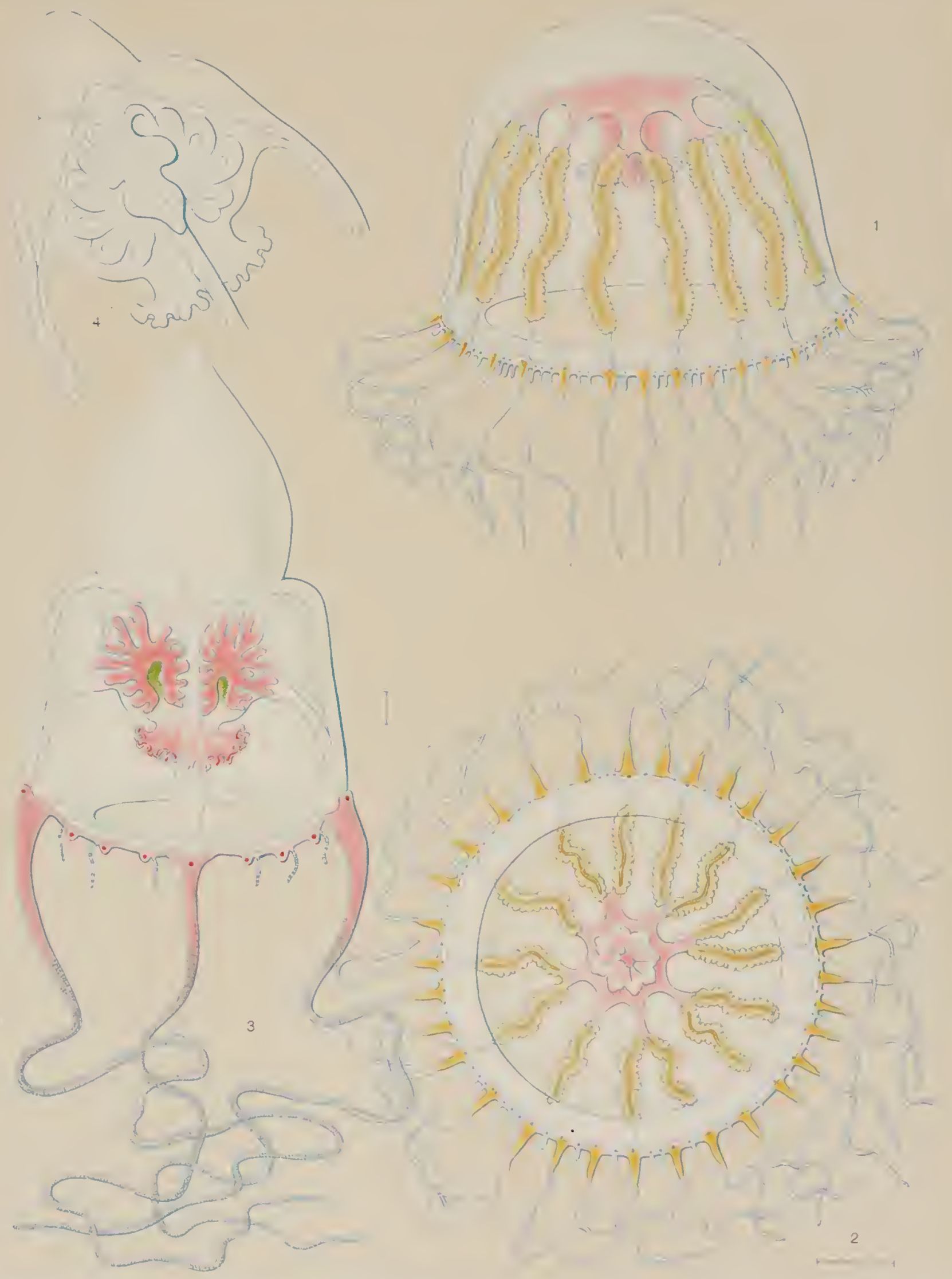





$$
\text { - }
$$




\section{Plate 29.}

Fig. 1. Dipleurosoma ochracea. Side view of an immature medusa.

Fig. 2. Dipleurosoma ochracea. Oral view of an immature medusa.

Fig. 3. Stomotoca pterophylla. Enlarged view of the medusa, showing the bell contracted so as to reduce the length of the peduncle. Nassau Harbor, Bahamas, April 20, 1907.

Fig. 4. Stomotoca pterophylla. Side view of the manubriun of a mature male. Off Miami, Florida, in the Gulf Stream.

Fig. 5. Stomotoca pterophylla. View of velum showing radial and circumferential muscle-fibers.

Drawn from life, by the author.

See page 133 for description of figures 3 to 5 ; page 226 for descriptions of figures 1 and 2. 

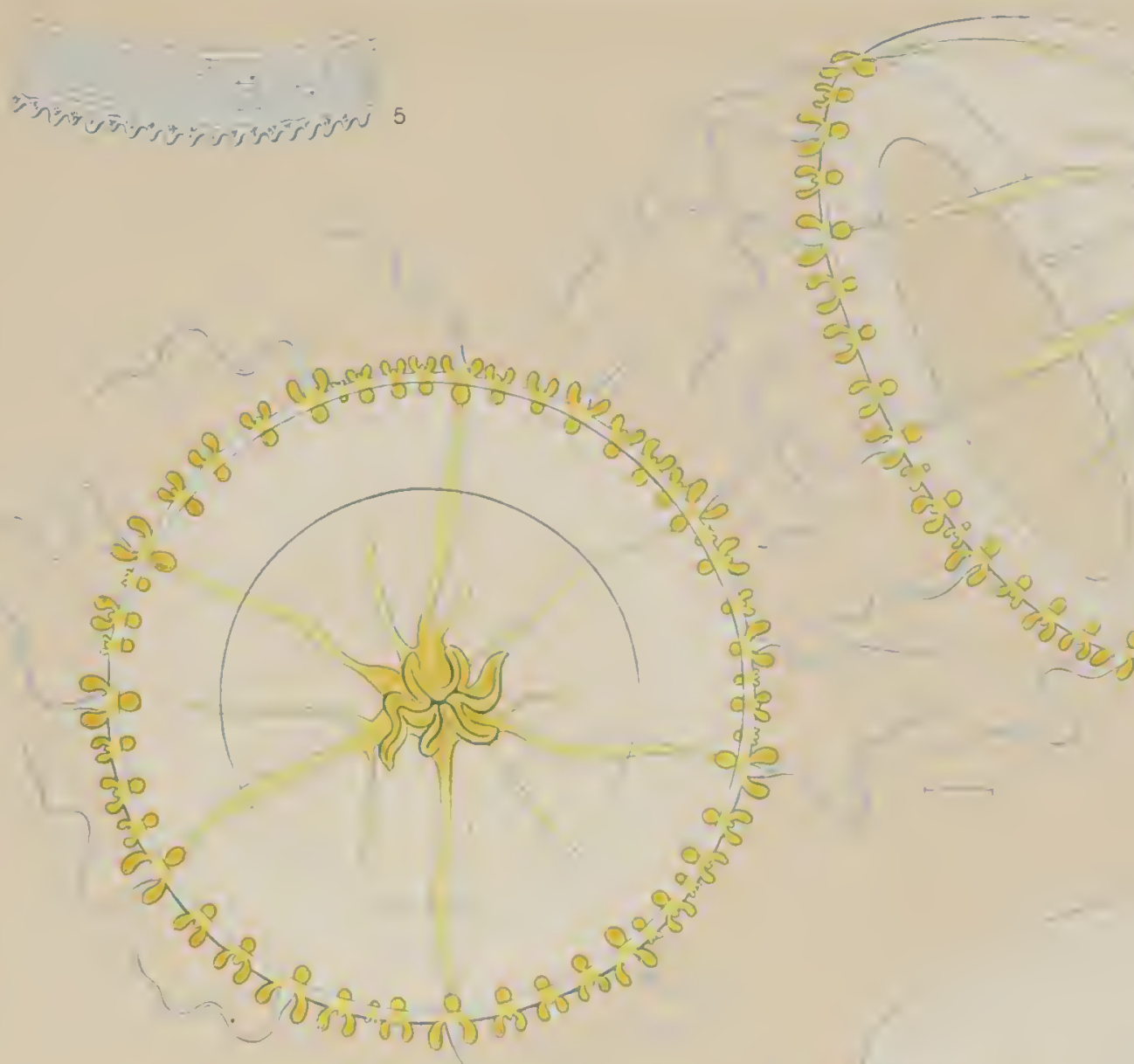

Stomach, lips, gonads, and tentacle-bulbs are yelfowish-brown, speckled with dark-red. Exumbrella besprinkled with reddish-brown spots.

Found by Haeckel at the Canary. Islands, Atlantic Ocean, in January. 1867.

Toxorchis kellneri sp. nov.

Plate 28, figs. 1 and 2.

This medusa is named in honor of the author's assistant, Mr. Carl Kellner, whose copies of figures of medusie by previous authors appear as text-figures in this work.

Bell aloout $15 \mathrm{~mm}$. wide, with moderately thin walls, thickest at center of hell and thin at edges. When in a normal resting state the hell is somewhat higher than a hemisphere, but when expanded it is slightly Hatter than a hemisphere. There are about 32 tentacles with fong, conical, tapering, hollow basal hulhs. The filiform shafrs of these tentacles are highly contractile and normally 2 to + times as long as the lofll-dianeter, hut may be contracted so as to become about as short as the bell-radius. There are ahout 50 small clubs upon the bell-nargin between the tentacles; but no coiled cirrinor lithocysts. There is a black entodermal ocellus within ring-canal at hase of each tentacle and marginal club.

Velum well-developed, ring-canal narrow. Stomach about one-fourth as wide as belldiameter. 8 flat, wide radial-canals arise from margin of stomach, $45^{\circ}$ apart. A short distance beyond the margin of the stomach most of these 8 primary ladial-canals bifurcare. Thus in the specimen here figured 6 of the 8 primary radial-canals are bifurcated and thus I4 slender radial-canals reached the marginal ring-canal.

The manubrium is shallow, only about one-fourth as long as the depth of the bell-cavity, and there are 8 lanceolate lips with folded, curtain-like margins. 'These lips are in the radii of the 8 main radial-canals. The gonads are developed upon the sides of the narrow outer branches of the radial-canals and do not touch the ring-canal.

Central stomach pink; gonads and tentacle-lulbs brownish-yellow; cntodermal ocelli very dark brown, almost black.

Several specimens of this medusa were found in a surface tow at Tortugas, Florida, on July 8, ig07. The figures represent a female.

This species differs from Ilaeckel's $\mathcal{T}$. arcuntus of the Canary Islands in its ligher betl, more numerous and more irregularly branching radial-canals, in the absence of marginal cirri, and in color. Unfortunately, Haeckel had but one specimen, and I have seen only three, and it is possible that future studies may show that the Canary Island medusa is identical with the Tortugas form.

Genus NETOCERTOIDES Mayer, I900.

Nelocertoides, Mayer, 1900, Bull. Mus. Comp. Zool. at Harvard College, vol. 37, p.45.-M1.4s, 1904, Sitzungsber. matls.-phys. Klasse kgl. Bayer. Akad. Wissenschaft., Bd. 34, P. 437.

\section{GENHRIC CIIARACTERS.}

Berenicidæ with 8 main radial-canals, which hifurcate so that 6 canals reach the circulas vessel at bell-margin. There are 16 long, hollow, tapering tentacles, one at the end of each radial-canal, and 16 to 25 short, cirrus-like tentacles, one or two between each pair of long tentacles. The manubrium has + simple lips. The gonads are developed upon the sides of the manubrium and upon the 8 main stems of the radial-canals.

The type species is $N$. brachintum Mayer, of the Bahamas and Tortugas, Florida. It is the only species of the genus.

Netocertoides brachiatum Mayer.

Plate 27, figs. $4-6$.

Netocertoides brachialum, MAYrer, 1900, Bull. Mus. Comp. Zool. at Harvard College, vol. 37, p. 45 , figs. $43^{-44}$, plate 18 ; Memoirs Nat. Sci. Museum Brooklyn Institute Arts and Sci., vol. 1, p. 12, fig. 7. plate 1.

Bell + to $5 \mathrm{~mm}$. high, miter-shaped, walls quite thin. 16 hollow tapering tentacles: one at hase of each of the 16 radial-canals. 16 to 25 small tentacles, one or two hetween each pair of long ones. Longest tentacles about one-fourth as long as belf-height, their ends tightly: 
coiled. The short tentacles are hardly more than cirri. No marginal sense-organs. Velum well developed. 8 main radial-canals arise from the manubrium, but each bifurcates, giving in all 16 terminal-canals, which extend straight toward the circular vessel. The 8 proximal roots of the radial-canals are bound to the manubrium by groined arches. Manubrium broad and disk-like. The mouth is at the extremity of a short neck, surrounded by 4 simple lips. Gonads along the main radial-canals, adjacent to the stomach. Entoderm of tentacles, radial-canals, and manubrium rosin-colored. Quite common at the Bahamas, but rare at the Tortugas, Florida. Seen only in summer.

This medusa is closely related to Dichotomia cannoides, but in Netocertoides 8 main radial-canals arise from the stomach instead of 4 as in Dichotomia, and the manner of branching is quite different, even in young medusæ.

\section{Monobrachium parasiticum Mereschkowsky.}

Monobrachium parasiticum, Merescrkowsky, 1877, Annals and Mag. Nat. Hist., ser. 4, vol. 20, p. 220, plates 5, 6.-W Wagner, I8S9, Zool. Anzeiger, Jahrg. 12, p. 116; 1890, Archiv. Biologie, tome 10, p. 273, plates 8, 9 (details of histology).

This interesting hydroid has only I tentacle. Its medusiform gonophore belongs apparently to the Thaumantiadx, but the free medusa is unknown, if, indeed, it be set free. The medusiform gonophore is oval and is developed in a sac which arises from the hydrorhiza. The hydroid grows upon the posterior part of the living shell of Tellina calcarea, near the siphon. The hydrorhiza is a flat expansion of anastomosing tubes covered with a thin chitinous membrane. The polypites are about $2 \mathrm{~mm}$. long, tubular, with a single tentacle. This is 4 to $6 \mathrm{~mm}$. long, tapering, lash-like, and arises from the side of the hydranth at a point about onethird the length of the polypite from the mouth. The gonophores are medusiform, about as long as the polypites, and they arise from the hydrorhiza by a short stalk. The contained medusa is oval with a short conical manubrium, 4 radial-canals, each with 2 gonads upon its sides. Ring-canal and 16 rudimentary tentacles. Color of colony, yellow. White Sea, Russia. 


\section{INDEX TO VHaUMES I AND II.}

Volume I cxlends from page I to 230 , volume if from page 23110 4y 5 .

Arochetcumena, +30

Iigima I $5,+48,+49$

exinuides, $+5+$

whermans, 153

brumea, +53

canariensis, +52

itren, $+50,15 I$

schscholizii, $+50,+53$

lactea, +53

pachydcrma, +73

rhodiun, $+50,+5^{2}$

rosea, $+5 \mathrm{I}$

Aigindlla, $+5+$

bitent aculata, +55

dissoncma, 456

Figineta, $+32,+67$

corolla, 437

Bavescens, +34

gemmifera, +80

globosa, +76

paupercula, $+3^{2},+37$

rosea, + so

Aiginida, $+28,+30,145$

Figinodiscus, $16,+49$, fiso actiundiscus, fiso

Eginorlorus, $+\$ 5$

Fimopsis, 15, +48, +50, +54, 17=

hensenii, +55

lanrentii, +72, fos

medituranea, $+5^{6}$

mestensii, +72

pachyderma, 773

Fgiumm, 15, $+48, .67$

grimaldii, $+68,17^{\circ}$

incisn, 47 ?

lanzerotis, +68, t6o $^{6}$

invosura, f65

weberi, +70

Equoren, 12, 324

alhin, 33 I

ciliata, 325

conica, $33 \%$

cubana, 325

cyanea, 326

cyanogramma, ++5

discus, 325

euchroma, 222

eurhodina, 326

foridumn, 330

forbesiana, 323

forskalea, $\hat{3} \geq 5$
Principal references are in italies.

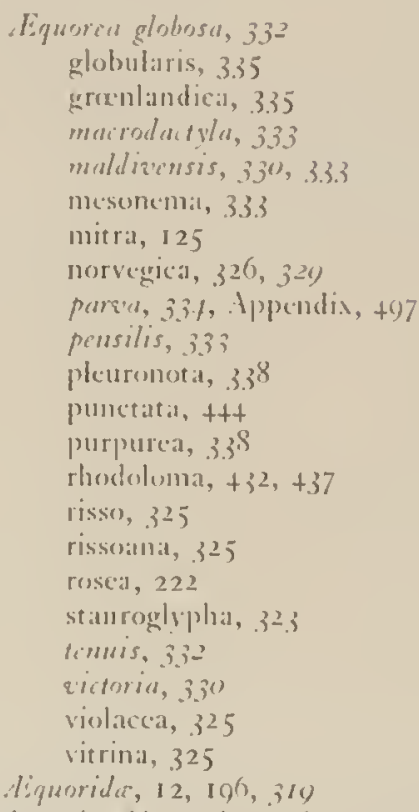

Agassiz, Aleximeler, ackmowledgment to, I Igastra, 10, 231, 231 caliculati, 234 miru, 23.1

lglumlua, 1 t, fort

conica, to2

digitati, for 2 ear. intemedia, fof ear. ncidemalis, jot

ilongata, fof

glohulig(ru, fl) t

iguid, 105

rosea, to2

Iglumrn, I t. 347

hemistoma, 307. jys

sar. laterna, poo

Ear. nansican, 100

v'ar. artagona, for

quar. prismation, fon

penicillat a, 218

Iglauride, 375,306

Aglauropsis, 13,361

agassizii. 363

collantii, 362 .

Aglisera, toI

clata, tot

clongata, tot

ignea, 405 
Aualthea, 5, 22

amuebigera, 22

jatuarii, 23

sarsii, 22

wvifera, 22

vardöensis, 23

Ametrangia, 224

hemispharica, 224

Amphinema, 108

apicatum, I09, 112

australis, Appendix, 490 ,

dinema, 109

titania, I00

turrida, Appendix, 490

Amphocodon, 37

amphipleurus, 39

fritillaria, 39

globosus, 39

gravidum, 39

unicus, 42

Amplogona, I 4,405

apsteini, 405

pusilla, Appendix, 497

Anthomedusa, 17 development, 3, 5

Atractylis, 20 I

Auliscus pulcher, 43

Bathycodon, 73

pyramis, 79

Berenice, 22I

capillata, 222

euchroma, 228

huxleyi, 222

Berenix, 22

thalassina, 228

Blackfordia, I I, 232, 276

manhattensis, 277

virginica, 277

Blastothela, 29

Botryuema, 14. 394

brucei, 395

Bougainvillea mediterranea, I 33

paradoxica, I 62

ramosa, I6 I

Bongainvillia, 2, 3, 8, I55

allmani, 160

autumnalis, $r 60$

bella, I6I

benedenii, I6I

britannica, 161

carolinensis, 165

dinema, 164

favida, 168

frondosa, I 7 I

fruticosa, I60, Appendix, 493

fulva, 16o, Appendix, 492

gibbsi, 160

glorietta, 172

kollikeri, I 79

macloriana, I60
Bougainvillna maniculata, I7o

multicilia, 164

muscus, I 55, I6 I

niobe, 166

nordgaardii, 168

obscura, I 72

octopunctata, I 77

platygaster, 165

principis, róo

prolifera, $I 70$

pyramidata, 168

rugosa, I7I

superciliaris, $I 62$

trinema, $I_{7} I$

xantlia, ${ }^{6} 6_{5}$

Budding in Medusx: Hybocodon, 39; Sarsia, 48 , 6I-64; Margelopsis, 8o; Lleutheria, 95; Cytæis, I 33; Bougainvillia, I63, I 66, I 7 I ; Rathkea, I 78, I 79, I \$2, Appendix, 493; Proboscydactyla, I 91,192 ; Phialidium mecradyi, 27I; Eucheilota paradoxica, 285; Eirene medusifera, 4I3; Gonionemus larva, 345; Limnocnida, 370; Narcomedusx, 429; I'cgantha, 447; Cunoctantha, 466; Cunina, 478, 48 I ; Rathkea, Appendix, 493.

Bythotiara, 8,185 murrayi, 185

Bythotiaridi, 183

Calcydion formosum, 136

Callitiara, I 46 polyopthalina, 147

Calycopsis, 7, I30, Appendix, 49I typa, I $3 I$ Appendix, 49 I

Calyptra, 376 umbilicata, 378

Campalecium, 201 inedusiferum, $29 \mathrm{I}$

Campanclla, 207, 449, 454 pachyderma, 473

Campanopsis, I96, 295, 298, 302, 304

Campanularia bilabiata, 233 caliculata, 234

compressa, 233

dichotoma, 246

dumosa, 20 I

flabellata, 249

gelatinosa, 255

geniculata, 244, 246, 249

inconspicua, 266, 269

johnstoni, 262

noliformis, 265

syringa, 269

volubilis, 262

Campanulina, 234, 266, 314, 320

acuminata, 3I 4 , 3 6

hincksii, 284

languida, 260

repens, 235,317

Cannota, I0, I 97, 2 I 3, 221

dodicantha, 221 
Cannotidx, 102, 196

Carmarina, 424 fungiformis, 425

hastata, $\$ 25$

hexaphylla, 425

Carmaris, 424

giltschii, 425

rusea, 425

umbella, 425

Carmintothe beroe, 105

Catablema, 120

campanula, 128

eurystoma, 128

vesicarium, 126

Charybdea bitentaculata, 455

Chiurclla, 8,182

centripetalis, 182

C'hromatonema rubrum, I 90

Circe, 401

c:1mtschatica, 402

elongata, 404

invertens, 404

rosea, 402

Circeadx, 396

Circella digitalis, 402

Cladocamna, 228

polyclada, $22 S$

thilassina, 228

Cladonema, $3,7,08$

maveri, IOI

perkinsii, IOr

radiatum, on

Cladonemidx $, 6, s_{3}$

Clavatilla, 93 prolifern, of

Clavula, Appendix, 49

fontata, Appendix, 49 I

gossei, 122

neglect $A$, Appendix, 401

papur, Appendix, $49 \mathrm{I}$

Cleodora tricuspidata, 122

Clytit, 10, 232, 26I

bakeri, 262,405

bicopliora, 262

compressa, 233

crlindrica, 262, 265

eucophora, 236

flavidula, 266

folleata, 264

fragilis, 262

geniculata, 262

johnstoni, 262

polynesix, 264

rangirna, 265

simplex, 262

universitatis, 265

qolubilis, 263

Codonider, 5,19

Codonium, +7

apiculum, 59

conicum, 58
Codonium codonophorum, 6I gemmiferum, 62 princeps, 60

Codonorchis, 108 octadrus, il

Colobunema, $3^{8} 3$ sericcunt, $3^{8} 4,3^{85}$ typicum, 385

Conis, 7,130 cyclophthalma, Ijo mitrata, I jo

Comrergence of: Ctenaria, Craspedotella, and l'elagothuria, 84 ; Narcomedusa and I.eptolina meduste, 15,84; Hydroctena and Cenophorat, 460; Mloerisia and Hydra, $48 S$

Corvdendrium minor, 122

Corymorplua, 22, 3I, 37 annulicornis, $3^{8}$ fritillaria, $3^{8}$ januarii, 23 nana, 35

nutans, 31, 41

pendula, ofl

uvifer:1, 22

virgulata, 35

Corvine, 47

eximi:1, 57

mirabilis, 5.3

pelagica, 80

producta, 63

rosaria, 59

Corynetes agassizii, 72

Corynida, in

Coryutis, 6, $7 t$ agassizii, 72 arcuta, 73 carruleus, 73

Consmetira, 201, 23I, $26 \mathrm{I}$ pilosella, 26I

salinarum, 202

Craspedacusta, $13,3^{6} 3$

kawaii, 365

sowerbii, $36_{3}$

Craspedotor, 16, 17

Crematostoma, 324 fava, 326

Crossota, 14, 395

brunnea, 396

norwegica, 390

Cryptocarpae, 17

Ctenaria, 6, of ctenophora, of

Cubaia, 12, 350 aplorodite, 351

Cubogaster, 132 dissonema, 134 gemmascens, I33, I 78

Cunantha, 15 , ffS petasoides, 449 primigenia, 449 striata, $1+9$ 
Cunanthida, $4+7$

Cunarcha, $4+9$ rginoides, +5+

Cuminal $15,4+8,+60,+73$

albescens, +82

campanulata, $+74,+76$

dodecimlobata, +76

duplicata, 475. $7 \mathrm{SI}$

globosa, $+7+,+7^{6}$

köllikeri, +64

lativentuis, 474,176

moneta, 482

mucilagiunsa, $475, f 3 I$

multifidia, 175

octonaria, +6r

parasitica, 465

perigrina, $x^{8 I}$

probosidea, 474,476

prolifera, $474,+80$

rhododactila, 480

solmaris, 482

striata, $4+0$

vitrea, 476

Cumissa, I6, $448,+{ }_{5}$

polyphera, +85

polyporpa, 45

Cunoctantha, 15, 448, 100

foulcri, foo

incisa, 472

aitomaria, for $^{2}, 4^{6} 4$ var. kollikeri, jof

parasitica, 105

polygona, fro $^{6}$

tcnella, $x^{6} 7$

Cunoctona, +67

grimaldi var. munda, $+70,+72$

guinensis, +70.472

lanzerota, +60

nausithoë, 460

obscura, $470,47 ?$

Cuspidella, 201, 204, 286, 285

Cuvieria, 10, 19\%, 22I

carisochroma, 222

euchroma, 228

huxleyi, 222

Cyanea bougainvillii, I 56, 160

Cutzandra, I35

areolata, I 40, I 54

polystyla, I 40

Cytcis, 7, I3I, I32, 175

exigua, 1,36

gracilis, I +I

herdmani, 135

nuacrogaster, 133

minima, I to

nigritina, I 33

octopunctata, 177

polystyla, I 43

pusilla, $\mathrm{I}_{3} \mathrm{f}$

tetrastyla, I33

qulgaris, I31, Appendix, 492
Cytology: Amalthxa, 22; Pennaria, 26; Steenstrupia, 3 I ; Hybocodon, +1 : Margelopsis, $8 I$; Fileutheria, 95; Cladonema, 100; Turritopsis, I44; Oceania, I48; Gonionemus, 348 ; Liriope, 4I4; Geryonia, 427 .

Degenerate medusx: Pachycordyle, 21; Bougainvillia maniculata, 170; Eucopella, 2.33; Agastra, 234; Eucope parvigastra, 238; Gastrodes, $46 \mathrm{I}$.

Dendrodava dolmmii, II7, II 8 , Appendix, 40

Deudronema, 7, 102 styladendron, 102

Dindrostaurina, 8,183

Development of: Millepora alcicornis, 16: P'(nn:aria tiarclla, 26, 27. Appendix, 487; Trichorhiza, 29; Steenstrupia rubra, 32; Hybocolon prolifer, 39; Sarsia, 52-64; Stauridiosarsia, 65; Hydriclathys, 66; Ectopleura, 60: Corynitis. 72; Margelopsis, 8I: Pelagohydra, 83; 7.anclea, 87-90; Eleutheria, 95; Mnestra, 97; Cladonema, Ioo; Stomotoca, II2, IIt; l'anlea, II 8 ; Turris, 123, 124: Crtxis, I33; Podocoryne, I37; Turritopsis, I +4; Oceania, I 48 ; Stylactis, I50; Bougainvillia, I 60. I 62, 163, г66, г68, г7г; Nemopsis, г74; Rathea, I 7 ; Niobia, I87; Proboscillactyla, I90. I92; IVillsia, I93, I94; Laodicea, 204; Melicertum, 207; Dipleurosoma, 226; Fucopella, 2.3.3; Agastra, 234; Eucope, 235; Obelia, 244-255: Tiaropsis, 258; Clytia, 263; Phialidium, 267, 27I; Gastroblasta, 28o; Fucheilota, 285; Mitrocoma, 287; Staurophora, 292; Eutina, 297, 304; Phortis, 307, 300; Eirenc medusifera, 3I4; Tima, 3I8; Fquorea, 328; Conionemus, 344; Cubaia, 351; Olindias, $355,35^{8}$; Craspedacusta, $364 ;$ Microhydra, 366 ; Limnocnida, 370; Rhopalonema, 379; Honceonema, $3^{8} 3$; Aglaura, 306,395 ; Liriope, 4 ro, f1, 123 ; Geryonia, 424, f26; Narcomedusix, +28; Solmaris, 434, 437; P'egantha, $4+7$; Cunoctantha, $46+, 465$; Cunina, $475,477,48 \mathrm{r}$; Ratlokea, Appendix, 403; Nocrisia, Appendix, $+88$

Dianza, i 6,265

bairdii, 3 I 9

bitentaculata, 294

conica, I I 8

digitale, 402

exigua, $4 \mathrm{I} 3$

funeraria, $3^{\text {So }}$

lucullana, $3 \mathbf{I} 4$

proboscidalis, 425

rotunda, 124

Dichotomia, 10, 197, 223

cannoides, 223, 230

Dicodonium, 5, 14 adriaticum, 17

cormutum, 46

dinema, 17

foridana, 16 
INIEX.

Dicolonium jeffersom, to

Dicranocanna, i 88 furcillat a, 180

Digestion, Intracellular, in Craspedacusta, $33^{65}$

Digitale medusa, f02

Dimorphism in hydroids: J'ennarial and corymorplaa, 2.3; Syncorrnc and Seauridia, $48,65$. 84, 99; Corsuitis and Sarsia, 72: Bouganvillia and Nimopsis, 172; Agastra, 234: Obelia, $25^{6}$

1) incmis, $+4,108$ ocellatum, to

1)inematellat, 108 (avosa, 100

Dioclatemuna, $+j 0$

1)iptasus, $3^{\text {too }}$ digonemus, 361

1)iple-uron, 28 ! parrum, $28_{3}$

Dipleurosoma, 10, 197, 22.1

hrorksii, $21+2,23$

collapsa, 226

oithacen, 230

puificu, 225

typicum, 224

Diplura, 37

Diplurella clavata, 70

1)ipurena, 7.3

catenat:i, 77

cervicata, -6

conica, -6

dolichugaster, 77

fertilis, $6_{3}, 77$

fragilis, 77

halterata, 75

ophiogaster, 79

picta, 77

strangulata, 76

Dissonima, 7,115

seiphetiella, 115

purida, 1s6, ippendix, t9o

Distrihution of: Trachymedusa, 3+0; I.imnocnida, males and females, 371

Dyscanmota, i $8 \&$ dysdiplcura, 189

Dismorphosa, I,35

carnea, 1,36

conchicola, 136

dubia, if

fulgurans, 139

gemunifora, 192

gracilis, $1+1$

minima, I 8 I

minuta, 1 to

tenuis, I $+1, I+2$

Ficopleura, $;, 65$

dumontici, 60, Appendix, fis

minerva, 70

ochracea, 60, Appendix, tiss

pacilica, $7^{\circ}$
Eirelte, 11, 232, 205, 3II

landuensis, $3 \%$

digitale, $\mathrm{fO}_{2}$

gibbosa, 307

kambara, 30 )

medusitera, 31,3

pellucida, lppendix, + )h

quadrigatum, 3t;

s'uriabilis, 31-

viridula, 311

Firenina, 11,232 , 3ur

Elewtheru, 6,93

claparedii, y5

dichoroma, 9 ;

qulleutim, of

limviromment, eHect of: light on regencration of ludendrium, 27; flowing water 11 pon Bou-

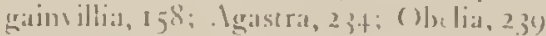

lipenthesis, 201

crmbaloides, $2(x)$

follcata, $262,26+$

meciadyi, 27

rangiruite, 205

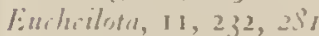

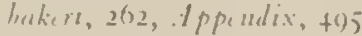

hirmulinsis, $2 \mathrm{~S}^{3} \mathrm{z}$

duodicimalis, 28 ; 8'tr. prus'um, $2 \hat{3}_{3}, 28_{4}$

marulata, 25

paradoxu, 28;

pitosellit, 261

Ecutriculurts, 25.2

Eucodomium, 5, 0.8

brencurit, os

Etropio, 10, 231, 23t, 238, 261

athinis, 262

alternatal, $2+0$

anmmlate, 237

articulatis, $2+6$

(ampanulatal, 262

diapliana, 2+()

dessomene, 237

falk!ninduca, 23T

fusiformis, 250,252

gemmugerat, $2 \lambda^{\prime}$;

glohinasa, 23;

hyaliua, 237

oblicpua, 250

parigastra, 2.3.

puta, 230

pulveastrica, 2,

polvena, 250, 251

polystyla, 255

pyrifomis, $2+7$

Fucopilla, 10, 231, 21-

hilabiatu, 2 के

campranuatria, 2.33

cremaltal, $23 t$

Finopide, 10, 196, 231

I:ucopium, 2it

parvigasi rum, 2,39 
liucopium pictum, 236 primordiale, 230

Fucoryne, 23 elegans, 25

Eudendrium, effect of light on regeneration of, 27 ramosum, 101

Euphysa, 29

aurata, 35

globator, 24

mediterranea, 35

tentaculata, 53

tetrabrachia, $3^{6}$

virgulata, 35

Euphysora, 29

bigelowi, $3^{6}$

tetrabrachia, $3^{6}$

Furybiopsis anisostyla, + It

Eurystoma rubiginosum, 480

Eutima, I 1, 232, 205

brownet, Appendix, to 6

campanulata, 296, 302, Appendix, 496

coerulea, 206, jof

cuculata, 296,209

curva, 296, joo

clephas, 296, 300

emarginata, 295

gentiana, 296, j02

gracilis, 295

insignis, 296, 299

lactea, 296, 300

levuku, 296, jor

var. occellata, 302

limpida, 295

mira, 205, 296

modesta, Appendix, +o6

orientalis, 296,299

pretiosa, 296, 306

pyramidalis, 308

variabilis, 3 I 2

l'utimalphes, 295

brownei, Appendis, +1j6

coerulea, 304

indicans, 306

pretiosa, 305

scintillans, 306

Eutimcta, 295

gentiana, 302

lactea, 300

levuka, zor

Eutimine, I1, 232, 20)3

Eutimium, 11, 232, 3015

elephas, $3^{\circ 0}$

scintillans, 306

serpentinum, 300

socialis, 306

Eutonina, 305

socialis, 306

Favonia, 153, 172

bachei, 173
Fission or scissiparity in Obelia, 24t, 249, 251; in Gastroblasta raffielei, 280

Fovedia, too $^{6}$

diadema, +45

mollicina, $4+5$

octonaria, for

Fresh-Water medusat: Thaumantias lacustris, I 99; Craspedacusta, $3^{6} 3-3^{6} 5$; Microhydra, 360 ; Limnocnida, 370; Moerisia, Appendix, 488

Fusion of blastula in Mitrocoma annx, 288

Gastrublasta, I 1, 232, 279

ovalis, $28 \mathrm{I}$

rafficlit, 250

rimida, 279

Gastrodes, $4^{60}$

parasiticum, 46 I

Gemmaria, 85

cladophor:1, 90

dichotoma, 9 I

gemmosil, 88

implexa, 89

nitida, 9 I

sagittaria, 88

Germ cells, origin of: I'ennaria, 25, 146; Dendroclava, 117,490 ; l'odocoryne, 1 36, 139; Bougainvillia, 162, 163: ()belia, 239, 251, 253 , 254; Cunina, 779; Sarsia, Appendix, 488

Geryones, +24

Gervonia, 14, 409, 124

appendiculata, 4 I 3

bicolor, 413

bitentaculata, 294

diania, 425

clepleas, 427

exigua, 413,420

fungiformis, +25

hastata, 425

hexapliylla, +25

mexicana, 425

octona, 12.3

pellucida, 314

praboscidalis, 425

rosacea, 417

tetraphylla, 417, 418

Gervonida, I + foo

Geryonopsis, 3II

forbesii, 3I I

gentiana, 302

pellucida, 3 It

Glands in Lymuorea alexandri, 75, I55

Globiceps, 23

globator, 24

tiarella, 25

Cilossocodon, tro

catharinensis, 421

hreckelii, +2 I

lïtkenii, 418

mucronatum, $4^{1} 3$

tenuirostris, 416,421

Glossoconus, 4 ro

[vi] 
Glossoconus canariensis, 418

Gonads, position of, secondary: of Slabberia halterata, 76 ; perradial, in Rathkea, 180; migration, in Obelia, 246, 253, 25t; in Ocemidie, 103

Gonionema, $3+1$ murbachii, $3+3$ vertens, habits of, it 3

Goncomeandrus, 219 chrysostcphanus, 220

Gonionemoides, 350 geophila, $35^{1}$

Gonionemus, 12, $3+1$ agassizii, $3+2,3+5$ de pressns, $3+2,3 / 5$ grafting of, 3.16 hornelli, $3+2,350$ murbaclii, $3+2,3+3,495$ ncrvous system, $3+6$ pelagicus, $3+2,3+9$ suqensis, $3+2,3.19$ vertins, $342,3.13$

Gonymema, $3+1$

Goodsirea, 293 mirabilis, 294

Gossea, 13, 367 bracliymera, 365 circiniata, 367 coryutetes, 367

(irouth, rate of in hydroids: Sarsia, 58; Bougainvillia, 162; Obelia, $2+6$

Gymopthalma, 17

IIabits: Collapsing of Dipleurosoma, 226; Figglaying of Stomctcca, II3; Uceanial, I48; Aqquorea, 328; Conionemus, 3tt; Liriope, $4 \mathrm{I}$; Geryonia, +26 ; Feeding of Z,anclea, S9; 'Turris, 126; Swimming of ()belia, 2+3; Cionionemus, 34t; Cubaia, 351; Olindias, 355; Craspedacusta, 365

Halatractus, 3 I

Halcordyle tiarella, 25

Ilalicalyx, 352 tenuis, $35+$

Halicreas, It, 390 alba, 393

conica, 394

glabrum, 392

minimum, 39r

papillosum. 39 I

racovitze, 393

rotundatum, 392

Haliscera, 390

conica, 394

Halitiara, 105

formosa, 107

11 alitiephes, 397 maasi, 397

IIalmomises, 198, 199 lacustris, 199

Halocharis, 85 spiralis, 72
II ulopsis, 286, 323

innat, 287

cruciata, $277,285,287,255,323$

megalotis, 280

ocellata, 323

llebella calcarata, 202

Hermaphroditism: Fleutheria, $8_{+}$; Cladomena, 99; Amphogona, 405. Appendix, 49j

Hetcrostephanus, 29

IIeterotiara, 7, yoanonyma, 107, Appendix, 480

llippocrene, 155

aurea, 162,104

bougainvillii, 16卫

britamnica, It I

carolinensis, 105

crucifer:1, 17 +

macloviana, 160

vetopunctat:1, 177

platygaster, 105

P) ramidata, 168

supercoliaris, 162

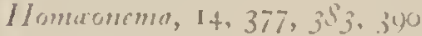

alli:1, 39.3

amplum, 30'

clongatum, 379

macrogaster, zis

miluture, $3^{6} 7$

platygonon, 350

racovitzar, 393

typicum, $38+385$

Mybocodon. 5, 37

amplipleurus, 39

annulicornis, 39

slillensis, 12"

cleristine, 12

forbesii, 12

gravidum, 39

islandicus, 39

jammarii, 23

occidentalis, +2

pendula, . II

pendulus, + I

prolifer, $35^{\circ}$

pulilier. 13

muicus, 12

11 ydractenal, $+5^{8}$

Mydractinia ancolata, 1 +o

Hydriclethys, 5 , 60 mirus, 67

Hydroctina, 15, $+48,15$ salcuskii, 1.50

$H$ yedromedersir, 5

Irene, 3II

cejloncmsis, 300

crerulea, .304

gibhosa, 307

mollis, 3I I

palkencis, 300

pellucida, $3^{1} 4, \lambda_{\text {ppendix, }}+96$ 
INDEX.

Irene viriclula, 3 I I

Ireniopsis primordialis, 351

Irenium, 3 i quadrigatem, 313

Irenopsis, 11, 232, 310 hexamemalis, 310

Isonema, 38, 3, 340 amplum, $3^{8}$;

Kermin beroe, 122

Kollikenia fasciculata, 170

L,afor:1, 20 I calc:all il a, 204 comutal, 201

Laodice, 201 collulisia, 108,109 inclica, 202, 204

Inodicen, 9, 197, 201 calcallata, 221, 204 (!) chapmani, 206

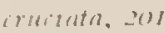

(!) (rucoupe, 200

(?) fertilis, 206 fifiann, 2015 val. indica, 205

maasi, 205

marama, 202, 204

(?) ueptuna, 206 pulihro, 202, 205 ulothrix, 202, 204

Laomedeal, 23 S dichotoma, 24t, 246, 255 divaricatal, 247 gelarinosa, $24+, 2+7$ geniculata, $2+9$

Lar sabellarum, 193

Leptomeduse, 9, 106, 231

Lessonia, $39-$

Leuckartia, $+2+$ proboscidalis, +25

Limuoc nida, 13. 370 tanganilict, $37^{\circ}$

Limnoimidide, 13,360

limnocodium. $3^{6} 3$ sowerbii, $3^{6} 3$ vietoria, $3^{6} 3$

Limnorea, 153 norvegica, I 54 prohoscidea, 153

l.iriantha, +10 catharinensis, +2I mucronata, $+1+$ tetraphylla, tis

Limopi, It, $+00, f^{\prime O}$ appendiculata, +1 I, +13 ianaricusis, +11 , fis

catharinensis, $+12, f^{2} 1$

cerasifrmis, $+\mathrm{II}, \mathrm{H}^{\prime} 3$

cerasus, +13

compacta, +17

conirostris, $4 \mathrm{I} 2$, 110
Limope crucifera, +17

distauogona, +12, t2o

cul ylia, $+12,+20$

cagua, +I I , f'3

laeckelii, +12, f21, Appendix, +97

hyalina, +21

levpertolica, fio

indica, $+12,+21$

ligurina, +20

lutkenii. $+12,+1 s$

minima, $+12, f^{2}+$

muremater, $+11,+13, f^{1} t$

prohoscislalis. +25

resaleed, 417 , Appendix, 497

siutigere, $+12,+13,+19,121$

temuirostris, +10

titraphy/la, +1 $2, / 15$

Liriopsis campanulit:1, 302

Lizusa, 155

multicilia, I6t

uctocilia, $16 \mathrm{I}$

prolifera, 170

Lizzella, 175

octcllar, I 80

Lizzia, $\mathbf{1 7 5}$

blondiua, i 8 i

claparedei, 18 I, Appondix, +9,3

formosissima, 177

grata, 177,179

köllikeri, I 79

octopunctata, $17 \%$

Limmorea, 8,153

ale and i, $I 5+$, Appendix, +02

horealis, $140,15 t$

dibalia, 153

mucrostoma, 153

ocellata, $I_{53}$

triedrai, 153

Mabella gracilis, 139

Matrias, 13,368

thexspectata, 3(ou)

Margelidire, 102

Margeline, $1 ; I$

Margelis, 155

autumnalis, 160

carolinensis, 105,167

nordgaardii, 168

principis, I60

ramosa, 16 r

trinema, I 7

$2 y$ gonema, $16+$

Margellium, 175

grata, 179

octopunctatum, 177

Magdopsina, 6, 20

Margelopsis, 6, So gibbesi, 82

hackelii, so

laatloubit, $S_{2}$

stylostomn, SI 
Marmanema, 376

clavigerum, $38_{2}$

manmaforme, $3^{8} 3$

velatoides, 378

tympanum, 378

Mccradia, 15.3 , 154

Meclusa acquorea, 202, 324, 325, .335

bimorplaa, 322

campanulat:1, 218

corlum pensile, 3.3.3

cruciata, 201, 202

cymbaloidea, 268

globularis, 335

hemisplierica, 266

marina, $23^{8}$

mucilaginosa, +81

patina, 325

pileata, 123

proluscidalis, +25

saltatrix, 210,220

Melicerta, 207

digitale, 402.

fisciculati, 179

pleurostoma, I +6

Mclicertella panocto, 209, 210

Melicertidium, 207, 200)

campanula, 207

octocostatum, 208

Melicertinar, 9, 107

Melicitissa, 9, 197, 200)

slarigera, 210

maloyica, 211

Melicertrim, 9, 197, 207, 210

campanula, 207

georgicum, 209

octocostatum, $205^{\circ}$

panocto, 200

penicillatum, 218

(؛) proboscifer, 209

Mesonema, $21 \mathrm{I}, 324$

abbreviata, 325

bairdii, 326

corrulescens, 326

cyanea, 326

dubium, 325

curystoma, 325, 327

macrodactyl:1, 3.3 .3

pencile, 333

pileus, 211

victoria, 3.30

Vicrocampana, 5, t4 canica, H

Microleydra, 1.3, 366 ryderi, 360

Microstoma, 92 ambigua, 92

Tlillepara, 16 alcicormis, 16

Milleporince, medusx of, 16

Vitrocoma, II, 232, 258, 295 ann $\alpha, 29_{7}, 288,290$
Mitrocoma cirrata, 2SS

crucialu, 255

discordea, $2 S^{\circ} \mathrm{O}$

lendenfeldi, 200

megalota, $2 S$ ?

miserve, 259

polydiadimata, zyo

Mitrocomella, 286

fulva, 290

polydiadkma, 290

Mit rocomium, 286

assimile, 288

cirratum, 288

. Vinstra, 6, o6 pentasites, 07

Mulecria, $7 \mathbf{I}, \mathbf{I}+3, \mathbf{I}+6, \mathbf{I}+7$

Marisin, Appendix, tis lyonsi, Ippendix, tis

Mollicina medusat, $4+5$

Mranberuhimm parasiticum, 23 in

Munocatulus perolulus, +1

Mlultioralis, 279 oralis, $28 \mathrm{r}$

Narcomedusar, origin of, 3, 15.128

Nimopsis, 3. 8, 80, 172, Ippendix, +9.3 haihei, 173

crucifere. $17 t$

gibbesii, 82,173

heteronema, 173

Netocertoides, 10, 197. 221)

hrachiatiom, $2 \geq 0$

Nigritina, 132

Nirlita, 8, is dendrotentuiula, $1 S_{7}$

Nucleifera, 103

Ohelia, to $10,23,235$

addungi, 25.1

andersoni, 255

angulosa. 257

arruensis, 250

anstralis, $2+6,247$

austro-georgia , 25t, 255

bicuspidata, $25+$

lidentifta, 251

lifmea, 254. Appendix, 195

bifurcata, 495

borealis, 2.19

chinensis, 256

commissuralis, $2 \%$. Appendix, t9t

coroma, 25;

delicutuli, 257

diaphana, $2+9,252$

dichoroma, $2+4.2+6$

divaricata, $2+7$

dubies, $2+6,245$

A abellata, $2+9$

fragilis. 2,5

gilutinosa, $2+4$

genirulnta, $2+9$ 
Obelia gracilis, 253

griffini, 252

gymnophthalma, $24+$

lielgolandica, 253

liyalina, 248

leucostyla, 244

linearis, 257

longissima, 255

lucifera, 249

nigra, 256

nigrocaulus, Appendix, 194

plana, 249

plicata, 256

polystyla, 255

purpurea, 243, 256, Appendix, $49+$

pyriformis, 247

rhunicola, 246

serratula, 257

spharulina, 246

striata, 248

surcularis, 252

Obelina, 10, 231, 232

Ocearia, 8, 120, I46, 265

ambigua, 274

armata, $I \neq 7$

blumenbachii, 177

brunescens, 274

carolin $x, 275$

coccinia, 123

conica, I I 8

coronata, 123

dinema, 109

discoidea, 272

flavidula, 147, 266

folleata, 264

gelatinosa, 272

globosa, I 22, 272

languida, 269

magnifica, 269

mccradyi, 27 I

octocostata, 208

octona, 123

pacifica, 273

phosphorica, 355

pileata, I 23

polycirrha, I 43

saltatoria, I 8

sedicimcostata, i i 8

singularis, 273

tetranema, I06

tubulosa, 52

turrita, 123

viridula, 3I I

Oceanide, 7, 17, 102

Oceanopsis, 28I bermudensis, 282

Octocanna, 12, 320

octonema, 325

polynema, 320

Octogonade, I 2, 321 mediterranea, 322
Octonema, 20 I

eucope, 206

gelatinosa, 2 I 4

Octorchandra, 295

canariensis, 302

germanica, 302

orientalis, 496

variabilis, $3^{\text {I } 2}$

Octorchidium, 305

tetranema, 302, 306

Octorchis, 295 campanulatus, 302 gegenbauri, 302 orientalis, 299

Octorphalon, 201 fertilis, 206

Olindiade, I2, 340

Olindias, I 2, 352 malayensis, 353,356

mulleri, 355

pliosphorica, 353. 355

sambaquiensis, 353,351

singularis, 353,357

tenuis, 353,354

Olindioides, I 3,358

formosa, $35^{8}$

Orchistoma, 9, 197, 211

agariciforme, 212

pileus, $2 I I$

steenstrupii, 2 I I

tentaculata, 212

Pacliycordyle, 5, 20, 21 degeneratus, $2 T$ weismanni, 21

Pachysoma flavescens, 434

Pandæa, I 6

Pandea, 7, 116

conica, 118

Havidula, I 47

masi, $I 19$

minima, 118

saltatoria, II 8

violacea, I19, Appendix, 490

Pantachogon, 14, 388

apsteini, 405

hackelii, 380

rubrum, 380

Parasitisin: Hydrichthys, I 9, 67; Mnestra, 96; Stylactis milloi, 149; Cunina, 379, 425, 427, 429; Cunoctantha, 461, 467, 465; Gastrodes, 461

Parvanemus, 2I

Pectanthis, $37^{2}$

asteroides, 374

Pectis, 372

antarctica, 375

Pectyllidae, 37 I

Pectyllis, 372 arctica, 372

Pegantha, 15, 430, 439 
INDEX

Pegantho aurcola, $\$ 10$

clara, $4+5$

cyanostylis, 4+1, +15

dactyletra, 440 , ift

dodecagona, $\mathrm{lt}$

godeffroyi, $\mathrm{HI}^{\prime}$

lavis, $4+4$

lunulat $a, H^{\circ}$

magnifica, Ho $^{\circ}$

martagon, $4+40,+3$

pantheon, $4+40,4 t^{2}$

punctata, 440, $14 \mathrm{t}$

quadriloba, +43

sieboldii, Htt

simplex, $4+3$

smaragdina, $+4 \mathrm{I},+16$

triloba, $4+4, \mathrm{H}_{3}$

weberi, $H^{I}$

l'eganthidx, +29, 4.3'

P'egasia, +39

dodecagona, 444

P'eligic hydroids: Margelopsis, 8o; Pelagohydra, $\delta_{3}$

Pelagoliydra, $6, s_{3}$

mirabilis, $S_{3}$

l'ennaria, 5,23

adamsia, 27

cavolini, 24

disticha, 24, Appendix, 487

gibbosa, 25

inomata, 487

marina, 24

pacifica, $2 S$

rosea, 27

symmetrica, 24, 25

tiarella, 25, Appendix, 487

ritrea, $2 S$, Appendix, 4is

P'erigonimus, iog

cidaritis, 115

jonesii, 'IIt

minutus, 124

napolitanus, Iog

repens, I 24

schneideri, Iog

steinachi, ron

sulphureus, 80

vagans, Appendix, 490

Persa, I4, 706

dissogonima, 407

incolorat $a, 408$

lucerna, 407

Petachnum, 360

tiaropsis, 361

Petasata, 360

eucope, $3^{61}$

rabbeana, 361

Petasina, 13,360

Petasus, 13,360

atavus, $36 \mathrm{I}$

tetranema, 36 I

Phialella, 234
I'lialclla falklandica, 237

l'hialidium, I I, 232, 205

ambiguum, 274

ampullaceum, 123

brunescens, 277

buskianum, 270

cymbaloideum, 235

duodecimale, 283

gclatinosum, 272

globosum, 272

gregarium, 272

hemisplaricum, 260

iridescens, 273

languidum, 200, Appendix, +45

lomat, Appendix, 495

mocrady? 3,5

pacificum, 273

simplex, 274

singular is, 273

timporarium, 266

icnue, 310

variabile, $235,266,280$

variabilis, 270

Phialina, 232, 261

lhialis, 286

cruciata, 288

Phialium, $28 \mathrm{I}$

bakeri, Appendix, 495

dodecascma, 283

duodecimalis, $28_{3}$

P'lisalopsis, 232, 266, 276, Appendix, 495 comata, 276

diegensis, Appendix, 495

Plrialucium, I I , 232, 277

carolina, 275

comata, 276

mbenglia, 275,276

sivens, 275,276

I'horcynia, 324

Phortis, II , 232, 305, jo

ceylonensis, 300

elliceana, 309

gibbosa, 307

kambara, 309

lactea, $30 \AA$

palkensis, 309, 313

pyramidalis, 308

Phyllirhoe, 97

Plancia, 293

gracilis, 294

Platypyxia cylindrica, 265

Plotocnide, 51, 66, 7 I

horealis, 106

incerta, 106

Podocoryne, 7, 135

ancclinata, Appendix, 492

areolata, 140

carnea, 136, Appendix, 492

conchicola, i 36

dehami, It2

dubia, $\operatorname{s!I}$ 
INDEX.

Podocoryne fulgurans, 139

gracalis, IfI

loumilis, $I f I, x \cdot f$ ?

minuta, $x \neq 0$

octosi yla, 1 fo

polystyla, Ifo

tenuis, IfI

Polycamna, 324, 3.35

ancricana, 320

crassa, $33^{6}$

forskalea, 326

fungia, 325

germanica, 325

grienlandica, 335

italica, $325 \cdot 327$

purpurostoma, 3.33

vitrina, 325

liblycolpal, +32

forskalii, $43.3,4.37$

zonatria, 433

zonorchis, 433

Polyorilis, 9, 197, 218

campanulata, 2 I 8

minuta, 219

penicillata, $21 S$

pimnatus, 2 i $\delta$

saltatrix, 220

l'olysenia, 337, 439

albescens, 482

cyanogramma, 44,3

cyanolina, 445

cyanostylis, 445

Havescens, 434

leucostyla, 4.33

pleuronota, $33^{8}$

I'ottsia, 366

ryderi, 360

Proboscidactyla, \&, ISS

brevicirrata, I 80

Anvicirrata, 1so

var. stolonifera, 191

gemmifera, r92

minima, 10?

ocidentalis, IO) 3

ornata, Isy

var. gemmife'ra, 102

var. stolonifera, IOI

tropica, I9I

varians, 194

Protiara, 7, 71. 105

heroc, 106

borealis, 106

formosa, 107

hackclii, 106

I'sendoclytia, I I, 232, $27 \mathrm{~S}$

gardineri, 279

pentata, 265, 275

Pterancma, 6, 92

ambiguin, 92

darwinii, 02

Piyclogastria, 13, 37?

antarctica, 375
Ptychogastria asteroides, $37+$ polaris, $37^{2}$

Piycliogastrider, 13, 371

Piychogena, 9, 197, 2It

(?) anturctica, 237

californica, Appendix, 194

ervtlungonon, 217

laten, 215

longigona, 2I7

pinnulata, 2 I 5

var. intermedia, 215

Tulsation of: Coryue pusilla, 5I; Sarsia, 52: Polyorchis, 2I9; Obelia, 243; Craspedacustil, 365: Gonionenus, 348; Gervonia, 426

l'urena, 73

brownei, Appendix, 480

gemmifua, 62

strangulat $a,-6,79$

Ruthkea, S, I75

blumenbachiana, 177

blumenbacliii, $17 \%$

degans, 1SI

fasciculata, $r 70$

formosissima, $I / 7$

actonemalis, ISo

actopumitata, 177 , Appendix, 49.3

var. grata, I 79

Reactions to light by Eudendrium, 4; Sarsiat, 52 ; mechanical stimuli by Rathkea, ISo; chemicals and electric current by Polyorchis, 219 ; chemicals by Obelia, 243; mechanical stimuli by Cosmetira, 26r; photic and mechanical stimuli by Eutimium, 306; light and other stimuli by Gonionemus, 347; various stimuli by Craspedacusta, 365 ; chemicals by Geryonia, 424,427

Regeneration: Eudendrium, 4, 27; Pennaria, 25; Obelia, 230; Tubularia, 239; Tima, 3 I 8 : Gonionemus, 346; Liriope, +10 ; Geryonia, 477: Solmaris, $4,3^{6}$

Rhacostoma, 324, 335

atlanticum, 335

dispar, 326

Rhegmatodes, 324

floridanus, $33^{\circ}$

globosa, $33^{2}$

lacteus, 333

tenuis, 332

Rlopalonema, I4, 376

clavigerum, $3^{82}$

caruleum, 350

polydactylum, 379

striotum, $3 S_{I}$

typicum, 378

vilatum, $377,37^{8}$

Rlopalonemina, 14,376

Sabellaria, I 12

Saphenclla, 234

dissonema, 237

Saplenia, I I, IO8, 232, 203 


\section{INDFX.}

Saphenia balearica, 203

bisentaculata, 20).1

dimemn, 109, 291

gracilis, 201

titania, 109

Sarsia, $5,+7$ augulata, 60

apicula, 59

barentsii, 53

brachygaster, 59)

clisata, 77

cocometra, Appendix, 488

cudonophora, 61

innica, $5 \delta$

dolichogaster, 77

eximia, 57

fammica, 61, 120

geminifera, 62

glacialis, 53

gracilis, 60

hargitti, 63

macrorhynchia, 52

minima, 59

mirabilis, 53

var. reticulata, 57

nodosa, +8

princeps, 60

prolifera, $6 I$

pulchella, 57, Appendix, t8s

radiata, 55

resplesuleus, Appendix, +87

rosaria, 50)

siphonophora, 62

strangulata, 79

iubulosa, 52

turricula, 57

(Stauridiosarsia) produitel, $6_{5}$

Sarsinute, 5, 20

Sarsiclla, tt

Schizocladium, $23^{8}$

Scrippsia, 197, Ippemelix, +4.3

paifica, Appendix, +93

Scrphis mucilaginusa, $f$ i

Seasonal dimorphism: P'ennaria, 26; Sirsia, 53. 55

Sertularia dichotoma, $2+6$

gelatinosa, $24+$

geniculata, $2+9$

longissina, 255

pennaria, $2+$

volubilis, 262

Sexual dichromatism: Stomotoca dinenat, III; Orchistoma pileus, $2 \mathrm{II}$

Sibngitu, 8, I\$6

geometrica, 186

nauarchus, Appendix, +or

simulans, ${ }_{1} \$ 7$

typa, Appendix, tor

Siphonorynchus, 293

bitentaculatus, $29+$

insignis, 209

Slabberin, 6,73
Slabberin banumei, Ippendix, 4 so

cateuata, 77

halterata, 75

ophingaster. 70)

piramis. 70

strangulata, 76

$$
\text { Ear. fragilis. } 77
$$

Simintlict, It, $3 \$ ?$

surygaster, $378,3 f_{3}$

leptogaster, $3 S_{3}$

tympanum, 378

Solmanider, $15,+30,131$

Solmonis, $15,+30,133$

ast rozuna, +4t

corona, $+32, .137$

coroninthis +37

Rareseens, $+32,+33,1 \%,+\delta_{t}$

forskalii, $+32,437$

gegenbauri, +.37

incisa, $+\delta_{3}$

insculpta, ++3

lenticula, $+32,138$

leucostyla, $+32,133$

mucilaginosa, 4 i

multilobuses, $+32,+35^{5}$

punctat $: 4,+4,+8+$

solmaris, 432,137

Solmissus, $16,+48, .182$

albesicus, . . . 2 ?

bekii, 192

eplecsius, is?

faleri, $15_{3}$

incisa, 18 ?

mershalli, 181

Sulmoncta, +39

flavescens, $+3+$

Solmundella, $15,+4.8,151$

lifentaculatin, $+5,5$

hernsenii, +55

meditiorane $1,+55,+5^{-6}$

Solmundus, $t+0$

glacialis, +72

tetrilinus, +52

cctranemus, +72

Spincodon, 9, 107, 219

saliatrix, 220

Stauraglawra, it, 106 tetragnema, $f^{06}$

Stauridia producta, 65

Stauridie, 99

Stancidium, 64, 99 productum, 65

Stavidiosarsin, 5.61

Staurodiscus, 9, 107, 213,221, 228

lieterosceles, 27

nigricans, 2 : I

tetrastaurus, 2I.

Stauroploora, II, 232, 291

falklandica, 203

kcithii, 202

laciniatis, 201 
INDEX.

Staurophora mertensii, 201

Staurostoma, 29 I

arctica, 292

Steenstrupia, 5, 29

aurata, 35

australis, 37

bigclowi, 36

cranoides, 3 I

galanthus, 3 I

globosa, 36

gracilis, 31

lineata, 31

oceidentalis, +2

mubra, $3^{I}$

tetrabrachia, 36

virgulata, 35

Stenyo, 47

Stomobraclium, 322

lenticulare, 322

octocostatuin, 208

stauroglyphum, 323

tentaculatum, 322

Stomotoca, 7, IoS

apicata, 109, II 2

atra, III

australis, I I I

dinema, 100

divisa, II4, Appendix, 490

jonesii, I I 4

octedra, III, Appendix, 490

periphylla, I 13

pterophylla, II 3

rugosa, $I I 2$

Stylactis, 8, 149

arge, $15 \mathrm{I}$

finciola, I 49

hooperi, I50

minoi, $I+9$

Syncoryna cleodorx, 122

Syncoryne densa, 53

eximia, 57

gravata, $5^{2}$

linvillei, 7 1, 72

producta, 63

prolifera, 6I

reticulata, 57

rosaria, 50

sarsii, 52, 6o, Appendix, 488

Syndictyon, 47

angulatum, 53, 59, 60

retieulatum, 57

Tentacles, hydra-like tentacles of Mœrisia, Appendix, 488

Tetracannota, 224 collapsa, 226

Tetranema xronauticum, 235 eucopium, I 99

Tetrorchis, $38 \delta$ erythrogaster, 398

Thalassantheæ, 428
Thamnitis, 8,152

tetrella, 152

Thamnostoma, 153 macrostoma, I 53

Thamnostylus, 8, I5I dinema, $15^{I}$

Thaumantiade, 9, 106

Thaumantias, 9, I 97, I9S, 20I, 238, 259, 265

louskeana, 270

cellularia, 198, I99

corynetes, 367

cymbaloides, 235,311

eschischoltzii, IgS

forbesii, 199

globosa, 235

hemisphærica, 266

inconspicua, 266

lacustris, 199

leucostyla, 266

lucifera (lucida), 250

maotica, 200

mediterranea, 202

melanops, 266

milleri, 208

multicirrata, 259

pilosella, 26 I

plana, 249

punctata, 355

quadrata, 200, 235

rubrum, 199

thompsoni, I 99, 270

undulata, 202

Tholus eurygaster, $3^{8} 3$

Tiara, I 20

coniferi, I 28

intermedia, 123, 125

oceanica, I 25

octona, 123

papilis, 123

papua, I25, Appendix, 49 I

prismatica, I 25

reticulata, I 25

rotunda, I 24

sarsii, I 23

smaragdina, 123

superba, I 26

Tiarella parthenopxa, 127,147

Tiaricodon, 7 I cœruleus, 73

Tiaridx, 102

Tiarina, 103

Tiarops, 286

Tiaropsidium, 495 kelseyi, Appendix, 495

Tiar,psis, 10, 2.31, 257

davisii, 259

diademata, $25 \delta, 260$

indicans, 306

kelseyi, Appendix, 495

madicayi, 259

mediterranea, 260 
Tiaropsis multicirrata, 259

oligoplocama, 259

polydiademata, 290

punctata, 260

rosea, 260

scotia, 259

Tima, II , 232, 3I I, 314

baidii, 315, 319

farilabris, 315, 319, Appendix, 497 formosa, 315, 317

lucullana, 314, 315, Appendix, 497

pellucida, $31 \mathrm{I}, 3^{\mathrm{I}}+$

teuscheri, 315,319

Timoides, 9, 197, 212

"gassizii, 212

Toxorchis, 10, 197,228

arcuatus, 228

kellneri, 229

thatassina, 228

Trachomcdusx, 339

Trachymedusce, 1 2, 339

origin of, 3,339

Trachynema, $376,3^{82}, 3^{8} 3$, +0 I

caintschatica, 402

ciliatum, 378

digitalis, +02

curygasecr, $3^{8} 3$

longiventris, $3^{85}$

octonarium, 378

Trachynemida, 13,375

Trichorhiza, 5,28

brunea, 29

Tubularia dumortieri, 69,70 prolifera, 43

Tulsulurix, 17

Turris, 7, 120

"Turris" $=$ Clavul $a$, Appendix, $49 I$

borealis, 402

brevicarnis, 127

campanula, $12 \delta$

caca, 127

conifera, $12 S$

digitalis, 129

episcopalis, 126

eurystoma, $12 \mathcal{S}$

fontata, $\Lambda$ ppendix, 491

neglecta, 122

papua, 125

pelagica, 127

pileat a, 123

prismatica, 125

reticulata, 125

rotunda, 124

superba, 126

vesicaria, 126

Turritopsis, 8, 135, 143

lata, ${ }_{4} 6$

nutricula, 136,143

polycirrha, 143
Turritopsis polyncma, $1+3$

V'allemtinia, 12, 352 falklandica, 352

Variation and Abcration in: I'cnnaria, 27; Sarsia, 55, 57; Bougainvillia, 160; Nemopsis, 17t; Kathkea, I82; Meticertum, 208; Dipleurosoma, 224; Obelia, 241; Clytia, 265; I'hialidium, 270; l'scudocly tial, 279; Ulindias, 358 ; Irenopsis, 311; Equorea, 328, 332; Gonionemus, 346; Ulindias, 358; Limnocnicla, 371; Aglaura, 399; Liriope, 4I2; Solmaris, $43+$; Cunina, 480 ; Mexisia, Appendix, 489

Veiled Medusar, 17

W'illett:1, 188 ornata, 189

Willia, 188 furcat:a, 193, 194 gemmifera, 192 occidentalis, 193 ornati, 189,192

Williadi, ist

II'illsin, $9,18+$, I88, 193 brooksii, 195, 196 mutabilis, ro.t

ornata, is?

stellata, 193

varians, 197

Wrightia, 269

Xanthea scutigera, +21 tetraphylla, +18

7anclea, 6, 85 ambigua, 92 cladophora, on costata, 87 gcmmosa. $\& \&$, Appendix, $+\$ q$ implexa, \&o nitida, $Q^{\prime}$

7.nucleopsis, 6, 9I dichotoma, gr

Z. yocanna, 12,337 costata, $33^{8}$ pleuronota, 338 purpurea, $33^{3}$

7.ygocannota, 337 purpurea, $33^{8}$

7. ygocannula, 12,338 diploconus, 339 undulosa, 339

$Z$ ygodactyla, $12,324,335$ crassa, $, 3,36$

cubana, 325 . cyanca, $326^{\circ}$ granlandicus, 335 rosea, 325

vitrina, 325 


$$
\text { - }
$$




\section{.}






$$
\text { • }
$$


